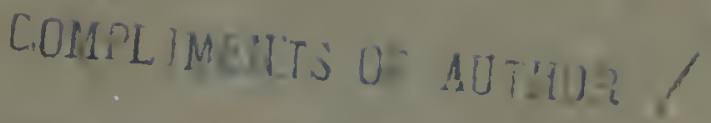

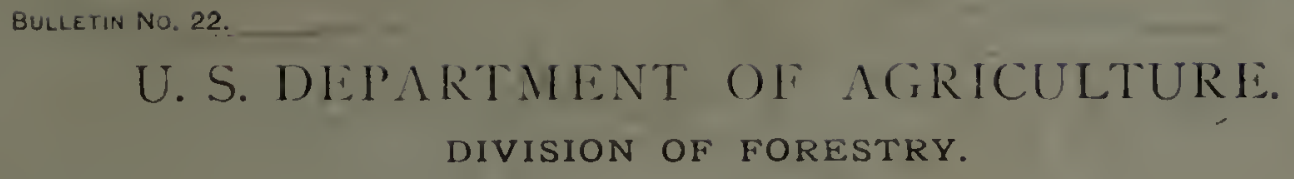

\section{THE WHIT E P I N E. (PINUS STROBUS Linnæus.)}

\author{
$13 Y^{\circ}$ \\ V. য়. SPALDING,

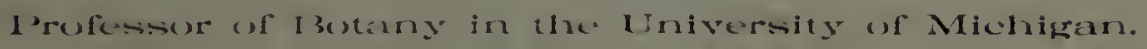

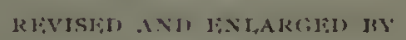 \\ B. F. FERNOW, \\ cinice or the divisiun of forestry.
}

WITH CONTRIBUTIONS:

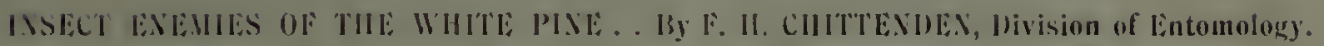

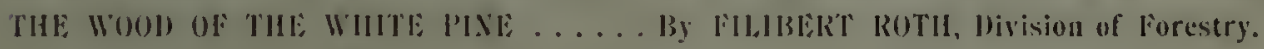

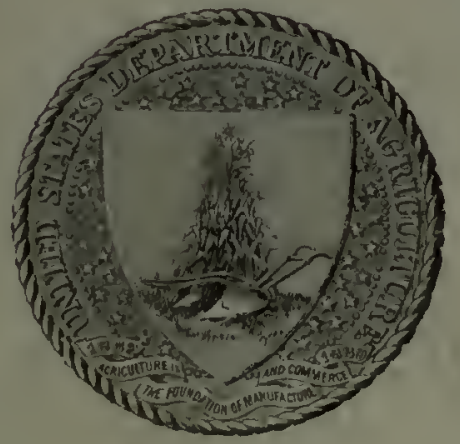

WASHITHOTON :

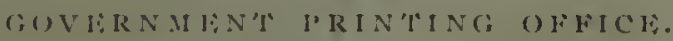
I 89\%. 


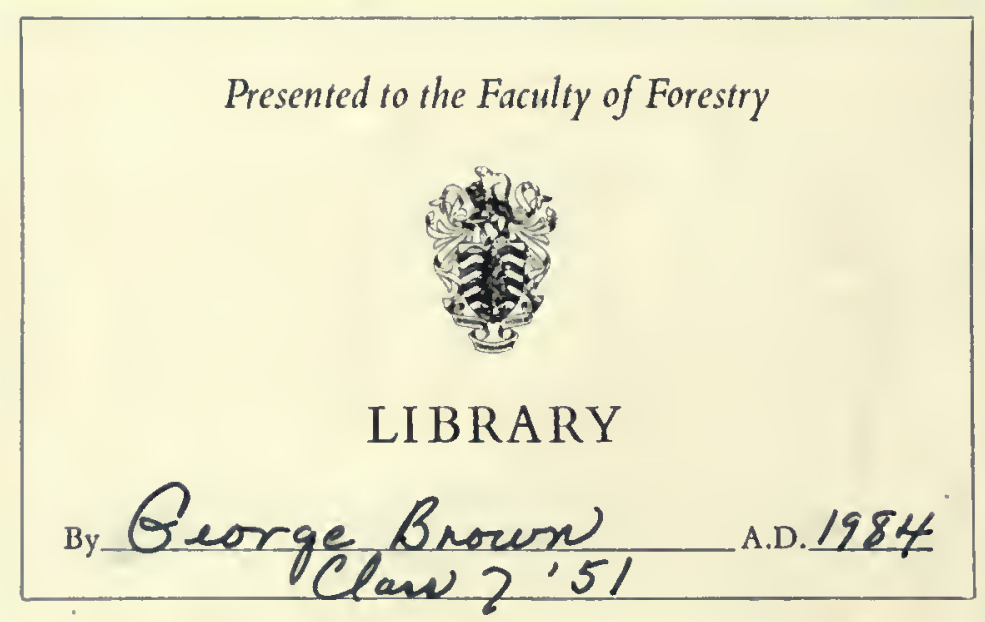




\section{FACULTY OF COREE

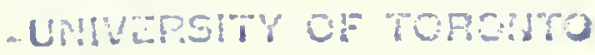

\section{APR 261984}


Digitized by the Internet Archive in 2007 with funding from Microsoft Corporation 


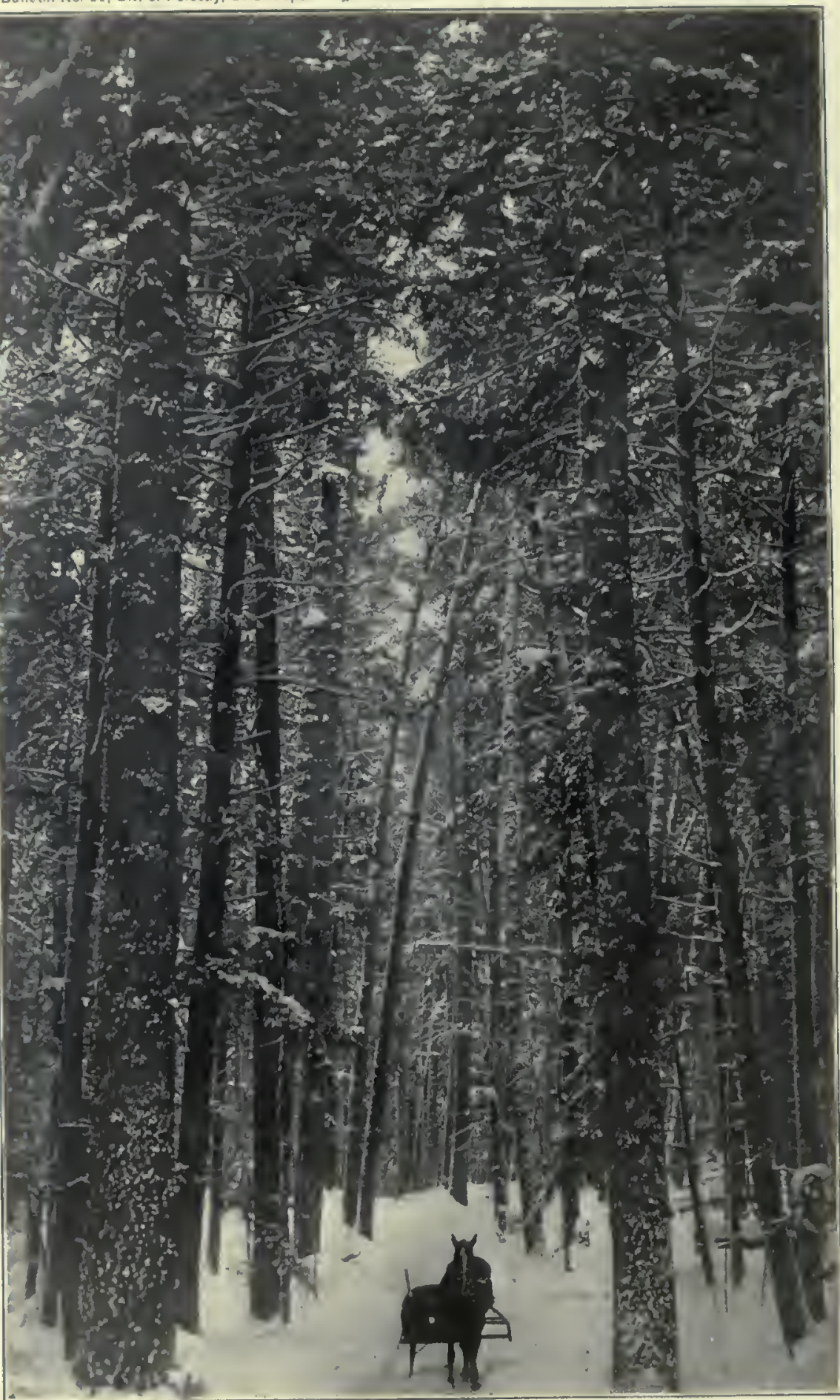

White Pine Forest. 
BULLETIN No. 22.

U. S. DEPARTMENT OF AGRICULTURE. DIVISION OF FORESTRY.

\section{THE WH I T E P I E. \\ (PINUS STROBUS Linnæus.)}

BY

V. M. SPALDING,

Professor of Botany in the University of Michigan.

REVISED AND ENLARGED BY

B. E. FERNOW,

Chief of the Division of Forestry.

WITH CONTRIBUTIONS:

INSECT ENEMIES OF THE WHITE PIXE. BY F. H. CHITTEXDEN, Division of Entomoiogy. THE WOOD OF THE WHITE PINE ..... By FILIBERT ROTH, Division of Forestry.

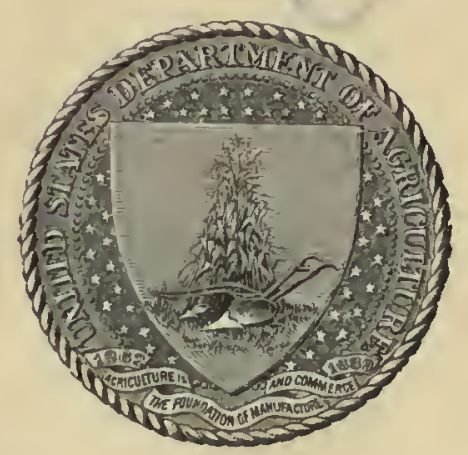

WASHINGTON :

GOVERNMENT PRINTING OFFICF.

I 899 . 

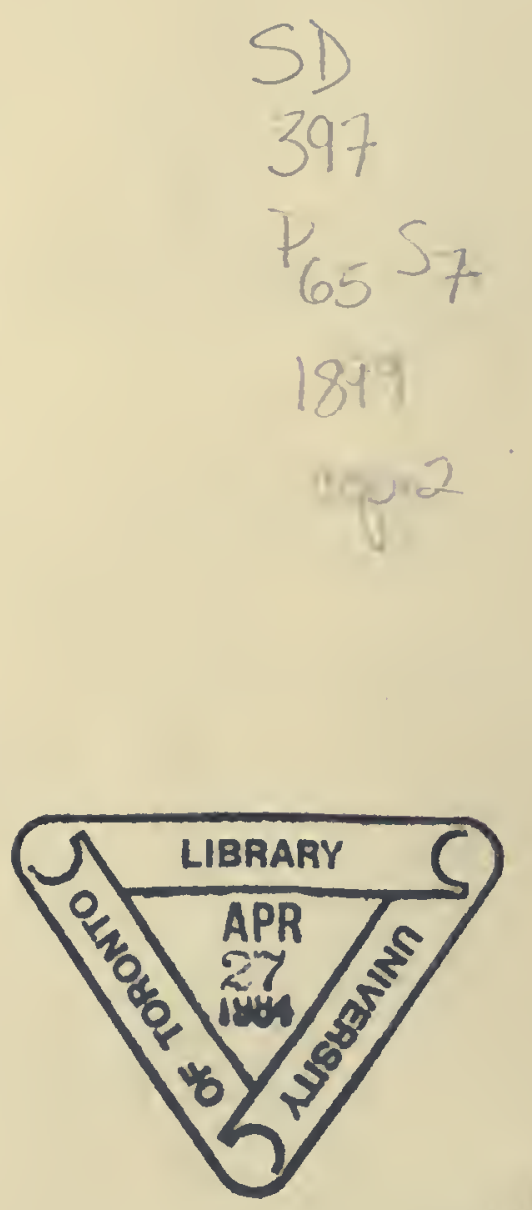


\section{LETTER OF TRANSMITTAL.}

\section{U. S. Departyent of Agriculture, DIVISION OF FORESTRY, Washington, D. C., March 15, 1898.}

SIR: I have the honor to submit herewith for publication a monograph on the White Pine of the Northern United States.

The first diaft of this monograph, like the one on "The Timber Pines of the Southern United States" (Bulletin No. 13, Division of Forestry), by Dr. Charles Mohr, was prepared more than ten years ago by Prof. V. M. Spalding, of Anu Arbor, Mich.; but it was then found that much information of practieal value was still laeking, and henee publieation was delayed until the deficiencies eould be supplied. Professor Spalding, after having made several revisions, under the pressure of other work had to abandon the idea of amplifying and perfeeting the monograph itself, and this was left to the undersigned, with the eollaboration of the staff of the Division of Forestry.

The undersigned is responsible not only for the plan of the work, but espeeially for the portions referring to forest conditions, forestal treatment, and for the diseussion on the rate of growth, to whieh Mr. Mlodziausky also coutributed.

Mr. Filibert Roth, of the Division, besides furnishing the study on the wood of the species, has also eontributed the portions on the history of the lumbering operations, while the discussion on the injurious inseets is by Mr. F. H. Chittenden, of the Division of Entomology.

A very eomprehensive investigation into the rate of growth of the White Pine lias been earried on sinee 1892 as opportunity afforded and funds permitted. The results of this investigation, eomprising the analysis of over seven luundred trees, in the form of tables and notes, will be fonnd in the Appendix. The measurements in the field were mainly executed by Mr. Austin Cary, of Bangor, Me., and by Mr. A. K. Mlodzinusky, of the Division. The latter also performed the ealenlations and tabulations in the Division, and in this work developed a short and satisfactory method of tabulating, analyzing, and using the large mass of data readily for the purpose of summarizing, averaging, and generalization. This method is deseribed in Bulletin No. 20, Division of Forestry.

The situation regarding White-Pine supplies has materially changed sinee this monograpli was first coneeived, so that it might almost be elarged that this publieation eomes too late. This would be a miseoneeption both as to the situation and the objeets of the monograpl. No infornation of any kind eould have arrested the deeimation of our White-Pine supplies, whieh proeeeds through the momentum of economie laws; and even now, when it is well known that a few years will see their exlıaustion, no ehange in the methods of milling with a view to lengtl. ening the supplies is eontemplated by the manufneturer, who is only eoneerned in keeping his mill running. The inanufaeturer is a harvester, not a forest grower.

The objeet of this monograph is to lay the basis for an intelligent recuperation of the virgin growth by the forest grower of the future, work whieh will surely be begun presently, but which would not liave been undertaken ten years ago.

In the preparation of this monograph use has been made of all available sources of inforna. tion. Acknowledgments are due to a large number of correspondents, named in the proper connection, who lave rendered valuable aid by contributing notes on distribution or have assisted in otlier ways. 
The botanical illustrations showing external characters are by Mr. Georgc B. Sudworth; those of the anatomy of the wood are by Mr. X. B. Picrce and Mr. Filibert Roth, and those of parasitic organisms and disease conditions are from Hartig's "Lelırbuch der Baumkrankhciten" and "Zersetzungserscheinungen des Holzes." The illustrations accompanying the section on injurious inscets were furnished by the Division of Entoinology. The map of distribution was prepared in the Division of Forestry.

The monograpl is believed to be just in time for the use for which it is intended, namely, to prepare for the application of sylviculture to the remnant of our pineries.

Respcctfully,

Hon. JAMES WILSON,

Secretary of Agriculture.
B. E. FerNow, Chief of Division. 


\section{CONTENTS.}

1'age

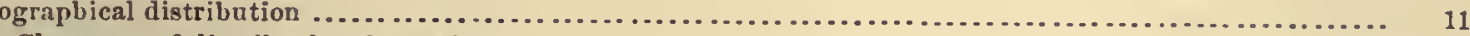

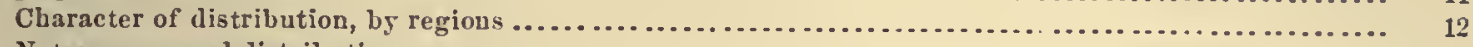

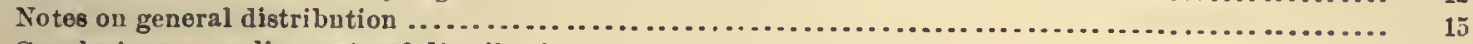

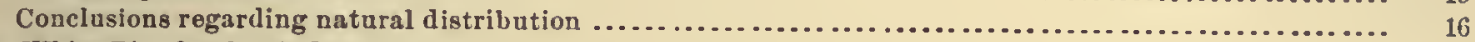

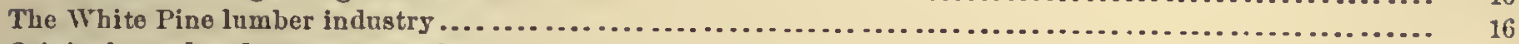

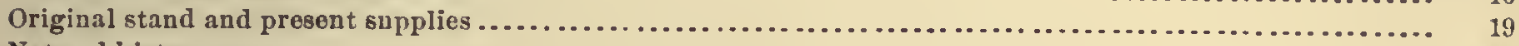

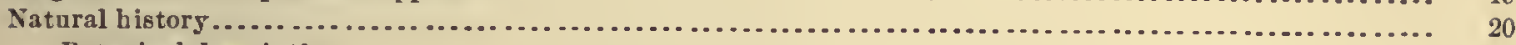

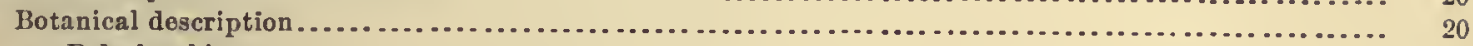

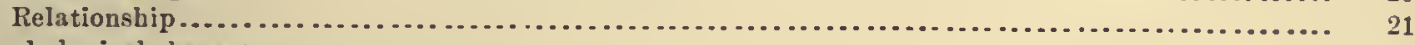

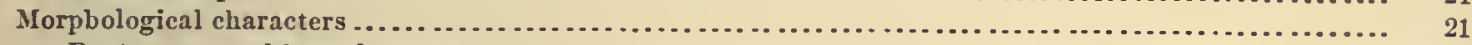

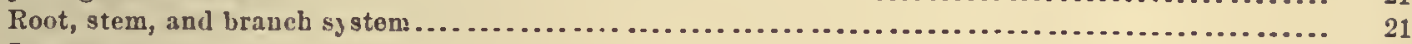

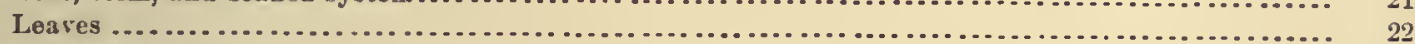

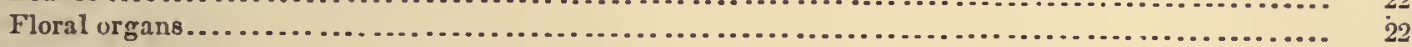

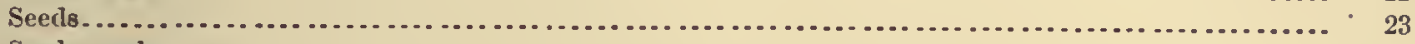

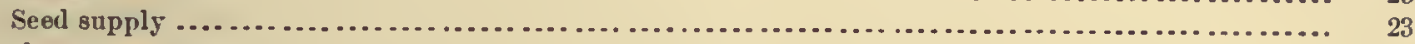

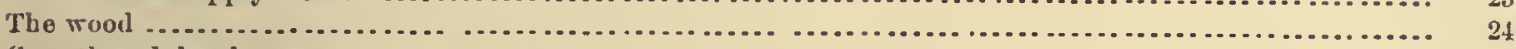

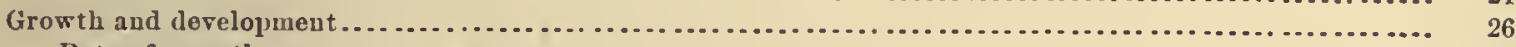

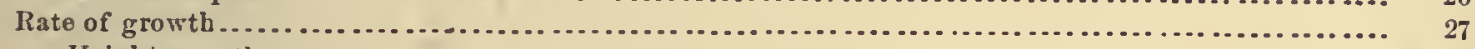

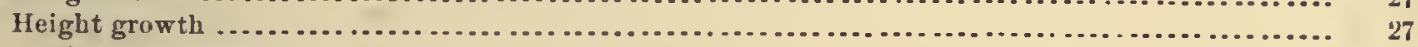

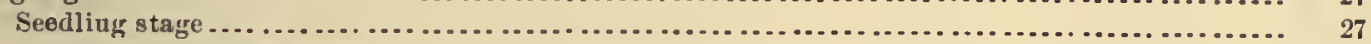

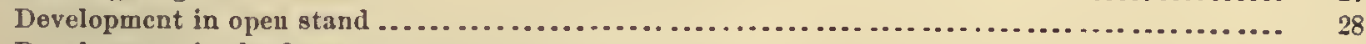

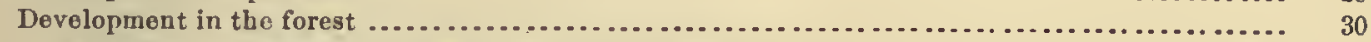

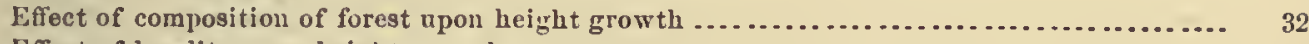

Effect of locality upon height grow th................................................ 33

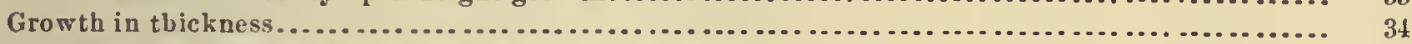

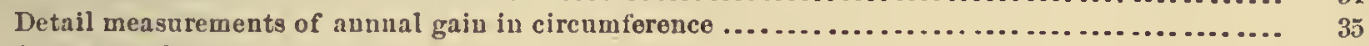

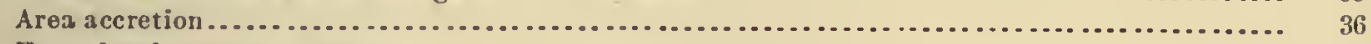

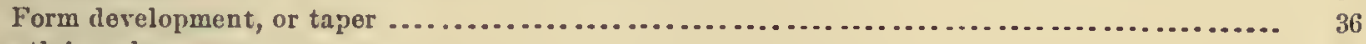

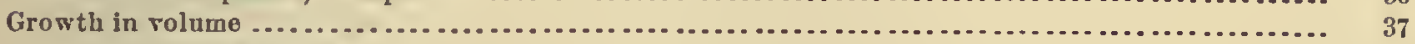

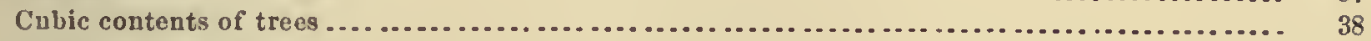

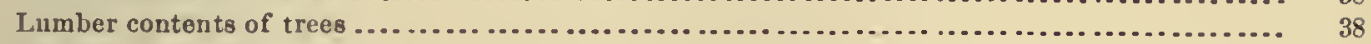

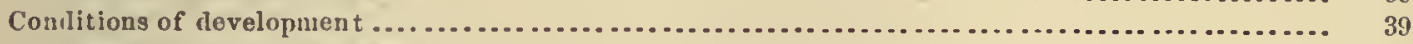

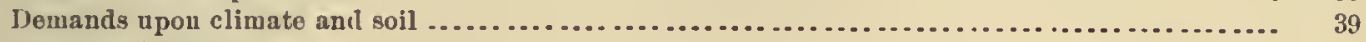

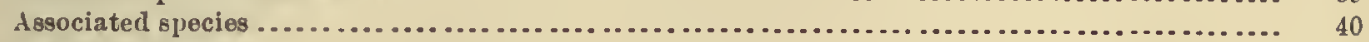

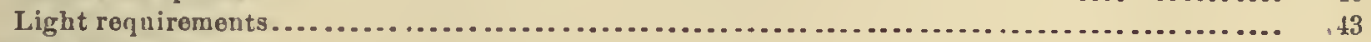

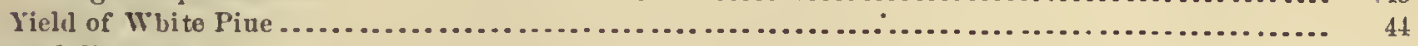

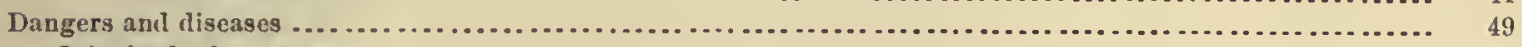

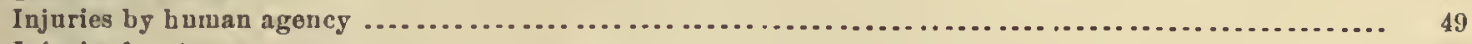

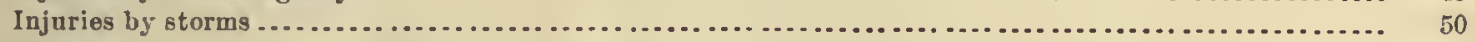

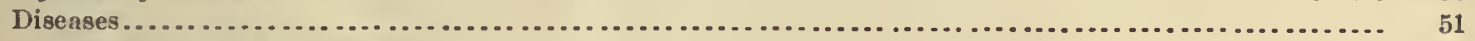

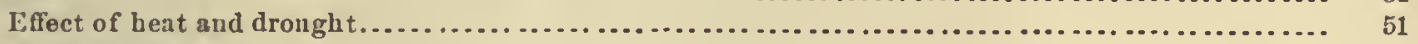

Parasitic diseases................................................................. 51

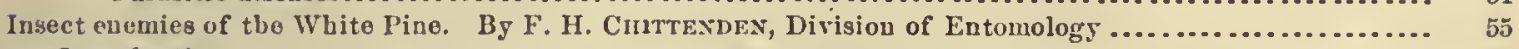

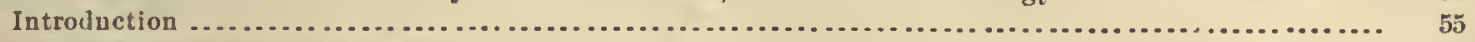

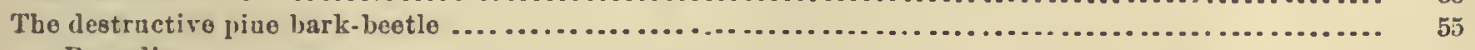

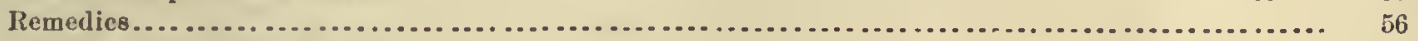

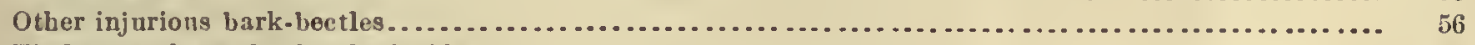

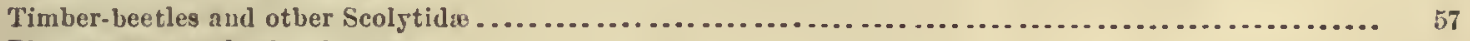

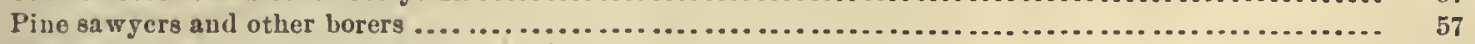

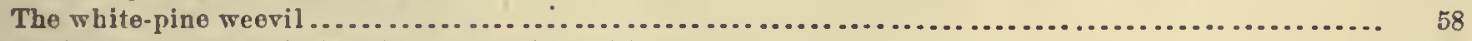

Moth caterpillars and plant-lice on trunks and limbs ...................................... 59

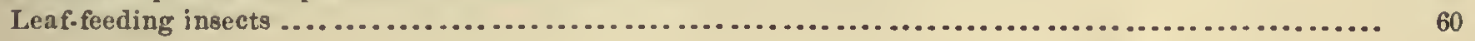


Forest managemeut

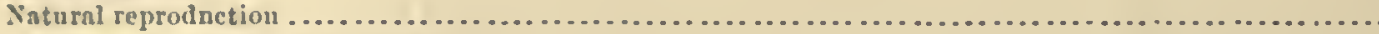
Notes on natural reproductiou.

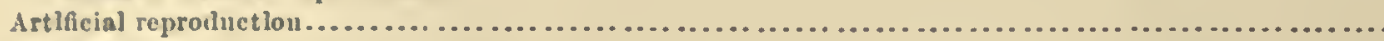

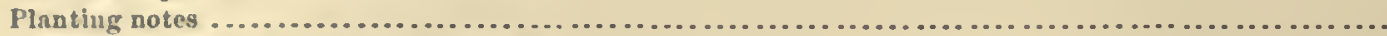

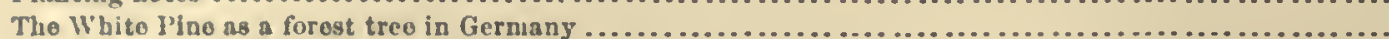

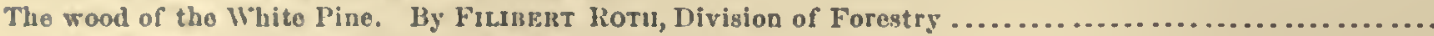
Character and physical properties of the rood

Specitic weight.

Shrinkege

"

Strength

Durabilits

Comparison with other woods.

Uses of White Pine.

Appendix :

Tables of measurements 


\section{ILLUSTRATIONS.}

PLATES.

PLate I. Map showing original distribution of White Pine (Pinus atrobus

II. Fig. 1.- White Pine mixed with hardwools in central New York. Fig. 2._old White Pine tree

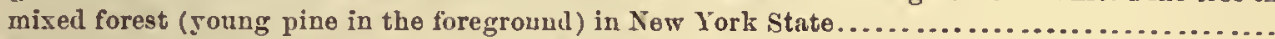

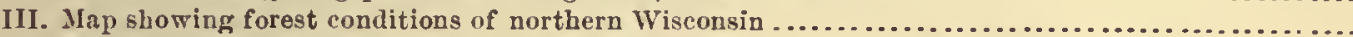

IV. Fig. 1.-Transporting $\log 8$ over ice road iu Miehigan. Fig. 2.-Lumber camp in Michigan ...........

$V$. Leares and bnd of the White Pine.

VI. Cones, seeds, ete., of the White Pine

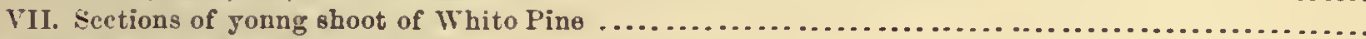

VIII. Sections of wood of White Pine

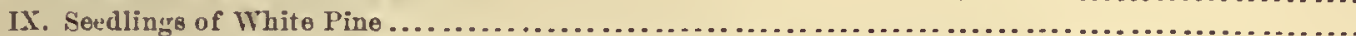

X. Fig.1.-A thinned pine grove in Now Hawpshire. Fig.2.-Young pine in New Hampshire.........

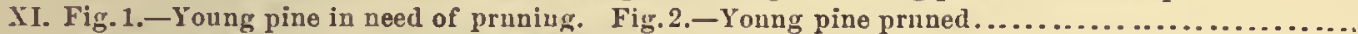

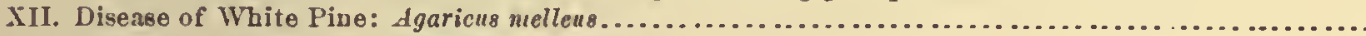

XIII. Disease of White Pine: Palyporus annosus.

\section{TEXT FIGURES.}

Fig. 1. Bark of old White Piue

2. Diagram showing height growth of mixed and of pure growth White Pine in Presque Isle County, Mlich

3. Diagram showing height growth of White Pine in forest of varying composition in Pennsylvania....

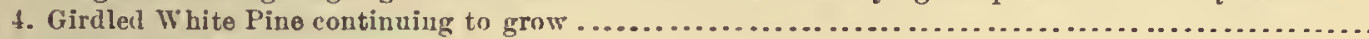

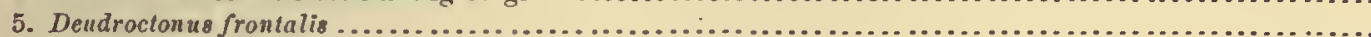

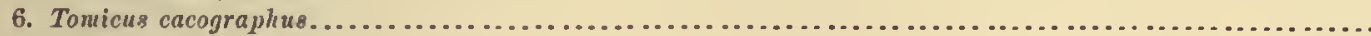

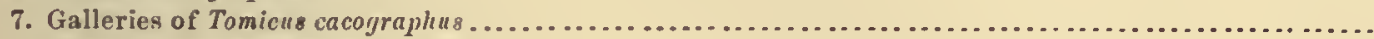

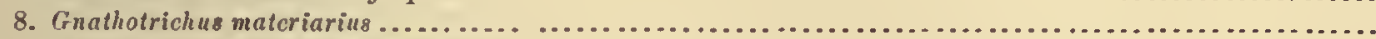

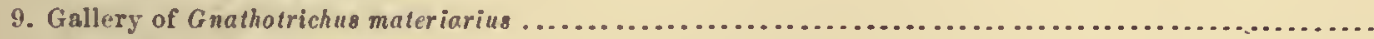

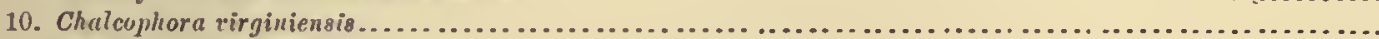

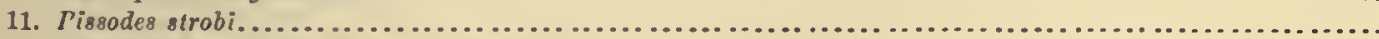

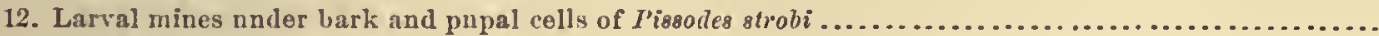

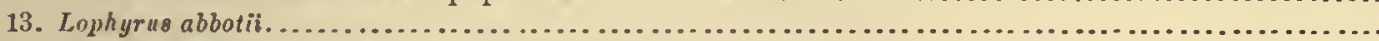

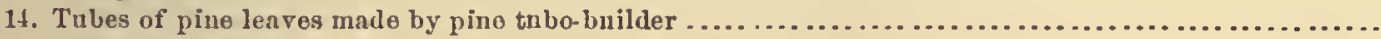

15. Chionaspis pinifolim.

16. Diagram showing specific weight of wood at cliffcrent cross sections of the stem; also a decrease of weight from the stump npward, anll tho similarity of the wood of different trees...............

17. Diagram showing specific weight of kilu-dry wood at differcnt points in the stem from ground upward.

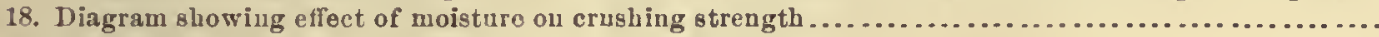

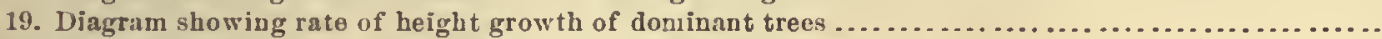

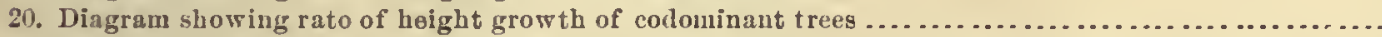

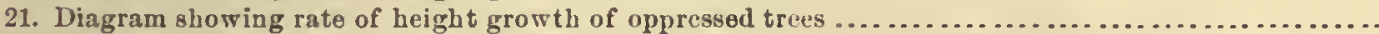

22. Diagram showing height growt h of dominant, collominant, and oppressed trees thronghout range....

23. Diagram showing rolume growth of dominant, codominant, and oppressed trecs thronghont range ...

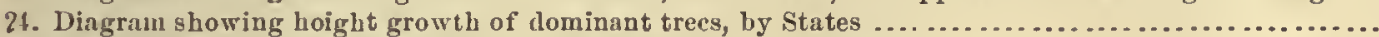

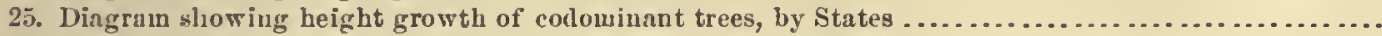

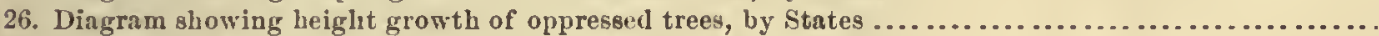

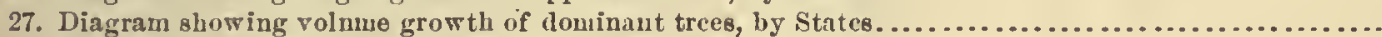

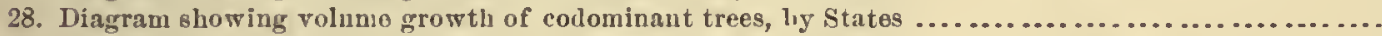

29. Diagrau showing volune growth of oppressed trees, by States. 
F1a. 30. Diagram showing a rerage progress of diameter growth (breast high) of doninaut trees .............

31. Diagram showiug dianeter growth of dominaut trees at various heights from ground (average

32. Diagram shoming dianeter growth of eodominant trees at various heights from ground (average

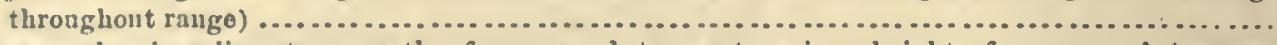

33. Diagram showing diameter growth of oppressed trees at rarions heights from ground (average

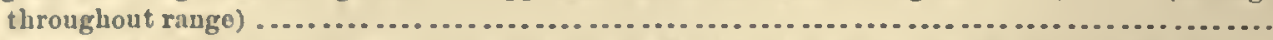

34. Diagram showing diameter growth of domiuant trees at various heights from ground in 7 isconsin .. . 111

35. Diagram showing diameter growth of oppressed trees at various heights from ground in Wiseousin.. 111

36. Dingram showing diameter growth of dominant trees at rarions heights from ground in Pennsyivania. 113

37. Diagram showing diameter growth of eodominant trees at various heights from ground in Pennsylvania 113

38. Diagram showing diameter growth of dominant trees at varions heights from gronud in $M$ iehigan... 115

39. Diagram showing diamotor growth of oodominant trees at various beiglits from ground iu Miehigan. 115

40. Diagram showing diameter growth of oppressed trees at varions hoights from ground in Mliehigun... 


\section{THE WHITE PINE. (PINUS STROBUS Linnæus.) \\ EYNoNYMs.}

Pinus strobus Linnaus, Spec. Pl. ed. 1, 1001 (1731).

Pinus tenuifolia Salisbury, Prodr. 399 (1796).

LOCAL OR COMMON NAMES.

White Pine (Maine, New Hampshire, Massachusetts, Rhode Island, Connecticut, New York, New Jersey, Pennsyltania, Delaware, Virginia, West Virginia, North Carolina, Georgia, Indiana, Illinois, Wisconsin, Michigan, Minnesota, Ohio, Ontario, Nebraska).

Weymonth Pine (Massachnsetts, South Carolina, European literatnre).

Soft Pine (Pennsylvania).

Northern Pine (Sonth Carolina).

Spruce Pine (Tennessee). 

BULLETIN NO, 22, DIV. OF FOREgTRY, U. 8. DEPT, OF AGR.

Plate I.

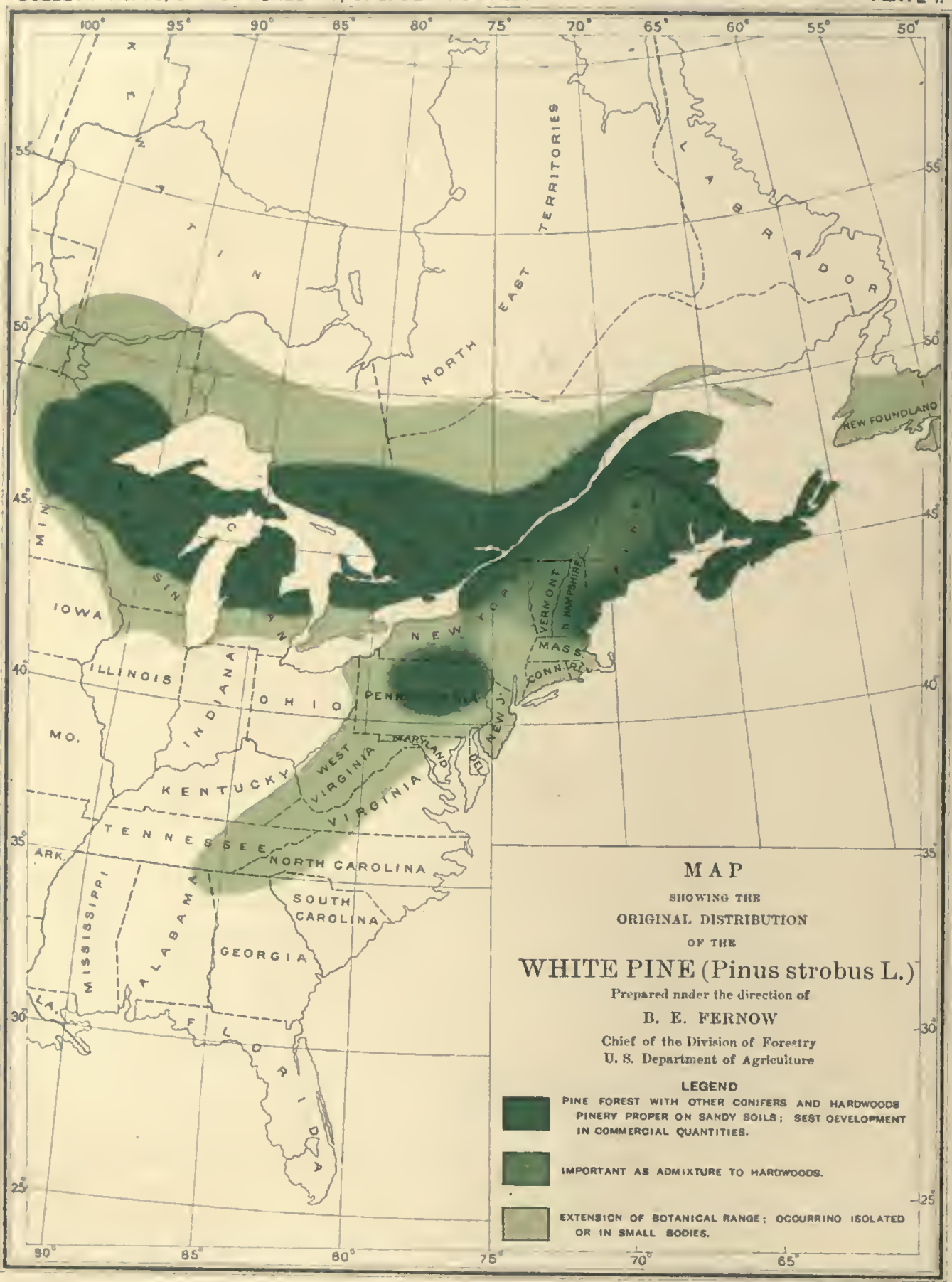

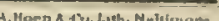




\section{THE WHITE PINE.}

\section{INTRODUCTION.}

For two centnries and a half the White Pine has been universally employed for purposes of construction in the Northern United States. Its abundance and the combination of qualities which adapts it to au almost unlimited number of, uses have made it the most important and the most highly prized of all the timber trees of the region to which it is indigenous. In several of the Northern States it has been a more constant source of wealth and has yielded larger returns than any other single product. Thus, for instance, in 1879, a fair year for comparison, the natural products of the State of Michigan were estimated by Governor Jerome as follows: ${ }^{1}$

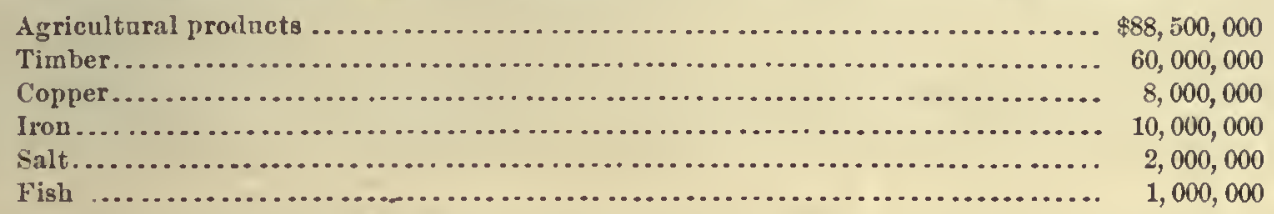

According to this estimate the value of the timber products, chiefly White Pine, was at that time, ill round nnmbers, six times that of the iron, seven and one-half times that of the copper, and thirty times that of the salt product of the State, and amounted to about 35 per cent of all the products of the State combined; and if the value of the entire White Pine prodnct of the present year (1S9S), some 7 billion to $S$ billion feet B. M., be taken into consideration, it will exceed in value at first points of production the cntire gold and silver output of the country, which is not much less tlian $\$ 100,000,000$.

Commercial interests of great magnitude, dependent upon the handling and transportation of the White Pine prodnct, have been built up in Chicago and other northern eities, and the diminution or failure of the supply must inevitably result in the transfer of the capital thus employed to other purposes or to other centers of distribution. In fact, such changes have already bcen and are now bcing made with grent rapidity, and mnch of the capital formerly invested in the pine lauds and mills of the nortlern lake region has been transferred to those of the Gulf States and the Pacifie coast.

A multitude of industrics is dependent upon a continued and large production of pine lumber, and its failure, though perhaps not threatening such a collapse of business interests as alarmists have pictured, will nevertheless involve serious if not disastrous consequences to the communities relying upon its continuance. The maintenance of an adequate future supply, especially in view of the well-known fact that the existing forests of White Pine can last bnt a few years longer, at most, is therefore a matter of great economical importance and can not receive too prompt attention.

\section{GEOGRAPHICAL DISTRIBUTION.}

The White Pine is a trec mainly of northern distribution, although it occurs along the monntain ranges as far south as northern Georgia. It occupies in this distribution the Boreal and Transition life zones, as defined by Dr. C. Hart Merriam. 
The botanical range of the White Pine may be eirenuseribed as follows: From Nerfoundland and the Atlantie coast north of the Gulf of St. Lawrenee its northern limit runs in a wary line between the forty-ninth and fifty-first legree of latitude, its most northern extension oecurring near its western lmit, when, skirting the sontheastern end of Lake Winnipeg, it turns sonthward, following more or less closely the ninety-sixth meridian of longitude, and in a southenstern direction the line whieh demarcates the boundary between forest and prairie to the Cedar River at the Iowa line, and along the Mississippi River, erossing it near Rock River, when, following this river for some time, it takes an easterly eourse to the head of Lake Miehigan, then in a northensterly direetion through Miehigan to the shores of Lake St. Clair and aeross Ontario, skirting the southern shores of Lake Erie in the two most northeasterly eounties of Ohio, then turns sonthwarl through the eastern eonnties of that State, and following into West Virginia near the 1,000-foot eontonr line along the foothills of the Alleghenies through Kentucky aud Tennessce, gradually withdrawing to higher elevations (1,200 feet) into northeastern Georgia; the line then returning northward along the eastern slope and crossing upper Delaware, reaches the Atlantic coast in southern New Jersey.

The distribution of eommercially valuable timber is, to be sure, very different and muel more confined. The uorthern parts of Minnesota, Wisconsin, and Miehigan contained probably the largest amount of White Pine, the broad belt of commercial pine of these States eontinning eastward through Ontario, northern New York, and the northern New England States to New Brunswiek and Newfoundland, and following the New England coast, while the higher elevations of the New England States showed preponderantly spruee with pine intermixed. The northeru eounties of western Pemsylvania also eontained a large amount of White Pine timber mixed with Hemloek and harlwoods. The charneter of this distribution is exfibifed by general ontlines and shadings on the aceompauying map (Pl. I). The extreme limits of its sporadie oeeurrenee ean not be fixed with absolute precision, and from the nature of the ease must remain unore or less indefinite. Similarly, the limits of greater or less development ean only be approximately stated.

The oecurrence of the White Pine was generally as a eomponent of the mixed hardwood forest of the Atlantic, even in the best developed portions of its range, and under sueh condi. tions, that is, in mixtme with other speeies, it seems to attain ity-most perfeet development.

The finest speeimens of the highly estcemed "Cork Pine" of Miehigan grew among hard. woods on a better quality of soils than those which produeed less valned grades. On the lighter sands true pinery (pure or nearly pure growth of White Pine) occurs. Here its admixtures are most frequently of Red Pine (Pinus resinosa) and in its northern limits of Jaek Pine (Pinus divar. icata), while on the better and eooler situations it aecompanies the spruces (Picea mariana and P. canadensis) with Balsum Fir (Abies lolsamea) anı Hemlock (Tsugu canadensis).

\section{CHARACTER OF DISTRIBUTION, BY REGIONS.}

The eharaeter of the oeeurrence of the White Pine in the forest within its field of clistribution will readily appear from the descriptions in the tables of acre yield in the Appendix.

In Mainc, the lotrer altitudes, along the coast and some of the river valleys, contained in their hardwood forests the White Pine in fine development, which gave to that State its eognomen of the "Pine Tree Statc." Reports of trees 6 to 7 fcet and over in diameter and up to 250 feet in height testify to the eapaeity of the species in this region. The original stand of this pine in the State is praetieally entirely removed, while the young growth furnishes now again small quantities of logging inaterial. The higher altitudes, with their slate aud granite soils, are stockel cutirely with the spruce and hardwood forest in which the pine ocenrs only as a scattering inixtnre and of inferior development.

This same manner of distribution applies more or less to Verc Irampshire and northern Vien Fork In the Allironlacks the pine, now almost entirely remored, fringes witl the Spruce and Balsam Fir the many lakes and water courses and kecps to the lower altitnles; mixel in with the Maples, Birches, Beeeh, a'id Spruee, it towers 50 to 60 feet above the general level of the woods, with dianeters of 30 to 40 inelies. Its reprotuction uncler the slialle of its eompetitors, liowerer, is prevented, young pine being rarely seen exeept on old abandoned openings iu the forest. (See Pl. II.) 


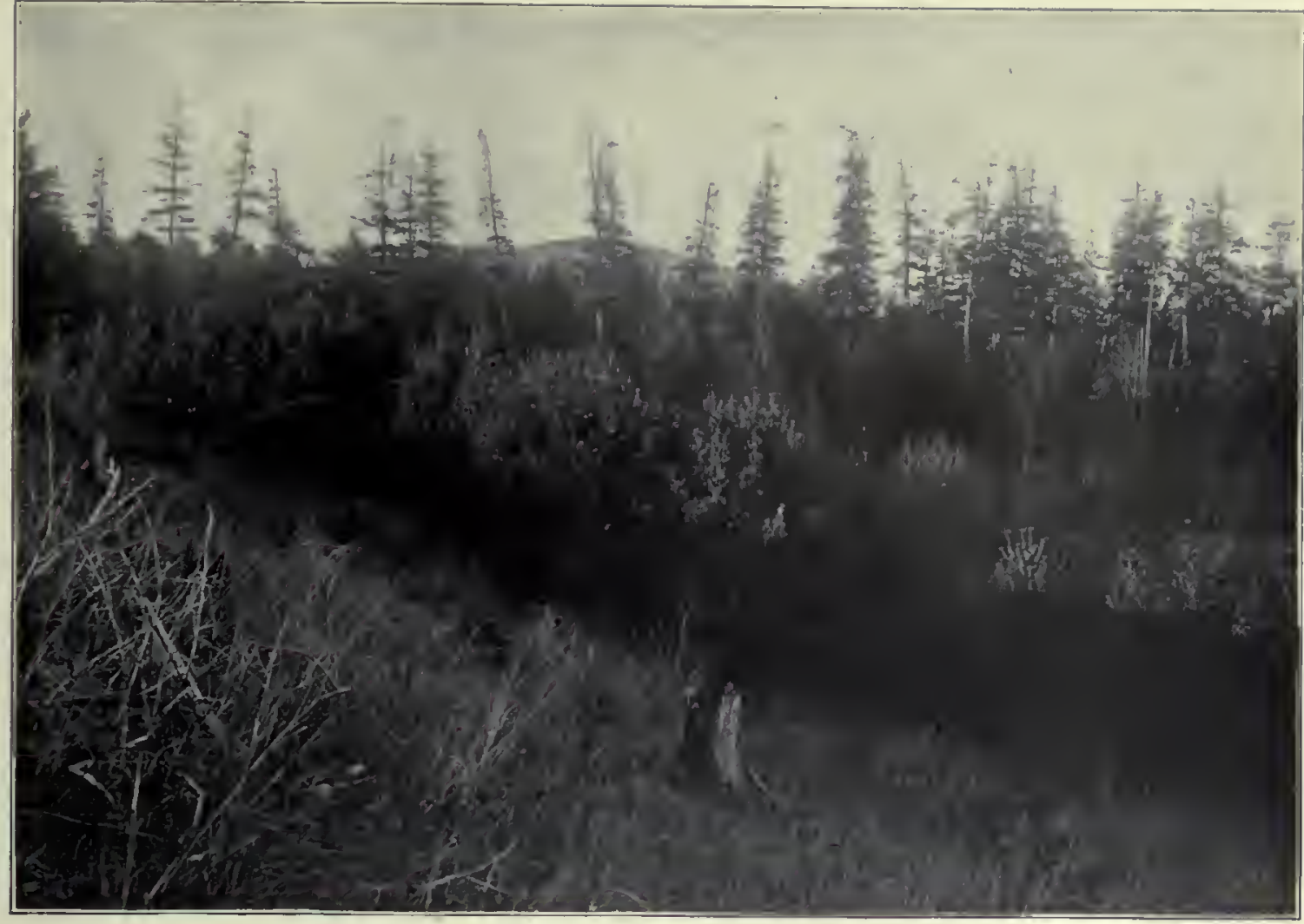

Fig. 1.-White Pine mixed With Hardwoods in Central New York.

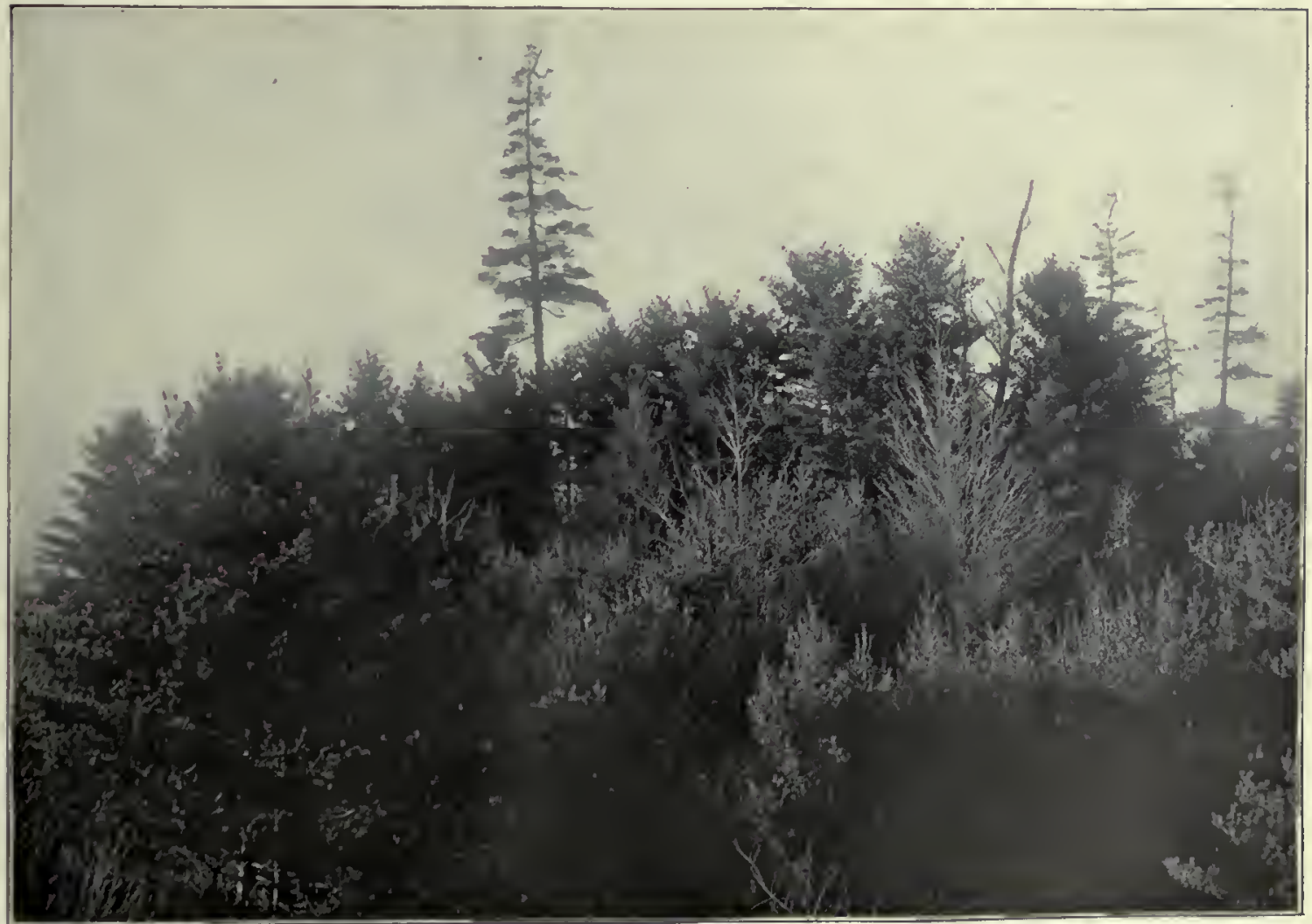

Fig. 2.-Olo White Pine Tree in mixed forest (Young Pine in the foreground) in New York State. 

In western Nelo Fork the White Pine was once quite abundant as a coneonitant of the hard. wood forest. Young growth is now crecping into every wood lot, while in Y'ennsylvania the White Pine occurred undonbtedly in the lower eastern counties in commercial quantities as well as in the adjoining counties of Nero Jersey, where it begins to be a tree of the mountains, the liigher slopes, ridges, and tops becoming its favorite habitat $\mathcal{I t}_{\mathrm{t}}$ is here largely associated with Hemlock, which often becomes the preponderait tree. Pure pine growth is rare, but the mixed hardwood forest is seldom without an admixture of White Pine to the extent, as a rule, of about 30 per cent numeri. cally, the soils within the range of its occurrence being seemingly everywhere quite favorable to its growth.

Besides the Hemlock, the coniferous specics with which it is found associated are Pitch Pine (Pinns rigida) and Spruce, while Red Pine (Pinus resinosa), the most successful rival of the White Pine in the lake region, is here rarely met, and then only in single individuals. The hardwoods most frequently represented are Maple, Beech, and Birch, more rarely Oak and Chestnut, with Basswood, Cucumber, Hickory, Cherry, etc., interspersed in single individuals.

The best development of the White Pine is usually found along the water courses. Thus, in Pennsylvania, in Luzerne County the White Pine is situated along Bear Creek and its tributaries; in Clinton Connty the pine is found on both branehes of Hyner Run and along Youngwomans Creek; in Clearfield County there were 20,000 acres along Sandy Creek and its tributaries heavily timbered with White Pine, of which about 2,000 acres of primeval timber are left, wlich would cut about 100 million feet B. M. of White Pine. In Jefferson County a tract of Hemlock and White Pine forest of about 90 square miles, known as the Hay's tract, is traversed by the North Fork and its tributaries. In Forest County the areas heavily covered with pine were situated along Hickory and Tionesta creeks. Therc is as yet standing over 100 million fect B. M. of White Pine along Hickory Creek and its tributaries.

The heavy cut of pine in Elk County came from Medix Run, Dents Run, and their tributaries. The courses of the streams follow the trend of the ridges, the substrata of which are usually of a porous natnre, consisting in most cases of slate or laminated shale, a soil very favorable to pine situated on moderately elevated grounds and slopes along the hollows and gorges, which, on account of the pervious substratuın, offer most satisfactory soil-moistnre conditions.

From Neio Jersey the White Pinc has practically vanished long ago as a factor in lumber production, and almost as a tree of common oeeurrence.

With the extension of the distribution southward, the White Pine becomes less frequent and of inferior devclopment; the climate forces it to higher and higher altitudes. It occurs in quantity only in islands or in small bodies on the erests and along the slopes of the Alleghenies, both east and west, nsually accompanying water courses in broader or narrower belts.

Regarding the manner of occurrence of the White Pine in these southern regions, the remarks of Mr. W. W. Aslie on the distribution in North Carolina (Bulletin No. 6, North Carolina geological survey, 1898) are more or less applicable:

The woodland in which White Pino is the dominant eoniferons tree is not extensive, but lics in isolated, small bodies along the crest and sonthern and eastern slopes of the Blne Ridge, or on the low hills on the west, " " " extensive forests sellom being found above the higher limit (3,000 feet in Maeon and Jaekson eounties), or perfect individual development attained below the lower $(2,800$ feet). In a few places on the southern slope of the Blue Ridge * " the White Pine is as sociated with Yellow Pines as well as with deciduous trees, but the treos are generally short-boled, and ncither so large nor tall as those growing at a higher elevation to the west of this range. Singlo specimens or small groups of trees are loeally dispersed in the broad-leaf forests throughout the moantain eounties between the limits of al titude given above.

It appears from thesc statements that in these latitudes below the 2,000 -foot level this pine ean hardly be expected to be of commercial or forestal value for the future.

The area of greatest quantitative devclopment is found around the Great Lakes and in the basin of the St. Lawrence and its tributaries, in the very places most perfectly adapted to its ready and economieal exploitation and easy shipment.to markets, the large number of streams that are capable of carrying logs, the accessibility of natural ports of distribution, and favorable elimatic eondıtions inviting the logger and lnmberman. Michigan, Wisconsin, and Minnesota have thus beeome known as the great lumber region of the United States. 
In Michigan the distribution of the speeies is entirely eontrolled by the eharacter of the soil, all sandy areas beung pinery proper, with large areas of pure growth of sereral square miles in extent eoutaining only Whitc Pine. Oeensionally, and espeeially on the driest and poorest sandy gravels, the Red Pine (Pinus resinosa) associates and sometimes predominates, the White Pine not representing more than 10 to 20 per cent of the number of trees. In the northern regions Jaek Pine (Pinus divaricata) takes the plaee of the Red Pinc.

The typical pine forest on fresh sandy soils eonsists of White Pine (45 to 55 per eent of the dominant growtlı) mixed with lied Pine (25 to 45 per eent) with scattering Hemloek (10 to 15 per cent) and oecasional Fir and lard roods. The undergrowth, usually uoderately dense, consists mainly of small Hemloek, Fir, and young liardwoods.

On moister sand with loam or clay snbsoil Hemlock and hardwoods replace the pines, the Red Pine vanishing entirely and the White P'ine oecurring only in large isolated individuals. Into wet or swampy plaees the White Pine also penetrates in single individnals among Arborvita, Haekmatack, and Spruee.

As the loam in the eomposition of the soil increases, the hardwoods inerease numerieally, the White Pine oeeurring only in single individuals and groups, and Red Pine and Hemlock only oecasionally. Finally, the heary elay soils toward the southeru range of the species give absolnte preponderance or exclusive possession to the hardwoods, mainly Sugar Maple, Yellow Bireh, and Beeeh, althongh oecasionally White Pine appears scattered, or even in smaller or larger gronps.

Lumbering of White Pine in Mieligan began about 1835, and was at its best in 1883, but now the virgin pine is nearly ent out. Reproduetion is satisfactory on the sandy areas wherever fires are liept ont, which is rare; on the clay-loam areas reprodnetion muler the shade of the hardwoods is practieally impossible.

In Wisconsin the same dependenee on soil eonditions in the distribntion of the speeies prevails as in Michigan. The aecompauying map of the forest areas of Wiseonsin, taken from Bulletin No. 16, of the Division of Forestry, will serve to give an ic.ea of the manner in which this distribution appears within the belt of best development. (See Pl. III.) From this map it will be seen that the distribution is to the largest extent dependent on soil conditions, the sandy soils representing the pinery areas, in whieh uerchantable hardwoods aud Henloeks are wanting; the loam and clay areas are stocked with the hardwood forest, in which both Hemloek and Pine oceur scattering or in isolated groves, represented almost entirely by matnre old timber. Saplings, bushy young trees, and seedlings are eomparatively senrec, an aetive rejroduetion of the pine evidently not going on. This condition is found espeeially on the heaviest soils, where the hardwoods crovd out the pine, while on the sandy or gravelly soils the pine holds its own and forms a fair proportion of the sapling timber. In the true pinery of the sandy soils the hardwoods are seantily representerl by small White Bireh, Aspen, and Maple. The Henlock is entirely wanting. On the barrens jroper the White Pine is replaeed by Jack Pine and Red Pine, one, or both together, forming forests of eonsiderable extcut, usually with hardly any undergrowth or admixture save some seattering Serul, Oak.

In Minnesota elimatic eonditions again begin to asscrt themselves in influencing the distribntion of the White Pine.

The conifers beeome preponderant over the hardwools everywhere. Pines, both Red and White, together irith Tanarack (Larix laricina) and Arborvite (Cedar-Thuja occidentalis) and some admixture of Sprnee oeeupy those sites, both swamp and dry lands, which elsewhere wonld be oeeupied by liardwoods. With this ellange in eomposition goes a deerease in development; the sizes both in dimneter and height are redneed.

It is an interesting faet that both in Wisconsin and Hinnesota the pine area does not, as in the eastern field of distribution, gradually facle ont toward the prairie, but the true pine woods cense abruptly within 30 or 40 miles at most from the demarcation line of the prairie, leaving the intervening gromud to Birch and Aspeu or Sernbby Oak and Jack Pine openings.

In the Canadian extension of the speeies pure pinery is very rare. The great bulk of the most proluctive pine country lies northward and westward from the month of the Ottawa River tu Georgian Bay in mixed growth, whieh consists mainly of hardwoods, with Hemlock, Spruee, Arborvitie (Cedar), and Balsam, while the lower, ticrs of Ontario are of the same character of hardwoods, with little scattering pine, as in southern Michigan. The eastern extension of the 


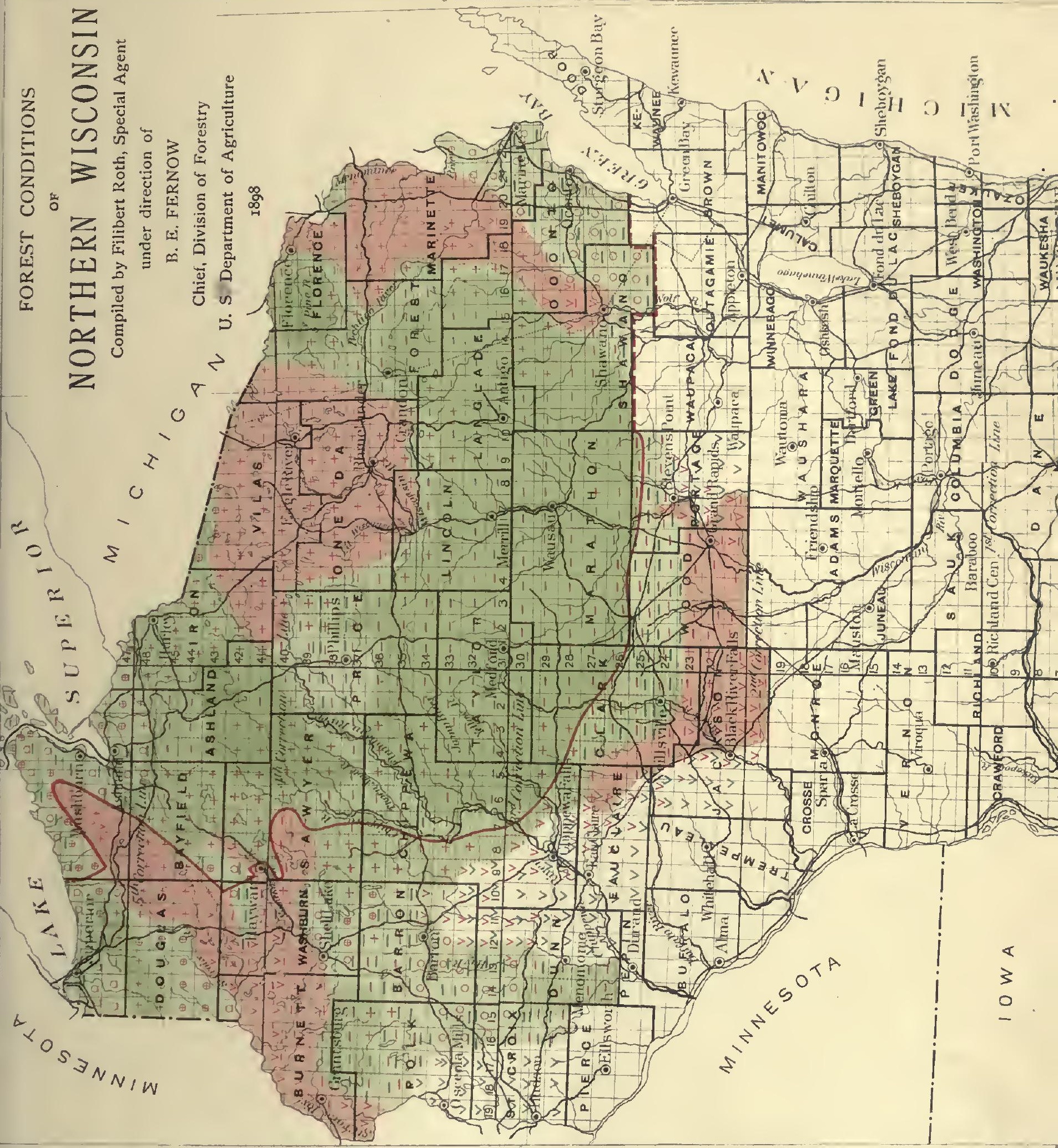

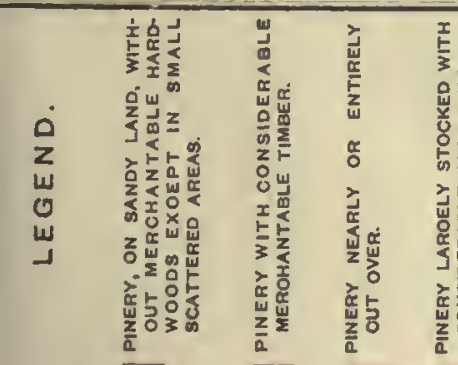

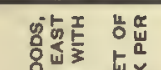
唡

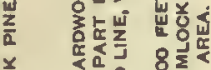

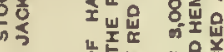

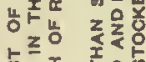

tro

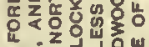

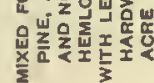

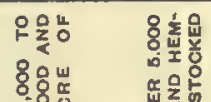

के

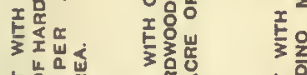

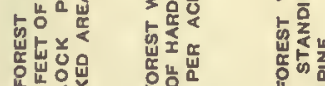

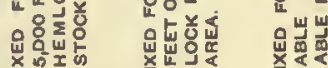

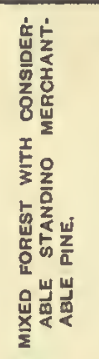

$\left[\begin{array}{c}+ \\ +\end{array}\right]$

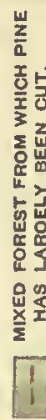

동중

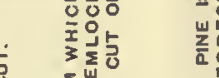

政

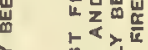

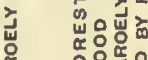

年

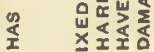

마

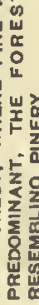

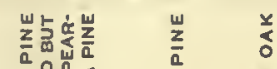

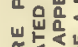

w 

field of commercial pine in Canada followed mainly the St. Lawrence River as far as Quebec. On Newfoundland the species is indigenous to nearly the whole of the island, and in some parts pro. duces considerable quantities of merchantable timber. At its northwesteru limit the forest fades out into prairie, the White Pine gradually disappearing, while at the northern limit the change is into Spruce forest.

\section{NOTES ON GENERAL DISTRIBUTION.}

Dr. N. L. Britton, for some years counected with the gcological survey of New Jersey, writes of the occurrence of White Pine in tbat State as follows:

Pine Brook Station and sparingly northward along the Southern Railroad of New Jersey (Brittou); sparingly 3 miles sonth of Woodbury, Gloucester County (Canby), and frequent in the middle and northeru portions of the state. There are uo White Pine forests in New Jersey, and the largest grove known to we is of lint a few acres in extent. It evidently prefers a beavier soil tban does $P$. rigida, which forms the forests of the pine barrens. On Staten Island, New York, there are a few scattered trees of $P$. strobus.

Mr. William M. Canby, of, Wilmington, Del, reports the existence of a grove of White Pine trees in upper Delaware, and Mr. Thomas Meehan, of Germantown, Pa., states tbat White Pine grows (or did recently) at the Soapstone quarry, on the cast side of the Scbuylkill, some 8 or 10 miles above Philadelphia. Mr. Canby adds: "1t is a very difficult thing to define the limit of a species that is being so rapidly destroyed, and doubtless the sonthern line is being rapidly cfaced."

Prof. Lester F. Ward, of Washington, D. C., is of the opinion that Pinns strobus is not indigenous around Washington, and that the fow trees met with in wild situations in its vicinity grew from seeds blown from planted trees. He has never met it in his botanical excursions into sontheastern Maryland and Virginia.

Mr. F. E. Boynton writes from Highlands, N. C.:

I have seen some very fine specimens growing in Pickens and Oconee counties, S. C., but I have never seen it in this part of the country except in high altitudes, say from 2,500 to 3,000 feet nsually. I bave never seen or beard of its forming forests here. I bave seeu groves of a few acres where it migbt be said to predominate. As a rulc, it is fonmil seattered among other forest trees. 1t nearly always grows in or quite near Rhododendron and Mlountain Laurel thickets, which inticate a moist soil. It often grows to be a very large trce here. 1 measured a log in the mill jard near bere last night that was 37 inches tbrough. Considerable lumber is cut from White Pine in this monitain region, bnt, as a rule, the lumber is of inferior quality, being very knotty and often sbaky. Cultivated specimens thrive and grow very fast. - It is usually found most common on southern exposnres. The rock formation is granite, and soil usnally a sandy or gravelly loam wherever I bave observed the Wbite Pinc in tbis region.

The following bas bcen fnrnished by Prof. W. R. Lazenby, of the Stato agricultural experiment station at Colnmbns, Ohio:

From all the data in my possession, I should say that White Pine is rarely met with in Obio ontside the borders of two of onr northenstern connties, viz, Ashtabula and Lake. Occasionally a sporadic patch hns been noted along the banks of streans in some of the eastern counties. 1 have never heard of its spontaneous occurrence aurwhere throughout the central or soutbern portions of the State. It appears to thrive well here at Columbus and sulmits kindly to elhange of soil. Wherever $I$ bave seen it in Ohio under artificial cnltivation it has presented a thrifty appearance, althougb the young plants do not make a very rapid growth for the first few ycars.

Concerning the vccurrence of White Pinc near the head of Lake Michigan, Prof. E. J. Hill, of Normal Park, 11l., writes:

It begins at Wbiting Station, on the Michigan Sonthern Railroad, and extends eastward to Michigan City. I came across a clnmp of White Pine once, alont a nile north of Otis, where tbe Michigan Sonthern Railioarl crosses the New Albany roal. " " Yon would be pretty safe in taking the Calumet River as tbe soutbern boundary. * ". I lo not know of a single native tree in Cook Connty, lil.

Mr. M.S. Bebb, of Rockford, 1ll., communicates the following concerning the occurrence of White Pine in the northern portion of that State:

In a few localities on Kcnts Creek and Rays Creek, in Winncbago County, and griving the name to Pine Creek in Ogle, the connty immerliately north of tbis, the White Pine is certainly indigenous, but occurring ouly as a sparse growtb, cresting precipituns banks, where it seems to have found a favorable environment.

To this Mr. S. B. Warlsworth, of Oregon, 11l., adds:

The White Piue in Ogle Connty groms in some cases to a height of 40 or 50 feet. * * * Nearly all the small streans in Pine Rock township luve some pines near the months of the streams if there are any rocks along the liaks. " Tbe White Pine prefers tho St. Peters sandstone, but in some eases grows on limestone rocks.

Mr. R. Williams, of Streator, Ill., sass:

Wilute Pine is withont doubt a native of La Salle County. It occurs on the Vermilion and its little tributaries wherever there is an exposure of carboniferous sandstone, and more frequently is seen close to the edge of the bighest bluffs, where the soil is largely composed of the disintegrated rock. To find onc bcyond tbe iutlueuce of the and rock would be almost plenomenal. The number is very small aud thcir sitnation cloes not permit them to ut tain much size. I tbink tbat 40 fcet is about the linut of height. Sull thrifty plauts from one to a fow feet in beight occnr liere and tbere, and are sometimes transplanted to the prairie soil, where they make a vigorous growth, outstripping Norway Spruce, Scotch and Austrian Pine, Hemlock, and Wbite Cedar. Pines planted hcre in 1854 or 1855 aro now $(1886)$ about 40 feet ligh.

The limiting line of the Wite Pine beyond tbo Mississippi nortbwestward is traced substantially as indicated by Mr. Warreu Upham in the Geological and Natural History Survey of Minnesota. Mr. Uphan sends tbe following:

'The White l'ine, wherever I have seen it 11 New Hampshire and other parts of New England and in the Northwest, prefers somewhat clajey land. It does not tbrive on wholly sandy plains ("moditied drift" of glacialists), 
which are denominnted "pine barrcns," the congenisl dwelling placo in tho Fast for the Pitch Pine ( $P$. rigida), and in the Northmest for tho Banksian or Jack Pino ( $P$. diraricata); nor does the White Pine in either regiou grow plentifulis and of largest sizo on very clayey land, which is the favorite location for MIaplos, l3asswood, Elms, aud other docldnons trees. The White Pino in this matter of its choice of soil follows tho injunction, Medio tutisaimus ibis. The Red Pine ( $P$. resinosa), so far as I have observed, can thrivo better on tho very sandy plains and "loar. rens" than tho Whito Pine, being intermediato in this hetween tho WVito Pine and the Pitch and Jack pines.

Prof. T. H. Macbride, of the State University of Iowa, says:

I haro coliected White Pino in the following conntios in this Stato: Mitchell, Iotrard, IVinneshick, Allamakee, Clayton, Dubuque, Dolaware, Jacksou, and Muscatino. It is, by others, roported from Scott. It ought to bo found also in Fayetto, bnt $I$ have nevor run across it there.

[This wonld confine the White Pino in Inwa to the connties borderiug the Mississippi River and the Minnesota State line as far west as the Cedar River Vailoy.]

\section{CONCLUSIONS REGARDING NATURAL DISTRIBUTION.}

The leading conelnsions to be drawn from what has been stated regarding the natural distribution of White Pine seem to be the following:

(1) Leaving out of consideration all the outlying portions of the region under diseussion, there is left an area of not less than 400,000 square miles in the United States and Dominion of Canada within whieh the White Pine is in its home and surronnded by the conditions of its own ehoice, throughout whieh its snccessful cultivation is fully assured.

(2) A mueh larger territory than this is inchnded within the limits of extreme distribution as defined above, and there is abundant evidence to show that over nearly the whole of this wide area, and in some direetions far beyond it, this species makes nnder cultivation a healthy and rapid growth. There is apparently no species of equal value indigenous to eastern North America that is at the same time adapted to so wide an area.

(3) The habits of this species ncar the western limit of its natural occurrence, as well as experimental planting, indieate plainly that its suceessful growth can not be depended upon much beyond this limit.

\section{THE WHITE PINE LUMBER INDUSTRY.}

No speeies of American timber has been so muel used for lumber as the White Pine, and the development of the lumber industry in this conntry is coincident with the exploitation of the White Pine forests.

The eommercial use of White Pine began with the first settlement of New England. The first sawmills were established in the seventeenth eentury, and numerous small sawmills, which rere usually an attaehment of the neighborhood gristmill, were in operation early in the eightcenth eentury. Timber was exehanged for merchandise, and the collections thus made were floated to ports of shipment, whence they were exported. This primitive industry, confined largely to White Pine, was eontinued well into the third decade of the present centnry. In 1850, J. S. Springer, of Maine, wrote: "Thirty years ago it was unneeessary to search for a locality for a lumber camp on the Penobseot, for a man could step from his honse to his day's work, the pine, that forest king, abounding on every side. Fifty years hence the vast pine forests through which the Penobscot flows will be on the eve of destruction." This prophecy has long since been verified, for the Spruee has practically taken the place of the White Pine in the lumber output of Mainc.

This early trade in White Pine, though involving small eapital and limited operations on the part of each dealer, was by no means unimportant in the aggregate, lumber being a leading industry in New England from the first. The Bangor Weekly Register of March 2, 1816, noted that between 300 and 400 sleigh loads of lumber, ctc., came in to Belfast in one day. The Gazette of July 10, 1822, says that 136,086 feet of lumber and 35,000 shingles were hauled in on one Saturday by teams. In 1825 twenty-five vessels were engaged in the lumber trade from Bangor to the West Indies. The mills of those days were all small affairs, generally single-sash saws, driven by water power, with a capacity of 1,000 to 3,000 feet per day. Abont 1830 the construction of larger mills began, and in 1890 a capital of nearly $\$ 12,000,000$ was invested in the sawmilling indnstry in the State of Maine alone.

In general, it may be said that the White Pine of New England was cut by numerous small eoneerns, and that the bulk of the supplies was cut before modern sa winilling began. 
Although the great forests of White Pine in Maine have disappcared, a small amount of this material is still cut in the State every year, so that since 1S81, on the Pcnobscot, for iustance, ont of a total cut of ahout 150 iuillion feet per year between 24 and 30 million feet have been pine, the pine thus geuerally forming 15 to 20 per cent of the entire outpnt.

In Pennsylvania the exploitation of White Pine likewise began quite early. Pittsburg furnished pine lumber to points along the Ohio and even to St. Louis, Mo. As late as 1850 Philadelphia received its 150 million feet of lumber, largely White Pine, from the State, inporting but very little from New England and the Sonth. At Williamsport, the center of White Pine Iumbering in Pennsylvania, the first large inills were erected about 1838, and the bulk of the pine was cut prior to 1570 .

In the forties the White Pine prodnct marketed at Williamsport excelled in quantity all otlicr points of production. The highest production was reached in 1873, with ucarly 300 million ficet B. M. in logs boomed, which in 1593 had sunk to a little over one-tenth of tliat amonut. While in 1873 the amount of timber standing was estimated as 3,300 million feet B. M., in 1896 the State commissioner of forcsts places the remainder at 500 million feet B. M.

The only unent White Piue forests of Pennsylvania now standing are isolated bodies in the more inaecessible parts of Clearfield, Lycoming, and Tioga counties.

In the State of New York, too, which in the Adirondacks and in the western countics con. tained considerable quantitics of White Pine, the species is largely cut out. Hardly more than $\tilde{5}$ per cent of the cnt is $10 \mathrm{w}$ of White Pine, the output from the Adirondack mills being in the neighborlood of 25 million fcet $\mathrm{B}$. M.

The exploitation of White Pine in the Lake region began during the thirties, when small mills werc erected at various points, both in Michigan and Wisconsin. The first steam sawmill at Saginaw was built in 1834, and the first mill at Alpena was built two years later. Nevertheless the lumber ind ustry of both Michigan and Wisconsin remained insignificant uutil toward the close of the fifties, when most of the present sites of manufacture had been established. 'Ten ycars later (1870) the auuual cut of White Pine in Michigan and Wisconsin amounted to nearly 4 billion feet; Miunesota had scarcely begun to contribute to the output; and in the marketing the railway was fast displacing the older nethod of rafting. The progress of lumbering is well illus. trated in the followiug figures from the Northwestern Lmmberman, representing the annal cut of lumber alone from 1873 to 1897 :

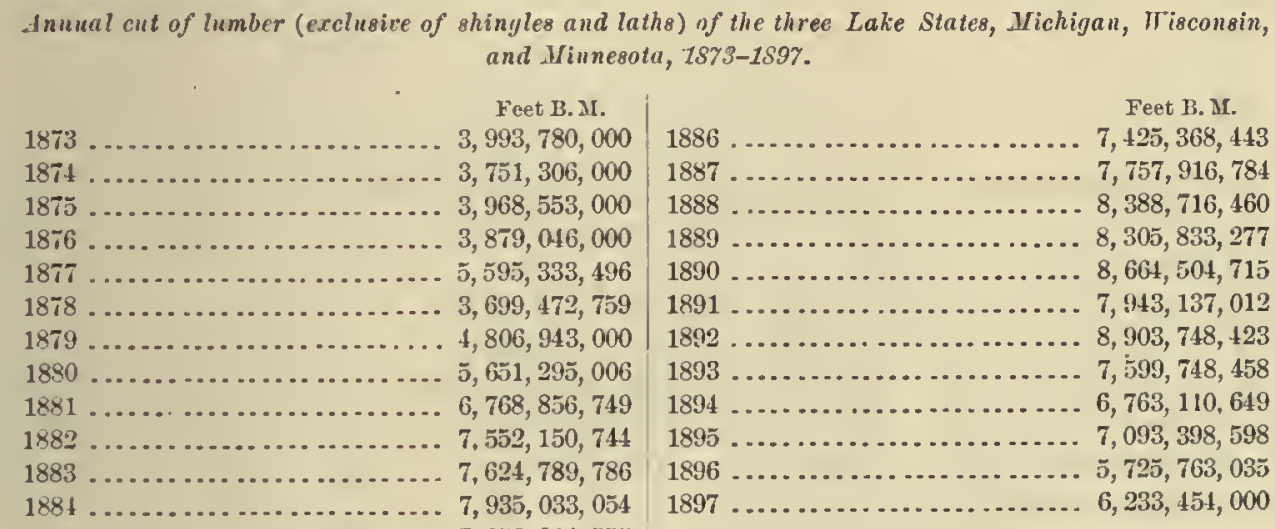

Or, dividing the time into pcriods of five ycars each, the figures arc as follows:

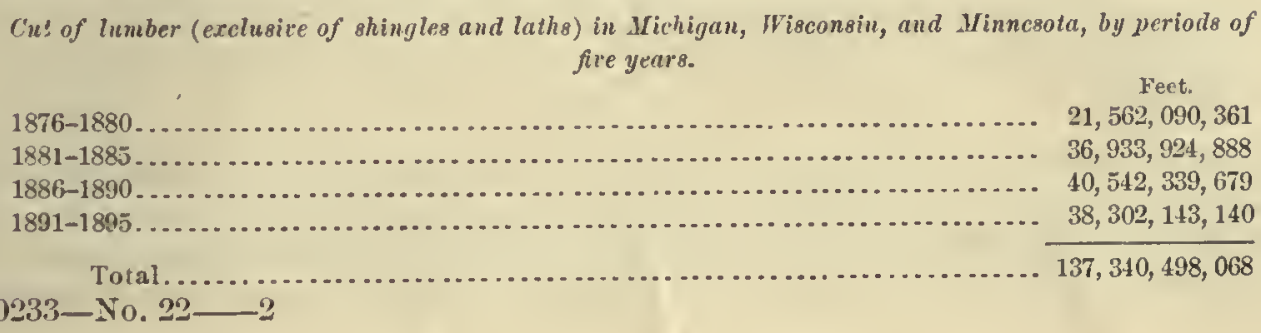

\footnotetext{
$20233-$ No. $22-2$
} 
From the figures, to which about 10 per cent must be added for shingles, laths, etc., it appears that tlie yearly outpnt did not reacl 4 billion feet until 1879 , aud that the greatest increase in the cnt occurred between 1876 and 1S82, when the 7-billion mark was reached. 'This enormous cnt continned nutil the general business depression of 1894 ealled a temporary halt. In Minuesota, pine lumbering began on the St. Croix and did not reacli conspicuous dinensions nutil during the eiglties, when the regions along the upper Mississippi, as well as the Dulnth district, were opened. This progress westward is well illustrated by the following fignres, which slow the percentage of the total eut of lumber alone from period to period, by districts:

rercentage of total cut of lumber, 1879 to 1895, by districts.

\begin{tabular}{|c|c|c|c|c|c|}
\hline \multirow{2}{*}{ Dlstriets. } & \multicolumn{5}{|c|}{ Lumber cut. } \\
\hline & 1873 & $15 \$ 0$ & 1S4.j) & 1690 & 1845 \\
\hline & Per cent. & Per cent. & Per cont. & Per cent. & Per cent. \\
\hline 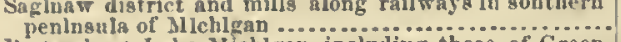 & 36 & 31 & 27 & 21 & 16 \\
\hline 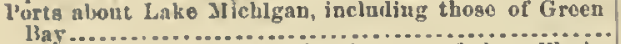 & 30 & 32 & 28 & 28 & \\
\hline District west of (ilicago, that is, most of $t$ he mills in & & & -0 & 20 & 26 \\
\hline 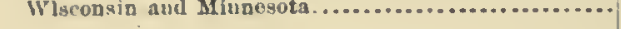 & 34 & 37 & 45 & 48 & 58 \\
\hline
\end{tabular}

In this connection the White Pine trade of St. Louis presents an interesting illustration. The first pine lumbrr was received from Pittsburg in 1819, and this point remained the principal source of supplies for years. In $18+3$ a boom on the St. Croix River broke and the liberated logs were gathered and rafted to St. Louis, where they were sawn. In 1850 the first regular raft of Wiscousin logs was brought to the city. In 1853 Schulenberg and Boeckler built a large sawmill on the St. Croix, and from this time on rafts of sawed White Pine were sent to St. Louis from the northern rivers.

The reeeipts of White Pine at St. Louis were: In 1853, about 60 million feet; in 1852, abont 162 million feet. Similarly the lnmber trade of the eity of Chicago, the greatest lumber market in the United States, if not in the world, illustrates well the development of the White Pine lumber industry. In 1847 only 32 million feet of Wlite Pine lumber were received. The annual receipts at intervals of tell years sinee 1855 to 1895 were as follows:

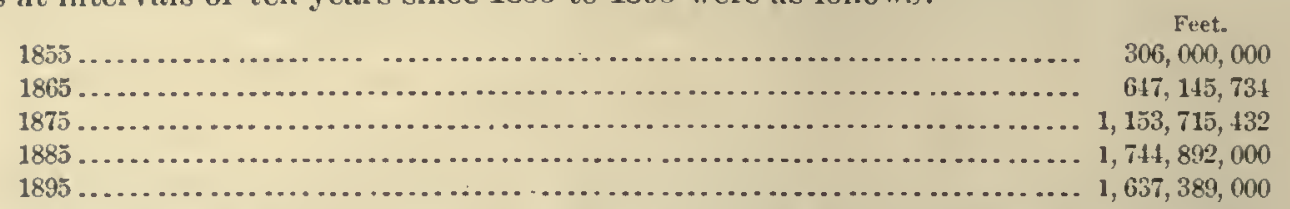

The receipts reached their maximum in 1892 with $2,203,874,000$ feet, and the heary diminution since that date is not greater than would be accounted for by the general business depression throughout the countiy.

In Canala, as in New England, the exploitation of White Pine began almost with the first settlement. Logs, hewn timbers, and espeeially ship spars, were exported in early days, and of late years an extensive trade in sawn lumber, as well as saw logs, has sprung up between that eountry and the United States. Since reliable statisties of the lumber ontput of this region are wating, tlie following figures for the dues on erown timber in Ontario and Quebee inust suffice to illustrate tlie development of the industry:

Arerage annual dues on crown timber for Ontario and Quebec.

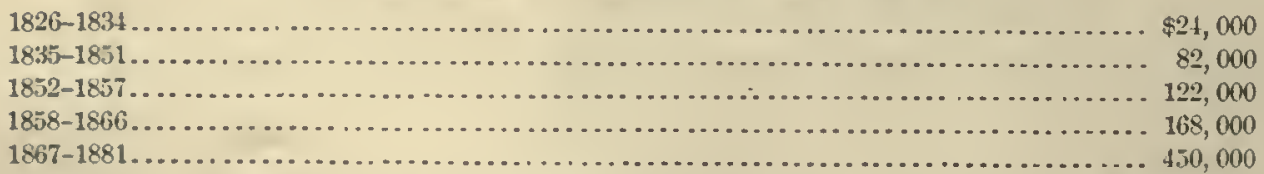

The export into the United States for 1994, the heaviest year, was: Lumber, 1,15j million feet ('ine and Spruce); pine logs, $277,947,000$ fcet, or less than $1+$ billion feet B. II.

Thongh scattering White Pine occurs in all provinces of eastern Canada, large bodies of merchantable timber are only to be fond on the upper waters of the Ottawa, and on the shores 
of Lake Hnron (Georgian Bay district) and Lake Superior, and the White Pine lumbering is praetically eonfined to these clistriets. The ontpnt of White Pine in the Dominion is estimated at $1 \frac{1}{2}$ to 2 billiou feet per year.

\section{ORIGINAL STAND AND PRESENT SUPPLIES.}

What the original stand of White Pine was is diffeult even to estimate. The amonnt of White Pine out in the Now England States, New York, Pennsylvania, and the eastern Provinces of Canada is nt known, and the only reliable figures whieh give an indication of what has been harvested are the figures for the Lake States above mentioned. For the Lake region alone the estimated original stand for Wiseonsin may serve as an illustration. For the pine-stoeked area of this State, a total stand of abont 150 uillion feet per township (23,1000 acres) has beeu shown to be a fair average. This would indieate a total of abont 130 billion feet, of whieh abont 66 billion feet were eut between 1873 and 1897 , and about 20 billion feet are supposed to have beell ent prior to 1873 , making a totat of abont 86 billion feet as aetnally harvested, while about 18 billion feet were believed to be still standing in 1897. These fignres are based upon a thorough eanvass made by Mr. Filibert Roth and pnblished in detail in Bulletin No. 16 of the Division of Forestry. On the same basis, Michigan possessed fully 150 billion feet and Minnesota may be assumed to have had abont 70 billion feet, whieh wonld make an aggregate of about 350 billion feet of pine for the Lake States. Of this abont 170 billion feet were ent between 1873 and 1897 , and abont 50 billion feet were probably eut prior to this time, aecounting for abont 220 billion feet ont of 350 billion feet. While it must remain mere eonjeetnre, it seems qnite fair, uevertheless, to issume that the total supplies of White Pine aggregated probably uot less thau 700 billion feet of standing timber originally. Of this total, theu, not less than 50 per eent was eontained in Canada and the Eastern States, the United States portion representing abont two-thirds of this heritage, the Canadian portion showing less than 20 per eent of total snpplies.

Of this large amount of virgin supplies, a little over 15 per cent, or 100 billion feet, may be estimated as standing. These supplies may be approximately distributed as follows:

Canada is credited by the statistieian of its department of agrieulture with about 37 billion feet of standing pine, an estimate probably far below the real trnth. For the Lake States the following estimates were made in 1897 by the best-iuformed man of the Lake region: Minnesota, 36 billion feet; Wiseonsin, 18 billion feet; Michigan, 10 billion feet. These estimates are considered quite high by many. The standing pine in Michigan is placed by a detail tornship canvass in 1890 at only about 6 billion feet; the standing White Pine of Minnesota is estimated by the State chief fire warden at only abont 12,600 million feet, while an estimate for Wisconsin made in 1895 places the standing pine of that State at only 8 billion feet.

Retaining the larger figures as probably the nearest eorrect, there exist to-day: In the Lake States, abont $6+$ billion feet; in Canada, over 40 billion feet; in New York and Pennsylvania, not over 2 billion feet; in New England, uot over 3 billion feet; in West Virginia and Tennessee, not over 1 billion feet; making a total of about 110 billion feet, or about 22 per eent of what may fairly be believed to have been standing originally. Of this standing supply, about 100 billion feet are so loeated that the present rate of exploitation (over 6 billion feet per year) ean be, and probably will be, continued until orer 75 per eent of the present snpply is eut, when, of eourse, a lack of logs will lead to a rednction in output. This condition may be looked for before the end of the next ten or twenty years, and from that time, unless recuperative measures are adopted, White Pine will cease to be the great staple of onr lumber markets.

In former years lumbering of all kinds was carcless, and even in the White Pine forests the prevailing "inexhaustible supply" notion led to enormons waste. Stumps were left 3 to 4 feet high, all defeetive trees were left, and top logs bnrned up with the débris. Many of these old slashings have been logged for the seeond and even the third time, often yielding a greater profit than when first culled.

At present this is no longer the case. High stumpage priees and a perfect market lave led to the elosest economy in logging, milling, and shipping of White Pine. The trees are felled with the saw, the stnmps are 18 incles and less, care is had in the marking and sawing of logs, and the top is utilized, irrespective of knots, just as far as it will make saw timber. Defeetive logs 
are rarcly left behind, and "clean cutting" now means the removal of all logs, however defective. In logging, iee roads, improved by nightly sprinkling, cuible the transport of enormous loads $(5,000$ fect and uore) by single or donble teams. The logging railway is fist finding favor, and in many places the logging is thereby made continnons, being carrich on at all seasons. (Sec Pl. IV.)

The yields in White Pine are, as might be expected, very variable.

A cut of 2 million fect B. M. on in "forty," or 50,000 fect per acre, was not a rarc one in the pineries of soutlern Michigan, and ocrasionally such euts are made in Wiseonsin and Mimnesota. "To yield such a result the entire "forty" must be well and evenly stockel. The best acre, then, need not be far above the arcrage, and, in faet, rarely excceds 75,000 feet.

A stand of 1 million fect on a "forty," or 25,000 feet per acre, is a good onc, bnt was of quite eommon occurrence in all White Pine districts, and may still be found in many places, while whole townships or eounties liave avcraged 10,000 feet per acre.

These yiclds depend, of eonrse, on the character of the forcst growth, the greater or smaller admixtmre of other specics oecasioniug the differences. Thus, if any large territory of the pine districts were taken into eousideration, a yield of 150 million feet per township would be found a fair statement for most parts of the pineries of Wisconsin and Michigan.

The best yiclds do not nsmally come from those tracts which contain the largest trces, bnt where the pine is least mixed with other species and stands most deuse.

Snch areas, pineries proper, where no merchantable lard woods wcre mixed with the pine, are nsually tracts of loamy sand, and occnr in extensive bodies in all tlirce of the Lake States. Generally, White Pine cuts more wastefnl than Norway or Red Pine, lias a thicker bark, more large dead limbs and knots, these latter often coming to within 20 fect of the gronnd, cven on large trees, and is quite given to forking. This latter pecnliarity seems natural to the trec, and has becn obscrved abroad as rell as herc. It seems independent of the character of the soil, as it oecurs on clay and sand alike, but it is often localized, so that on a small tract of 10 or 20 acres nearly all trecs are forked. Trees witl three and four forks are not rare, and five forks oecnr. In addition. White Pinc is extensively defective by decay. so much so that in some localities 15 to 20 per cent must be allowed for the loss from this source.

\section{NATURAL HISTORY.}

The oldest description of the White Pine appenrs to be that of Plukenet, published in 1700 . Its scicntific name of Pinus strobus was given the species by Linniens in 1753, and unlike most trees but one other scientific name lias becn applied to it, the synonym being Pinus tenuifolia Salisbury, 1796. Besides tle generally accepted common name of White Pine, the species is locally known in the United States as Soft Pine, Northern Pine, and Sprnce Pine, and to a limited extent by its usnal Enropcan name of "Wcymouth Pine.

The speeics was first introduced in Europe at Badminton, Eugland, and was soon after extensively planted on the cstate of Lord Weymouth, whenee its gommon name abroad. It was also cxtensively planted in Germany at the end of the last century under the same name, Weymuthkiefer.

\section{BOTANICAL DESCRIPTION.}

White Pine (Pinns strobus $\mathrm{L}_{\text {. }}$ ) in its natural habitat is a trce of large size, 100 feet or more in height (not unfrequently attaining a height of orer 150 fcet, cren trees of 250 feet in licight having been reported), with smooth, thin, grayish bark (fig. 1), bccoming at the base thick and deeply furrorred with age. The lcaves are slender, straight, triangular in scction, five in a sheath, $2 \frac{1}{2}$ to $4 \frac{1}{2}$ inclies long; resin ducts, chicfly two uear the dorsal face; stomata in tlirce to five rows on the ventral faces; fibro-vascular bundle, one. Cones, single or-in groups of two to three, stalked and pendulous, 4 to 6 inches long; eylindrical, slightly tapering and cnrved, frnit-scales oblong wedgeshaped, the apopliysis half pyramidal, with a triangnlar blunt point. Seeds, one-fifth to onc-fonrth inch long, grayish-brown, witl a thin mcmbranaceons wing. Cotyledons, seven to cleven.

A number of varieties, more or less distinctly narked, are rccognizcd in cultivation. Among these are nana, a dwarf, bushy form, cultivated in gardens in the Old World; nirea, viridis, and aurea, named from the color of their leaves; brevifolia, and several others (umbraculifera, minima, 
Bulletin No. 22, Div, of Forestry, U. S. Dept of Agriculture.

$$
\left(.0 Y^{4}\right.
$$

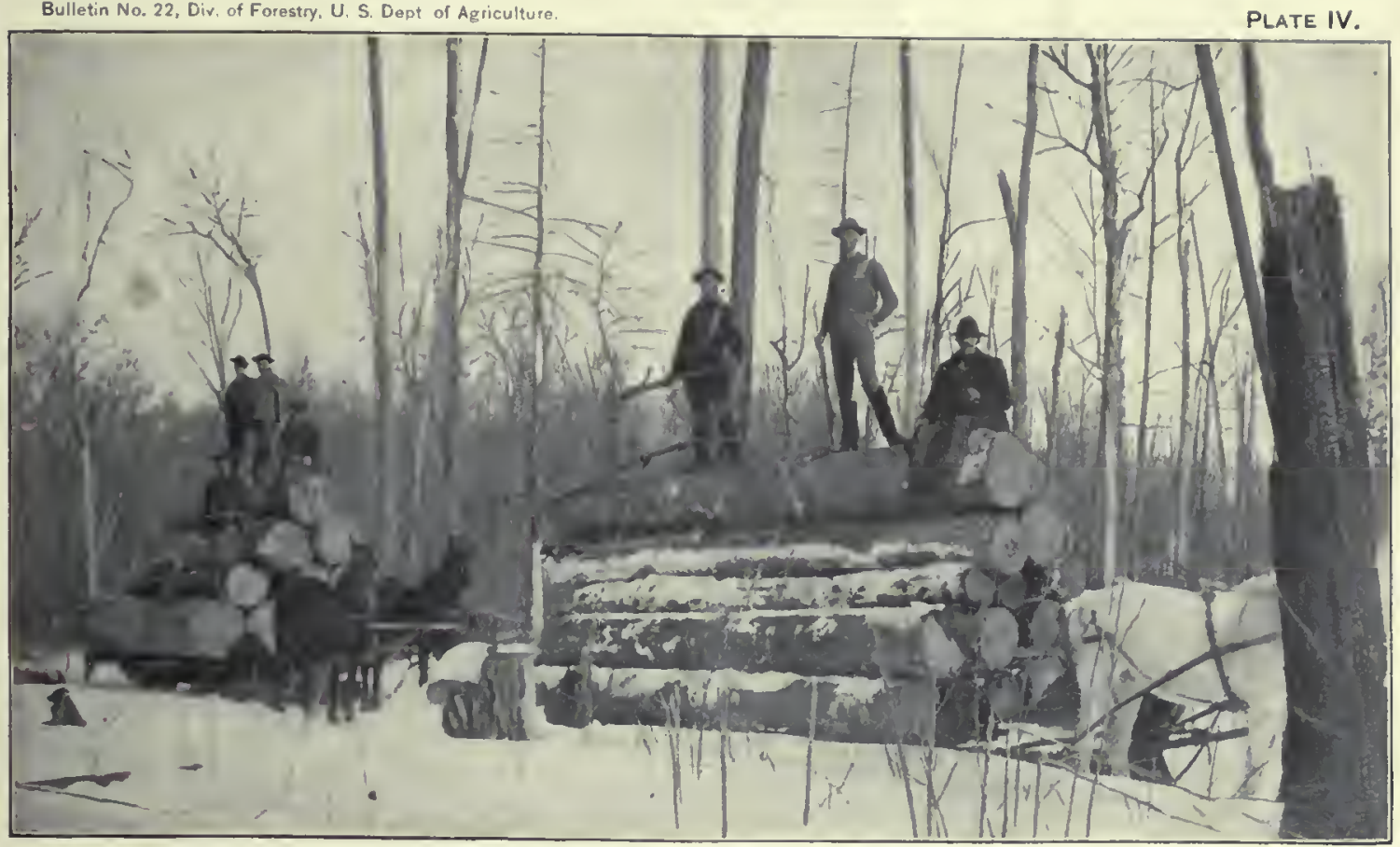

Fia. 1,-Transporting logs over ice Road in Michigan.

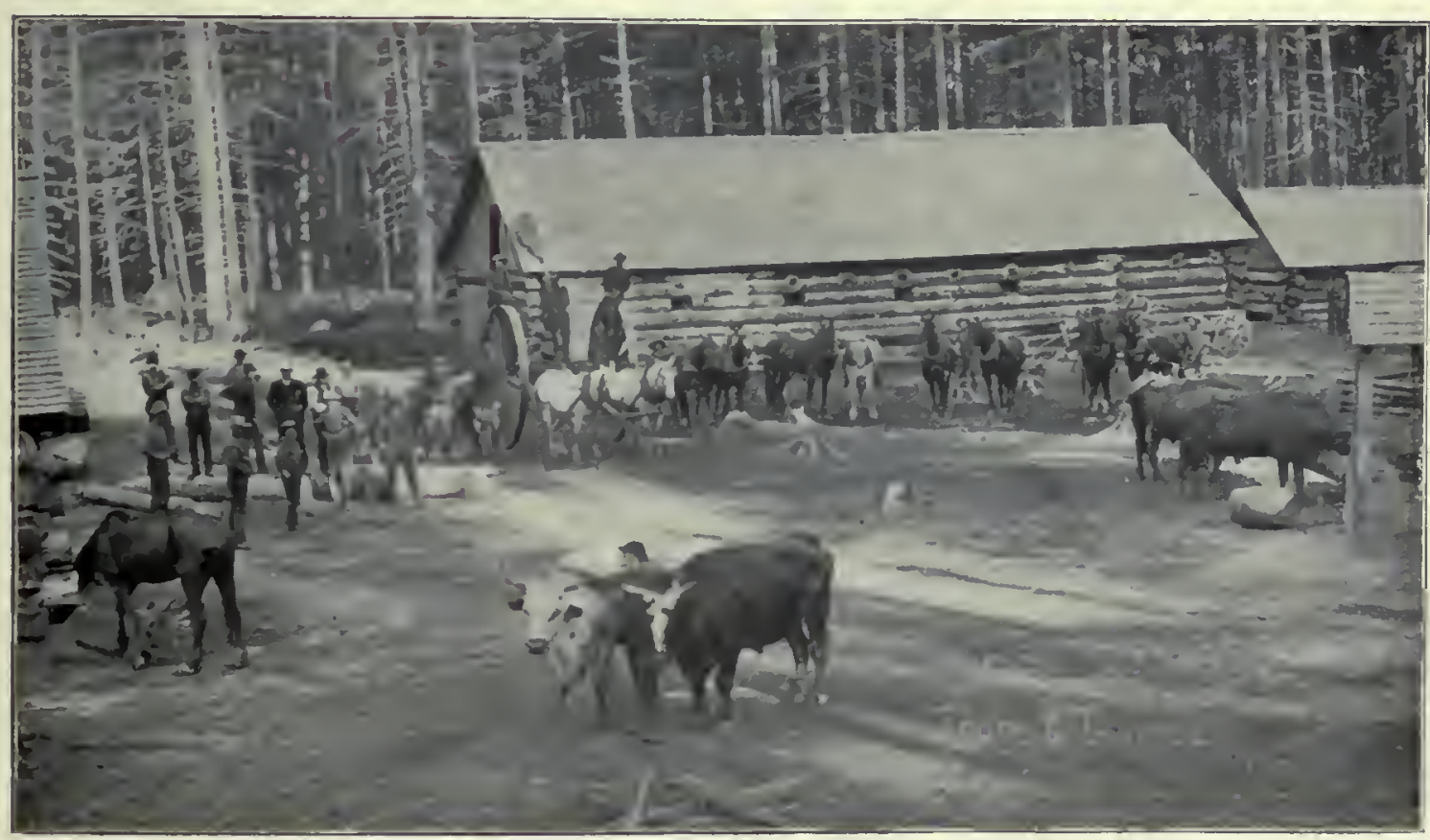

Fig. 2.-Lumber Campin Michigan. 

fastigiata, gracilifolia, variegata, zcbrina, and prostrata), some of which aro propagated and sold as speeial attraetions in nurseries.

RELATIONSHIP.

The White Pine (Pinus strobus) is closely related to the Bhotan Pine (Pinus excelsa) of India, the Swiss Stone Pine (Pinus cembra) of southern Europe, the White Pine (Pinus flexilis) of the Rocky Mountains, the Sugar Pine (Pinus lambertiana) of the Paeifie eoast, and a number of otbers less generally known, of whieh Pinus monticola, $P$. albicaulis, $P$. strobiformis, $P$. quadrifolia, $P$. purryana, and $P$. cembroides are natives of the United States.

The species belonging to this seetion of the pine geuns are distinguished by their slender, delicate leares, five in a sheath; by the exceptionally soft and even texture of their wood, and by certain well-rlefined botanieal eharaeters, by whiel they are marked as a natnral and easily reeoguized gromp.

The group of species just named shows a preferenee, generally characteristic of this seetion of pines, for elevaterl, mountain regions, and a light rather than a heavy soil, niking, as a rule, a healthy growth on sandy and rocky places, and manifestly preferring these to low and heavy soil. All are handsome trees, symmetrical in form, some of them, as the Sugar Pine (Pinus lambertiana), of rapid growth, and forming magnificent specimens from 150 to over 200 feet in height, while others nre of slow growth, as the Stone Pine of the Alps, which prodnees. however, a beantiful, fine-grained wood, extensively used by the Swiss peasants for earving. The Bhotan Pine of the Himalayas is the representative of the White Pine in Asia, resembling it very elosely in habit, size, structure of wood, and varions technical eliaracters.

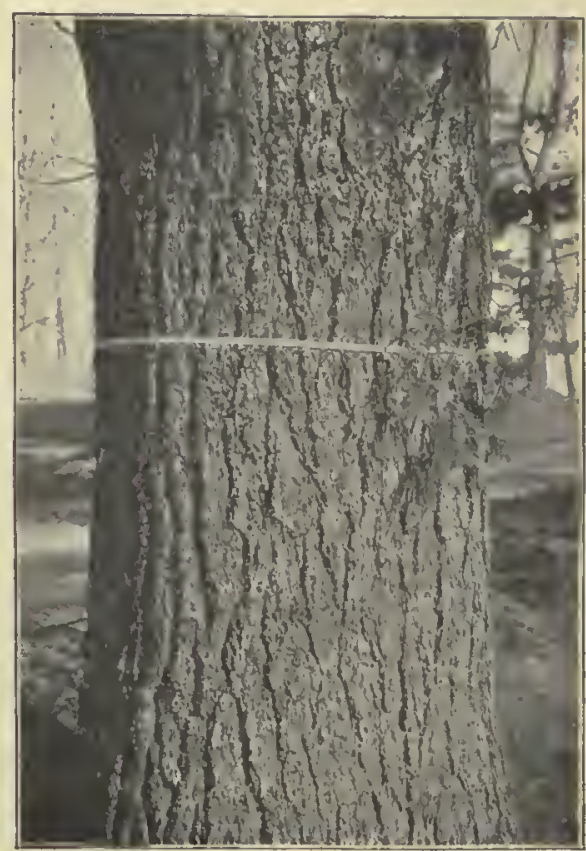

Fig. 1.-Bark of old White Pine.

Admitting the eommon aneestry of these various species, a more extended comparative study of their preferenees and habits would be of innch interest in relation to their eultivation beyond their natural range, eousidering the fact that, whatever their environment, sueh ancestral traits are certain to manifest themselves.

\section{MORPHOLOGICAL CHARACTERS.}

ROOT, STEM, AND BRANCH SYSTEM.

In the natnral forest, with a due amonnt of sliade, the White Pine has at maturity a straight colnmnar trunk, clestitnte of branches for half to two-thircls of the distance from the ground to the tip of the learler.

The branches are for many years disposed regnlarly in whorls, and dnring this early period the tree retains a symmetrieal, conical form, and is one of the most grnceful of the pines for orna. mental eultivation, but, as is the ease witl other eonifers, the lower branehes are short lived, and nltimately, by their clecny, the tree beeomes unsightly. This fact, whieh renders this speeies, in eommon with all other conifers, undesirable during part of their lifetime for ornamental purposes, gives it the greater valne as a timber tree.

The crown, at first pyramidal, is finally less regular, althongh rarely thattening, and, owing to the rapid and persistent growth of the tree, eouspicuousiy overtops the surrounding forest of decidunts trees. The root system is small eompared with the size of the tree and spreads near the surface of the gromnd; its eomparatively slight development is in liarnony with the less pronounced dependence of this species on the soil and its greater dependence on the atmosphere. 
Ynrsery seedlings produce numerons slender, fibrous roots, the delicate tissues of whieh are as in inost eonifers easily dried at the time of transplinting, resulting in very serions injury or loss of plant material. White Pines planted upon the dry sand along the Lake Miclrigan shore and trimmed of their lower brauches have been observed restoring these lower limbs and forming a thick, green covering over the roots before making any heiglit growtl, snggesting in a striking manner the necessity of protecting the root system aguinst too rapid evaporation and a too highly lieated soil. In the natural forest, and in artificial groves properly planted, the fallen lenves finlfill this function by making a deep, thiek eoating over the roots.

\section{LEAVES.}

The leaves arise fron greatly rednced short branchlets and are prodnced five together, sur. romided at the base by a thin decidnous sheatl, and are further distinguished by being more slenler and delicate than those of our other native pines. (Pl. V, 1,2,3,1.) The relative position of the five leaves inclosed in their eommon sheath is shown in Pl. V, $\overline{0}$, and in Pl. V, C, is represented a eross section of a single leaf, magnified snfficiently to show the characteristic arrange. ment of the tissues.

Witlont entering into a detailed aceount of its fnuctions, which wonld here be irrelevant, it may nevertheless be remarked that the leaf of the White Pine constitutes a highly eomplicated and delicate piece of apparatns. Like all foliage leaves, the leaf of the Irite Pine fnlfills the important functions of respiration and the mannfacture of starehy food, during which processes large amounts of watery vapor are exhaled.

A healthy pine seedling, three years old, in the air of a dry room, lost by evaporation in twenty-fonr hours 81.1 per cent and in the following twenty-fice hours 96.7 per cent of its entire dry weight.' The evaporation, chiefly throngl the leaves, is more rapid in the daytime than in the night, in clear than in clondy weatler, and most rapid of all in a drying wind. It will readily be seen that if a tree is planted on a clear, dry, and windy day, the conditions are the most unfavorable that could possibly be chosen, the rapid evaporation earrying off the water of the plant beyond the capaeity of the roots, not yet adapted to their new place, to meet the demand, which results in the drying up of the tissues and often in the death of the tree.

The various forms of modified leaves are characterized by extreme delicacy. Winter bnds $(P l . V, 7)$, with their thin and small scales, present a striking contrast to those of Longleaf Pine, for example, and other speeies that produee large buds with relatively thick and coarse scales. The very loose leaf sheaths and scale-like leaves of the yonng slioots are early decidnous, a fact that contributes to the growth of the smooth, elean bark eharacteristic of the branehes of White Pine, in which it differs in so unarked a way from the species of the Yellow l'ire gromp.

In Pl. Y, 1, the modified, scale-like leaves that constitnte the loose sheaths are conspienonsly shown. Separate faseieles, with their sheaths, are represented in Pl. V at 2 and 3 , while at $t$ is an older one as it appears at the end of the snmmer after the sheath lias fallen.

EXPIANATION OF PLATE V.

1. Shoot showing foliago and seale learcs of different ages.

8. Yonng fasciele with shenth.

3. Yonng fascicle further dereloped.

4. Still older fascicle from which the sleciduous shenth has fallen.

5. Section of fascicle inclosed in sheath.

6. Soctiou of leaf magnified.

7. Winter bud.

FLORAL ORGANS.

Finwers and frnit are rurely prodncel to any eonsiderable extent before the tree has attained the age of fifteen or trenty years, thongh ocensionally trees may bear frnit at ten to twelre years of age.

The staminate and pistillate florers are separate, bnt prodnced on the same tree. They appear in May, the pollen ripening and pollination taking place (in the latitude of Am Arbor,

${ }^{1}$ Accorling to deteruinatious uade in the botanical laboratory of tho Ĺniversity of Michigan, November $18,1886$. 


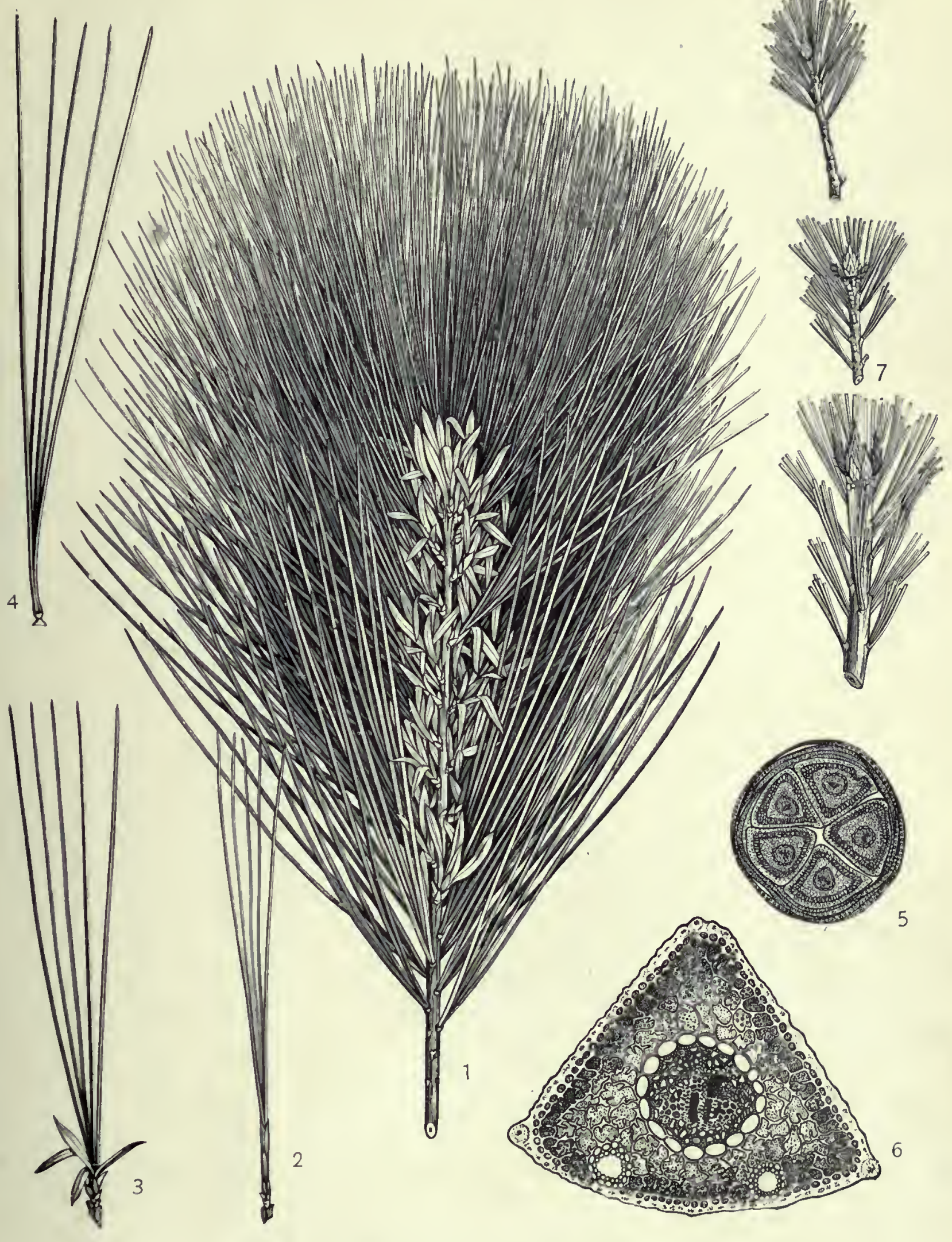




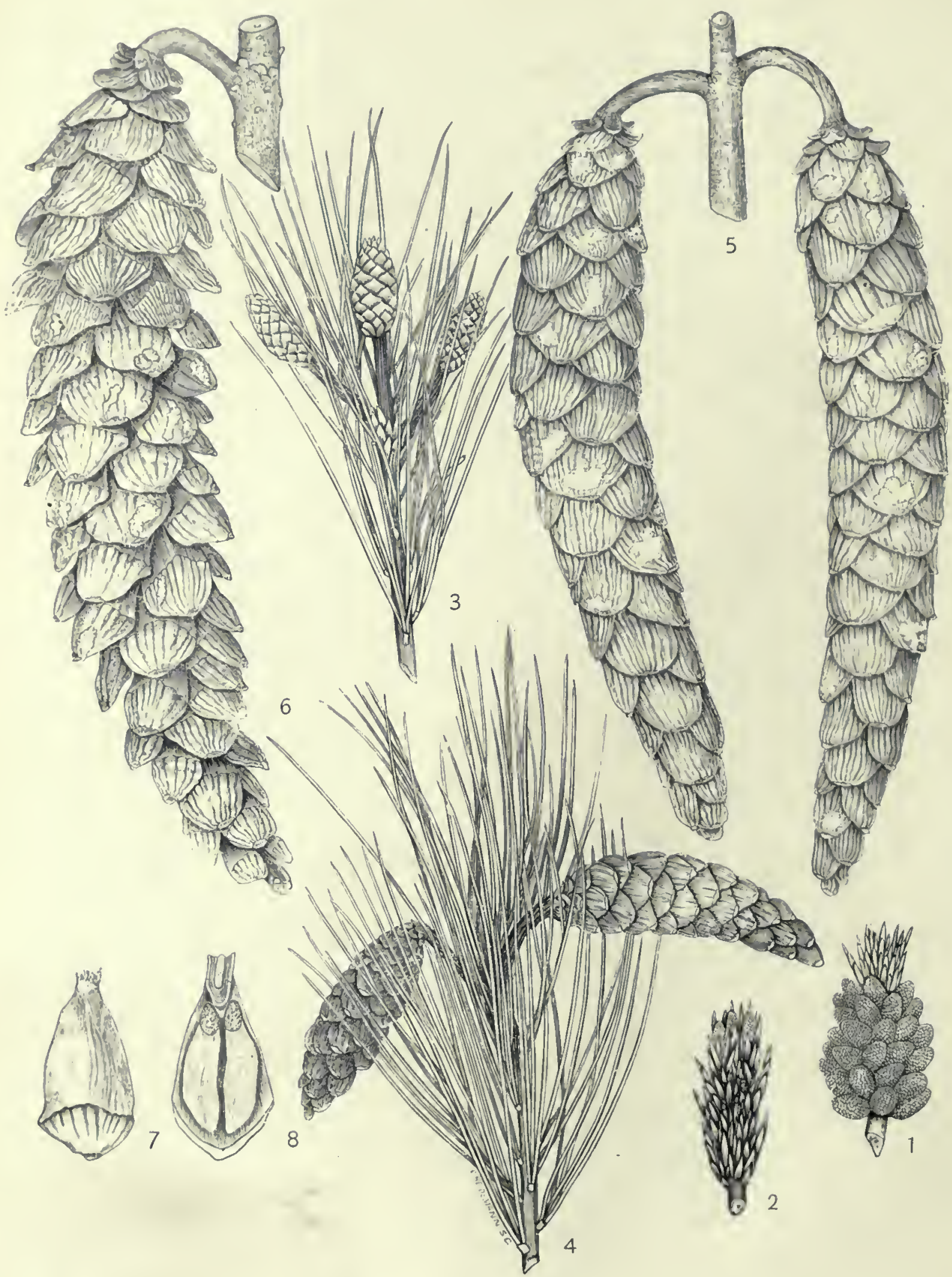

Cones, Seeds, etc., of the White Pine. 
Mich.) between the middle and the end of the mouth. The staminate flowers are borue laterally on the shoots of the season (Pl. VI, 1). They are extremely simple in strueture, consisting of numerous polleu sacs borne in pairs on the outer face of the scale-like stanninal lcaves. The polleu is prodnced iu great abundance and is carricd by the wind to great distances. Fertilization, however, notwithstanding the profuse production of pollen, often fails to take place. In fact, failure appears to be rather the rule than the exception, if we consider the frequency of "off" years," in which little, if any, good seed is produced. But donbtless other causes often combine to prevent the production of a full crop of seeds.

The pistilate flowers occupy the apex of the young shoot (PI. VI, 2), finally forming a bunch of cones pendent from the ends of the branches. At the time of pollination they are about onefourth of an iuch in length and have the appearance of minute fleshy cones, which by the end of the first summer's growth have attained the length of three-fourths of an inch to an inch, and have the appearance represented in Pl. VI, 3. They are not ripe until the fall of the succeeding year, when the cones, having now attained their full size, as shown in Pl. VI, 5 and 6, open and allow the winged seeds to escape. In order to prevent loss of seeds it is uecessary to gather the cones a little before they ripen, which occurs during early September in most localities of the natnral range. Afterwards, if kept in a dry place, they will open readily themselves and allow the seeds to fall out. The ripening is signalized by the change of color to a yellow browu and the forming of a resin coat.

\section{SEEDS.}

The seeds are oue-fourth of an inch iu length by about half that measure in breadth, of an oval form, grayish-brown in color, sprinkled with darker spots, and provided with a thin, delicate wing, by means of which they are disseminated through the agency of the wiud (Pl. VI, 8). The seed coats consist of a hard outer shell, or testa, inside of which is a thinuer membrane, the endopleura: Inside of the seed coats is the whitish endosperm; constituting the food" of the germinating plant, within which, ocenpying the eenter of the seed, is the small; straight embryo, the three parts of which, stem, radicle, and cotyledons, are plainly distinguishable.

To get 1 ponnd of seed from 2 to $2 \frac{1}{2}$ bushels of cones are uecessary.

Concerning the production of seed, the experience in this country is but fragmentary. The individual tree begins to bcar quite early. Isolated specimens, or trees in open groves, bear cones before they are twenty years old, aud even trees in the dense forest seem to bcar geuerally before they are forty years of age. The capacity to bear abundantly is retained to old age, the oldest trees seen still bearing heavily; and even nutilation by fire or otherwise does not prevent the trees from bearing.

FXPLANATION OF PLATE VI.

1. Staminate flowers of Pinus strobus just before shedding of pollen.

2. Pistillate flowers, terminating joung shoot.

3. Young cones in autumn of first jear.

4. Young eones early in snmmer of seeond year.

5. Cones at close of second jear's growth before opening of scales.

6. Mature eone, the seales separated to admit of dissenuination of seeds.

7. Single scale, showing onter surface.

8. Single seale, showing inner surface with seeds in place.

SEED SUPPLY.

A full'crop of seeds is usually produced by the same tree only at intervals of scveral jears. Cones may be formed year after year, but upon examination it is often found that many of the sceds are abortive. Of a large number of cones gathered at Ann Arbor, Mich., in 1886, not a single one showed a perfect seed. Mr. John E. Hobbs states that the same year (1886) was a good seed year in Maine, and that trees had not produced so largely before since 1879. According to Mr. J. Dawson, of the Aruold Arboretum, a crop of seed may be looked for about once in five years, though others make intervals between seed years shorter. The frequency of seed years has not been sufficiently noted as yet to warrant any general statement, but it is known that during eertain seasons the seed production is perfectly general over large areas, while in other years it is not. Thus, in 1897 the White Pine bore heavily in every piue county in northern Wiscousin. 
The frennency of seed years varies of conrse not only on account of more or less favorable seasons, but according to locnlity and climatic conditions. In Europe the White Pine is regarded as a freqnent and lieavy seec'er, one year out of three being generally yentuetive. A grove of 8 acres near lirankfort on the Main produced during twenty years, on an average, $\$ 100$ worth of seed, with a maximum yield of $\$ 500$, and witl but three "ofl" or fail years in the twenty. Similarly an area of about 40 acres in the Palatiuate furnishes as high as 1,700 bushels of cones, or about 1,300 pounds of seed, supplying all the unrseries of the Palatinate State forests witl seed.

\section{THE WOOD.}

The strncture and developinent of the rood of the White Pine may be studied to the best advantage by beginning witl a young sloot cut from a vigorons tree in early summer. $\Lambda$ cross section of sucl a shoot in the first season of its growth (Pl. VIl, 1) shows three plainly marked zones-the plth $(m)$ surmunded by the wood $(x)$ and the inner bark $(p h)$, which together form the ennspicuons zone crossed by radiating bands, the so-called mednllary rays, and outside of the parts just described, a broal zone of cellular tissne, constituting the midlle bark, which is bounded exterually by the epidermis.

The jith, medullary rays, and middle bark consist of simple cells, originally of an irregularly rounded form. Together they constitute the so-called ground tissue of the stem, as distingnished from the fibro-vaseular portion, which inchules the wood and inner bark.

Within the cortical portion of the ground tissne nimuerous large openings (Pl. VII, 1, rd) are seen, of different sizes and apparently without definite arrangement. These are the resin lncts. Fach duct runs longitudinally through the stcm, and consists of a central eavity filled with resin, around which is a single layer of secreting cells, easily distinguished by the uature of their eontents from the surromuling cells of the cortex. At this stage of development the resin ducts are eonfined to the cortical parenchyma, none having yet been formed in the woody portion of the stem; but later in the season, as may be seen in older sectious, a number of dncts are formed, arranged in a circle near the periphery of the wood. These have essentinlly the same structure as those of the cortes, but are of smaller size and are surrounded by fewer secreting cells. In cross sections of older stems tlie resin ducts are seen, arranged in an irregular circle, in each aununl ring. Their physiological significance is uot fully understood, though there can be little doubt that Do Vries is correct in assuming that the abundant resin is of service to the growing tree, when wounded, in preventing decay of the wool, and that its preservative influence is contimned after the tree has been cut into lumber.

In snch a young shoot as lias been deseribed the cells are vitally active, and are filled with granular protoplasm, in addition to which several other substances are either prodnced or stored 11p in them, particularly in the cells belonging to the ground tissne. Chlorophyll oecurs in the pith and medullary rays as well as in the cortical portion. It is most abundant in the cells of the cortical parenelyyua, ocenrring in the form of minnte grains, irregular in shape and size. Starch, in ronuded granules, occurs abunduntly throughont the groumd tissue, the eells of the enrtex containing a larger proportion than those of the pith. Resin, as already stated, fills the resin ducts and the secreting cells around them, thongh starch is often found in the latter.

Passing now to the woody portion immediately surronuding the pith, two characteristic fea. tures at once attract attention. The elemeuts composing the wood, $x$ ( Pl. VII, 1 and 3), have a inuch narrower lumen than those of the pith, an! are regularly disposed in radiating rows. These elements, the tracheids, are elongated thiels.walled cells, four to six sided, aceording to the number of tracheids by which they are surromuled. Their walls are lignified and are marked by the pecnliar structures called bordered pits. Their strncture, when fully developed, is slown in Pl. VIII, 1,2, and $\%$ In the econouy of the tree the wood fulfitls the function of mechanical support, and serves as the conlucting tissne through which the water, evaporated from the leaves, is carried ni) from the roots.

The medullary rays are composed of cells so flattened by the pressure of the tracheids that on longitndinal sections they appear as represented in Pl. VIII,3. They contain a conspicuous nuclens, are closely packed with granular fool substauees, and serve collectively as a storehouse 
of reserve materials. Commnnication between these and the tracheids is effected by means of simple pits on their radial walls.

The inner bark, or phloem, ph (Pl. VII, 1 and 3 ), closely resembles the young wood on eross section, its elements being arranged in radiating rows and traversed in like manner by the medullary rays. The cells composing it differ, however, in various important particnlars from those of the wood. Their walls are of cellnlose, and although important as conducting tissue, they eontribute comparatively little to the rigidity of the stem.

Between the wood and inner bark is the cambium or formative tissue, represented in Pl. VII, 1, as a light band of extremely small and delicate cells, and in the same plate as a zone of cells with thin walls and large lnmen, contrasting strongly with the wood elements and those of the inner bark betwcen which they lie. It is from the cells of the cambium that those of the wood are formed on the one hand and those of the bark on the other. The process is a grad ual onc, and no absolute line of demarcation can be drawn between the cambinm and the tissues derived from it. The cells of the cambinm multiply by tangential division. The essential features of this process, as regards the position of the cell walls, are represented in Pl. VIII, 4, in which the lightest lines represent the youngest walls and the heavier ones those of greater age, snccessively. It is by the constant repetition of this process of tangential division aud the subsequent thicken. ing of the walls of the cells thus formed that the wood and inner bark wake their yearly increase in thickness. In the spring the cells of the cambium are large and vigorous, and a rapid forma. tion of woorl elements with relatively thin walls and large cavities takes place, while latcr in the season much smaller tracheids with thicker walls are formed. This results in the strong contrast between the wood last produced in any given year and that formed at the beginning of the next season's growth, giving rise to the sharp distinction of annual rings so clearly brought out in Pl. VIII, 1 .

The histological characters thus briefly summarized hold true, in a general way, for other conifers as well as the White Pine. This species, however, presents a number of peculiarities that are of both physiological and economical interest.

The resin dncts of the $W$ hite Pine are larger and more numerous in the cortex than in the wood, an arrangenent well adapted to secure the protective action of the resin contained in them without introdncing an element of weakness into the wood. Comparisons with other species bring out this fact in a striking manner. Thus, npon comparing the distribution of the resin ducts in stems of the White and Scotch pines, as nearly alike as possible, it was found that in the cortex of White Pine stems of one year's growth the number of resin passages ranged from 20 to 47 , the average being abont 33 . The number in the wood was more uniform and averaged abont 13 . In the Scotch Pine the average for the wood was fnund to be 33 and for the cortex 10. Taking the second year's growth in the same way, the average number for cortex of White Pine in the specimens examined was $2 S$ and for wood 27 ; in Scotch Pine, for cortex 9 and for wood 37.3 The sinall size of the resin ducts in the wood contrasts strongly with the very large ones of Scotch Pine, which serionsly interfere with the continuity of the wood and tend both to weaken it and to give it an uneven texture.

'The extremely small number' of thick-walled tracheids constituting the summer wood of the White Pine is in marked contrast with the broad band of summer wood formed in various other speeies. Comparing the annual riugs of White Pine with those of Longleaf Pine, for example, it is seen that while the thick-walled tracheids of the former make hardly morc than the mere outer elge of each ring, those of the latter constitute one-third or more of its entire widtl. Moreover, the gradual, almost imperceptible, transition from spring to summer wood in the White Pine contrasts strongly with the abrupt line of demareation seen in Longleaf Pine and all other Yellow Pines. It is to this very gradual transition that the uniform texture of the wood of White Pine is chiefly due. The medullary rays of the different groups of pines show certain structural peculiarities that appear to be constant for the gronp of species in which they occur. The writer is indebted to Mr. Filibert Roth for the following notes in regard to this feature:

In all pines the mednllary ray is made ap of two kinds of cells which difier in their general form, and still more in the configuration of the cell wall and pits. The one kind occupies the upper and lower rows of each ray, 
and aro thenefore termed the onter celle; tho other kind unakes up the internediato rows and are known as tio inner eelis.

In the appenance of l,uth outer aul iuner eeils there is a uarked and constaut ditlerence in difterent gronps of pines. While the interior of tho wall of the outer cells (transverse tracheids) is suooth in somo gronjp, it is beset with nnuerous bolel projections in otherw. Sinilarly the inner cells (parenehyma) of tho spring wood of each rar in sous gronps bave but a single largo pit communieating with tho weighloring tracheid, while in other gronps this is bronght about by thre'o to six smaller pits.

13ised npon these ilfferences, the following classification of the wool of dillerent species of pines is proposed ly. Dr. J. Schtoeder:!

SEction I. Walls of the trachelds of lle pith ray with dentate projectlous.

a. One lo twolargc, simple pits 10 each trachefl on the rallal walls of the cells of the pilh ray.-Group 1. Iiepresented in this conntry only ly $l$ '. revinova.

6. Three to six almple plis to each tracheld, on the walls of the cells of the pith ray.-Group 2. $\boldsymbol{l}^{\prime}$. tasia, palustris, etc. Including most of our "hard" aul " sellow" pines.

Secrux II. Walls of tracheld of pili ray smooth, without dentale projections.

a. One or two large plts to each tracheld on the rallal walls of each cell of the pith my.-Gronp 3. P. strobis, lambertiana, aud other true White Pines.

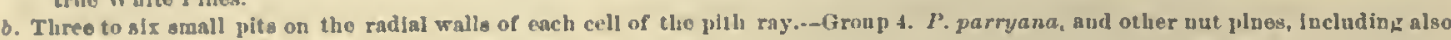
P. balfouriana.

Returning to the medullary ray of the Whito Pine, it is observed that the walls of the onter cells are thin $(1.5 \mu$ to $2 \mu)$; tho round pits quite variable in uumber and size, but always as small, and often smallor, than the pits of the traclioids in the summer wood; also that tho walls of the inger cells aro thin (1.5 $\mu$ to $3 \mu$ ), for tho most part very thin, being largely oceupierl by pits; that tho pits are large ovals on the radial walls of the cells in the spring wood, small erect orals in the summer wood, and small and irregular in ontline above and below where the inner cells eommunicato with cach other. Tho leugth of these cells varies, even in the same ray, between $50 \mu$ and $300 \mu$; the width was found to be abont $7 \mu$ for tho outer and $12 \mu$ for the inner cells; the height, nore variable in the onter than in the inner cells, and less variahlo than either width or length, may he set at abont $23 \mu$ for onter and inuer cells. Tho averago number of coll rows in ono ineilnllary ray, for tho spocimens stndied, is 7.5 , whereof 2.6 fall to the onter cells and 4.9 to the inncr colls. The limits of tho total uumber of cell rows wero 2 and 16 ; the height of tho ray, theruforo, $46 \mu$ to $368 \mu$, dimensions scarcely appreciable to the unaider cye. What is lost in size is gained in numbor; on an average 21.3 mednllary rays were connted on 1 square milimeter, or 13,312 to 1 square inch of tangential section.

A study of the wood in its physieal and meehanieal properties, by Mr. Filibert Roth, will be found further ou in this monograph.

EXPLANATION OF I'LATE VII.

1. Transverso seetion of fresh shoot, eut in sumuor of first year $\times 25$. The zone of sunall cells snrrounding the pith includes tho wood and inner bark, both of whieh aro traversed radially hy the medullary rays. The thick cortical parenehyma outside of theso is marked by the presence of a number of large resin ducts.

2. Portion of epidermis, with appendages. Bcneath tho epidermis a fow eells of tho cortical parenchyma containing starel.

s. Highly magnified view of a part of the transverse section, showing the strnctnre of wool and inner bark, with the thin-walled cells composing the cambinm lying hetreen them.

[Figs. 2 aud 3 were drawn with great care with the camera, but nufortunately no statement of the magnifieation was preserved with them.]

\author{
ExPLANATION OF PLATE VIII.
}

1. Cross soetion of wool $\times 175$. The section iucludes parts of three medullary rays, the midelle ono of which is cut partly throngh the inner cells and partly throngh the cross tracheids. The gradual transition from spriug to suumer wood is clearly shown. Part of a rosin duet is seen on the right.

8. Radial longitudinal soetion of wood $\times 200$, showing a fow of the thick-walled trachcids of tho sunner wool followed by. the large thin-walled ones of the sncceding spring, both erossed by a mednllary ray. The borlered pits of the outer cells of tho ray, shown both in sectiou and surface view, are in stroug coutrast with the simple pits of the inner cells.

3. Tangential section of wood $\times 200$.

4. Cross section of part of twig colleeted May 20,1886, $\times 175$, showing eanıbium and development of wood and bark. Tho woody ring is abont one-third its final thickuess.

\title{
GROWTH AND DEVELOPMENT.
}

The seets of the White Pine retain their vitality for a long period. Trustworthy observers state that a fair pereentage will grow after being kept five years or more. The eonditions of germination and suceessful growth are, in generul, the same as for other pines, namely, a suitable 

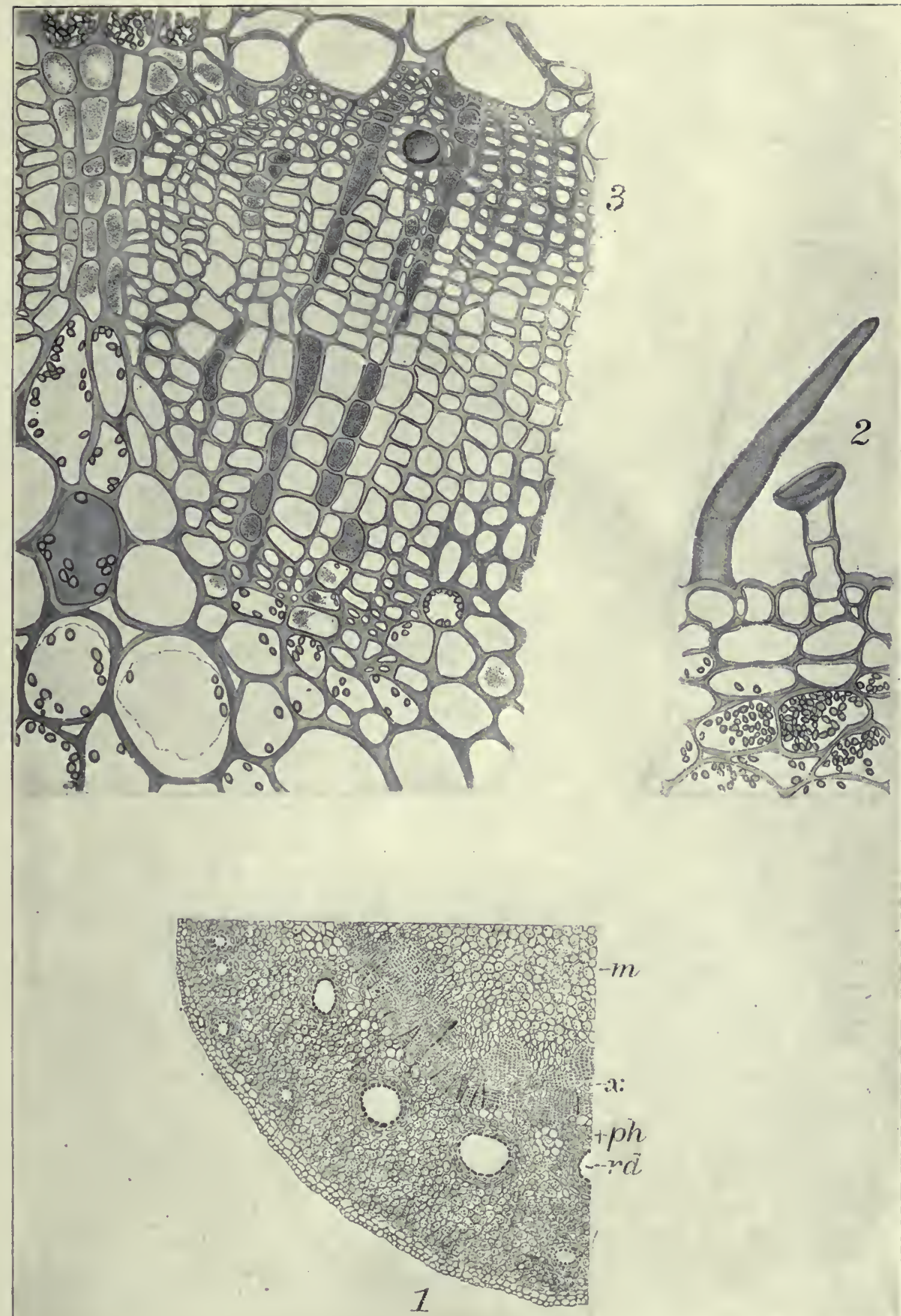

SECTIONS OF YOUNG SHOOT OF WHITE PINE. 


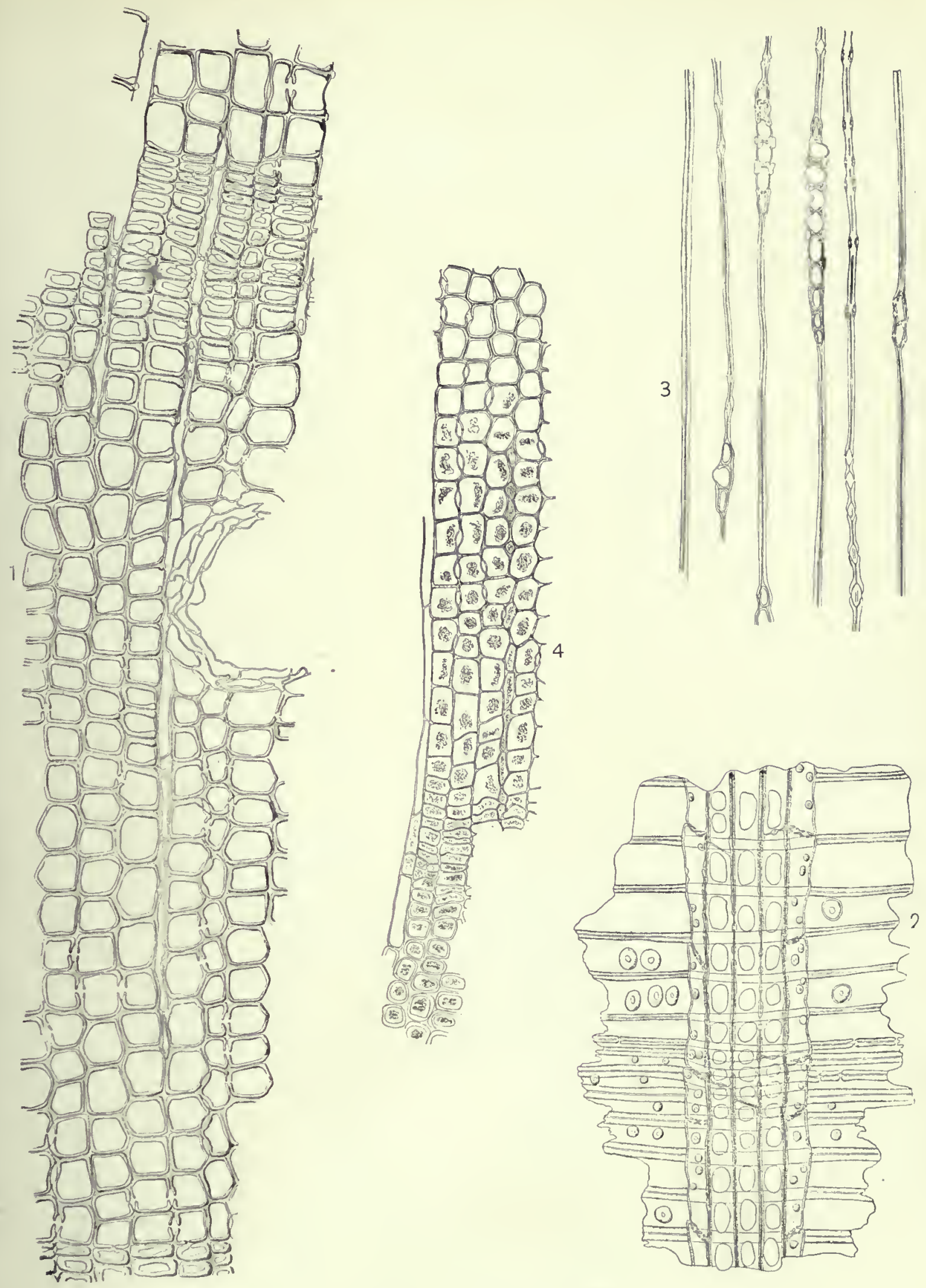

Sections of Wood of White Pine. 

soil, moderately warm and moist (not wet), in which the sceds are covered at a depth not exceeding twice their awn diameter, ant, further, protection of the young scedlings against the hot sun and drying winds. Special attention is required in the nursery to avoid undue noisture wheu the seedlings appear above the ground, as they are often attacked by a destructive discase very common in propagating beds, known as "danping off." If, lowever, no adverse influences have interfered with its normal development, the young plant presents itself-after-some-months? growth as a slender shoot, crowned-by the persistent seed Teaves, in the midst of which is the terminal bud, the latter having already formed nunerous short foliage leaves. No branches have appeared, an the foliage leaves-arise singly instead of in groups of five. The whole plant, as it appears at this time, with its slender stem and long taproot, is represented, natural size, in Pl. IX, drawn from a specimen obtaincl in the pine woods of Michigan, in September, 18\$6. Earlier and later stages of levelopinent of the seedlings are shown in the same plate $(1,2,3,4,5,6)$ drawn from inursery specimens.

For the first two or three years the growth of the seedling is slow, and is so greatly influeneed by its surronudings as to make it impossible to give averages that will fairly represent the yearly increase in height and diameter.

Thus, a healthy seedling, three years old, from the nursery row, measured 4.6 inches, while a self-sown speeinen from Maine, four years old, measured only 2.7 inches in height. But, if the eircumstances are favorable, after the third year a growth of one to several inches is made cach year, and from this time on the yearly increase in height is clearly defined by alternating nodes and internodes, a whorl of branches being formed at each node.

The leading shoot is from the first the most conspicuons aud the most important part of the plant, branches being manifestly subordinatc, dying off in later years as in other conifers. 'The rate of growth being of inost inportant practical interest, much space has been devoted to this part of the developmental history.

The trec rarely reaches a height of more than 160 feet and diametcrs of more than 40 inches, more usually 30 inches. Occasionally these dimensions are exceeded; trees of 200 feet in height and of 60 inches in diameter have been reported. The largest actually measured by the Division of Forestry was 48 inches in diameter breast high and 170 feet in height, with an age of about four hundred and sixty years, eontaining $73^{\circ}$ cubic feet of wood, standing in a group of similarly old and large pines in Michigan. Another trce of this group, with 47 inches diameter and 162 feet in height, contained $85 ̃$ cubic feet, bcing less tapered.

FXPLANATION ÖF PLATF IX.

1. Seedling as it first appears with seed coat attached to seed leaves.

2. Seedling with seed coat detached.

3. Seedling with seed leaves and primary foliage leaves disposer singly on stern; five months old.

4. Seedling in its second year, showing primary leaves and secondary leaves (mature form), the latter in clusters of five.

5 and 6 . Seedlings three to five years old.

\section{RATE OF GROWTH.}

The following statements regarding the progress and rate of grow th of White Pine are based mainly upon the very comprehensive data collected by the Division of Forestry in Mainc, New Hampshire, Massachnsetts, Pennsylvania, Miehigan, and Wisconsin. These data, involving measurcments and detailed analyses of over seven hundred trees grown under varying conditions, together with records of the conditions under which they grew, and the amounts of timber which were prodnced under such conditions per aere, are presented fully in the tables, with accompanying notes, in the Appendix to this monograph. It appeared, however, desirable to present in the text not only the generalizations and conchusions, but also some typical cases. Some other measurements, marle before this comprehensive investigation and recorded by the writer in his original manuscript, are also prodnecd.

\section{HEIGHT GROWTH.}

SEEDLING STAGF.

The growth of the seedling is variable, aecording to the conditions under whieh it grows. In the forest it is much slower than nnder cultivation, as would naturally be expeeted. The common 
praetice of nurserymen is to sow the seed broadcast in carefully prepared beds, where the seed. lings stand from two to fonr years before transplanting. Standing rery close, the trees do not make as stocky growth as they otherwise would. Under these conditions the average growth of nutransplanted scedlings, according to statements by the well-known unrserymen, Thomas Meehan \& Sons, is as follows: One.year seedlings, 2 to 3 inehes high; two years, 4 to 6 inches; three years, 12 to 15 inches; four years, 24 to 36 inclies.

The late Mr. Robert Donglas, the veteran uurseryman, of Waukegan, 111., wrote:

Whito Pine seedliugs one yoar old are 1 to 2 inclics high and altogether too small and teniler for transplanting. At two years old thoy aro much stronger, from 3 to 5 inches bigh, with fine librons roots and in fine eouditiou for transplanting. At throo years old they are 6 to 9 juches high aud shonld not bo allowerl to stand another year, as thes would add abont 10 inches to their height during the next year and would not be suitalolo for planting.

The first season after transplanting, the White Pine (liko other trecs) will not increaso nneh in beight, bnt will ostablish itself, oxtending its roots and forming a stroug terminal bnd, so that when it is six years old it will exceed in weight and bulk over one lundred times its proportions when transplanted, aul therenftcr will increase in growth from 18 to 30 inches in hoight annually in gool soil for many yoars.

Garlner \& Sons, whose nursery is about 90 miles west of the Mississippi River, in Iowa, and therefore outside of the natural range of the species, submit the following measurements, coinciding with the above, as representing average growths at their nurseries before and after trans. planting: One-year-old seedling, $1 \frac{1}{2}$ inches high; two-year-old seedling, 4 inches high; three-yearold scedling, 7 inches high. The trees are transplanted at three years of age and thereafter the average height for the three following seasons are: Four years old, 12 inehes high; five years old, 16 inches high; six years old, 33 inehes high. Another establishment reports als the average height of two year-old trees in seed bel, $3 \frac{1}{2}$ inches; of three-year seedlings, 7 inches.

Casual observations and measurements of some forty.five seedlings in the forest permit the following as to the height growth of seedlings in the forest:

IIeight grouth of White Pine in the forest for the first six years.

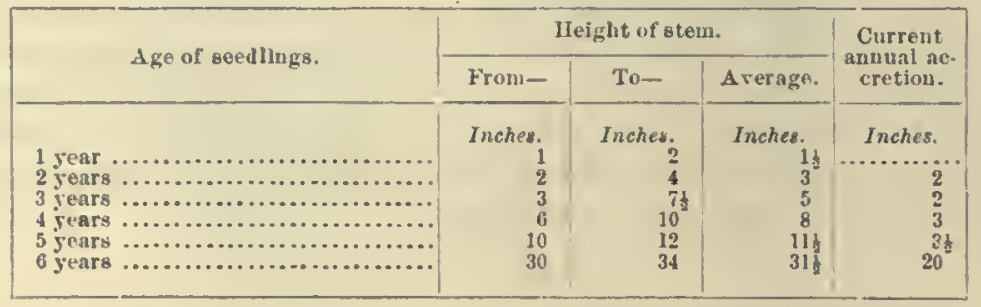

These mensurements show that the rapid height growth begins with the sixth year, when the total growth of the first five years is almost doubled in one season. This, to be sure, holds ouly for seedlings favorably situated. In those less favored the rapid stage of development comes more gradually. This slor progress in younger years is naturally retlected in a retardation of the year of maximum lieight growth, which in dominant trees occurs about the trcntieth year, while in oppressed trees it may not eome bufure the fortieth year.

DFVFLOPMEXT IX OPEX STAND.

Trees on lawns and in plastures, which grow up in full enjoyment of light, are somewhat different from trees in the forest. The slow seedling stage is followed by a very rapid increase in the rate, which attains its maximun before the twentieth year and then declines gradually.

Table I, on the uext page, presents a eomplete record from year to year of the growth of eight trees planted on a lawn at Ann Arbor, Mich., which were measured in 1556, the annual increase being measured between the whorls of branches. These measurements also exhibit the great variability of growth from season to senson and from tree to tree, even under otherwise siuilar conditions. In some of the trees, evidently, injurics or accidents retarded derelopment. Such apparent deficiencies have been left out of eonsideration in averaging the data. 
TABLE I.-Height growth of White Pine planted in lawn at Ann Arbor, Mich., by years, in inches.

\begin{tabular}{|c|c|c|c|c|c|c|c|c|c|c|c|c|c|c|c|c|c|c|c|c|c|c|c|c|c|c|c|c|}
\hline \multirow{2}{*}{ Number of tree. } & \multirow{2}{*}{ Age. } & \multirow{2}{*}{$\begin{array}{c}\text { Diame } \\
\text { ter } \\
\text { breast } \\
\text { high. }\end{array}$} & \multirow{2}{*}{ Height. } & \multicolumn{25}{|c|}{ Heigbt, by years. } \\
\hline & & & & 1 to 6 & 7 & 8 & 0 & 10 & 11 & 12 & 13 & 14 & 15 & 16 & 17 & is & 19 & 20 & 21 & 28 & 23 & 24 & 25 & 26 & 27 & 28 & 20 & 30 \\
\hline 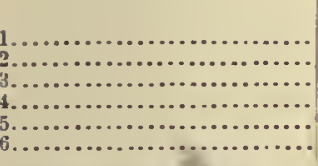 & $\begin{array}{r}\text { Yr8. } \\
17 \\
19 \\
19 \\
21 \\
23 \\
29\end{array}$ & \begin{tabular}{|r|} 
Inchez. \\
5.1 \\
3.8 \\
6 \\
6 \\
8.2 \\
12.8
\end{tabular} & \begin{tabular}{r|} 
Feet. \\
30.5 \\
23.5 \\
30.5 \\
26.6 \\
34.5 \\
44.5
\end{tabular} & $\begin{array}{l}\text { In } \\
20 \\
20 \\
25 \\
41 \\
33 \\
50\end{array}$ & $\begin{array}{r}\operatorname{In} \\
15 \\
3 \\
10 \\
6 \\
12 \\
7\end{array}$ & $\begin{array}{r}\text { In } \\
22 \\
5 \\
4 \\
12 \\
14 \\
16\end{array}$ & $\begin{array}{l}I n \\
21 \\
11 \\
14 \\
24 \\
14 \\
17\end{array}$ & $\begin{array}{l}I n \\
23 \\
16 \\
32 \\
23 \\
20 \\
24\end{array}$ & $\begin{array}{l}\text { In } \\
28 \\
11 \\
24 \\
18 \\
40 \\
28\end{array}$ & $\begin{array}{l}7 n \\
39 \\
19 \\
23 \\
26 \\
29 \\
20\end{array}$ & $\begin{array}{l}I n \\
37 \\
24 \\
23 \\
23 \\
20 \\
30\end{array}$ & $\begin{array}{l}I n \\
39 \\
33 \\
32 \\
5 \\
37 \\
21\end{array}$ & $\begin{array}{l}T \text { Th. } \\
39 \\
32 \\
35 \\
29 \\
30 \\
27\end{array}$ & $\begin{array}{c}\text { In } \\
39 \\
35 \\
32 \\
25 \\
10 \\
21\end{array}$ & $\begin{array}{r}\text { In } \\
30 \\
28 \\
36 \\
5 \\
32 \\
25\end{array}$ & $\begin{array}{l}\text { In. } \\
24 \\
24 \\
26 \\
19 \\
30 \\
17\end{array}$ & $\begin{array}{r}\text { In } \\
321 \\
32 \\
20 \\
7 \\
34\end{array}$ & $\begin{array}{l}I n \\
\cdots \\
\cdots \\
25 \\
26 \\
25\end{array}$ & \begin{tabular}{c}
$I n$ \\
$\cdots \cdots$ \\
\hdashline \\
19 \\
24 \\
23
\end{tabular} & $\begin{array}{l}I n I \\
\cdots \\
\cdots \\
\cdots \\
21 \\
22\end{array}$ & $\begin{array}{l}I n \\
\ldots \\
\cdots \\
0 \\
15 \\
17\end{array}$ & \begin{tabular}{c} 
In \\
$\ldots$. \\
$\cdots$. \\
$\cdots$ \\
\hdashline \\
20
\end{tabular} & \begin{tabular}{l}
$I n$ \\
$\cdots$ \\
$\cdots \cdots$ \\
$\cdots$ \\
\hdashline \\
12 \\
\end{tabular} & \begin{tabular}{c}
$I n$. \\
$\cdots$ \\
$\cdots$. \\
\hdashline \\
\hdashline \\
29
\end{tabular} & \begin{tabular}{l} 
In \\
$\cdots$ \\
$\cdots$ \\
$\cdots$ \\
\hdashline \\
25
\end{tabular} & $\begin{array}{c}I n \\
\cdots \\
\cdots \\
\cdots \\
\cdots \\
17\end{array}$ & $\begin{array}{c}I n \\
\cdots \\
\cdots \\
\cdots \\
\cdots \\
\cdots\end{array}$ & $\begin{array}{l}I n \\
\cdots \\
\cdots \\
\cdots \\
\cdots \\
\cdots\end{array}$ \\
\hline 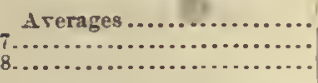 & $\begin{array}{l}30 \\
30 \\
\end{array}$ & $\begin{array}{l}15 \\
13.5\end{array}$ & $\begin{array}{l}53 \\
47.5 \\
\end{array}$ & $\begin{array}{l}32.5 \\
41 \\
39\end{array}$ & $\begin{array}{r}9 \\
22 \\
22\end{array} \mid$ & $\begin{array}{l}12 \\
14 \\
20\end{array}$ & $\begin{array}{l}17 \\
14 \\
24\end{array}$ & $\begin{array}{r}24 \\
9 \\
35\end{array}$ & $\begin{array}{r}25 \\
3 \\
18\end{array}$ & $\begin{array}{l}26 \\
13 \\
15\end{array}$ & $\begin{array}{l}26 \\
18 \\
14\end{array}$ & $\begin{array}{l}32 \\
38 \\
18\end{array}$ & $\begin{array}{l}32 \\
27 \\
24\end{array}$ & $\begin{array}{l}27 \\
40 \\
31\end{array}$ & & $\begin{array}{l}32 \\
41 \\
22\end{array}$ & $\begin{array}{l}27 \\
30 \\
23\end{array}$ & $\begin{array}{l}25 \\
28 \\
36\end{array}$ & $\begin{array}{l}22 \\
44 \\
29\end{array}$ & $\begin{array}{l}22 \\
36 \\
12\end{array}$ & $\begin{array}{l}16 \\
38 \\
15\end{array}$ & ig & $\begin{array}{l}\ddot{2} \\
31\end{array}$ & $\mid \begin{array}{c}\ddot{2} \\
24\end{array}$ & $\begin{array}{l}\dddot{26} \\
22\end{array}$ & $\begin{array}{l}31 \\
17\end{array}$ & 21 & $\dddot{12}$ \\
\hline Arerage hy 6. year periods. & & & & 6.3 & & & & & & 18 & & & & & & 27.6 & & & $\cdots$ & & & 28 & & & & & & $\cdots$ \\
\hline
\end{tabular}

Yore.-Trees Nos. 1 to 6 stood in shallow soil on grarel subsoil; Nos. 7 and 8 in deep loam.

From this table it appears that these eight trees grew on an average hardly morc than 6 inches during the first six years, more than three times as fast during the next six years, and rcached a inaximum rate of over 27 inches per year during the third period of six years, the decline beginning after the twentieth year and the rate decreasing until it has fallen to about 15 inches near the thirticth ycar.

To show how, under less favorable conditions, the progress of self-sown trees is very nearly the same, the following measurements may serve, from which it appears that natural seedlings on pastures, standing morc or less crowded, reach at ten jears a height of 10 feet; at the age of twenty years about 25 feet, and trces thirty-five to forty years of age, with diameters of 6 to 9 inclies, attained and even passed the height of 60 feet, showing an average growth for that period of 15 to 13 inches per year:

Tamb. II.-Measurements of self-soun White Pine on pasture.

[Furnlshel by Mr.J. E. Hobhs, of North lerwick, Me.; altitude, 250 feet.]

\begin{tabular}{|c|c|c|c|c|c|c|c|}
\hline Number of tree. & $\begin{array}{l}\text { Nnmber of } \\
\text { riugs on } \\
\text { stump cut } \\
\text { at grunnd. }\end{array}$ & $\begin{array}{l}\text { Number of } \\
\text { rings } 1 \text { fout } \\
\text { ahoro } \\
\text { groumd. }\end{array}$ & $\begin{array}{l}\text { Dianseter of } \\
\text { stnmp at } \\
\text { grouud. }\end{array}$ & $\begin{array}{l}\text { Dinucter } 4 \\
\text { feet high. }\end{array}$ & $\begin{array}{l}\text { Height of } \\
\text { tree. }\end{array}$ & $\begin{array}{l}\text { Length of } \\
\text { leader at } \\
\text { tume of } \\
\text { measure- } \\
\text { ment. }\end{array}$ & $\begin{array}{l}\text { Length of } \\
\text { leader for } \\
\text { last five } \\
\text { years. }\end{array}$ \\
\hline 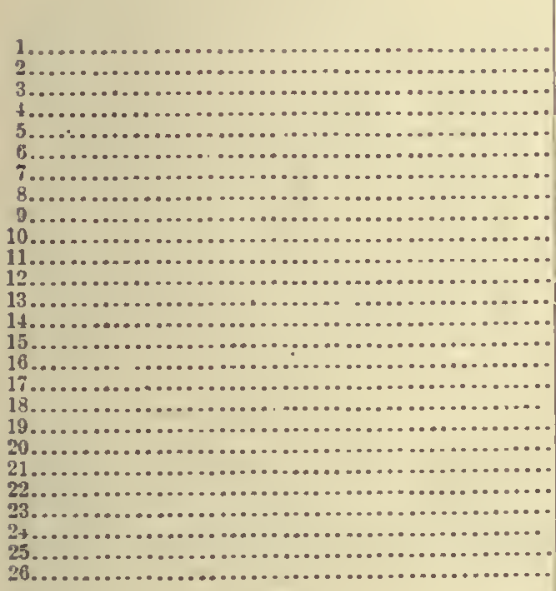 & $\begin{array}{l}10 \\
10 \\
10 \\
10 \\
11 \\
12 \\
12 \\
13 \\
13 \\
14 \\
14 \\
14 \\
14 \\
15 \\
15 \\
18 \\
18 \\
18 \\
20 \\
22 \\
20 \\
36 \\
38 \\
39 \\
39 \\
40\end{array}$ & 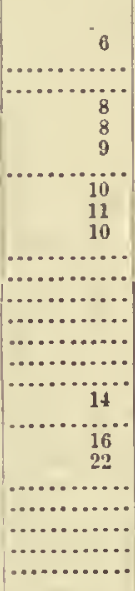 & 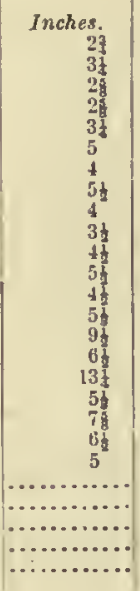 & 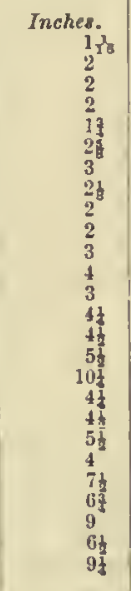 & \begin{tabular}{cc}
$F t$. & $i n$. \\
8 & 10 \\
13 & 6 \\
12 & 9 \\
12 & 9 \\
11 & 3 \\
13 & 9 \\
\hdashline$\ldots \ldots$ \\
15 & 9 \\
13 & 9 \\
13 & 9 \\
16 & 6 \\
21 & 0 \\
16 & 6 \\
25 & 0 \\
20 & 8 \\
28 & 4 \\
$\cdots \ldots$ & $\ldots$ \\
25 & 6 \\
25 & 6 \\
28 & 10 \\
29 & 9 \\
61 & 0 \\
60 & 0 \\
64 & 0 \\
60 & 0 \\
60 & 0
\end{tabular} & $\begin{array}{c}\text { Inches. } \\
23 \\
32 \\
28 \\
28 \\
293 \\
16 \\
22 \\
21 \\
25 \\
24 \\
21 \\
13 \\
21 \\
18 \\
18 \\
33\end{array}$ & 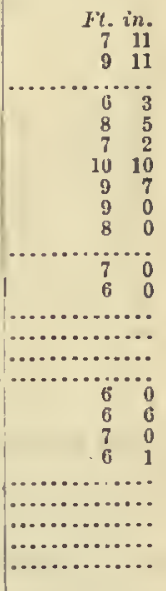 \\
\hline
\end{tabular}

NOTES TO TABLE 11.

Xo.1. From old pastnre after ono jear's tllage; 5 feet from No. 6; boro cones.

No.2. With Nos. 1 and 3 , and from similar trees.

Yo. 3. Old pasture, suil shallow. gravelly loam on compact suhsoil of sand; pine mixed with Henlock, Oak, and Maple.

Xio. 4. Level ground, soil heavy loam, somewhat shaded.

Xo. 5. From old pasture after one year's tillage; 3 feet from No.6; bore cones.

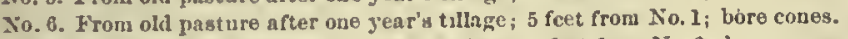

No. 7. From old pastnre after one jear's tillage; 5 feet from No.6; boro cones; distant from noigblsors 8,34 , aud 19 inches.

No. 8 . From old pasturo after ono year's tillage; 5 feet trom No. 6; bore cones; touclierl auother 4 -incb dianeter. 
So. 9. Lerel gronud, noll heary lnam, somewhat whaded.

io. 10. From old lasture aftor one year's tlligge; 5 feet from $\mathbf{3 0 . 6}$; hore cones.

o. 11. (1) pasture, soll shallow, starelly loan ou cosupnet suhsoil of anud; pine mixcd with Hemlock, Oak, and Maple.

No, 12. On alight incline to north; soll nearly 3 laches from simllar tree, will others quite nenr; crowilesl.

No. 13. Level ground, soll heavy Lовл, somewhat sladed.

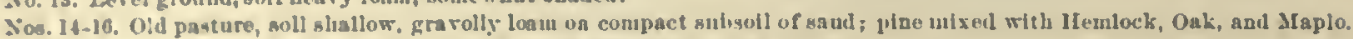

No. 17. 1solsted; lost lealer six years prevlous, appareutig I hrough leader worm.

So. 18. Level ground, soil heary loan, somewhat sinded.

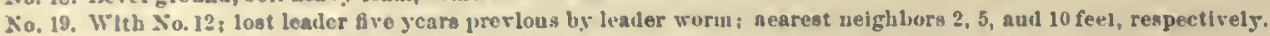

So. 30. Lorel ground, solt heary lonm, somew hat shaded.

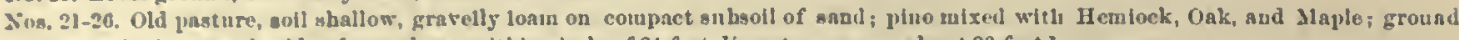
slope to westi all nix trees. hesides four others. within circle of $2 t$ feet dianeter; crown alont 20 fect long.

Coneerning trees $1,2,5,6,7,8$, and 10 (Table IL), Mr. Hobbs sent the following interesting conmunication, under date of Jamnary 11, 188i:

All these trees were found in an old pasture adjoining my land on the north and having similar aspect and soil. A fringe of tall White Pino timber surronnds it on throe sides, north, east, and sontl. Tho distance across this open land from north to soutl is about 60 rols. This land has heen in pasture from fity to ono huudred years. It was formorly thiekly covered with moss, sweet feru, nnd other low-growing bushes, in the shade of which animals found somo grass. Althongh thus sirrounded by tall pines their secds seldom sprung up.

Not many Jears bcfore these trees started a portion of this land was plowerl aud planted with potatoes ono year, and then turned out to pasture again, wherenpon yonng pines immediately sprnug up. Theso wero cut down first, but they eontinued to come up so abundantly that thes were allowed to grow, and now the pateh that was planted with potatoes is quite thickly covered, in many places too thickly, with trees like those measured. This fact shows the inportauce of turning up the soil so that the seods that fall npon it may haro a chanee to take root. Only here and there a seed will find lodgment on land that is eovered with moss and low-growing bushes, no matter how abnndantly sceds mas be sown upon it.

How such trees continue to grow is shown in Table III. From the measurements it appears that a steady growth continues, whieh, by the hundredth year has brought the tree to a height of near 100 feet.

TA131.E III.-Measurements of Thite Pine, groun on abandoned field8.

[Furnished by Mr. J, L. Hobls, of Yorth I3erwick, Me.]

\begin{tabular}{|c|c|c|c|c|c|c|c|c|c|c|c|c|c|c|c|c|c|c|c|c|}
\hline \multirow{2}{*}{$\begin{array}{c}\text { Namber of } \\
\text { tree. }\end{array}$} & \multirow{2}{*}{ Age. } & \multirow{2}{*}{$\begin{array}{c}\text { Diam. } \\
\text { eter } \\
\text { hreast } \\
\text { hlgti. }\end{array}$} & \multirow{2}{*}{$\begin{array}{c}\text { Diaa. } \\
\text { eter } \\
\text { below } \\
\text { crown. }\end{array}$} & \multirow{2}{*}{\multicolumn{2}{|c|}{$\begin{array}{l}\text { Lengtb } \\
\text { of } \\
\text { crown. }\end{array}$}} & \multirow{2}{*}{$\begin{array}{c}\text { Length! } \\
\text { ot } \\
\text { leader } \\
\text { for last } \\
\text { flve } \\
\text { years. }\end{array}$} & \multirow{2}{*}{\multicolumn{2}{|c|}{$\begin{array}{c}\text { Total } \\
\text { height. }\end{array}$}} & \multicolumn{12}{|c|}{ Height at - } \\
\hline & & & & & & & & & $\begin{array}{c}10 \\
\text { yrs. }\end{array}$ & $\begin{array}{c}\text { go } \\
\text { srs. }\end{array}$ & $\begin{array}{l}30 \\
\text { srs. }\end{array}$ & $\begin{array}{r}40 \\
\text { yrs. }\end{array}$ & $\begin{array}{l}50 \\
\text { yrs. }\end{array}$ & $\begin{array}{c}60 \\
\text { yra. }\end{array}$ & $\begin{array}{l}\text { z0 } \\
\text { Jrs. }\end{array}$ & $\begin{array}{c}\text { so } \\
\text { yrs. }\end{array}$ & $\begin{array}{c}90 \\
\text { yrs. }\end{array}$ & $\begin{array}{l}100 \\
\text { rrs. }\end{array}$ & $\begin{array}{l}110 \\
\text { gre. }\end{array}$ & $\begin{array}{l}120 \\
\text { yrs. }\end{array}$ \\
\hline $\begin{array}{l}1 \ldots \\
2 \ldots \\
3 . . . \\
4 \ldots \\
5 \ldots\end{array}$ & $\begin{array}{r}\text { Year: } \\
58 \\
59 \\
61 \\
64 \\
70\end{array}$ & $\begin{array}{c}\text { Inches. } \\
18 \\
14 \\
12 \\
15 \\
15\end{array}$ & $\begin{array}{c}\text { Inches. } \\
13 \\
10 \\
73 \\
10 \\
114\end{array}$ & $\begin{array}{r}\boldsymbol{F} t . \\
50 \\
30 \\
33 \\
28 \\
43\end{array}$ & $\begin{array}{r}\text { In. } \\
0 \\
0 \\
0 \\
6 \\
6\end{array}$ & $\begin{array}{r}\text { Inches. } \\
66 \\
69 \\
48 \\
56 \\
50\end{array}$ & $\begin{array}{l}F t . \\
80 \\
67 \\
78 \\
70 \\
84\end{array}$ & $\begin{array}{r}I n . \\
10 \\
6 \\
3 \\
2 \\
6\end{array}$ & $\begin{array}{c}\text { Feet. } \\
15 \\
10 \\
12 \\
11 \\
11 \frac{1}{2}\end{array}$ & $\begin{array}{r}\text { Feet. } \\
28 \\
20 \\
25 \\
24 \\
30\end{array}$ & $\begin{array}{c}\text { Feet. } \\
42 \\
31 \\
37 \\
36 \\
46\end{array}$ & $\begin{array}{r}\text { Feet. } \\
55 \\
45 \\
47 \\
47 \\
60\end{array}$ & $\begin{array}{r}\text { Feet. } \\
69 \\
57 \\
62 \\
58 \\
68\end{array}$ & $\begin{array}{c}\text { Feet. } \\
\cdots \ldots . \\
\cdots \\
77 \\
68 \\
76 \frac{1}{2}\end{array}$ & 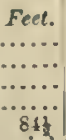 & $\begin{array}{c}\text { Feet. } \\
\ldots \ldots \\
\ldots \ldots \\
\ldots \ldots \\
\ldots \ldots \\
\ldots \ldots\end{array}$ & $\begin{array}{l}\text { Feet. } \\
\ldots \ldots \\
\cdots \ldots \\
\cdots \ldots \\
\cdots \ldots \\
\cdots\end{array}$ & $\begin{array}{l}\text { Fert. } \\
\cdots \ldots . . \\
\cdots \ldots \ldots \\
\cdots \ldots \\
\cdots \ldots\end{array}$ & $\begin{array}{c}\text { Feet. } \\
\ldots \ldots . \\
\ldots \ldots \\
\ldots \ldots \\
\ldots \ldots \\
\ldots \ldots\end{array}$ & $\begin{array}{l}\text { Feet. } \\
\cdots \ldots . \\
\cdots \ldots \\
\ldots \ldots \\
\ldots \ldots \\
\ldots \ldots \\
\ldots \ldots\end{array}$ \\
\hline 6... & 82 & 113 & 81 & 38 & 0 & 72 & 91 & 1 & & Only & & cut; & loight & at fift & y-cigh & $t$ years & $8,61 \mathrm{fet}$ & 10 in & nches. & \\
\hline $7 .$. & 84 & $20\}$ & 13 & 38 & 8 & 40 & 100 & 8 & 9 & 21 & 39 & 54 & 71 & 82 & 91 & 99 & ... & $|\cdots \cdot \ldots|$ & & - \\
\hline $8 .$. & 83 & 23 & 104 & 45 & 6 & be & 01 & 6 & 9 & 19 & 28 & 41 & $5:$ & 63 & 75 & 86 & & & & \\
\hline $9 \ldots \ldots \ldots$ & 85 & 18 & 12 & 39 & 4 & 62 & 92 & 7 & 8 & 16 & 26 & 39 & 52 & 04. & 76 & 87 & ...... & $\cdots \cdots$ & .... & ...... \\
\hline $10 \ldots \ldots \ldots \ldots$ & $\begin{array}{l}87 \\
87\end{array}$ & $\begin{array}{l}25 \\
19 t\end{array}$ & $\begin{array}{l}18 \\
128\end{array}$ & $\begin{array}{l}49 \\
40\end{array}$ & $\begin{array}{r}10 \\
4\end{array}$ & 36 & 104 & 10 & $\begin{array}{l}8 \\
9\end{array}$ & 10 & $\begin{array}{l}28 \\
35\end{array}$ & 47 & 66 & 78 & 87 & $\begin{array}{l}97 \\
93\end{array}$ & ….... & $\cdots \cdots$ & & \\
\hline & 108 & 32 & $21 \frac{\pi}{4}$ & 52 & 6 & 28 & 112 & 9 & 13 & 25 & $\begin{array}{l}35 \\
39\end{array}$ & $\begin{array}{l}48 \\
53\end{array}$ & 60 & 79 & 86 & 92 & 99 & $10 \dot{\theta}^{*}$ & & $\because$ \\
\hline & 109 & 31 & $21^{\circ}$ & B] & 4 & 40 & 112 & 9 & & & & & Not & cut in & & ton6. & & & & \\
\hline & 117 & 29 & 23 & 57 & 0 & $\because \cdots$ & 101 & 10 & 14 & 27 & 40 & 48 & 55 & 62 & 69 & 76 & 83 & 90 & 97 & \\
\hline & 122 & 23 & 16 & 55 & 0 & 30 & 107 & 5 & 8 & 16 & 25 & 36 & 49 & 62 & 70 & 77 & $8 t$ & 92 & 99 & 1061 \\
\hline & 123 & 28 & 19 & 50 & 0 & 24 & 27 & 4 & 10 & 21 & 35 & 52 & 58 & 63 & 69 & $7 t$ & 80 & 85 & 90 & $96^{\circ}$ \\
\hline
\end{tabular}

NOTES TO TABLE III.

So. 1. North Berwick, Mte, uear foot of hill sloplng to gortí, growth, denge; apparently abaudoned farm land; shailow, sandy soil.

No. 2. South Berwick, Mo.; thrify second grow tb, In ralley of Great Works hiver; exhaustcd farm land on grautio formation; ent over 20 feet deep, weil stocked with whito Plue.

No. 3. North Berwlck, Me.; near foot of hlll sloping to north; growth, deuse; apparently ahandoned farm land; shallow, sandy" soll.

No. 4. Sorth Berwick, Me.; near foot of hill sloplag to north; growth, denso; apparently abaudoued farm laud; shallow, saniy soil.

No. 3. South Berwick, Mo.; tirifty second growth, In vallos of Great Works Firer; exhausted farn land ou granitic formation; sand over 23 fcot deep, well stocked with White Pine.

Nos, 6-16. Norih Berwlck, 3lc.; near fout of hill sloping to north ; growth, deuse; apparently ahandoned farm land; sballow, saudy goil.

I)EYLLOPMENT IX THE FOREST.

In the dense forest the same general law of development, namely, of slow and rapid stages, prevails for dominant trecs as is exemplified by the foregoing measurements of trees grown in the fieli, although the quantitative progress varies somewhat. According to the relative amount 
of light at the disposal of the erown the rate of growtli differs, and there is found, therefore, in the forest trees, though very nearly the same age, trees of different heights, aeeording to the sueeess of the struggle for light whieh they have had with their neighbors. At every stage of the devel. opment of a forest growth, after its juvenile period, the trees can be elassified in to dominant, the tallest, whieh grow with their entire erown in full enjoyment of light and spaee, overtopping their neighbors; codominant, whieh, although of same height, have their erowns narrowed in, but still nnimpeded at the top; while others (oppressed) are pressed in from sides and top, and finally are eutirely suppressed and die. This relationship of individuals ehanges from time to time, some of the eodominant gradually falling into the elass of oppressed, and of these a large number become suppressed. Oeeasionally a eodominant beeomes dominant, or an oppressed one, by liberation of its oppressors, through storms or aecident, fulds opportunity to push forward and make np for lost time. Thus, a natural growth may start with a huudred thonsaud seedlings per aere; by the twentieth year these will have been redueed by death to 6,000 , aud by the hundredth year hardly 300 may be left, the rest having sueembed under the shade of the survivors.

It is owing to these elanges that in analyzing tree growth we find great, often unaeeountable, variation in the rate of growth of eren the same individual, and henee, in order to reegnize the average, a very large number must be measured to even out the deviations from the law.

For the same reasou it is desirable to elassify the trees as indieated above and aseertain the rate of growth of trees grown uuder different light eonditions. To be sure trees behave also somewhat differently under varying conditions of soil, elimate, and exposure; henee, a further elassifieation is necessary if it is desired to establish more than the mere general law of progress and also to aseertain the influenee of these variable eonditions.

In a general way, we find, as in the trees grown in the open, the slow seedling stage followed by a very rapid inerease in the annual rate of growth, begiming with the sixth year and reaehing a maximum of 16 inehes with the tenth year iu dominant trees. With trees which have not enjoyed aceess to light to the same extent the maximum oceurs later; henee, in eorlominant trees it is reached, with 13 inelies, in the twentieth year, while the oppressed trees reach their maximum eurrent aeeretion still later, nauely at forty years, with less than 12 iuehes for the year. As soon as this highest rate is reaehed deeline takes place gradually in all elasses, mueh faster in the dominant trees than in the less-favored ones, whieh deeline in the rate of aunual height growth mueh more slowly.

By the one hundreth year the anlual height growth is redueed to from 6 to 7 inehes, the dominant trees slowiug the lower rate, which eontinues to deeline until about the one hnudred and sixtieth to one hundred and seventieth year, when all tree elasses have eome to a rate of about 2 incles, at whieh they eontinue to grow, slowly but evenly, for another eentury.

This persistenee of the height growth, which makes old trees tower 40 to 50 feet above their broad-leafed neighbors, influenees also the shape of the erown, whieh does not flatten, as is the ease with most pines. Very old trees, four hundred years and over, rarely exeeed a height of 160 feet, although exeeptional iudividuals have beeu found of the unusual height of 200 feet.

It will thus appear that the prineipal height growth is made during the first century, the seeond eentury noting a persistent but only slow progress.

If we take the average of all the yearly aeeretions at any oue year of the life of the tree (the average annual aeeretion at that year), the influenees whieh have been at work during the whole lifetime are of course refleeted; therefore, sinee the juvenile period shows a slow growth, the average aceretion attains its maximnm mueh later. This eulmination of the average anuual aecretion takes place mueh earlier in the more favored tree elasses, namely, at about the twentieth to fortieth year, after that deelining, while in the oppressed it does not oecur until the seveutieth year, maintaining itself afterwards for a long period.

This differenee would also appear if we eompared better and poorer sites. In other words, when the annual rate of growth is slow it remains more persistent than when it is rapid. The persistenee noted in oppressed trees indieates also the shade enduranee of the species. From Table IV, whiel gives the aeeretions from deeade to deeade (periodie aecretion), we see the eapaeity of the species to thrive in spite of the shade, even in later stages of its life. Even after ninety years of oppression, when the tree is given opportunity by inerease of light, it is still able 
to make as good an anunal height growth as its more-favored neighbors, and can eontinue the same to the second eentury. From the table of heights at various ages it is learued that the success in the juveuile stages after all tells on the total height growth.

TABLE IV.-Periodic height growth, by decades, of dominant, codominant, and oppressed pine.

\begin{tabular}{|c|c|c|c|c|c|c|c|c|c|c|c|c|c|c|c|c|c|c|c|c|c|c|c|c|c|}
\hline \multirow{2}{*}{ Claะs. } & \multicolumn{25}{|c|}{ Ducates. } \\
\hline & $I$ & $\mathbf{Z}$ & 8 & 4 & 5 & 6 & 7 & 8 & 9 & 10 & II & 12 & 18 & 14 & I5! & 16 & 17 & Is & 19 & 20 & 21 & $2 \pm$ & 23 & 24 & 25 \\
\hline 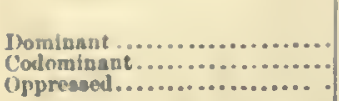 & $\begin{array}{r}F t \\
8 \\
1 \\
4\end{array}$ & $\begin{array}{r}F t . \\
12 \\
12 \\
8\end{array}$ & $\begin{array}{r}F \mathrm{~L} \\
13 \\
10 \\
7\end{array}$ & $\begin{array}{r}F C_{2} \\
13 \\
10 \\
8\end{array}$ & $\begin{array}{c}F Y . \\
11 \\
12 \\
9\end{array}$ & $\begin{array}{r}F t_{0} \\
10 \\
6 \\
9\end{array}$ & $\begin{array}{c}F t \\
8 \\
8 \\
8\end{array}$ & $\begin{array}{c}F \gamma . \\
7 \\
8 \\
8\end{array}$ & $\begin{array}{c}F c \\
6 \\
7 \\
6\end{array}$ & $\begin{array}{c}F t . \\
0 \\
0 \\
6\end{array}$ & $\begin{array}{c}F y . \\
5 \\
5 \\
0\end{array}$ & $\begin{array}{r}F Y . \\
5 \\
5 \\
5\end{array}$ & $\begin{array}{r}F t \\
4 \\
4 \\
5\end{array}$ & $\begin{array}{r}F t \\
3 \\
4 \\
4\end{array}$ & $\begin{array}{r}F t \\
3 \\
3 \\
1\end{array}$ & $\begin{array}{r}F t . \\
3 \\
3 \\
4\end{array}$ & $\mid \begin{array}{c}F t \\
3 \\
2 \\
2 \\
3\end{array}$ & $\begin{array}{c}F t . \\
3 \\
21 \\
3\end{array}$ & $\begin{array}{c}F t \\
3 \\
2 \\
3\end{array}$ & $\begin{array}{c}F y . \\
3 \\
2 \\
21\end{array}$ & $\begin{array}{r}\boldsymbol{F} t \\
3 \\
2 \\
2\end{array}$ & $\begin{array}{c}F \\
\cdots \\
2 \\
\ldots\end{array} \mid$ & $\left|\begin{array}{c}F t \\
\cdots \\
2 \\
\cdots\end{array}\right|$ & $\begin{array}{c}F t \\
\cdots \\
2 \\
\cdots\end{array}$ & $\begin{array}{c}F Y . \\
\cdots \\
\cdots\end{array}$ \\
\hline
\end{tabular}

\section{Effeet of composition of forest upon height grouth.}

The height development of White Pine seems to progress more rapidly when it grows mixed with other speeies. A striking instance showing low the height growth of White Pine is benefited by the presence of other species is given in the diagram (fig. 2), which represents the height growth of White Pine taken from two sites $(a$ and $b)$ in Presque Isle County, Mieh. The sites

Fin. 2.-Diagrau showlng height growth of 11 hite Pine in Presque Inle County, Mlleh.: SIte $a_{1}$ In mlsed growth; sIto $b$, in pure growth.

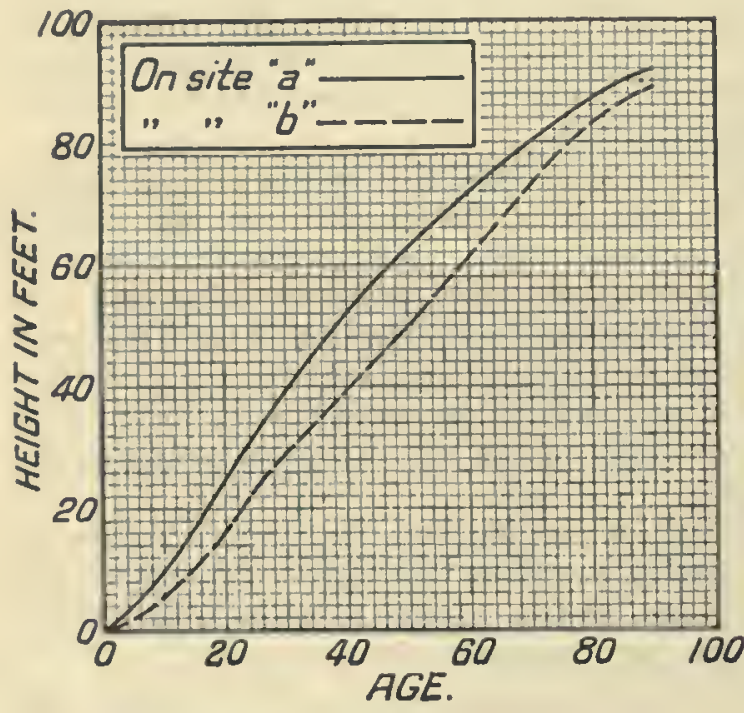
were about 5 or 6 miles distant from each other. The soil and the moisture conditions on both sites were apparently identical (fresh sand), as were the total number of trees to the acre (the sample area on site $a$ contained 181 trees and that on site $b 159$ trees) and the agc of the trees and their distribution over the ground (density of erown cover). The only difference found between the sample areas staked off on both sites was the composition of the forcst. Site $a$ consisted of a mixed growth of Norway and White Pine, while site $b$ represented practieally a pure growth of White Pine save a few small Hemlock and an occasional Norway Pine. The diagram shows that the White Pine on site $a$ was exceed. ingly stimulated in its height growth by the presence of the Norway Pine.

The associated speeies entering into the struggle for light with the Whitc Pine naturally affect the progress of the height growth of the pine. The effects of the associated species npon the height growth of White Pine and the period of their influenee depend upon the capacity of the associated species to grow in height as well as upon the time when the assoeiated species are either introduced among the pine or received it under their shelter. In case, for instance, hardwoods accompany White Pine from the very start the influence of the hardwood upon the height growth of the pine will last only for the first sixty or seventy years, that is, up to the age at which most of the hardwoods practically reach their maximum height. In case the Norway Pine or the Hemloek stairts simnltaneonsly with the White Pine, the height growth of the White Pine will be stimulated to a cousiderably later age, beenuse the Henloek or Norway Pine eontinues to grow in height at a similar rate for a longer time. When the White Pine happens to start on gronnd already covered with other species in such a manner as not to be interfered with in its growth the assoeiatcil speeies, if capable of growing in height to a later age, will stimulate the height growth of the White Pine for a considerably longer period. All this is clearly demonstrated in the accompanying diagram (fig. 3), representing the height growth of White Pine taken from three sites $(f, k$, and $i)$ of identically the same conditious except as to composition of the forest and the difference in the ages between the pine and associated specics. All three sites had a well-diained clayey loam underlaid by a laminated shale of indefinite depth. The White Pine on site $f$ (Clear. fiell Connty, Pa.) was mixed with Hewlock of a large size; the pine on this site had started 
among the Hemloek, whieh stimulated the height growth of the pine during all its lifetime. The White Piue on site $k$ (Jefferson County, Pa.) was mixed with Hemlock of a small uumerchantable size. The pine here had started simnltaneously with the Hemlock, wlieh stimulated the height growth of the pine only for a eertain period, after which the Hemlock, being overtopped by the pine, was out of the struggle and left in the eapaeity of an underwood. The White Pine on site $i$, whieh merged into site $k$, was mixed with bardwoods, whieh stimulated the height growth of the pine for the first sixty years, when the hard woods reaehed their maximum height and then withdrew from the eompetition, leaving the pine to inercase the height on its own aceount.

The influenee of elimate and soil on height growth will further appear from a study of the tables in the Appendix. This influence on height growth is not very great, if we eonfine our inquiry to regions of best development, the differenee rarely exeeeding from 5 to 10 per eent.

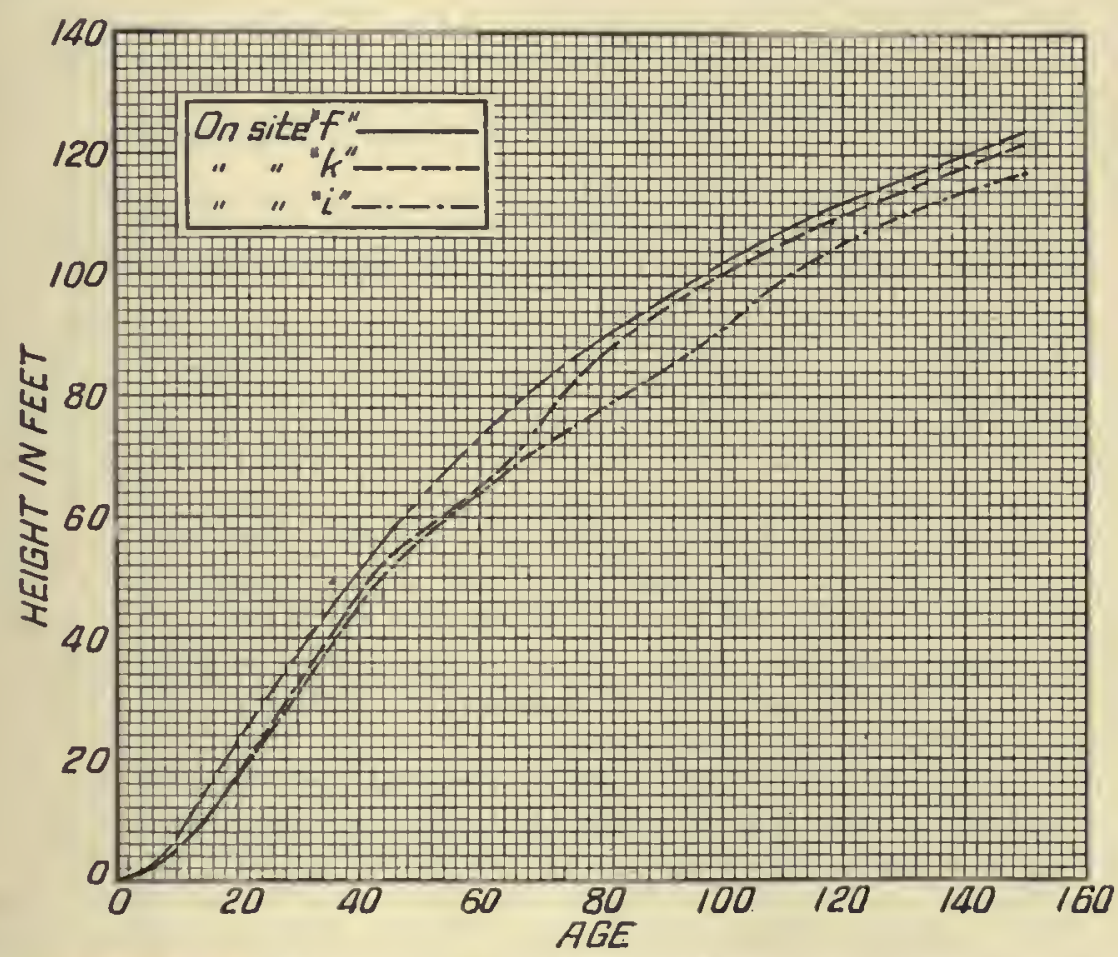

Fto.3.-Diagram shuwing height growth of White Pne in forest of varying compesition in Ponusylvania: Sito $f$, Clearfield County; sites $\boldsymbol{k}$ and $i$, Jefferson County.

\section{Effect of locality upon height gronoth.}

Comparing the growth in different localities, it appears that the trees from Feunsylvania started at a lower rate than those in all other loealities, but after the twentieth to the twenty-fifth year they surpass all others. If tlis ean be aecepted as eorrect, the deduetion of the development in early youth from old trees being subjeet to errors, it may be explained by the fact that these trees grew in mixture with Hemloek and were kept baek by the shade of their neighbors, but when they had outgrowl these they felt the stimulus exerted by thein.

The trees from Maine and Wisconsin, also starting more vigorously than those from Michigan, declinc and sink below the Micligan trees between the eightietl and ninetieth year, which may for Wiseousin be possibly explained by the retarding influenee of winds after the pines have outgrowu the hardwoods, while in Maine the poorer soil may aecount for it. Michigan, with its tempered lake elimate, presents a most regular and persistent height curve, eoming nearest to the average of all loeations.

In colominant and oppressed trees these differcices do not come to an expression, but sinee the classification is somewhat doubtful and variatious within wide ranges are possible, these data are liardly to be used for eomparison as to locality effects.

$$
20233-\text { No. } 22-3
$$




\section{GROWTH IN THICKNESS.}

The growth in thickiness, or dianeter accretion, althongh remarkably regular in this species, is much more variable, but it is alsn more persistent, than the lieight growth, as will a plyear from the following comparisons: Thus, in five groups of trees from different sites, ninety-fonr to oue hundrel and nine years old, the heights differ only by a little over 8 per cent, varying from 91 to $9 S_{\frac{1}{2}}^{+}$feet, while the diameters differed by almost 50 per cent, varying from 16 to 23.7 iuches. A gain the persistence is illnstrated by the comparison of the height growth of five groups from two hundred and seven to two lundred and thirty-three years old, which showed an increase over the gromp just inentioned of somewhat over 20 per cent, while the diameters were by 30 per cent greater; and if the poorest groups of the tro sets lad been compared the difference would have been still more striking, namely, 15 per cent for the height as against 37 per cent for the diameter's.

This is in part explained by the fact that, where the seedling springs up in the virgin forest, it is very apt to be suppressed for a longer or shorter period by the large mother trees and the host of deciduons and other forms which make up the forest cover. While the height growth is by this slade also inpeded, this is not so to the same degree as the diameter, which is a direct function of the amount of foliage that is at work.

'The sapling may thus remain a slender polo for many years, and not until it is able to lift its head above its erowding ueighbors, or nutil light has been arlmitted to its branches, does it begin to expand its crown and consequently thicken its stem.

In managed forests, or in tracts where from any cause crowding has been prevented, the growth in diameter progresses somewhat more in the manner of the height growth, namely, slowly at first, then rapidly nutil the maximum is attained, when a slowly decreasing rate sets in. In the seedling the diameter growth is exceedingly small, very rapid in the yonng trees, when the anmul ring is often one-sixth to one-half of an inch wide, but decreases with the slower rate of height growtl. When the tree is sixty to eighty years old, the ycarly ring is commonly not unore than one-twelfth of an inch wide; it then gradually sinks to one-fifteenth of an inch, which is then maintained throughout life, rarely falling to one twenty-fifth of an inch.

The average annnal accretion reaches its maximum about the fiftieth to the sixtieth year with somewhat over one-fiftli of an inch on the diameter of dominant trees, which rate is nearly maintained to the one hundred and fifticth year.

Thrifty trees at forty years of age grown in the forest, measure from 6 to 9 inches in diameter breast high; at fifty yenrs, from ro to 12 inches; at eighty years, 15 to 17 inches; and they reach a diameter of 18 to 20 inches by the time they are a hundred years old.

To attain a diameter of 30 to 40 inches, which represents the best merchantable material of days now almost passed, more than two hundred years have been required, while trees four hundred to four luundred and fifty years old attain diameters of 50 to 60 inches and over. Trees of 40 inches dianeter at three hundred years were by no means rare.

To be sure, there are exceptional individnals which exceel these dimensions, and variation in the rate of growth, due to soil, climate, and surrounding conditious, are naturally as frequent as in heiglit growth.

The progress of dianneter development of dominant, codominant, and oppressed tree classes, and in different localities, is exhibited in the tables and diagrams in the Appendix.

The usual method is to (letermine the diameters at $4 \frac{1}{2}$ feet from the ground (breast high), not ouly beenuse when measuring standing trees the measurement is most conrenieutly made at this height, but beeause the lower diameters show. much mors irregularity. There is also more wood deposited near the base at and above the root collar, giving rise to the so-ealled root swelling (butt swelling), uudoubtedly a provision to strengthen the stability of the tree. Unfortunately for the investigations here recorded, it was not practicable to have the trees cut and inensured at breast ${ }^{*}$ height, since the measurements were made on trees felled in regnlar lumbering operations, exposing ouly the cross sections at the height of the stump, mostly $2 \frac{1}{2}$ feet above ground, and at log lengths. Eren at that height (2.3 feet above ground), a difference in the progress of diameter growth from that on higher cross sections is noticeable and becomes especially pronounced in later life, as is shown in the curves representing the progress of dianeter growth on cross sections at varions heights.

The dianeters lere given for the lowest section are, therefore, somewhat lirger than those usually employed, namely, breast higl, especially in later years. 
The higher sections exhbit not only a regular course, but an entirely similar one, from cross seetion to cross section. There is no reasou to assume that the course at breast lieight would not follow the same law; therefore there ean be eonstrueted a eurve for this height similar to the eurves of higher seetious, using for guide points the data obtained from a series of measurements made to establish the yield of pine in which trees were measured at breast height (compiled in tables in the Appendix). This has beeu done on the diagram iu the Appendix, wlieh shows the diameter development of different eross scctions for dominant trees. From this ean be read the following average dimeusious as approximating the dianeters of each deeade, leaving out the uneertaiu juvenile stage:

Diameter, breast high, of White Pine (averages approximated), in inches.

\begin{tabular}{|c|c|c|c|c|c|c|c|c|c|c|c|c|c|c|c|c|c|c|}
\hline \multicolumn{19}{|c|}{ Decade. } \\
\hline 20 & 30 & 40 & 50 & 60 & 50 & so & 90 & 100 & 110 & 120 & 130 & 140 & 150 & 160 & 170 & 150 & 190 & 200 \\
\hline $\begin{array}{l}I n . \\
4.5\end{array}$ & $\begin{array}{l}I n . \\
5.5\end{array}$ & ${ }_{8}{ }_{8}$ & ${ }_{11.5}^{I n}$ & $\begin{array}{l}\text { In. } \\
13.5\end{array}$ & $I_{15}$ & $\begin{array}{l}\text { In. } \\
16.5\end{array}$ & $\begin{array}{l}\text { In. } \\
17.8\end{array}$ & $\begin{array}{r}I n . \\
19\end{array}$ & $\begin{array}{c}\text { In. } \\
20.2\end{array}$ & $\underset{21.3}{I n}$ & $\underset{22.2}{I n}$ & ${ }_{23} n_{2}$ & $\begin{array}{l}I n . \\
23.8\end{array}$ & ${ }_{24.5}^{I n .}$ & $\begin{array}{l}I n . \\
25.2\end{array}$ & $\begin{array}{l}I n . \\
26.4\end{array}$ & $\begin{array}{l}I n . \\
26.8\end{array}$ & $\begin{array}{l}I n_{0} \\
27.5\end{array}$ \\
\hline
\end{tabular}

That these figures may be eonsiderably exceeded (even by 50 to 60 per eent) under favorable eonditions will appear from the various tables of measurements in the Appendix. Espeeially is this the case in the second-growth groves of pine.

As will be readily seen in the eurves after the juvenile stage, during whieh the diameter grows very slowly, an aeeeleration in the rate takes plaee, which soon reaches a maximum, eoutinning at that for a short time, and then slowly and persistently decliuing from about 3 inehes per decade between forty and fifty years to $1+$ inehes at one huudred years, and half that amount at two hundred years.

DETAIL MEASUREMENTS OF ANYUAL GaIN IN CIRCUMFERENCE.

An interesting set of most aceurate observations have been made and reported by Mr. Nathaniel Morton, of Plymouth, Mass., exhibiting 38 young trees of White Pine, which had sprung up amoug oak and other hardwoods, mixed with White Pine and a few Pitch Pine in an old, rather-neglected pieec of woods, aud whieh were measured every year from 1891 up to 1898. The trees stand rather opeu. The age varied from twenty-eight to forty-two years, most trees being between thirty aud thirty-six years old and their average age thirty-six years in 1891 .

In 1891 the arerage cross section 3 feet from ground was 131 square inehes; in 1898, 197 square inches; the growth 66 square inehes, or about 9 square inehes per year, one tree inaking 15 square inehes per year. This growth eorrespouds to a growth in circumferenee of about 1.3 inehes per year, or a growth in dianeter of four.tenths of au ineh per year.

The detail neasurements are given in the following table:

TABLE V.-Annual gain in circumference of White Pine trees in Massachusetts.

\begin{tabular}{|c|c|c|c|c|c|c|c|c|c|c|c|c|c|c|c|c|c|}
\hline \multirow{2}{*}{ Namber of tree. } & \multirow{2}{*}{$\begin{array}{l}\text { Clrenm- } \\
\text { ference } \\
\text { in } 1890 .\end{array}$} & \multicolumn{6}{|c|}{ Gain, in quarter inches. } & \multirow{2}{*}{$\begin{array}{l}\text { Total } \\
\text { in six } \\
\text { years. }\end{array}$} & \multirow{2}{*}{ Number of tree. } & \multirow{2}{*}{$\begin{array}{l}\text { Cirenu- } \\
\text { ference } \\
\text { in } 1890 .\end{array}$} & \multicolumn{6}{|c|}{ Gain, in quarter inches. } & \multirow{2}{*}{$\begin{array}{l}\text { Total } \\
\text { in six } \\
\text { years. }\end{array}$} \\
\hline & & 1891 & 1592 & 1598 & 1804 & +1895 & 1596 & & & & 1891 & 1892 & 1893 & 1894 & 1895 & 1896 & \\
\hline 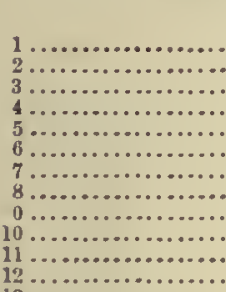 & $\begin{array}{c}\text { Inches. } \\
55 \\
26 \\
26 \\
50 \\
28 \\
383 \\
44 \\
27 \\
35 \\
40 \\
34 \\
22 \\
\end{array}$ & $\begin{array}{l}3 \\
3 \\
4 \\
1 \\
1 \\
0 \\
1 \\
2 \\
3 \\
2 \\
1 \\
3\end{array}$ & $\begin{array}{l}5 \\
6 \\
5 \\
1 \\
3 \\
1 \\
3 \\
3 \\
3 \\
4 \\
2 \\
2\end{array}$ & $\begin{array}{l}5 \\
5 \\
6 \\
2 \\
4 \\
3 \\
4 \\
4 \\
3 \\
6 \\
4 \\
4\end{array}$ & $\begin{array}{l}5 \\
6 \\
6 \\
2 \\
3 \\
3 \\
4 \\
3 \\
6 \\
6 \\
3 \\
5\end{array}$ & $\begin{array}{l}4 \\
4 \\
5 \\
3 \\
3 \\
1 \\
2 \\
1 \\
4 \\
4 \\
3 \\
3 \\
3 \\
3\end{array}$ & $\begin{array}{l}5 \\
5 \\
6 \\
2 \\
3 \\
1 \\
2 \\
5 \\
4 \\
4 \\
4 \\
5\end{array}$ & $\begin{array}{l}27 \\
29 \\
32 \\
10 \\
15 \\
10 \\
18 \\
23 \\
22 \\
25 \\
17 \\
22\end{array}$ & 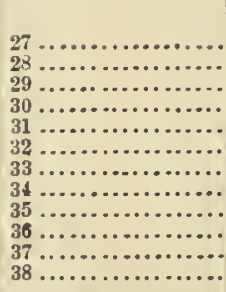 & \begin{tabular}{|c|c|} 
Inches. \\
31 i \\
47 \\
42 \\
$40 \frac{1}{2}$ \\
57 \\
44 \\
42 \\
44 \\
463 \\
$44 \frac{1}{2}$ \\
47 \\
$36 \frac{1}{2}$
\end{tabular} & $\begin{array}{l}4 \\
5 \\
4 \\
4 \\
0 \\
5 \\
1 \\
3 \\
4 \\
3 \\
4 \\
2\end{array}$ & $\begin{array}{l}6 \\
7 \\
4 \\
5 \\
2 \\
4 \\
5 \\
5 \\
4 \\
3 \\
4 \\
4\end{array}$ & $\begin{array}{l}6 \\
7 \\
6 \\
6 \\
5 \\
6 \\
5 \\
6 \\
6 \\
4 \\
7 \\
6\end{array}$ & $\begin{array}{l}7 \\
6 \\
5 \\
5 \\
5 \\
6 \\
4 \\
5 \\
4 \\
4 \\
5 \\
3\end{array}$ & $\begin{array}{l}7 \\
7 \\
5 \\
5 \\
4 \\
4 \\
5 \\
4 \\
5 \\
3 \\
4 \\
4\end{array}$ & $\begin{array}{l}8 \\
6 \\
5 \\
5 \\
4 \\
5 \\
5 \\
4 \\
5 \\
3 \\
5 \\
4\end{array}$ & $\begin{array}{l}38 \\
38 \\
29 \\
30 \\
20 \\
30 \\
25 \\
27 \\
28 \\
20 \\
29 \\
23\end{array}$ \\
\hline $13 \ldots \ldots \ldots \ldots \ldots \ldots \ldots$ & 337 & 1 & 4 & 7 & $\begin{array}{l}3 \\
5\end{array}$ & $\frac{2}{5}$ & $\begin{array}{l}2 \\
4\end{array}$ & $\begin{array}{l}16 \\
29 \\
28\end{array}$ & Total... & & 103 & 139 & 190 & 181 & 157 & 168 & 938 \\
\hline $15 \ldots \ldots \ldots \ldots \ldots \ldots \ldots \ldots \ldots \ldots$ & $\begin{array}{l}24 \\
201\end{array}$ & 3 & $\begin{array}{l}4 \\
5\end{array}$ & $\begin{array}{l}5 \\
6\end{array}$ & $\begin{array}{l}7 \\
6\end{array}$ & $\begin{array}{l}4 \\
5\end{array}$ & 4 & $\begin{array}{l}28 \\
31\end{array}$ & Total in inchea. & & $25 ?$ & 347 & $47 \frac{1}{1}$ & 451 & 394 & 42 & 2343 \\
\hline 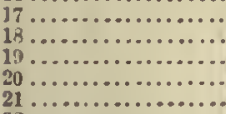 & $\begin{array}{l}284 \\
39 \\
483 \\
503 \\
493\end{array}$ & $\begin{array}{l}1 \\
1 \\
1 \\
2 \\
5\end{array}$ & $\begin{array}{l}3 \\
2 \\
1 \\
4 \\
6\end{array}$ & $\begin{array}{l}3 \\
4 \\
4 \\
5 \\
7\end{array}$ & $\begin{array}{l}4 \\
3 \\
2 \\
5 \\
6\end{array}$ & $\begin{array}{l}3 \\
3 \\
3 \\
4 \\
7\end{array}$ & $\begin{array}{l}3 \\
3 \\
2 \\
6 \\
6 \\
8\end{array}$ & $\begin{array}{l}17 \\
16 \\
13 \\
26 \\
39\end{array}$ & $\begin{array}{l}\text { Percentage of } \\
\text { gain as com. } \\
\text { pared } \mathrm{w} 1 \mathrm{tb} \\
\text { gain of } 1891 \ldots\end{array}$ & & 100 & 135 & 184 & 176 & 152 & 163 & \\
\hline $23 \ldots \ldots \ldots \ldots \ldots \ldots \ldots \ldots \ldots \ldots \ldots \ldots$ & $\begin{array}{l}49 \\
354\end{array}$ & $\begin{array}{l}4 \\
3\end{array}$ & $\begin{array}{l}2 \\
4\end{array}$ & $\begin{array}{l}3 \\
5\end{array}$ & $\begin{array}{l}6 \\
6\end{array}$ & $\begin{array}{l}5 \\
6\end{array}$ & $\begin{array}{l}4 \\
5\end{array}$ & $\begin{array}{l}24 \\
29\end{array}$ & Average gain & & & $=$ & & & & & \\
\hline 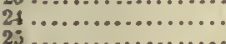 & 33 & 4 & 3 & 5 & 5 & 5 & 6 & 28 & per troo (in & & & & & & & & \\
\hline $\begin{array}{l}23 \ldots \ldots \ldots \ldots \ldots \ldots \\
26, \ldots \ldots \ldots \ldots\end{array}$ & $\begin{array}{l}51 \\
371\end{array}$ & $\begin{array}{l}2 \\
3\end{array}$ & $\begin{array}{l}3 \\
3\end{array}$ & $\begin{array}{l}6 \\
6\end{array}$ & $\begin{array}{l}5 \\
5\end{array}$ & $\begin{array}{l}5 \\
5\end{array}$ & $\begin{array}{l}7 \\
5\end{array}$ & $\begin{array}{l}28 \\
27\end{array}$ & & & กั0 & 100 & 188 & $\frac{1}{108}$ & 188 & 180 & \\
\hline
\end{tabular}


While the dianeter accretion deereases in rate continuously after the juvenile stage, the growth of the areas or layer of wood corresponding to the diameter increments follows by no incaus the same course.

After the juvenile stage, which is determined by the formation of a definite crowu, and when the diancter has attained at least 6 inches the cross-seetion area begins to increase in arithmetieal progression; a coustantly increasing rato prevails mintil a maximum is attained, whicli comes between the sixtieth and one hundred and twentieth year, and then continues remarkably uniform for a long period. No deeline is noticeable until after the second century has begun. In corloninant and oppressed trees the area as well as the diameter accretion move somewhat differently, the maximum rate coming later and lasting a shorter time, the decline foliowing soon after the maximnm.

FORM DEVELOPMENT, OR TAPER.

Sinee size of crown and light conditions regulate the amomt of diameter growth, it is evident that trees with well-dereloped fiee erowns form more wood than those crowded, the dominant more than the oppressed, and those on lawns more than those in the dense forest. Moreover, in these latter the wood is differently disposed along the trunk than in tile former. Not only do trees grown in the open throw their energy into branch growtl, but the accretion on the bole is laid on in layers, inereasing in width from top to base. The result is a more rapirl taper than in forestgrown trees, in which each annnal layer is wider at the top than at the base of the trec, producing thereby a more cylindrical form.

The following table exhibits in the measurements of six trees this variation in the widtli of the same annual rings at different heights, and also in general the mode of diameter growth in these trees. More elaborate tables, showing the cliameter growth of White Pine at various heights trom the ground for dominant, codominant, and oppressed trees in various parts of its rauge, together with diagrans, will be found in the Appendix:

Diameter growth of forest-grown trees at rarious heights from ground.

\begin{tabular}{|c|c|c|c|c|c|c|c|c|c|c|c|c|c|c|c|c|c|c|c|c|}
\hline \multirow{3}{*}{$\begin{array}{l}\text { Helght } \\
\text { of sec- } \\
\text { tion } \\
\text { from } \\
\text { ground. }\end{array}$} & \multicolumn{19}{|c|}{ Width of rings, in millimeters. } & \multirow{3}{*}{$\begin{array}{l}\text { Age of } \\
\text { tree. }\end{array}$} \\
\hline & \multicolumn{9}{|c|}{$\begin{array}{l}\text { Single groups of ten rings, beginning } \\
\text { at periphery. }\end{array}$} & \multicolumn{10}{|c|}{$\begin{array}{l}\text { Accumulative, ly groups of ten rings, beginning at } \\
\text { periphery. }\end{array}$} & \\
\hline & 1 & 2 & 3 & 4 & 5 & 6 & 7 & $\mathrm{~s}$ & 9 & 10 & 20 & 30 & 40 & 50 & 60 & 70 & so & 90 & 100 & \\
\hline $\begin{array}{r}\text { Feet. } \\
17 \\
33 \\
49 \\
68\end{array}$ & $\begin{array}{l}14 \\
15 \\
19 \\
27\end{array}$ & $\begin{array}{l}19 \\
21 \\
28 \\
58\end{array}$ & $\begin{array}{c}21 \\
32 \\
39 \\
\ldots . .\end{array}$ & $\begin{array}{c}17 \\
28 \\
27 \\
\ldots\end{array}$ & $\begin{array}{c}17 \\
34 \\
\cdots \\
\ldots\end{array}$ & 13 & 18 & 22. & .... & $\begin{array}{l}14 \\
15 \\
19 \\
27\end{array}$ & $\begin{array}{l}33 \\
36 \\
47 \\
85\end{array}$ & $\begin{array}{l}54 \\
68 \\
86\end{array}$ & $\begin{array}{r}71 \\
96 \\
113\end{array}$ & $\begin{array}{r}88 \\
130\end{array}$ & $\begin{array}{c}101 \\
\ldots \ldots . . \\
\ldots \ldots .\end{array}$ & 119 & $1 \$ 1$ & & & $\left\{\begin{array}{r}\text { Years. } \\
115\end{array}\right.$ \\
\hline $\begin{array}{l}16 \\
34 \\
50 \\
66\end{array}$ & $\begin{array}{r}9 \\
14 \\
16 \\
19\end{array}$ & $\begin{array}{l}10 \\
16 \\
22 \\
19\end{array}$ & $\begin{array}{l}16 \\
23 \\
25 \\
32\end{array}$ & $\begin{array}{l}20 \\
27 \\
37\end{array}$ & $\begin{array}{l}21 \\
31 \\
40\end{array}$ & $\begin{array}{c}40 \\
52 \\
\ldots . . \\
\ldots . .\end{array}$ & 39 & $\cdots$ & $\begin{array}{c}\ldots . . \\
\cdots . . \\
\cdots . . \\
\cdots\end{array}$ & \begin{tabular}{r|r}
9 & \\
14 & 16 \\
19 &
\end{tabular} & \begin{tabular}{l|l}
19 & 3 \\
30 & 5 \\
38 & \\
38 & $?$
\end{tabular} & $\begin{array}{l}\mathbf{3 5} \\
53 \\
63 \\
70\end{array}$ & $\begin{array}{r}55 \\
80 \\
100\end{array}$ & $\begin{array}{r}76 \\
111 \\
140\end{array}$ & $\begin{array}{c}116 \\
163 \\
\cdots \cdots \\
\cdots . .\end{array}$ & 155 & & & & 100 \\
\hline $\begin{array}{l}18 \\
34 \\
50 \\
68\end{array}$ & $\begin{array}{l}11 \\
12 \\
13 \\
14\end{array}$ & $\begin{array}{l}13 \\
15 \\
17 \\
25\end{array}$ & $\begin{array}{l}16 \\
18 \\
23 \\
24\end{array}$ & $\begin{array}{l}15 \\
20 \\
31 \\
35\end{array}$ & $\begin{array}{l}15 \\
22 \\
30 \\
42\end{array}$ & $\begin{array}{c}20 \\
36 \\
39 \\
\ldots . .\end{array}$ & $\begin{array}{l}32 \\
50\end{array}$ & 48 & $\begin{array}{c}\ldots . . \\
\cdots . . . \\
\cdots . . .\end{array}$ & $\begin{array}{l}11 \\
12 \\
13 \\
14\end{array}$ & $\begin{array}{l}24 \\
27 \\
30 \\
39\end{array}$ & $\begin{array}{l}40 \\
45 \\
53 \\
63\end{array}$ & $\begin{array}{l}55 \\
65 \\
84 \\
98\end{array}$ & $\begin{array}{r}70 \\
87 \\
123 \\
140\end{array}$ & $\begin{array}{r}90 \\
123 \\
102\end{array}$ & $\begin{array}{l}122 \\
173\end{array}$ & $\begin{array}{c}170 \\
\cdots \cdots\end{array}$ & & & 105 \\
\hline $\begin{array}{l}10 \\
28\end{array}$ & $\begin{array}{l}13 \\
20\end{array}$ & $\begin{array}{l}26 \\
24\end{array}$ & $\begin{array}{l}21 \\
28\end{array}$ & $\begin{array}{l}24 \\
31\end{array}$ & $\begin{array}{l}24 \\
39\end{array}$ & 28 & ... & $\ldots$ & .... & $\begin{array}{l}13 \\
20\end{array}$ & $\begin{array}{l}39 \\
44\end{array}$ & $\begin{array}{l}60 \\
72\end{array}$ & $\begin{array}{r}84 \\
103\end{array}$ & $\begin{array}{l}108 \\
142\end{array}$ & $\begin{array}{l}136 \\
170\end{array}$ & 177 & & & & \\
\hline $\begin{array}{l}42 \\
58 \\
76\end{array}$ & $\begin{array}{l}19 \\
20 \\
24\end{array}$ & $\begin{array}{l}28 \\
33 \\
19\end{array}$ & $\begin{array}{c}31 \\
45 \\
\cdots . .\end{array}$ & 41 & $\cdots$. & & $\ldots$ & $\begin{array}{ll}\cdots \\
\ldots\end{array}$ & $\cdots$ & $\begin{array}{l}19 \\
20 \\
24\end{array}$ & \begin{tabular}{l|l}
47 & 7 \\
53 & 7 \\
03 &.
\end{tabular} & $\begin{array}{c}78 \\
08 \\
\cdots\end{array}$ & 119 & $\begin{array}{ll}155 \\
\cdots . . .\end{array}$ & & & & & & 102 \\
\hline $\begin{array}{l}18 \\
84 \\
50 \\
66\end{array}$ & $\begin{array}{l}19 \\
23 \\
24 \\
25\end{array}$ & $\begin{array}{l}25 \\
33 \\
34 \\
35\end{array}$ & $\begin{array}{c}27 \\
85 \\
34 \\
\ldots . .\end{array}$ & $\begin{array}{l}28 \\
14 \\
40\end{array}$ & $\begin{array}{l}26 \\
31\end{array}$ & $\begin{array}{l}31 \\
\cdots \\
\cdots\end{array}$ & 35 & & $\begin{array}{c}\ldots . . \\
\ldots . . . \\
\ldots . .\end{array}$ & $\begin{array}{l}19 \\
23 \\
24 \\
25\end{array}$ & $\begin{array}{l}44 \\
56 \\
58 \\
60\end{array}$ & $\begin{array}{c}-71 \\
91 \\
92 \\
\ldots . .\end{array}$ & $\begin{array}{r}99 \\
135 \\
132\end{array}$ & $\begin{array}{c}125 \\
160 \\
\cdots \ldots . .\end{array}$ & $\begin{array}{l}156 \\
\ldots \ldots\end{array}$ & $\begin{array}{c}191 \\
\cdots \cdots . . \\
\cdots . . .\end{array}$ & ?....... & & & 110 \\
\hline $\begin{array}{l}18 \\
42 \\
58 \\
70 \\
86\end{array}$ & \begin{tabular}{l|}
13 \\
13 \\
13 \\
16 \\
11
\end{tabular} & $\begin{array}{l}18 \\
19 \\
21 \\
25 \\
20\end{array}$ & $\begin{array}{l}21 \\
20 \\
22 \\
25 \\
29\end{array}$ & $\begin{array}{l}21 \\
22 \\
26 \\
32 \\
\ldots . .\end{array}$ & $\begin{array}{l}24 \\
25 \\
27 \\
35\end{array}$ & $\begin{array}{l}25 \\
27 \\
32\end{array}$ & $\begin{array}{l}21 \\
35 \\
40\end{array}$ & $\begin{array}{l}21 \\
32 \\
32\end{array}$ & \begin{tabular}{c|}
18 \\
23 \\
$\ldots .$. \\
$\cdots .$. \\
$\cdots .$.
\end{tabular} & $\begin{array}{l}13 \\
13 \\
13 \\
16 \\
11\end{array}$ & \begin{tabular}{l|l}
31 & 5 \\
32 & 5 \\
34 & \\
41 & \\
40 &
\end{tabular} & $\begin{array}{l}52 \\
52 \\
56 \\
66 \\
69\end{array}$ & $\begin{array}{l}73 \\
74 \\
82 \\
98\end{array}$ & $\begin{array}{r}97 \\
99 \\
109 \\
133\end{array}$ & $\begin{array}{l}122 \\
126 \\
141\end{array}$ & $\begin{array}{l}143 \\
161 \\
181\end{array}$ & $\begin{array}{l}164 \\
193 \\
213\end{array}$ & $\begin{array}{l}182 \\
216\end{array}$ & $\begin{array}{c}193 \\
\ldots \ldots\end{array}$ & 165 \\
\hline
\end{tabular}

From sueh tabulations the taper, faetor of shape, or form faetor, may be derived (see Tables II and $\mathrm{V}$ in Appendix), whieh denotes the deviation of the shape of the tree from a eylinder. This factor varies between 0.40 for the older trees and larger diameters to 0.50 for younger and 
more slender trees, a faetor of 0.45 being about the average for eentenarians-that means the volume of a hundred-year-old tree is forty-five one-hundredths of a cylinder of the diameter, measured at breast height and the height of the tree.

This faetor varies, of eourse, aecording to the ratio between diameter and heiglit, and sinee in eodominant and oppressed trees this ratio is a different one from that of dominant trees, as we have seen, their factor of shape is also different from that for dominant trees, that is, their taper differs, the former being more eylindrieal than the latter. This will appear from a eomparison of the taper of trees as recorded in Table II of the Appendix, in whieh small diameters witli eompara. tively long shafts indieate the codominant and suppressed trees. Those with short lengths and large diameters are trees grown in open stand.

From Table II, Appendix, we also see that the taper varies within wide limits from less than 1 ineh to 5 inches for every 16 feet, althongh in the majority of eases it lies between 2 and 3 inches. The tops taper, to be sure, mneh faster than the middle portion; and, again, in older trees espeeially, the butt logs mneh faster than the upper portions, which are outside of the influence of the root swelling.

In young trees whieh make three log lengths of 16 feet, it will be safe to allow $1 \frac{1}{2}$ inehes for the first two $\operatorname{logs}$ and 2 inches for the last one as the average taper. In medium-sized trees, making four to tive log lengths, an allowance of 2 inehes on the whole will fairly represent the average taper, or one-eighth of an iuelı for every foot in leugth. In old trees whieh furnish five and six or more $\operatorname{logs}$, an allowance of 4 to 5 and even 7 to 8 inehes must be made for the first $\log$ and 3 to 4 inches for the two top logs, while the middle portions show a more regular and less variable taper of about 2 inehes, or one-eighth of an ineh per foot.

\section{GROWTH IN VOLUME.}

During the juvenile stages the volume growth of the White Pine, as of most trees, is insig. nifieant, a dominant tree of twenty years measuring not more than 0.5 cubie foot, whieh means an average accretion of 0.025 eubie foot per year. For the third decade the amount of wood formed is over three times what it was during the first two decades, and at fifty years the bole of a domiwant tree may eontain from 10 to 14 cubie fect and over, the average annual accretion having eome up to one-fourth of a eubie foot, or tell times what it was at twenty years.

Now, after the rapid lieight-growth period, witl fully developed erowns, a rapid rate of volume growth scts in, inereasing with eaeh year, in arithmetical progression, until at sixty to seventy years the eurrent aeeretion has become 1 cubic foot and over, and at one hundred years as mueh as $1 \frac{1}{2}$ cubie feet is attained. After the one hundred and twenty-fifth year the inerease in the rate abates, yet before the seeond century it has become 2 eubie feet, and remains then praetieally stationary for another eentury at least.

Some of the oldest trees (four hundred and fifty years and over) measured eontained 600 to 800 enbie feet of wood in the stem alone, the largest, with 855 enbie feet, indieating an average aunual aecretion for this long life of over 1.8 cubic feet.

While the eurrent annual aecretion after the fiftieth year is rapidly inereasing, the average anuual aeeretion, affected by the earlier stages of slow growth, increascs naturally more slowly. For the first one hundred years the average is about two.tlirds to three-fourths of a enbie foot for dominant pine, making the volume about 70 eubic fcet. It increases to 1 eubic foot at one hundred and fifty years and $1 \frac{1}{4}$ eubic fcet at two hundred years, and, as shown above, gains gradually until old age.

The progress in volume growth naturally varies under different soil eonditions and with tree elasses. In a general way, the oppressed trees and those on poorer sites do not begin the pcriod of rapid volume growth as early as the dominant elasses, but just as in the height growth, which is similarly delayed, the rate when onee at its maximum persists with great nniformity until about the one hundred and forticth to one hundred and sixtieth year, when a deerease beeomes noticeable.

The tables and diagrans in the Appendix show, by figures and graphieally, the progress of diameter, hcight, and volume aecretion for dominant, codominant, and oppressed trees throughout the range of the species. Comparing the growth from the scveral localities, represented, a striking 
difference is not observed. It wonld appear that in similar soils the White Pine grows at about tlie sane rate, with similar persistence, and to the same dimensions in all parts of its range.

In Linrope, too, as appears from a table on page 69, its growtl as well as its gencral behavior, at least in the forests of Germauy, is fully as favorable as at home.

Besides differences as result of soils, an influenee of the eomposition of the forest is noticcable. White Pine mixed with Hemlock (Penusylvauia stations) shows a more rapid growtl for the first one liundred and thirty years, while among hardwoods (Wisconsin stations) the next one luundred years secin to produce the thriftiest growth. This is perhaps explained by the fact that in the latter mixture the White Pine has after the first one hundred years its entire crown above the shorter hardwoods, aud henee is in full enjoyment of light.

Tho so-ealled "seeond growth" pine develops somewhat differently, because, as a rule, it does not start in a dense growth, enjosing the light conditions of the open stand, the single individuals make a more rapid volume growth, until they lave elosed up, and forest conditious prevail. This is fully exlribited in the measurements of yonng groves in Massachusetts aud New IIampshire, tabulated in the Appeudix.

In managed woods, where the number of trees allowed to grow per acre is under control, the volume accretion may also be aceclcrated; the growth energy of the site being theu exerted on fewcr individuals, ench one deposits larger amonnts. What this increase can be may be inferred from the table on page 69 , which records the growth of White Pine in Germany.

CUHC CONTENTS OF TRFES.

Having ascertained by a large number of measurements the diancters, heights, and factors of shape possessed by trees under all sorts of conditions, the cubic coutents of such trces can be calculated and recorded in a table for further usc, by rcference, in measuring contents of trecs. Snch table for White Pine of different diameters and heights will be fonnd in the Appendix, from which the contents in cubic feet of the bole of a tree whose diameter at breast height has been mensured and whose height has been estimatcd or measured can at once be read off.

LUMBFR CONTENTS OF TREES.

The total eubic contents, being lased on mathematical considerations alone, is the ouly rational measure of the volume. By stating contents in board measure wc introduce at ouce a number of uncertain factors, which are variable in the practice, such as the lowest-sizc diameter to which logs are taken; the size of the lnmber that is cut, from onc-half-iuch boards to squarc beans; the saw used, which determines the loss in kerf, and the skill of the sawyer, who can waste a large proportion in slabs and inconsiderate use of the logs. ${ }^{1}$

In these losses there is no allowance male for crooks or rot, which would reduce the results still further, so that hardly one-third of the total volume of the tree would secm to reappear in the shape of lumber, provided the log scales used are correct, wlich anticipate a loss of $t t$ per eent (Scribner) to 50 per ccut (Doyle) in sawdust, slabs, and elgiugs for 14 -inch logs, the averagc size of logs in the northern pineries.

As a matter of fact, in good modern mill praetice, not ouly locs no snch waste occur as is indicated in these !og scales, even if all logs were cut into inch boards, but in addition small logs are worked into dimension material "' by 4,2 by 6,4 by 4 , etc., in which the loss is reduced to a minimnm; thus an 8 .incl $\log$ may be cut to 6 by 6 inclies. It then would make, if 16 feet long, not 16 to 25 feet $B$. M., but 48 feet. Since the bulk of our pine material is now obtained from small logs (over one-half below 14 inches diameter), these differences are of considerable praetical importance.

'A enreful examination and measurement of one hunilred trees of White Pine was mado by Mr. Filibort Roth to ascertain what rational nllowance slould be made on the eubie eontents of trees when converted into lumber. The average diamoter of the t.ces measured was 28 inches, breast high with bark, and the licight 100 feet, tho factor of shapo 0.43 , that is to say, they wero old trees with a moderate tapor. They averaged $4.2 \log 8$ of 16 feet per tree, whieh represented 76 per cent of the total rohme of the bole with bark, 24 per cont being lost in the top and stump and in tho bark. Tho lumber contents of these logs, ealeulated by Scribner's log rule, representer only 39.5 per eent of tho total volnme of the tree, that is to say, over 60 per cent of tho whole tree is supposed not to reappoar in the lumber, the saw wasto representing 48 per cent of the log volume and 36 per cent of the total volume of the tree. 
Based upon a proper consideration of these practices, it will appear that an average allowanee of 30 per eent in saw waste on the volume of logs of all sizes is more than ample, and that the lumber yield given in the following table and computed on this assumption of waste, although being for same sizes even 100 per cent above the log scales in use, remains still below the practically obtainable results:

Lumber contents in 16-foot logs.

\begin{tabular}{|c|c|c|c|c|c|c|}
\hline \multirow{2}{*}{$\begin{array}{l}\text { Diameter } \\
\text { nt small } \\
\text { end. }\end{array}$} & \multirow{2}{*}{$\begin{array}{l}\text { Judson's } \\
\text { favorite. }\end{array}$} & \multirow[b]{2}{*}{ Doyle rule. } & \multirow[b]{2}{*}{$\begin{array}{l}\text { Scribner } \\
\text { rule. }\end{array}$} & \multirow{2}{*}{$\begin{array}{l}\text { Compnted } \\
\text { for } 30 \text { per } \\
\text { cent waste. }\end{array}$} & \multicolumn{2}{|c|}{ Waste. } \\
\hline & & & & & $\begin{array}{c}\text { By Scrib. } \\
\text { ner. }\end{array}$ & By Doyle. \\
\hline Inches. & Feet $B, M$. & Feet $B$ aI. & Feet $\boldsymbol{B} . \boldsymbol{M}$. & Feet B. $M$. & Per eent. & Per cent. \\
\hline 8 & 22 & 16 & 25 & $\frac{32 \text { to } 48}{46}$ & 61 & 76 \\
\hline 10 & 37 & 36 & 49 & $\frac{60 \text { to } 85}{72}$ & 50 & .65 \\
\hline 12 & 64 & $6 t$ & 79 & $\frac{100 \text { to } 130}{105}$ & 47 & 57 \\
\hline $\begin{array}{l}14 \\
16\end{array}$ & $\begin{array}{r}95 \\
142\end{array}$ & $\begin{array}{l}100 \\
144\end{array}$ & $\begin{array}{l}114 \\
159\end{array}$ & $\begin{array}{l}105 \\
142 \\
187\end{array}$ & 44 & $\begin{array}{l}51 \\
46\end{array}$ \\
\hline 18 & $\begin{array}{l}196 \\
197\end{array}$ & 196 & 213 & $\begin{array}{l}186 \\
237\end{array}$ & 37 & $\begin{array}{l}80 \\
42\end{array}$ \\
\hline 20 & 248 & 256 & 280 & 292 & 33 & $3 y$ \\
\hline 22 & 324 & 324 & 334 & 336 & 34 & 36 \\
\hline 24 & 392 & 400 & 404 & 420 & 33 & 33 \\
\hline 26 & 476 & 484 & 500 & 492 & 30 & 32 \\
\hline & 562 & 576 & 582 & 564 & 28 & 30 \\
\hline
\end{tabular}

In estimating the cut of lumber that may be obtained from a given area, there must, to be sure, an allowance be made in addition for unserviceable, crooked, knotty, rotten material, which may reach from 15 to 20 per eent, and, furthermorc, an allowance for the loggers' risk in breakages and other losses, which may be figured at 10 to 12 per cent.

To give, however, an approxinate idca of the lumber contents of trecs of various diameters and heights, these have beel1 calculated for a number of trees and recorded in Table II, p. 87, in the Appendix.

From these measurements, which are based upon Doyle's log scale, the following tabulation is made, showing approximately the increase of lumber contents with diameter growth and age. From this it would appear that the greatcst per cent of increase occurs during the period from the fortieth to seventieth year, while in the forticth ycar the average annual growth in voiume has been about one-third of a eubic foot, in the seventieth year it is nearly 2 cubic feet, sr six times as great, and by the one hundredth year this rate is clonbled, centenarians containing about 400 fcet B. M. During the ncxt century the trees make twice as much lnmber wood, for now all wood deposited makes lumber:

Increase in lumber contents with size.

\begin{tabular}{|c|c|c|c|c|c|c|}
\hline $\begin{array}{c}\text { Diameter } \\
\text { breast } \\
\text { high. }\end{array}$ & Height. & $\begin{array}{l}\text { Approxi- } \\
\text { mate age. }\end{array}$ & Lumber. & $\begin{array}{c}\text { A rerage } \\
\text { annual ac- } \\
\text { cretion. }\end{array}$ & $\begin{array}{l}\text { Periotic ac- } \\
\text { cretion. }\end{array}$ & $\begin{array}{l}\text { Per cent of } \\
\text { increase } \\
\text { per yenr } \\
\text { during pre- } \\
\text { ceding. } \\
\text { period. }\end{array}$ \\
\hline $\begin{array}{l}\text { Inches. } \\
7 \text { to } 9 \\
10 \text { to } 12 \\
13 \text { to } 15 \\
16 \text { to } 18 \\
19 \text { to } 21 \\
22 \text { to } 24 \\
25 \text { to } 27 \\
28 \text { to } 30\end{array}$ & $\begin{array}{l}\text { Feet. } \\
50 \text { to } 70 \\
50 \text { to } 80 \\
55 \text { to } 115 \\
75 \text { to } 125 \\
80 \text { to } 135 \\
85 \text { to } 140 \\
85 \text { to } 150 \\
85 \text { to } 150\end{array}$ & $\begin{array}{c}\text { Tears. } \\
40 \\
55 \\
70 \\
85 \\
110 \\
140 \\
185 \\
230\end{array}$ & $\begin{array}{c}\text { Feet } B . M r . \\
14 \\
50 \\
130 \\
260 \\
440 \\
650 \\
040 \\
1,200\end{array}$ & $\begin{array}{l}\text { Cubic feet. } \\
0.35 \\
.0 \\
1.8 \\
3 \\
4 \\
4.6 \\
5 . i \\
5\end{array}$ & \begin{tabular}{|c|} 
Feet $\boldsymbol{B} . \boldsymbol{M} \boldsymbol{Y}$. \\
$3 \mathbf{3 6}$ \\
80 \\
130 \\
180 \\
210 \\
290 \\
260
\end{tabular} & $\begin{array}{c}\text { Per cent. } \\
\cdots 17 \\
17 \\
7 \\
3 \\
1.7 \\
1.6\end{array}$ \\
\hline
\end{tabular}

CONDITIONS OF DEVELOPMENT.

JEMANDS UPON CLIMATE AND SOIL.

The wide field of its natural distribution and the thriftiness with which the White Pine develops in climates outside of its native home show that it is quite adaptive as far as elimatic conditions are eoncerned. Yet, from the manner of its development within the climatic range of its 
occurrence, its nse for forestal purposes would scem to be circumscribed by conditions of humid and cool atmospheres, such as are found in northeru latitudes and high altitudes. Its distribution is manifestly more dependent on lumidity than on temperature, or rather, on a low transpiration factor, that is, such a relation of heat aud moisture, both at the foot and at the top, that the thin folinge can readily perform its functions; hence, its failure in cultivation in the trans-Missouri States, the contraction of its southern field to the high altitudes, and its best development in quautity if not in quality within the influence of the Great Lakes and to the uorthward and eastwarl.

W'hile adapting itself realily to almost any variety of soil, the White Pine manifestly prefers one with a fair admixture of sand, insuring a moderately rapid drainage. The pine tribe in gencral occupics the sancly soils, to which it is better adapted than most of the decidnous trce specics; but the White line is capable of disputing possession witl its competitors even of the fresh medium-hcary loam and clay soils, making here the best individual growth.

Its shallow root system, in which it resembles, as in many other respects, the spruces, permits it to accompany the latter to the thinuer soils of the rocky slopes in the Adirondacks and New England States, although here its devclopment is naturally less thrifty. Its growth on the rocky hills of Massachusetts within the hardwoods of that region is, however, at least for the first sixty to eighty years not mnch less thrifty than in the better soils in the vallcys. It docs not shuu cren the wetter and occasionally overflowed and swampy ground, and is herc found, together with the Fir, Arborvitre, and even Tamarack; yet, on the dry, light sandy, coarse, and gravelly soil the Red Piue and Jack Piue seem to be able to ontdo it.

Associatei SPECIES.

The White Pine is less gregarious than any other pines of the Eastern United States. Although it occurs in pure growths as true pinery on the red clays and moister gravels, it more frequently is an admixture in the hardwoods, sharing with them the compacter, hearier soils from which the other pincs are excluded.

Spruce, Hemlock, and Arborvite (Cerlar) are nost frequeut concomitants of the White Pine in Canada; varions species of Birch and Maple with Beech and Spruce form the compositiou of the forest in the Adirondacks, overtowered by the pines, and there is hardly any species of the Northern Atlantic forest which iu onc or the other region of its distribution may not be fonnd in association with the White Pine.

Oming to the fact that the hardwoods as a rule occupy tho better soils, the best individual development of the White Pine is also fonnd in these mixturcs. In the pinery of the northrest Red Pine and Jack Pine are the associntes, whilc the Pitch Pine ( $P$. rigida), and, in the southern field, the Shortleaf Pine ( $P$. cchinata) are not unfrequently found in its company.

The samples of "acre yiclds" following will serve to illustrate more in detail the manner of distribution, the associations, and the capacity of White Pine in the native forests in different parts of its range. More cxtensive tabulation will be found in the Appendix. 
ganl

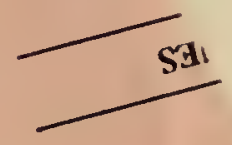

CONDITIONS OF DEVELOPMENT.

TABLE VI.-Acre yield of White Pine on siles in Tisconsin, Michigan, Pennsyltania, and Maine.

WISCONSIN.

SITE a: Washburu Connts.

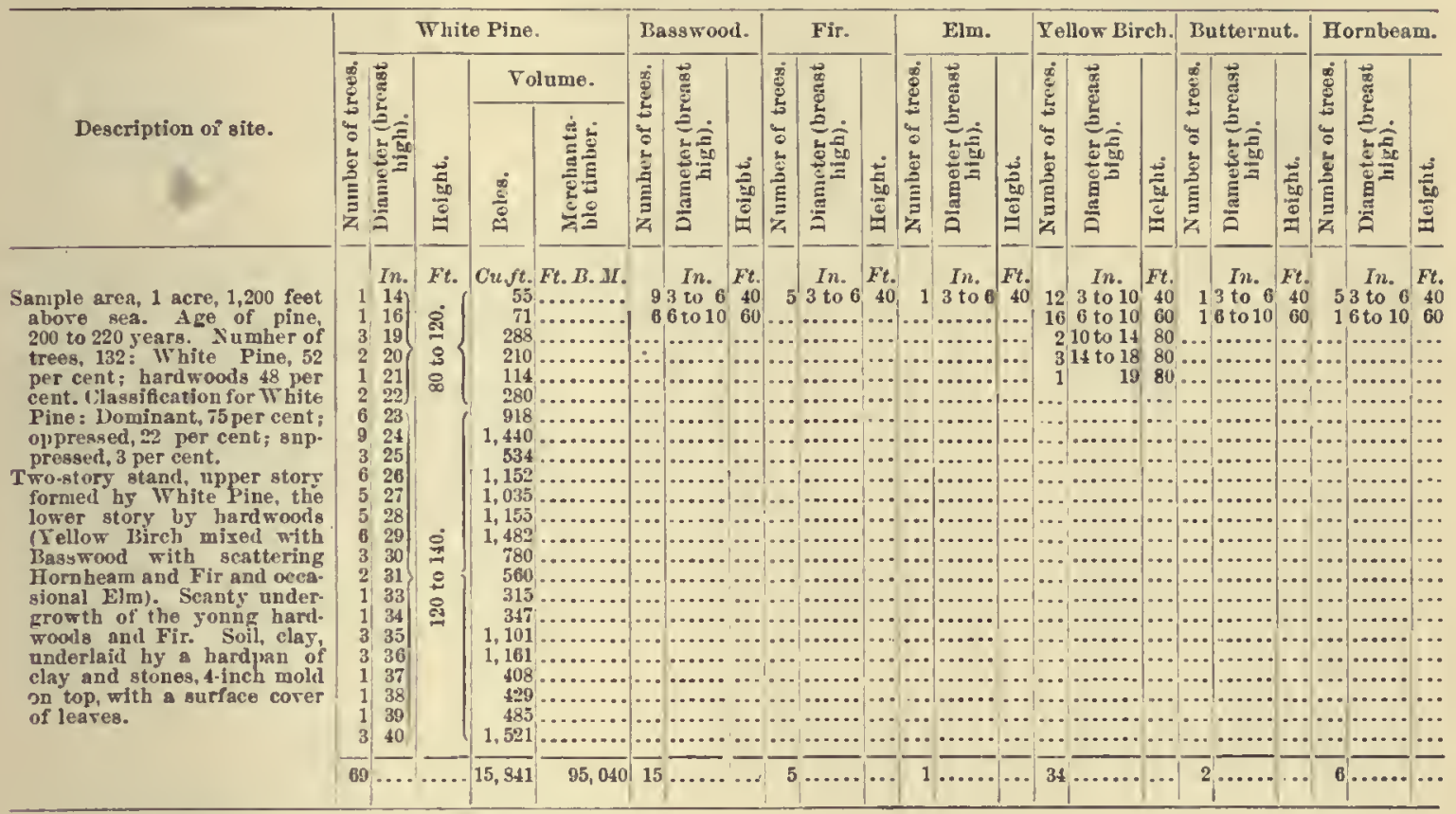

$\Delta$ xerage annual accretion: White Pine, 75 cubic feet.
452 feet B Y.

MICHIGAN.

Site $d$ : Montmorency County.

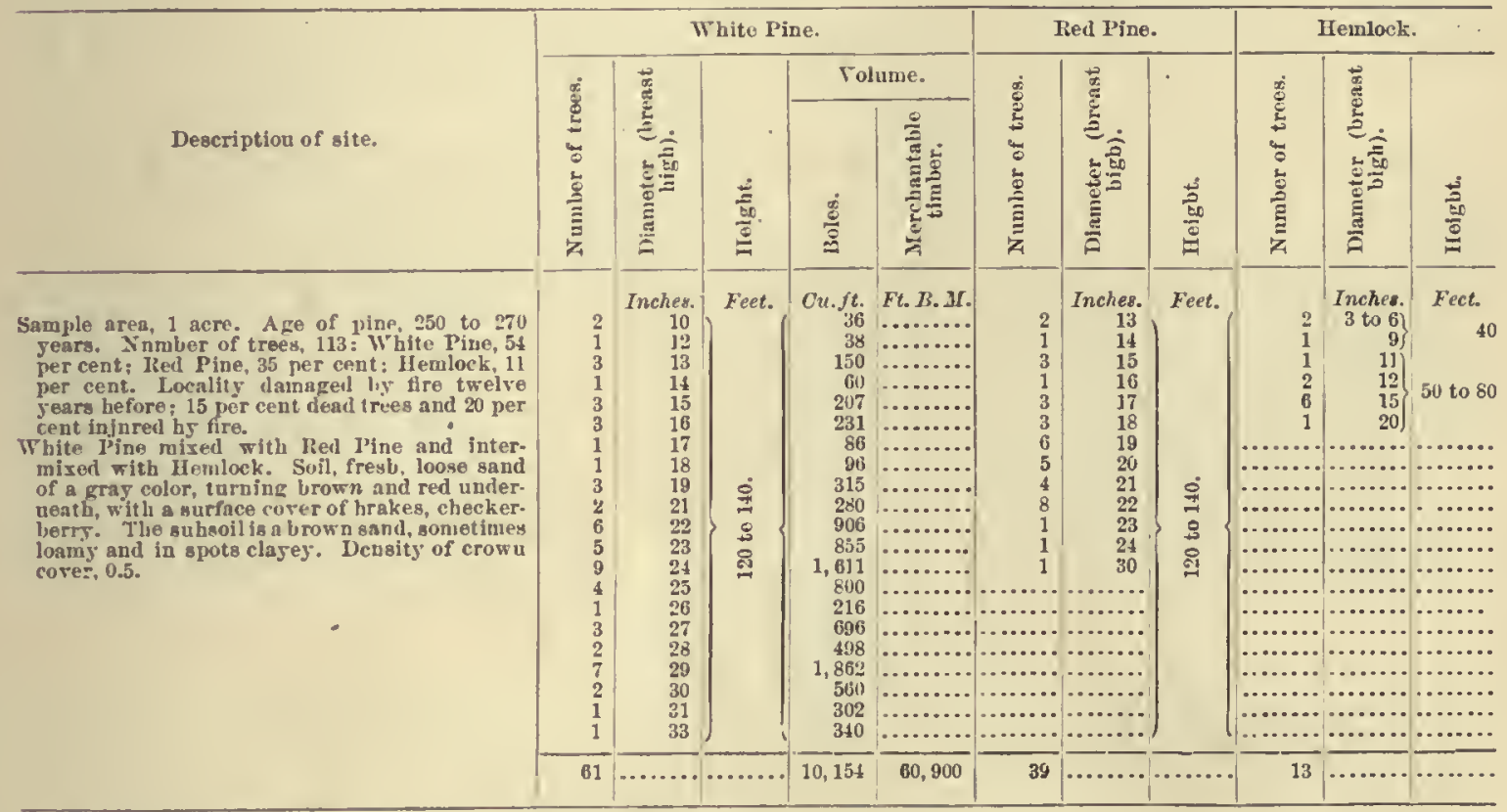

Total yield : 86.100 feet B. Mro, of which White Pine 66 per cent.

Folume of Red Pine: 13oles, 5,256 cubic feet; inerchantable timber, 25,200 feot 13. M.

Average annual accretion: White l'fne, 59 culicic feet.

331 feet B. II. 
Tanle VI. - Acre yield of Thite Pine on sites in Wisconsin, Michigan, Penneylvania, and Maine-Continued.

PEXXSTLFANIA.

Srre f: Dnbola, Clearfield Connty.

\begin{tabular}{|c|c|c|c|c|c|}
\hline \multirow[b]{3}{*}{ Deseription of site. } & \multicolumn{5}{|c|}{ White Plne. } \\
\hline & \multirow[b]{2}{*}{ 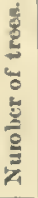 } & \multirow[b]{2}{*}{ 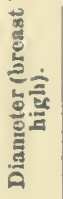 } & \multirow[b]{2}{*}{$\stackrel{\vec{E}}{\stackrel{a}{0}}$} & \multicolumn{2}{|c|}{ Tolnme. } \\
\hline & & & & Boles. & 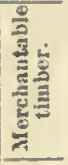 \\
\hline & & In. & Fcel. & Cu. st. & $\boldsymbol{F}, \boldsymbol{B}$. \\
\hline Samplo area, 1 acre, 1,200 to 1,500 & 2 & 15 & 120 & 360 & 1,360 \\
\hline $\begin{array}{l}\text { feet above sea. Ago of plne, } 240 \text { to } \\
260 \text { yesrs. Namber of trees, } 132 \text { : }\end{array}$ & $\begin{array}{l}2 \\
2\end{array}$ & $\begin{array}{l}17 \\
18\end{array}$ & $\begin{array}{l}120 \\
130\end{array}$ & 000 & \\
\hline Whlte P'rne, 37; Hemlock, 84; Ma: & 1 & 19 & 130 & & \\
\hline plo, 5; Ileech, 3; Bireh, 3. & I & 20 & 130 & 1,370 & 6,620 \\
\hline $\begin{array}{l}\text { Hemlock milxed with White Pine, } \\
\text { wlth occastunal Maple, Beech, and }\end{array}$ & 1 & $\begin{array}{l}21 \\
22\end{array}$ & $\begin{array}{l}130 \\
130\end{array}$ & & \\
\hline Burch, on a hill sloping towarcls & 2 & 23 & 130 & 570 & 3,000 \\
\hline sonthwest, where it is bounded by & 1 & 24 & 130 & & \\
\hline tho left-hand brancli of tho Nar- & 3 & 25 & 135 & 651 & 3,690 \\
\hline row Creek. The undergrowth, & 1 & 26 & 135 & 257 & 1,390 \\
\hline moderately dense, consists of rery & 2 & 27 & 135 & & \\
\hline 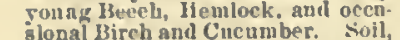 & $\begin{array}{l}1 \\
1\end{array}$ & $\begin{array}{l}28 \\
29\end{array}$ & $\begin{array}{l}135 \\
135\end{array}$ & 1,160 & 6,600 \\
\hline yellow clayey loam of a tuedium & 2 & 30 & $1+5$ & 610 & 3,900 \\
\hline grain (6ue shales in lt, deep. treah, & 1 & 3) & 145 & 1,220 & 7,800 \\
\hline well dralned, with 2 to 3 inclies & I & 32 & 145 & 390 & 2. 300 \\
\hline wold out top, wlth surface cover of & 2 & 3 & 14 & 800 & 4. 800 \\
\hline scanty leares, fern, toaborries, and & 1 & 10 & & 511 & 3,300 \\
\hline scattering dogwoml (lanrel, north. & 1 & 41 & 145 & 511 & 3,300 \\
\hline east corner and nortli gille). Sub- & 1 & 45 & 145 & 638 & $\$ .400$ \\
\hline $\begin{array}{l}\text { depib. Density of crown corer, } \\
0.7 \text { (in plnees } 0.8 \text { ). }\end{array}$ & 37 & & & 9,028 & 52,260 \\
\hline
\end{tabular}

Total yield: 00,103 feet B. MI.

decrage annual aceretion: White pine, 36 enble feet.
200 feet B. II.

MAINE.

SITE a: Fork County.

\begin{tabular}{|c|c|c|c|c|}
\hline \multirow[b]{2}{*}{ Description of site. } & \multicolumn{4}{|c|}{ White Plne. } \\
\hline & 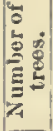 & 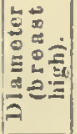 & 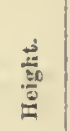 & $\begin{array}{l}5 \\
\frac{2}{3} \\
\frac{2}{3} \\
5\end{array}$ \\
\hline 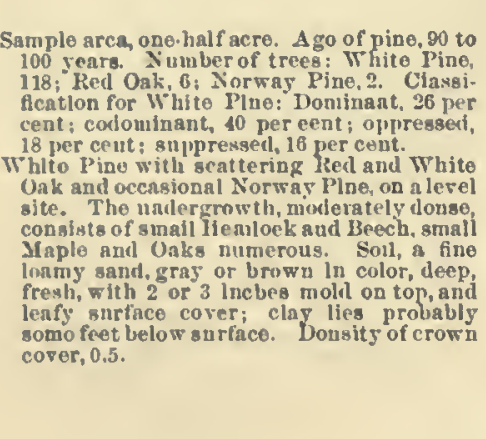 & $\begin{array}{r}2 \\
8 \\
8 \\
4 \\
6 \\
4 \\
8 \\
8 \\
8 \\
8 \\
10 \\
18 \\
2 \\
4 \\
6 \\
6 \\
2 \\
2 \\
4\end{array}$ & $\begin{array}{r}I n . \\
10 \\
11 \\
12 \\
12 \\
13 \\
14 \\
14 \\
15 \\
16 \\
17 \\
18 \\
19 \\
20 \\
21 \\
22 \\
23 \\
24 \\
25 \\
26\end{array}$ & $\begin{array}{r}F c c \ell . \\
75 \\
75 \\
75 \\
85 \\
85 \\
75 \\
85 \\
85 \\
85 \\
85 \\
85 \\
85 \\
85 \\
85 \\
85 \\
85 \\
95 \\
95 \\
05\end{array}$ & $\begin{array}{r}C u, f . \\
42 \\
192 \\
2: 33 \\
120 \\
222 \\
154 \\
332 \\
384 \\
408 \\
528 \\
690 \\
1,323 \\
152 \\
320 \\
534 \\
660 \\
250 \\
280 \\
560\end{array}$ \\
\hline & 118 & & & 7,384 \\
\hline
\end{tabular}

A veragc anmual accretion: White PIne, 77 cabic feet.

Current acction: White Pino, 160 cubio fest.
MAINE.

Stre b: Fork Connty.

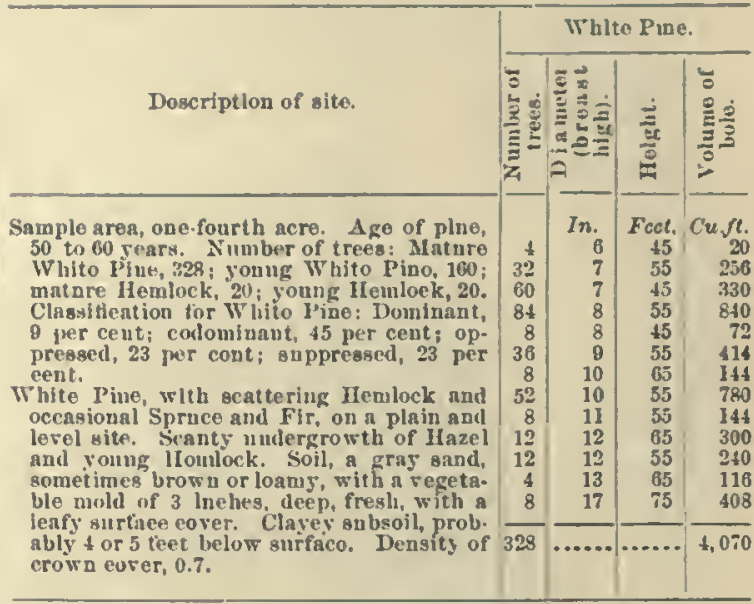

Aceragc annual accretion: White Pine, 74 enbic feet.

Current accrction: White Pino, 133 enblo feet.

MAINE.

SITE c: Tork Connty.

Sasupio area, one fourth acre. Age of pine, 50 to 60 sears. Nusuber of trees: Matnre Wine: Doune, 390 . Classification for White Tine: Dounnant, 18 pet cent; codominant, 27 per cent; oppressed, 24 per cent; sup juressed, 31 per cent.

Wbito Piue, with ocrasional Norway Pino, on alope to worth $5^{\circ}$ to $10^{\circ}$. Seanty indergrowth of Homlock, Oak, and Fir. Soll, a sandy loam, witb little pehbles in it, of a brown color, deep and fresh, with black soil and mold of 3 Inches on top and leafy suriace cover; clay probably 8 to 12 feet down. Density of crown corer, 0.8 .

\begin{tabular}{|c|c|c|c|}
\hline \multicolumn{4}{|c|}{ White Plne. } \\
\hline 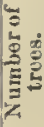 & 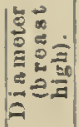 & $\frac{\frac{\dot{E}}{\vec{E}}}{\overrightarrow{0}}$ & 总 \\
\hline & In. & Fcet. & $C_{1 L} \sqrt{\prime}$. \\
\hline 28 & 6 & 65 & 28 \\
\hline 28 & $\begin{array}{l}6 \\
7\end{array}$ & $\begin{array}{l}55 \\
65\end{array}$ & $\begin{array}{l}108 \\
180\end{array}$ \\
\hline 2 & 7 & 55 & 160 \\
\hline 84 & 8 & 65 & 1,008 \\
\hline 2 & 8 & 55 & 240 \\
\hline 3 & 9 & 65 & 52 \\
\hline 32 & 10 & 65 & 57 \\
\hline 8 & 10 & 75 & \\
\hline 40 & 11 & 65 & \\
\hline & 11 & 7 & 1 \\
\hline 16 & 12 & 65 & 08 \\
\hline 24 & 12 & 75 & 698 \\
\hline 8 & 13 & 65 & 232 \\
\hline 16 & 13 & $\tilde{i}$ & \\
\hline & 14 & 6 & 13 \\
\hline 12 & 14 & 75 & 462 \\
\hline 8 & 1 & 65 & 29 \\
\hline 1 & 16 & 75 & 18. \\
\hline 4 & 17 & 75 & 204 \\
\hline & & & 7,20 \\
\hline
\end{tabular}

Average annual aceretion: Whito Pine, 131 eubio foot. 
LIGHT REQUIREMENTS.

The capacity of the White Pine to keep its place in mixture with the lardwoods is probably mainly due to its shade endurance. In this respect it excels all pines with which we are acquainted. Pines are, as a rule, rather light-needing species, and are usually at a disadvantage in the inixed forest, unless compensating influences are in their favor. The White Pine is an exception. As a consequence, it is capable of forming dense thickets, supporting a larger number of trees per acre and produciug a larger amount of material than the more light-needing species. Also, as a consequence of its shade endurauce, it does not clean itself of its branches as readily as other pines; not only do the lower branches remaiu grecn for a long period in spite of the shade of the superior tiers of foliage, but they persist after they are dead for many years.

As this shadle endurancc is, however, only relative, and as many of the associates possess it in greater degree, the additional advantage of rapid height growth alone saves the pine from being after all suppressed by its shadier conpanions. Yet, these succeed in keeping the young progeny of the pine subdued, and hence the observation that in the dense virgin forest of hardwoods the reproduction of White Pine is scanty.

The difficulty of cleaning itself of dead branches seems to be overcome by association with shadier companions, for, as a rule, the best quality, cleauer boles, and absence of black knots, which denotes earlier cleaning, are found in such associatiou. Yet, in these mixtures the trees arc apt to be shorter bodied, since the hardwood companions are shorter bodied and the stimulus to height growth ceases sooner. In the piuery proper the stimulus to height growth exerted by the neighbors continues longer; hence, longer shafts are found here, other conditions being the same, although the boles are less clean and less free of knots.

Its shade endurance is decidedly less than that of the Spruce, which maintains itself, but not thriving under the dense shade of Maple, Birch, and Beech, where White Pine seedlings and saplings are not to be found, although they sustain perfectly the shade of oaks. To be sure, this shade endurance is to some extent dependent on moisture conditions of soil, being less on the drier than on the fresher soils.

This relatively high shade endurauce permits ready natural reproduction of the pine, especially where the hardwoods have been thinned out to some extent, or where, after clearing, all species start their race for reoccupation of the soil with equal chance. The pine then appears in the young hardwood growth in single individuals at first, somewhat behind iu height, but finally, when it enters upon the period of rapid height growth, it outgrows its competitors aud is assured of its place.

More frequently does the reproduction tako place in groups, smaller or larger, the many areas of "secoud growth" of" several acres in cxtent, which are found throughont the hardwood coppice of Massachusetts, showing that tendency toward gregariousness so characteristic of the conifers. A further discussion of the conditions of reproduction and the yield occurs in the portion devoted to the discussion of forest management and of forest yield.

In these natural reproductions the trees grow close together, that is, close for unaided nat. ural reproduction, as is apparent from the following table of acre yields of young growth taken at various places in New England:

TABLE VII.-Acre yiela of young pine groves.

\begin{tabular}{|c|c|c|c|c|c|c|c|c|c|c|}
\hline \multirow{2}{*}{ State. } & \multirow{2}{*}{\multicolumn{2}{|c|}{ Soll. }} & \multicolumn{6}{|c|}{ Whito Pine. } & \multicolumn{2}{|c|}{ Specics iutermixed. } \\
\hline & & & Age. & Number. & $\begin{array}{l}\text { Diancter } \\
\text { (breast }\end{array}$ & \multicolumn{2}{|c|}{ Length of log. } & \multirow{2}{*}{$\begin{array}{r}\begin{array}{r}\text { Tolnme } \\
\text { of logs. }\end{array} \\
\begin{array}{r}\text { Cu. feet. } \\
54 \\
1,611.2 \\
348.9\end{array} \\
\ldots \ldots\end{array}$} & \multirow{2}{*}{$\begin{array}{r}\text { Numhor. } \\
\\
147 \\
52 \\
21 \\
8\end{array}$} & \multirow{2}{*}{$\begin{array}{l}\text { Naneaud remarks. } \\
\text { Oak. } \\
\text { Chestnut. } \\
\text { Maple. } \\
\text { All other. }\end{array}$} \\
\hline Massachusetts... & $\begin{array}{l}\text { Fresl, well-drained } \\
\text { and sandy loam. }\end{array}$ & loam & $\begin{array}{r}\text { Years. } \\
35\end{array}$ & $\begin{array}{r}2 \\
128 \\
281 \\
75 \\
1\end{array}$ & $\begin{array}{r}\text { Inches. } \\
14 \text { to } 18 \\
10 \text { to } 14 \\
6 \text { to } 10 \\
3 \text { to } 6 \\
\end{array}$ & $\begin{array}{r}\text { Max. } \\
40 \\
40 \\
35 \\
\ldots \ldots \ldots . . .\end{array}$ & \begin{tabular}{r}
\multicolumn{1}{|r}{ rin. } \\
35 \\
20 \\
20 \\
$\ldots \ldots \ldots . .$.
\end{tabular} & & & \\
\hline Total... & . & & & 490 & $\cdots \cdots \cdots$ & ............. & ............ & $2,014.1$ & 228 & All small. \\
\hline New Lampshire... & $\begin{array}{l}\text { Dry, well.dralned } \\
\text { loain. }\end{array}$ & aandy & 35 & $\begin{array}{r}3 \\
13 \\
79 \\
231 \\
181 \\
5\end{array}$ & $\begin{array}{r}18 \text { to } 24 \\
14 \text { to } 18 \\
10 \text { to } 14 \\
\text { ti to } 10 \\
3 \text { to } 6 \\
\end{array}$ & 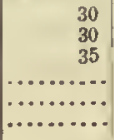 & 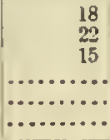 & $\begin{array}{c}178.9 \\
372.4 \\
1,007 \\
\ldots \ldots \ldots \ldots \\
\ldots \ldots \ldots \\
\ldots \ldots\end{array}$ & 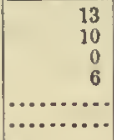 & $\begin{array}{l}\text { Maplo. } \\
\text { Gray Birch. } \\
\text { Pitch Pine. } \\
\text { All other. }\end{array}$ \\
\hline Total .... & ..... & & . & 512 & ......... & (........ & .......... & $1,558.3$ & 38 & \\
\hline
\end{tabular}


TABLE: VII.-Acre yield of young pine groces-Continued.

\begin{tabular}{|c|c|c|c|c|c|c|c|c|c|}
\hline \multirow[b]{2}{*}{ State. } & \multirow[b]{2}{*}{ Soll. } & \multicolumn{6}{|c|}{ Whlto Plne. } & \multicolumn{2}{|c|}{ Species lntermlxed. } \\
\hline & & Ago. & Numbor. & Dinneter & \multicolumn{2}{|c|}{ Length of log. } & $\begin{array}{l}\text { Tolume } \\
\text { of loges. }\end{array}$ & Nunber. & Nane and remarks. \\
\hline alassacbnsetts..... & $\begin{array}{l}\text { Fresh, well-drained sandy } \\
\text { loatu. }\end{array}$ & Tears. & $\begin{array}{r}14 \\
130 \\
177 \\
32 \\
3\end{array}$ & 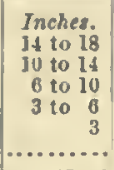 & 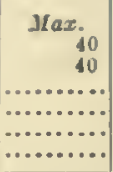 & 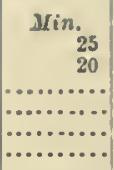 & 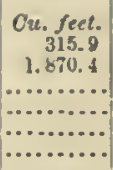 & $\begin{array}{r}133 \\
204 \\
19 \\
15 \\
11 \\
15\end{array}$ & $\begin{array}{l}\text { Oak. } \\
\text { Mlaple. } \\
\text { Chestnut. } \\
\text { firay I3lrch. } \\
\text { Cherry. } \\
\text { All other. }\end{array}$ \\
\hline Total........ & $\ldots \ldots \ldots$ & 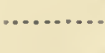 & 362 & ... & $\cdots$ & (.......... & $2,186.3$ & 397 & $\begin{array}{l}\text { All leas than 3-Iuch } \\
\text { diameter. }\end{array}$ \\
\hline New IIanupahlro... & $\begin{array}{l}\text { Dry, well-drained loamy } \\
\text { sand. }\end{array}$ & 10 & $\begin{array}{r}46 \\
65 \\
184 \\
615 \\
150\end{array}$ & $\begin{array}{r}14 \text { to } 18 \\
10 \text { to } 14 \\
0 \text { to } 10 \\
3 \text { to } 6 \\
3\end{array}$ & 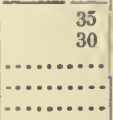 & 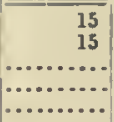 & 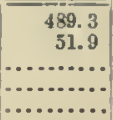 & 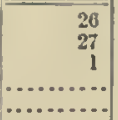 & $\begin{array}{l}\text { Hemlock. } \\
\text { lied l'ine. } \\
\text { Gray Birch. }\end{array}$ \\
\hline Total ........ & n............................. & .......... & 1.060 & ............ & ........... & ........... & 511.2 & 54 & Small. \\
\hline Mfassachnsetts..... & $\begin{array}{l}\text { Fresb, well-drained sandy } \\
\text { luan. }\end{array}$ & 48 & $\begin{array}{r}11 \\
158 \\
277 \\
18\end{array}$ & $\begin{array}{l}14 \text { to } 18 \\
10 \text { to } 14 \\
6 \text { to } 10 \\
3 \text { to } 6\end{array}$ & $\begin{array}{r}40 \\
40 \\
4 \ldots+\cdots\end{array}$ & $\begin{array}{r}30 \\
15 \\
\cdots\end{array}$ & $\begin{array}{r}258.2 \\
2,090.9 \\
\cdots \\
2 \ldots \\
\end{array}$ & $\mid \begin{array}{ll}\cdots \\
\cdots \cdots \cdots \\
\cdots \cdots \cdots\end{array}$ & Sone. \\
\hline Total.......... & .......................... & .......... & 464 & ........... & ........... & (n......... & $2,355.1$ & -......... & \\
\hline Mfassachusetts..... & $\begin{array}{l}\text { Ury, rell-dralned loamy } \\
\text { sand. }\end{array}$ & 50 to 55 & $\begin{array}{r}1 \\
48 \\
126 \\
147 \\
15\end{array}$ & $\begin{array}{l}18 \text { to } 24 \\
14 \text { to } 18 \\
10 \text { to } 14 \\
6 \text { to } 10 \\
3 \text { to } 6\end{array}$ & $\begin{array}{r}35 \\
40 \\
40 \\
30 \\
3 .\end{array}$ & $\begin{array}{r}20 \\
15 \\
18 \\
\ldots\end{array}$ & \begin{tabular}{|c|}
102 \\
902 \\
$1,311.5$ \\
132.2 \\
$\cdots \cdots$
\end{tabular} & 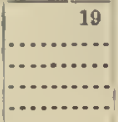 & $\begin{array}{l}\text { Representingseren } \\
\text { species. }\end{array}$ \\
\hline Total. & ........ & & 337 & & & & $2,467.7$ & 19 & \\
\hline
\end{tabular}

It would be possible to increase thrs number of trees that conld grow per acre and develop satisfactorily by attention of the forester, as will appear from the statements regarding the White Pine forest plantations in Germany, where pure White Pine growths showed at sixty-eight years still over six hundred and seventy trees, and in another place at eighty-two years seven hundred and twenty-three trees, and at one lundred and four years over two hundred and fifty trees per acre. Even in such close staud the crown of living branches remains long, occupying one.third of the bole, and dry branches persist down to over half the leugth. The stems are straight and cylindrical, in this respect also reminding one of the Norway Spruce, although the tendency to fork seems more frequently developed.

\section{ITELD OF WIITE PINE.}

The question as to the amount of material which the Whitc Pine is capable of producing per acre is diffienlt to answer. It cau not, of course, bededuced from a knowleige of the development of the individnal tree, since there remains one factor unknown, uamely, the number of trees of different classes that cau occupy an acre. Nor can the capacity of production, as a rule, be ascertained from the actual production or acre yield of natural virgin growtlıs, for these usually not only do not oecur in pure growths, but also are usually not developed under most arlvantageous eonditions, and do not, therefore, represcut the possible or uormal yield which could be secured. Only by selecting smaller, seemingly normally and farorably developed groups in the forest at different ages and in various localities and measuring the same may we arrive at an approximation of what the speeies is capable of producing by itself.

Sich measurements have uot been attenpted, but the yield of virgin acres under varying eonditious has been ascertained to give at least a forecast of the possibilities, althougl not representing the normal or possible yield of fully stocked acres of White Pine. In addition we may utilize the results recorded from Germany (page 69) of a number of plautations, which have had the adrantage of at least the partial care of forest managcincut.

From these inclications, we are justifiel in the assertion that the White Pine produces per acre as well as any species with which we are acfuainted in our northeasteru roods, and at a rate whiel is not exeelled by any of the lumber trees withiu its range.

In this respect, again, it approaehes the German Spruce, thougl it probably excels this species in persistency, as it does in the dimensions which it can produce. We can, thercfore, for the first 
huudred years at least, approximate the eapaeity of our White Pine by referenee to experienee tables of the Germau Spruce.

As with all eonifers, the rate of production at first is very slow, not more than 40 to 70 eubie feet in the average per year for the first twenty years. With the better development of erowus and the assertion of individual superiority in the struggle of neighbors, whieh leads to the establishment of dominant elasses, the production inereases rapidly, and by the fiftieth year, in fully stoeked areas, the arerage rate of 140 to 160 eubie feet per aere inay be attained, so that at that age we may, with five hundred to six hundred trees to the aere, fiud 7,000 to 8,000 eubic feet of wood stored up in the boles of the trees. The eurrent annual aeeretion, then, may readily be at the rate of 160 to 180 eubie feet, keeping the average annnal aeeretion of fully stocked aeres very uearly to those figures, so that at one hundred years we should find, under favorable eonditions, as mueh as 15,000 enbic feet of wood, of whieh at least 80,000 to 90,000 feet B. Mr. is saw material.

The persisteney of growth seems to eontinue beyond that age, and the indications are that the deerease of the eurrent as well as average aeeretion per aere during the next eentury takes plaee so gradually that at one hundred and fifty years it may still be over 100 eubic feet, and not mueh below at two hundred years, when the burden of the aere may be near 20,000 eubie feet, with over 120,000 feet B. M., and double the amount iu the oldest growths of two hundred and fifty or more years, which may possibly be the limit of prodnetion.

While these figures, whieh differ very materially from those proposed in the tables by Messrs. Pinehot and Graves, may stand for the better soils, as ideally possible, praetienlly, perhaps, rarely attainable, especially in older stands, poorer soil sites will vary from them by from 20 to 40 per eent, so that a yield of 9,000 eubie feet at a hundred years, or 50,000 feet of lumber, would still be quite reasonable to expeet on the poorest soils on which White Pine ean be satisfactorily grown. On the sandy soils of Wiseonsiu whole forties are fouud to average 50,000 feet per aere of naturally growu unattended forests of one hundred and fifty years of age.

Table VIII summarizes the measurements of sample areas, whieh are given in detail iu the Appendix. It will serve to show what our native woods, without attention, stocked with partly useless trees and in open stand, exhibiting mueh wastage in unoceupied ground, are eapable of produeing.

If we assume that the areas might have been stoeked with piue alone, that they would have produced at only the same rate as they have under tlieir present conditions, even though the acres had been fully stoeked and not in the fraetional manner which is indieated by the deeimal giv. iug density of eover (all assumptions), and if iu eonnection with the density faetor we eonsider the number of all trees per aere and the percentage which the pine represents, we may, as a mere matter of judgment not fit for tabulation, arrive at an indicatiou as to what the aere might possibly have produeed. Such indieation of possibility has been attempted in the last eolumn of the table, and has served in the above disenssion in eonuection with all other data presented. This is all that ean be done in the absence of the measurements above indieated. These figures are of no direct praetieal application exeept to give a general notion of the productivity of White Pine and the variability of yields.

An inspeetion of the table of yield in Germauy, on page 69, will show that these approximations are not unreasonable. The lumber contents in board feet niay be approximated by multiplying these figures by 4 or 5 iu the younger growths aud by 6 or 7 in the older. Assuming a moderately eareful praetiee of logger aud sawyer, by no means mathematieally tenable, the above tentative propositions for normal yields might be even inereased.

To assume, as is done by eertain authorities, that tables of normal yield eould be eonstrueted by using the density indicated by a deeimal as a matlematieal faetor, using that faetor as a divisor of the aetually measured yield in order to arrive at the normal, is to mistake the valne of the density faetor. Not only wonld trees and whole aeres have developed very differently wheu grown under different density eouditions during their life, but the estimate of the density is sneh a vague and uneertain one, a mere opinion, that eveu if the greatest eare were exercised, its use as a mathematieal faetor would not be admissible. It is a mere indieation of the present condition of the growth, and its meaning at different periods of life is very different in its physiologieal effeets as expressed in volume aeeretion. 
THE WIITE IINE.

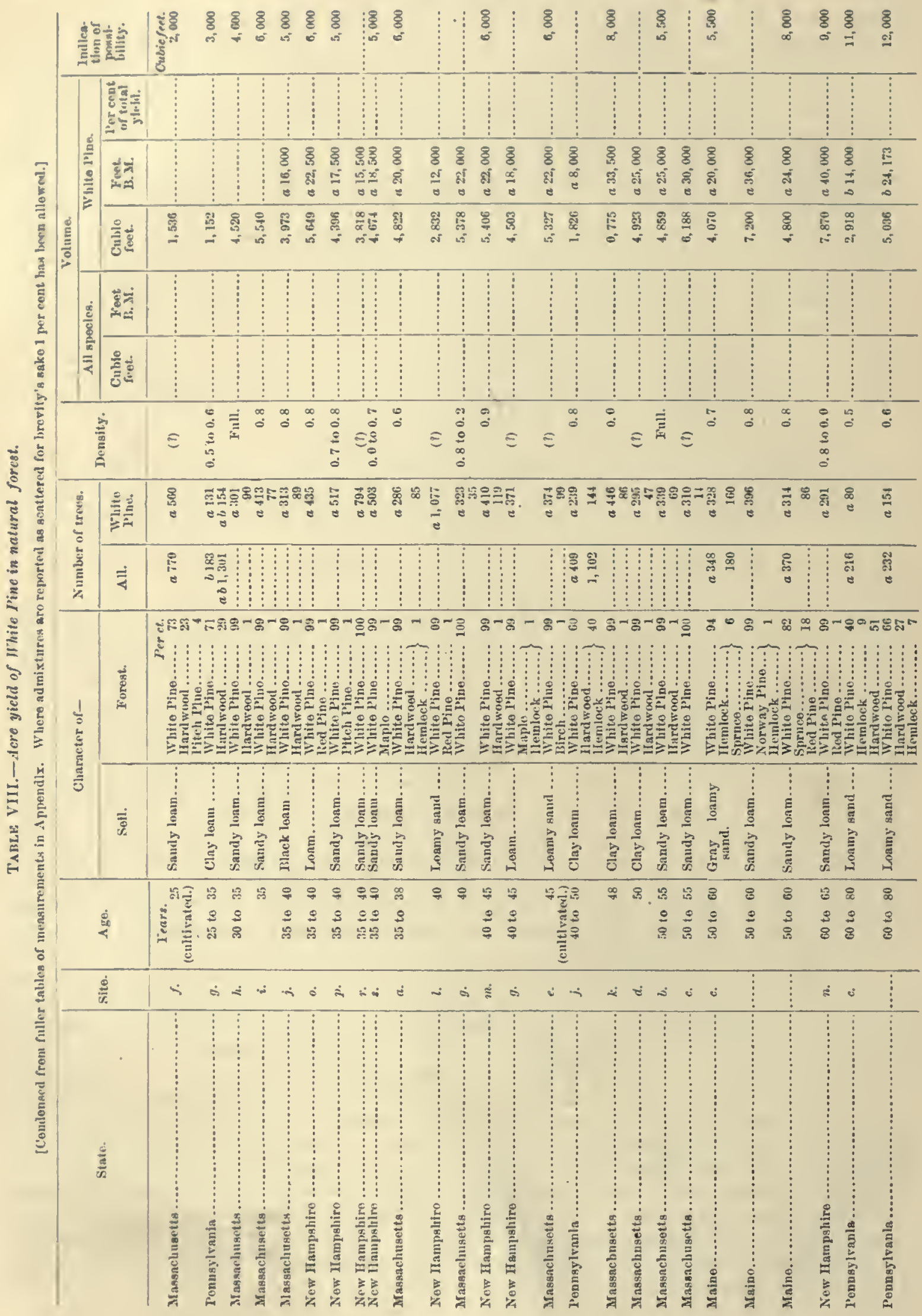




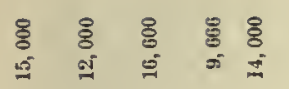

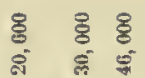

产

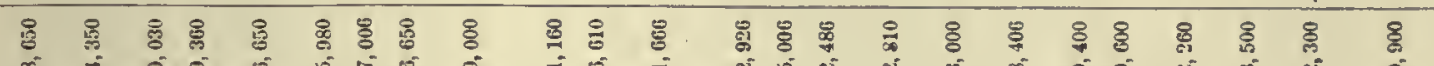

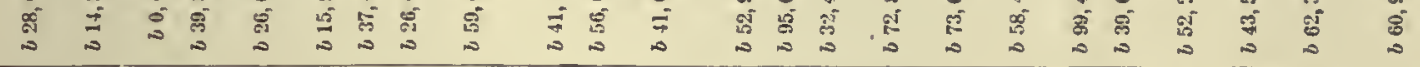

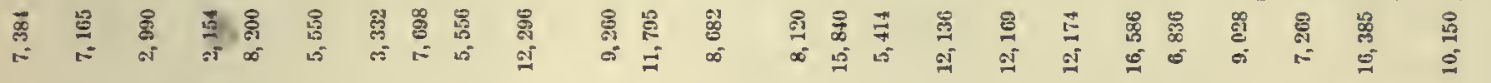

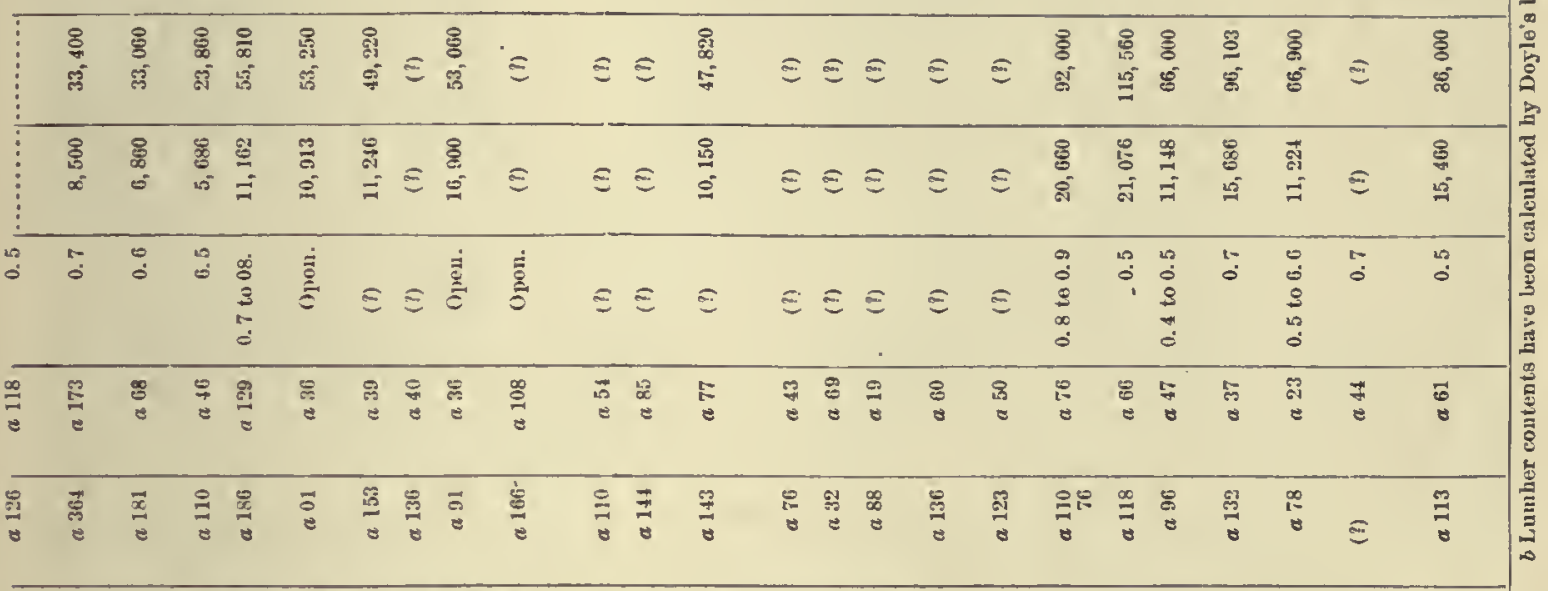

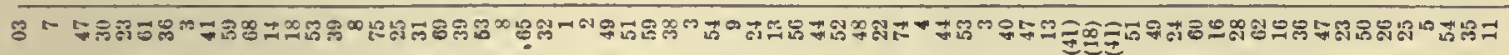
:

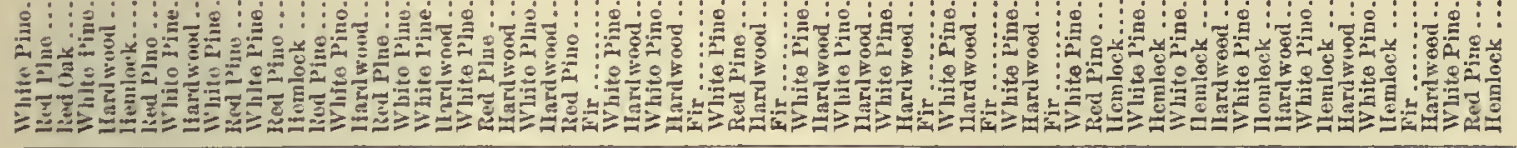

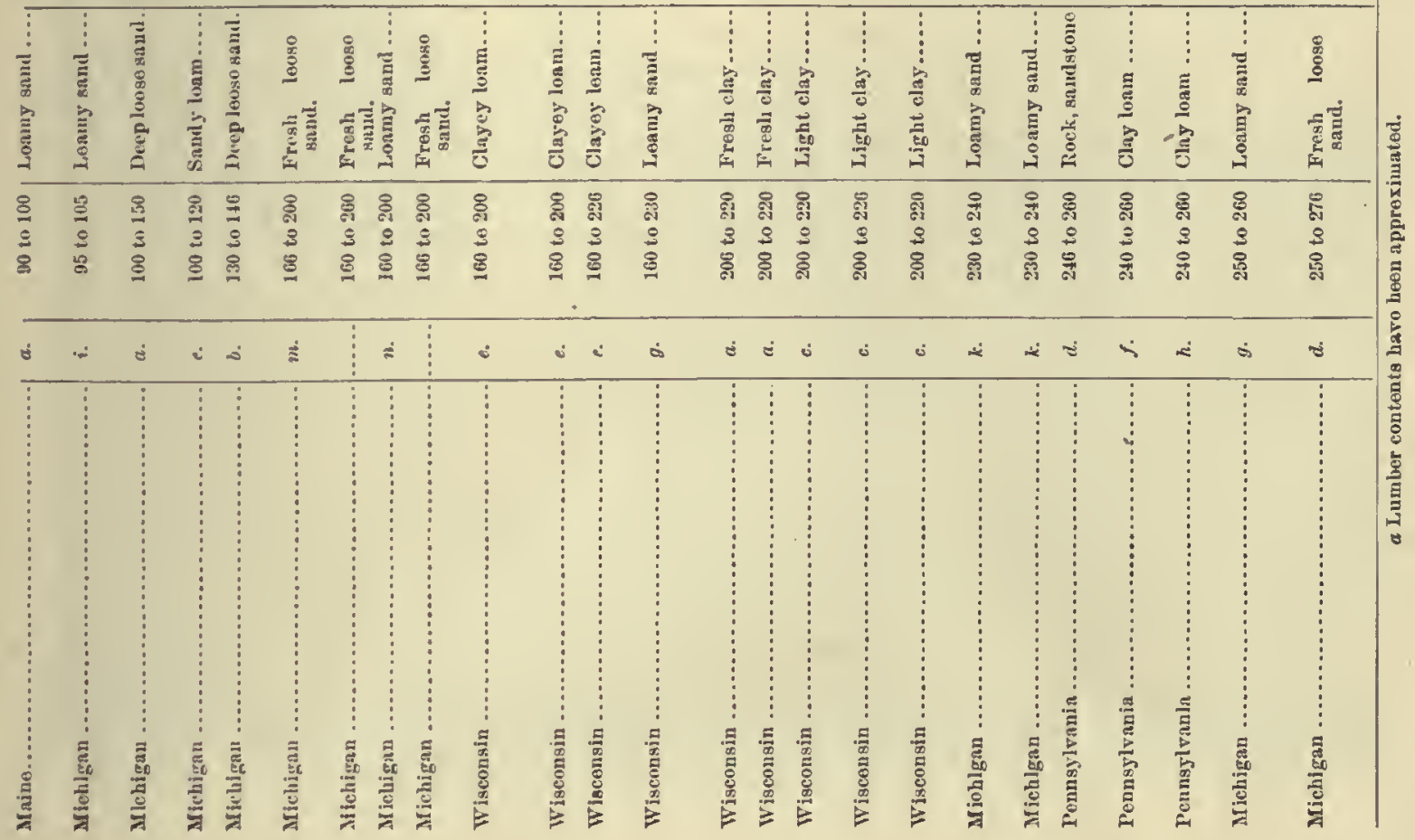


It may be of interest to reeorl more especially tlie data of a small elump of yonng White Pino sprung np natnrally on an abandoned field of less than three-fonrths of an acre in extent, sitnated near Farnington, N. H., which its owner (Mr. J. D. Lyman, of Exeter) had from time to time thinnel ont for the last twenty.two years, with a view of aeelerating the growth of the trees. Unfortunately, no reeord of previous eonditions anl frequency and extent of operations was attainable, but the present eondition (three or fonr ycars ago) is exhibited in the following table:

Data of a clump of naturally grown young White Pine.

[Age: Forty-gix to fifty-alx years; arerage, fifty-one yenrs. Height: 70 to 80 feet. A rea : 108 square rods.]

\begin{tabular}{|c|c|c|}
\hline Xumber of trees. & $\begin{array}{c}\text { Diameter } \\
\text { (breast high). }\end{array}$ & Tolune. \\
\hline 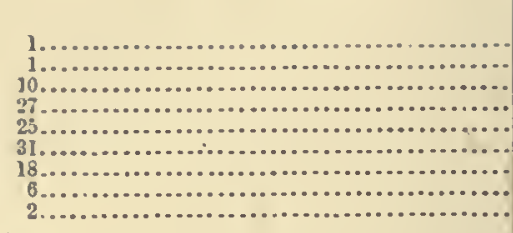 & $\begin{array}{l}\text { Inches. } \\
22 \\
16 \text { to } 19 \\
14 \text { to } 10 \\
13 \text { to } 14 \\
11 \text { to } 12 \\
10 \text { to } 11 \\
9 \text { to } 10 \\
7\end{array}$ & $\begin{array}{r}\text { Cubic sect. } \\
85 \\
84 \\
600 \\
1,169 \\
875 \\
806 \\
360 \\
96 \\
20\end{array}$ \\
\hline $121 \ldots$ & & 4,005 \\
\hline
\end{tabular}

This would indieate a yield per aere of abont 6,000 eubie feet, from whieh, with tlie dimensions attained under earefnl mill practice, some 36,000 feet of lumber might be ent. To be sure, with sueh open stand mneh of this mnst be knotty, even though the trees were prnned as far as possible.

By eomparison with the measurements of naturally grown unthinned aeres, we find that two to three times the number of trees of the age indieated in the above table might stand on an aere and make as mmeh total product (see Massaehusetts, site $c$, which, with $32 \pm$ trees, produeel 6,188 enbie feet); and although a few trees in the thimed grove had reached larger dimensions, the total produet of trees over 12 inches in diameter is almost the same, the difference in favor of the thinned part being only 100 eubie feet. From this eomparison it would appear that the thinning was too severe to seenre the most desirable results. Pl. X shows the eondition of the grove when the measurenents wero taken.

Allowanee, however, should be made for the amount utilized in thinnings. Whether this inferior material would pay in most eases the eost of its removal is questionable. A very uneertain estimate by the man who performed the thimnings plaees the amount of wood removed equal to that now standing, amoug which is 5,000 shingles.

The following table shows the measurements of one of the largest trees in the grove:

Measurements of tree.

[Age: Flfty-six years. Height: 80 feet.]

\begin{tabular}{|c|c|c|}
\hline Height of section, in feet. & $\begin{array}{l}\text { Diameter, in } \\
\text { inches. }\end{array}$ & $\begin{array}{l}\text { Number of } \\
\text { rings on sec- } \\
\text { tion. }\end{array}$ \\
\hline 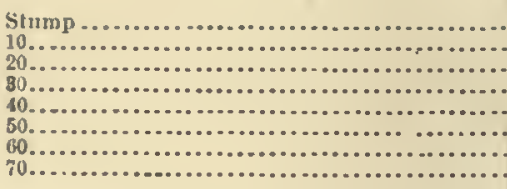 & $\begin{array}{r}191 \\
14 \\
127 \\
12 \\
101 \\
8 \\
5 \frac{1}{3} \\
3\end{array}$ & $\begin{array}{r}54 \\
46 \\
42 \\
37 \\
32 \\
24 \\
15 \\
8\end{array}$ \\
\hline
\end{tabular}

This tree, when felled and eut into waney.edged boards, made lumber to the amount of $36+$ fcet. 


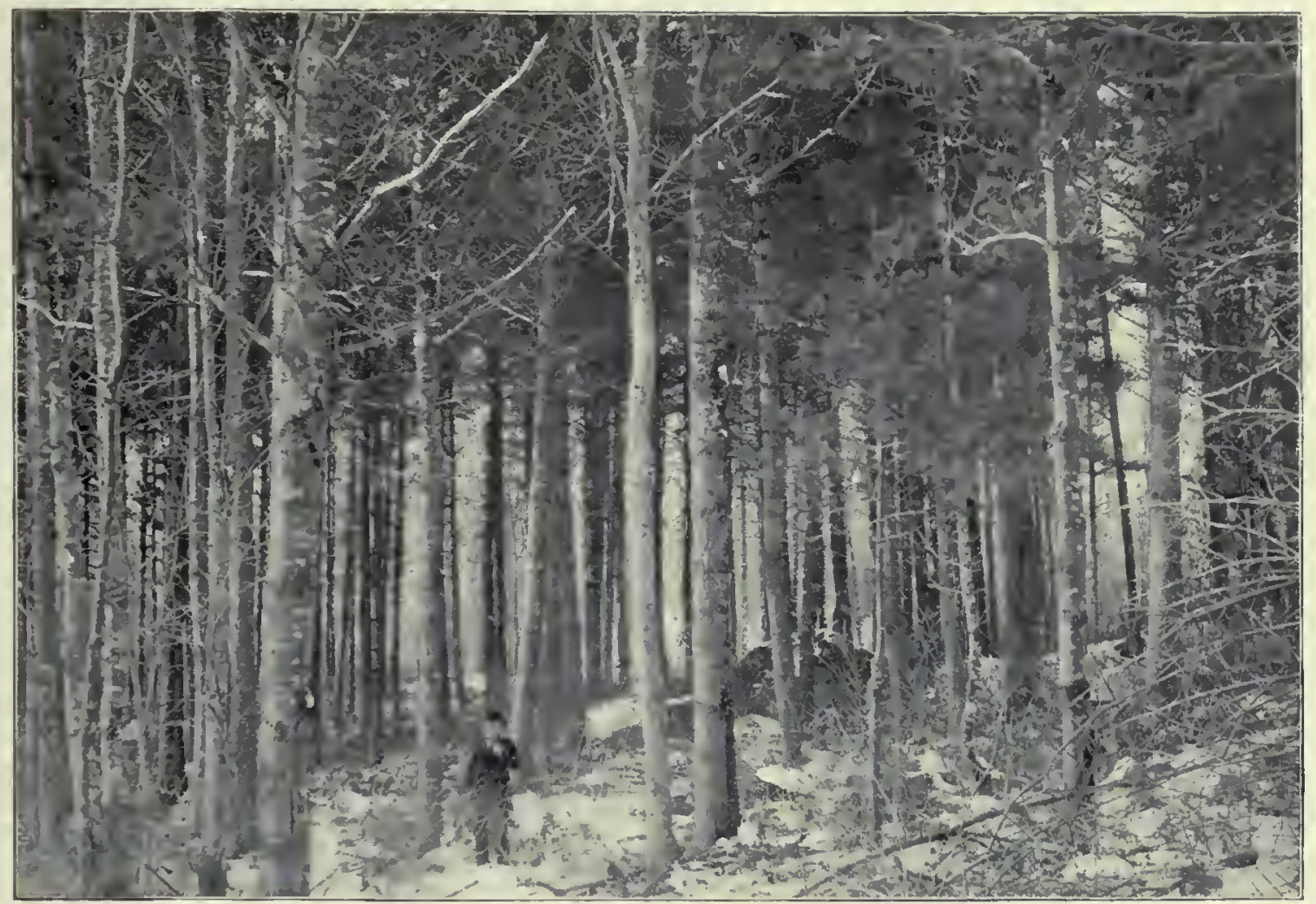

Fig. 1.-A thinned Pine Grove in New Hampshire (Trees 51 Years Old-186 to the acre).

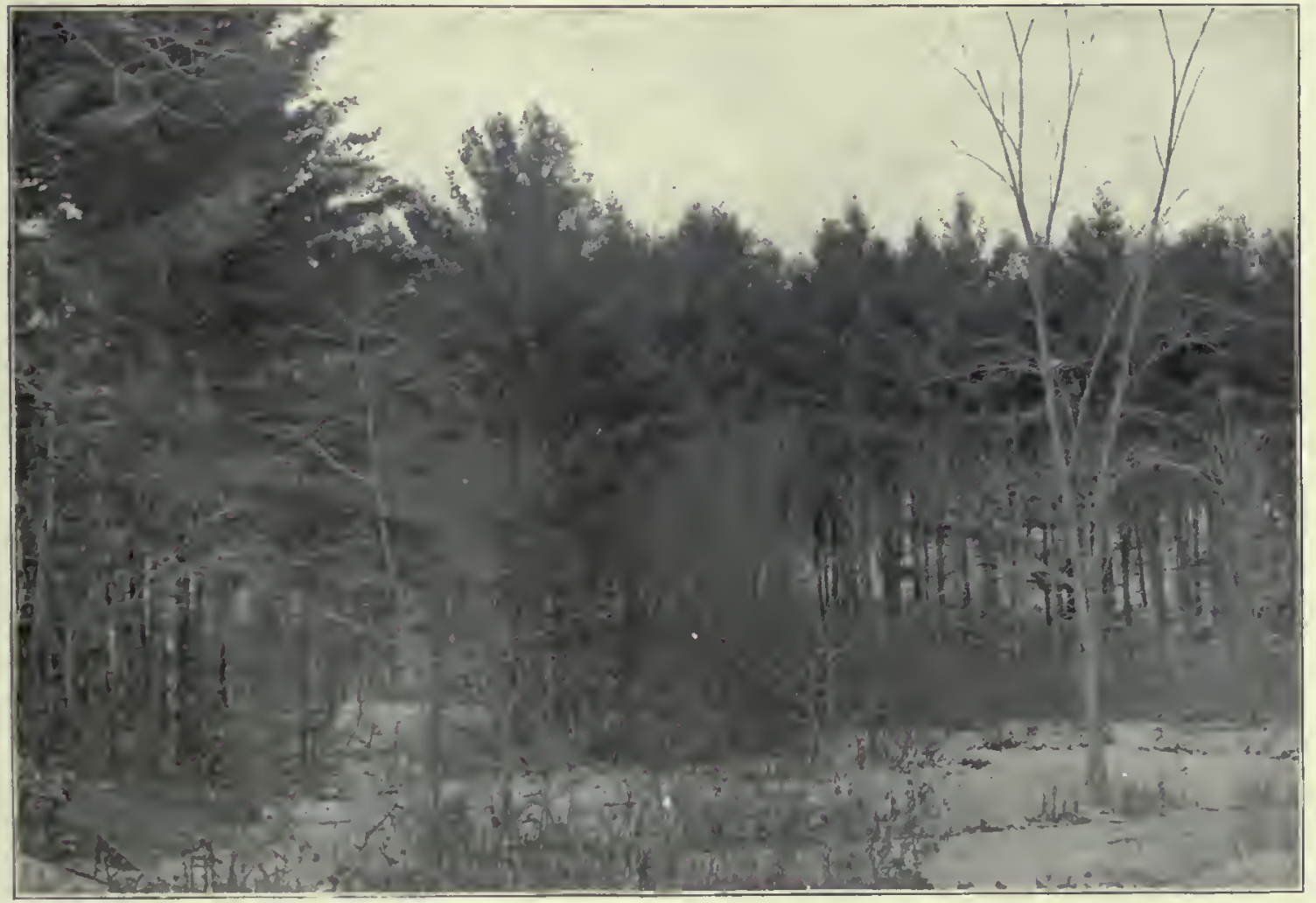

Fig. 2,-Young Pine in New Hampshire (Trees 20 Years Old). 

DANGERS AND DISEASES.

The White Pine is snbject to a considerable number of destruetive influences even when growing spontaneously, but a large proportion of these might be avoided if properly understood and guarded against, sinee they are in great part due to human ageney.

\section{INJURIES BY HUMAN AGENCY.}

The snbjeet of forest fires has been so fully discussed that it is unnecessary here to treat it in detail, althongh the pine forests of the Northern Stutes have suffered more irreparable injury from this than from all other destruetive agencies combined. From the numerous suggestions that have been made respecting protection from fire and from unnecessary injuries in general, the most important appear to be:

(1) That a well-digested code of laws, eapable of prompt enforcement, based upon the reeommendation of a nonpolitical torest eommission, is of primary inportance.

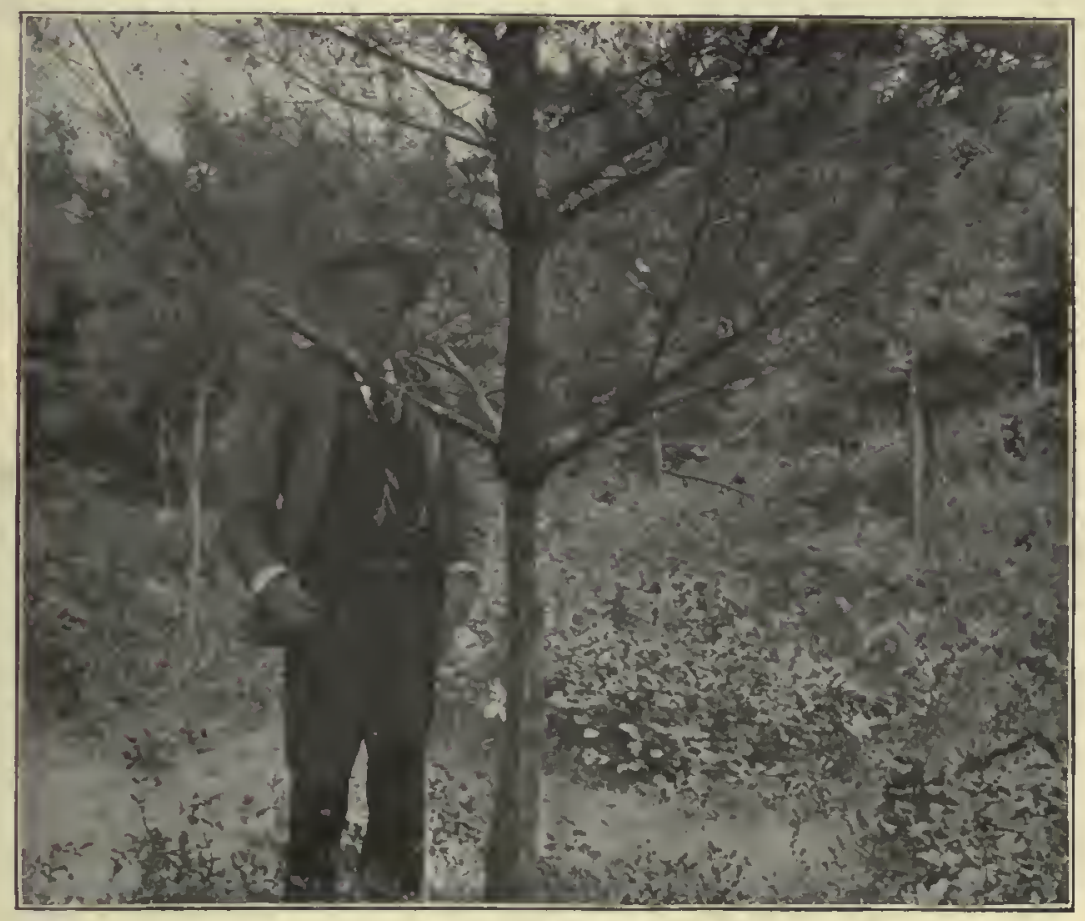

FIG. 4.-Girdled White Pine continuing to grow.

(2) That a correct public sentiment, encouraged by a wider dissemination of information eoneerning the value of forest produets and the time reqnired for their growth, will have more influenee than all other means together in preventing umeessary destruetion.

Unlike the Loblolly Pine of the Sonthern States, or the Red Pine with which it is eommonly associated, White Pine has a thin bark during the first thirty to fifty years, which affords but slight protection from fire. Consequently, the speeies suffers much in young growths from surfaee fires, which do little or no harm to the thick-barked pines and hardwoods. In the mature trees the growing layer is mueh better protecterl, as the tark with age becomes proportionately thieker than that of Red Pine.

Related to the foregoing, and properly placed under the head of injuries to be charged to human respousibility, are wounds occasioned by eattle. A pine forest is less liable to injury from the browsing of eattle than one composed of deciduous trees, and in the Eastern States old pastures commonly grow up to pine, the decidnons speeies being kept down by the cattle. Bút in 20233-No. $22-4$ 
any ease, when the growth of timber is the primary object, domestie animals should be rigorously excluded, as they are certain to do more or less injury to the growing trees. A pine forest, or a forest of any kind, is no more properly a "run" for eattle than a field of standing grain, and the damage is likely to be more extensive and less capable of repair in the former than in the latter case.

The White Pine shors considerable recuperative power, which is exhibited in the ready reestublishment of broken leader and the healing of wounds, in which the prolific resin exudations assist by leeping out water and fungi.

The experiences of Mr. Nathaniel Morton, of Plymouth, Mass., in trimining pines, recorded in The Forester ( $J$ une, 189S), show the absolnte safety of pruning live limbs of 3 to 5 inches and more in diameter, which are eoveresl in a few years by new growth (Pl. XI). An interesting case of pertinacity of life and recuperative power, which at the same time throws light on the muchdebated question of food and water movement in trees, is also reported from the same source, and represented in fig. 4.

A yomg pine in the forest ras, tro years ngo, not only girdled, but the bark peeled off for 11 inches all around the tree. The tree has a perfectly healthy appearanee, and lias continued to grow in length, althougl apparently about half as fast as before. The measurements of internodes of this tree during the last six years follow. The diameter growth above the wound has continued, while below the wonnd it lias remained stationary, as will appear from the measurements made two years after the removal of the bark.

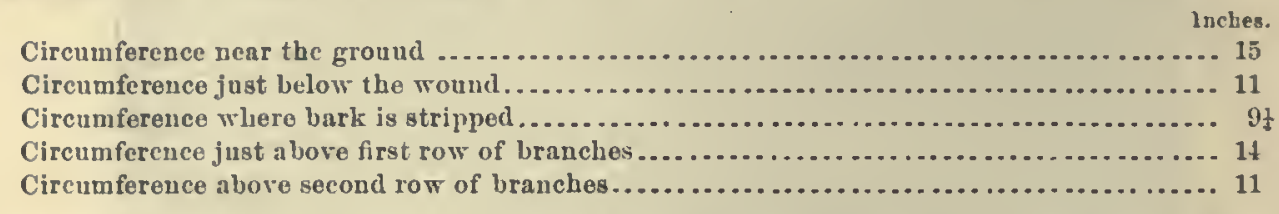

The wound is entirely covered by pitch. The growth just above the wound has a baggy appearance, showing an accumulation of wood deposit, which shows the arrest of the food materials due to the absence of the cambium la yer and bark.

It would appear that the roots could either live without the food supply from above (at least for two years), or else that a sufficient anount can pass through the dead wood of the trunk, and at least the water necessary for the elaboration of food materials in the foliage can be supplied through the old wood. The writer inspected this tree, and cau vouch for the truthfulness of the description. A similar case with a southern pine (species undetermined) came to his attention, where the tree was older and had grown over twenty years above the wound; but as only a cut was inspected the possibility of a cambial connection of the upper and lower parts was wot absolntely excluded, as in the present cise.

\section{INJURIES BY STORMS.}

Of injuries not within human control may be mentioned, first, those resulting from storms, snow, and ice. The soft texture of the rood and the short-lived branches of the White Pine would naturally snggest its being nore liable to injury by storms than are deciduous trees. This, however, is not the case. The angle which the branches make with the trunk admits of their readily bending, and under such a woight it is found that Maples and other liardwood trees break down much more freqnently. Mr. B. F. Hoyt, of Manchester, Towa, states that "a whole summer"s observation among the White Pines of Tennessee failed to reveal a single ease in whieh a tree of that species was injured by the wind," attributing the fact to the mechanical disposition and structure of the trunk and branches.' In this respect, then, the White Pine stands at a decided advantage as eompared with many deciduons trees with which it is naturally associated.

I,ike the shallow-rooted Spruce, the White Pine is liable to be uprooted and throwu by storms, although to a less degren.

While, however, the meehanical effects of the wind and of storms of suor and ice are not sufficient to require special eonsideration, the injurions conseqnences of drying winls are snch as 

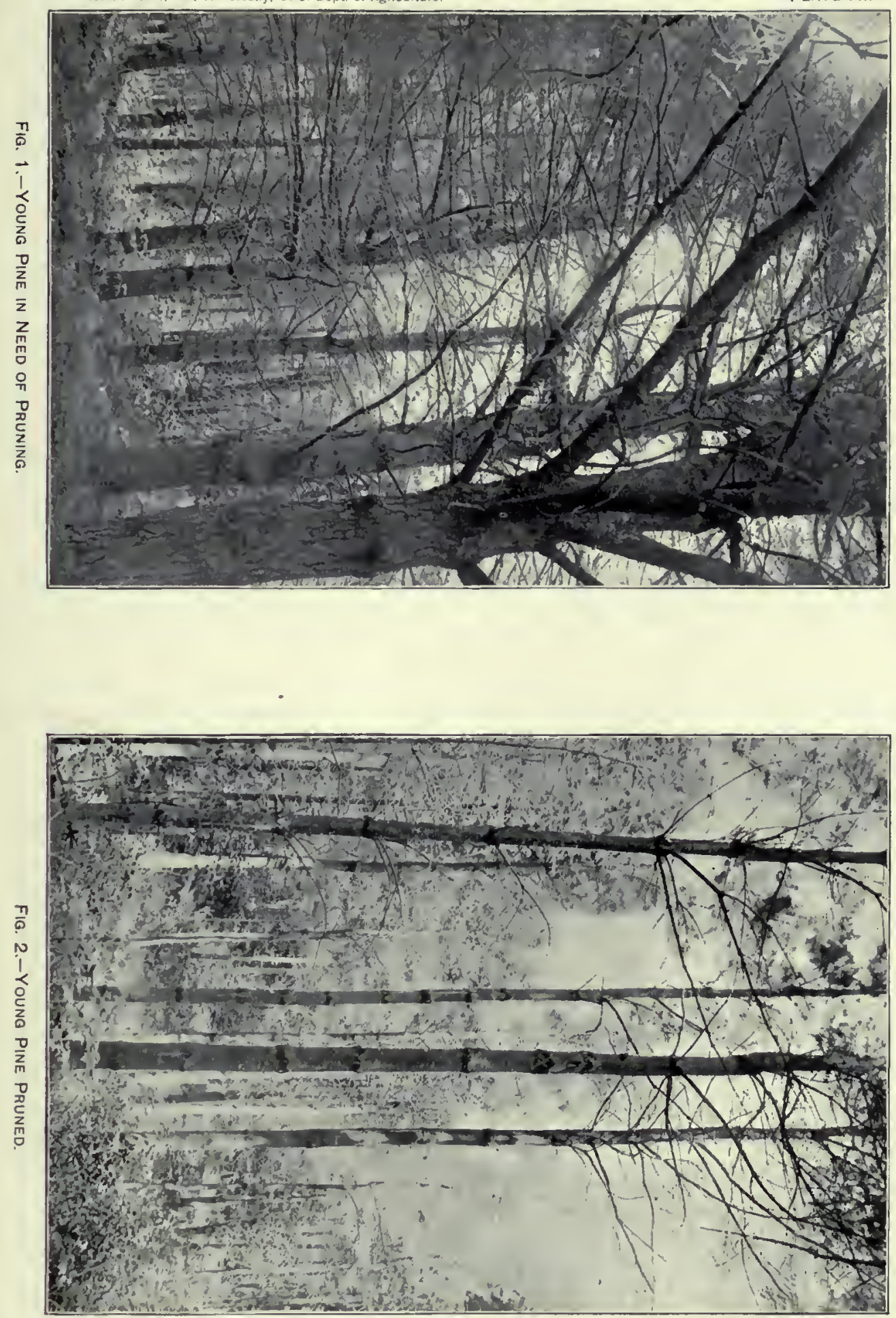

to become an important factor in determining the limits of the artificial cultivation of this species. At the time of plauting, deciduous trees are not in leaf, and aceordingly there is but little evaporation of water, while the leaf surface of conifers is exposed then ns much as ever to the drying effects of the atmosphere, often resulting in their death before they are fully established in the soil. It is for this reason and because of the general lack of a sufficient amonnt of atmospheric mois. ture that comparatively slight success has attended the cultivation of the White Pine on the plains west of the Mississippi. The raw winds from the Atlantic agaiu have been found to be mach more injurious to this species than to the Pitch Pine (Pinus rigida), and the latter is therefore decicledly preferable for planting in the immediate viciuity of the coast.

\section{DISEASES.}

\section{EFFECT OF HEAT AND DROUGHT.}

In Germany, plantations of White Pine thirty-five to forty years old have suffered much injury from a disease which appears to be occasioned by unusual heat and drought, and which was particularly severe after the hot, dry summer of 1876. ${ }^{1}$ The disease manifests itself externally by dried-up patches on the trunks, the spots being largest 3 to 6 feet from the ground, gradually ruming out above and below this, and often reaching a height of 15 to 18 feet. The spots may be only an inch or two wide, but frequently the bark is dead nearly around the entire trunk. As a rule, these dead spots are ou the south and west sides of the tree. The wood is often penetrated by larrie of insects, but these are not the cause of the disease, since in many cases they are not present.

Dr. R. Hartig, from a comparison of specimeus aud study of the disease in question, concludes that it is due to extreme dryness and that the White Pine can not be trusted to endure such extremes. He further states that it suffers greatly from dry air even in the wiuter time.

\section{PARASITIC DISEASES.}

The White Piue is subject to a number of parasitic diseases, some of which attack it when growing spoutaneonsly in the forest, while others are highly destructive to the tree in cultivation, especially in Europe under changed climatic conditions. A few only of the best known of these, including scveral due to fungi, will be cousidered in detail.

(1) Aguricus melleus Vahl.-This fuugus, of common occurreuce in the United States as well as Enrope, is exceedingly destructive to coniferous trees, the White Pine iu particular suffering greatly from its attacks. It also fasteus upon various deciduous species as a parasite, attacking living trees of all ages, but living as well upon dead roots and stumps and ou wood that has beeu cut and worked up, occurring frequently on bridges, railroad ties, and tlie like, and causing prompt decay wherever it has effected an entrance. The most conspicuous part of the fungus is found freqnently in the summer and fall on the diseased parts of the tree or timber infested by it. It is one of the common toadstools, this particular species being rccognized by its yellowish eolor, gills extending downward upon the stem, which is encircled a little lower down by a ring, 'and by its habit of growing iu tufts or little clumps of several or many individuals together (Pl. XII, 1 and 2). It is also particularly distinguished by the formation of slender, dark-colored strings (Pl. XII, 2 and 3), cousisting of compact mycelium, from which the fruiting parts just described arise. These hard root-like strings (called rhizomorphs) extend along just beneath the surface of the ground, often for a distance of several feet, and penetrate the roots of sound trees. By carefilly removing the bark from a root thus invaded the fungus is sceu in the form of a deuse, nearly white, mass of mycelium (Pl. XII, 3, c), which, as the parts around decay, gradually produces again the rhizomorphs already described. These rhizomorphs are a characteristic part of the fungus. Occurring both in the decayed wood, from which they spread to the adjacent parts, and extending in the soil from root to root, they constitute a most effective agency in the extension of the disease.

The symptoms of the disease are marked, and, taken together, sufficiently characteristic to admit of its ready recoguition. Exterunl symptoms, to be observed especially in young specimens 
recently attacker, consist in a change of the lcaves to a pale sickly color and often the prodnction of slort stuntel shoots. A still more marked symptom is the formation of great quantities of resin, which flow downwarl through the injurcd parts and ont into the gromnd, resulting in the sticking together of the roots and masses of dirt that have been penctrated by the resin. Passing up a little way into the trunk, the cause of this is sccn in the active working of the fungus in the mednllary rays and around the resin canals, where apparently both cell walls and cell contents undergo degencration and partial eonversion into resiv. This flows downward, as alrcady statel, and also works laterally into the cambinm, prodncing great blisters in the younger parts wherc growth is going on, and also resulting in the formation of abnormally large resin canals.

As the discase alvances the fungus continnes to attack the tracheids of the sonnd wood and soon indnces marked changes. Under its influcnce the walls lose their lignified character, become softer, and give the cellulose reaction, while the myceliun of the fungus penetrates and fills the enlarged cavitics of the tracheids. (PI. XII, 4, 5, 6.)

The wliole insicle of the trunk may fiully become hollow for some distance above the stmun, its interior being filled with a loose rotting mass, penetrated by rhizomorph strings, and only becoming worse the longer it stands. The disense having once reached this stage, there is of conrse nothing to be done for the trec bnt to fell it as soon as possible and save whatever wood remains nnaffected.

(2) Polyporus annosus Fries (Trametes radiciperda R. Hartig).-This is one of the most dangerons parasites of coniferons trees, cansing "red rot" and the dying ont of plantations botl of young and old pincs. In Germany it infests varions species of pincs, including Pinus strobus and Pinus syllestris; also Picea excelsa, Juniperus communis, and others. It is morc destructive to the White Pine than to the Scotch Pine.

The diseasc appears in plantations of various ages, from five to oye hundred ycars old, slow. ing itself by single plants here and there becoming pale, then yellow, and suddenly dying. These extcrnal symptoms are altogether similar to those observed in trees infected by Agaricus mclleus. Other trees are attacked in the neighborhood of the infected ones, and so the disense spreads centrifugally.

The fruiting portion of the fingis (PI. XIII, 1 to 6$)$ grows on the roots near the surface of the ground, forming yellowish-white cushious (white on the sporc-bearing surface) that may finally, though rarcly, become a foot or more in diameter. Between the wood and bark of the affected tree are extremely thin layers of mycelium, distinguished from those of Agaricus melleus by their softucss and delicacy. The tissne of the roots and the inside of the stem is decayed to a considerable height.

The discase is spread by the spores, which are carried away by mice and other burrowing animals and deposited on the roots of adjacent trees, where they germinate and penetrate the living tissues of the bark, passing thence into the wood elemcuts and growing in them toward the stcm. It is also commmicated by the roots of infected trees crossing those of sound ones in the gromnd (Pl. XilI, 7), the fingus growing directly from one to the otler.

A violct discoloration of the wood is the external symptom of beginning decomposition, in which the contents of the parenchyna cells die and turn brown throngh the action of the mycelinm. This color disappears with the loss of the cell contents, and a clear brownish-ycllow takes its placc, with scattering black spots here and there. These are surrounded at a later period with a white zone (PI. XII, 8), and at the same time the wood becomes continnally lighter and more spongy. At last numerous openings arise, the wood is separated into its constitnent fibers, and becomes watery and of a clear brownisl-yellow color. The cell wall undergocs decomposition, giving the cellulose reaction instead of remaining lignified, and finally even the cntirc middle lamella disap)pears. The process may go on until the wood clements are isolated, so that they are casily picked apart like threads of asbestos.

The parasitc advances rapidly in the wood elements, dceomposition sometines going on in this way to the lieight of 2 i) fect. In the bark it proceeds more slowly, but is linally none the less dangerous, since it canses the denth of the cortical part of the root in which it originates, and when after reaching the trunk it passes into the other roots, their denth finally resulting in the deatl of the wholc tree. 
In the Scotch Pine a great amount of resin is prorlueed, and this, accunulating in the lower part of the stem, probably aets as a barrier to the growth of the mycelium upwarl. In the White Pine the fungus extends much farther in the trunk.

Pl. XII, $\%$, represents a stump of White Pine that has been attacked by Polyporus annosus. The heart is surrounded by decayed wood and spots filled with inasses of resill. Pl. XII, 9, represents parts of adjacent wood elements of Norway Spruce after they have been acted upon by the fungus; the mycelium hyphre and spores, highly magnitied, are represented in 10 of the same plate.

(3) Coleosporium senecionis Pers.-This fungus, under the name of "pine blister," infests various speeies of pines, growing in the recidium stage on both leaves and bark, and sometimes proving very destructive. When growing on the lenves it affects but little the vitality of the tree, but is highly injurious when the bark is the place of attack. It penetrates the bark, apparently through wounds occasioned by insects, woodpeckers, or other agencies, and its mycelium spreads through the eortieal parenchyma and bast, and into the wood to the depth of several inches, passing through the medullary rays.

Under its influence the stareh and other cell contents disappear and a resinous substance collects in their stead, a mass of dead tissue soou taking the place of the living cells. This change of the cell contents results in a great accumulation of resin, which often exudes in large quantities from the diseased parts of the tree.

The mycelium is perenuial, extending itself through the stem from year to year, particularly in a longitudinal direction. Where it is present the growth of the stem is prevented and the formative materials are diverted to the opposite side of the stem, causing there a greatly stimulated and abnormal growth. The death of the leader often results, especially in dry sunmers, for the reason that the wood, thins choked with resin, is unable to supply it with sufficient water.

The researches of Wolf lead to the eonclusion that this parasite of the pine lives in the form known as Coleosporium senecionis on various species of Senecio, and that it is communicated to pine shoots from them. He proposes the extermination of these hosts as a preventive measure. Later investigations of Kleebahn go to show that a blister rust which he olserved badly affecting the bark of Pinus strolus, in the neighborhood of Bremen, is causerl by a closely related parasite form which he names Peridermium strobi, and considers to be the recidium stage of Cronartium ribicola.

All these fungi have probably caused far more destruction of timber than casual observation would indicate, but the limited extent to which artificial cultivation of forests has thus far been carried on in this eountry gives comparatively few exact data regarding them. The facts, as above stated, have therefore been drawn largely from the works of Hartig and other European authorities. With increasing cultivation of timber and probable increase of such diseases, their investigation and the employment of protective measures must neessarily receive far more attention.

Several diseases attributable to the action of fungi, but as yet imperfectly investigated, are of frequent occurrenee in this country. One of these, known as "damping off," characterized by the sudden deeay of seedlings at the surface of the ground, is common in nurseries, and attacks young plaints of different kinds, the $W$ hite Piue anong them.

The disease is most prevalent in plants growing in a damp soil in a warm, moist atmosphere. As observed in the Amn Arbor (Michigan) greenhouses for several years in various plants propa. gated from slips, the disease appears a few days after the slips are set, giving the lower part of the stem a wet, unhealthy mpearance, which extends to the lower leaves, particularly where these touch the sand in which they are growing. Upon taking up the specimens, the parts affected are found to be in the early stages of decay, and penetrated throughout, even in the interior of the epidermal appendages, by the branching filaments of a fungus. The fungus appears to live in the saud in which the plants are propagated, and to run in it from one to another, resulting often in the rapid destruction of the plants in the bed.

"Danping off" is due to the action of several different parasitic organisms, of which the potting-bed fungus, Pythium de baryanum Hesse, is one of the most common, though a number of other species have been shown to be capable of produeing the disease. The relief mcasures recommended by those who have studied the disease are the use of fresh soil free from decaying 
matter, as muclı smulight as the plants will édure withont wilting, a fairly low temperature, and an abnulant supply of fresh air. Mr. J. Dawson, of the Arnold Arboretun, suggests watering the young plants from below, so as to avoid wilting the leaves; as a means of prevention. Other snggestions will be found in recent literature of the subject, practically in the reports of varions agricultural experiment stations.'

$A$ disense which attacks the trunk of the tree, at various ages, is very prevalent in pine forests, and occasions the condition known among humbermen as "punky pine." A diseased tree can frequently be recognized by its having one or more knots with a rougl, irregnlar contonr, at a considerable height above the gronud, commonly conspicuous by a considerable ont tlow of resin. These seem to result from the breaking oft of brauches, followed by gradual deeay at the place where they have separated from the tree, in such a way as to admit water into the trnnk, the opening being afterwards partially covered by subsequeut growth of the tree while decay is going on inside.

Upon examining the wool of snch a tree, it is seen to be discolored and in varions stages of decay, the diseased condition cxtending inward from the linot hole, and both upward and downward from it in the truuk. By inspeeting logs cut from sneh trees, it will be noticed that the decayed portion may have filled np the.center, making a rotten heart; or it may follow the rings of growth for some distance, midway from the center to the periphery; or it may be still nearer to the surface, its position and extent being very variable and following no recognizable rule. The parts diseased are utterly worthless, though boards containing a greater or less amonnt of wood thus affected are common in the market. Microseopic examination shows that the woor is peuetrated by the filaments of a fungns, and that the elements of whicli the wood is male up have becn greatly altered, and to a considerable extent decomposed by its action.

Continued observation in the pine woods of Michigan, in different years, does uot so far justify' the reference of this disense to any single species of the various fungi found growing upon the trunks and logs of decaying pine trees. But whatever the species, one or several, concernerl in producing or hastening the condition described, the general facts, as stated above, appear to be that the disease finds its way where the separation and decay of a brauch presents a favorable place for the entrance of water and the spores of fungi, and that it spreads so extensively in the trnnk as to entirely rnin large and valuable trees.

In our natural forests tliere is, of conrse, neitler remedy nor prevention, but in artificial cultivation careful and seasonable pruning would doubtless be the most effectual preventive, since, if properly performed, the wounds left by the removal of branches would soon be grown over and there woukd be no further danger from this source.

FXPLANATION OF PLATE XII.

1. Agaricus melleus, elnster of young sporopliores.'

2. Agaricus melleus, larger sporophore with root-like organ of attaehment.

3. Root of spruce tree invaded by mycelinm of Agaricus mellews; rhizomorph of same fungus ou the right.

4-6. Fragnents of pine wool slowing the destructive action of Agaricus melleus.

7. Stump of White Pine attacked by Polyporus annosns; the heart is still sound, but is surromnled by decased wood and spots filled with masses of resin.

S. Wool of Norway Spruce in early stages of decay ocensioned by action of I'olyporus annosus; tho wlite areas have become delignified, nurl the wood elements composing them are soft anil ensily separable.

9. Wood elements of Norway Spruec isolater and showing the myeelinm of the Polyporus annosus.

10. Fruiting hyphre and spores of Polyporns annosus.

\section{EXILAXATION OF PIAATH XIII.}

1. Stump of Norway Spruee, with a sporophore of Polyporus annosus several years old; the iuner portions of the stump wholly decayed.

2. Roots of a cliseased sprnee tree, with unmerous small sporophores of Polyporus annosus attaehed.

3. Stump and part of root systen of a young pine tree killed by the action of Polyporus aurosus, the sporophopes of which have grown entirely around the base of the trunk.

4. Mature sporophore of Polyporus annosus secu from below, showing the porous spore-bearing surface.

5. Jature sporophore of Polyporus annosus from above, showing the velvety npper surface and eoncentric bands.

6. Mature sporophore of Polyporus annosus in section.

7. Mode of infection; where the sunaller diseaserl root crosses the larger one, the myeclium of the Polyporus annosus has penetrated the latter and spreal in both direetions for some distanee. 

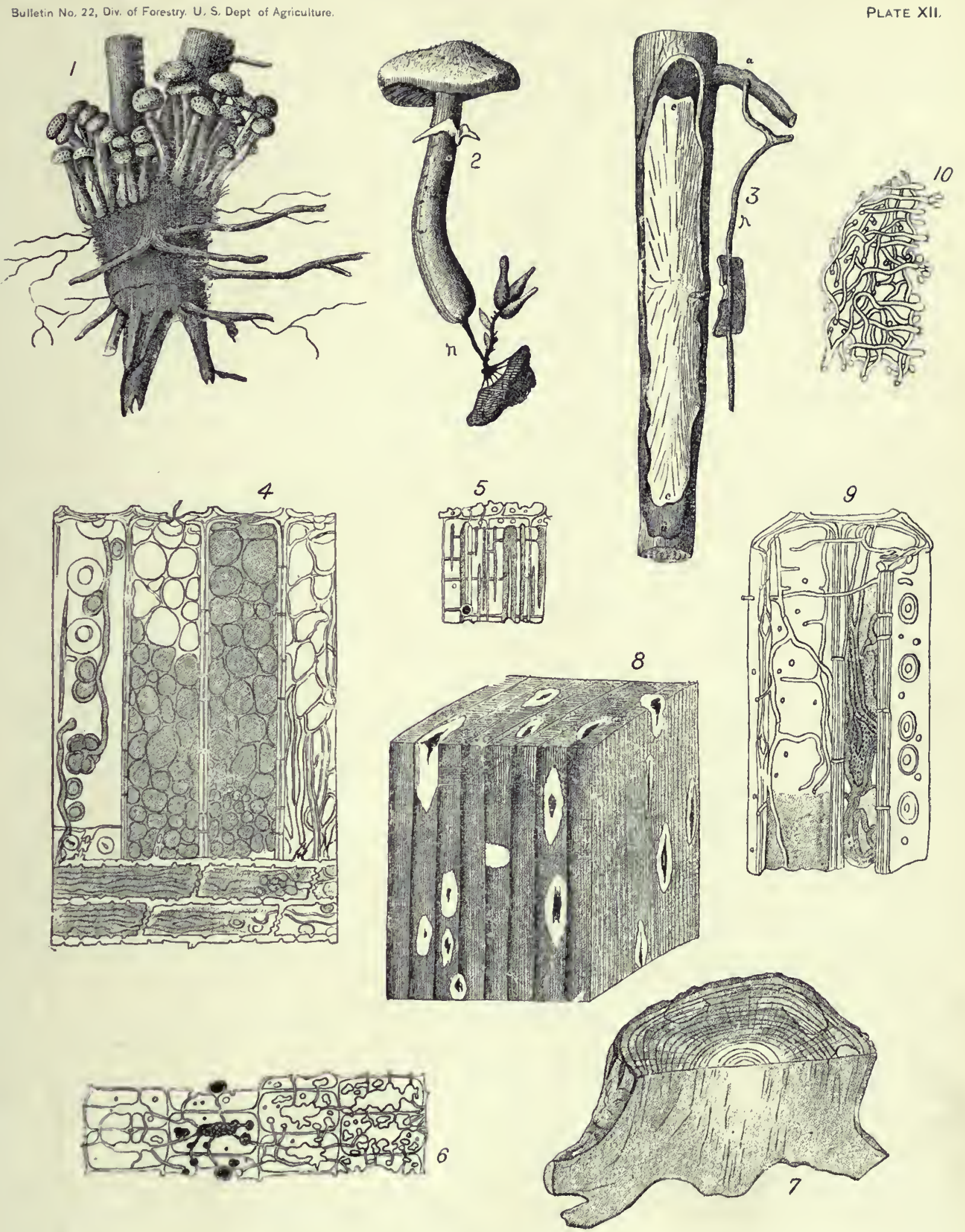

Disease of White Pine: Agaricus melleus. 


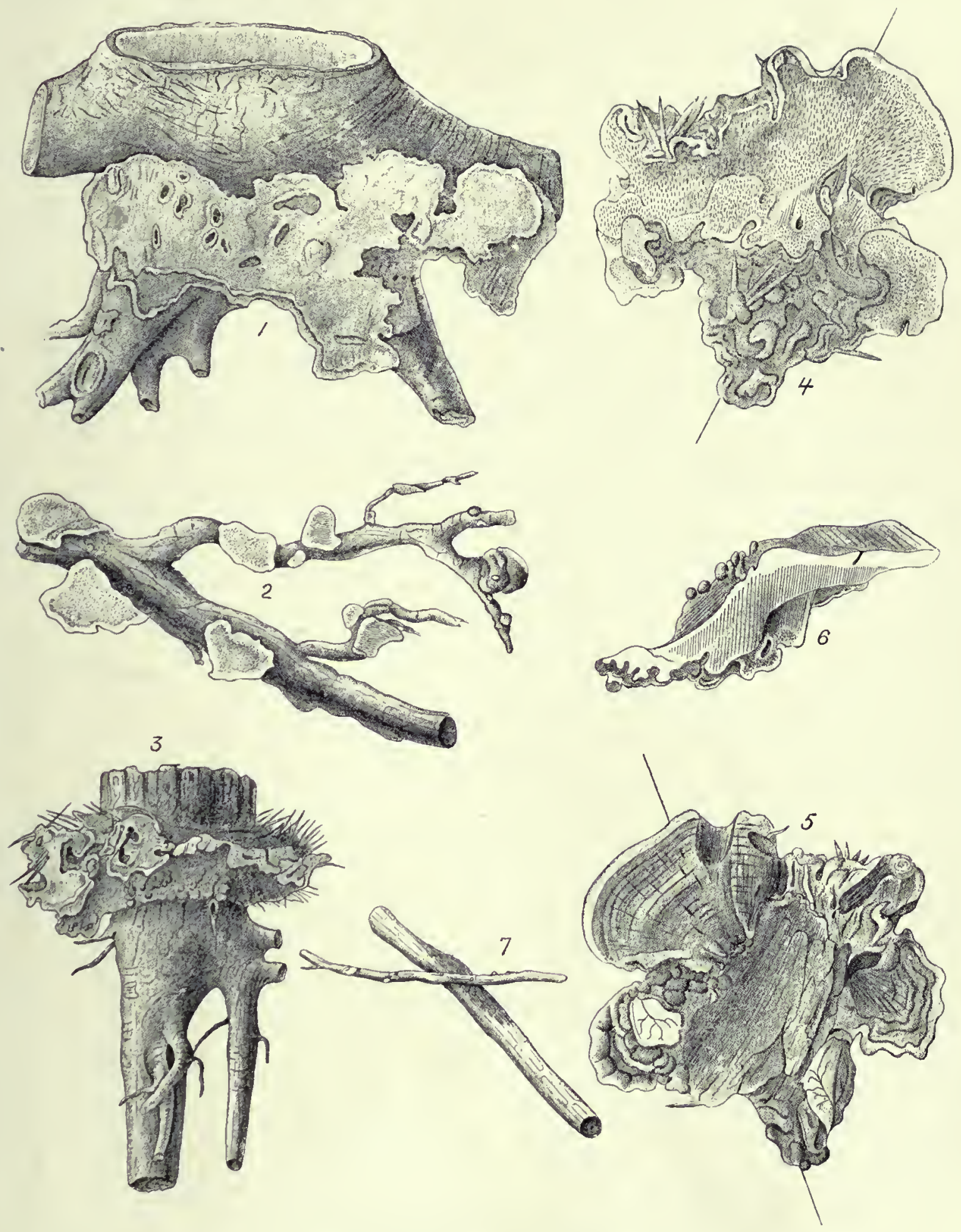

Disease of White Pine: Polyporus annosus. 



\section{INSECT ENEMIES OF THE WHITE PINE}

By F. H. Chittenden, Division of Entomology.

\section{INTRODUCTION.}

Of all coniferous plants, perhaps none are more subjeet to insect attaek than the Whito Pine. Upward of a hundred species are reported to affect this tree, and a carefin compilation of all known speeies would probably ada many more to this list. The more important are found in tlie order Coleoptera, and of these the eylindrical bark-beetles of the fanily Scolytidae hold the lighest rank. Most of the Seolytide live within the cambinm of dead or dying trees, but a few penetrate the solid wood, and several forms, when excessively abundant, do not hesitate to attack healthy growth. Nunerons other Coleoptern belonging to the families Cerambyeidre and Buprestidre similarly infest the White Pine, but are for the most part secondary iu the nature of theil attaek, and will therefore require only passing mention. One species, however, the white-pine weevil (Pissudes strobi Peek), is a pest of the most peruicious typer In addition to the bark-boring and wood-boring insects, several species infest the roots, some only the branclies or twigs, some the eones, and others injure growing trees by defolintion. The leaf-feeding species comprise the larva of several sawflies, the eaterpillars of numerous moths, and a number of beetles. Various species of plant-lice and scale insects also occur npon the leaves, and often the limbs and trunks of trees are injured by them.

Most of our injurious forest insects are native to this eountry, in which respeet they differ markedly from those which affect field and garden erops. Only such speeies as experienee has shown to be more or less injurions either to living trees or to cut timber will be eonsidered in this paper. Some few forms that have not been recorded on White Pine are inentioned, as it is more than probable tlat they are capable of injury to this tree. The majority, however, have been observed on White Pine.

In the preparation of the present paper the writer has drawn freely from the published works of Packard, Fitch, and Hopkins, as well as from personal experienee in pine forests, particnlarly of New York.

\section{THE DESTRUCTIVE PINE BARK-BEETLE.}

The last decade witnessed very extensive destruction of pine and sprnee forests in portions of the United States east of the Roeky Mountains. The prineipal injury, which dates from about the year 1888, has been attributed to the so-called destrnetive pine bark-beetle (Dendroctonus frontalis Zimm.), one of a genus of six deseribed speeies, all of wide distribution and all destrnctive to the Coniferre. It is quite possible that some predisposing agency had first cansed a weakened eondition of the trees in the infested districts, but it is fairly certain that this species of beetle Was responsible for much injury. The infested area observed eomprised the pine and spruce forests from Maryland in the Nortl to and ineluding Yorth Carolina-ill-the Sonth, an area estimated at upward of 10,000 square miles in extent. In some sections entire forests were killed. $h$

The accompanying illustration of this speeies (fig. 5) will

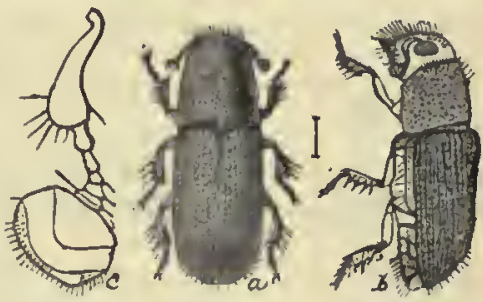

Fia. 5.-Dendroctonus frontalis : $a_{1}$ dorsal view of beotle; $b$. lateral viow-enlarged about six times; c. antenna-greatly eularged (author's illustration).

enable its recognition. - It ranges from reddish to dark brown in eolor, and meisures about one. ciglith of an inch in length, being the smallest species of its genus. Its eredited distribution includes Lako Superior to Georgia, and it is reeorded also from Arizona and Cálifornia. The adnlt beetle appears some time in May, the date depending npon season and loeality, bores into living trees and its larvic develop under the green. sappy barl Copions quantities of turpentine exnde from the holes made by tho beetles and dry in masses upon tho bark. The manner of work of the larve in great numbers beneath the bark produces abont the same effeet as that of girdling, thus cutting off the tlow of sap, the natural supply of plant food and moisture, greatly wcakeiing and evcntually killiug the trees. The first ontward manifestation of injury is tho accumulated masses of pitch, followed by the leaves turning yellow and then red, as though scorehed. by fire. 
A singular feature in connection with the irruption of this species is that it was practically nuknown save in the collections of specialists until its suclden appearance in 1858, but still nore remarkable is its unacconntable, but almost entire, disappearance in 1S93, not, however, before it hat done a great amount of damage, which has bcen estimated at upwarl of a million dollars. The apparcut extermination of this bark-bectle in the district where it was most destructive is believed to have becin due to a fungoid disease.

\section{REMEDIES.}

After boring insects of this class once gain access to a tree it is practically impossible to eject them, and to save the tree recourse must be had to preventive ineasures. For this purpose various protective washes are in use. One of these consists of lime, to which has been added a sufieient quantity of Paris green to give it a slight green color and enongh gluc to canse it to be adlesive. Another wash consists of soft soap reduced to the consistency of a thick paint by the addition of washing soda in water. A thick wash of soap, plaster of Paris, and Paris green is also of valuc. A carbolated wash, which is in successful use against the peach-tree borer, is prepared by mixing a pint of crude carbolic acid with a gallon of soft soap in eight gallons of soft

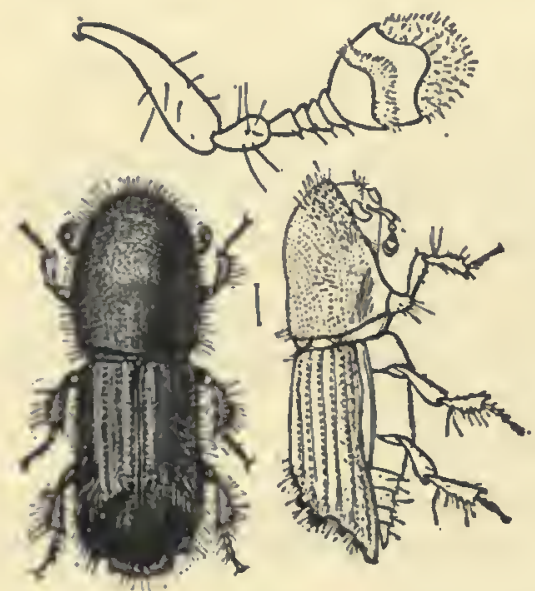

Fro. 6.-Tomicus cacographus: beetle, showing dor al viow at left, in profile at right-enlarged about ten times; antenna abore, higbly mag. nifled (original).

water. Fish or train oil is valuable as a deterrent, but should not be used except with the greatest caution upon young trecs. Whatever rash is employed should be applied to the trees on the first appearance of the beetles in May, and should be renewed if found necessary.

Better than any other ineasure, however, is the observ. ance of clean cultural methods. Owuers of pine forests or groves will do well to cut down all dead aud trim all injured trees. For the protection of pines, dead spruces and other coniferous trees, and such as are infested and too much weakened to recuperate, should be cut down and destroyed by burning. A great deal of good ean be accomplished merely by removing the bark of dead timber. The progeny of the insects that have deposited their eggs in one scason so loosen the bark that it is an casy unatter to remove and burn it before the following spring. By pursuing this method millions of the insects will be destroyed before they have an opportunity to issue and lay their eggs for the destruction of other valuable trees. A practice known as "rossing" is in nse on borer-infested lumber in Cauala. It consists in cutting a strip of bark along the full length of the upper side of a log, which causes the bark to dry up and eventually drop away.

\section{OTHER INJURIOUS BARK-BEETLES.}

Of the other species of Dendroctonus, one has recently been reported as ravaging the spruce forests of New Hanpshire. It is the species at present known as D. rufipennis Kby., and although not known to affect White Pine, it is not impossible that it might attack this tree in case it extends its present depredations. The species of Dendroctonus are peculiarly periodical in their attacks. There is, however, one exception, I. terebrans $\mathrm{Ol}$, which is usually common at all times over a very wide aren of the United States and Canada, infesting all the pines. According to information received in May, 1898, this or a related species is now ravaging the pine forests of a portion of southern New Jersey.

The genus Tomicus contains perhaps quite as dangerous forms as those which have just been mentioncd. The appearance of the beetles is somewhat similar, as is also their method of life. A species that has been associated with the mortality of pines in the region about and south of the District of Columbia is T. creographus Lec., or southern pinc bark-beetle, which is illustrater much cularged at fig. 6. It is reddish in color and may be rendily separatel from any of the preceding 
species by the structure of its antennæ and by the toothed apex of the elytra or wing-covers. Its mine is shown as it appears on the under side of the bark of a tree at fig. 7.

Tomicus pini Say, the northern pine bark-beetle, is destructive to pine forests in the North in a very similar manner to the preceding species, which it much resembles in structure as in habit, but is less injurious farther South. T. calligraphus Germ., a similar spceies to the two preceding and about equally destruc. tive, abounds in the pine woods of both the North and South, and T. cclatus Zimm. and T. avulsus Eich. also infest White Pine. Among other well-known white-pine bark-bcetles may be mentioned Crypturgus pusillus Gyll., Hylurgops glabratus Zett., and several species of Hylastes and Dryocœtes.

The remedies to be employed against these insects are practically the same as for the destructive pine bark-beetle.

\section{TIMBER-BEETLES AND OTHER SCOLYTIDI.}

While the majority of the pine-infesting Scolytidæe breed between the bark and the wood, a considerable number, called timber-beetles, live entirely within the sapwood; others, the twig-beetles in the small twigs and branches, and a third group, represented by Pityophthorus coniperda Sz., inhabits the cones.

The chief danger from the bark-beetles, as has been shown, is from their attacks on living trees. They do comparatively little damage to timber, except as they looscn the bark and thus afford ready access to water and mold and to other destructive insects. The timber-beetles, or ambrosia beetles, as they are sometimes called, live almost exclusively in greenwood, preferring that which is slightly injured, of impaired vitality, or such as has been nerrly felled, but they often attack and kill healthy growth, and in the process of their work in timber cause a staining or "bluing" which entails a still greater loss than results from their direct attack to living trees. The presence of these beetles in a tree is manifested by the little piles of white sawdust which they eject from the "pin-hole" entrance to their

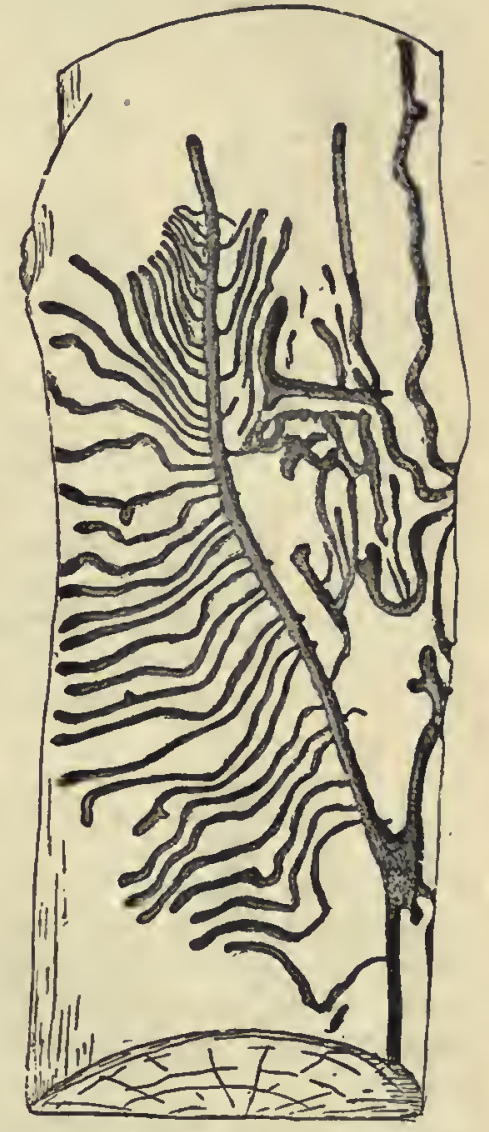

FIG. 7.-Galleries of Tomicus cacographus on wood under bark of pine (original). galleries. The pine timber-beetles are found in the genera Gnathotrichus, Xyloterus, Xyleborus, and Platypus. Gnathotrichus materiarius Fitch is the commonest of three species of the

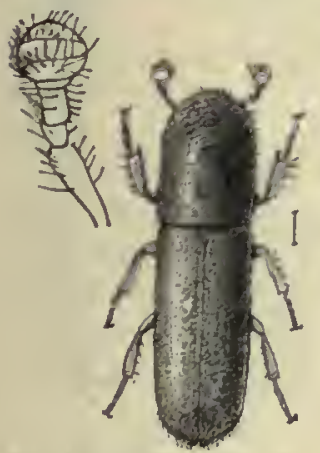

Fio, 8.-Gnathotriclis ma. leriarius: beetle, enlarged; antenna stlll more enlarged at left (Marz del.). genus, all of which attack pine. This species is shown greatly enlarged at fig. 8 , and its characteristic galleries in the wood of pine are well illustrat $d$ at fig. 9.

The same remedies advised against bark-beetles will prove valuable against the timber-beetles. Kerosene emulsion or a carbolated wash would accomplish the destruction of the timber-beetles even after they have attaiued entrauce to a tree, provided the application be made in time.

The twig.beetles are represented by the genera Pityophthorus and Hypothenemus. Of the former genus, P. sparsus Lec., cariniceps Lec., pullus Lcc., lautus Eich., plagiatus Lec., are all well-known pine species. The genus Hypothenemus inhabits alike deciduous and coniferous trces.

Remedies are the same as for bark-beetles. Pruning and burning infested twigs and branches and the clearing away and burning of brush heaps during winter are indicatcd. For choice ornamental trees in private grounds and in parks plugging the "pin holes" with wire and stimulating the trees with manures and fertilizers to assist then to recuperate from attack are advisable.

\section{FINE SAWYERS AND OTHER BORERS.}

Of all the insects that occur in pine timber the Cerambycid, or long-horned beetles, of the genus Monohammus, are the best known, and are credited with being the most destructive. If 
we except the losses oceasioned by the more or less sporadic attacks of certain speeies of the Scolytide alrealy mentioned, probably this opinion is about correct. Fivo of these speeies liavo been described, all pine fecders and beetles of the largest size, with elongate cylindrical bodies and extremely long antenne, those of the male being two or three times as long as the remainder of the insect. The pine sawyers are most troublesome in the mill yard, and their large white larvie often do much damage to logs by eating great holes through their solid interior. While burrowing in the wool the larvie make a peculiar grating sound that may be heard on quict nights at a considerable distance. This is a familiar sound in the lumber eamps of the North, aud las probably

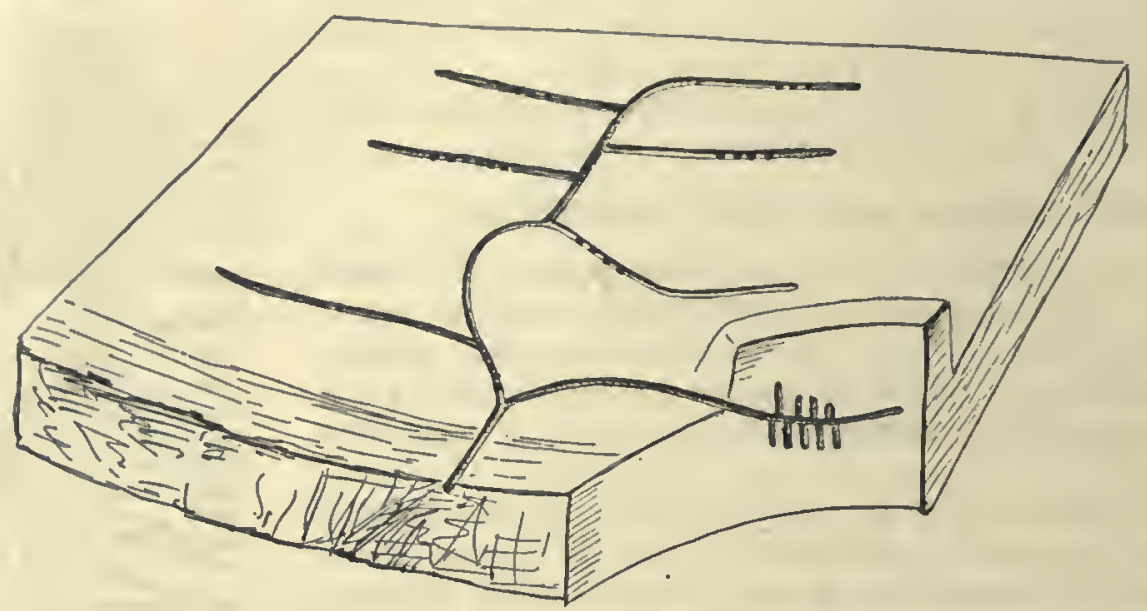

Fin. 9.-Gallery of Gnatholrichus materiarius in pine (adapted from a drawing by A. D. IIopkins).

given rise to the name of pine sawyers, by which these insects are known. Monohammus confusor Kby. is a large gray species destructive in the lumbering districts of the Nortliern United States and Canada; $M$. titillator Fab., a mottled brown bectle, replaces the above species in the South, and Mr. maculosus Hald. occurs in the West; Mr. scutellatus Say. is widely distributed and abundant from the Atlantic to the Pacific, and Mf. marmorator Kby. is a rather rare northern form.

Among other borers belonging to the sane family as the sawyers, the majority of which infest White Pine, may be mentioned Criocephalus agrestis Kby., $C$. obsoletus Rand., Asemum moestum Hald., Orthosoma brunneum Forst., Prionus pocularis Dalu., Hylotrupes bajulus Linn., Callidium

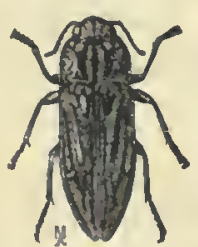

Fro. 10.-Chalcophora virginiensis - natural size (Jarx dlel). antennatum Newm., Rhagium lineatum Ol., Graphisurus pusillus Kby., Acanthocinus obsoletus O1., A. nodosus Fab., and Neoclytus muricatulus Kby.

In the Coleopterous family Buprestida are many borers which infest pine. These include fivo species of Chalcophora, one of which, $C$. virginiensis Dru., is figured (fig. 10); Dicerca punctulata Sch., D. tenebrosa Kby., Buprestis striata Fab., Mclanophila fuicoguttata Harr., M. longipes Say., Chrysobothris dentipes Germ., C. floricola Gory, and C. scabripennis Lap. and Gory. These beetles are graceful in form, hard of texture, and many aro brilliantly metallic. Their larva are slender, white grnbs with very large, round flat heads. Some of this family attack living trees and do injury to the sapwood and to felled timber in the same mamer as the sawyers, but the majority of them prefer devitalized material, and their attacks are usually secondary to some more injurious speeies.

\section{THE WHITE-PINE WEEVIL.}

In the White Pine forcsts of the Northern States, particnlarly in those of a second growth, onc's attention is often drawn to the great mmber of deformed trees. They sometimes occur singly, but more often in groups. The inscet that is responsible for this damage is the white.pine weevil (P'issolles strobi Peek). This beetle is a member of the family Cnrculionide, and is about a fourth of an inch in length, of oval form, red and brown in color, with its elytra marked with white 
spots, as shown in the aecompanying illustration (fig. 11). It is provided with a rather long rostrum or snout to whieh are attached its elbored antenne. The larva, whieh is white and foot. less, is illnstrated at $a$, and the pupa, also white, is fignred at $b$.

This weevil is one of the first spring visitants in the North, oecurring as early as Mareh about Washington City and in A pril or May farther north. Its eggs are deposited on the terminal shoots of pine, particularly of young trees, but sometimes also in the bark of old trees. The larva, when hatched, bores into the pith or mines the sapwood. 'Towarl the end of suminer it attains full growth, when it goes into hibernation until the next spring, transforming to pupa and soon afterward to the mature or beetle form. The presence of this insect in a tree is first manifested by the wilting of the leadiug shoots, which becomes most evident toward the close of summer: The identity of the speeies at work may be established at once from its peculiar eells benenth the bark. (See fig. 12.) These cells, which are destined for its winter nest and for further transformation, are sunk into the pith and covered over with long fibers of chipped

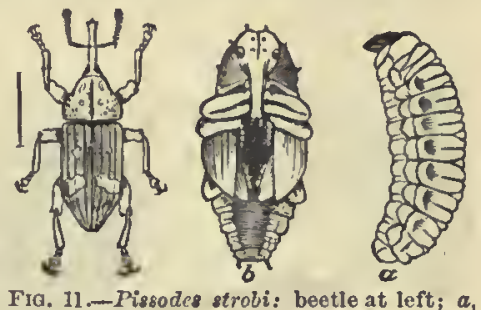
Fra. 11.-Pissodes stroli: beetle at left; $a_{1}$ larrn; $b$, pupa-enlarged about three times (from Packard). woot. When a terminal shoot of a small tree becomes filled in the summer with these larva, to the number sometimes of a score or more, the shoot, with its lateral branches, as well as the stoek below, wilt and gradually die, tho bark becomes loosened, pitch oozes out, and by antmmn the shoot turus black, and the bark is eovered with masses of pitel. A tree thus damaged will fail sometimes for several suceessive seasons to send ont a new terminal shoot, with the result that

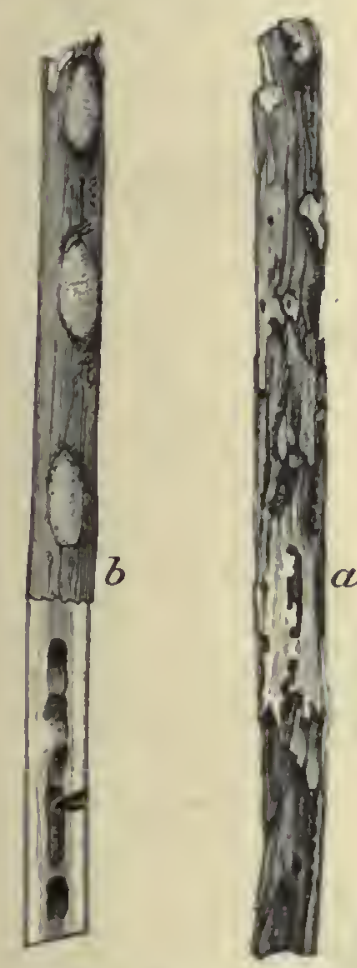

Frg. 12.-Pissodes strobi: $a$, larral zoines under bark; $b$, pupal cells-nataral aize (from Riles). the lateral shoots continue to grow, and the tree beeomes more or less distortel.

Owners and overseers of pine groves will ho well to make a practice of examining the young trees each year, say in Angust, and when one with a wilting terminal shoot is found to eut or break it off and eommit it to the flames. With every blighted twig thus treated from a dozen to fifty or more weevils will be destroyed, and thus the numbers of the insects for the eoming year will be greatly lessened. All dead growth or such trees as have from any canse been injured beyond recovery and which might serve as eenters of infestation by harboring this weevil or other injurious species shonld be similarly treated. What is most needed is a preventive, and for this purpose a good thick fish-oil soap mixed with Paris green and earbolie aeid, in the proportion of about a pound of the former and a quart of the latter to 100 gallons of the wash, is recommended. It should be sprayed in April and May on the terminal shoots of the trees and repeated at the end of a month if neeessary.

\section{MOTH CATERPILLARS AND PLANT-LICE ON TRUNKS AND LIMBS.}

The trunks and limbs of pine are also subject to the attack of several insects besides those in the order Coleoptera that have been mentioned. Of these are three tortrieid moths of the genus Retinia, which affect the pitch and other pines. Two other moths of similar habits to the abore oecur on White Pine, wounding the trunk below the insertion of the branehes and.eausing the resinous sap to exulde. These are the pitel.drop worm (Pinipestis zimmermanni Grote) and Harmonia pini Kell.

The same remedies advisel for other boring speeies, and particularly those speeified to be used against the white-pine weevil, are indicated for the present elass of inseets.

Several speeies of plant-lice affect the White Pine. The white-pine aphis (Lachnus strobi Fiteh) is very abundant in the Northern States, living in eolonies on the branehes of trees and puncturing aud extraeting their juices. The so-ealled "pine blight," Chermes pinicorticis Fitch, is sometimes very destruetive, its presenee being manifested by large patehes of a white, floeeulent 
secretion, beneatl which covering aro concealed myriads of minute lice. Sehizoneura pinieola Thos., feels on the tender shoots of young White Pine.

lierosene emulsion applied as a spray is the appropriate remedy for these plant-lice.

\section{LEAF-FEEDING INSECTS.}

The most destructive insects of the foliage of pine are several speeies of sawfies of the genera Lophyrus and Lyda, one of which is represented in its several stages at fig. 13. It is called

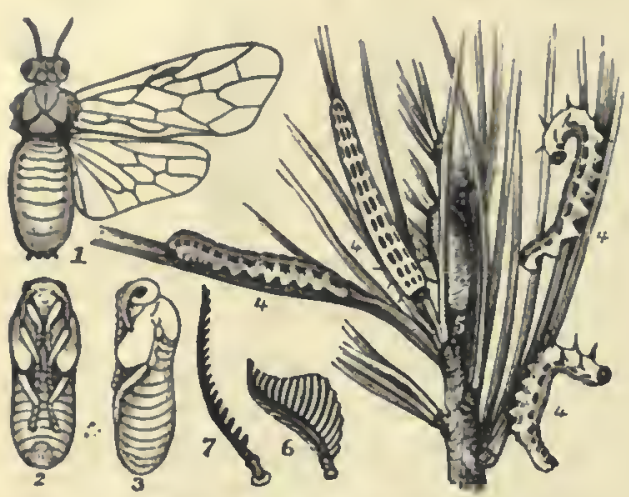

Fio. 13.-Lophyrus abbotii : 1 female, enlarged; 2, 3, pnpa, enlargol; 4, 4, larre, natural size; 5, coeoon, natural slze; 6 , unale antenna, 7 , female antenna, enlarged (from Riley).

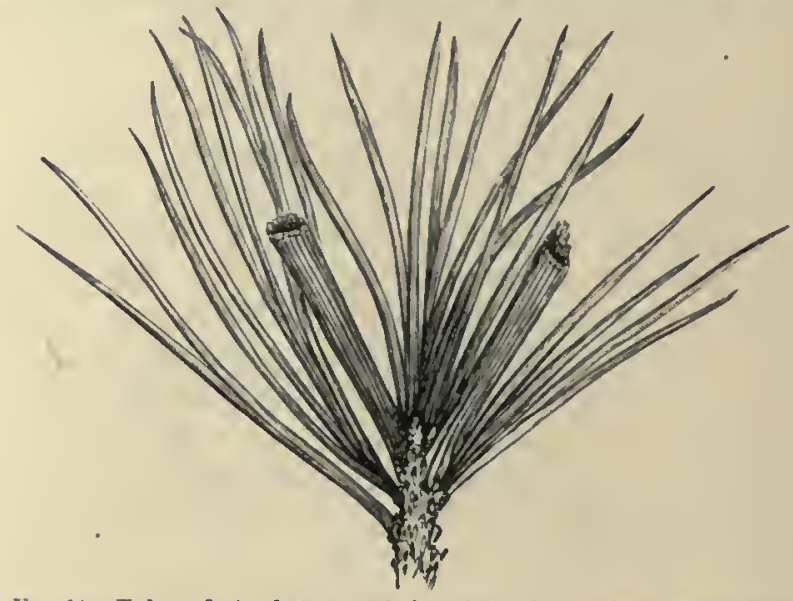

Fro. 14.-Tubes of pine leaves made by pine tube-bnilder-uatural size (from Packard).

Abbot's white-pine sawfy (Lophyrus abbotii Leach.), and is perhaps the most injurious foliage feeder which infests the pine woods of the North.

The caterpillar of a single species of butterfy, Theela niphon Hbn., is known to feed upon the foliage of White Pine, but among the larvo of moths of different families are innnmerable pine-

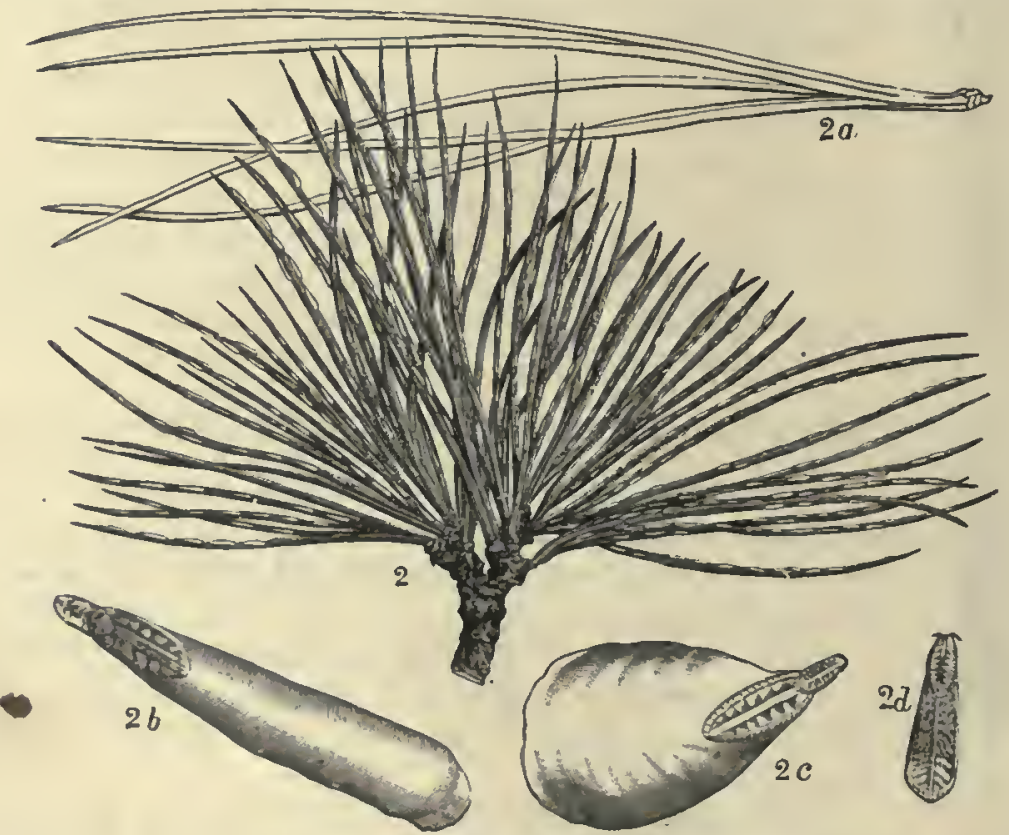

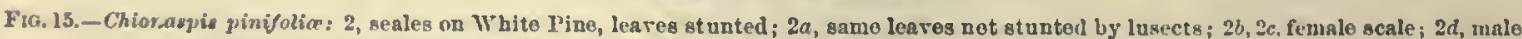
seale -2 and $2 a$ natnral size, $2 b$ and $2 c$ much cularged (from Comstoek Ann., Rept. Dept. Agr., 1880).

feeding species. Prominent among them is the magnificent sulphur-yellow imperial moth (Eacles imperialis Dru.), whose larva attacks the leaves of varions forest trees. Of other moths whose eaterpillars devonr the foliage of White Pine may be mentioned: Harris's pine hawk moth (Ellema harrisii Clen.), E. coniferarum S. and A., E. pineum Lint., Tolype la rieis Fitch, the white-pine tufted caterpillar (Platyecrura fureilla Pack.), tho redhead inehworm (Semiot).isa bisignata Walk.), 
the sulphur leaf-roller moth (Dichelia sulphureana Clem.), Teras ferrugana S. V., and Amorbia humerosana Cleni. An interesting species is tho pine tubo-bnilder (Lophoderus politana Haw.), which, in its larval stage, lives within a tube formed by webbing together a number of pine needles as shown iu fig. 14.

A number of specics of adult Coleoptera, whose larval habits are imperfectly understood, sub. sist upon the leaves of White Pinc. Uf these are the Scarabeid, Dichelonyeha albicollis Burm., and the Chrysomelid, Glyptoscelis pubescens Fab.

The best remedy for the sawfly larve, caterpillars, and beetles is a spray of Paris green, applicd upon the first appearance of these insects on the trees.

The eonsideration of the inscct enemies of the White Pine may conclude with the mention of the pine-leaf scale insect (Chionaspis pinifolice Fitch), which forms its scales upou the leaves, exhansting them of their juices and eausing them to turn yellow. This species is illustrated at fig. 15.

A strong spray of kerosene emulsion will be found an efficient remedy against these scale iusects.

\section{FOREST MANAGEMENT.}

As regards forest management, we have, unfortunately, in this country no experiences whieh would permit ns to form very positive opinions based ou actual observation regarding this species or any other. The study of the uatural history of the spccies in its native occurrence permits us, nevertheless, to draw eonclusions which may at least serve as a basis for its future sylvicultural treatment.

In the first place, it may be declared that the White Pine is the most important and promising species upon which to expend atteution in our coming forestry operations within the limits of its natural occurrence. Its adaptation to a variety of soils and situations within these limits, its rapid growth, its cxcellent form, its remarkable mass development per acre, its shade endurance, its all-rouud usefnl wood proluct, and its propagation, both by natural and artificial reproduction, give it a position among our timber trees hardly approached by any other.

There are eertaiu general principles which are the resnlt of experience in forest management in Enrope and elsewherefapplying to this as to most species. The first is, that unixed growth is in every respect superior to pure growth; it will therefore be proper policy to grow White Piue preferably, if not altogether, in mixture with other species. This advice is given in spite of the fact that the White Pine grows rather well iu pure stand, and that, owing to its shady crown during a long period of its life and the density of stand in which it can develop, and the large quantity of foliage which it sheds, the soil conditions are not in danger of deteriorating, as would be the ease witl more light-needing species. But, as has been observed in its natnral occurrence, its development is more favorable iu companionship, and especially is this the case with regard to the cleaning of the bole of its brauches, which are peculiarly persistent. Whether it would pay to substitute an artificial cleaning by pruning the young growths is still doubtful; meanwhile the self-pruning performed by mixture with slady companions will have to be encouraged, especially as thereby other valuable advantages are secured which attach to the inixed forest in general.

Unfortunately, onr irrational exploitation has reduced the White Pine in the natural forest areas often to such an extent that its reestablishment is possible only by artificial means. Wherever the culling las not been too severe, and either young growth has developed or seedling trees have becn left, the natural reproduction should be enconraged by favoring the young growth and by removing or thiuning out other species which interfere with the starting of a young growth. Fortunately, the White Pine, owing to its shade endurance, is specially fitted for natural reproduction from the seed of mother trces, more so than most other pincs, and the rapidity of its growth, in which it excels most other shade-enduring species, is also favorable in this respect.

Wo are not yet prcpared to determine the most profitable rotation iu which the species is to be managed under varying conditions. The fact that it is not only a very rapid but one of the most persistent growers, trees makiug wood at the rate of $1 \frac{1}{2}$ to 2 cnbic feet per year up to the one hundred and fortieth year, perinits a wide range of choice for rotatious, and since its wool, being rapidly clianged into lieartwood, becomes serviccable very early, the rotations may be either low or high, varying from fifty to one hundred aud fifty years, according to local economic and soil conditious. 


\section{NATURAL REPRODUCTION.}

The White Pine reproduees itsclf readily in the virgin forest on all sandy and loamy sand soils where the hardwoods do not interfere. On these areas thickets of joung growth, sapling timber, and dense groves of mature trees are scattered without regularity, and there is no indiention that this pine forest has undergone material change for eenturies. In the hardwood distriets of the licavier soils of the Lake region, where the pine is met with chictly as old, overripe timber, the reproduction of the pine seems, temporarily at least, to be interfered with by the associated growtl. Large, old trees occur, thinly scattered or in clusters, but sapling timber and young growth is often entirely wanting over considerable arcas. Similar conditious prevail, or have prevailed, in the mountains of Penusylvania, and also in New Eugland and in the Adirondacks. Where the pine is cut and some seed trecs arc left the ground soon covers itself with young growth. This, eontrary to the common notion, is truc even where fire has run over the slashings and the ground for a time is stocked with l'oplar and other brush. Such groves or thiekets of young pine occur in all parts of the pinery of the Lake region, and in the aggregate cover several hundred thousand aeres. Generally, however, the fire returns from time to time, the young seedlings, as well as the mother trees, are finally all destroyed, and thus the rcproduction is eompletely prevented. On sueh lands, imporerished by fire and exposure to sun and wind, not even the Poplar returns. In the hardwood, Spruce, and Hemlock regions the cutting of the pine in the usual manner simply assists its competitors, and its reproduction is seriously hampered and frequently prevented altogether. Where these clay and loam lands are completely cleared and then abandoned, as las been the case with thousands of acres of New England forests, the White Pine is one of the first to return if any seed trees exist in the vicinity. Hundreds of groves have sprung up in New England in this way.

\section{NOTES ON NATURAL REPRODUC'ION.}

A case of the kind above referred to was observed in 1886 in York County, Me., and the following notes on the subject will, no doubt, prove of interest:

In company with Mr. John E. Hobbs, who is thoronghly familiar with the history of the varions pieces of forestexamined, a visit was made to a numher of places on which white Pine was growing, others on which young pine seedlings were coming in, and still others in the immediate vicinity where none were to be seen, althongh the general eonditions of soil and situation were practically identieal. Tho soil, mueh of it, was light and sands, with a growth of Comptonia, Pteris, Gaultheria, and other plants common on pine land.

A large number of trees had a erop of eones, the last year before this visit in which there was a good erop having been 1879, aceorling to Mr. Hobbs. Going first to an open field that was formerly eovercd with pine trees, it was found to be very thickly oovered with young seedlings, from a few inehes to 2 feet or more in height, that liad sprung up in sneh abundanee that a bare spot was hardly to be seen over the whole traet. This piece was ent over in the winter of 1879-80, the gronud was not burned over, and there being a good crop of seeds, these had growu promptly and a young forest was rapidiy eoming ou to take the place of the one removed.

On going to other pieces in the vieinity, from which the pine had been ent at different times since 1879, a most striking contrast was observed. On these pieces that seomed otherwise just like the first, and with the conditions just as favorablo for a seeond growth, only a very few pine seellings were to be seen. Theso few may have eome from sceds carried by wiud from the neighboring forests, bnt evidently the ground had not been seeded as the first pieco had, and it was impossihle not to draw tho conelnsion that the differenee was due simply to tho fact that the first piece was fully seeded, while the others wcre not. Repeated ohservations of similar pieces of laud led further to tho conelusion that no dependeuee can be placod npon the springing up of seeds that have lain dormant in the ground for a term of years; or, in other words, although tho scols of the White Pine retain their vitality for a long time if kept in a dry place, there is a lack of cridenee to show that this is the ease in the natural forest, where they are alteruately dry and wet.

Other interesting couditions of growth were noticed in the same region. In the ricinity of standing pine forcsts, partieularly on their leeward sido, seedlings of different ages were coming up, often very thickly, but ulon cntering the forest, after the first 2 or 3 rods, no more of these were to he seen, their growth having evidently been prevented by tlie dense shado of the standing trees. In hardwoods, on the other hand, whero the surroundings wero a little more favorable, somo young piues were growing here and there.

All ohservations rcenforced tho truth that there is no mysterious sucecssion of forest growth, involving necessary alternations, and that the White Pine does actually grow aud flourish for an indofinite number of generations on the samo laud, if only the necessary seeding has been insured.

In such regions as have just been descrihed reforesting with the Whito Pine is a comparatively simple matter. Where nothing more is done than to tako advantage of natnral conditions hy felling the trees in seed years, or by leaving seod trees here aud there, an ahundautcrop of youug pines may ofton be secured. As a matter of faet, large 
tracts in Maine and Massachusetts are coming up in this way to secoud-growth pine, and as the profit arising from the protectiou of these youur forests is better uuderstood, there is no reason to doubt that the whole unatter will in a great measure regnlate itself.

In the Adirondack regiou and in the pine belt of Michigan, Wisconsin, and Minuesota the case is far different. Under the present system forest fires are au almost necessary result of all lumbering operations. To start with, all trees that are large enough are cut, and if by chance here and there one has escaped that might produce a crop of seeds, it perishes iu the tires that soon sweep over the ground, leaving hardly a living thing behind them, and burning the seeds that under other conditions uight have sprung up to form a sccond growth of pine. On all such bnrned tracts pine seedlings are rarely fonud in any number, and yet here aud there they are seen growing where the fire had left a seed tree by the side of a stream or a piece of unburued ground, thus giving the seed a chance to grow?

After making a careful study of the pine lands of Michigan for several years the conelusion seems plain that here, exactly as in New England, everything practically depends npon reseeding. Here in the Northwcst the seed trees have been destroyed, the seels in the ground have been burned, and, as an inevitable conscquence, the land remains a wilderness and must remain so nutil some meaus are found of restoring the forests by artificial sowing or planting. There is nothing in the soil itself that prevents reforesting the pine lands of Michigan at once. It is becanse seeds are, to a great extent, wanting, and the seedlings that do start are not protected, that these pine lands are left in their desolate and unproductive conditiou.

The experience with White Pine in Enrope fully confirms the correetness of the observations above recited. White Pine abroal reprodnces well, sceds abundantly, and is so partieularly well snited to natural reprodnction that the most experienced and eompetent reeent writers claim that this tree fairly "demands" this form of regeneration.

\section{ARTIFICIAL REPRODUCTION.}

Concerning the artificial reproduction by seeding or planting, the experience, both in this country and Europe, is quite extensive. Not only has this species been planted frequently and for a long time in New England and in other parts of its natural range, even for forest purposes, but thrifty groves have been established also in the Western prairies beyond the limits of natural distribution. In Germany larger or smaller plantations were made in many localities near the beginning of the century.

The planting in this eountry has, however, not usnally procecded with a knowledge of proper forestiy practice. As a rnlc, plants have been set ont too old, and henee the planting has proved expcusive; usnally, also, it has bcen too wide spaced to secure the most desirablc result in form development. Another point also usially neglected is the admixture of other spccies to stimulate the growth of the pines and possibly to reduce the expcnse of covering the ground.

In Enrope the majority of pine plantations made with Scotch Pine (Pinus silvestris) is made with one-ycar-old scedlings, which is donc very cheaply and expeditiously, often on unprepared gronnd, when one man may set 1,000 to 1,500 plants in a day.

For White Pine, especially under our conditions, where the young plants have much to eontend with in the way of climatic ills, weed growth, etc., this method is probably not applicable.

Two-year and cren three-year old plants, grown in seed beds and once transplanted in nursery rows, to produce a stocky root system and growth, will probably be more successful, being better prepared to overcome adversities.

The seedlings, grown from seed sown either broadcast or in drills in the seedibeds, must be shaded during the first two years, as is usual with conifers in this conntry. After the second year they will endure the hottest sun. The shade must be graduated according to the weather, as the seedlings are liable to damp off the first season if too mneh shaded and to burn off if not shaded enongh.

As there are abont 1,800 seeds to the onnce, it will take abont 5 to 6 ounces to the 100 fect of drill, unless the sced be specially poor, when greatcr allowance will have to be made in proportion

I We are likely to repeat in the Northwest, on an extensive scale, the history of several of the Eastcru States. Under indnccments hell out to enconrage immigration, many settlers have been led to take up land all through the worst part of Michigan and Wisconsin, including the "barrens." They clear the land, seed it, if they can, with clover, and put in other crops, work in the adjacent pine woods for a living, and "develop the country," thus doing for the State exactly what needs to be done and what the State has neglected to do for itself; but it is a disastrous experiment for the settlers. The many farms kept up iu this way for a while may finally be abandoned, but the whole region will then be in a great measure secured against extensive fires, and the lands that have been plowed and worked over will be in a bettcr condition for reforcsting. 
to the percentsge of germination. In orlinary colleeting the percentage of germinating seeds may unt exceed in per cent, and, as is indicated in the discussion on seed supply (page 23), it may full far below this figure in some years. Even if 20,000 to 25,000 secds shonld germinate per pound, it wonld not be safe to count on more thin 5,000 to 8,000 scedlings that will grow to use, and in the transplanting to nursery rows an allowance of at least 5 to 10 per cent shonld be made for losses, so that to seeure 10,000 transplants at least $1 \frac{1}{2}$ pounds of seed is needed, to secure whicli it may take from 3 to 4 bushcls of cones.

Close planting is indicated on account of the difficulty with whieh this pine cleans itself of its branches. It should be planted not more tlian 4 feet apart or, preferably, set out in mixture with a shady, slower growing companion, the Black Sprnce (Picca nigra) being an ideal choice within its liabitat, and of broall-leafed trees the Sngar Maple (Acer saccharinum), which, for the sake of cconomy, may be sown between the wider spaced ( 8 feet or more) plants of White Pinc. The mixture should not stop here, but other kinds chosen with circunspection from the many that are found associated with the White Pine in its natnral habitat shonld be added, as Chestnnt, Yellow, and Red Birch, Basswood, Hickories, and Oaks, and of conifers, the Red Pine, Hemlock, and oceasionally in some loealities Arborvitre.

Dr. Fernow has for some time (since 1887) advoeated a method of forest planting in whieh the main or "final harvest crop" is distinguished from the mere "nnrse crop" or "filler," when only 500 or 600 trecs per acre, or even less, of the better kinds are set out with care as the main erop, reeeiving dne attcntion in their further development, and the nurse crop is introdnced of the cheapest kinds and in the cheapest manner to act as soil eover to check weed growth and stimulate height growth, straight form, and clcaning of the main erop. The White Pine would, of eourse, be a most excellent main crop.

By the fiftieth year or so the pines, if set out at the rate of 500, will have overtopped the nurse erop, cxcept where trees of the latter have taken the place of a failing pinc, and their crowns will have closed up, their boles straight and clean, furnishing elear lnmber, if the nurse erop was properly chosen and has done its duty. The further management then wonld concern itself mostly with gradual thinning ont of the main crop to secure the diameter accretion dne to inereased crown development and light. By the one hundredth year it will be reasonable to expcet at least half the trees set out to have reached their highest value in matnrity and size, with 15,000 to 20,000 cubic feet to the acre, for the White Pine is not only a rapid grower, but a large producer, its shade endurance permitting as large a number of trees to develop satisfactorily per acre as the Spruce, whieh it outgrows in height and diameter.

While planting nursery-grown secllings as a rule furnishes better resnlts, sowing the sccds into permanent sites may, under certain conditions, espceially on soils not too prone to weed growth and in the more humid climate of the Northeastern States, prove satisfactory and clieaper.

Varions methods can be employed according to circumstances. On liglit soils sowing broadeast on snow may furnish satisfactory results; on heavicr soils preparation of the ground to reccive the seed will prove indispensable. This may be done by plowing furrows or by hoeing plats of 2 or 3 feet square (the larger size where overgrowing by brushwood is to be feared) and sowing into these in drills or broalcast. Dr. Fernow devised such a method for reelothing cnt-over lands on slopes in Pennsylvania grown up with brush, where it wonld be too expensive to prepare the entire ground. Here the plats were made larger, 4 or 'ven 6 feet squarc, and into these not only pines were either planted or sown but also a nurse crop surrounding the pines, cxpectation being that this nurse erop will protect the pines against the encroachment of the surrounding brush growth until the pines are tall enough to fight their own battle and finally kill ont the brush. A fuller description of these plantings is to be fonnd in Bnlletin 17, "Check list of the forest trces of the United States," ctc., of the Division of Forestry.

\section{PLANTING NOTES.}

The following notes on planted groves, their condition, growth, and results arc given a place here as recorling individual experienees in various parts ot the conntry, withont intending to recommend the practices of the planters, which, from the forester's point of view, are faulty in some directions, especially in the open stand, which is advocaterl:

In linstern Massachusetts, particularly in Plymouth and Bristol counties, there are numerous small bodies of Whito Pino that were set ont from forty to fifty years ago, and whose rapid growth and healthy couditions show that 
there the work of planting at least has been successful. The trees composing them areraged at thirty to thirty-five Fears from the time of planting, not far from 45 feet in height, and measured approximately 2 feet 6 inches in circumference, hreast high. These measnrements vary for different bodies of pine, but are helieved to represent very closely the average size at the age indicated, and in many cases the trees are considerably larger (see measurements of growth on page 88). This growth of pine is of such value that according to competent judges of proporty in that region, much of the land that without the pine would be worth only $\$ 3$ to $\$ 10$ per acre, is worth with the standing pine $\$ 50$ to $\$ 75$ or more per acre according to location.

Upon visiting these different groves and conversing with men who had planted some of them, it was found that opinions and practice were quite variable, both as to time and manner of planting. Mr. S. E. Hall, of Raynham, who has had long experience, states that he has set the White Pine successfully every month in the year. The soung trees, 60 inches, or even a foot high, are taken up with a piece of sod on their roots and set out in a wet time. These two conditions were particularly emphasized by Mr. Hall, who says that if they are observed the trees "will grow anywhere." He plants 10 feet apart each way and recommends this as the best distance, which is, however, not good forestry practice. In a grove set hy him forty jears ago the trees were set in rows at the ahore distance and had mado a vigorons and healthy growth. In another grove, planted ahout the same time, the trees stood 8 feet apart each way and were apparently doiug quite as well as in the first one. On the other hand, Mr. Spencer Leonard, of Bridgewater, after many years of practical trial and observation, states that having formerly set ont pine trees 10 feet apart, he is now setting them at a distance of 15 feet, with a view to reduce the expense of planting and becanse thoy soon hecame crowderl if plauted closer. He, too, sets ont the trees with a sod, simply plowing a furrow and setting the seedlings at the right distance. Mr. Hall digs a holo for each tree, hnt says that the work can he done very rapidly, aud that he has himself set an acre a day.

One of the many plantations in sontheastern Massachusetts known as "Leb. Pratt's grove," is within less than a mile of the village of North Middlehoro. It was set ont forty-two years ago. The trees wore set in rows 10 feet apart each way. The grove twelve years ago even was practically impenetrable by reason of the dead interlocking hranches that had never been removed.

Fonr trees of average size were measnred in 1886 and showed diameters of 7 to 9 inches. Some were of larger and others of smaller size, though the growtl was fairly even. The average height was estimated at 40 feet; the hranches were dead three-qnarters of the way to the tep, the remaining one-fourth, say 10 feet, constituting the crown, was green and healthy. The soil was poor, that passed over from the road in reaching the grove being light sand with some gravel.

Another grove, some 3 miles northwarl of North Middlehoro, was visited in 1886, and a greater number of measnremeuts made. According to Mr. S. Hayward, near whose farm it stands, this grove was sot ont rather more than thirty, not more than thirty-five, years ago, hnt had not made quite as good a growth as some others have. Tho trees are in rows, $7 \frac{1}{2}$ to 8 feet apart each way, and are quite uniform in size. Beginning with the third from the north side, a fair average row, tho following measurements were mado of the trees taken in order as they stood. The circnm ference, hreast high, was:

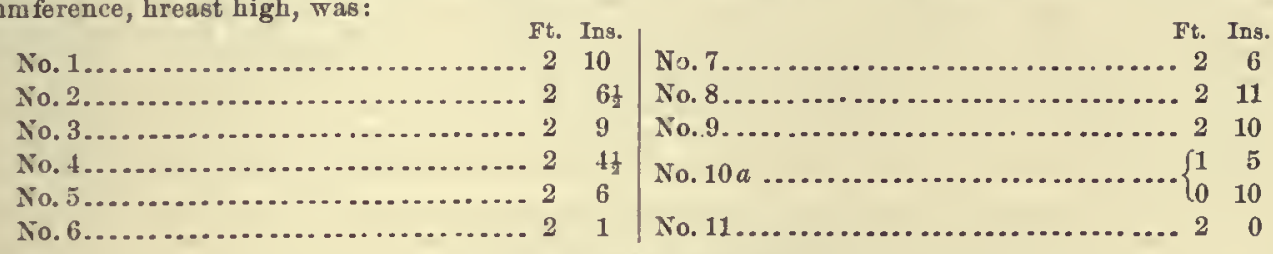

a Two main stems and had lost a third.

The largest tree measnred in the grovo was 3 fcet 1 inch in oircunference or 1 foot in diameter, hreast high. A very fow have been choked ont and havo died after living fifteen or twenty jears. An average tree on the south side measured 45 feet in height. All the trees of the grovo that were still living seemed healthy and vigorous. The lower brancies had died at an earlier age than in tho preceding grove and tho trunks were freo from them for some 8 feot or more. Above this line the dead hranches still remained on the trees, only those of the crowns being green and living.

Near Bridgewater, Mass., a piece of land had been sown with pine seeds some thirty. five years hefore, the seeds heing sown broadcast and dragged in. The trees were sleuder and too nuch crowded, the smallest ones dying ont. They secmed much in need of proper thinning. Soine of the hest specimens measured 2 feet 7 inches in circumferenee, breast high, hnt they wero very nineven in size, and did not impress one nearly as favorably as thoso in the groves that lial been regnlarly planted at a distance of 8 or 10 feet apart.

This sccond growth pino finds a ready market at the hox factories of Bridgewater, Halifax, Taunton, and varions other towns in this part of the State. Six dollars per cord is the price paid at present (1886; now $\$ 8$ to $\$ 9$ ) for $\log s$ delivered at the factory. Logs are accepted down to 8 inches iu diameter, and in establishments where gtaves are made a smaller size is taken. Thero is no trouble in obtaining all that is wanted, there being an abnndant supply of pile for hox boards, stavos, and the like in the immediate vicinity of the towns where they are manufactured.

A few notes on plantations made on the Western border and outside of the natural range of the White Pine will show the adaptability of the species in those regions:

There is an instructive plat of White Pines in the forest plantation of the State Unirersity of Illinois. This institntion is located at Champaign, abont 200 miles sonth of Chicago and much beyond the natnral range of the 20233 -No. $22-5$ 
plne. The history of the plat, as given in Bulletiu No. 26 of the Uuiversity Agricultural Experiuent Station, is as follows:

White Pine seedlings were collected in the spring of 18039 , pnt in close nursery rows and shaded with lath frames. Ahont 8 per cont died the first renr. Of a few hnudred trees, pnrposely left without shaling, 32 per cent died. After having grown In the nnrsery three years, they were deened in good condition for transplanting. They were at this time 12 to 15 iuches high, well-forued, liealthis trees.

The laud, 1 acre, wliere the White Pines are planted, is quite flat, what slope there is being to the south; and at least oud-lialf of it is too wet iu spring, and often in the early part of summer, for the best resnlts iu tillage. The soil is black, part of it luucky, 1 to 2 feet in depth, and underlaid, for the most part, with a rather stiff, blue clay. 'The trees were plauted May 4, 1872, 4 feet apart each way. The White Pine is a comparatively hard tree to transplaut successfully $(\ell)$. The roots are soft, long and naked, witl very few small or fibroits roots near the tree. kuowing the necessity of eareful handling, no effort was spared, from digging in the nnrsery to setting in permanent place, to secure suecessfil results.

Fliroughout the season the gronnd was kept in a good state of tillage $1 \mathrm{y}$ frequent cultivation, but it was cxceediugly dry; and of nearly three thousand trecs planted, two-thirds died during the sumuer. Of Norway Spruce, planted the same day, in the same manner, and ou very simllar soil, not more than 2 per cent died. It is difficnlt to cxplain this greater per cent of loss in the pines, except as we take into acconnt the comparatire inethod of developusont of the roots of the two species [aud its higls transpiration factor.-B. E. F.].

In the spriug of 1873 the vacant spaces were filled from the unrser, and again in $187 t$ trees were set where neeled. The resnlt of the three plantiugs was an almost perfect stand of trees. The cultivation with horse aud hoe was kept up thoronghly for three rears. Dnring the fourth, fiftl, and sixth vears the weeds were mowed. But little cnltivating was done, because the ground was too wet in the early part of tho season.

lor $n$ umber of years after the Wlite Pines were fairly started they made admirable growth, and promised to fnrnish very valuable timber for the prairie soil here, as well as for their uative regions. In a report made in 1886 the following statement is unde: "Froun the first the living trees have dlone exceediugly well. Very few trees have died from any canse since ther began their growth in their present position. 'They are vow remarkably healthy and vigorons, nnd the plantation vies with that of the European Larch in beanty and prospective value." At present they are not main taiuiug the early promise.

No thinning or pruning of auy kind was done, except what natnre does, until the winter of 1889-90. During that winter and the uext the dead hrauches, to an average heiyht of ahout 10 foet, were trimmed off, and the dead trees (some more than three huudred and fifty) were cut ont. During the winter of 1891-02 sixty-eight more dead trees were cut ont, and there are at present fifty-two still standing that have died since the last were cut. The trees cut ont tho first time had not all died recently. Some of them gave evidence of having been dead for a nnmber of years, while others had died so lately that they still carried dead leaves. Ilost of the trees that have died were the smaller ones, such as were overgrown or hadly crowded. A few only of the larger trees have died. Of the trees still alive, very fow have any lire branches lower than 20 feet. Jany of them have an nuthrifty look, either in the top or on the trunk, and the prospect is that there will be a iery considerable number of trees to cut ont year by year for some time.

The priucipal reason for so many trees dying is probably overcrowding [more likely owing to the stifi subsoil.B. E. F.]. As the trees now staud they occnpy a space of less than 7 feet square each. The trees hare heen damagred in other wass than crowding, but not, so far as can be judged, until after they had already begnn to die. There is continually a thick mat of leaves on the gronnd, and these have been partially burned off twice, hoth times injuriug the trees more or less from tho ground np 2 or 3 feet, but apparcntly not any higlier. Boys seem to delight to cnt their names or designs in the smooth hark of the trees. Occasionally a tree is entirely girdled. Tho girdling soon kills the trees, but most of the smaller damage to bark soon grows over. A woolly plant lonse (Churnus pinicortiris Fitch) has been very abundant on many of the trees, attacking the trunks and larger hranches for several years. They are souretimes so abundant that the whole trunk has from a little distance a white or gra rish-white appearance.

The White Pines do not cast so dense a shade now as they did ten years ago. At that time there was no nudergrowth among them. At preseut there are small wooded plants, snch as Grape, Raspberry, Cherr., Box Filder, etc., besides weeds, couring in, and there would likely he more of these were it uot for the heary mulch of leares that covers the gronnd.

In 1886 the average size of the better trees was: Height, 24 feet 9 inches, and a little less than 6 inches in diameter. At present, 1895, tho better trees are 38 to 40 feet high, and 8 to 9 inches in diameter. During the winter of 1882-83 the leaders of a considerable proportion of tho trees were hroken down hy the weight of sleet. This was the cause of many trees being crooked at that point, and of others having moro than one leader. Except for the trees deformed in this way uearly all have almost perfectly straight trunks. The trees are much more nearly nuiform in height than iu diameter. The sizes of the trees in the plat are as follows: Fifty-eight are 3 inches in diameter; ono hundred and ninety-fonr, 4 inches; two hnnired and fifty-six, 5 inches; two hmndred and thirty-six, 6 inches; one hundrod and forty-fonr, 7 iuches; seventy, 8 inclies; eleven, 9 inches; fire, 10 inches.

In the antumn of 1895 the thirty-nine trees constitnting the central row of the plantation wero mensured, and the average diameter, breast high, was 5.9 inches, the range heing from 4.1 inches to 8.6 inches.

At the old Elgin nurseries, planted in open prairie about $1 \frac{1}{2}$ miles west of the Fox River, black loam soil, from 4 to 5 feet to gravel, Whito Pines, forty to forty-fire years old, with Norway Sprnco and Scotch Pine as neighbors, measure 22 inches iu diameter, breast high, and are 52 feot high. In a neighboring grove, twenty-fire years from seed, planted oxclusively to White Pine, the trees arerage 11 inches in diameter and 45 fcet high. When planted alternately with European Larch 5 to 6 feet apart, the .White Pines, thirty-five to thirty-six years old, are perfectly straight and arerago 13 inches iu diameter and 75 feet in height. The Enropean Larch prores to be the hest tree to plant with White Pine as a urse. When planted with Box Elder and Ash the growth of the pines is not so satisfactory. Whero Scotch Pine has been planted alternately with White Pine the latter has outgrowu tho Scotch, nearly all of which aro killed ont. In the groves whero Larch is planted with White Pine the gronnel is completely mulched from the foliago of the Larch; drought has uever affectel tho trees, and no grass or weeds can grow among theil.

Mr. Thomas Hunt, of Ridott, Ill, sct out White Pine in a plantation of 10 acres twenty-two years ago. The trees wero 10 to 18 inches high when set, making their ngo at time of ueasurement ahout twenty-seven years.

The grove is planted ou a ridge with thiu clay loan underlaid with hroken laminated limestone. Mr. Innt fonnd tho land improfitable under tillage after severnl years' trial. The trees of each variety are planted in solid rows, hardwoods and conifors alternating. In a plat of White and Scotcls Pine, Norway Spruce, Arborvita, Enropeau Larch, White Elm, Box Elder, Green Ash, and Willow, the conifers have almost shaded ont the hardwoods. The 
Larch are the tallest and the Arborvite the lowest, the remaining conifers heing of about equal height, averaging 35 feet. Seventy White Pines were measured, taking all the trees as they eame in the rows, and including the center of the plantation. The average diameter, hreast high, was 6.2 inches. The hranches were dead, but still persistent to a height of 18 to 20 feet.

At the Bryant nurseries, Princeton, Ill., somewhat south of the natural limit of the White Pine, trees that were grown as ornamental nursery stock have been permitted to stand, giving some notion of the growth of the species in the rieh prairie loam of that regiou. The oldest speeimens were set in 1858 and were imported seedliugs. They are now abont forty-two years of age, and average about 65 feet in height. Measured trees rauge from 9 inehes to 26 inehes in diameter. Norway Spruee of the same plauting equal the pines in height, hut the average diameter is less. These trees stand ahout 30 feet apart. On the margiu of a natnral hardwood grove an acre of the riehest prairie land was-planted to White and Scotch Pine seedlings about twenty-two years ago. The trees were set 3 ly 4 feet, aud have never been thinned. Eaeh species was planted pnre, and one of the tallest White Pines measured 33 feet high, the average height being estimated at 26 feet. Fifty White Pines, taken as they eame in the rows, were measured, hreast high, the average diameter heing $4 \frac{1}{8}$ iuches. Seoteh Pine showed ahont equal growth.

At the Iowa Agrieultural College, Ames, Iowa, in the ccnter county of the State, a piece of waste land of ahout 3 acres was planted to White Pine, Enropean Larch, Box Elder, Green Ash, and Cottonwood in 1875. The plat oceupies a gravelly knoll sloping to the north. The soil is a yellow elay, with mueh gravel, and of unknown depth. The top of the knoll forming the south side of the plantation is set with pure Larch. The Pine, Box Elder, and Ash are mixed, evidently without order. The original planting was $3 \frac{1}{4}$ by $3 \frac{1}{4}$ feet apart, and the trees now average ahont 10 feet apart each way. The White Pines are estimated to a verage 30 feet high, and twenty-six measured trees, taken as they came, ranged from 5 to 14 inches in diameter, the average being 8.7 inehes. The pines are now the dominant trees of the mixture and are fully 10 feet higher than the Box Elder, which exceed the Ash 5 feet. The following diameter measurements will serve as an additional basis of comparison:

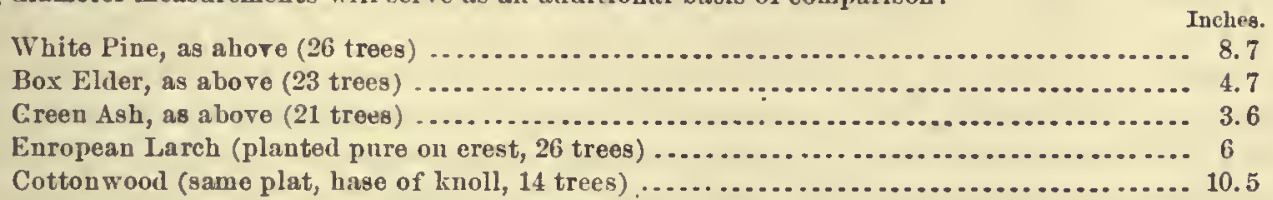

It shonld be added that the Cottonwoods stand wider apart than the mixture of Pine, Box Elder, and Ash, while the Larch stand closer together. All were set originally $3 \frac{1}{2}$ hy $3 \frac{1}{2}$ feet, and the alternate rows have been removed thronghont the plantation.

At Windom, Minu,, in the southwest part of the State, Mr. E. Sevatson has included two rows of White Pine in a plantation covering 10 acres. These trees were set about thirteen years ago, when 8 to 12 iuches high, and are presnmahly not over eighteen sears old. The two rows of pine are between rows of Arhorvitio and Balsam Fir. They are about 25 feet in height, and the average diameter, hreast high, of seveuteen trees, taken as they eame in the rows, was 5 inclies. The soil is a stiff elay loam, and the plantation is about 100 feet ahove the surface of a lake whieh joins the farm. The entire country is treeless, except for groups of trees on the lake shore and groves along the Des Moines River, 3 miles distant. The White Pine in this location is less vigorous than Scotch Pine, Enropean Lareh, or Norway Spruee.

Fine trees of White Pine, set in single specimens abont thirty years ago, are growing at Arhor Lodge, Nebraska City, Nohr., the home of I Ion. J. Sterling Morton, ex. Secretary of Agriculture. These stand in hluff soil (a fine loann) about 2 miles west of the Missouri River. A few fine specimens may also he seen in the lawn at the homestead of Hon. A. H. Whiting, at Whiting, Monona County, Iowa, in the deep hlaek loam of the Missouri hottoms. At Brookings, S. Dak., within 17 miles of the Minuesota line, repeated plantings of the White Piue have resulted in failure. At Franklin, Nehr., ahont halfway across the State, near the Kansas line, this speeies has failed after extended trial. Very fow trees can he seen in Lineoln, Nehr., though it has been repeatedly tested there as an oruamental tree. The diminished amont of atmospheric moisture will uecessarily prevent general satisfactory eultivation beyond the western boundary of Missouri, Iowa, and Minnesota.

A nnmber of fine specimens of White Pine stand is the lawn of the Rollins homestead at Columhia, Mo., about 10 miles north of the Missouri River and halfway between the east and west houndaries of the State. The soil is a clay loam, underlaid with limestone, which outerops at mauy places in the vicinity. These trees were plauted in 1855 , when two or three years old, hy Col. J. H. Rollins. The largest is now (1897) 29 inches in diameter, hreast high, and 61 feet 9 inches in height. One of the suallest is ahout 56 feet high and 16 inches in diameter.

Additional notes of plantations in the West might be given, but the above is snfficient to show the White Pine can be successfully grown somewhat heyoud its natural range, hut does not well endure the dry conditions of soil and atmosphere which it mnst meet in the region west of the Mrissouri River.

\section{THE WHITE PINE AS A FOREST TREE IN GERMANY.}

As has been stated, the White Pine was introduced quite early into England, and from there it found its way into various parts of the Continent. In England it remained largely a park tree. In Germany it has been a forcst tree proper for over a century, being used quite frequently, on account of its hardiness and. shade endurance, as "gap cover" to fill fail places. It has also been planted in many places on small areas as pure growth or mixture with the common European or Scotch Pine (Pinus silvestris) and Spruce. For a long time this "newcomer" was regarded with a 
feeling of doubt and even suspicion, and long before anything definite could possibly be said about the matter the merits and faults of the White Pine were cxtensively discussed. The "practical" man, and with him some scientiffe nıcn, wcre satisfied that such a light-colorel softwood could not possibly be durable or otherwise desirable, and the small quantities offered from time to time did not always find ready market. Of late ycars this condition has changed. In a scrics of excellent articles, Dr. L. Wappes, a Bavarian forester, records the experience had in one of the oldest bodies of White Pine in Germany, in which he shows that the tree in pnre growtl, and also as mixtmre with pine, spruce, or hard woods, has proven a most excellent factor of the German forest; that it scerls early and heavily, and as plant material is casily and cheaply sccnred; that it is readily and even preferably reprodnced by natural secding, a rapid grower, capable to withstand erowd. ing and shading, and that it is a tree cspecially capable of producing a large amount of timber even on poor soils, all of which coincides with the obscrvations on its native habitat laid down in this monograph. He shows that besides the Fir (Balsam), the White Pine is the only tree which, in the Palatinate and on poor soils will, at the age of one Lundred and ten years, make timber of Class I (according to German notation, dianeter at half length, 22 inches and better); that while the com. mon pine at that age furnishes only 13 per cent of Class III aud better (diameter 12 inches and over), the White Pine furnishes 27 per cent, or more than double this amount of these and more valnable diameter classes. Dr. Wappes emphatically states that White Pine, wherever kuown, is eagerly bought, and that the opinion of the consumers lias radically changed. He proves by the figures of large sales from the State forests, that since 1882 the valne of White Pine has ncarly doubled, while that of Spruce and common Scotch Pine has increased by only 20 per cent, and that of Fir and Larch has actually declined during this period. The following fignres give an idea of the growth of White Pine abroad. The groves of the Palatinate are stocked on very inferior soil, nearly all other groves cited being on loamy sand. The fignres for total volume are somewhat misleading, since they do not include the timber which has been removed from the older groves in thinnings, which would add probably from 10 to 15 per cent to make up whole prodnction.

It will be of interest to give more in detail the conditions of the last-mentioned plantation, reported this year in Dr. Lorey's Allgemeine Forst und Jagdzeitung:

The plantation of about 9 acres, on fresh loamy sand, situated at an elevation of 2,200 feet above sea level in Wurtemberg, consists of White Pine mixed with Scotch Pine, Spruce, and Fir in single individnals or groups. The White Pine represents, nnmerically, two-thirds of the total number, Scotch Pine is found among the dominant growth in part, bnt the Spruce and the small number of Firs show only collominant and oppressed trees.

The density of the growth was reported as satisfactory until in 1875, when a snowstorm broke down much material, so that at present the density does not average over 0.7 .

The stand, originating from seed, was several timcs thinned, and the last time, occasioned by the snowstorm, 400 White Pines were rcmoved, with over 10,000 cubic feet of wood. The nnmber of trees averaged 183 per acre, of which 142 White Pines, with diameters varying from 7 to 24 inches, and 16 inches in the average, yielded altogether 9,510 cnbic feet, while the other species added only 1,290 cnbic feet. Comparison with the other acre yields recorded shows that under these conditions the product was less than in more favored sitnations, either the site or light eonditions reducing the growth.

The diameters represented on a sample area were distribnted as follows:

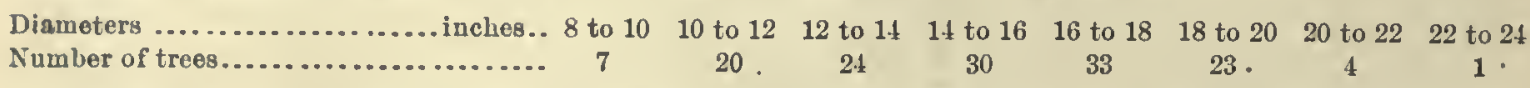

Of the Scotch Pincs only four had reached diameters over 16 inches, and of the Spruces none over 14 inches. The superiority of the White Pine also appears from the comparison of height growtl, which was established for every five jears by the mcasurement, of average sample trees, as follows:

Height growth of White Pine, Scotch Pine, and Spruce, by years.

\begin{tabular}{|c|c|c|c|c|c|c|c|c|c|c|c|c|c|c|c|c|c|c|}
\hline \multirow{2}{*}{ Sample trees. } & \multicolumn{18}{|c|}{ Ago (years) and height growth (In feet). } \\
\hline & 5 & 10 & 15 & 20 & 25 & 30 & 85 & 40 & 40 & 50 & 55 & 60 & 65 & 80 & 75 & 80 & \$5 & 90 \\
\hline $\begin{array}{l}\text { White Plne belght growth ..... } \\
\text { Scotoh Plne helght growth ..... } \\
\text { Sprtice hoight growth ......... }\end{array}$ & $\begin{array}{l}2.1 \\
4 \\
2\end{array}$ & $\begin{array}{r}9 \\
12 \\
8\end{array}$ & $\begin{array}{l}18 \\
20 \\
16\end{array}$ & $\begin{array}{l}29 \\
29 \\
24\end{array}$ & $\begin{array}{l}38 \\
35 \\
35\end{array}$ & $\begin{array}{l}45 \\
42 \\
42\end{array}$ & $\begin{array}{l}52 \\
49 \\
48\end{array}$ & $\begin{array}{l}59 \\
54 \\
54\end{array}$ & $\begin{array}{l}65 \\
60 \\
59\end{array}$ & $\begin{array}{l}71 \\
65 \\
63\end{array}$ & $\begin{array}{l}76 \\
69 \\
68\end{array}$ & $\begin{array}{l}81 \\
73 \\
72\end{array}$ & $\begin{array}{l}85 \\
75 \\
75\end{array}$ & $\begin{array}{l}89 \\
80 \\
78\end{array}$ & $\begin{array}{l}92 \\
82 \\
80\end{array}$ & $\begin{array}{l}95 \\
84 \\
8: 2\end{array}$ & $\begin{array}{l}97 \\
87 \\
84\end{array}$ & $\begin{array}{r}100 \\
88 \\
86\end{array}$ \\
\hline
\end{tabular}


The preceding table shows how the slow growth of the first five years which the White Pine has in common with the Norway Spruce is overcome before the fifteenth year, and by the twen. tieth year the White Pine has distanced the Scotch Pine, gaining on it eonstantly until, by the ninetieth year, it has outgrown it 12 per eent.

Dimensions and yields of Thite Pine in German forests.

\begin{tabular}{|c|c|c|c|c|c|c|}
\hline Lncality. - & Character of forest. & Age. & $\begin{array}{l}\text { Number } \\
\text { of trees } \\
\text { per acre. }\end{array}$ & $\begin{array}{l}\text { Average } \\
\text { diameter } \\
\text { (withont } \\
\text { bark). }\end{array}$ & Height. & $\begin{array}{l}\text { Volume of } \\
\text { wood, ex. } \\
\text { clusire of } \\
\text { limbs aud } \\
\text { stumps. }\end{array}$ \\
\hline 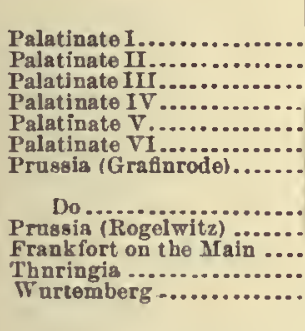 & 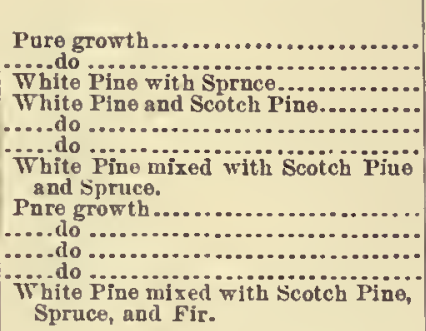 & $\begin{array}{r}\text { Tears. } \\
104 \\
68 \\
68 \\
58 \\
40 \\
25 \\
(75 \text { to } 80) \\
(75 \text { to } 80) \\
95 \\
82 \\
78 \\
93\end{array}$ & $\begin{array}{r}250 \\
660 \\
550 \\
330 \\
600 \\
2,200 \\
452 \\
\\
410 \\
333 \\
723 \\
415 \\
183\end{array}$ & \begin{tabular}{c|} 
Inches. \\
15.6 \\
9.1 \\
10.4 \\
10.3 \\
7.4 \\
4 \\
$(6$ to 28$)$ \\
\\
$(8$ to 18$)$ \\
15 \\
9.7 \\
11.7 \\
16
\end{tabular} & \begin{tabular}{r|} 
Feet. \\
02 \\
66 \\
79 \\
64 \\
49 \\
34 \\
$(72$ to 87$)$ \\
$(80$ to 87$)$ \\
88 \\
72 \\
$(79$ to 89$)$ \\
98 \\
$-\quad 9$
\end{tabular} & $\begin{array}{r}\text { Oubic feet. } \\
13,300 \\
10,000 \\
12,000 \\
6,000 \\
4,000 \\
3,200 \\
13,224 \\
13,000 \\
14,298 \\
12,024 \\
13,027 \\
10,800\end{array}$ \\
\hline
\end{tabular}

From these figures the capacity of the White Pine to produce large amounts of valuable stemmood is apparent. Thus, on soil on which the 100-year-old trees developed only a height of 92 feet, over 13,000 cubic feet of stemrood, corresponding to about 60,000 to 70,000 feet B. M., Amcrican scale, were cut per acrc over and above about 1,200 cubic feet of material removed in previous thinnings. In every case the White Pine excels the common pine, and even the Sprucc in this respect. It should be added that most of these plantations, made in the early part of this century, were not executed according to present superior methods, the species being an exotic and expensive was set out more in orchard fashion, as most planters in our country have been apt. to do, at distances of 8,12 , and more feet apart. Owing to this fact the development was probably not as satisfactory in the earlier ycars as it might have been had the method of close planting, cither pure or in mixture, prevailed.

The superiority of grow th over the German Spruce and Pine is more fully illustrated in the following table, which shows the distribution and proportion of trees of White Pine and Spruce and of White Pine and Scotch Pine that are found in given diameter classes in two mixed planted growths of these species:

Diatribution and proportion of White Pine and Spruce and White Pine and Scotch Pine.

\begin{tabular}{|c|c|c|c|c|c|}
\hline \multicolumn{3}{|c|}{$\begin{array}{l}\text { White Pine and Norwas Sprnce, } \\
\text { alxty-eight years old. } \\
\text { [65 per cent Pine; } 35 \text { per cent } \\
\text { Spruce.] }\end{array}$} & \multicolumn{3}{|c|}{$\begin{array}{c}\text { White Pine and Scotch Pine, fifty- } \\
\text { eight jears old. } \\
\text { [50 per cent of each.] }\end{array}$} \\
\hline $\begin{array}{l}\text { Diaineter } \\
\text { of trees. }\end{array}$ & $\begin{array}{l}\text { White } \\
\text { Pine. }\end{array}$ & $\begin{array}{l}\text { Norway } \\
\text { Spruce. }\end{array}$ & $\begin{array}{l}\text { Diameter } \\
\text { of trees. }\end{array}$ & $\begin{array}{l}\text { White } \\
\text { Pine. }\end{array}$ & $\begin{array}{l}\text { Siotch } \\
\text { Pine. }\end{array}$ \\
\hline $\begin{array}{l}\text { Inches. } \\
4 \text { to } 6 \\
6 \text { to } 8 \\
8 \text { to } 10 \\
10 \text { to } 12 \\
12 \text { to } 14 \\
14 \text { to } 10 \\
16 \text { to } 18\end{array}$ & $\begin{array}{c}\text { Per cent. } \\
0 \\
15 \\
30 \\
22 \\
20.5 \\
10.5 \\
1.5\end{array}$ & $\begin{array}{c}\text { Percent. } \\
0.5 \\
30 \\
27 \\
26 \\
6.8 \\
0 . . .6 . . .6\end{array}$ & $\begin{array}{r}\text { Incher. } \\
\text { \& to } 6 \\
6 \text { to } 8 \\
8 \text { to } 10 \\
10 \text { to } 12 \\
12 \text { to } 14 \\
14 \text { to } 16 \\
16 \text { to } 18 \\
18 \text { to } 20\end{array}$ & $\begin{array}{c}\text { Percent. } \\
1 \\
19.5 \\
18.7 \\
26 \\
23.5 \\
8 \\
2.4 \\
1\end{array}$ & $\begin{array}{c}\text { Per cent. } \\
2.4 \\
32 \\
35 \\
24 \\
4.9 \\
1.0 \\
\ldots \ldots \ldots\end{array}$ \\
\hline
\end{tabular}

It appears that nearly 32 per cent of the White Pinc is over 12 inches in diameter, as against less than 7 per cent of the Spruce, whilc 35 per cent of White Pine, as against 6.5 per eent of Scotch Pine, developed over 12 inches in the mixturc of these two, and over 11 per cent of the former belongs to sizes above 14 inches, which is hardly reached at that age by its competitor. These figures prove elearly that the White Pine cxcels the Seotch Pine even during the age of 
most rapid growth, so that the differenee, in view of the steady growth of White Pine and the marked dlecrease in rate of growth in the Seoteh Pine, wonld be markedly greater if older timber had been comparel.

Just as in its untive range, the White Pine is deeidedly a heart pine, the sapwood ehanging early into the durable and more valuable heartwood. In timber one humdred years old grown in the Palatimate the sap in many cases is less than 1 inch thick, so that 75 per eent and more of the entire stem is composed of leartwood.

In vien of these faets it is quite safe to say that the White Pine in the future will be one of the prominent forest trees of Germany, and perhaps of Europe, as it will always be the king of woods in our Northern and Eastern States. 
THE WOOD OF THE WHITE PINE. 



\section{THE WOOD OF THE WHITE PINE.}

By Filibert Roth, Division of Forestry.

White Pine is a favorite material with the wood eonsumer in the Nortleastern States on account of the eombination of qualities it possesses. It is a light, soft, uniform, straight-grained timber, to be had in all markets in any quantity and in all dimensions, from the ship's mast to the elapboard. It seasons well, shrinks and warps but little, is quite dnrable, inseet-proof, and takes oil and paint and has a good eolor, is light to handle, easy to saw and plane, takes nails without splitting, and is, in short, the ideal material for the earpenter and joiner, who handles the bulk of the 30 to 40 billion feet of sawed timber and lnmber aunually used in this conntry, of whieh White Pine furnishes over 30 per eent.

\section{CHARACTER AND PHYSICAL PROPERTIES OF THE WOOD.}

The strueture of White Pine, like that of other pines, is simple. Ninety per cent and more of the weight of the dry wood is formed by the eommon wood fibers, or tracheids, 0.12 to 0.20 inehes long, well suited for pulp material. The spring wood of eaeh annual ring passes gradually into the summer wood and thns the sharply defined bands of hard, dark and soft, light-eolored material so eonspieuons in the rings of all hard pine, espeeially Longleaf and Cuban Pine, are absent in White Pine, making tle cutting of the wood by either plane or saw mueh easier than is the ease witl hard pines. Sapwood and heartwood are quite distinct-the former white, the latter with a slightly brownish east. The change from sapwood to heartwood takes plaee earlier in the young tree and the younger portions of old trees than in older timber. Thus, in a thrifty sapling thirty years old the sapwood shows about eighteen rings on the stump, but only ten rings 35 feet from the ground. In trees over one hundred years old the unmber of rings in the sapwood is generally over thirty at the stump, deereasing often to fifteen or twenty near the top. The number of rings in the sap, as in other pines, is smaller in thrifty and greater in slow-growing trees, while the width of the sapwood is generally least in slow-growing timber. Compared to other pines, White Pine has a narrow sap at all periods of its growth. While in the hard pines, like the Longleaf Pine, and still more in Loblolly and Shortleaf Pines, the sap forms generally from 50 to 75 per eent of the $\log$, it is generally less than $3 \tilde{5}$ per eent of mill-sized timber in White Pine. This highly valuable property of the White Pine is fonnd in all loealities, even iu Europe, where the tree has been widely planted.

\section{SPECIFIC WEIGHT.}

To determine speeifie the weight of the wood and other physieal properties a eolleetion of seventy-threc trees was made, ineluding material from the New England States, Miehigan, and Wisconsin, and also from the mountains of North Carolina.

The speeifie weight of the greenwood varies shiefly with the amount of sapwood and eonse. quent abnndanee of moisture, since the heartwood eontains but little water outside of its cell walls (except in some eases where the heartwood near the stump also contains liquid water). Generally the weight of the greenwood varies from about 40 to 50 ponnds per eubic foot, and is greater in young poles than in old timber, which latter on this aecount floats readily, rarely sink. ing, even after years of inmersion.

The specific veight of the kiln.dry wood varies, generally from 0.33 to 0.40 (20 to 25 ponnds per enbie foot), is greater in the old tree than in the young sapling, is greater at the stump than 
THE WHITE: IPINE.

farther up in the sane stem, is independent of orientation (as great on the nortli side as on the south side), is no greater on clay land than on the sandy soils, and seens in these partieulars quite independent of loeality. The wood from the swamp trees is no heavier nor lighter than the wood from the upland trees, the trees from New England differiug apparently in no way from those of either the Lake region or North Carolina.

l.eaving out of consideration the speeifie reight of the limbs and knots (these being always heavy, as in all pines), the average speeifie weight of the dry wood of the stem was found to be for-

\begin{tabular}{|c|c|}
\hline$\checkmark$ & $\begin{array}{l}\text { Speclfic } \\
\text { grarity. }\end{array}$ \\
\hline 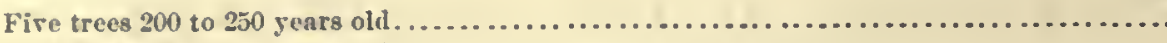 & . 0.386 \\
\hline 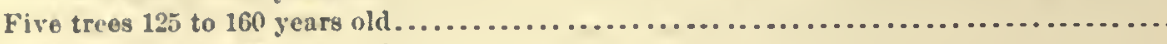 & $: 388$ \\
\hline 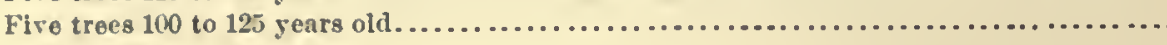 & 383 \\
\hline 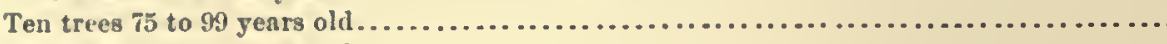 & .378 \\
\hline 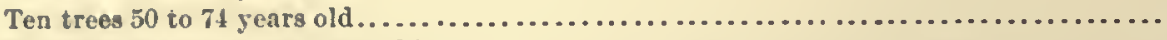 & .366 \\
\hline 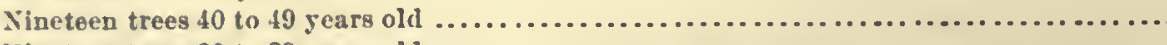 & .353 \\
\hline ineteen trees 30 to 39 years old & .351 \\
\hline
\end{tabular}

From the above, and still more from the table following, in which the troes are gronped aeeording to age, it will be seen that White Pine displays a nniformity of speeifie weight, and other properties dependent on weight, sueh as is entirely unknown in any other pine of the Eastern United States.

Average weight (hiln dry and green), moisture content, and shrinkagc per cent of White Pine.

I.-TREES 200 TO 250 TEARS OLD.

\begin{tabular}{|c|c|c|c|c|c|c|c|c|}
\hline \multirow{2}{*}{ Locality. } & \multirow{2}{*}{$\begin{array}{l}\text { Original } \\
\text { namber of } \\
\text { trees. }\end{array}$} & \multirow{2}{*}{$\begin{array}{l}\text { Approxi- } \\
\text { mato age } \\
\text { of trees. }\end{array}$} & \multirow{2}{*}{$\begin{array}{c}\text { Diameter } \\
\text { breast high } \\
\text { without } \\
\text { bark. }\end{array}$} & \multirow{2}{*}{$\begin{array}{l}\text { Width of } \\
\text { rings. }\end{array}$} & \multicolumn{2}{|c|}{ Specific gravity $\times 100$. } & \multirow{2}{*}{$\begin{array}{l}\text { Moisture as } \\
\text { per cent } \\
\text { of the } \\
\text { weiglit of } \\
\text { dry wood. }\end{array}$} & \multirow{2}{*}{$\begin{array}{l}\text { Shrinkage } \\
\text { In volume }\end{array}$} \\
\hline & & & & & Kiln dry. & Green. & & \\
\hline 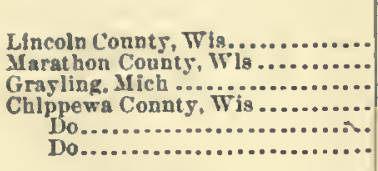 & $\begin{array}{r}5 \\
16 \\
3 \\
1 \\
2 \\
3 \\
3\end{array}$ & $\begin{array}{r}\text { Years. } \\
225 \\
250 \\
205 \\
209 \\
202 \\
202\end{array}$ & $\begin{array}{r}\text { Inches. } \\
23.0 \\
22.0 \\
19.0 \\
27.0 \\
19.4 \\
20.5\end{array}$ & $\begin{array}{r}m m .1 \\
.8 \\
1.3 \\
1.6 \\
1.0 \\
1.2\end{array}$ & $\begin{array}{l}38.1 \\
38.5 \\
36.0 \\
38.0 \\
38.5 \\
39.2\end{array}$ & $\begin{array}{l}69 \\
62 \\
64 \\
66 \\
66 \\
67 \\
\end{array}$ & $\begin{array}{r}\text { Per cent. } \\
93 \\
73 \\
05 \\
85 \\
100 \\
81\end{array}$ & $\begin{array}{r}\text { Percent. } \\
7.6 \\
8.6 \\
8.5 \\
8.1 \\
8.0 \\
7.9\end{array}$ \\
\hline Arerage..... & ........... & ...... & ................. & ............... & 38.6 & 65 & 88 & 8.1 \\
\hline \multicolumn{9}{|c|}{ II.-TREES 125 TO 160 FEARS OLD. } \\
\hline 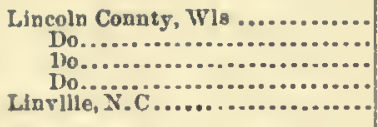 & $\begin{array}{r}1 \\
2 \\
3 \\
4 \\
458 \\
\end{array}$ & $\begin{array}{l}146 \\
140 \\
141 \\
140 \\
158\end{array}$ & $\begin{array}{l}19.0 \\
22.0 \\
12.0 \\
15.0 \\
33.0\end{array}$ & $\begin{array}{l}1.5 \\
1.0 \\
1.0 \\
1.2 \\
2.1\end{array}$ & $\begin{array}{l}42.0 \\
36.4 \\
38.4 \\
40.5 \\
37.1 \\
\end{array}$ & $\begin{array}{l}74 \\
72 \\
65 \\
72 \\
72 \\
\end{array}$ & $\begin{array}{r}92 \\
113 \\
92 \\
87 \\
110 \\
\end{array}$ & $\begin{array}{l}9.0 \\
8.7 \\
9.1 \\
9.8 \\
7.7\end{array}$ \\
\hline$\Delta$ verage..... & .......... & (........... & $\mid \cdots \ldots \ldots \ldots$ & (n........... & 38.8 & 71 & 95 & 8.9 \\
\hline \multicolumn{9}{|c|}{ III.-TREES 100 TO 122 YEARS OLD. } \\
\hline 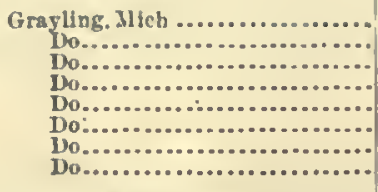 & $\begin{array}{r}1 \\
2 \\
1 \\
5 \\
7 \\
8 \\
9 \\
10\end{array}$ & $\begin{array}{l}110 \\
122 \\
114 \\
105 \\
115 \\
108 \\
112 \\
111\end{array}$ & $\begin{array}{r}17.5 \\
17.7 \\
9.5 \\
7.5 \\
7.8 \\
7.8 \\
7.8 \\
5.0\end{array}$ & $\begin{array}{l}2.2 \\
1.8 \\
1.1 \\
.9 \\
1.1 \\
1.2 \\
1.3 \\
.8\end{array}$ & $\begin{array}{l}36.0 \\
35.0 \\
39.8 \\
38.3 \\
46.8 \\
38.0 \\
38.0 \\
36.7\end{array}$ & $\begin{array}{r}64 \\
64 \\
70 \\
76 \\
100 \\
78 \\
85 \\
71\end{array}$ & $\begin{array}{r}96 \\
99 \\
120 \\
121 \\
138 \\
122 \\
147 \\
109 \\
\end{array}$ & $\begin{array}{r}9.2 \\
9.0 \\
9.8 \\
8.5 \\
10.5 \\
8.8 \\
8.8 \\
8.5\end{array}$ \\
\hline Arerago...... & & & $\cdots \cdots$ & (............. & 38.3 & 74 & 119 & 8.9 \\
\hline \multicolumn{9}{|c|}{ IF.-TREES 75 TO 100 YEARS OLD. } \\
\hline 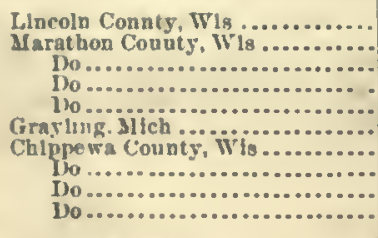 & $\begin{array}{r}6 \\
12 \\
13 \\
14 \\
15 \\
6 \\
5 \\
6 \\
7 \\
9\end{array}$ & $\begin{array}{l}75 \\
84 \\
90 \\
81 \\
95 \\
93 \\
83 \\
94 \\
81 \\
78\end{array}$ & $\begin{array}{r}4.0 \\
14.0 \\
12.0 \\
15.0 \\
10.0 \\
7.0 \\
7.0 \\
0.3 \\
10.4 \\
10.2\end{array}$ & $\begin{array}{l}0.8 \\
2.0 \\
2.1 \\
2.7 \\
1.4 \\
1.6 \\
1.5 \\
1.0 \\
2.4 \\
1.8\end{array}$ & $\begin{array}{l}36.3 \\
39.4 \\
37.0 \\
36.0 \\
40.4 \\
40.1 \\
36.3 \\
37.0 \\
37.1 \\
38.5\end{array}$ & $\begin{array}{l}68 \\
76 \\
85 \\
73 \\
72 \\
90 \\
70 \\
74 \\
76 \\
76\end{array}$ & $\begin{array}{r}111 \\
110 \\
148 \\
121 \\
88 \\
149 \\
132 \\
115 \\
128 \\
118\end{array}$ & $\begin{array}{l}8.4 \\
8.0 \\
9.8 \\
9.0 \\
9.4 \\
8.7 \\
9.8 \\
8.0 \\
9.8 \\
8.7\end{array}$ \\
\hline Average.............. & ...... & .............. & ................ & .............. & 37.8 & 76 & 112 & 9.0 \\
\hline
\end{tabular}


Average weight (kiln dry and green), moisture content, and shrinkage per cent of White Pine-Continued.

V.TREES 50 TO 74 LEARS OLD.

\begin{tabular}{|c|c|c|c|c|c|c|c|c|}
\hline \multirow[b]{2}{*}{ Locality. } & \multirow{2}{*}{$\begin{array}{l}\text { Original } \\
\text { number of } \\
\text { trees. }\end{array}$} & \multirow{2}{*}{$\begin{array}{l}\text { Approxi- } \\
\text { mateage } \\
\text { of trees. }\end{array}$} & \multirow{2}{*}{$\begin{array}{c}\text { Diameter } \\
\text { breast high } \\
\text { without } \\
\text { bark. }\end{array}$} & \multirow[b]{2}{*}{$\begin{array}{l}\text { Width of } \\
\text { rings. }\end{array}$} & \multicolumn{2}{|c|}{ Specific gravity $\times 100}$. & \multirow{2}{*}{$\begin{array}{l}\text { Moistureas } \\
\text { per cent } \\
\text { of the } \\
\text { weight of } \\
\text { dry wood. }\end{array}$} & \multirow{2}{*}{$\begin{array}{l}\text { Shrinkage } \\
\text { in rolume. }\end{array}$} \\
\hline & & & & & Kiln dry. & Green. & & \\
\hline 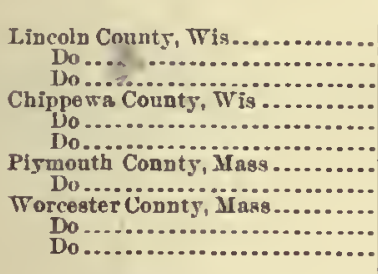 & \begin{tabular}{r|r}
7 \\
8 \\
11 \\
8 \\
4 \\
10 \\
1 \\
4 \\
16 \\
17 \\
18
\end{tabular} & $\begin{array}{r}\text { Tears. } \\
60 \\
50 \\
52 \\
65 \\
73 \\
07 \\
50 \\
52 \\
54 \\
65 \\
60\end{array}$ & $\begin{array}{r}\text { Inches. } \\
4.5 \\
2.0 \\
5.5 \\
8.0 \\
7.0 \\
4.2 \\
13.0 \\
11.0 \\
14.0 \\
10.0 \\
10.0\end{array}$ & $\begin{array}{r}m m . \\
1.3 \\
.1 \\
1.7 \\
2.9 \\
1.5 \\
1.2 \\
4.0 \\
2.8 \\
3.0 \\
2.4 \\
2.3\end{array}$ & $\begin{array}{l}34.3 \\
39.3 \\
33.8 \\
38.7 \\
39.0 \\
35.7 \\
35.3 \\
38.5 \\
39.0 \\
36.5 \\
35.5\end{array}$ & $\begin{array}{l}80 \\
70 \\
86 \\
78 \\
64 \\
72 \\
68 \\
73 \\
69 \\
67\end{array}$ & $\begin{array}{r}\text { Per cent. } \\
148 \\
\cdots \\
122 \\
84 \\
121 \\
112 \\
106 \\
93 \\
103\end{array}$ & $\begin{array}{r}\text { Per cent. } \\
8.5 \\
8.5 \\
8.6 \\
9.0 \\
10.1 \\
8.0 \\
8.6 \\
8.6 \\
8.4 \\
7.3 \\
7.5\end{array}$ \\
\hline A verage.... & $\ldots \ldots \ldots$ & & ........... & ......... & 36.8 & $7 t$ & 115 & 8.0 \\
\hline
\end{tabular}

VI_-TREES 40 TO 49 YEARS OLD.

\begin{tabular}{|c|c|c|c|c|c|c|c|c|}
\hline Lineoin Connty, Wis ............. & 9 & 48 & 2.3 & 0.6 & 43.3 & 81 & 102 & 8.5 \\
\hline Do & 10 & 47 & 6.0 & 2.0 & 31.3 & 86 & 162 & 8.9 \\
\hline Marathou Connty, Wia............ & 17 & 40 & 6.0 & 2.2 & 33.5 & 85 & 173 & $\ddot{\theta .0}$ \\
\hline Do $\ldots . . . \ldots \ldots \ldots \ldots \ldots$ & 18 & 40 & 6.0 & 2.3 & 34.5 & 81 & 149 & 8.6 \\
\hline 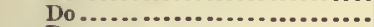 & 19 & 40 & 2.0 & 1.1 & 33. 7 & 71 & 124 & 8.3 \\
\hline Do $\ldots . . . \ldots \ldots \ldots \ldots \ldots$ & 20 & 42 & 2.8 & 3.0 & 35.0 & 67 & 105 & 8.4 \\
\hline $\bar{D}_{0} \ldots \ldots \ldots \ldots \ldots \ldots \ldots \ldots$ & 21 & 44 & 4.0 & 1.4 & 33.8 & 82 & 158 & 7.9 \\
\hline Pigmonth Convty, Jass ........... & -1 & 46 & 8.5 & 2.6 & 36.2 & 58 & 76 & 8.4 \\
\hline 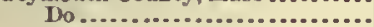 & 3 & 45 & 0.2 & 3.0 & 36.2 & 65 & 05 & 8.5 \\
\hline Do ............................ & 5 & 49 & 13.7 & 3.9 & 35.0 & 61 & 93 & 8.4 \\
\hline Do .................................. & 6 & $\$ 7$ & 0.5 & 2.8 & 38.0 & 64 & 81 & 8.1 \\
\hline Do & 10 & 48 & 12.5 & 3.6 & 34.5 & 65 & 108 & 9.3 \\
\hline Do $\ldots \ldots \ldots \ldots \ldots \ldots \ldots \ldots \ldots$ & 11 & 49 & 10.3 & 3.1 & 39.0 & 07 & 89 & 9.3 \\
\hline Do $\ldots \ldots \ldots \ldots \ldots \ldots \ldots$ & 12 & 48 & 10.2 & 2.9 & 37.2 & 70 & 104 & 7.0 \\
\hline Worcester County, Mass......... & 25 & 46 & 10.0 & 2.7 & 35.0 & 68 & 103 & 8.1 \\
\hline Do & - 26 & 45 & 12.8 & 3.8 & 35.5 & 67 & 106 & 8.6 \\
\hline Do & $\begin{array}{ll}27 \\
-2\end{array}$ & 45 & 9.1 & 2.0 & 37.7 & 75 & 118 & 9.4 \\
\hline Merrimack Connty, $\mathbf{N} . \mathbf{H}$........ & 32 & 41 & 10.3 & 3.4 & 33.0 & 61 & 98 & 7.9 \\
\hline Do & 33 & $\$ 0$ & 8.6 & 3.1 & 31.7 & 64 & 122 & 8.4 \\
\hline Arerage.... & & & & $\ldots$ & 35.3 & 70 & 113 & 8.4 \\
\hline
\end{tabular}

VII.-TREES 30 TO 39 YEARS OLD.

\begin{tabular}{|c|c|c|c|c|c|c|c|c|}
\hline 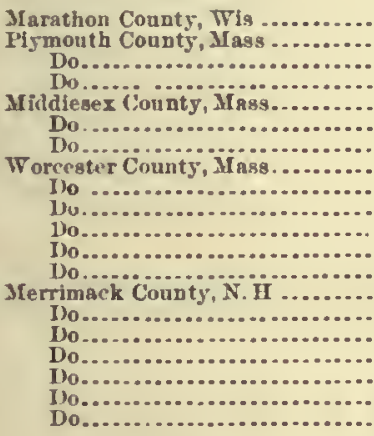 & \begin{tabular}{r|}
22 \\
7 \\
8 \\
9 \\
13 \\
14 \\
15 \\
19 \\
20 \\
21 \\
22 \\
23 \\
24 \\
28 \\
29 \\
30 \\
31 \\
34 \\
35 \\
36
\end{tabular} & $\begin{array}{l}38 \\
36 \\
34 \\
35 \\
38 \\
38 \\
37 \\
35 \\
33 \\
31 \\
33 \\
36 \\
35 \\
38 \\
37 \\
37 \\
39 \\
34 \\
35 \\
35\end{array}$ & $\begin{array}{r}16 \\
8.3 \\
9.1 \\
12.0 \\
11.0 \\
10.8 \\
10.8 \\
9.2 \\
11.2 \\
6.5 \\
10.5 \\
9.2 \\
7.0 \\
6.8 \\
7.1 \\
8.2 \\
9.5 \\
7.5 \\
9.3 \\
10.3\end{array}$ & $\begin{array}{l}1.5 \\
3.5 \\
3.4 \\
4.7 \\
3.4 \\
3.6 \\
3.7 \\
3.6 \\
4.8 \\
2.9 \\
4.4 \\
3.6 \\
2.9 \\
2.4 \\
2.8 \\
3.0 \\
3.2 \\
3.3 \\
3.7 \\
3.9\end{array}$ & $\begin{array}{l}31.3 \\
36.5 \\
35.2 \\
35.7 \\
35.2 \\
33.7 \\
36.0 \\
36.1 \\
33.6 \\
35.2 \\
33.0 \\
35.2 \\
34.5 \\
38.5 \\
36.7 \\
36.7 \\
37.7 \\
32.7 \\
34.5 \\
30.0\end{array}$ & $\begin{array}{l}77 \\
64 \\
66 \\
66 \\
74 \\
74 \\
83 \\
61 \\
65 \\
63 \\
72 \\
68 \\
66 \\
66 \\
67 \\
71 \\
65 \\
71 \\
74 \\
64\end{array}$ & $\begin{array}{r}162 \\
93 \\
105 \\
100 \\
131 \\
147 \\
146 \\
85 \\
108 \\
99 \\
143 \\
111 \\
109 \\
89 \\
108 \\
111 \\
99 \\
129 \\
123 \\
147\end{array}$ & $\begin{array}{r}8.2 \\
8.3 \\
9.2 \\
7.7 \\
9.1 \\
8.2 \\
7.5 \\
8.1 \\
7.0 \\
0.5 \\
9.3 \\
8.7 \\
8.2 \\
9.8 \\
10.2 \\
8.5 \\
9.0 \\
7.5 \\
9.2 \\
8.0\end{array}$ \\
\hline Arerage................. & n......... & .............. & .............. & ............ & 35.1 & 68 & 104 & 8.5 \\
\hline \multicolumn{9}{|c|}{ VIII.TREES 20 TO 30 TEARS OLD. } \\
\hline 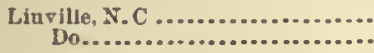 & $\begin{array}{l}459 \\
460\end{array}$ & $\begin{array}{l}22 \\
26\end{array}$ & $\begin{array}{l}1.0 \\
7.0\end{array}$ & $\begin{array}{l}2.7 \\
2.8\end{array}$ & $\begin{array}{l}34.7 \\
36.9\end{array}$ & $\begin{array}{l}83 \\
85\end{array}$ & $\begin{array}{l}104 \\
156\end{array}$ & $\begin{array}{r}9.4 \\
10.2\end{array}$ \\
\hline Average................ & & & & & 35.5 & 81 & 165 & 9.8 \\
\hline
\end{tabular}


From the table it appears that the speeifie weight of the timber is quite independent of the rate of growth, and that the individual variation generally moves within very narrow limits. The diagrams (figs. 16 and 17) show the relation of weight for the different seetions from the stump

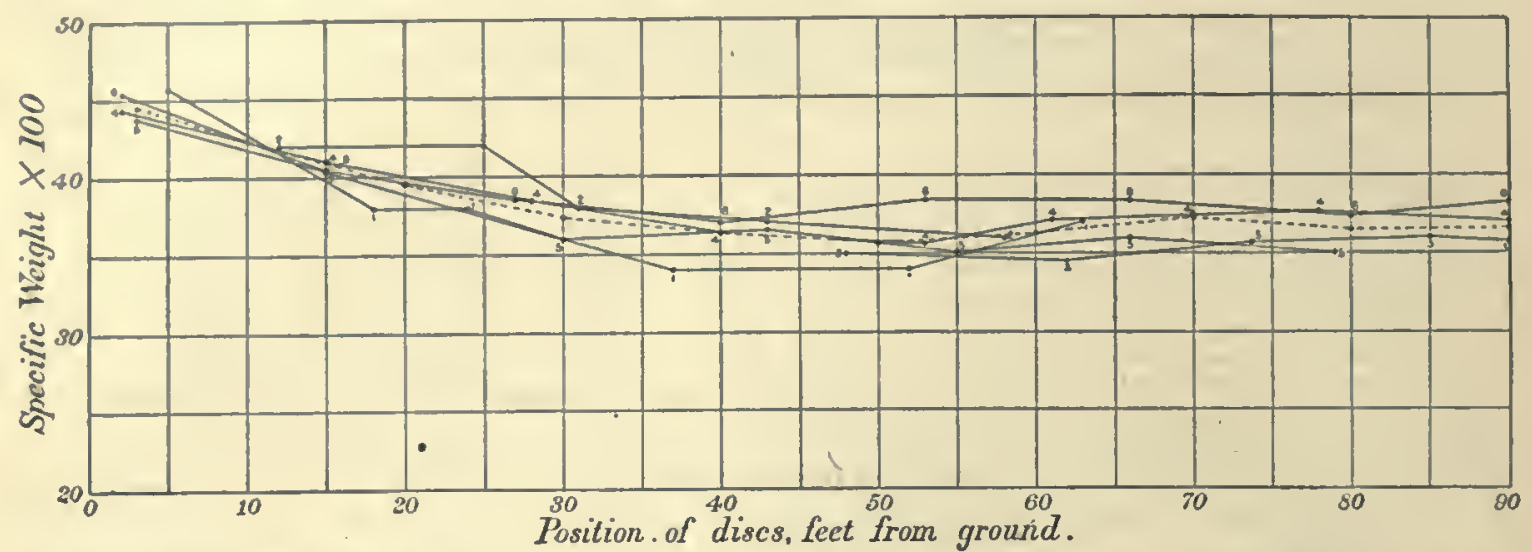

F16. 16.-Diagram sbowing speclfo weight of wood at different cross sections of the stem; also a decrease of weight from the stump upward, and the simllarity of the wool of difforent trees. (Firotrees, over 200 5ears old. Dotted line indicates the average.)

upward; the slightly greater weight of the older timber, as eompared to sapling material, the uniform deerease in weight from stump npward, and also the uniformity of the several individuals of any group of trees is elearly apparent from the lines. The same deerease in weight from below

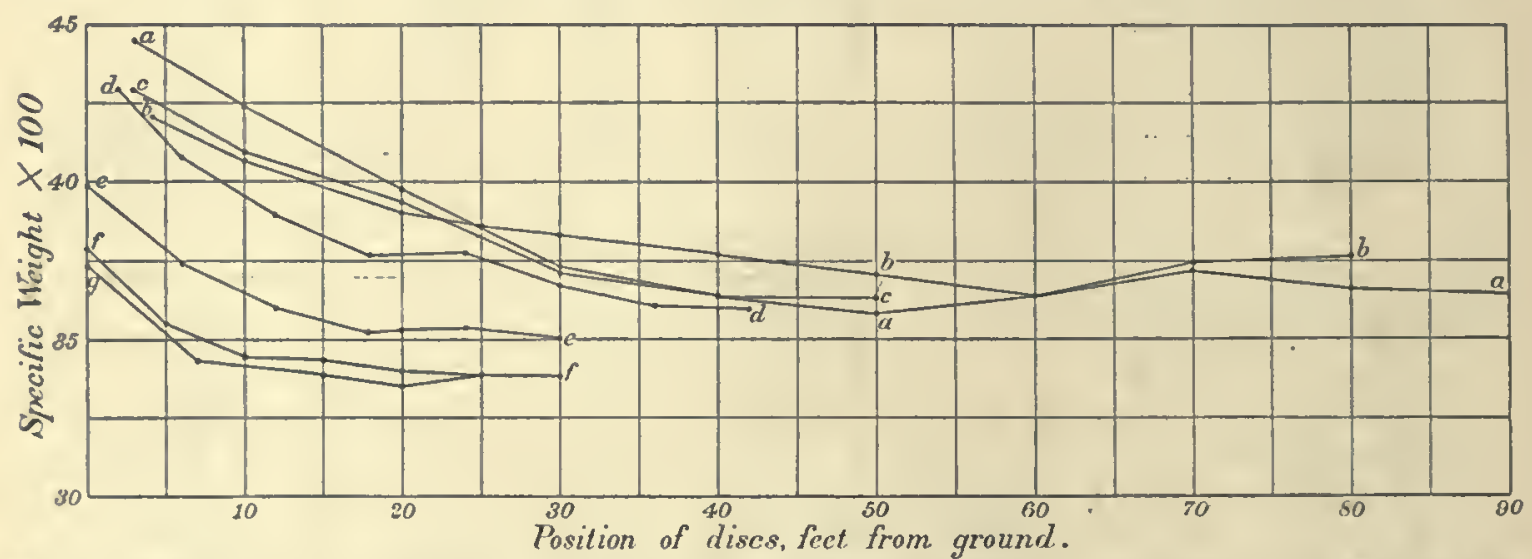

Fio. 17.-Diagram showlng spcclfo welght of klin.dry wood at different polnts in the stem from grouvd upward: $a$, six trees, 200 to 250 years old; $b$, fivo trees, 125 to 160 jears old; $c$, seven trees, 100 to 125 jears old; $d$, ten trees, 75 to 100 years old; $e$, ten trees, 30 to 74 years old; f, eighteen troes, 40 to 49 years old; $g$, nlnetecn trees, 30 to 39 years old.

upward is observed in the wood of any given period of growth; thus, the wood of the last forty rings (next to the bark) was found to be as follows:

Decrease in uceight of the wool of the last (outer) forty rings in the several disk from stumu upurari.

\begin{tabular}{|c|c|c|c|c|}
\hline \multirow[b]{2}{*}{ Jisk number. } & \multicolumn{4}{|c|}{ Speelfio gravlty. } \\
\hline & $\begin{array}{c}\text { Tree No. } \\
458 .\end{array}$ & Tree to. 1. & Tree No.2. & Tree No.3. \\
\hline 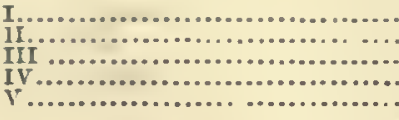 & $\begin{array}{l}0.37 \\
.31 \\
.30 \\
.293 \\
.31\end{array}$ & $\begin{array}{r}0.42 \\
.39 \\
.36 \\
.35 \\
.33\end{array}$ & $\begin{array}{r}0.44 \\
.40 \\
.36 \\
.36\end{array}$ & $\begin{array}{l}0.43 \\
.405 \\
.39 \\
.36 \\
.37\end{array}$ \\
\hline
\end{tabular}


As in other piues, there is usually an increase of weight in the crown, apparently due to an infuence of the limbs, bnt as this influence is local, so the appareut result is local, aud the weight is very irregular for the crown part of the stem; the pronounced increase is apparent only in the immerliate vicinity of the limbs. The absence of a pronounced or sharply defined summer wood makes it difficult and impracticable to apply the microscopic methods to detcrmine the variation of weight from pith to bark on any cross section. From the actual determinations of weight, it appcars that for the lower portions of any normally grown tree there is usually at first an increase of weight from the pith ontward, reachiug a maximum somewhere between the fiftieth and eiglitieth ring, maintalined for a long period and usually followed by a very slow decrease in wcight from there on ontward. This variation is generally small, and never reaches the proportions met in sections of hard pine, such as Longleaf Pine, where it commonly amounts to 75 to 100 per cent of the weight of the lightest portion.

Usually abont half the wcight of a green $\log$ is water. The amount of inoisture generally varies in the sapwood from about 120 to 160 per cent and from 40 to 60 per cent in the heartwood, the amonnt for the entire log, therefore, varying with the proportion of sap and heart is greatest in saplings and least in large mature trees, in the latter from about 90 to 120 per cent of the weight of the timber after it is kiln-dried. The wood parts with its moisture as easily as any wood iu the market, dries rapidly, with little injury, and may safely be kiln-dricd fresh from the saw, though in actual practice this method is almost unknown iu the White Pine regious, the usual way of drying by carefully piling in immense piles, being the universal way of seasoning. Well air-dried Whitc Pine, as iu an ordinary room, still retains 8 to 9 per cent moisture, and if unprotected by oil, paint, ctc., is quite susceptible to changes of humidity, absorbing and giving off moisture at every change of temperature and humidity of the air.

\section{SHRINKAGE.}

Iu keeping with its smaller specific wcight, the shrinkage of White Pine is less than that of other pines. It is greater for sap than heart, and therefore greater for sapliug timber thau for oldcr trees. From the table on page 74 it appears that the shrinkage in volume varies for the several gronps of trees from 8 to 9 per ceut, and, like the weight, is quite uniform for the differcut individuals of each group.

The ease and rapidity with which White Piue seasons, and the manner of distribution of White Pine Inmber, encouraging proper scasoning beforc use, have done much to earu for White Pine the fame of bcing one of the woods which do "not shrink" nor "work," a virtue which is not only in part due to the small weight and consequent small shrinkage, but is largely the result of proper haudling.

\section{STRENGTE.}

Being the lightest, White Pine is also the weakcst among the pines of the Eastern Unitcd States, as appears from the following general avcrage:

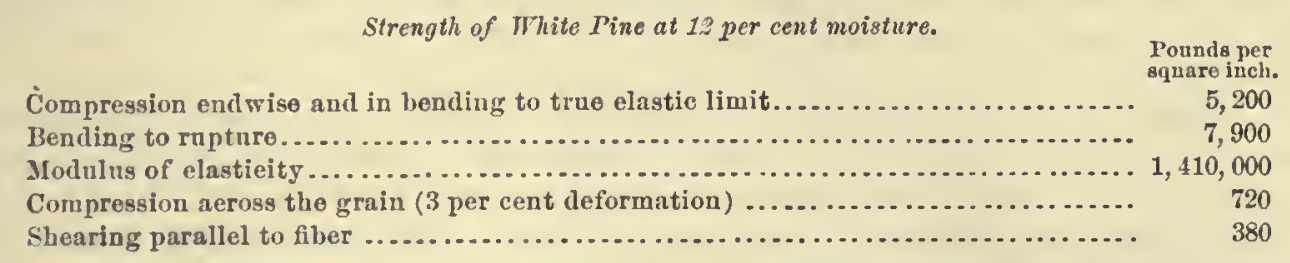

Ont of about scven hundred tests made by the Division of Forestry, about 55 per cent fall within 10 per cent of this general avcrage, and 90 per cent within 25 per cent of the same. Though the test series for White Pine was by no mcans as full as is desirable, the above average results will probably be found fairly accurate and sufticicnt for geueral purposes. The table on the next page presents the average results for the several trees. 
THE WHITE PINE.

Arerage strength of the wood of White l'ine of different trees at 12 per cent moisture.

\begin{tabular}{|c|c|c|c|c|c|c|c|c|}
\hline \multirow[b]{2}{*}{ Locality. } & \multirow{2}{*}{$\begin{array}{l}\text { Original } \\
\text { namber of } \\
\text { trees. }\end{array}$} & \multirow{2}{*}{$\begin{array}{c}\text { Modulus of } \\
\text { Nostleity } \\
\text { (1,000 } \\
\text { pounds). }\end{array}$} & \multicolumn{2}{|c|}{ Mendlng to- } & \multirow{2}{*}{$\begin{array}{l}\text { Compres- } \\
\text { sion end- } \\
\text { wise. }\end{array}$} & \multirow{2}{*}{$\begin{array}{l}\text { Compres- } \\
\text { slon across } \\
\text { gralr to } 3 \\
\text { per cent de- } \\
\text { formation. }\end{array}$} & \multirow{2}{*}{$\begin{array}{l}\text { Shearlog } \\
\text { parallel to } \\
\text { fiber. }\end{array}$} & \multirow{2}{*}{$\begin{array}{l}\text { A rerago } \\
\text { speclfio } \\
\text { welght. }\end{array}$} \\
\hline & & & Rupturo. & $\begin{array}{l}\text { Relatiro } \\
\text { elagtio } \\
\text { limit. }\end{array}$ & & & & \\
\hline 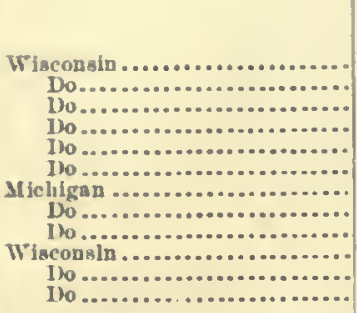 & $\begin{array}{l}101 \\
102 \\
104 \\
112 \\
114 \\
116 \\
601 \\
602 \\
603 \\
637 \\
608 \\
609\end{array}$ & $\begin{array}{l}1,860 \\
1,520 \\
1,350 \\
1,330 \\
1,190 \\
1,350 \\
1,370 \\
1,470 \\
1,470 \\
1,380 \\
1,560 \\
1,510\end{array}$ & $\begin{array}{r}\text { Punde per } \\
\text { s?. in. } \\
8,100 \\
7,400 \\
7,800 \\
8,300 \\
\text { a } 6,800 \\
8,300 \\
7,400 \\
7,800 \\
7,850 \\
8,000 \\
8,900 \\
8,200\end{array}$ & $\begin{array}{c}\text { Pounde per } \\
\text { q. in. } \\
6,200 \\
\varepsilon, 300 \\
6,000 \\
6,300 \\
5,600 \\
5,900 \\
6,300 \\
6,700 \\
6,650 \\
6,800 \\
7,450 \\
6,700\end{array}$ & $\begin{array}{c}\text { Pounde per } \\
\text { s. in. } \\
4,600 \\
4,200 \\
4.800 \\
5,000 \\
4,250 \\
5,000 \\
5,500 \\
5,700 \\
5,400 \\
5,700 \\
5,700 \\
6,200\end{array}$ & \begin{tabular}{|c|} 
Pounds per \\
og. in. \\
690 \\
560 \\
620 \\
650 \\
630 \\
560 \\
810 \\
860 \\
790 \\
910 \\
670 \\
880
\end{tabular} & \begin{tabular}{c|} 
Pounds per \\
q. in. \\
400 \\
320 \\
430 \\
410 \\
400 \\
470 \\
350 \\
420 \\
330 \\
840 \\
330 \\
340
\end{tabular} & $\begin{array}{l}0.42 \\
.36 \\
.40 \\
.30 \\
.36 \\
.385 \\
.38 \\
.37 \\
.38 \\
.38 \\
.385 \\
.392\end{array}$ \\
\hline Arerago................... & ............. & 1,410 & 7,810 & 6,300 & 5,200 & 720 & 380 & .384 \\
\hline A rerage for trees 601 to $609 . . .$. & ............ & 1,460 & 8,000 & 6,760 & 5,700 & 8,200 & 350 & 38.3 \\
\hline
\end{tabular}

a Insuftident data for a fair arerage.

In the above table the data for trees 101 to $\mathbf{1 1 6}$ are insufficient. Botli material aud tests for trees 601 to 609 were satisfaetory in every respect, aud the results, therefore, of far greater value than those for trees 101 to 116.

In leeping with its greater weight, the wood of the butt logs is slightly stronger thau that of the toll $\operatorname{logs}$, and there is generally a regular difference betweeu different parts of the same eross seetion, the eenter, as appears nsual in pine, being the weakest, the heavier intermediate portion the strongest, and the periplieral part lying between the two.

For a more eareful study of this relation, tests were made of a set of 2 by 2 inel stiels eut out of one $\log$ from each of three trees, in sueh a manner that the eenters of the logs formed one set, the part midway from center to bark another set, aud the outer portion of the logs a third or outer set, the latter two being all quarter-sawed pieecs. The tests furnished the followiug average results:

Strength of 2 by 2 pieces at 12 per cent moisture.

\begin{tabular}{|c|c|c|c|}
\hline Kind of test. & Treo No.601. & Tree No. 602. & Tree No.603. \\
\hline 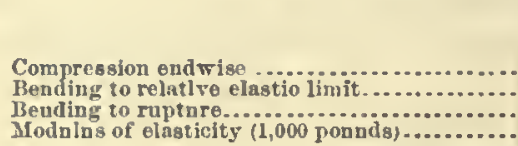 & $\begin{array}{r}\text { Pounds per } \\
\text { og. in } \\
6,710 \\
7,960 \\
9,360 \\
1,306\end{array}$ & $\begin{array}{c}\text { Pounds per } \\
8 q . \text { in. } \\
6,890 \\
7,970 \\
9,630 \\
1,291\end{array}$ & $\begin{array}{r}\text { Pounds per } \\
\text { Bq. in. } \\
6.340 \\
7,890 \\
9,340 \\
1,285\end{array}$ \\
\hline
\end{tabular}

It is apparent from the above that the perfect quarter-sawed material eonfirmed the other test results in showing the great similarity of the wood of these thrce trees. It also shows, however, that the effeet of defeets in an nuseleeted lot reluces the strength values markedly in this speeies.

Arranging the results aeeording to the positiou of the test piees in the log, it is found that in compression endwise the strength was: Center pieces, 5,520 pounds, or 78 per eent; intermediate, 7,000 pounds, or 100 per eent; outside pieees, 6,680 pounds, or 95 per eent; showing that the heart pieees, as lias been found in other conifers, are always the reakest, thus verifying the results of the general series. The sliglit decrease from the intermediate to the outside piees is in keeping with the smaller weight of the latter and need not be aseribed to the faet that these pieees eontained small proportions of sapwood. As miglit be expeeted, the uniformity of results in this properly seleeted and prepared material was greater than in the ordinary series. Of 58 tests, all fell within 25 per eent of the a verage strength and 76 per eent withiu 10 per eent of the average.

In conneetion with a general study into the maximum miformity of wood, three seautlings of White Pine, with an average speeifie gravity of about $0.3 \pm$ and au average eompressive strength at 8 per eent moisture of 4,900 pounds, were examined, two being tested air-dry ( 8 per eeut) and 
the other after being soaked for three months in cold water. The results of these tests on White Pine are embodied in the following table:

Strength of contiguous blocks of the same scantling of White Pine, select material, in compression endwise.

[Dimensions generally, 2.76 by 2.76 by 2.76 inches.]

\begin{tabular}{|c|c|c|c|c|c|c|c|}
\hline \multirow{2}{*}{ Number of block. } & \multicolumn{2}{|c|}{ Dry scautling. } & \multirow{2}{*}{$\frac{\begin{array}{c}\text { Soaked } \\
\text { acantling- }\end{array}}{3}$} & \multirow{2}{*}{ Number of block: } & \multicolumn{2}{|c|}{ Dry seantling. } & \multirow{2}{*}{$\frac{\begin{array}{c}\text { Soaked } \\
\text { seantling. }\end{array}}{3}$} \\
\hline & 1 & 2 & & & 1 & 2 & \\
\hline 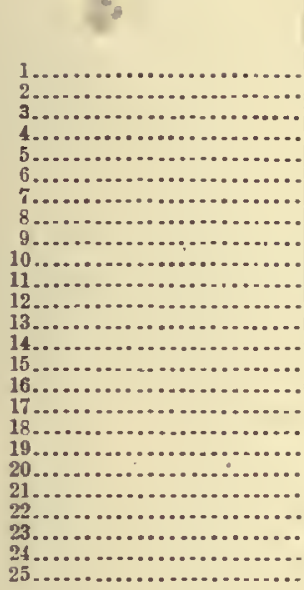 & \begin{tabular}{|c|} 
Pourd ds per \\
sq. in. \\
4,850 \\
4,860 \\
4,690 \\
4,840 \\
4,760 \\
4,720 \\
4,730 \\
4,760 \\
4,750 \\
4,770 \\
4,730 \\
4,760 \\
4,770 \\
4,670 \\
4,600 \\
4,660 \\
4,590 \\
4,600 \\
4,610 \\
4,880 \\
4,920 \\
4,870 \\
4,970 \\
4,940 \\
..$\ldots \ldots$
\end{tabular} & 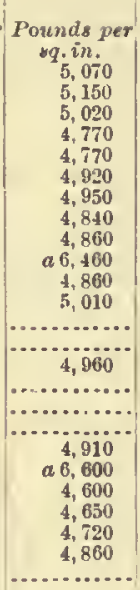 & \begin{tabular}{|c|c|} 
Pounds per \\
$8 \eta$, in. \\
2,270 \\
2,390 \\
2,300 \\
2,260 \\
$a 5,700$ \\
2,390 \\
2,300 \\
2,310 \\
2,290 \\
2,310 \\
2,340 \\
2,210 \\
2,370 \\
2,340 \\
2,340 \\
2,340 \\
2,330 \\
$a 5,710$ \\
2,310 \\
2,260 \\
2,180 \\
2,130 \\
$\ldots \ldots . . . .$. \\
$\ldots . . . .$.
\end{tabular} & 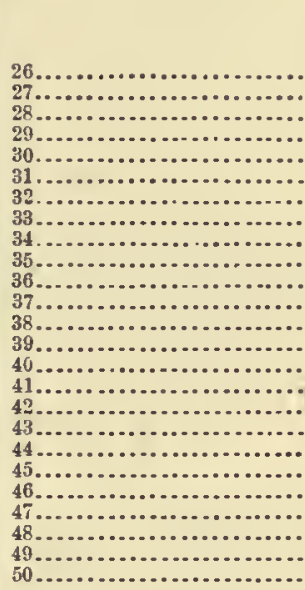 & \begin{tabular}{|c|} 
Pounds per \\
$8 q$, inh \\
5,070 \\
4,940 \\
5,020 \\
5,110 \\
5,020 \\
4,050 \\
4,820 \\
4,950 \\
4,900 \\
5,040 \\
5,160 \\
5,120 \\
5,100 \\
5,230 \\
5,280 \\
5,260 \\
5,280 \\
5,300 \\
5,310 \\
5,300 \\
5,350 \\
5,406 \\
5,360 \\
5,360 \\
5,510
\end{tabular} & 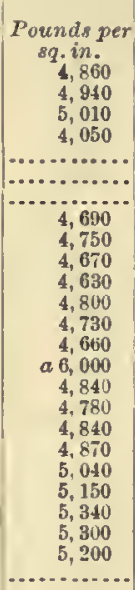 & 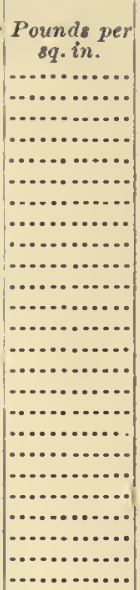 \\
\hline
\end{tabular}

a Dried at 1800 F. (to about 2 per cent moisture) before testing.

It appears that in the tests on dry material the greatest differenee between any two eontiguous blocks of select quarter-sawed White Pine was 190 pounds per square incl, or 3.8 per cent of the total strength; that generally it was, less tlian 2 per cent, and several times only about 0.2 per eent, but that in tests of this kind less then 200 pounds in the results can not be regarded as any difference at all, this anonnt being dne to indeterminable differenecs found even in the best material, and partly dne also to imperfeetions in tlie means and methods of testing. It is also elear that in the same seantling, thongh seleet and of small dimension (only 6 feet long) a difference of nearly 900 pounds per square ineh, or 18 per eent of the strengtli, in eompression endwise may be found, so that any inferenees from seantling to seantling must be taken with great eaution, and any aeeurate relations, such as the influenee of seasoning, etc., can be made only in a manner similar to that employed in these uniformity tests.

From the general series of tests, also from the tests on the select 2 by 2 inch pieces, and in way of indieation also from some of the tests in maximum uniformity, it appears that seasoning affeets the wood of White Pine to about the same degree as that of other pines. The strength of greenwood, or wood soaked to a point where additional immersion no longer ehanges the volume, is independent of differenees in moisture. This is quite elear from the test in uniformity of the seantling immersed for three montlıs. Though the blocks differed (especially near the ends) within wide limits as to the amount of moisture they contained, yet the strength was fonnd to be as uniform as in evenly dried timber. By drying green or fully saturated wood to about 2 per cent moisture (kiln-drying at $80^{\circ} \mathrm{C}$.), the strength is more than doubled; and even if pieces well airdried are kiln-dried the strengtl is still inereased by over 40 per cent. For timber to be used under cover and kept properly ventilated, it is safe to presume that the strength, once seasoned, will be 50 per cent greater than when green, and if used in heated rooms, an increase of 100 per cent on the strength of the green timber may reasonably be expected. The diagram (fig. 18) well illustrates this feature. 


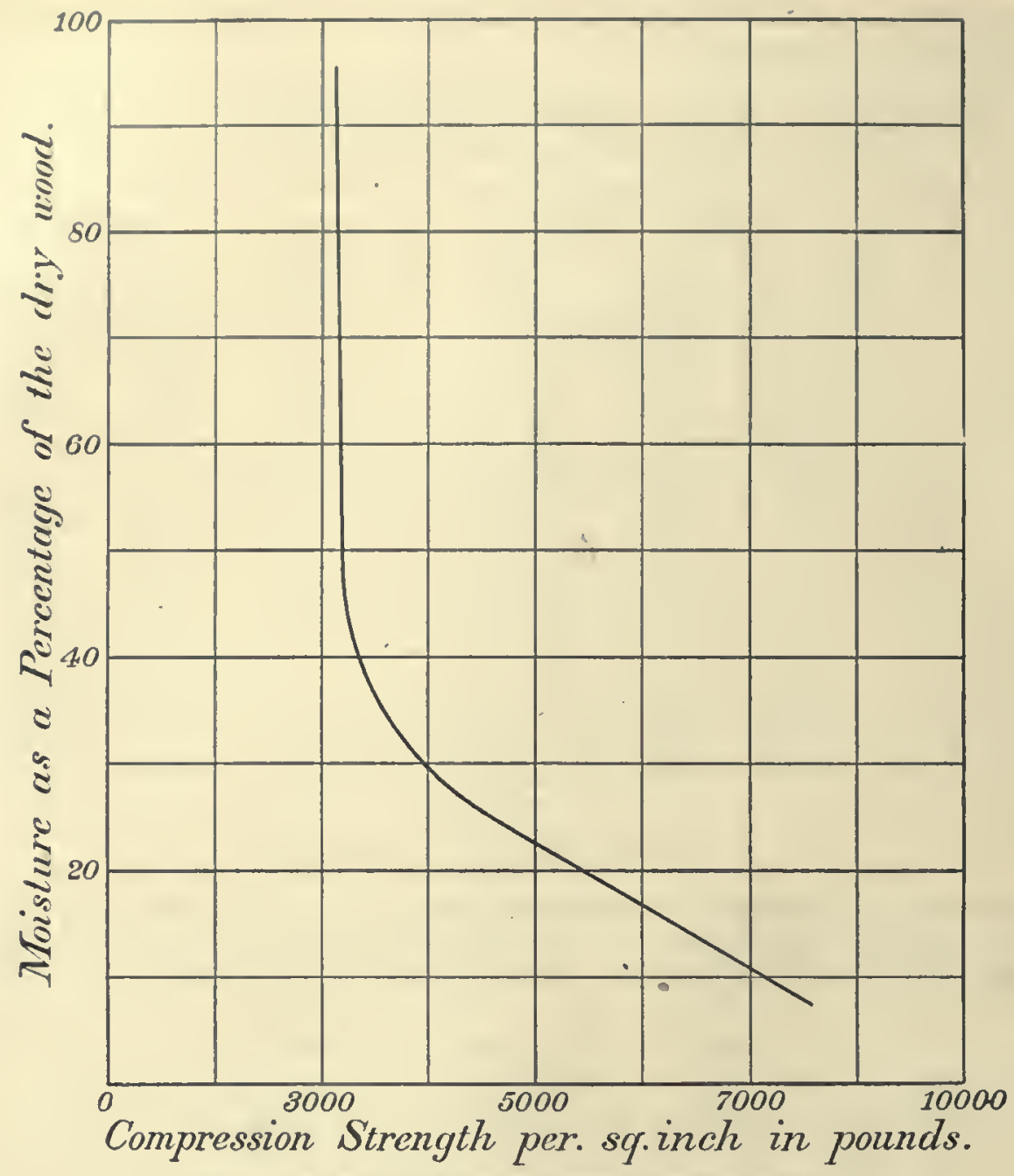

FIG. 18.-Diagrau showing effect of moisture on crushing strength.

\section{DURABILITY.}

With regard to its durability, White Pine is generally underrated. The soft, light-eolored wood suggests general frailty and a lack of resistance, in which resistance to decay is included. In the region where it grows the nuusual great durability of the heartwood of White Pine is well known; "the stumps of White Pine last a lifetime;" old logs, covered with moss and often with young Poplars and Birch growing from their surface aro uncovercd and utilized as shingle bolts. White Pine shingles wear ont, but rarely decay, and a good sidewalk of White Pine is considered the best to bo lad. As in other pines, the sapwood decays readily, but this being narrow in good logs, more than half of all Whitc Pine sawed is good durable heart, a wood which is ncither subject to decay nor to the boring insects any more than the heavy resiuons heart of the Red Pine or of the Southern pines.

\section{COMPARISON WITH OTHER WOODS.}

Generally White Pine is logged and milled on a large seale, cut mostly into boards and plank, and there is to-day no common wood which is more economieally handled and more carefully scleeted.

Compared to other pines, the White Pine is offered more extcnsively and has a greater influence on lumber markets than any other wood used. It is more uniform, lighter, softer, and 
shrinks less than any other pine; it is durable, inseet proof, aud suited to a much greater number of nses than the wood of other pine.

The following table exhibits the position of White Pine as to weight and strength:

Teight and strength of White Pine compared with other pines.

\begin{tabular}{|c|c|c|c|c|c|c|c|c|}
\hline \multirow{3}{*}{ Name of pines. } & \multirow{2}{*}{\multicolumn{2}{|c|}{ Spocific gravity. }} & \multicolumn{4}{|c|}{ Bending. } & \multirow{2}{*}{\multicolumn{2}{|c|}{ Compresslon endwise. }} \\
\hline & & & \multicolumn{2}{|c|}{ Rnpture. } & \multicolumn{2}{|c|}{ To relative elastle limlt. } & & \\
\hline & Actual. & Relatíre. & $\begin{array}{l}\text { Pounds } \\
\text { per sqnaro } \\
\text { inch. }\end{array}$ & Relative. & $\begin{array}{l}\text { Ponnds } \\
\text { per square } \\
\text { inch. }\end{array}$ & Relativo. & $\begin{array}{c}\text { Ponnds } \\
\text { per square } \\
\text { inch. }\end{array}$ & Relative. \\
\hline 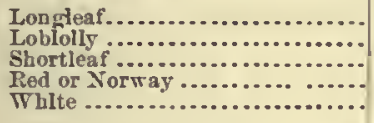 & $\begin{array}{l}81 \\
53 \\
51 \\
48 \\
38\end{array}$ & $\begin{array}{r}100 \\
87 \\
84 \\
78 \\
62\end{array}$ & $\begin{array}{r}12,800 \\
11,800 \\
10,400 \\
2,100 \\
7,900\end{array}$ & $\begin{array}{r}100 \\
82 \\
81 \\
71 \\
62\end{array}$ & $\begin{array}{r}10,300 \\
9,500 \\
7,800 \\
7,700 \\
8,400\end{array}$ & $\begin{array}{r}100 \\
92 \\
76 \\
75 \\
62\end{array}$ & $\begin{array}{l}8,306 \\
7,800 \\
6,500 \\
6,700 \\
5,200\end{array}$ & $\begin{array}{r}100 \\
94 \\
78 \\
81 \\
62\end{array}$ \\
\hline
\end{tabular}

Of the several eolumns, that on specific weight beiug at onee the simplest and most truly representative of the eutire stem of mature timber, illustrates probably the relative position of these fivc pines most perfectly. The Southern pines, if only the saw timber is considered, will prove even heavier and stronger by several per cent than appears from this table.

\section{USES OF WHITE PINE.}

There is no wood in the Uuited States, perhaps in the world, of whieh there is a greater quautity used, nor one which is put to a greater variety of uses than that of the White Pine. At present the great mass of White Pine, probably not less than 95 per cent of the entire output, is cut into even lengths, usually 12 to 18 fcet long, preferably 16 feet (full 75 per cent being 16 fcet), and is converted prineipally into boarcis, plauk, and "dimension stuff," 1 to 4 inches thick and 4 inches and upward iu width, the widths varying always by an even number of inches.

In all the better mills the slabs are cut into laths, pickets, ete., while the thickest slabs and the souud portions of very defective logs are cut into shingles. These "shingle cants" are of variable sizes, nsually containing knots and decayed portions; these defects in the shingle are cut out subseqnently by the knot sawyers. Shingles of regular widths are rarely made. In the sawing of the great mass of lumber the main saw merely ents slices of various thicknesses from the logs, and their conversion into eertain widths, as well as the removal of uneven edges, is left to the edger, on whose kuowledge and skill inuch of the success of the nill depends.J Usually the elcar stuff, whenever possible, is lcft in broad and thick planks; the rest is cut into different widths so as to insure the greatest value, in most cases boards of extra width and select boards, for siding, ctc., receiviug prefcrence and determining the conversion. The clear stuff, or "uppcrs," rarely forming over 15 per cent of the cut in our times, are used by manufacturers of sash, doors, and blinds, and by furniture men, and the inost select portions by model makers and other special manufactnrers where the price of the material is of secondary consideration. For inaterial of this kind the consnmer generally pays over $\$ 50$ per 1,000 feet B. M., and in some cases it is retailed at over \$100. Of the remainder, the great mass is used in the construction of frame houses, where eommonly everything of wood, from cellar to roof, is made of this material. Of the inferior grades, enormous qnantities are used for boxes, and much also is used as fencing and barn lumber.

For box shooks, straight-stave coopcrage, pails, tubs, etc., a great deal of small sapling pine is employed. Smaller quautities of better-grade Whitc Pine are used in mill coustructions for chutes, elevators, etc.); also in the mann facture of farm implements, for large surfaces, panelwork, etc., aud in boat-and suip building for decking, in fitting up cabins, for all kinds of spars, where its lightuess, stiffness, aud durability, togetler witl its tine form and dimcnsions, render it a speeial favorite.

Considcrable quantities of hewn and rouud timbers are still brought to market for export, but on the wholc this trade is insignificant when compared to the entire output.

White Pine is universally seasoned in the yard; most of the lumber does not reaeh the consumer until a year after manufacture. The ease of working induces the eonsumers to do a great deal of $20233-$ No. $22-6$ 
resaring. The flooring, and even siding for the smaller markets, and for eheap construetion are eommonly the seleeted parts of sheathing and other inferior grades, as classed at the mill, and it is rare to find, iu recent years, the best grades of White Pine in the sinaller retailers' yards.

In the elassifieation of White Pine a great degree of finesse has been introduced, and the elosest attention is paid here, as well as in edging and trimming, to the probable fnture use of a given picee of material.

From the enormons eonsumption of White Pine alone, and also froin the great variety of uses to whieh it is put, it is elear that any material diminution of supplies must affect extensively and intimately the wood market and wood industries of this eountry. The eommon elaim of substi. tution of some other pine or eonifer, and stlll more the belief in the use of bardwoods in the place of White Pine, have but little in their favor. / A shipping ease of White Pine requires about half the effort to make and only 50 to 65 per eent of the effort to haul or handle as one made of Southern Pine, its most natural substitute. Similarly, a White Pine lath nails with half the effort, shrinks less, and thus is far more satisfactory than one made of hard pine. For a good door or for satisfactory sash and blinds only the Cypress and White Cedar can enter as a substitute, and both are too restrieted iu their oeeurrenee, and the Cypress has too little ehance of futnre regeneration to deserve eonsideration as a general substitute. The transportation of Paeific coast timbers, a small portion of whieh have the properties of White Pine, to the densely popnlated Eastern United States is not likely to oecur on a large scale, for the cost of hauling alone equals the value of good grades of Lastern lumber. 
,

APPENDIX.

TABLES OF MEASUREMENTS. 



\section{APPENDIX.}

\section{TABLES OF MEASUREMENTS.}

The following tables record the detail investigations, measurements, and tabulations whieh have served as a basis for the discussion of the growth of the White Pine. The measurements in the field were made by Mr. Austin Cary, of Bangor, Me., and by Mr. A. K. Mlodziansky, of the Division of Forestry. Mr. Mlodziansky has also executed the laborious calculations, and is responsible for their accuracy.

The methods employed in this investigation have been described in general in Bulletin No. 20, "Measuring the forest crop," of the Division of Forestry. They are in the main similar to those practiced by European foresters, with some minor and one important modification, which latter Mr. Mlodziansky has developed during the course of his work in collating the data. This moditication, which refers to the analyzing of trees for asccrtaining the rate of growth, consists in gronping by age elasses, and instead of analyzing each siugle-measured tree, as is usually done in European practice, averages the data of measurement from a number of trees grouped and then analyzes the growth of the average tree thus constructed of each age class or group. In this way the work of collating is very considerably reduced and the measurements of a very much larger number of trees call be expeditiously utilized for average statement. It is needful, however, in order to be quite satisfactory, that the classification or grouping of trees be made in the woods while measuring, $a$ task which requires considerable judgment. When the classification is so done in the woods, the mechanical work is further simplified by eutering the measurements for each group in sets, the measurements of cross sections taken at the same height being entered on the same sheet for all trees of the group, wheu the averaging of the measurements can at once be performed ou the same sheets.

The forms used in the investigatiou are also appended, and will serve to further elucidate the methods pursued.

Since it was not expedient to fell trees specially for these measurements, it was not always possible to secure all measurements in the most desirable form; for instance, the desirable measurement and eorrelation to age of diameters at breast height, and at short intervals of the height, eould not be obtained, because the work was performed on trees cut in regular lumbering operations; henee, the data had to be mauipulated and interpolations used so as to secure satisfactory approximations for the periodic growth. The number of trees aualyzed (some 700) is so large that any deficieney of method may be considered as neutralized.

\section{TABLES OF CUBIC AND BOARD CONTENTS OF WHITE PINE.}

The tables of eabic and board contents of White Pine are based upon the measurements of pine taken for analysis from the various sites described in the tabulations of aere yields.

The stem of eaeh individual tree was calipered at intervals of 4 or 8 feet, aud the volumes of the portions between two sueeessive diameter measurements were calculated separately, eonsidering them as frustrums of cones. From the volumes of stems of similar height and diameter, breast high, the average volume was noted. The volumes of stems of missing dimensions was calculated by employing the corresponding factors of shape. The factor of shape is determined by dividing the volume of a tree by that of a cylinder of the same height and diameter, breast high; it shows the taper of the stem aud is usually expressed in decimals, thus representing arithmetically the form of the stem. For determining the volume of a trce by means of the factor of shape, it is necessary only to measure the diameter and height of the trec, find the volume of a cylinder of the eorresponding height and diameter, and inultiply that volume by the factor of shape.

The lumber of stems in board feet was determined by employing Seribuer's rule. 
THE WHITE PINE.

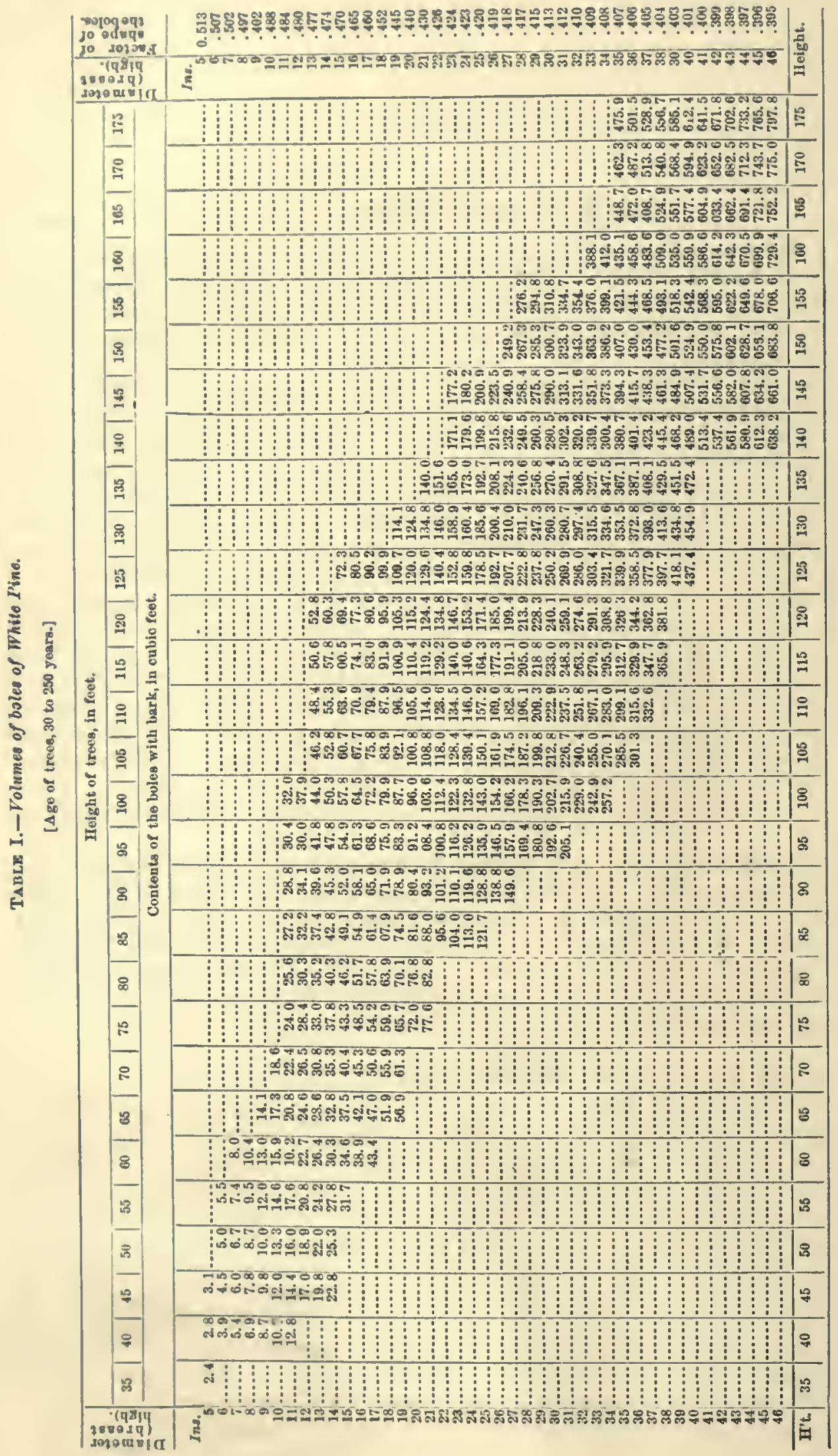


TABLES OF MEASUREMENTS.

TABLE II.-Actual tapering and board contents of stems of White Pine from 5 to $51 \frac{1}{2}$ inches in diameter, breast high.

\begin{tabular}{|c|c|c|c|c|c|c|c|c|c|c|c|c|c|c|c|c|c|c|c|c|}
\hline 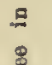 & Diam & er $(1$ & 1 inct & e8) Wi & bar & & & & 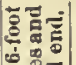 & & 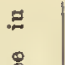 & Dian & zeter & frch & $\begin{array}{l}\text { es) } w 1 \\
\text { groun }\end{array}$ & $\begin{array}{l}\text { barl } \\
\text { of }-\end{array}$ & & & & 0 \\
\hline 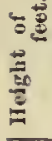 & 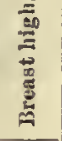 & 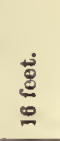 & 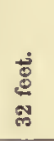 & 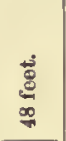 & $\frac{3}{8}$ & $\begin{array}{l}\stackrel{3}{\circ} \\
\stackrel{0}{0} \\
8\end{array}$ & 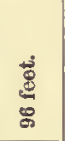 & 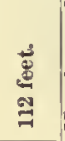 & 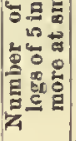 & 吾 & 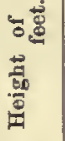 & 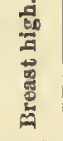 & 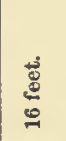 & 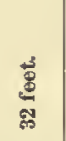 & 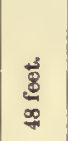 & $\frac{8}{0}$ & 总 & $\frac{8}{8}$ & $\begin{array}{l}\underset{\mathbb{E}}{\mathbb{E}} \\
\stackrel{\Xi}{\exists}\end{array}$ & 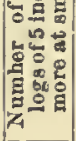 \\
\hline & 5. 2 & 4.0 & & & & & & & & & & & & & 19.2 & & & & & \\
\hline 45 & 5.1 & 4.3 & & & & & & & & & 145 & 25.1 & 22.2 & 20.6 & 18. 8 & 17.4 & $\begin{array}{l}15.2 \\
5\end{array}$ & 12.6 & $\ddot{\theta 0.8}$ & - \\
\hline $\begin{array}{l}40 \\
55\end{array}$ & $\begin{array}{l}6.0 \\
6.2\end{array}$ & $\begin{array}{l}5.0 \\
5.4\end{array}$ & $\begin{array}{r}2.3 \\
3.9\end{array}$ & 1.7 & & & & & 1 & & $\begin{array}{r}90 \\
105\end{array}$ & $\begin{array}{l}26.5 \\
26.0\end{array}$ & $\begin{array}{l}21.3 \\
21.9\end{array}$ & $\begin{array}{l}19.3 \\
20.2\end{array}$ & $\begin{array}{l}16.4 \\
18.5\end{array}$ & $\begin{array}{l}12.3 \\
11.8\end{array}$ & 6.8 & & & \\
\hline 45 & 7.1 & 5.7 & 3. 2 & & & & & & & 8 & 115 & 25.9 & 22.7 & 21.3 & $\begin{array}{l}18.0 \\
19.0\end{array}$ & $\begin{array}{l}18.8 \\
16.7\end{array}$ & $\begin{array}{l}9.1 \\
12.9\end{array}$ & 8.9 & & \\
\hline 6 & 7.2 & 6.2 & 5.0 & 2.4 & & & & & 2 & 12 & 125 & 20.1 & 22.5 & 20.5 & 19.0 & 16.6 & 13.5 & 10.1 & & 6 \\
\hline 5 & 8.1 & 6.7 & 4.2 & 2.2 & & .. & & & 1 & 8 & 135 & 26.2 & 22. & 21.0 & 19.7 & & & 13. 8 & 10.2 & 7 \\
\hline 5 & 8.0 & $\begin{array}{r}6.8 \\
7.7\end{array}$ & $\begin{array}{l}5.3 \\
5.6\end{array}$ & $\begin{array}{l}2.2 \\
2.8\end{array}$ & $\ldots$. & $\ldots$. & $\cdots$ & .... & $\begin{array}{l}2 \\
2\end{array}$ & $\begin{array}{l}12 \\
19\end{array}$ & $\begin{array}{l}145 \\
105\end{array}$ & $\begin{array}{l}26.0 \\
27.1\end{array}$ & $\begin{array}{r}22.2 \\
22.9\end{array}$ & 21. & 19.5 & 17.9 & 16.1 & 13.6 & 10.6 & 7 \\
\hline 5 & $\begin{array}{l}9.1 \\
9.5\end{array}$ & $\begin{array}{l}7.7 \\
8.0\end{array}$ & $\begin{array}{r}4.2 \\
4.2\end{array}$ & & & & .... & & ${ }_{1}^{2}$ & $\begin{array}{l}19 \\
15\end{array}$ & $\begin{array}{l}105 \\
115\end{array}$ & $\begin{array}{l}27.1 \\
27.0\end{array}$ & $\begin{array}{l}22.9 \\
22.6\end{array}$ & $\begin{array}{l}21 . \\
20 .\end{array}$ & $\begin{array}{l}18.8 \\
18.7\end{array}$ & $\begin{array}{l}15.0 \\
16.5\end{array}$ & $\begin{array}{r}11.7 \\
9.3\end{array}$ & 5.6 & & $\begin{array}{l}5 \\
6 \\
6\end{array}$ \\
\hline & 9.2 & 7.7 & 6.5 & & & & & & 2 & 23 & 125 & 27.0 & 22.7 & 21.1 & 4 & $\begin{array}{l}16.5 \\
16.4\end{array}$ & $\begin{array}{r}9.3 \\
14.1\end{array}$ & 10.4 & 5.3 & 7 \\
\hline 5 & 10.1 & 8.7 & 6. 3 & 3.6 & & & & & 2 & 30 & 140 & 26.8 & 23.6 & 22.2 & 0.8 & 19.0 & 15.1 & 12.6 & & 8 \\
\hline 70 & 10.2 & 9.1 & 8.1 & 5.5 & & & & & $\overline{3}$ & 48 & 150 & 27.0 & & 21.0 & 9.0 & 17.5 & 15. 2 & 12.0 & & 6 \\
\hline 4 & & $\begin{array}{l}8.8 \\
9.2\end{array}$ & $\begin{array}{l}4.1 \\
6.8\end{array}$ & 3.4 & ... & & & & 1 & 22 & 70 & & 24.2 & 21.0 & 18.0 & & & & & 3 \\
\hline 6 & 11.2 & 9.6 & $\begin{array}{l}6.8 \\
8.2\end{array}$ & $\begin{array}{l}5.4 \\
5.5\end{array}$ & $\ddot{2} \ddot{7}$ & 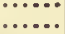 & $\ldots$ & ... & 3 & $\begin{array}{l}37 \\
55\end{array}$ & $\begin{array}{r}90 \\
105\end{array}$ & $\begin{array}{l}28.0 \\
28.0\end{array}$ & $\begin{array}{l}23.6 \\
22.9\end{array}$ & $\begin{array}{l}9 \\
6\end{array}$ & 9.5 & $\begin{array}{l}15.5 \\
14.2\end{array}$ & $\begin{array}{l}7.3 \\
9.3\end{array}$ & 40 & & \\
\hline & 12.3 & 10.0 & 7.0 & 3.0 & & $\ldots$ & $\cdots$ & $\cdots$ & 2 & 44 & 115 & 28.3 & 23.0 & 21.0 & 3 & 16.5 & 12.9 & 7.8 & & 6 \\
\hline 8 & 12.1 & 10.6 & 9.3 & 7.5 & 4.2 & & ........ & & 3 & 80 & 125 & & & & & 18.4 & 15.1 & 8.4 & 4.7 & 7 \\
\hline (4) & 12.0 & $\begin{array}{l}10.0 \\
10.9\end{array}$ & $\begin{array}{l}7.5 \\
4-2\end{array}$ & 3.8 & & & & & 2 & 44 & 140 & 28.3 & & 23.1 & 1.6 & & 17.4 & 14.5 & 11.7 & 7 \\
\hline . & $\begin{array}{l}13.5 \\
13.2\end{array}$ & $\begin{array}{l}10.9 \\
10.9\end{array}$ & $\begin{array}{l}4.2 \\
8.1\end{array}$ & 3.4 & . & & .... & & $\begin{array}{l}1 \\
2 \\
\end{array}$ & $\begin{array}{l}36 \\
58\end{array}$ & 155 & 8.1 & & $\begin{aligned} 24.2 \\
21.2\end{aligned}$ & 2.5 & 20.7 & 19.0 & 16.7 & 12.0 & \\
\hline 7 & 13,0 & 11.1 & 10.0 & & 5. 00 & & & & & $\begin{array}{l}58 \\
87\end{array}$ & 85 & 29.0 & & & & 5 & 10.4 & 8.6 & & \\
\hline & 13.1 & 11.8 & & 8.5 & & 4.7 & & & & 115 & 115 & 29.1 & & & & 17 & 12.5 & 7.9 & & \\
\hline & 13.2 & 12.0 & & & & & & & & & 130 & 29.0 & & & & & & & & \\
\hline & 13.0 & 12.2 & 11.5 & 10.3 & 9.5 & 8.0 & 6.5 & & & 193 & 145 & 29.1 & & & & & 2 & 15.4 & 12.1 & \\
\hline 6 & $\begin{array}{l}14.2 \\
14.2\end{array}$ & $\begin{array}{l}11.9 \\
12.0\end{array}$ & $\begin{array}{l}8.2 \\
9.7\end{array}$ & $\begin{array}{l}3.7 \\
4.5\end{array}$ & ..... & & & & 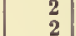 & 71 & $\begin{array}{l}100 \\
110\end{array}$ & $\begin{array}{l}30.0 \\
30.1\end{array}$ & & & 5 & 16 . & & & & \\
\hline 7 & $\begin{array}{l}14.2 \\
14.2\end{array}$ & 12. 1 & 10.8 & 8.5 & 4.9 & & & & 4 & $\begin{array}{r}95 \\
126\end{array}$ & $\begin{array}{l}110 \\
120\end{array}$ & $\begin{array}{l}30.1 \\
30.1\end{array}$ & $\begin{array}{l}24.6 \\
25.1\end{array}$ & 23.1 & $\begin{array}{l}0.4 \\
1.0\end{array}$ & $\begin{array}{l}6 \\
4 \\
4\end{array}$ & $\begin{array}{l}12.5 \\
14.3\end{array}$ & $\begin{array}{l}6.5 \\
9.3\end{array}$ & & \\
\hline 85 & 14.2 & 12.9 & 11.3 & 8.7 & 5.5 & 4.0 & & & 4 & 139 & 130 & 30.1 & & 23.6 & 21. & 19. & & 10.7 & 8.0 & \\
\hline 9 & 14.0 & 12.3 & 11.4 & 9.5 & 7.0 & 3.3 & & & 4 & 157 & 145 & 30.0 & & & & & & & 12.3 & \\
\hline & & 13.0 & & 7.2 & & & & & 3 & 115 & 95 & 31.0 & & 23.8 & 19. & 2 & 11.7 & & & \\
\hline & 15.0 & 13.3 & 11.8 & 9.7 & 6.2 & & & & 4 & 167 & 115 & 31.1 & 27. & 3 & 21.2 & 18. & & & & \\
\hline 0 & 15. 0 & 13.4 & & 10.2 & 7.8 & 5.1 & & & 5 & 200 & 125 & 31.0 & & & & & & & & \\
\hline 115 & 15. 1 & 13.9 & 12. & 11.7 & 10.3 & 8.5 & 6.8 & & 6 & 28 & 135 & 1.2 & & & & & & & 10.2 & \\
\hline 6 & 16. 0 & & 9.5 & & & & & & 3 & 11 & 145 & & & & & & & & 11.5 & \\
\hline 8 & 16.1 & 14. 0 & 12.3 & 10.0 & 6.6 & & & & 4 & & 105 & & & & & & & 0 & & \\
\hline & 16.4 & 14. 1 & & 11.1 & 8.3 & 5.5 & & & & & 115 & & & & & & & & & \\
\hline 10 & 16.4 & 14.3 & & & 9.6 & 6.8 & & & & 2 & 125 & & & & & & & & 5.4 & \\
\hline 12 & 16.5 & 15.5 & 14.0 & 13.0 & 12.0 & 10.0 & 7.5 & & & 31 & 19 & & & & & & & & 10.0 & \\
\hline 12 & $\begin{array}{l}17.0 \\
17.0\end{array}$ & $\begin{array}{l}14.3 \\
14.9\end{array}$ & $\begin{array}{r}8.0 \\
13.0\end{array}$ & 11.6 & 10.0 & 6.8 & 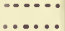 & & 5 & $\begin{array}{r}96 \\
257\end{array}$ & $\begin{array}{l}145 \\
155\end{array}$ & & & & & & & & 13.3 & \\
\hline 7 & 17. 0 & & & & & & & & & $\begin{array}{l}257 \\
193\end{array}$ & $\begin{array}{l}155 \\
110\end{array}$ & $\begin{array}{l}32.2 \\
33.2\end{array}$ & $\begin{array}{l}27.4 \\
29.4\end{array}$ & $\begin{array}{l}26.1 \\
20.2\end{array}$ & $\begin{array}{l}24.3 \\
22.6\end{array}$ & $\begin{array}{l}9 \\
2 \\
\end{array}$ & $\begin{array}{r}21.3 \\
11.0\end{array}$ & 8.5 & 15.4 & \\
\hline & 17. 1 & & & & 6.7 & 2.6 & & & & 20 & 125 & 3.1 & & & 8 & & & 11.6 & & \\
\hline & & & & & 9.1 & 5.6 & 2.0 & & & & 13 & 3.1 & & & & & & & 9.0 & \\
\hline 11 & 16.9 & 15. & & & 10.7 & 8.0 & & & & & & 33.2 & & & & & .0 & 16.8 & 12.7 & \\
\hline & 18.5 & & & & & & & & & & & 3 & & & & & & & & \\
\hline & & & & & & 3.0 & $\ldots$ & & & & & & & & & & & 9.0 & & \\
\hline & 18.0 & & & & & & .... & & & & & & & & & & & & 5. 1 & \\
\hline & 18. & & & & & 7.2 & $\because \ldots$ & & & & & & & & & & & & 11.7 & \\
\hline 12 & 17 & & & 14. & & 10.0 & 7.0 & & & & & & & & & & & & & \\
\hline & 17.8 & & & & 5.0 & & & & & & & & & & & & & & 15.3 & \\
\hline & & & & & & & & & & & & & & & & & & & & \\
\hline & & & & & 7.9 & & & & & & & & & & & & & & & \\
\hline & & & & & & 6.0 & & & & & & & & & & & & & 12.7 & \\
\hline 10 & & & & & & 8.2 & 7.1 & & & & & & & & & & & & 12.2 & \\
\hline 12 & & & & & & 12.0 & 9.5 & 9.1 & & & & & & & & & & & 15,7 & \\
\hline 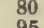 & & & & & & 3.0 & & & & & & & & & & & & 23.0 & 18.0 & \\
\hline & 20. & & & & & & & & & & & & & & & & & & & \\
\hline 10 & & & & & & & 3.0 & & & & & & & & & & & & & \\
\hline 12 & 20.3 & & & 35. & 13. & 11.9 & 9.2 & 5.0 & & & & & & & & & & 14.0 & & \\
\hline & & & & 13. & & 5 & 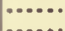 & & & & & & & & & & & 8.9 & 15.0 & \\
\hline & & & & & & & 3.5 & & & & & & & & & & & & & \\
\hline 1 & & & & & 13.6 & & 7. 0 & & & & & & & & & & & & 6.0 & \\
\hline 13 & & & 15 & & & 11.3 & 0.5 & & 6 & & & & & & & & & & & \\
\hline 8 & & 18 & & & 7 & 3.2 & & & 4 & & & & & & & & & & 14.5 & \\
\hline & & 10 & & & & & & & & & & & & & & & & & & \\
\hline 1 & & 19 & & & & & & & & & & & & & & & & & & \\
\hline 1. & & 19 & & & & 10. & 6.5 & & & & & & & & & & & & 10.0 & \\
\hline & 22 & 19 & & & & & & & & & & & & & & & & & & \\
\hline & & 19 & & & & & & & & & & & & & & & & & 8.8 & \\
\hline & & & & & & & 7.7 & & & & & & & & & & & & & \\
\hline 1 & & 20 & & & 16 & 14. & 11.9 & 9.0 & & & & & & & & & & & 5.7 & \\
\hline & & & & & & & & & & & & & & & & & & & & \\
\hline & & & & & & & 7.5 & & & & & & & & & & & & $8:$ & \\
\hline & & & & & & & & & & & & & & & & & & & & \\
\hline 1 & & & & & & & 9.9 & 5.7 & & & & & & & & & & & & \\
\hline 14 & & 21 & 19.3 & & 16.4 & 14.5 & 9.8 & 8.0 & & & & & & & & & & & 0 & \\
\hline 8 & & 21. & & & & 3. & & & 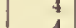 & 62 & 165 & 46.0 & 38. & & & & & & & \\
\hline & 25. & 21 & & 16 & 10.7 & 4.4 & ... & & 4 & 60 & 160 & & & & & & & & & \\
\hline 10 & 25.1 & 21. & 19 & 17 & 13.9 & 10.1 & & & & & 140 & & & & & & & & & \\
\hline 115 & 23.0 & 21.0 & 19.2 & 17.3 & 14.7 & & 7.6 & 8.5 & 7 & $\begin{array}{l}760 \\
012\end{array}$ & 150 & 51.5 & 41.5 & 38. 0 & 34.0 & 31.5 & 23.0 & & 15.5 & \\
\hline 125 & 25.0 & 22.0 & 20.3 & 19.3 & 17.3 & 14.5 & 11.0 & 8.5 & 7 & 012 & & & & & & & & & & \\
\hline
\end{tabular}


TABLF. III.-. Yeasurements of Thile Pine grown under similar conditions, grouped in age classes for areraging.

[The gronps of trees measuretl are sample trees recorded in Table VI.]

\section{$\frac{\text { Gronp, location, aud descriptiou of slte. }}{\text { Gasuachuetts and Ner Hampshire. }}$}

White Pine mixed wlth bardwools on a hill. Soll, bromn or gcliowlsh sandy losm, medjum.sized grsin, brown or scllowls bandy losm, medium. Bized grain, fice corer. Treos, $400-500$ to tho acre.
A rerage.

\section{GROCT B.}

Jassachusetts and New Hampshire.

Whito Pine on a level plain ste. Son, a brown or Jel. low-brown loamy sand, underlaid by sand or and with grarel in merlum or sometlues coarse grain; shallow, porous, light, moderately loose, fresh, and well drained, wlth an abund
to the acre.

A rerage

\section{Pennsylvania.}

Whito Pino Intermixed wlth hardwoods and occasional Hemlock. Soil, clayey loam, with yellow-brown shales in it, deep. frosh, and well drained.
A rerage

GROTP C.

Maine.

White Plne with scattering Hemlock, occasional Sprnco and Fir, on a lovel plain site; scanty nndergrowth of llazel and sonng lewlock. boll, pray sand, sometimes hrown or foamy, with 3 inchos vegotable mold leop, fresh, leaty surface coror; clarey subsoil probahly 4 or 5 feet below surtace. Density of crown cover, 0.7. Trees, 370 to the Acro.

Average

\section{Pennsylvania.}

From a soung Whito Pine grove mixed with maturo Spruco, llomlock, and scattering hardwoods. Sojl, fresb eand, woll drajned.

\section{GROUP D.}

Thisconsin.

An open grose of hardwoods, in whlch White Pine ls scattered ln rarging proportions, on broken inad. wit h frequeut awumps in the hosiows; undergrowth, of roung hardwoods, lir, fow Iiemlock, and Ilorubeam. Solf. Tight-hrown sandy loam, medfum fue grnin, lonse, feep, fresh, and well diraluel, with au abuniaut leufy surfaco corer.

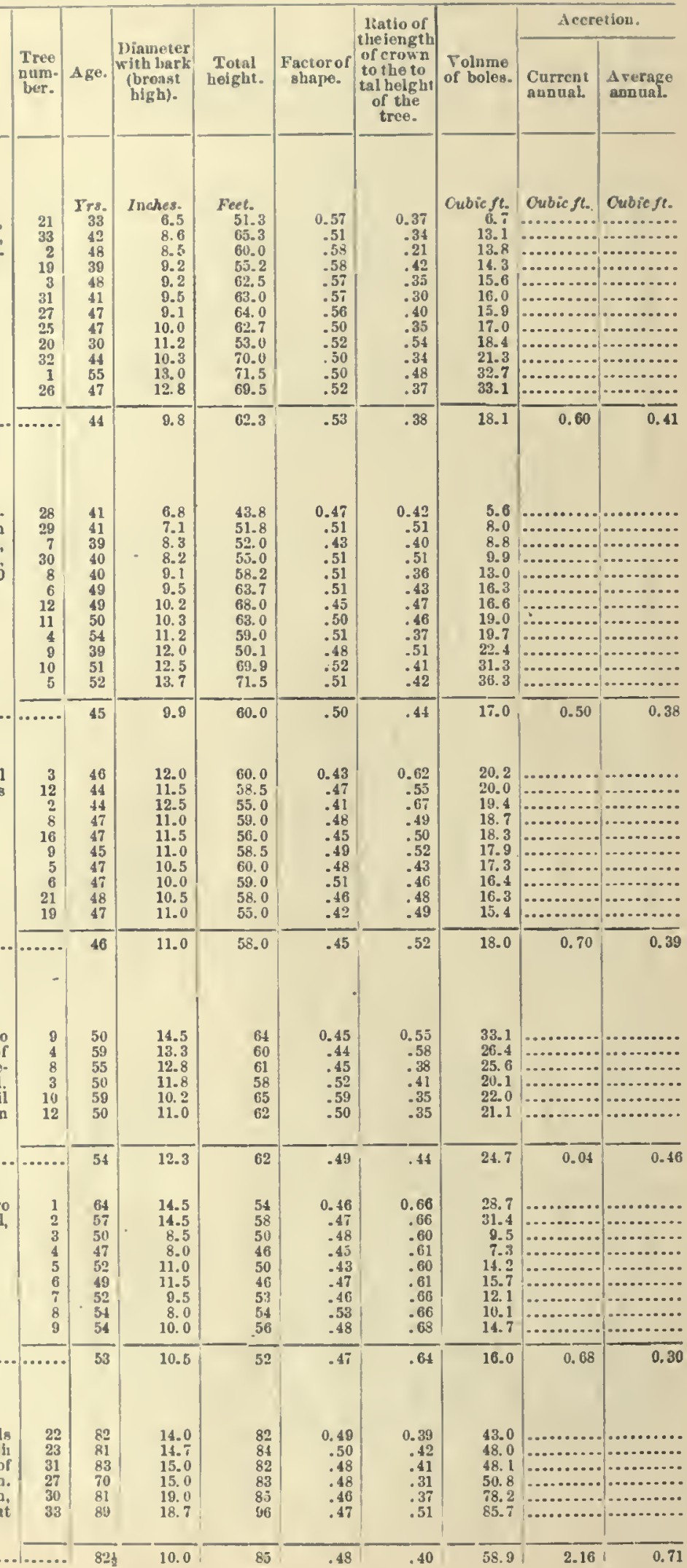


TABLE III.-Measurements of Thite Pine grown under similar conditions, grouped in age classes for averaging-Continued.

\begin{tabular}{|c|c|c|c|c|c|c|c|c|c|}
\hline \multirow[b]{2}{*}{ Gronp, location, and deseription of site. } & \multirow[b]{2}{*}{$\begin{array}{c}\text { Tree } \\
\text { nnm- } \\
\text { ber. }\end{array}$} & \multirow[b]{2}{*}{ Age. } & \multirow[b]{2}{*}{$\begin{array}{c}\text { Diameter } \\
\text { with hark } \\
\text { (hreast } \\
\text { high). }\end{array}$} & \multirow[b]{2}{*}{$\begin{array}{c}\text { Total } \\
\text { helght. }\end{array}$} & \multirow{2}{*}{$\begin{array}{l}\text { Factor of } \\
\text { shape. }\end{array}$} & \multirow{2}{*}{$\begin{array}{l}\text { Ratic of } \\
\text { theiength } \\
\text { of crown } \\
\text { to tho to- } \\
\text { tal height } \\
\text { of the } \\
\text { tree. }\end{array}$} & \multirow{2}{*}{$\begin{array}{l}\text { Volnme } \\
\text { of boles. }\end{array}$} & \multicolumn{2}{|c|}{ Accretion, } \\
\hline & & & & & & & & $\begin{array}{l}\text { Cnrrent } \\
\text { annual. }\end{array}$ & $\begin{array}{l}\text { A rerago } \\
\text { annual. }\end{array}$ \\
\hline $\begin{array}{l}\text { GRGcP E. } \\
\text { Mraine. } \\
\text { White Pine with scattering Red and Thite Oak, and } \\
\text { occasional Norway Pine, on a level; nndergrowth, } \\
\text { moderately dense, of small Hemlock and Beech, with } \\
\text { nnmerous stoall Haple snd Oak. Soll, gray or hrown, } \\
\text { fine, loamy sand, fresh, with } 2 \text { or } 3 \text { inches mold on } \\
\text { top, and leafy surface cover; clsy probahly some feet } \\
\text { bolow surface. Density of crown, } 0.7 \text {. Trees, } 126 \text { to } \\
\text { the acre. }\end{array}$ & $\begin{array}{r}7 \\
12 \\
13 \\
17 \\
18 \\
23 \\
21 \\
16 \\
9 \\
20\end{array}$ & $\begin{array}{r}\text { Frs. } \\
98 \\
92 \\
98 \\
92 \\
92 \\
97 \\
97 \\
90 \\
102 \\
100\end{array}$ & $\begin{array}{r}\text { Inches. } \\
28.0 \\
28.0 \\
25.0 \\
25.5 \\
25.0 \\
22.0 \\
20.6 \\
22.5 \\
20.0 \\
20.3\end{array}$ & $\begin{array}{r}\text { Feet. } \\
100 \\
103 \\
92 \\
91 \\
88 \\
98 \\
102 \\
91 \\
100 \\
103\end{array}$ & $\begin{array}{r}0.41 \\
.36 \\
.46 \\
.42 \\
.44 \\
.46 \\
.35 \\
.46 \\
.47 \\
.41 \\
\end{array}$ & $\begin{array}{r}0.60 \\
.61 \\
.48 \\
.56 \\
.46 \\
.49 \\
.45 \\
.52 \\
.43 \\
.40\end{array}$ & $\begin{array}{r}\text { Cubic ft. } \\
175.3 \\
161.0 \\
140.3 \\
136.3 \\
131.7 \\
119.4 \\
118.1 \\
115.1 \\
104.0 \\
98.8 \\
\end{array}$ & 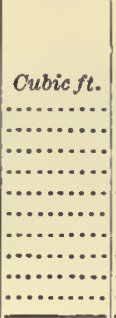 & 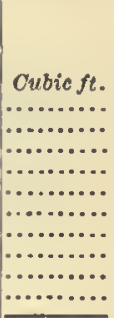 \\
\hline $\begin{array}{c}\text { Average.................................. } \\
\text { GRoCP F. } \\
\text { Maine. }\end{array}$ & (....... & 96 & 23.7 & 97 & .42 & .50 & 130.0 & 2.10 & 1.35 \\
\hline $\begin{array}{l}\text { White Pine with scattering Red and Thite Oak, and } \\
\text { occasional Norway Pint, on \& level; nndergrowth, } \\
\text { moderately dense, of small Hemlock and Beech, with } \\
\text { nnmerons small \$aple and Oak. Soll, gray or brown, } \\
\text { fine, loamy sand, fresh, with } 2 \text { or } 3 \text { inches mold on top, } \\
\text { and leafy surface cover; cias probahiy some teet below } \\
\text { snrface. Density of crown cover, } 0.7 \text {. Trees, } 126 \text { to } \\
\text { the acre. }\end{array}$ & $\begin{array}{r}4 \\
8 \\
22 \\
10 \\
14 \\
28 \\
19 \\
15 \\
11\end{array}$ & $\begin{array}{r}101 \\
98 \\
98 \\
69 \\
93 \\
93 \\
89 \\
99 \\
89\end{array}$ & $\begin{array}{l}20.5 \\
19.5 \\
19.0 \\
16.8 \\
18.5 \\
18.5 \\
18.7 \\
17.2 \\
17.2 \\
\end{array}$ & $\begin{array}{l}95 \\
99 \\
90 \\
99 \\
92 \\
80 \\
79 \\
87 \\
89\end{array}$ & $\begin{array}{r}0.43 \\
.43 \\
.45 \\
.46 \\
.41 \\
.48 \\
.45 \\
.49 \\
.43 \\
\end{array}$ & $\begin{array}{r}0.40 \\
.33 \\
.35 \\
.40 \\
.52 \\
.41 \\
.48 \\
.46 \\
.38 \\
\end{array}$ & $\begin{array}{l}93.3 \\
88.4 \\
84.9 \\
71.3 \\
69.9 \\
68.4 \\
67.2 \\
67.0 \\
60.7 \\
\end{array}$ & (n....... & (2...... \\
\hline 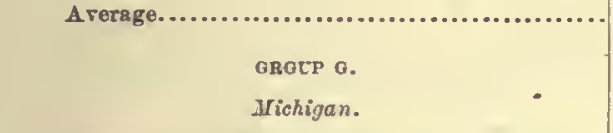 & (...... & 95 & 18.5 & 91 & .45 & .41 & 74.5 & 1.55 & 0.78 \\
\hline $\begin{array}{l}\text { Open grove on a level plain, along the banks of a river, } \\
\text { of mixed White and Norway Pine, with scattering } \\
\text { White birch, and occaslonally Oak, Hackmatack, and } \\
\text { Banksian l'ine; undergrowth seanty, of roung Fir, } \\
\text { Cedar (Thuja occidentalis), and few smail Oaks. Soli, } \\
\text { gray or light brown, sand, medinu fno-gralned, } \\
\text { porons, llght, loose, dry (in places fresh), with a } \\
\text { leafy snrace oover. }\end{array}$ & $\begin{array}{r}1 \\
24 \\
18 \\
9\end{array}$ & $\begin{array}{r}100 \\
96 \\
82 \\
99\end{array}$ & $\begin{array}{l}13.5 \\
14.4 \\
16.5 \\
20.0\end{array}$ & $\begin{array}{r}94 \\
90 \\
94 \\
100\end{array}$ & $\begin{array}{r}0.44 \\
.47 \\
.47 \\
.41\end{array}$ & $\begin{array}{l}0.57 \\
(?) \\
.53 \\
.46\end{array}$ & $\begin{array}{l}\mathbf{4 1 . 0} \\
48.7 \\
65.7 \\
90.9\end{array}$ & 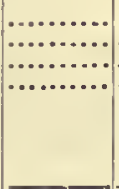 & $\begin{array}{c}\ldots \ldots \ldots \ldots \\
\cdots \ldots \ldots \ldots \\
\cdots \ldots \ldots \ldots\end{array}$ \\
\hline $\begin{array}{l}\text { Arerage .................... } \\
\qquad \begin{array}{r}\text { GRGCP } \\
\text { MIichigan. }\end{array}\end{array}$ & ..... & 94 & 16.0 & $94 \frac{1}{2}$ & .45 & .51 & 61.5 & 2.13 & 0.65 \\
\hline $\begin{array}{l}\text { Open grore on a lerel plain, along the hanks of a river, } \\
\text { of mixer Whlte and Jorway Pine, with scattering } \\
\text { White Bireh, and occasionally Oak, Hackmatack. } \\
\text { and Bankian Hine; undergrowtl seanty, of young } \\
\text { Flr, Codar (Thuja occidentalin), and a few small Oaks. } \\
\text { Soll, gray or light hrown, sandy, medium, fine- } \\
\text { grained, porons, light, loose, dry (in places fresh), } \\
\text { wlth a leafy surface corer. }\end{array}$ & \begin{tabular}{r|}
5 \\
23 \\
22 \\
15 \\
7 \\
6 \\
20 \\
4 \\
19 \\
21
\end{tabular} & $\begin{array}{l}109 \\
112 \\
109 \\
106 \\
110 \\
109 \\
112 \\
112 \\
108 \\
109\end{array}$ & $\begin{array}{l}13.0 \\
14.0 \\
14.8 \\
15.3 \\
16.5 \\
17.0 \\
17.0 \\
18.3 \\
20.5 \\
20.8\end{array}$ & $\begin{array}{c}941 \\
96 \\
93 \\
85 \\
104 \\
101 \\
100 \\
103 \\
105 \\
105\end{array}$ & $\begin{array}{r}.52 \\
.47 \\
.45 \\
.47 \\
.41 \\
.42 \\
.45 \\
.44 \\
.41 \\
.39\end{array}$ & $\begin{array}{r}0.51 \\
.47 \\
.47 \\
.37 \\
.30 \\
.59 \\
(1) \\
.50 \\
.49 \\
.42 \\
\end{array}$ & $\begin{array}{l}45.7 \\
50.2 \\
51.4 \\
53.3 \\
64.3 \\
67.6 \\
72.4 \\
85.3 \\
99.1 \\
99.8\end{array}$ & 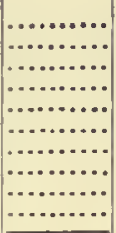 & 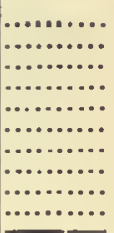 \\
\hline $\begin{array}{l}\text { Average .................. } \\
\qquad \begin{array}{r}\text { Grote I. } \\
\text { Mrichigan. }\end{array}\end{array}$ & .... & $109 \frac{1}{2}$ & 16.7 & $98 \frac{1}{2}$ & .44 & .40 & 68.9 & 1.64 & 0.63 \\
\hline $\begin{array}{l}\text { Norway Pine (67 per cent), mlxed with White Pine } \\
\text { (32 per cent), and occasional Rock Maple, on a level } \\
\text { piain. Soll, jellow or gray sand, fresh, moderately } \\
\text { loose, with a snrface corer of hrakes; subsoll, sandy. } \\
\text { Density of crown corer, } 0.7 \text {. Trees, } 182 \text { to the acre. }\end{array}$ & $\begin{array}{r}1 \\
22 \\
48 \\
47\end{array}$ & $\begin{array}{l}123 \\
101 \\
105 \\
104\end{array}$ & $\begin{array}{l}20.0 \\
20.8 \\
20.5 \\
22.7\end{array}$ & $\begin{array}{r}102 \\
90 \\
99 \\
04\end{array}$ & $\begin{array}{r}0.40 \\
.42 \\
.42 \\
.39\end{array}$ & $\begin{array}{r}0.54 \\
.51 \\
.44 \\
.59\end{array}$ & $\begin{array}{r}89.7 \\
92.7 \\
96.7 \\
103.0\end{array}$ & $|\cdots \cdots \cdots \cdot|$ & (n) \\
\hline $\begin{array}{r}\text { Arerago .................. } \\
\text { GrocP } \mathrm{E} . \\
\text { Wisconsin. }\end{array}$ & 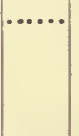 & 108 & 21.0 & 96 & .41 & .51 & 95.5 & 1.81 & 0.89 \\
\hline 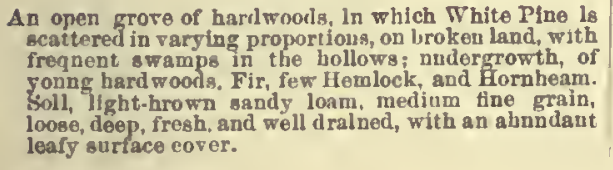 & $\begin{array}{l}14 \\
28 \\
15 \\
16 \\
17\end{array}$ & $\begin{array}{l}121 \\
125 \\
125 \\
125 \\
119\end{array}$ & $\begin{array}{l}20.2 \\
24.5 \\
26.5 \\
26.3 \\
29.0\end{array}$ & $\begin{array}{r}91 \\
89 \\
96 \\
105 \\
97\end{array}$ & $\begin{array}{r}0.45 \\
.45 \\
.39 \\
.47 \\
.42\end{array}$ & $\begin{array}{r}0.50 \\
.58 \\
. \quad .46 \\
.53 \\
.57\end{array}$ & $\begin{array}{r}90.9 \\
131.8 \\
141.5 \\
176.8 \\
189.5\end{array}$ & 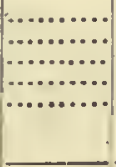 & .............. \\
\hline Average .............. & & 123 & 25.3 & 95 & .44 & .53 & 145.5 & 2.92 & 1. 19 \\
\hline
\end{tabular}


TABLE III.-Mcasuremento of Thite Pine grown under similar conditions, grouped in age olasses for areraging-Continned.

\begin{tabular}{|c|c|c|c|c|c|c|c|c|c|}
\hline \multirow[b]{2}{*}{ Gronp, focation, and doseription of site. } & \multirow[b]{2}{*}{$\begin{array}{c}\text { Tree } \\
\text { num- } \\
\text { ber. }\end{array}$} & \multirow[b]{2}{*}{ Ago. } & \multirow{2}{*}{$\begin{array}{l}\text { Diameter } \\
\text { with hark } \\
\text { (hreast } \\
\text { high). }\end{array}$} & \multirow[b]{2}{*}{$\begin{array}{l}\text { Total } \\
\text { belght. }\end{array}$} & \multirow[b]{2}{*}{$\begin{array}{l}\text { Factor of } \\
\text { shape. }\end{array}$} & \multirow{2}{*}{$\begin{array}{l}\text { Ratlo of } \\
\text { the length } \\
\text { of crown } \\
\text { to the to- } \\
\text { tal helght } \\
\text { of tho } \\
\text { troe. }\end{array}$} & \multirow[b]{2}{*}{$\begin{array}{l}\text { Folnme } \\
\text { of boles. }\end{array}$} & \multicolumn{2}{|c|}{ Accretion. } \\
\hline & & & & & & & & $\begin{array}{l}\text { Current } \\
\text { annaal. }\end{array}$ & $\begin{array}{l}\text { A rorago } \\
\text { annnal. }\end{array}$ \\
\hline 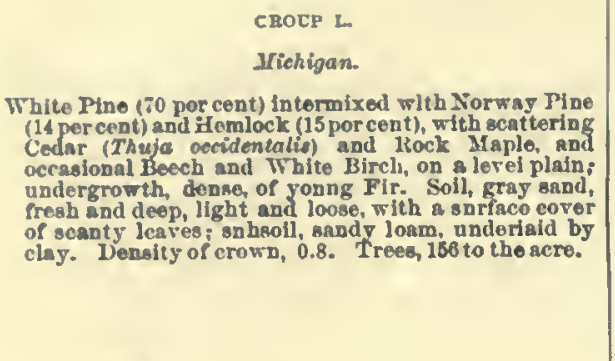 & $\begin{array}{r}34 \\
9 \\
33 \\
37 \\
36 \\
35 \\
2 \\
22 \\
4 \\
3 \\
1 \\
16 \\
\end{array}$ & $\begin{array}{r}\text { Trs. } \\
110 \\
136 \\
135 \\
134 \\
136 \\
135 \\
138 \\
133 \\
130 \\
135 \\
138 \\
139 \\
\end{array}$ & $\begin{array}{r}\text { Inches. } \\
19.5 \\
10.7 \\
20.0 \\
22.0 \\
22.5 \\
21.7 \\
22.8 \\
23.2 \\
24.0 \\
21.0 \\
23.5 \\
25.0\end{array}$ & $\begin{array}{r}\text { Feet. } \\
124 \\
114 \\
115 \\
113 \\
123 \\
122 \\
119 \\
116 \\
108 \\
108 \\
113 \\
122 \\
\end{array}$ & $\begin{array}{r}0.42 \\
.49 \\
.48 \\
.31 \\
.39 \\
.44 \\
.40 \\
.42 \\
.43 \\
.42 \\
.43 \\
.44\end{array}$ & $\begin{array}{l}0.34 \\
.31 \\
.32 \\
.27 \\
.30 \\
.32 \\
.30 \\
.38 \\
.10 \\
.35 \\
.28 \\
.50 \\
\end{array}$ & $\begin{array}{r}\text { Cubic ft. } \\
100.8 \\
115.1 \\
121.5 \\
123.5 \\
130.1 \\
136.4 \\
138.5 \\
111.1 \\
143.5 \\
144.7 \\
146.5 \\
187.3 \\
\end{array}$ & 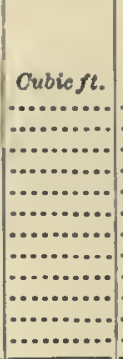 & 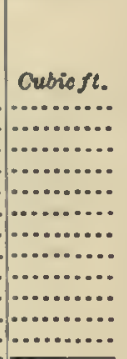 \\
\hline $\begin{array}{l}\text { Arerago ................................................ } \\
\text { Mrichigan. }\end{array}$ & $\ldots . .$. & 130 & 22.3 & 116 & .42 & .34 & 136.0 & 1.60 & 1.00 \\
\hline $\begin{array}{l}\text { A two-roof grove, npper roof formed of White Pine, } \\
\text { nnder roof of Beeob, Maple, Fir, and occasionally } \\
\text { White Blrch and Hemiock; undergrowth, moderately } \\
\text { dense, of Joung hardwoods and Fir. Soll, brown } \\
\text { loany aand, fresh, moderately loose, with a surface } \\
\text { cover of brakes and grass; subsoll, sand with stones. }\end{array}$ & $\begin{array}{r}32 \\
37 \\
12 \\
40 \\
25 \\
27 \\
9 \\
28 \\
31 \\
11\end{array}$ & $\begin{array}{l}133 \\
141 \\
132 \\
145 \\
128 \\
153 \\
131 \\
148 \\
153 \\
136 \\
\end{array}$ & $\begin{array}{l}15.2 \\
15.5 \\
16.3 \\
18.6 \\
20.5 \\
19.0 \\
22.5 \\
23.0 \\
23.0 \\
24.6\end{array}$ & $\begin{array}{r}92 \\
92 \\
88 \\
100 \\
98 \\
104 \\
112 \\
116 \\
100 \\
115\end{array}$ & $\begin{array}{l}0.43 \\
.46 \\
.47 \\
.38 \\
.42 \\
.41 \\
.41 \\
.41 \\
.47 \\
.41\end{array}$ & $\begin{array}{l}0.43 \\
.42 \\
.66 \\
.44 \\
.47 \\
.38 \\
.46 \\
.46 \\
.30 \\
.40\end{array}$ & $\begin{array}{r}48.6 \\
55.3 \\
61.7 \\
71.1 \\
94.6 \\
8 \% .0 \\
129.4 \\
137.9 \\
137.6 \\
154.1 \\
\end{array}$ & 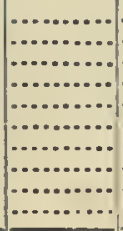 & 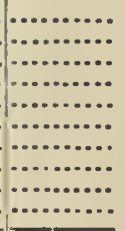 \\
\hline 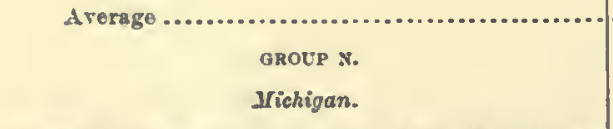 & $\ldots \ldots$ & 140 & 19.8 & 102 & .43 & .44 & 95.3 & 1.49 & 0.70 \\
\hline $\begin{array}{l}\text { Norway Pins ( } 67 \text { per cent) mixed with White Pine } \\
\text { ( } 32 \text { per cent), and occasional Rock Maple, on a level } \\
\text { plain. Soll, y eliow or gray gand, freah, moolerately } \\
\text { loose, with a snrface cover of brakes, snbsoil, andy. } \\
\text { Density of crown cover, } 0.7 \text {. Trees, } 182 \text { to the acre. }\end{array}$ & $\begin{array}{r}5 \\
6 \\
35\end{array}$ & $\begin{array}{l}149 \\
135 \\
135\end{array}$ & $\begin{array}{l}20.8 \\
21.1 \\
22.0\end{array}$ & $\begin{array}{l}105 \\
114 \\
121\end{array}$ & $\begin{array}{r}0.39 \\
.39 \\
.40\end{array}$ & $\begin{array}{r}0.50 \\
.57 \\
.43\end{array}$ & $\begin{array}{r}88.9 \\
107.9 \\
139.6\end{array}$ & 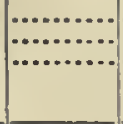 & … \\
\hline $\begin{array}{l}\text { Average..................... } \\
\text { GROCP } 0 . \\
\text { Jlichigan. }\end{array}$ & $\cdots \cdots$ & 140 & 21.0 & 113 & .39 & .50 & 112.1 & 2.08 & 0.80 \\
\hline $\begin{array}{l}\text { Whlto Pine (70 per rent) intermixed with Norway Pine. } \\
\text { (14 per cent) and Hemlock (15 per cent), with acatter. } \\
\text { ing Cedar (Thuja occidentalis) and Rock Maple, and } \\
\text { occasional Beech and White Birch, on a level plain; } \\
\text { nndergrowth dense, of Joung Fir. Soll, gray gand, } \\
\text { freah and deep, light and inose, with a sn rface coror } \\
\text { of scanty leaves s subsoil, sandy loam, nnderlaid by } \\
\text { clay. Density of crown cover, } 0.8 \text {. Trees, } 156 \text { to the } \\
\text { acre. }\end{array}$ & $\begin{array}{r}27 \\
26 \\
11 \\
20 \\
30 \\
24 \\
5\end{array}$ & $\begin{array}{l}142 \\
142 \\
142 \\
142 \\
143 \\
149 \\
148\end{array}$ & $\begin{array}{l}23.0 \\
24.0 \\
23.5 \\
22.0 \\
24.2 \\
25.0 \\
26.3\end{array}$ & $\begin{array}{l}117 \\
110 \\
114 \\
119 \\
116 \\
113 \\
115\end{array}$ & $\begin{array}{r}0.41 \\
.41 \\
.43 \\
.49 \\
.45 \\
.46 \\
.46\end{array}$ & $\begin{array}{r}0.30 \\
.39 \\
.38 \\
.36 \\
.38 \\
.34 \\
.39\end{array}$ & $\begin{array}{l}138.9 \\
140.6 \\
148.0 \\
157.3 \\
164.3 \\
168.8 \\
205.4\end{array}$ & $|\cdots \cdots \cdot|$ & 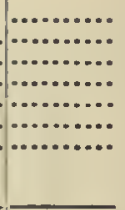 \\
\hline 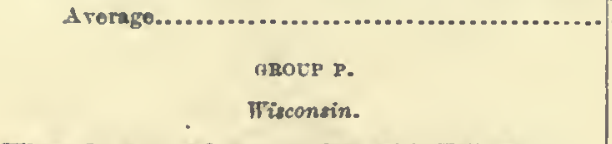 & $\cdots \cdots$ & 142 & 24.0 & 115 & .44 & .34 & 160.5 & 2.20 & 1.10 \\
\hline $\begin{array}{l}\text { White Pine mixed more or less with Fellow Birch, } \\
\text { Rock Maple, Norwas Pine, and occasional Bass, Pop- } \\
\text { ler, and Elm, on uneren la od, fnll of drift ridges and } \\
\text { hoilows, freqnently fnll of water. Soll, a mixture } \\
\text { of loam, sand, and gtones, with } 2 \text { to } 3 \text { inches black } \\
\text { mold on top, and fairly corered with leaves. }\end{array}$ & $\begin{array}{r}3 \\
4 \\
5 \\
6 \\
7 \\
8 \\
15 \\
9\end{array}$ & $\begin{array}{l}160 \\
170 \\
178 \\
170 \\
175 \\
168 \\
185 \\
173\end{array}$ & $\begin{array}{l}23.5 \\
24.0 \\
24.2 \\
25.7 \\
27.3 \\
30.5 \\
23.2 \\
26.0\end{array}$ & $\begin{array}{l}104 \\
119 \\
114 \\
111 \\
122 \\
114 \\
110 \\
112\end{array}$ & $\begin{array}{l}0.40 \\
.46 \\
.48 \\
.45 \\
.43 \\
.44 \\
.42 \\
.46\end{array}$ & $\begin{array}{l}0.40 \\
.41 \\
.88 \\
.41 \\
.48 \\
.42 \\
.34 \\
.28\end{array}$ & $\begin{array}{l}127 \\
172 \\
176 \\
181 \\
217 \\
256 \\
138 \\
190\end{array}$ & 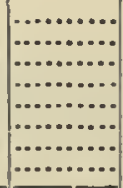 & \begin{tabular}{l}
$\ldots \ldots \ldots$ \\
\hdashline$\ldots \ldots$ \\
\hdashline$\ldots \ldots$ \\
\hdashline$\ldots \ldots$
\end{tabular} \\
\hline 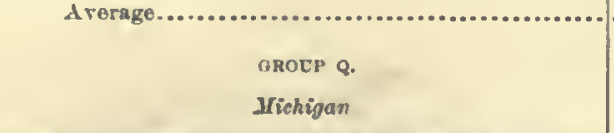 & ....... & 172 & 25.5 & 113 & .44 & .39 & 182 & 1.44 & 1.00 \\
\hline $\begin{array}{l}\text { Norway l'ine fntermixed with Whito Pine in rarying } \\
\text { proportions, on rolling land, with open liaces of Red } \\
\text { Onk, Mapie, and Beech, no nndergrowth. Soll, } \\
\text { light-brown sand (silghtly loamy) rery deep, me. } \\
\text { dium fine, light, loose, dry, and weil dralned, with a } \\
\text { moderntely leary surfsce corer. }\end{array}$ & $\begin{array}{r}34 \\
18 \\
5\end{array}$ & $\begin{array}{l}182 \\
188 \\
180\end{array}$ & $\begin{array}{l}25.2 \\
26.7 \\
31.0\end{array}$ & $\begin{array}{l}118 \\
118 \\
119\end{array}$ & $\begin{array}{r}0.43 \\
.45 \\
.45\end{array}$ & $\begin{array}{r}0.53 \\
.59 \\
.40\end{array}$ & $\begin{array}{l}173.0 \\
202.1 \\
286.6\end{array}$ & $\mid \begin{array}{l}\cdots \ldots \ldots \\
\cdots \ldots \ldots \ldots\end{array}$ & …................... \\
\hline Averago............. & & 185 & 27.6 & 118 & .44 & .81 & 220.5 & 2.22 & 1.19 \\
\hline
\end{tabular}


TABLE III.-Measurements of White Pine grovn under similar conditions, grouped in age classes for averaging-Continued.

\begin{tabular}{|c|c|c|c|c|c|c|c|c|c|}
\hline \multirow[b]{2}{*}{ Gronp, location, and description of site. } & \multirow[b]{2}{*}{$\begin{array}{l}\text { Tree } \\
\text { num- } \\
\text { ber. }\end{array}$} & \multirow[b]{2}{*}{ Age. } & \multirow[b]{2}{*}{$\begin{array}{c}\text { Diameter } \\
\text { with bark } \\
\text { (breast } \\
\text { high). }\end{array}$} & \multirow[b]{2}{*}{$\begin{array}{c}\text { Total } \\
\text { helght. }\end{array}$} & \multirow{2}{*}{$\begin{array}{l}\text { Factor of } \\
\text { shape. }\end{array}$} & \multirow{2}{*}{$\begin{array}{l}\text { Ratio of } \\
\text { the leugth } \\
\text { of erown } \\
\text { to the to- } \\
\text { tal height } \\
\text { of the } \\
\text { tree. }\end{array}$} & \multirow{2}{*}{$\begin{array}{c}\text { Volume } \\
\text { of boles. }\end{array}$} & \multicolumn{2}{|c|}{ Accretion. } \\
\hline & & & & & & & & $\begin{array}{l}\text { Corrent } \\
\text { annual. }\end{array}$ & $\begin{array}{l}\text { Average } \\
\text { aunual. }\end{array}$ \\
\hline $\begin{array}{l}\text { GRovP R. } \\
\text { Ticonsin. } \\
\text { White Pine intermixcel with Iellow Birch, Rock Maple, } \\
\text { Bass, and Norway PIne, on ridge land, with hollows } \\
\text { sometimes fnll of water, more often open grassy } \\
\text { swamps, with slder snd Hackmatack, fringed hy } \\
\text { pine. Soil, red clayey loam, mired with sand and } \\
\text { stones of all slzes, woist; suhsoil, sometimes of clay, } \\
\text { sometimes of sand. }\end{array}$ & $\begin{array}{l}1 \\
2 \\
3 \\
4 \\
5 \\
6 \\
7 \\
8 \\
9\end{array}$ & $\begin{array}{l}\text { Frs. } \\
204 \\
210 \\
207 \\
200 \\
206 \\
205 \\
210 \\
214 \\
210\end{array}$ & \begin{tabular}{r|} 
Inches. \\
27.3 \\
25.2 \\
31.0 \\
29.5 \\
29.2 \\
30.0 \\
34.0 \\
36.0 \\
39.0
\end{tabular} & $\begin{array}{r}\text { Feet. } \\
123 \\
137 \\
127 \\
116 \\
130 \\
133 \\
118 \\
113 \\
130\end{array}$ & $\begin{array}{r}0.44 \\
.48 \\
.37 \\
.43 \\
.46 \\
.43 \\
.39 \\
.39 \\
.38\end{array}$ & $\begin{array}{l}0.50 \\
.40 \\
.35 \\
.51 \\
.29 \\
.52 \\
.37 \\
.38 \\
.49 \\
\end{array}$ & \begin{tabular}{|r|} 
Oubic ft. \\
219 \\
227 \\
246 \\
239 \\
282 \\
284 \\
292 \\
312 \\
415
\end{tabular} & 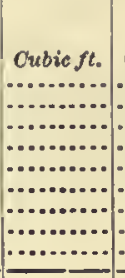 & 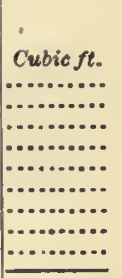 \\
\hline $\begin{array}{c}\text { Average........................................... } \\
\text { ORotP 8. } \\
\text { Tisconsin. }\end{array}$ & $\ldots \ldots$ & 207 & 31.2 & 125 & .42 & 43 & 279 & 1.67 & 1.34 \\
\hline $\begin{array}{l}\text { White Pine intermired with Yellow Birch, Rock Maple, } \\
\text { Bass, and Norway Pine, on ridge land, with hollows } \\
\text { sometimes full of water, more often open grassy } \\
\text { swamps, with Alder and Hackmatack, friuged by pine- } \\
\text { Soll, red clasey loam, mlred with sand and stones of } \\
\text { all sizes, moiet; subsoil, sometimes of elay, sometimes } \\
\text { of sand. }\end{array}$ & $\begin{array}{l}10 \\
11 \\
12 \\
13 \\
14 \\
15 \\
16 \\
17\end{array}$ & $\begin{array}{l}211 \\
228 \\
220 \\
207 \\
204 \\
205 \\
212 \\
204\end{array}$ & $\begin{array}{l}20.2 \\
23.6 \\
22.8 \\
27.2 \\
27.0 \\
27.0 \\
27.8 \\
27.3\end{array}$ & $\begin{array}{l}116 \\
113 \\
121 \\
107 \\
121 \\
122 \\
104 \\
112\end{array}$ & $\begin{array}{r}0.51 \\
.43 \\
.45 \\
.46 \\
.42 \\
.43 \\
.41 \\
.41 \\
\end{array}$ & $\begin{array}{r}0.64 \\
.42 \\
.45 \\
.28 \\
.43 \\
.25 \\
.51 \\
.41 \\
\end{array}$ & $\begin{array}{l}132 \\
148 \\
153 \\
200 \\
204 \\
210 \\
180 \\
186\end{array}$ & 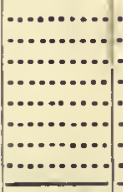 & 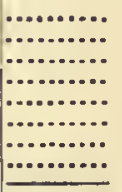 \\
\hline $\begin{array}{c}\text { Aterage } \\
\text { GRotP } \mathrm{T} . \\
\text { Wisconsin. }\end{array}$ & $\ldots \ldots$ & 211 & 25.4 & 114 & .44 & .42 & 176.5 & 0.88 & 0.83 \\
\hline $\begin{array}{l}\text { White Pine mlxed with hardwoods, on drift and some- } \\
\text { what nneven land; t undergrowth, of young hardwoods } \\
\text { and Ftr. Soll, clayey, underlaid hy a hardpan of clay } \\
\text { and stones, fresh with 4-inch mold on top. }\end{array}$ & $\begin{array}{l}1 \\
2 \\
3 \\
4 \\
5 \\
6 \\
7 \\
8 \\
0\end{array}$ & $\begin{array}{l}204 \\
221 \\
213 \\
214 \\
216 \\
202 \\
204 \\
212 \\
213\end{array}$ & $\begin{array}{l}24.7 \\
27.0 \\
27.0 \\
26.0 \\
26.8 \\
24.0 \\
29.0 \\
290 \\
30.0\end{array}$ & $\begin{array}{l}102 \\
113 \\
121 \\
126 \\
126 \\
134 \\
132 \\
133 \\
133\end{array}$ & $\begin{array}{l}0.40 \\
.41 \\
.39 \\
.43 \\
.42 \\
.44 \\
.39 \\
.41 \\
.44\end{array}$ & $\begin{array}{r}0.45 \\
.33 \\
.37 \\
.41 \\
.40 \\
.42 \\
.37 \\
.39 \\
.42 \\
\end{array}$ & $\begin{array}{l}166 \\
183 \\
191 \\
201 \\
210 \\
187 \\
238 \\
250 \\
291\end{array}$ & 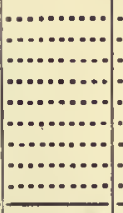 & 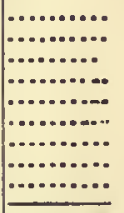 \\
\hline 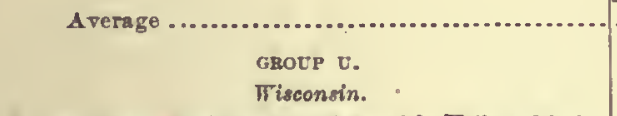 & & 211 & 27.0 & 124 & .42 & .44 & $\overline{213}$ & 1.49 & 1.00 \\
\hline $\begin{array}{l}\text { White Pine mlxed more or less with Yellow Birch, } \\
\text { Rock Maple, Norway Pine, and oceasional Bass, Pop- } \\
\text { lar, and Elm, on nneven land, fnll of drift ridges } \\
\text { and hollows, frequently full of water. Soll, a mlk- } \\
\text { ture of loam, and, and stones, wlth } 2 \text { to } 3 \text { lnches hlack } \\
\text { mold on top, and fairly covered with leares. }\end{array}$ & $\begin{array}{l}10 \\
11 \\
12 \\
13 \\
16 \\
17\end{array}$ & $\begin{array}{l}210 \\
222 \\
228 \\
220 \\
220 \\
218\end{array}$ & $\begin{array}{l}31.8 \\
35.0 \\
24.8 \\
24.0 \\
24.5 \\
29.0\end{array}$ & $\begin{array}{l}121 \\
123 \\
116 \\
100 \\
107 \\
118 \\
\end{array}$ & $\begin{array}{r}0.43 \\
.42 \\
.41 \\
.49 \\
.45 \\
.44 \\
\end{array}$ & $\begin{array}{r}0.40 \\
.46 \\
.40 \\
.27 \\
.35 \\
.49 \\
\end{array}$ & $\begin{array}{l}287 \\
344 \\
160 \\
156 \\
157 \\
249\end{array}$ & (n............. & | \\
\hline 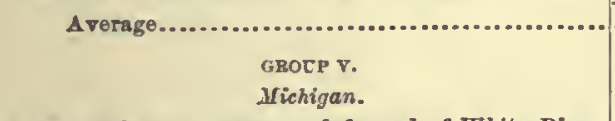 & ........ & 221 & $\overline{28.2}$ & 114 & .44 & .30 & 224 & $\overline{1.57}$ & $\overline{1.01}$ \\
\hline $\begin{array}{l}\text { A two-roof grore, npper roof formed of White Pine, } \\
\text { under roof of Beech, Maple, Fir, und occasionally } \\
\text { White Blrch and Hemlock, nndergrowth, moderately } \\
\text { dense, of young hardwoods and Fir. Soll, hrown } \\
\text { loamy sand, fresh, moderately loose, with a surface } \\
\text { cover of hrakes and grass; suhsoll, sand wlth stones. }\end{array}$ & $\begin{array}{r}41 \\
8 \\
30 \\
1 \\
28 \\
31 \\
10 \\
33 \\
39 \\
29 \\
3\end{array}$ & $\begin{array}{l}245 \\
242 \\
226 \\
226 \\
220 \\
250 \\
219 \\
226 \\
237 \\
233 \\
245\end{array}$ & $\begin{array}{l}20.0 \\
24.5 \\
27.5 \\
27.5 \\
28.3 \\
30.2 \\
33.0 \\
33.0 \\
33.0 \\
37.0 \\
40.0\end{array}$ & $\begin{array}{l}120 \\
137 \\
138 \\
129 \\
143 \\
141 \\
121 \\
140 \\
144 \\
147 \\
125 \\
\end{array}$ & $\begin{array}{r}0.43 \\
.42 \\
.38 \\
.41 \\
.42 \\
.42 \\
.44 \\
.38 \\
.45 \\
.41 \\
.43 \\
\end{array}$ & $\begin{array}{c}0.46 \\
(i)^{.41} \\
.38 \\
.60 \\
.31 \\
.43 \\
.49 \\
.77 \\
.55 \\
.40\end{array}$ & $\begin{array}{l}112.56 \\
191.07 \\
215.28 \\
222.29 \\
264.49 \\
281.03 \\
317.85 \\
321.86 \\
389.57 \\
455.05 \\
479.51\end{array}$ & 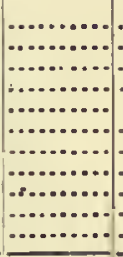 & 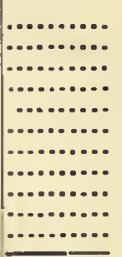 \\
\hline 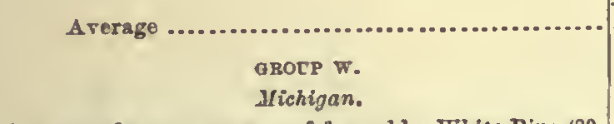 & ........ & 233 & 30.3 & 135 & .41 & .48 & 296.6 & 1.05 & 1.27 \\
\hline $\begin{array}{l}\text { A two-roof grore, npper roof formcd by Whito Pine ( } 80 \\
\text { per cent) and Norway Piue ( } 20 \text { per cent), under roof of } \\
\text { fne, tall Hamlock; nudergrowth, of young Hemlock, } \\
\text { Beech, and Dwart Mraple. Soll, brown loamy and, } \\
\text { deep, f ne (for sand), porons, loose, and well drained } \\
\text { (water stauds in low grotud), with a moderately leafy } \\
\text { surface cover; suhsol, same as soll. }\end{array}$ & \begin{tabular}{r|}
3 \\
2 \\
11 \\
1 \\
6 \\
20 \\
17 \\
10 \\
10 \\
15 \\
18 \\
9 \\
4 \\
8 \\
19 \\
12 \\
\end{tabular} & $\begin{array}{l}234 \\
236 \\
235 \\
237 \\
237 \\
251 \\
232 \\
233 \\
237 \\
235 \\
245 \\
236 \\
236 \\
238 \\
244 \\
233\end{array}$ & $\begin{array}{l}23.2 \\
23.8 \\
24.5 \\
23.5 \\
24.5 \\
27.0 \\
24.5 \\
25.5 \\
25.5 \\
26.0 \\
30.0 \\
20.2 \\
27.0 \\
29.0 \\
34.0 \\
32.0\end{array}$ & $\begin{array}{l}137 \\
142 \\
142 \\
140 \\
145 \\
120 \\
145 \\
143 \\
145 \\
143 \\
122 \\
145 \\
150 \\
140 \\
130 \\
144\end{array}$ & $\begin{array}{l}0.43 \\
.44 \\
.43 \\
.46 \\
.43 \\
.43 \\
.48 \\
.42 \\
.44 \\
.43 \\
.38 \\
.44 \\
.45 \\
.43 \\
.42 \\
.43 \\
\end{array}$ & $\begin{array}{l}0.39 \\
.43 \\
.43 \\
.36 \\
.40 \\
.36 \\
.47 \\
.42 \\
.44 \\
.23 \\
.35 \\
.42 \\
.41 \\
.40 \\
.62 \\
.30 \\
\end{array}$ & $\begin{array}{l}169.0 \\
197.3 \\
199.1 \\
202.6 \\
205.4 \\
206.8 \\
207.0 \\
212.6 \\
227.3 \\
231.1 \\
233.8 \\
240.2 \\
271.5 \\
281.1 \\
348.1 \\
349.6\end{array}$ & 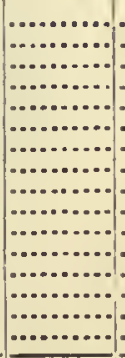 & 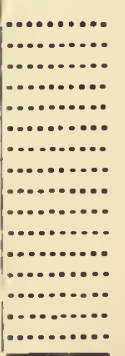 \\
\hline Fer & & 237 & 26.5 & 140 & .43 & .41 & 236.4 & 1.64 & 0.99 \\
\hline
\end{tabular}


TABLE. III.-Measurements of Thite Pine groern under similar conditions, grouped in age classes for averaging-Continued.

\begin{tabular}{|c|c|c|c|c|c|c|c|c|c|}
\hline \multirow[b]{2}{*}{ Group, location, and deseription of site. } & \multirow[b]{2}{*}{$\begin{array}{l}\text { Tree } \\
\text { num- } \\
\text { her. }\end{array}$} & \multirow{2}{*}{ Age. } & \multirow{2}{*}{$\begin{array}{l}\text { Uiameter } \\
\text { with bark } \\
\text { (brenst } \\
\text { lilgh). }\end{array}$} & \multirow[b]{2}{*}{$\begin{array}{c}\text { Total } \\
\text { hejglt. }\end{array}$} & \multirow{2}{*}{$\begin{array}{l}\text { Faetor of } \\
\text { shape. }\end{array}$} & \multirow{2}{*}{$\begin{array}{l}\text { Ratlo of } \\
\text { the length } \\
\text { of erown } \\
\text { to the to- } \\
\text { tal lioight } \\
\text { of tho } \\
\text { tree. }\end{array}$} & \multirow{2}{*}{$\begin{array}{l}\text { Tolume } \\
\text { of boles. }\end{array}$} & \multicolumn{2}{|c|}{ Aceretion. } \\
\hline & & & & & & & & $\begin{array}{l}\text { Cnrrent } \\
\text { annual. }\end{array}$ & $\begin{array}{l}\text { Arerage } \\
\text { annual. }\end{array}$ \\
\hline 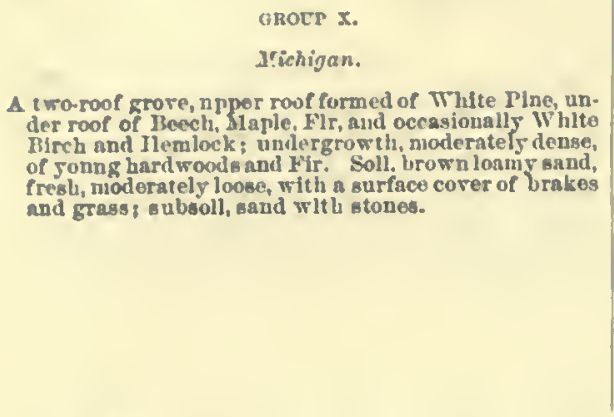 & $\begin{array}{r}14 \\
7 \\
38 \\
23 \\
13 \\
30 \\
4 \\
42 \\
10 \\
2 \\
35 \\
6 \\
15 \\
5 \\
17\end{array}$ & $\begin{array}{l}\text { Tr8. } \\
258 \\
252 \\
252 \\
205 \\
253 \\
250 \\
260 \\
200 \\
251 \\
256 \\
265 \\
260 \\
256 \\
258 \\
260\end{array}$ & $\begin{array}{r}\text { Inches. } \\
26.0 \\
29.2 \\
25.5 \\
27.0 \\
30.0 \\
32.0 \\
31.5 \\
29.5 \\
33.0 \\
31.0 \\
31.5 \\
33.0 \\
32.0 \\
34.0 \\
36.0\end{array}$ & $\begin{array}{r}\text { Feet. } \\
119 \\
139 \\
157 \\
126 \\
135 \\
182 \\
132 \\
155 \\
114 \\
145 \\
144 \\
139 \\
154 \\
138 \\
149\end{array}$ & $\begin{array}{r}0.37 \\
.41 \\
.35 \\
.11 \\
.39 \\
.34 \\
.38 \\
.42 \\
.33 \\
.41 \\
.40 \\
.38 \\
.41 \\
.42 \\
.37\end{array}$ & $\begin{array}{l}0.40 \\
.46 \\
.58 \\
.44 \\
.45 \\
.39 \\
.48 \\
.48 \\
.41 \\
.49 \\
.33 \\
.51 \\
.33 \\
.59 \\
.45\end{array}$ & $\begin{array}{r}\text { Cubio jl. } \\
102.54 \\
193.21 \\
205.21 \\
207.67 \\
258.13 \\
207.87 \\
275.89 \\
311.99 \\
313.07 \\
314.06 \\
314.38 \\
310.81 \\
360.75 \\
370.50 \\
404.18\end{array}$ & 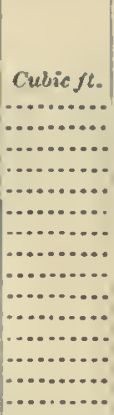 & 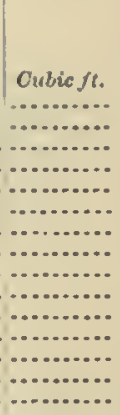 \\
\hline $\begin{array}{r}\text { Average .................... } \\
\text { Gichigan. }\end{array}$ & .... & 258 & 30.5 & 141 & .39 & .40 & 235.00 & 1.50 & 1. 10 \\
\hline 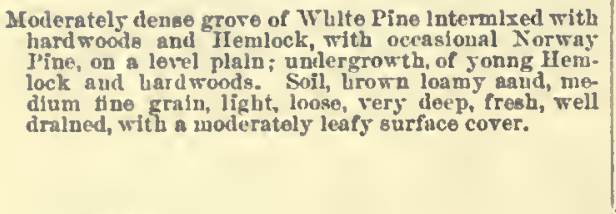 & \begin{tabular}{r|r}
5 \\
1 \\
4 \\
9 \\
8 \\
7 \\
3 \\
6 \\
10
\end{tabular} & $\begin{array}{l}417 \\
415 \\
455 \\
426 \\
460 \\
457 \\
461 \\
435 \\
458\end{array}$ & $\begin{array}{l}37.0 \\
35.5 \\
41.0 \\
43.0 \\
46.0 \\
47.0 \\
48.0 \\
40.0 \\
47.0\end{array}$ & $\begin{array}{l}155 \\
141 \\
152 \\
160 \\
150 \\
160 \\
170 \\
168 \\
162\end{array}$ & $\begin{array}{r}0.37 \\
.52 \\
.41 \\
.42 \\
.40 \\
.37 \\
.38 \\
.42 \\
.43\end{array}$ & $\begin{array}{l}0.45 \\
.39 \\
.53 \\
.56 \\
.48 \\
.45 \\
.56 \\
.51 \\
.57\end{array}$ & $\begin{array}{l}433.2 \\
510.5 \\
5.3 .7 \\
677.3 \\
694.1 \\
721.9 \\
737.9 \\
819.6 \\
855.3\end{array}$ & 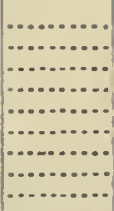 & 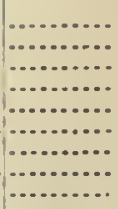 \\
\hline $\begin{array}{c}\text { Aroce z } \\
\text { Pennsylvania. }\end{array}$ & ......... & 46 & 43.0 & 157 & .41 & .50 & 670.4 & 2.60 & 1.50 \\
\hline 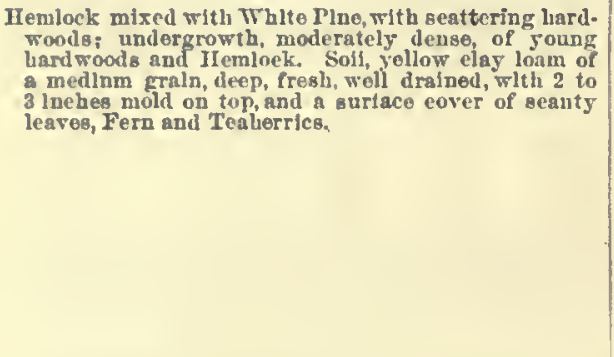 & $\begin{array}{r}1 \\
2 \\
3 \\
4 \\
10 \\
12 \\
18 \\
19 \\
20 \\
21 \\
23 \\
33 \\
34 \\
35 \\
36 \\
37 \\
3\end{array}$ & $\begin{array}{l}260 \\
260 \\
259 \\
211 \\
244 \\
262 \\
265 \\
250 \\
260 \\
245 \\
248 \\
259 \\
202 \\
263 \\
241 \\
261\end{array}$ & $\begin{array}{l}35.5 \\
36.0 \\
32.0 \\
32.0 \\
33.0 \\
28.0 \\
39.0 \\
34.0 \\
44.0 \\
34.0 \\
34.0 \\
33.0 \\
33.0 \\
31.0 \\
31.5 \\
37.0\end{array}$ & $\begin{array}{l}158 \\
157 \\
152 \\
150 \\
146 \\
156 \\
153 \\
150 \\
114 \\
146 \\
142 \\
133 \\
146 \\
144 \\
134 \\
146\end{array}$ & $\begin{array}{l}0.40 \\
.43 \\
.46 \\
.41 \\
.42 \\
.43 \\
.40 \\
.42 \\
.42 \\
.40 \\
.42 \\
.40 \\
.42 \\
.36 \\
.42 \\
.44\end{array}$ & $\begin{array}{l}0.43 \\
.42 \\
.44 \\
.59 \\
.34 \\
.43 \\
.42 \\
.48 \\
.30 \\
.37 \\
.37 \\
.31 \\
.38 \\
.43 \\
.34 \\
.27\end{array}$ & $\begin{array}{l}435.4 \\
481.3 \\
396.0 \\
347.7 \\
365.9 \\
285.8 \\
511.1 \\
402.4 \\
638.1 \\
366.7 \\
373.4 \\
304.5 \\
369.2 \\
275.2 \\
307.7 \\
482.9\end{array}$ & 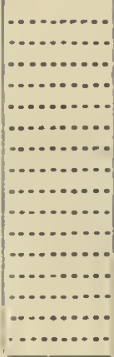 & 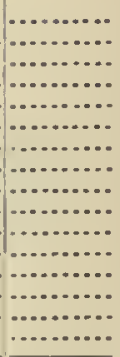 \\
\hline Arerago ......................................... & .... & 2505 & 34.0 & 147 & .41 & .39 & 390.0 & 2.16 & 1.53 \\
\hline
\end{tabular}


TABL: IV.-Dimensions, volume, and rate of growth, by decades, based upon analyses of trees in Tables III and VI. (A) OLD-GROWTH PINE.

(1) DOMLAXTT TREES.

Arerage throughout the range.]

(224 trees.)

\begin{tabular}{|c|c|c|c|c|c|c|c|c|c|c|c|}
\hline \multirow{2}{*}{ Age. } & \multirow{2}{*}{$\begin{array}{l}\text { Diameter } \\
\text { at height } \\
\text { of } 2 \text { foet } \\
\text { (without } \\
\text { brus). }\end{array}$} & \multirow{2}{*}{$\begin{array}{l}\text { Total } \\
\text { hoight } \\
\text { of tree. }\end{array}$} & \multirow{2}{*}{$\begin{array}{c}\text { Volnmo } \\
\text { of atem } \\
\text { (without } \\
\text { bark). }\end{array}$} & \multicolumn{3}{|c|}{$\begin{array}{l}\text { Relative per cent of total } \\
\text { volume. }\end{array}$} & \multicolumn{3}{|c|}{ Periodic accretion. } & \multirow{2}{*}{$\begin{array}{c}\text { A verago } \\
\text { annual } \\
\text { accretion. }\end{array}$} & \multirow{2}{*}{$\begin{array}{l}\text { Current } \\
\text { annunl } \\
\text { accretion. }\end{array}$} \\
\hline & & & & $\begin{array}{l}\text { Heart- } \\
\text { sood. }\end{array}$ & Sapwood. & Bark. & Decade. & Height. & Volume. & & \\
\hline Tears. & Inches. & Feet. & Oubieft. & Per cent. & Per cent. & Per cent. & & F'eet. & Cubioft. & Cubio ft. & Culic ft. \\
\hline 10 & 0.9 & 7.7 & (?) & ........... & & ........... & 1 & 7.7 & (l) & (1) & (?) \\
\hline 20 & 2.5 & 21.0 & 0.5 & & & .... & $\overline{2}$ & 13.3 & (i) & 0.02 & (i) \\
\hline 30 & 4.8 & 33.7 & 2.2 & & & & 3 & 12.7 & 1.7 & .07 & 0.17 \\
\hline$\$ 0$ & 6.9 & 46.0 & 5.6 & & & 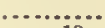 & 4 & 12.3 & 3.4 & .13 & .34 \\
\hline 50 & 8. 7 & $56 . \bar{T}$ & 10.8 & 40 & 47 & 13 & 5 & 10.7 & 5.2 & .22 & .52 \\
\hline 60 & 10.5 & 66.3 & 18.6 & & & & 6 & 9.7 & 7.7 & .31 & .77 \\
\hline 70 & 12.1 & 74.7 & 28.0 & & & & 7 & 8.3 & 9.5 & .40 & .95 \\
\hline 80 & 13.8 & 82.0 & 38.8 & & 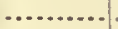 & & 8 & 7.3 & 10.8 & .49 & 1.08 \\
\hline 90 & 15.5 & 89.0 & 50.9 & & & ... & 9 & 7. 0 & 12.1 & .56 & 1.21 \\
\hline 100 & 17.2 & 91.3 & 66.0 & & & & 10 & 5.7 & 15. 1 & .66 & 1.51 \\
\hline 110 & 18.9 & 99.0 & 82.7 & 55 & 33 & 12 & 11 & 4.3 & 16. 7 & .75 & 1.67 \\
\hline 120 & 20.6 & 108.7 & 100.3 & & & & 12 & 4. & 17.6 & .84 & 1. 76 \\
\hline 130 & 22.2 & 107.7 & 118. 5 & & & & 13 & 4. & 18.2 & .91 & 1.82 \\
\hline 140 & 23.7 & 111.3 & 137.3 & & & & 14 & 3. & 18. & .9 & 1.8 \\
\hline 150 & 25.0 & 114.4 & 155.7 & ..... & •........ & ........... & 15 & 3. & 18.4 & 1.04 & 1.84 \\
\hline 160 & 26.3 & 117.3 & 175.3 & ........... & ........... & - & 16 & 3. & 19. 6 & 1.09 & 1.96 \\
\hline 170 & 27.5 & 120.7 & 194.6 & , & ............. & ............. & 17 & 3. & 19.3 & 1.14 & 1.93 \\
\hline 180 & 28.7 & 123.7 & 214.8 & ..... & $\ldots \ldots \ldots$ & . & 18 & 3. & 20.2 & 1.19 & 2.02 \\
\hline 190 & 29.8 & 126.3 & 234.7 & & & & 19 & 2. & 19.8 & 1.23 & 1.99 \\
\hline 200 & 31.0 & 129.0 & 254.7 & 65 & 23 & 12 & 20 & E. & 20.0 & 1.27 & 2.00 \\
\hline 210 & 30.7 & 134.5 & & & ......... & & 21 & 3. & 20.6 & 1.25 & 2.06 \\
\hline 220 & 31.6 & 137.5 & & & ........... & & 22 & 3. & 21.5 & 1.30 & 2.15 \\
\hline 230 & 32.0 & 110.5 & ........ & 69 & 21 & 11 & 23 & 3.0 & 21.6 & 1.34 & 2.16 \\
\hline
\end{tabular}

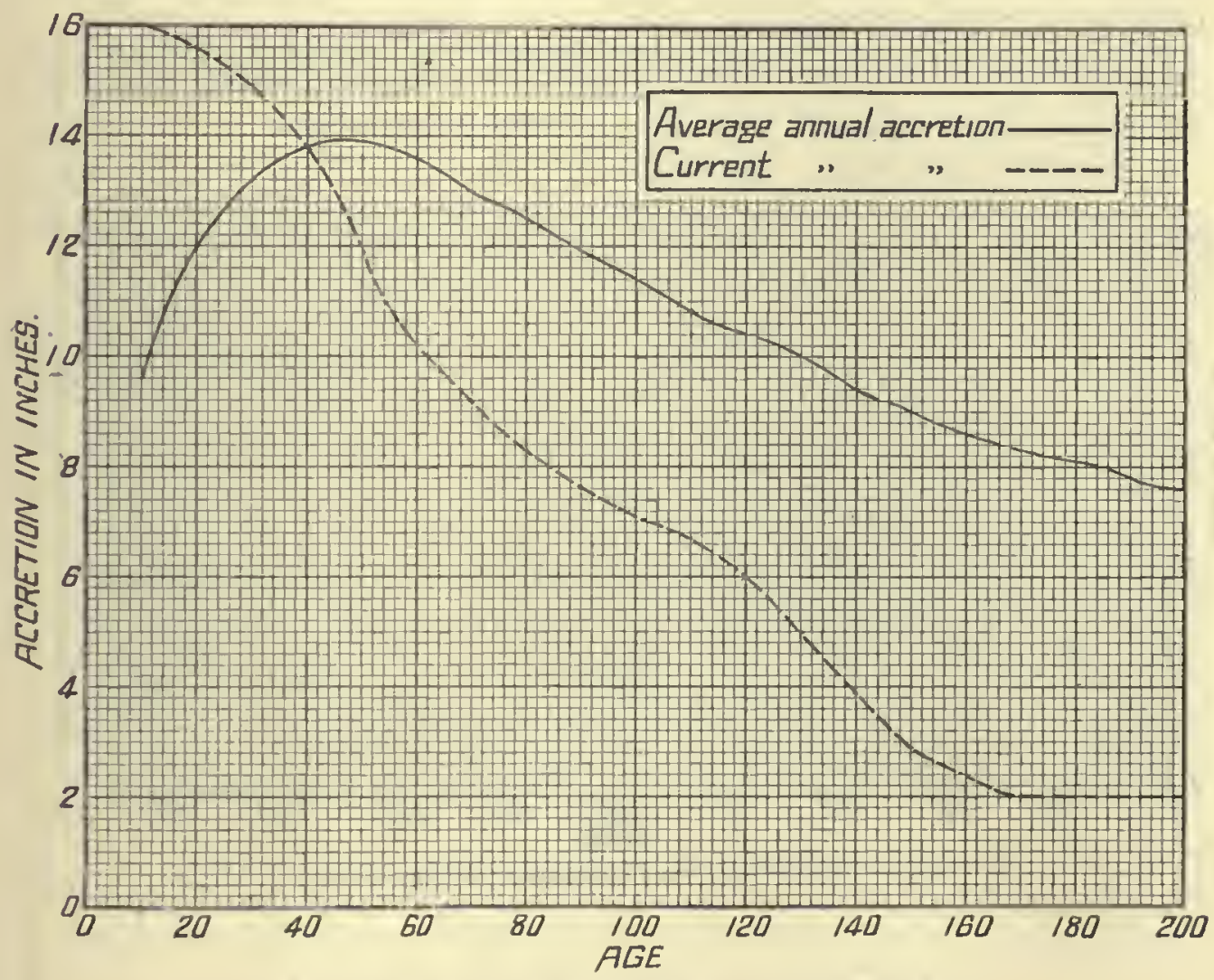

Fu. 19.-Diagram slowing rate of height growth of dominant trees. 
THE WHITE PINE.

TAnz: IV.-Dimenoions, volume, and rate of growth, by decades, etc.-Continued.

(1) OLD-GRoWTH PINE-Continned.

(2) CODOMINANT TREES.

[Arerage thronghout the range.]

(106 trees.)

\begin{tabular}{|c|c|c|c|c|c|c|c|c|c|c|c|}
\hline \multirow{2}{*}{ Ago. } & \multirow{2}{*}{$\begin{array}{l}\text { Diameter } \\
\text { at height } \\
\text { of } 2 \text { feet } \\
\text { (wilhout } \\
\text { bark). }\end{array}$} & \multirow{2}{*}{$\begin{array}{c}\text { Total } \\
\text { height } \\
\text { of tree. }\end{array}$} & \multirow{2}{*}{$\begin{array}{c}\text { Volnme } \\
\text { of ntem } \\
\text { (witbont } \\
\text { bark). }\end{array}$} & \multicolumn{3}{|c|}{$\begin{array}{l}\text { Relatiro per cent of total } \\
\text { volune. }\end{array}$} & \multicolumn{3}{|c|}{ Periodio accretion. } & \multirow{2}{*}{$\begin{array}{l}\text { Average } \\
\text { annual } \\
\text { accretion. }\end{array}$} & \multirow{2}{*}{$\begin{array}{c}\text { Carrent } \\
\text { annual } \\
\text { accretion }\end{array}$} \\
\hline & & & & $\begin{array}{l}\text { 1Feart. } \\
\text { wood. }\end{array}$ & Sapwood. & 13ark. & Decade. & Helght. & Volume. & & \\
\hline Tears. & Inehes. & Feet. & Cubic ft. & Per cent. & Por cent. & Per cent. & & Feet. & Oubio ft. & Orbic ft. & Culic ft. \\
\hline$\frac{10}{20}$ & 0.8 & 6. 0 & (1) & $\ldots \ldots \ldots$ & & & 1 & 6.0 & (1) & (?) & (i) \\
\hline $\begin{array}{l}20 \\
80\end{array}$ & 2.8 & $\begin{array}{l}16.0 \\
28.5\end{array}$ & $\begin{array}{l}0.4 \\
1.6\end{array}$ & (............ & & & $\frac{2}{3}$ & 10.0 & (1) & 0.02 & (1) ${ }_{0.12}$ \\
\hline 40 & 5.8 & 38.0 & 4.4 & & & & 4 & 9.5 & 2.0 & .11 & .29 \\
\hline 80 & & 47.5 & 7.7 & & & $\cdots \cdot$ & 5 & 9.5 & $\begin{array}{l}3.3 \\
3.6\end{array}$ & .15 & .33 \\
\hline $\begin{array}{l}\infty 0 \\
70\end{array}$ & $\begin{array}{r}9.0 \\
10.5\end{array}$ & 56.5 & 11.3 & $\ldots$ & & & 7 & $\begin{array}{l}9.0 \\
7.5\end{array}$ & $\begin{array}{l}3.6 \\
6.1\end{array}$ & .25 & .36 \\
\hline 80 & $\begin{array}{l}10.5 \\
11.9\end{array}$ & $\begin{array}{l}64.0 \\
71.5\end{array}$ & $\begin{array}{l}17 . \frac{1}{24.9} \\
\end{array}$ & ...... & ....... & & 8 & 7. & 7.5 & .31 & .75 \\
\hline 90 & 13.3 & 79.0 & 34.8 & & & & 9 & 7.5 & 8.5 & .38 & .95 \\
\hline 100 & 14.7 & 84.5 & 44.5 & & & & 10 & 5. & 10.2 & .45 & 1.02 \\
\hline 110 & 16.0 & 89.5 & 55.5 & & ...... & & $\frac{11}{12}$ & $\begin{array}{l}5.0 \\
5.0\end{array}$ & $\begin{array}{l}11.0 \\
12.0\end{array}$ & $\begin{array}{l}.50 \\
.56\end{array}$ & $\begin{array}{l}1.10 \\
1.20\end{array}$ \\
\hline & 17.3 & & & & $\ldots$. & & 13 & 4.5 & 11.2 & .61 & 1.12 \\
\hline 13 & $\begin{array}{l}18.6 \\
19.8\end{array}$ & $\begin{array}{r}19.0 \\
1030\end{array}$ & & & & & 14 & 4. & 12. & .66 & 1. 29 \\
\hline $\begin{array}{l}140 \\
150\end{array}$ & $\begin{array}{l}19.8 \\
20.8\end{array}$ & 107.0 & 104.0 & $\cdots$ & & & & 4. & 12. & .69 & 1.25 \\
\hline 16 & & & & $\ldots$ & & * & 16 & 4. & 12 & .72 & 1. 20 \\
\hline 17 & & & & $\cdots$ & & $\ddot{*}$ & 17 & 3. & $\begin{array}{l}11 . \\
13 .\end{array}$ & $\begin{array}{l}.75 \\
.72\end{array}$ & $\begin{array}{l}1.18 \\
1.39\end{array}$ \\
\hline 180 & & & & & & $\ddot{. .} \quad$ & 19 & 2. & 13. & .75 & 1.39 \\
\hline 190 & $\begin{array}{l}24.7 \\
25.6\end{array}$ & $\begin{array}{l}120.0 \\
12.5\end{array}$ & $\begin{array}{l}142.9 \\
152.7\end{array}$ & & & & 20 & 2. & 9. & .76 & $\begin{array}{l}1.81 \\
.98\end{array}$ \\
\hline 21 & & 125 & & & & & 2 & 2. & 12. & .79 & 1.28 \\
\hline 03 & & & 179.3 & & & & 22 & 2. & 13. & .81 & 1.38 \\
\hline 230 & 27.7 & 130.0 & 193.0 & & & & 23 & 2.5 & 15.7 & .84 & 1.57 \\
\hline
\end{tabular}

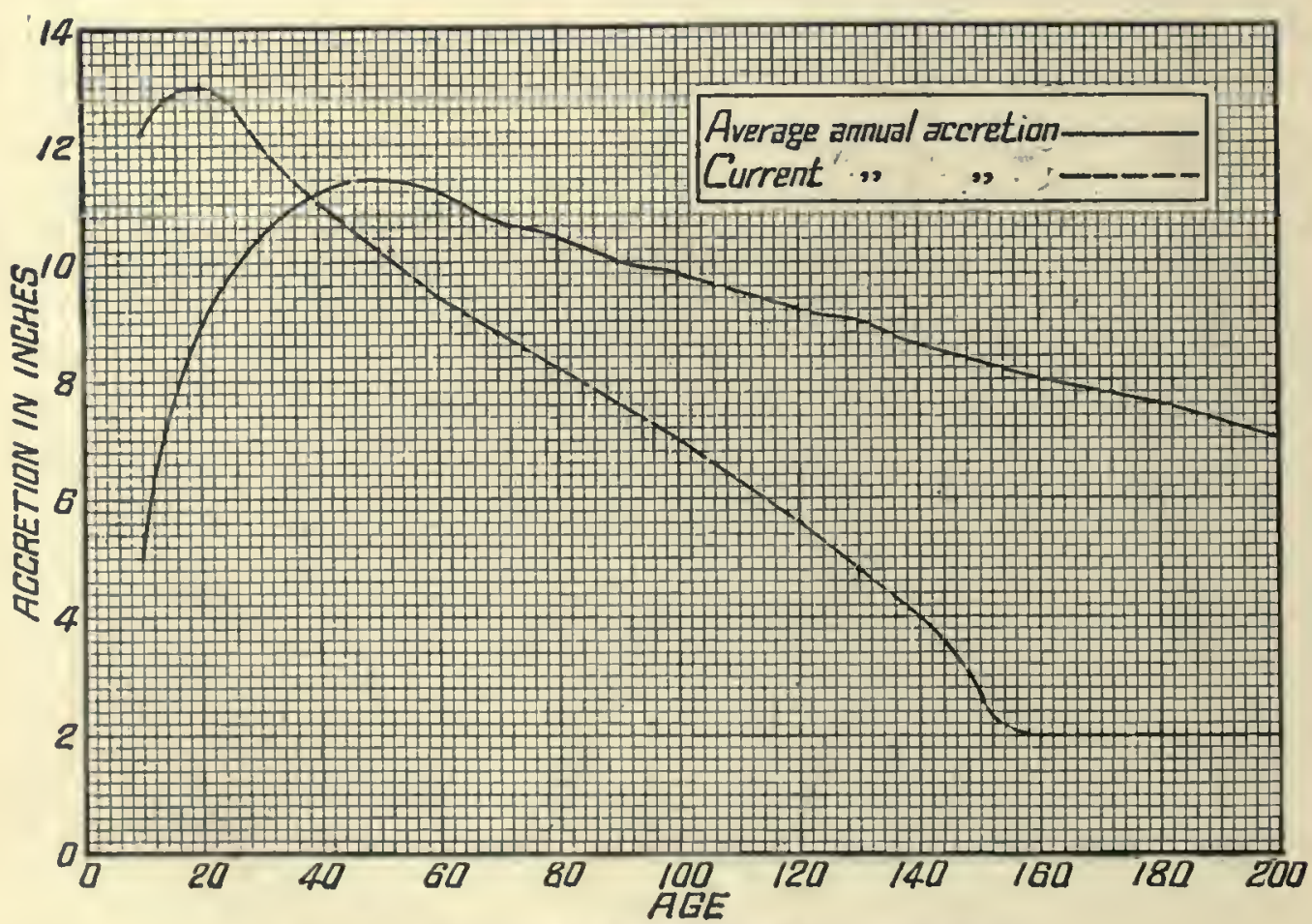

F1a.20.-Diagram abowing rate of height growth of codominant trees. 
TABLES OF MEASUREMENTS.

TABLF IV.-Dimensions, volume, and rate of growth, by deoades, etc.-Continued.

(A) OLD-GROWTH PINE-Continued.

(3) OPPRESSED TRERS.

[A verage thronghout the range.]

(104 treos.)

\begin{tabular}{|c|c|c|c|c|c|c|c|c|c|c|c|}
\hline \multirow{2}{*}{ Age. } & \multirow{2}{*}{$\begin{array}{l}\text { Diameter } \\
\text { at height } \\
\text { of } 2 \frac{1}{3} \text { foet } \\
\text { (withont } \\
\text { bark). }\end{array}$} & \multirow{2}{*}{$\begin{array}{c}\text { Total } \\
\text { height } \\
\text { of tree. }\end{array}$} & \multirow{2}{*}{$\begin{array}{c}\text { Volume } \\
\text { of stem } \\
\text { (withont } \\
\text { bark). }\end{array}$} & \multicolumn{3}{|c|}{$\begin{array}{l}\text { Relative per cent of total } \\
\text { volnme. }\end{array}$} & \multicolumn{3}{|c|}{ Periodic accretion. } & \multirow{2}{*}{$\begin{array}{c}\text { A rerage } \\
\text { annual } \\
\text { aceretion. }\end{array}$} & \multirow{2}{*}{$\begin{array}{l}\text { Current } \\
\text { annual } \\
\text { accretion. }\end{array}$} \\
\hline & & & & $\begin{array}{l}\text { Heart- } \\
\text { wood. }\end{array}$ & Sapwood. & Bark. & Decade. & Height. & Volumo. & & \\
\hline Feare. & Inches. & Feet. & Cubic ${ }^{\prime}$. & Percent. & Per cent. & Per cent. & & Feet. & Oubioft. & Culie ft. & Oubic ft. \\
\hline 10 & 0.9 & 4.0 & (i) & ........... & ............ & ........... & 1 & 4.0 & (i) & ( $)$ & (?) \\
\hline 20 & 2.0 & 11.0 & 0.1 & ........... & ........... & …....... & 2 & 7.0 & (3) & 0.02 & (i) \\
\hline 30 & 3.7 & 18.0 & 0.7 & & ......... & & 3 & 7.0 & 0.4 & .02 & 0.04 \\
\hline 40 & 5.2 & 26.0 & 1.7 & .... & $\ldots \ldots \ldots$ & .... & $\leq$ & 8.0 & 1.0 & .04 & .10 \\
\hline 50 & 6.7 & 34.5 & 3.6 & & ........... & & 5 & 8.5 & 1.9 & .07 & .19 \\
\hline 60 & 8.0 & 43.5 & 6. 5 & $\ldots \ldots \ldots$, & .... & ...... & 6 & 9.0 & 2.9 & .11 & .20 \\
\hline 70 & 9.2 & 51.5 & 10.3 & ......... & ......... & $\ldots$ & 7 & 8.0 & 3.8 & .15 & .38 \\
\hline 80 & 10.6 & 59.5 & 15.1 & .......... & & & 8 & 8.0 & 4.8 & .19 & .48 \\
\hline 90 & 11.9 & 66.5 & 26.5 & & & & 9 & 7.0 & 6.5 & .24 & .65 \\
\hline 100 & 13.3 & 73.0 & 29.0 & & & & 10 & 6.5 & 7.5 & .29 & .75 \\
\hline 110 & 14.7 & 79.0 & 37.5 & 51 & 36 & 13 & 11 & 6.0 & 8.5 & .35 & .85 \\
\hline 120 & 15.9 & 84.5 & 46.8 & & & & 12 & 5.5 & 9.3 & .39 & .93 \\
\hline 130 & 17.1 & 89.0 & 57.0 & & & & 13 & 4.5 & 10.3 & .44 & 1.03 \\
\hline 140 & 18.2 & 98.5 & 68.5 & ........ & $=\ldots \ldots$ & .er & 14 & 4.5 & 11.5 & .49 & 1.15 \\
\hline 150 & 19.3 & 97.0 & 79.5 & …....... & ........... & & 15 & 3.5 & 11.0 & .54 & 1.10 \\
\hline 160 & 20.3 & 100.5 & 90.8 & $\ldots \ldots \ldots$ & .......... & ........... & 16 & 3.5 & 11.3 & .57 & 1.13 \\
\hline 170 & 21.2 & 108.5 & 102.3 & . & .......... & $\ldots \ldots \ldots \ldots$ & 17 & 3.0 & 11.5 & .60 & 1.15 \\
\hline 180 & 22.2 & 100.5 & 114. 0 & ............ & ........... & & 18 & 3.0 & 11.8 & .64 & 1.18 \\
\hline 190 & 23.2 & 109.0 & 125.0 & .......... & & & 19 & 2.5 & 11.0 & .66 & 1.10 \\
\hline 200 & 23.9 & 111.5 & 136.0 & 60 & 28 & 12 & 20 & 2.5 & 11.0 & .68 & 1.10 \\
\hline
\end{tabular}

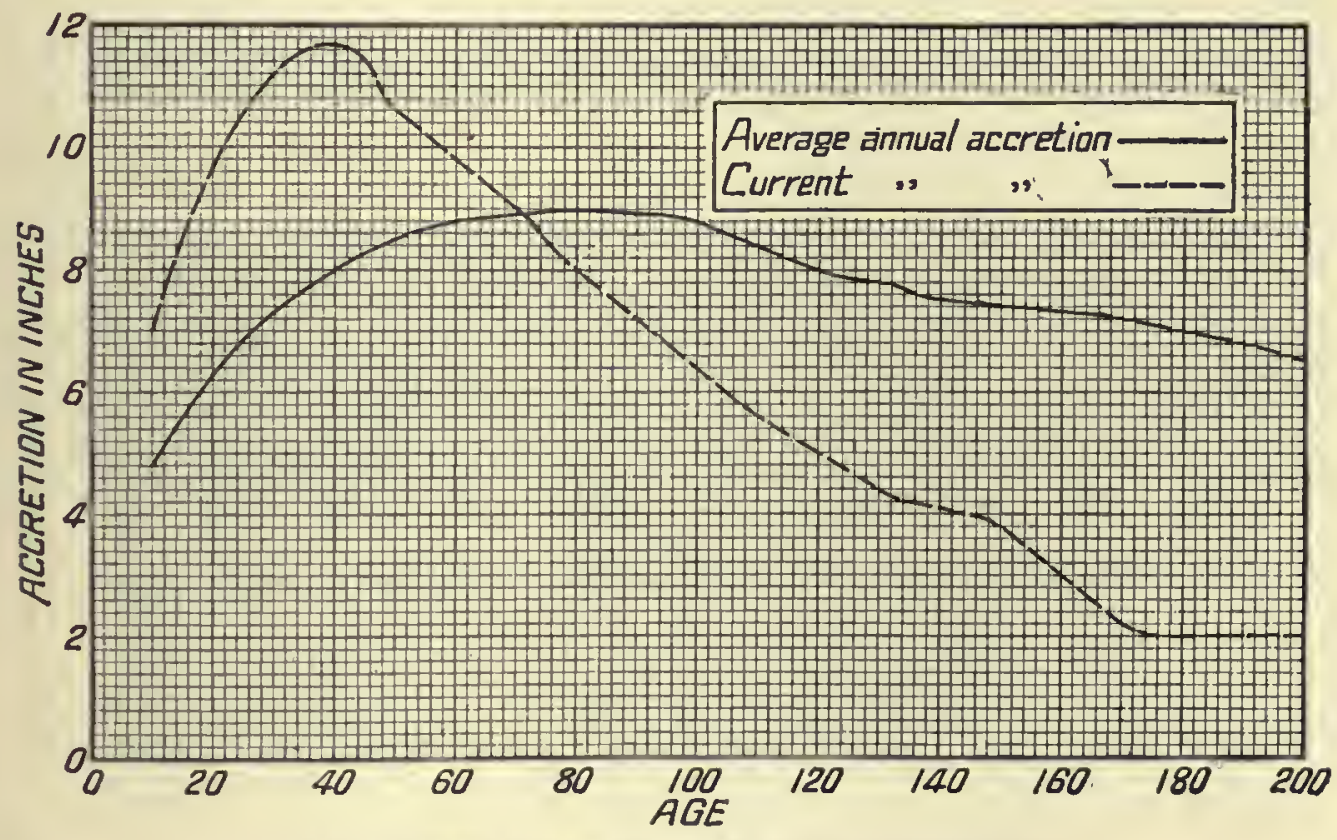

FIG. 21.-Disgram showing rate of height growth of oppressed trees. 


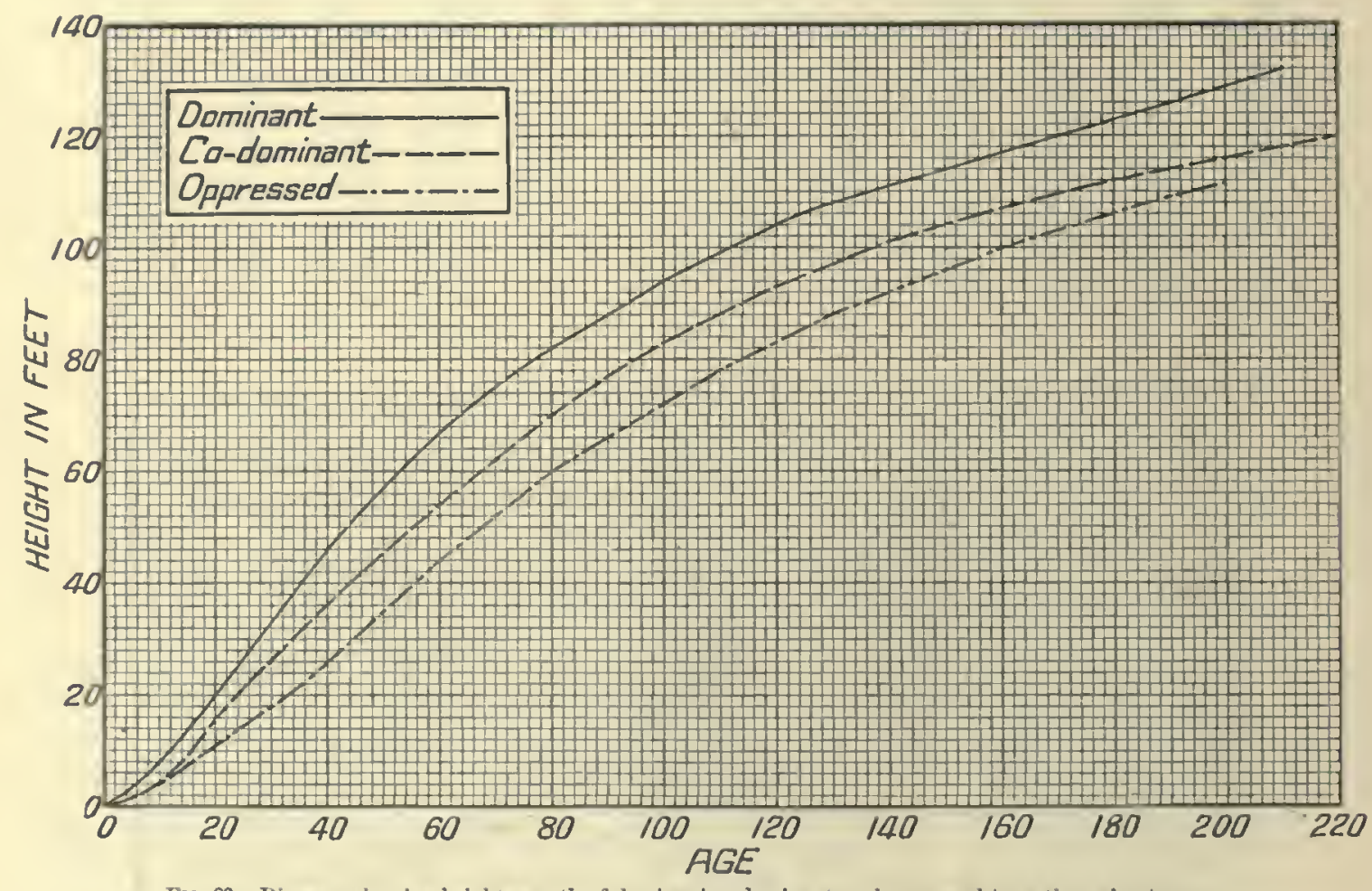

Fia. 22.-Diagram showing height growth of dominant, codominant, and oppressed trees throughout rango. 


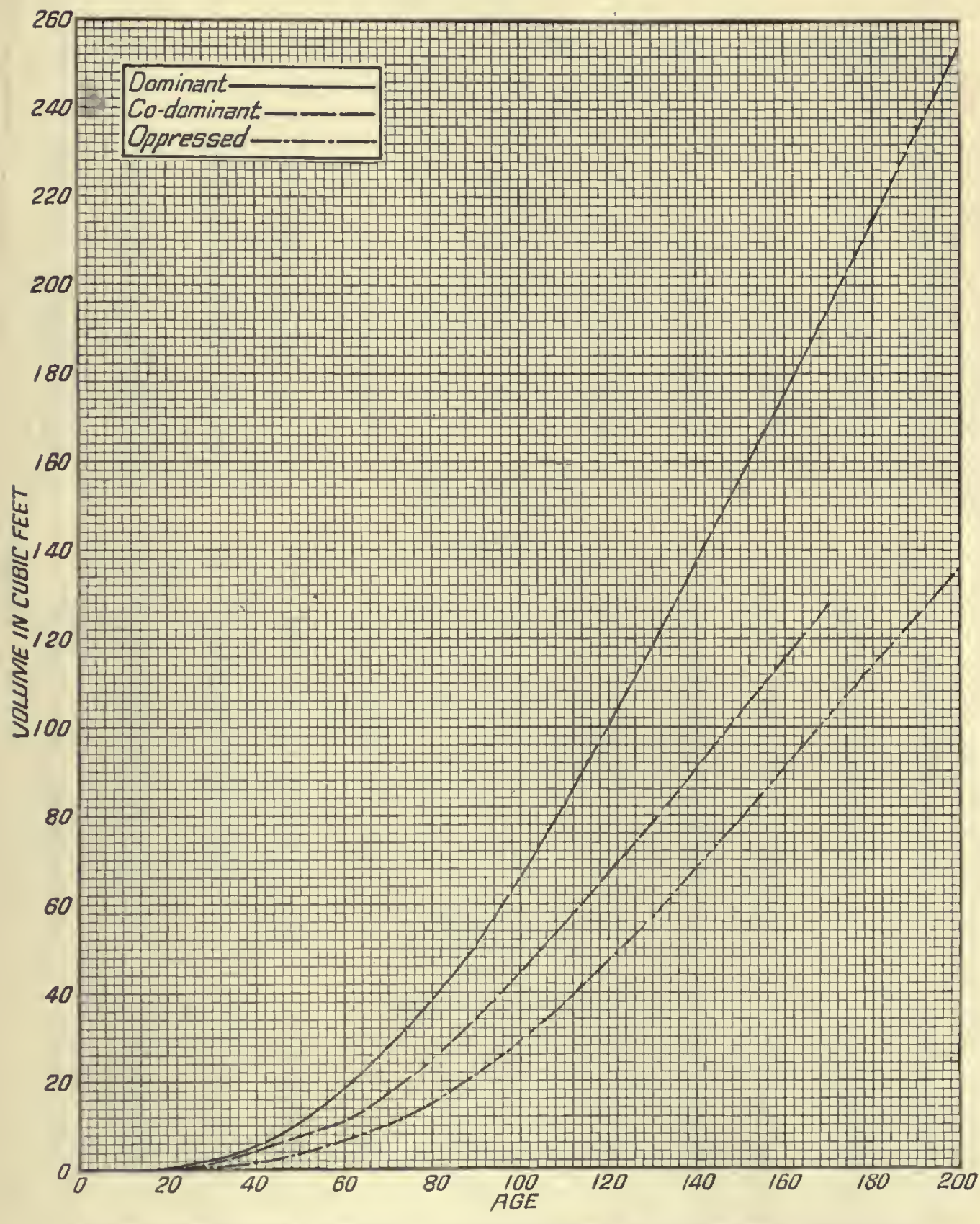

Fif. 23.-Diagram showing volnme growth of dominant, codominant, and oppressed trees throughout range.

20233-No. 22-7 
THE WHITE PINE.

TABLE IV.-llimensions, volume, and rate of grouth, by decádes. etc.-Continned. (A) OLD-GRoWTII PINL-Continued.

(4) DOMUSANT TREES.

[Arorago lu Wisconsin.]

(68 trees.)

\begin{tabular}{|c|c|c|c|c|c|c|c|c|c|c|c|}
\hline \multirow{2}{*}{ A g. } & \multirow{2}{*}{$\begin{array}{l}\text { Diameter } \\
\text { at beigbt } \\
\text { of } 2 \text { feet } \\
\text { (witliont } \\
\text { bark). }\end{array}$} & \multirow{2}{*}{$\begin{array}{l}\text { Total } \\
\text { heiglit } \\
\text { of tree. }\end{array}$} & \multirow{2}{*}{$\begin{array}{c}\text { Volume } \\
\text { of stem } \\
\text { (withont } \\
\text { bark). }\end{array}$} & \multicolumn{3}{|c|}{$\begin{array}{l}\text { Relative per cent of total } \\
\text { volune. }\end{array}$} & \multicolumn{3}{|c|}{ Periodic aceretion. } & \multirow{2}{*}{$\begin{array}{l}\text { A verage } \\
\text { annual } \\
\text { accretion. }\end{array}$} & \multirow{2}{*}{$\begin{array}{c}\text { Current } \\
\text { anninal } \\
\text { accretion. }\end{array}$} \\
\hline & & & & $\begin{array}{l}\text { IIeart. } \\
\text { wood. }\end{array}$ & Sipwood. & I3ark. & Decade. & Helght. & Volume. & & \\
\hline $\begin{array}{c}\text { Ycars. } \\
10 \\
20 \\
30 \\
10 \\
50 \\
60 \\
70 \\
80 \\
90 \\
100 \\
110 \\
120 \\
130 \\
110 \\
150 \\
160 \\
170 \\
180 \\
190 \\
200\end{array}$ & $\begin{array}{r}\text { Inches. } \\
1.0 \\
2.2 \\
3.8 \\
3.3 \\
6.6 \\
8.0 \\
0.3 \\
11.0 \\
13.0 \\
15.2 \\
17.4 \\
19.6 \\
21.8 \\
24.0 \\
25.7 \\
27.4 \\
29.0 \\
30.5 \\
32.0 \\
33.3\end{array}$ & $\begin{array}{r}\text { Fet. } \\
9 \\
22 \\
34 \\
40 \\
58 \\
66 \\
74 \\
80 \\
86 \\
91 \\
95 \\
100 \\
104 \\
108 \\
111 \\
114 \\
117 \\
120 \\
122 \\
124\end{array}$ & $\begin{array}{c}\text { Cubic ft. } \\
\text { (1) } \\
0.5 \\
1.9 \\
3.5 \\
7.6 \\
13.2 \\
21.0 \\
30.0 \\
41.3 \\
58.0 \\
78.0 \\
100.5 \\
124.0 \\
147.5 \\
169.0 \\
190.5 \\
212.5 \\
234.5 \\
230.0 \\
277.0\end{array}$ & 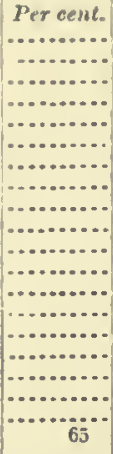 & $\begin{array}{l}\text { Per cent. } \\
1 \\
1 \\
1\end{array}$ & 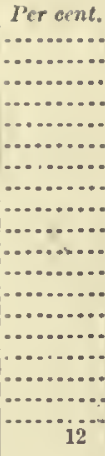 & $\begin{array}{r}1 \\
2 \\
3 \\
4 \\
5 \\
6 \\
7 \\
8 \\
9 \\
10 \\
11 \\
12 \\
13 \\
14 \\
15 \\
16 \\
17 \\
18 \\
19 \\
20\end{array}$ & $\begin{array}{r}\text { Fcet. } \\
0 \\
13 \\
12 \\
12 \\
11 \\
0 \\
8 \\
0 \\
6 \\
5 \\
4 \\
5 \\
4 \\
4 \\
3 \\
3 \\
3 \\
3 \\
2 \\
2\end{array}$ & $\begin{array}{c}\text { Cubie ft. } \\
(\eta) \\
(y) \\
1.4 \\
1.6 \\
4.1 \\
5.0 \\
7.8 \\
0.0 \\
11.5 \\
16.5 \\
20.0 \\
22.5 \\
23.5 \\
23.5 \\
21.5 \\
21.5 \\
22.0 \\
22.0 \\
21.5 \\
21.0\end{array}$ & $\begin{array}{c}\text { Cubieft. } \\
\text { (1) } \\
0.02 \\
.00 \\
.02 \\
.15 \\
.22 \\
.30 \\
.38 \\
.46 \\
.58 \\
.71 \\
.84 \\
.95 \\
1.05 \\
1.13 \\
1.19 \\
1.25 \\
1.30 \\
1.35 \\
1.38\end{array}$ & $\begin{array}{c}\text { Cubieft. } \\
\text { (1) } \\
\text { (1) } \\
0.14 \\
.10 \\
.11 \\
.54 \\
.78 \\
.90 \\
1.15 \\
1.65 \\
2.00 \\
2.25 \\
2.35 \\
2.35 \\
2.15 \\
2.15 \\
2.20 \\
2.20 \\
2.15 \\
2.10\end{array}$ \\
\hline
\end{tabular}

(5) OPPRESSED TREES.

[A verago in Wisconsin.]

(55 trees.)

\begin{tabular}{|c|c|c|c|c|c|c|c|c|c|c|c|}
\hline 10 & 1.0 & 4 & (l) & & & & 1 & 4 & (?) & (l) & (l) \\
\hline 20 & 2.2 & 10 & 0.4 & .... & ............ & ................. & 2 & 6 & (?) & 0.02 & (i) \\
\hline 30 & 4.0 & 16 & .7 & $\ldots$. & ..... & ............. & 3 & S & 0.3 & .02 & 0.03 \\
\hline 40 & 5.4 & 24 & 1.6 & ........... & ....... & ............... & 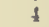 & 8 & .8 & .04 & .09 \\
\hline 50 & 6.8 & 32 & 3.2 & & & $\ldots$ & 5 & 8 & 1.6 & .06 & .16 \\
\hline 60 & 8. 0 & 40 & 6.0 & ............. & & .............. & 0 & 8 & 2.8 & .10 & .28 \\
\hline 70 & 9.2 & 47 & 0.5 & ................ & & .............. & 7 & 7 & 3.5 & .13 & .35 \\
\hline 80 & 10.6 & 55 & 13.5 & & & & 8 & 8 & 4.0 & .17 & .40 \\
\hline 90 & 12.0 & 62 & 20.0 & $\ldots$. & $\ldots$ & ............. & 9 & 7 & 6.5 & .22 & .65 \\
\hline 100 & 13.4 & 69 & 28.0 & & & & 10 & 7 & 8.0 & .28 & .80 \\
\hline 110 & 14.7 & 75 & 38.0 & .......... & $\ldots .$. & 1............ & 11 & 0 & 10.0 & .35 & 1.00 \\
\hline 120 & 16.0 & 81 & 48.5 & & & ............ & 12 & 6 & 10.5 & .40 & 1.05 \\
\hline 130 & 17.2 & 86 & 60.0 & & & ............... & 13 & 5 & 11.5 & .40 & 1.15 \\
\hline 140 & 18.3 & 90 & 73.0 & & & ........... & 14 & 4 & 13.0 & .52 & 1.30 \\
\hline 150 & 10.5 & 94 & 85.0 & ........... & ........... & ............ & 15 & 4 & 12.0 & .57 & 1.20 \\
\hline 160 & 20.6 & 98 & 97.5 & .......... & ............ & .............. & 16 & 4 & 12.5 & .61 & 1.25 \\
\hline 170 & 21.6 & 101 & 109.5 & .......... & ........ & ............ & 17 & 3 & 12.0 & .64 & 1.20 \\
\hline 180 & 22.7 & 104 & 122.0 & .......... & ........... & ............ & 18 & 3 & 12.5 & .68 & 1.25 \\
\hline 190 & 33.7 & 107 & 134.0 & $\ldots . . . \ldots$ & ........... & ............. & 19 & 3 & 12.0 & .70 & 1.20 \\
\hline 200 & 24.6 & 110 & 116.0 & $60^{\circ}$ & 28 & 12 & 20 & 3 & 12.0 & .73 & 1.20 \\
\hline
\end{tabular}

(6) DOMINANT TREES.

[Arerage in Michigan.]

(75 trees.)

\begin{tabular}{|c|c|c|c|c|c|c|c|c|c|c|c|}
\hline 10 & 0.8 & 7 & (?) & & & & 1 & 7 & (l) & (?) & (?) \\
\hline 20 & 2.6 & 20 & 0.5 & & ........ & 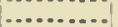 & 2 & 13 & (i) & 0.02 & (?) \\
\hline 30 & 5.2 & 32 & 2.0 & & ............ & [........... & 3 & 12 & 1.5 & .07 & 0.15 \\
\hline 10 & 7.4 & 13 & 5.5 & ............ & ............ & ............ & 4 & 11 & 3.5 & .16 & .35 \\
\hline 50 & 0.1 & 53 & 10.5 & & ............ & & 5 & 10 & 5.0 & .21 & .50 \\
\hline 60 & 11.3 & 63 & 17.6 & $\ldots \ldots$ & ......... & & 6 & 10 & 7.1 & .29 & .71 \\
\hline 70 & 13.1 & 72 & 27.0 & $\ldots . . .$. & & & 7 & $\theta$ & 0.1 & .39 & .94 \\
\hline 80 & 14.8 & 80 & 38.2 & $\ldots . . .$. & & & 8 & 8 & 11.2 & .18 & 1.12 \\
\hline 80 & 16.4 & 85 & 51.6 & $\ldots . . .$. & & & 9 & 8 & 13.4 & .57 & 1.34 \\
\hline 100 & 17.9 & 94 & 65.5 & & & & 10 & 6 & 13.9 & .65 & 1.39 \\
\hline 110 & 19.8 & 98 & 79.4 & & & & 11 & 4 & 13.9 & .72 & 1.39 \\
\hline 120 & 20.6 & 108 & 03.0 & 57 & 31 & 12 & 12 & 5 & 14.2 & .78 & 1. 12 \\
\hline 130 & 21.8 & 107 & 108.0 & ) & & & 13 & 4 & 14.4 & .83 & 1.44 \\
\hline 140 & 23.0 & 110 & 123.5 & & & & 14 & 3 & 15.5 & .88 & 1.55 \\
\hline 150 & 24.0 & 113 & 140.0 & $\begin{array}{ll}\cdots \\
\cdots \ldots\end{array}$ & ......... & ( & 15 & 3 & 16.5 & .93 & 1.65 \\
\hline 100 & 25.1 & 116 & 158.5 & $\ldots \ldots \ldots$ & & ......... & 18 & 3 & 18.3 & .09 & 1.85 \\
\hline 170 & 26.1 & 120 & 175.0 & ........ & ......... & (.). & 17 & 4 & 16.5 & 1.03 & 1.05 \\
\hline 180 & 27.0 & 123 & 192.5 & ................ & ............ & .......... & 18 & 3 & 17.5 & 1.07 & 1.75 \\
\hline 190 & 27.9 & 126 & 210.0 & ........... & ......... & (.). & 19 & 3 & 17.5 & 1.10 & 1.75 \\
\hline 200 & 28.8 & 120 & 226.5 & …… & ......... & ........ & 20 & 3 & 16.5 & 1,13 & 1.05 \\
\hline 210 & 29.5 & 132 & 244.0 & ......... & ... & 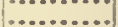 & 21 & 3 & 17.5 & 1.10 & 1.75 \\
\hline 220 & 30.3 & 135 & 201.5 & ............. & ........... & ........... & 22 & 3 & 37.5 & 1.19 & 1.75 \\
\hline 250 & 31.0 & 138 & 279.0 & 69 & 20 & ii & 23 & 3 & 17.5 & 1.21 & 1.75 \\
\hline
\end{tabular}


TABLES OF MEASUREMENTS.

TABLE IV.-Dimensions, volume, and rate of growth, by decades, etc.-Continued.

(d) OLD-GROWTH PLNE-Continued.

(7) CODOMUNANT TREES.

[Aterage in Michigan.]

(28 trees.)

\begin{tabular}{|c|c|c|c|c|c|c|c|c|c|c|c|}
\hline \multirow{2}{*}{ Age. } & \multirow{2}{*}{$\begin{array}{l}\text { Diameter } \\
\text { at height } \\
\text { of } 2 \text { feet } \\
\text { (withont } \\
\text { hark). }\end{array}$} & \multirow{2}{*}{$\begin{array}{l}\text { Total } \\
\text { height } \\
\text { of tree. }\end{array}$} & \multirow{2}{*}{$\begin{array}{l}\text { Volnme } \\
\text { of stem } \\
\text { (without } \\
\text { bark). }\end{array}$} & \multicolumn{3}{|c|}{$\begin{array}{l}\text { Relative per cent of total } \\
\text { volnme. }\end{array}$} & \multicolumn{3}{|c|}{ Pcriodic accretion. } & \multirow{2}{*}{$\begin{array}{c}\text { Arerage } \\
\text { aunual } \\
\text { accretion. }\end{array}$} & \multirow{2}{*}{$\begin{array}{c}\text { Current } \\
\text { mnnunl } \\
\text { accretion. }\end{array}$} \\
\hline & & & & $\begin{array}{l}\text { IIteart- } \\
\text { wood. }\end{array}$ & Sapwood. & Bark. & Decade. & Height. & Volume. & & \\
\hline Tears & Inches. & Feet. & Cubic $f t$. & Per cent. & Per cent. & Per cent. & & Feet. & Cubieft. & Cubic ft. & Oubic ft. \\
\hline $\begin{array}{l}10 \\
20\end{array}$ & $\begin{array}{l}0.7 \\
2.2\end{array}$ & $\begin{array}{r}7 \\
16\end{array}$ & (?) & -........ & $\ldots \ldots \ldots$ & $\cdots$ & $\frac{1}{2}$ & & (1) & (i) & (1) \\
\hline 30 & 4.0 & 29 & 1.3 & & & & 3 & 13 & & $\begin{array}{r}0.02 \\
.04\end{array}$ & 0.09 \\
\hline 40 & 5.7 & 37 & 4.0 & ... & $\ldots$ & .......... & 4 & 8 & 2.7 & .10 & .27 \\
\hline 50 & 7.3 & 47 & 7.6 & & & .... & 5 & 10 & 3.6 & .15 & .36 \\
\hline 60 & 8.8 & 57 & 11.5 & $\ldots \ldots \ldots$ & ..... & ..... & 6 & 10 & 3.9 & .19 & .39 \\
\hline 70 & 10.1 & 65 & 18.0 & ........... & .......... & .... & 7 & 8 & 6.5 & .26 & .65 \\
\hline 80 & 11.7 & 74 & 26.1 & .......... & 年 & ..... & 8 & 9 & 8.4 & .33 & .84 \\
\hline 90 & 13.2 & 83 & 38.0 & ........... & $\ldots .$. & ..... & 8 & 9 & 11.6 & .42 & 1.16 \\
\hline 100 & 14.6 & 89 & 50.0 & & & & 10 & 6 & 12.0 & .50 & 1.20 \\
\hline 110 & 15.9 & 94 & 63.0 & ......... & ....... & ..... & 11 & 5 & 13.0 & .57 & 1.30 \\
\hline 120 & 17.2 & 99 & 77.0 & ......... & . & & 12 & 5 & 14.0 & .64 & 1.40 \\
\hline 130 & 18.5 & 104 & 92.0 & . & . & $\mid \ldots \ldots \ldots$ & 13 & 5 & 15. 0 & .71 & 1.50 \\
\hline 140 & 19.8 & 108 & 106.0 & ......... & ......... & ......... & 14 & 4 & 14.0 & .76 & 1.40 \\
\hline 150 & 20.9 & 112 & 119.0 & $\ldots \ldots$ & . & ............. & 15 & 4 & 13.0 & .79 & 1.30 \\
\hline 160 & 22.1 & 116 & 130.0 & ......... & .......... & $\ldots \ldots$ & 16 & 4 & 11.0 & .81 & 1.10 \\
\hline 170 & 23.2 & 119 & 140.0 & & .......... & & 17 & 3 & 10.0 & .82 & 1.00 \\
\hline 180 & 24.1 & 123 & (3) & ........... & & $\ldots .$. & 18 & 4 & $\ldots \ldots \ldots$ & $\cdots \cdots$ & \\
\hline 190 & 25.1 & 126 & (?) & $\ldots \ldots \ldots$ & ......... & ..... & 19 & 3 & $\ldots \ldots$ & ....... & \\
\hline 200 & 26.0 & $\begin{array}{l}129 \\
132\end{array}$ & (?) & $\cdots$ & & & 20 & 3 & ...... & ...... & \\
\hline $\begin{array}{l}210 \\
220\end{array}$ & $\begin{array}{l}26.7 \\
27.4\end{array}$ & $\begin{array}{l}132 \\
135\end{array}$ & (i) & 63 & 24 & 13 & $\begin{array}{l}21 \\
22\end{array}$ & $\begin{array}{l}3 \\
3 \\
3\end{array}$ & … & $\because$ & \\
\hline 230 & 28.0 & 138 & (8) & & & & 23 & 3 & 然 & & \\
\hline
\end{tabular}

(8) OPPRESSED TREES.

[Average in Michigan.]

(36 trees.)

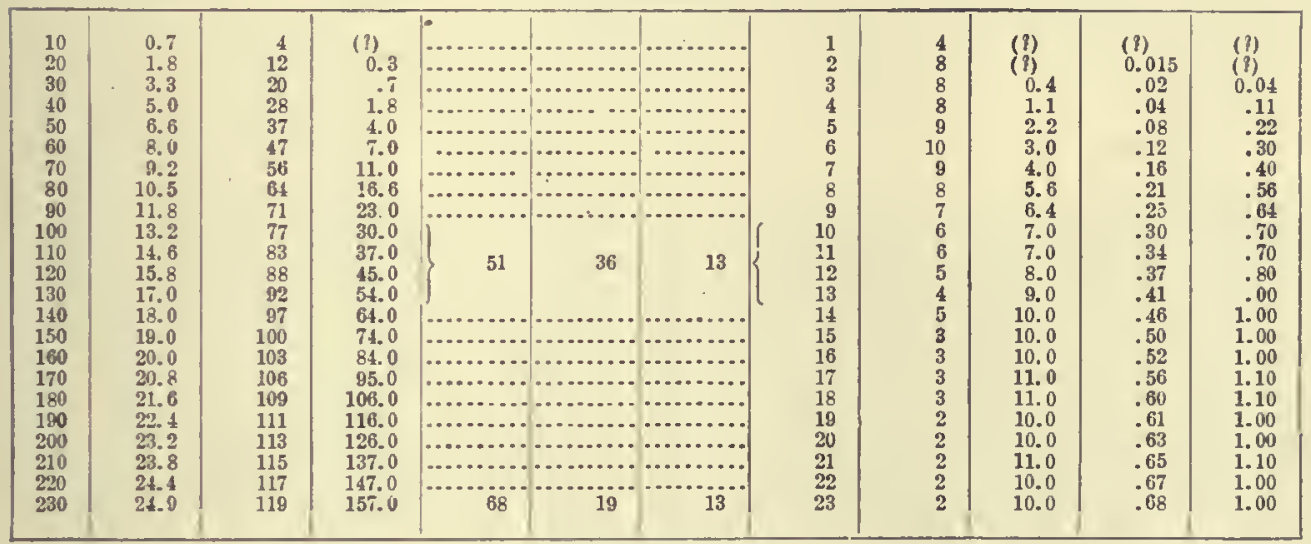

(9) DOMINAXT TREES.

[A rerage in Penpsylvania.]

(81 trees.)

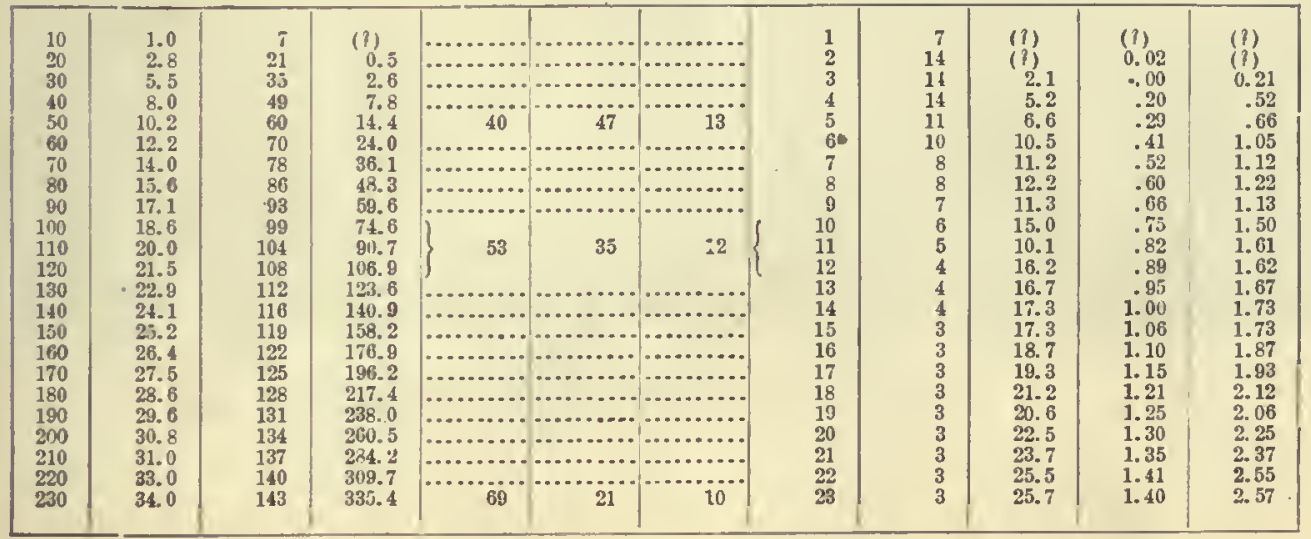


TABLE IV.-Dimensions, rolume, and rate of yrowth, by decades, etc.-Continued.

(A) OLD.GROWTII PINE-Continued.

(10) CODOMHANT TREES.

[A rerage in Penusylvania.]

(78 trees.)

\begin{tabular}{|c|c|c|c|c|c|c|c|c|c|c|c|}
\hline \multirow{2}{*}{ Age. } & \multirow{2}{*}{$\begin{array}{c}\text { Diametes } \\
\text { at lieight } \\
\text { of } 2 \text { leot } \\
\text { (wle hout } \\
\text { bark). }\end{array}$} & \multirow{2}{*}{$\begin{array}{l}\text { Total } \\
\text { lolghit } \\
\text { of tree. }\end{array}$} & \multirow{2}{*}{$\begin{array}{c}\text { Folnme } \\
\text { of aten } \\
\text { (withont } \\
\text { bark). }\end{array}$} & \multicolumn{3}{|c|}{$\begin{array}{l}\text { Relative per cent of total } \\
\text { rolume. }\end{array}$} & \multicolumn{3}{|c|}{ Periodic accretion. } & \multirow{2}{*}{$\begin{array}{l}\text { A rerago } \\
\text { aunual } \\
\text { accretion. }\end{array}$} & \multirow{2}{*}{$\begin{array}{c}\text { Current } \\
\text { annual } \\
\text { accrotion. }\end{array}$} \\
\hline & & & & $\begin{array}{l}\text { Heart- } \\
\text { wool. }\end{array}$ & Sapwood. & 33ark. & Decade. & Ieight. & Volume. & & \\
\hline Years. & Inches. & Feet. & Cubieft. & I'er cent. & Per cent. & Per cent. & & Fcet. & Cubic ft. & Cubic ft. & Oubie ft. \\
\hline $\begin{array}{l}10 \\
20 \\
30\end{array}$ & $\begin{array}{l}0.9 \\
2.3\end{array}$ & $\begin{array}{r}5 \\
16\end{array}$ & (i) & & & & $\frac{1}{2}$ & $\begin{array}{r}5 \\
11\end{array}$ & (?) & $\begin{array}{l}(f) \\
0.32\end{array}$ & (i) \\
\hline 30 & 4.0 & 28 & 1.8 & & & .... & 3 & 12 & 1.4 & .08 & 0.14 \\
\hline & & 39 & 4.8 & & ..... & ............ & 4 & 11 & 3.0 & .12 & .30 \\
\hline 50 & & & $\begin{array}{r}7.8 \\
11.1\end{array}$ & …..... & & ................ & $\begin{array}{l}5 \\
6\end{array}$ & $\stackrel{9}{8}$ & $\begin{array}{l}8.0 \\
3.3\end{array}$ & .15 & .30 \\
\hline 70 & $\begin{array}{r}9.3 \\
10.8\end{array}$ & $\begin{array}{l}56 \\
63\end{array}$ & 16.7 & (n........ & & . & 7 & $\frac{0}{7}$ & 5.6 & .24 & $\begin{array}{l}.33 \\
.50\end{array}$ \\
\hline 80 & 12. 0 & 69 & 23.3 & .......... & & & 8 & 6 & 6. 6 & .29 & .66 \\
\hline 90 & 13. 4 & 73 & 30.7 & & & 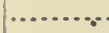 & 9 & 6 & $7 \cdot \frac{1}{8}$ & .34 & .74 \\
\hline 100 & 14.7 & 80 & 39.0 & & 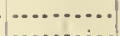 & ............. & 10 & $\begin{array}{l}5 \\
5\end{array}$ & $\begin{array}{l}8.3, \\
8.8\end{array}$ & .39 & .83 \\
\hline 110 & $\begin{array}{l}16.0 \\
17.3\end{array}$ & $\begin{array}{l}85 \\
90\end{array}$ & $\begin{array}{l}47.9 \\
57.9\end{array}$ & (............ & (.......... & ................. & $\begin{array}{l}11 \\
12\end{array}$ & $\begin{array}{l}5 \\
5\end{array}$ & 10.0 & 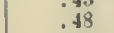 & 1.00 \\
\hline 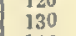 & $\begin{array}{l}17.3 \\
18.6\end{array}$ & 04 & $\begin{array}{l}31.0 \\
65.2\end{array}$ & …....... & & ............ & 13 & 4 & 7.3 & .50 & .73 \\
\hline 140 & 19.7 & 98 & & & & …....... & 14 & 4 & 11.7 & .55 & 1.17 \\
\hline & 20.7 & & & & . & ….... & $\begin{array}{l}15 \\
16\end{array}$ & 4 & $\begin{array}{l}12.0 \\
12.9\end{array}$ & $\begin{array}{l}.09 \\
.03\end{array}$ & $\begin{array}{l}1.20 \\
1.29\end{array}$ \\
\hline $\begin{array}{l}160 \\
170\end{array}$ & $\begin{array}{l}21.8 \\
22.7\end{array}$ & $\begin{array}{l}106 \\
100\end{array}$ & $\begin{array}{l}101.8 \\
115.3\end{array}$ & n.............. & & n.......... & 17 & 3 & 13.5 & .68 & 1. 35 \\
\hline 180 & 23.5 & & & ............. & ............ & ............ & 18 & 3 & 13.9 & .72 & 1.39 \\
\hline 190 & 24.3 & & & ............. & & ............ & 19 & 2 & 13.7 & .75 & 1.37 \\
\hline 20 & & 11 & & ............ & $\cdots$ & ............ & 20 & 2 & 9.8 & .76 & .98 \\
\hline 21 & 25.8 & 11 & & …......... & & … & 21. & 2 & $\begin{array}{l}12.8 \\
13.8\end{array}$ & .78 & 1.28 \\
\hline $\begin{array}{l}220 \\
230\end{array}$ & $\begin{array}{l}26.5 \\
27.3\end{array}$ & $\begin{array}{l}120 \\
122\end{array}$ & $\begin{array}{l}179.3 \\
195.0\end{array}$ & $\cdots \cdots \ldots$ & $2 j$ & 10 & $\frac{22}{23}$ & ${ }_{2}^{2}$ & $\begin{array}{l}13.8 \\
15.7\end{array}$ & .81 & $\begin{array}{l}1.38 \\
1.57\end{array}$ \\
\hline & & & & & & & & & & & \\
\hline
\end{tabular}

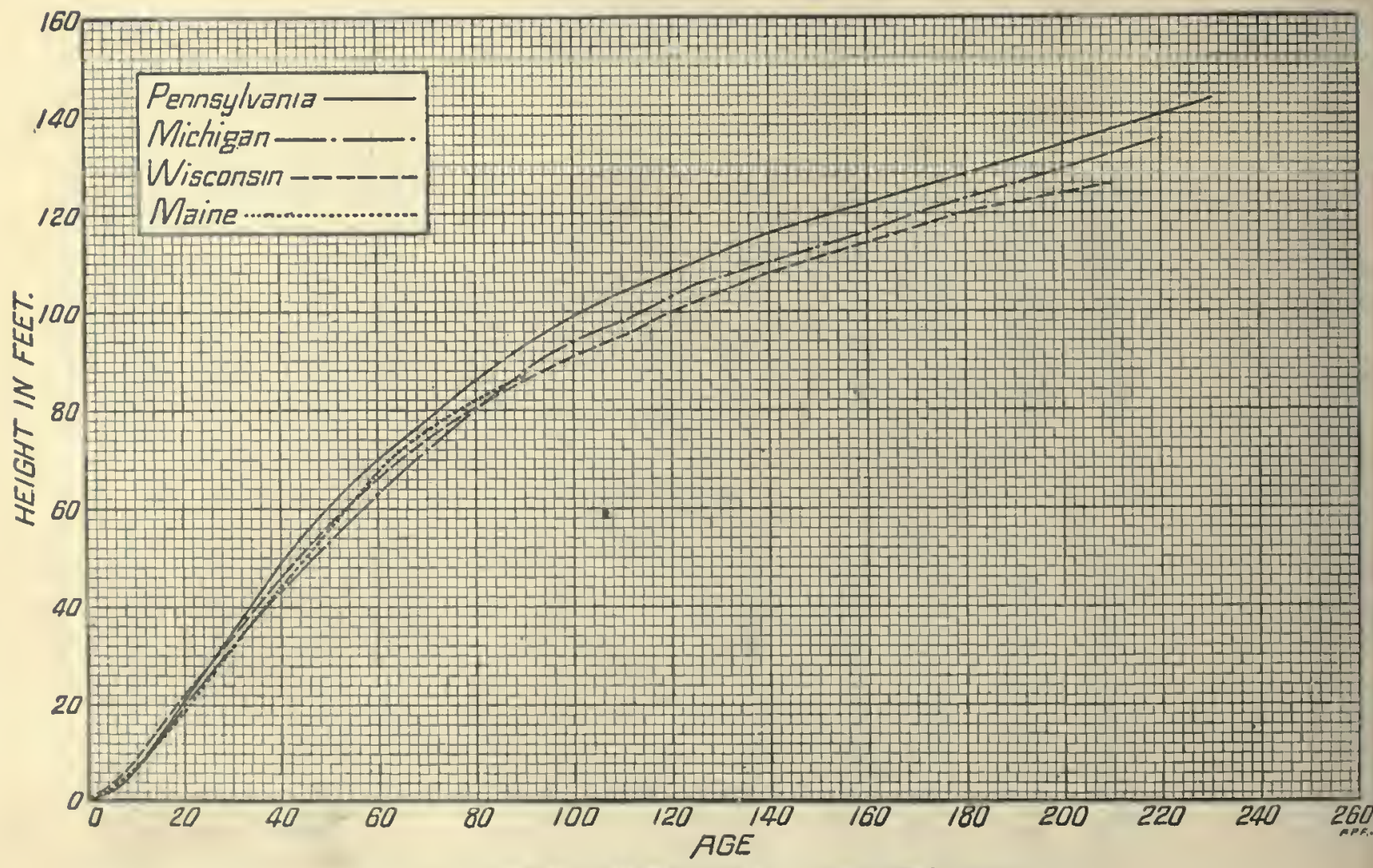

Fio. 24.-Diagram slrowing helght growth of dominant trees, by States. 


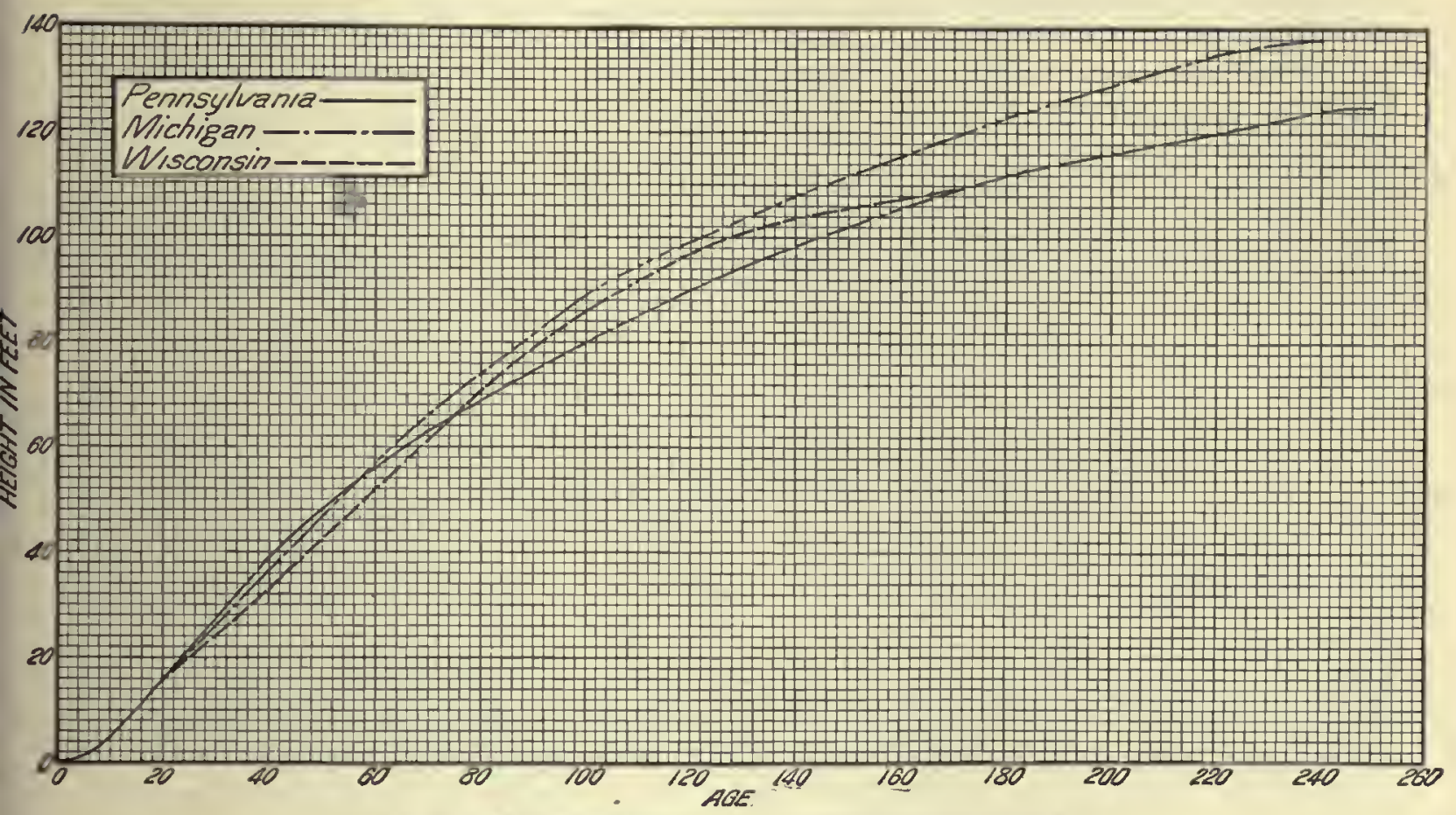

Fto. 25.=Diagram showing height growth of codominant troes, by States.

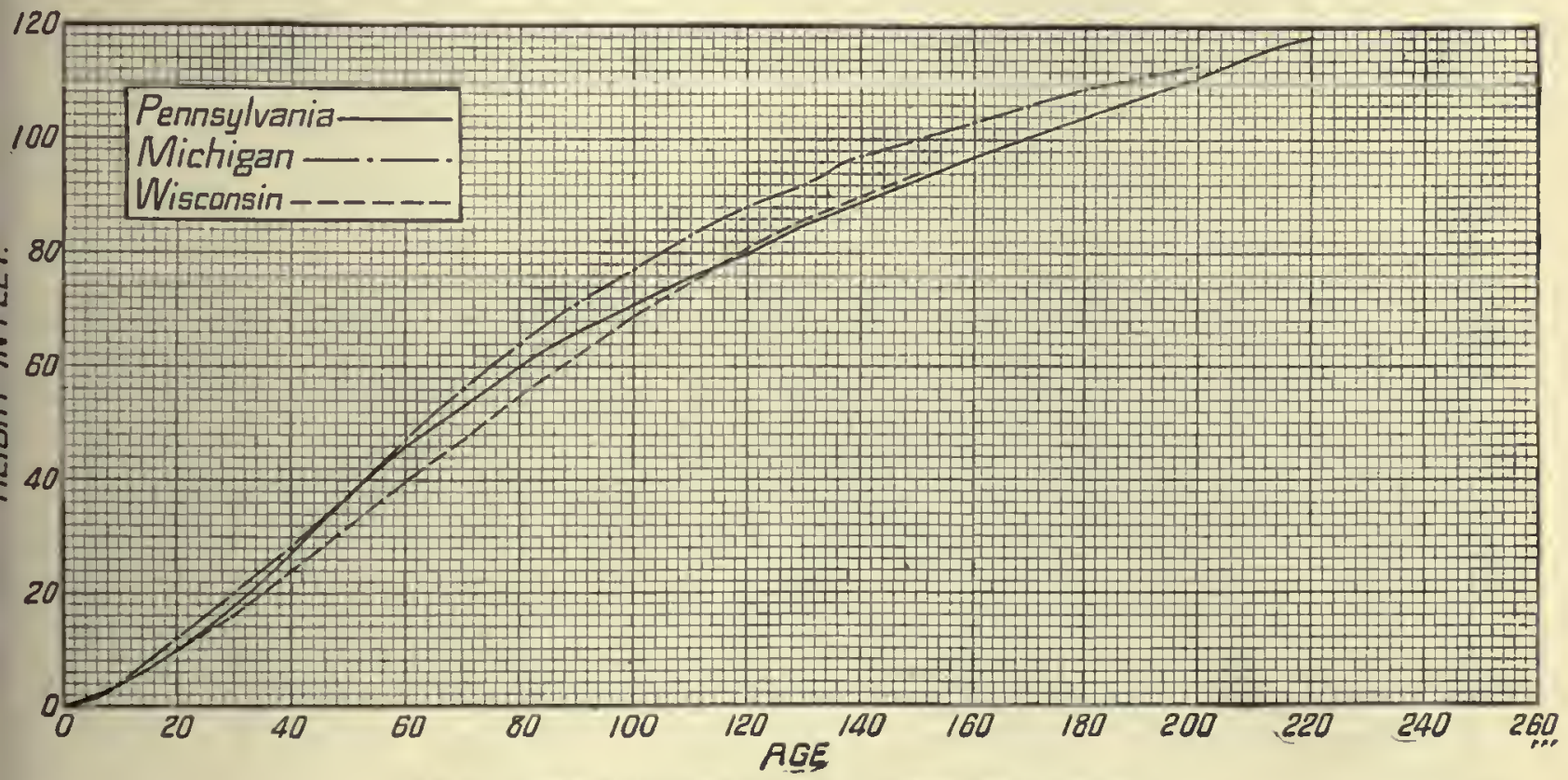

F'tc. 26.-Diagram showing height growth of oppressed trees, by States. 
THE WHITE I'INE.

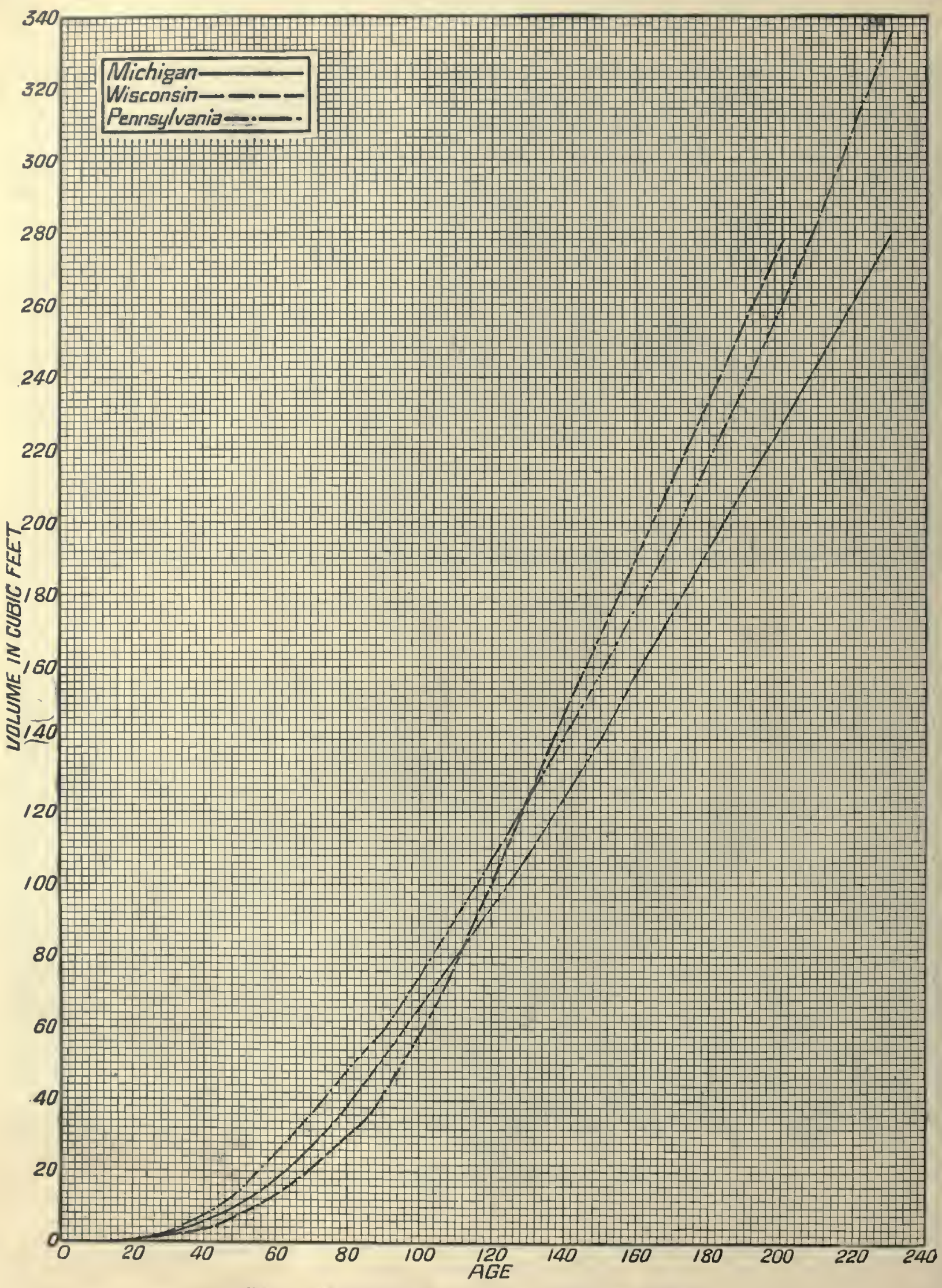

F16. 27.-Diagram showing volume growth of domfuant trees, by States. 
TABLES OF MEASUREMENTS.

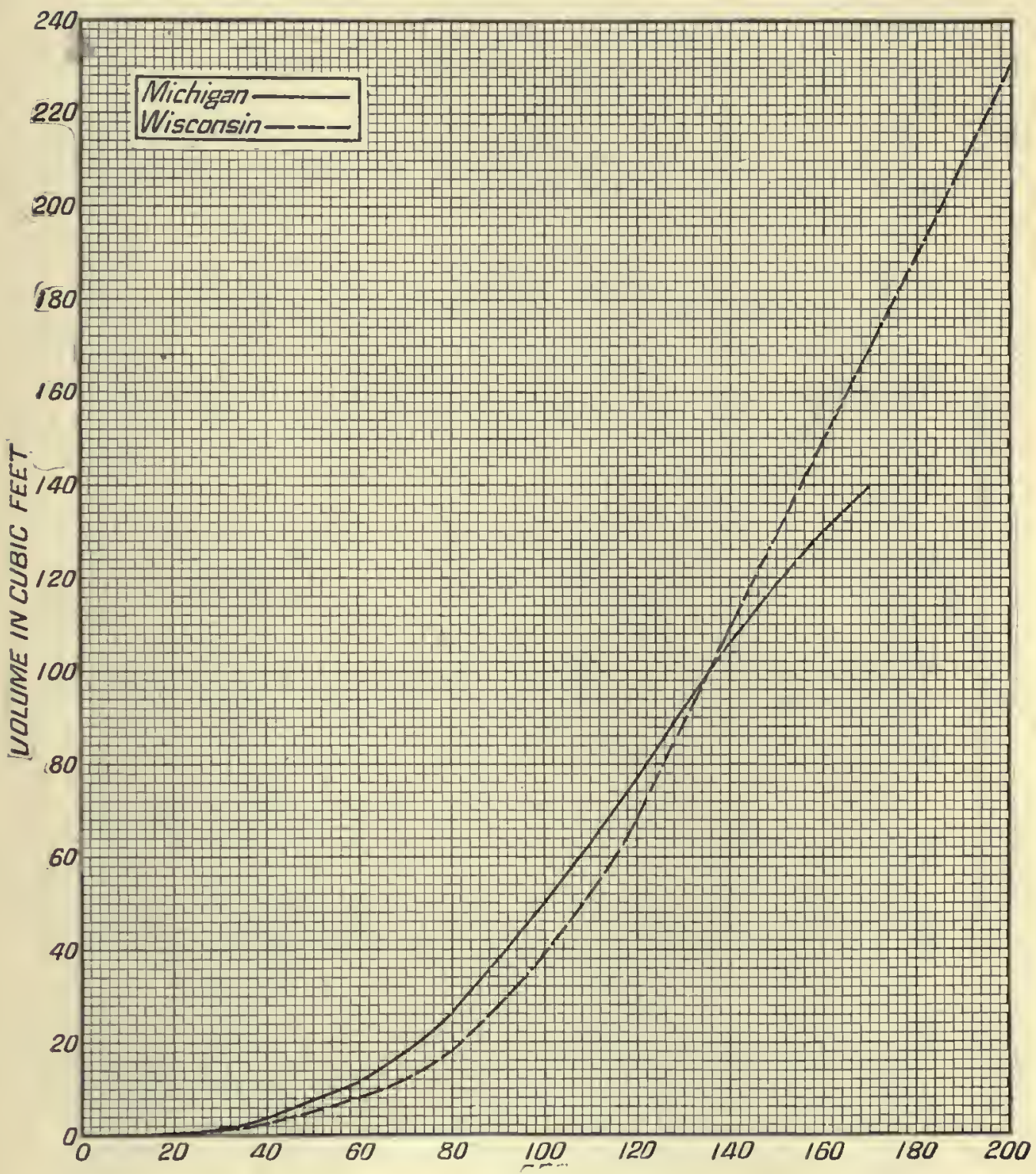

Furb. 28.-Dixgran showing volume growth of codominant trees, by States. 


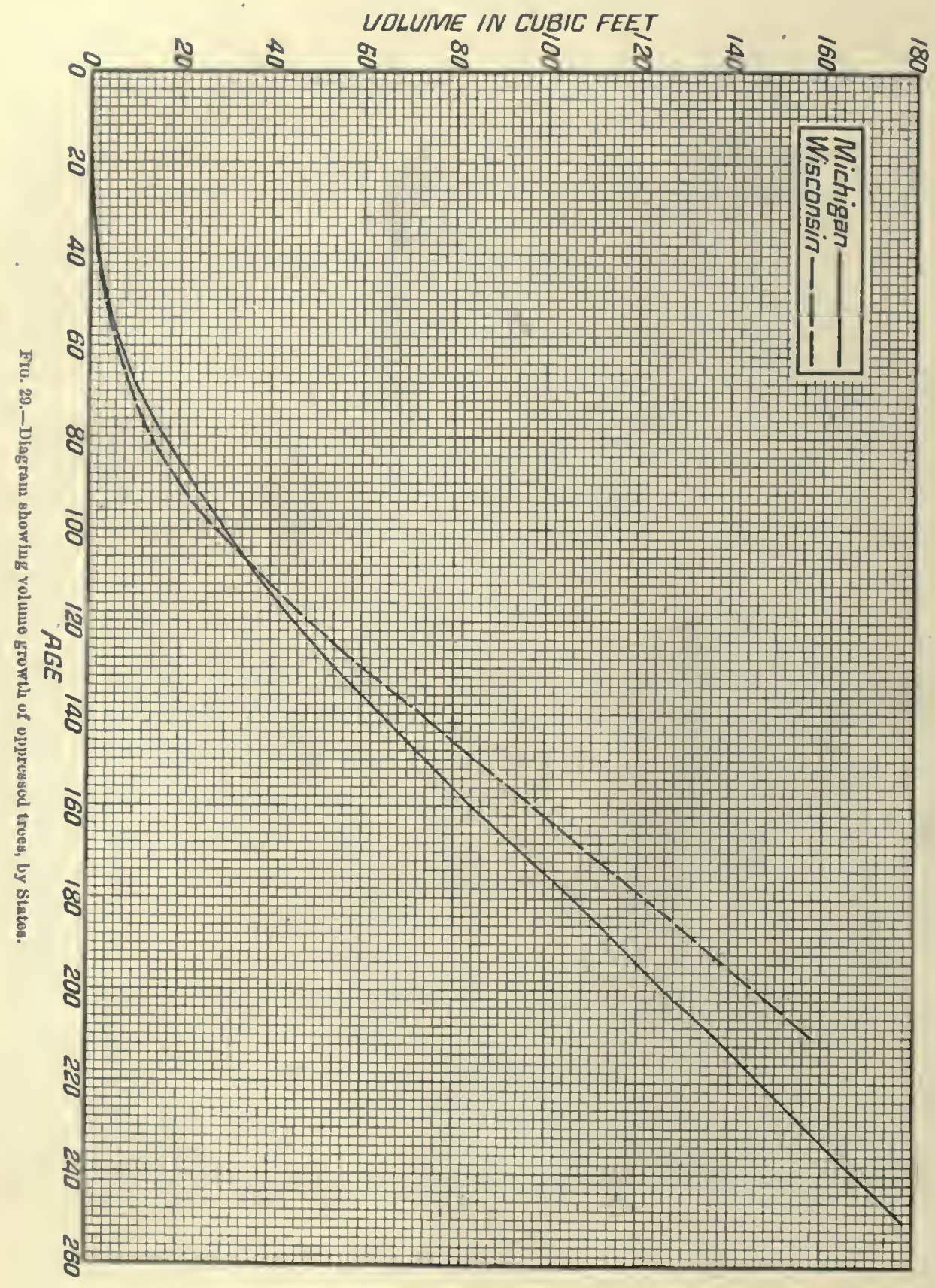


TABLES OF MEASUREMENTS.

TABLE IV.-Dimensions, rolume, and rate of growth, by decades, etc.-Continued.

(B) SECOND-GROWTH PINE.

(11) SITR $a:$ York COUNTY, Mr. DOMNANT TREES.

(11 trees.)

\begin{tabular}{|c|c|c|c|c|c|c|c|c|c|c|c|}
\hline \multirow{2}{*}{ Age. } & \multirow{2}{*}{$\begin{array}{l}\text { Diameter } \\
\text { at heigbt } \\
\text { of } 2 \text { foet } \\
\text { (without } \\
\text { bark). }\end{array}$} & \multirow{2}{*}{$\begin{array}{c}\text { Total } \\
\text { height } \\
\text { of tree. }\end{array}$} & \multirow{2}{*}{$\begin{array}{l}\text { Volnme } \\
\text { of stem } \\
\text { (writhout } \\
\text { bark). }\end{array}$} & \multicolumn{3}{|c|}{$\begin{array}{c}\text { Relative per cent of total } \\
\text { volumo. }\end{array}$} & \multicolumn{3}{|c|}{ Perfodic accretion. } & \multirow{2}{*}{$\begin{array}{l}\text { Average } \\
\text { annual } \\
\text { accretion. }\end{array}$} & \multirow{2}{*}{$\begin{array}{l}\text { Current } \\
\text { annual } \\
\text { accretion. }\end{array}$} \\
\hline & & & & $\begin{array}{l}\text { Heart- } \\
\text { wood. }\end{array}$ & Sapwood. & Bark. & Decade. & Height. & Volume. & & \\
\hline $\begin{array}{c}\text { Years. } \\
10 \\
20 \\
30 \\
40 \\
50 \\
60 \\
70 \\
80 \\
90\end{array}$ & $\begin{array}{r}\text { Inehes. } \\
2.1 \\
5.7 \\
10.2 \\
14.2 \\
18.6 \\
22.1 \\
24.6 \\
26.2 \\
\end{array}$ & $\begin{array}{c}\text { Feet. } \\
7 \frac{1}{2} \\
21 \\
37 \\
491 \\
601 \\
69 \\
77 \\
85 \\
90\end{array}$ & $\begin{array}{r}\text { Cubie ft. } \\
0.5 \\
2.1 \\
6.5 \\
17.0 \\
34.0 \\
60.3 \\
82.2 \\
100.0 \\
(?)\end{array}$ & \begin{tabular}{r} 
Per cent. \\
\hdashline$\ldots$ \\
\hdashline \\
\hdashline \\
58 \\
to \\
60
\end{tabular} & \begin{tabular}{c} 
Per cent. \\
\hdashline$\ldots \ldots$ \\
\hdashline$\ldots$ \\
\hdashline
\end{tabular} & \begin{tabular}{r} 
Per cent. \\
\hdashline$\cdots$ \\
\hdashline$\cdots$ \\
\hdashline \\
\hdashline \\
$\cdots$ \\
10 \\
to \\
11
\end{tabular} & $\begin{array}{l}1 \\
2 \\
3 \\
4 \\
5 \\
6 \\
7 \\
8 \\
9\end{array}$ & $\begin{array}{c}\text { Feet. } \\
7 \frac{1}{12} \\
13 \frac{1}{2} \\
16 \\
12 \\
11 \\
8 \frac{1}{2} \\
8 \\
8 \\
5\end{array}$ & $\begin{array}{r}\text { Cubic ft. } \\
0.9 \\
1.6 \\
4.4 \\
10.5 \\
17.0 \\
26.3 \\
21.9 \\
17.8\end{array}$ & $\begin{array}{c}\text { Oubic ft. } \\
0.05 \\
.10 \\
.21 \\
.42 \\
.68 \\
1.00 \\
1.17 \\
1.25\end{array}$ & $\begin{array}{c}\text { Cubic ft. } \\
0.05 \\
.16 \\
.44 \\
1.05 \\
1.70 \\
2.63 \\
2.19 \\
1.78\end{array}$ \\
\hline
\end{tabular}

CODOMLNANT TREES.

(33 trees.)

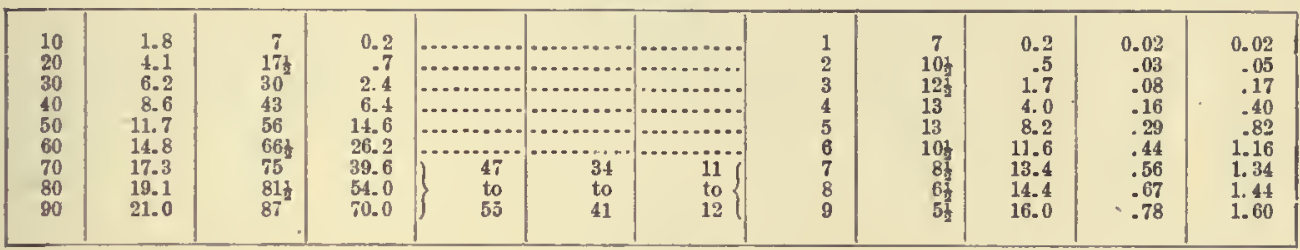

OPPRESSED TREES.

(12 trees.)

\begin{tabular}{|c|c|c|c|c|c|c|c|c|c|c|c|}
\hline $\begin{array}{l}10 \\
20 \\
30 \\
40 \\
50 \\
60 \\
70 \\
80 \\
90\end{array}$ & $\begin{array}{r}1.5 \\
4.5 \\
7.2 \\
9.5 \\
11.2 \\
12.8 \\
14.0 \\
15.0 \\
15.4\end{array}$ & $\begin{array}{c}6 \\
18 \\
30 \\
41 \frac{1}{2} \\
53 \\
664 \\
75 \frac{1}{2} \\
794 \\
83\end{array}$ & $\begin{array}{l}\text { (?) } \\
0.7 \\
2.8 \\
6.6 \\
12.3 \\
19.0 \\
26.0 \\
32.4 \\
39.0\end{array}$ & 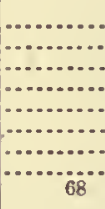 & 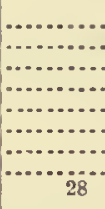 & 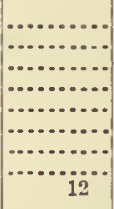 & $\begin{array}{l}1 \\
2 \\
3 \\
4 \\
5 \\
6 \\
7 \\
8 \\
9\end{array}$ & $\begin{array}{c}6 \\
12 \\
12 \\
11 \frac{1}{13} \\
11 \frac{1}{2} \\
13 \frac{1}{2} \\
9 \\
4 \\
4\end{array}$ & $\begin{array}{l}(?) \\
(?) \\
2.1 \\
3.8 \\
5.7 \\
6.7 \\
7.0 \\
6.4 \\
6.6\end{array}$ & $\begin{array}{l}(?) \\
0.03 \\
.09 \\
.16 \\
.25 \\
.31 \\
.36 \\
.40 \\
.43\end{array}$ & $\begin{array}{l}(7) \\
(7) \\
0.21 \\
.38 \\
.57 \\
.67 \\
.70 \\
.64 \\
.66\end{array}$ \\
\hline
\end{tabular}

(12) Srte c: YoRK CountY, ME.

DOMNANT TREES.

(10 trees.)

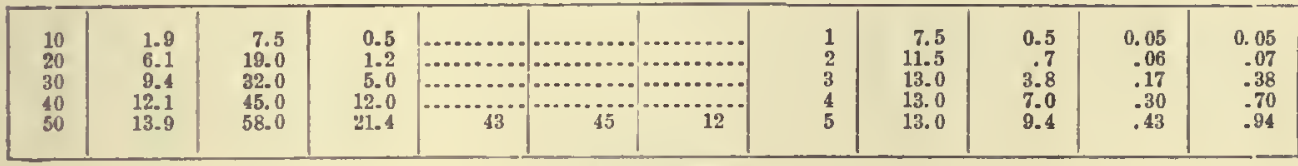

DOMINANT TREES.

(8 trees.)

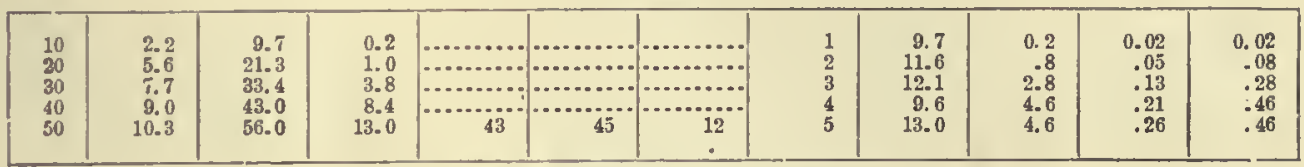

(13) Massachugetts and NeW Hasprhire. DOHINANT TREES.

(12 trees.)

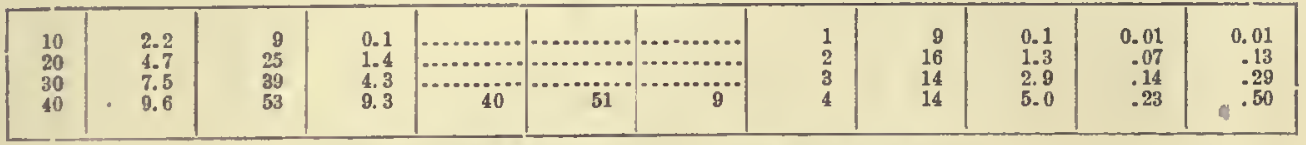

(A verago in Massacbusette and New Hampshire of 12 trees.'

\begin{tabular}{|c|c|c|c|c|c|c|c|c|c|c|c|}
\hline $\begin{array}{l}10 \\
20 \\
30 \\
40\end{array}$ & $\begin{array}{l}2.5 \\
5.4 \\
7.8 \\
0.4\end{array}$ & $\begin{array}{l}10 \\
33 \\
48 \\
58\end{array}$ & $\begin{array}{r}0.5 \\
2.0 \\
6.5 \\
12.5\end{array}$ & 48 & 46 & $\left(\begin{array}{ll}\cdots \\
\cdots\end{array}\right.$ & $\begin{array}{l}1 \\
2 \\
3 \\
4\end{array}$ & $\begin{array}{l}10 \\
23 \\
15 \\
10\end{array}$ & $\begin{array}{l}0.5 \\
1.5 \\
4.5 \\
6.0\end{array}$ & $\begin{array}{l}0.05 \\
.10 \\
.22 \\
.31\end{array}$ & $\begin{array}{r}0.05 \\
.15 \\
.45 \\
.60\end{array}$ \\
\hline
\end{tabular}


TABLE IV.-Dimensions, rolnme, and rate of grouth, by decades, eto.-Continued. (B) SECOXD-GRoWTH P1NE-Contlnned.

(14) Sitz g: Clearfielo Codsty, 'M. DONINANT TREES.

(14 trees.)

\begin{tabular}{|c|c|c|c|c|c|c|c|c|c|c|c|}
\hline \multirow{2}{*}{ Ago. } & \multirow{2}{*}{$\begin{array}{l}\text { Dlameter } \\
\text { at helght } \\
\text { of } 21 \text { feet } \\
\text { (wifbout } \\
\text { bark). }\end{array}$} & \multirow{2}{*}{$\begin{array}{l}\text { Total } \\
\text { height } \\
\text { of tree. }\end{array}$} & \multirow{2}{*}{$\begin{array}{l}\text { Tolnme } \\
\text { of sten. } \\
\text { (without } \\
\text { bark). }\end{array}$} & \multicolumn{3}{|c|}{$\begin{array}{l}\text { Relativo per cent of total } \\
\text { volune. }\end{array}$} & \multicolumn{3}{|c|}{ Perlodle accretlon. } & \multirow{2}{*}{$\begin{array}{l}\text { Arerage } \\
\text { anaual } \\
\text { eccretion. }\end{array}$} & \multirow{2}{*}{$\begin{array}{l}\text { Cnrrent } \\
\text { annual } \\
\text { aceretion. }\end{array}$} \\
\hline & & & & $\begin{array}{l}\text { Heart- } \\
\text { wood. }\end{array}$ & Sapwood. & Jark. & Docade. & Height. & Volume. & & \\
\hline $\begin{array}{c}\text { Teara. } \\
10 \\
20 \\
30\end{array}$ & $\begin{array}{r}\text { Inches. } \\
2.6 \\
7.3 \\
13.2\end{array}$ & $\begin{array}{c}\text { Feet. } \\
9 \\
27 \\
41\end{array}$ & $\begin{array}{c}\text { Cubic ft. } \\
0.1 \\
3.0 \\
13.5\end{array}$ & \begin{tabular}{c} 
Per cent. \\
\hdashline$\ldots . .$. \\
\hdashline$\ldots$
\end{tabular} & 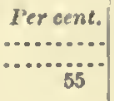 & \begin{tabular}{c} 
Per cent. \\
\hdashline$\ldots$ \\
\hdashline
\end{tabular} & $\begin{array}{l}1 \\
2 \\
3\end{array}$ & $\begin{array}{c}\text { Feet. } \\
9 \\
18 \\
14.1\end{array}$ & $\begin{array}{c}\text { Cubie } r \text {. } \\
0.1 \\
2.9 \\
10.5\end{array}$ & $\begin{array}{c}\text { Cubic } f \text {. } \\
0.01 \\
.15 \\
.45\end{array}$ & $\begin{array}{c}\text { Cubic ft. } \\
0.01 \\
.29 \\
1.05\end{array}$ \\
\hline
\end{tabular}

CODOMIXANT TREES.

(5 trees.)

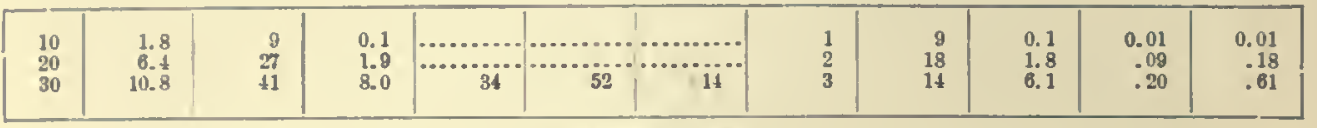

OPPRESSED TREES.

(3 trees.)

\begin{tabular}{|c|c|c|c|c|c|c|c|c|c|c|c|}
\hline $\begin{array}{l}10 \\
20 \\
30\end{array}$ & $\begin{array}{r}1.6 \\
4.1 \\
6.3\end{array}$ & $\begin{array}{r}75 \\
25\end{array}$ & $\begin{array}{r}0.04 \\
.60 \\
2.90\end{array}$ & 27 & 60 & (n............ & $\begin{array}{l}1 \\
2 \\
3\end{array}$ & $\begin{array}{r}7 \\
18 \\
10\end{array}$ & $\begin{array}{r}0.04 \\
.56 \\
2.30\end{array}$ & $\begin{array}{l}0.004 \\
.03 \\
.10\end{array}$ & $\begin{array}{r}0.004 \\
.056 \\
.230\end{array}$ \\
\hline
\end{tabular}

SCPPRESSED TREES.

(3 treos.)

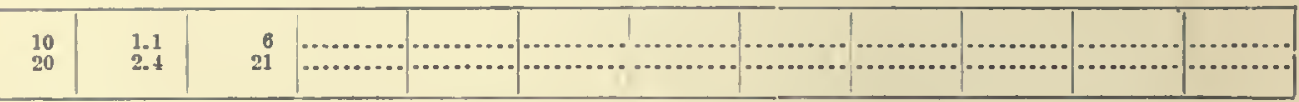

(15) SITE i: Forest CotNTy, PA. DOMISAXT TREHS.

(2 trees.)

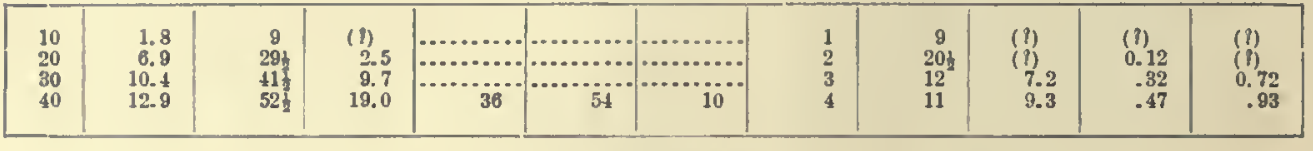

DOMINANT THEES.

(10 trees.)

\begin{tabular}{|c|c|c|c|c|c|c|c|c|c|c|c|}
\hline $\begin{array}{l}10 \\
20 \\
30 \\
10\end{array}$ & $\begin{array}{r}2.1 \\
5.9 \\
8.7 \\
11.0\end{array}$ & $\begin{array}{l}9 \\
27 \\
417 \\
53\end{array}$ & $\begin{array}{r}\text { (1) } \\
1.8 \\
6.0 \\
13.0\end{array}$ & $\ldots$ & 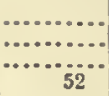 & …........ & $\begin{array}{l}1 \\
2 \\
3 \\
4\end{array}$ & $\begin{array}{c}9 \\
18 \\
11 \frac{1}{12} \\
114\end{array}$ & $\begin{array}{l}(?) \\
(8) \\
\$ .2 \\
7.0\end{array}$ & $\begin{array}{l}\text { (l) } \\
0.09 \\
.20 \\
.32\end{array}$ & $\begin{array}{l}(l) \\
(1) \\
0.42 \\
.70\end{array}$ \\
\hline
\end{tabular}

CODONIXANP TREES.

(10 trees.)

\begin{tabular}{|c|c|c|c|c|c|c|c|c|c|c|c|}
\hline $\begin{array}{l}10 \\
20 \\
30 \\
40\end{array}$ & $\begin{array}{l}1.9 \\
4.8 \\
6.8 \\
8.5\end{array}$ & $\begin{array}{r}9 \\
27 \\
40 \\
52\end{array}$ & $\begin{array}{l}\text { (1) } \\
1.3 \\
4.7 \\
8.8\end{array}$ & ${ }_{36}$ & 58 & 1i & $\begin{array}{l}1 \\
2 \\
3 \\
4\end{array}$ & $\begin{array}{r}9 \\
18 \\
13 \\
12\end{array}$ & $\begin{array}{l}\text { (i) } \\
(?) \\
3.4 \\
5.1\end{array}$ & $\begin{array}{l}(1) \\
0.06 \\
.16 \\
.24\end{array}$ & $\begin{array}{l}\text { (1) } \\
(1) \\
0.34 \\
.51\end{array}$ \\
\hline
\end{tabular}

OPPREESED TRKES.

(5 trees.)

\begin{tabular}{|c|c|c|c|c|c|c|c|c|c|c|c|}
\hline $\begin{array}{l}10 \\
20 \\
30 \\
10\end{array}$ & $\begin{array}{l}2.1 \\
4.2 \\
5.7 \\
6.6\end{array}$ & $\begin{array}{r}7 \\
293 \\
30 \\
44\end{array}$ & $\begin{array}{l}\text { (f) } \\
1.0 \\
2.7 \\
4.8\end{array}$ & 34 & $\ldots$ & …............. & $\begin{array}{l}1 \\
2 \\
3 \\
4\end{array}$ & $\begin{array}{r}7 \\
16 \\
13 \\
8\end{array}$ & $\begin{array}{l}\text { (?) } \\
\text { (?) } \\
1.7 \\
2.1\end{array}$ & $\begin{array}{l}\text { (?) } \\
0.05 \\
.09 \\
.12\end{array}$ & $\begin{array}{r}0.17 \\
21\end{array}$ \\
\hline
\end{tabular}

(16) Sitz 6: LCterNe Cocsty, PA.

DOMIXANT TREES.

(9 trees.)

\begin{tabular}{|c|c|c|c|c|c|c|c|c|c|c|c|}
\hline $\begin{array}{l}10 \\
20 \\
30 \\
40 \\
50\end{array}$ & $\begin{array}{r}1.0 \\
3.2 \\
5.9 \\
8.7 \\
11.5\end{array}$ & $\begin{array}{c}6 \\
19 \\
33 \\
44 \frac{1}{2} \\
51\end{array}$ & $\begin{array}{r}\text { (1) } \\
0.4 \\
2.5 \\
7.2 \\
14.0\end{array}$ & 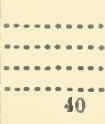 & ${ }_{47}$ & $\begin{array}{c}\cdots \ldots \ldots \\
\cdots \ldots \ldots \ldots \\
\cdots\end{array}$ & $\begin{array}{l}1 \\
2 \\
3 \\
4 \\
5\end{array}$ & $\begin{array}{c}6 \\
13 \\
14 \\
11 \\
63\end{array}$ & $\begin{array}{l}(1) \\
(1) \\
2.1 \\
4.7 \\
6.8\end{array}$ & $\begin{array}{l}\text { (P) } \\
0.02 \\
.08 \\
.18 \\
.28\end{array}$ & $\begin{array}{l}\text { (I) } \\
\text { (I) } \\
0.21 \\
.47 \\
.68\end{array}$ \\
\hline
\end{tabular}


TABLES OF M EASUREMENTS.

TABLE V.-Growth of diameter and cross-section area at various heights from the ground.

(1) AVERAGE THROEGHOUT THE RANGE.

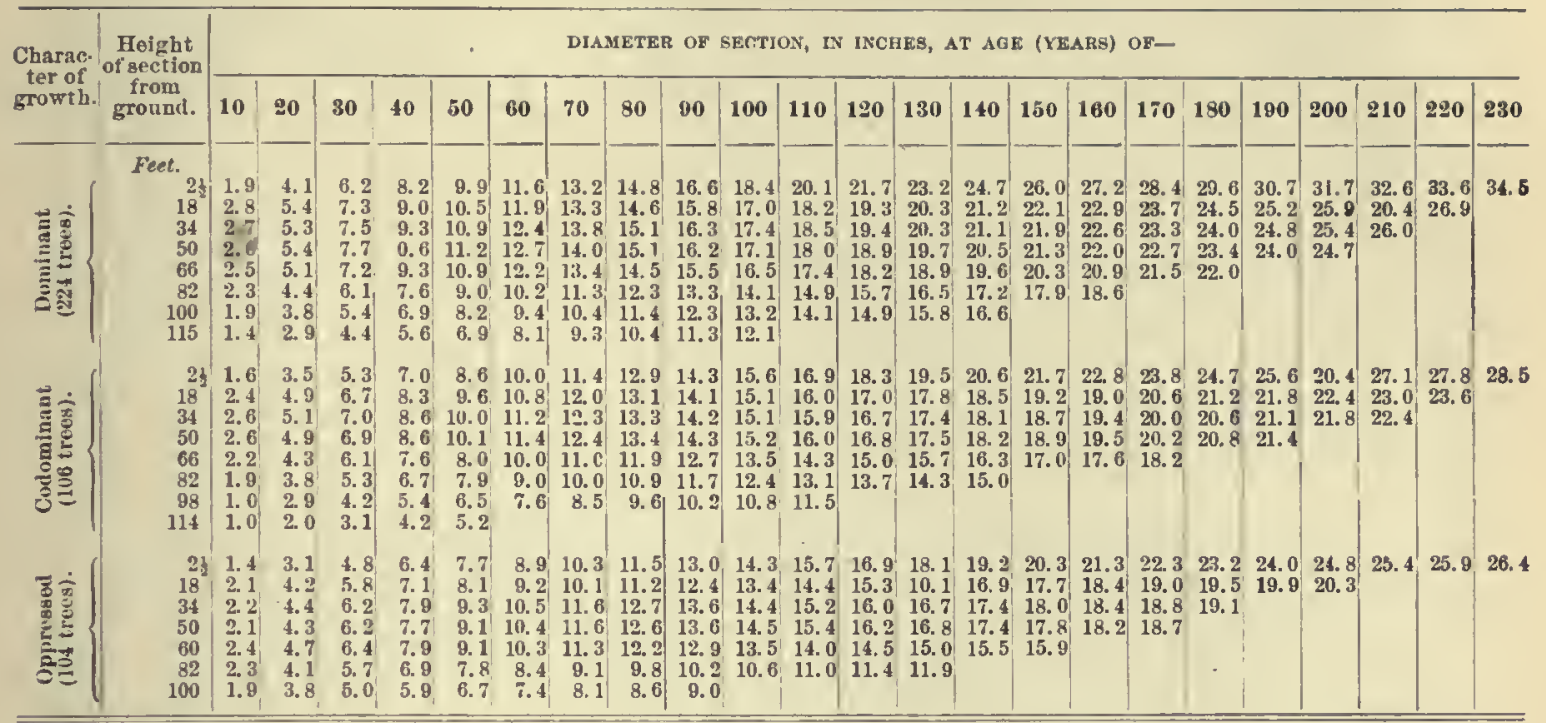

\begin{tabular}{|c|c|c|c|c|c|c|c|c|c|c|c|c|c|c|c|c|c|c|c|c|c|c|c|c|}
\hline \multirow{2}{*}{$\begin{array}{c}\text { Charac- } \\
\text { ter of } \\
\text { growth. }\end{array}$} & \multirow{2}{*}{$\begin{array}{l}\text { Height } \\
\text { of section } \\
\text { from } \\
\text { ground. }\end{array}$} & \multicolumn{23}{|c|}{ DIAMETER ACCRETION, IN INCHES, FOR DECAUES- } \\
\hline & & 1 & $\mathbf{z}$ & 3 & 4 & 5 & 6 & 7 & $\mathbf{8}$ & $\mathbf{9}$ & 10 & 11 & 12 & 13 & 14 & 15 & 16 & 17 & 18 & 19 & $\mathbf{2 0}$ & 21 & 22 & 23 \\
\hline 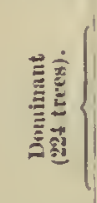 & $\begin{array}{r}\text { Feet. } \\
21 \\
18 \\
34 \\
50 \\
66 \\
82 \\
100 \\
115\end{array}$ & $\begin{array}{l}1.9 \\
2.8 \\
2.7 \\
2.6 \\
2.5 \\
2.3 \\
1.9 \\
1.4\end{array}$ & $\begin{array}{l}2.2 \\
2.0 \\
2.6 \\
2.8 \\
2.6 \\
2.1 \\
1.9 \\
1.5\end{array}$ & $\begin{array}{l}2.1 \\
1.9 \\
2.2 \\
2.3 \\
2.1 \\
1.7 \\
1.6 \\
1.5\end{array}$ & $\begin{array}{l}2.0 \\
1.7 \\
1.8 \\
1.9 \\
2.1 \\
1.5 \\
1.5 \\
1.2\end{array}$ & \begin{tabular}{l|}
1.7 \\
1.5 \\
1.6 \\
1.6 \\
1.6 \\
1.4 \\
1.3 \\
1.3
\end{tabular} & $\begin{array}{l}1.7 \\
1.4 \\
1.5 \\
1.5 \\
1.3 \\
1.2 \\
1.2 \\
1.2\end{array}$ & \begin{tabular}{l|}
1.6 \\
1.4 \\
1.4 \\
1.3 \\
1.2 \\
1.1 \\
1.0 \\
1.2
\end{tabular} & \begin{tabular}{l|}
1.6 \\
1.3 \\
1.3 \\
1.1 \\
1.1 \\
1.0 \\
1.0 \\
1.1
\end{tabular} & $\begin{array}{l}1.8 \\
1.2 \\
1.2 \\
1.1 \\
1.0 \\
1.0 \\
0.9 \\
0.9\end{array}$ & $\begin{array}{l}1.8 \\
1.2 \\
1.1 \\
0.9 \\
1.0 \\
0.8 \\
0.9 \\
0.8\end{array}$ & $\begin{array}{l}1.7 \\
1.2 \\
1.1 \\
0.9 \\
0.9 \\
0.8 \\
0.9\end{array}$ & $\begin{array}{l}1.6 \\
1.1 \\
0.9 \\
0.9 \\
0.8 \\
0.8 \\
0.8\end{array}$ & $\begin{array}{l}1.6 \\
1.0 \\
0.9 \\
0.8 \\
0.7 \\
0.8 \\
0.9\end{array}$ & \begin{tabular}{l|l}
1.5 \\
0.9 \\
0.8 \\
0.8 \\
0.7 \\
0.7 \\
0.8
\end{tabular} & $\begin{array}{l}1.3 \\
0.9 \\
0.8 \\
0.8 \\
0.7 \\
0.7\end{array}$ & $\begin{array}{l}1.2 \\
0.8 \\
0.7 \\
0.7 \\
0.6 \\
0.7\end{array}$ & $\begin{array}{l}1.2 \\
0.8 \\
0.7 \\
0.7 \\
0.6\end{array}$ & $\begin{array}{l}1.2 \\
0.8 \\
0.7 \\
0.7 \\
0.5\end{array}$ & \begin{tabular}{l|}
1.1 \\
0.7 \\
0.8 \\
0.6
\end{tabular} & $\begin{array}{l}1.0 \\
0.7 \\
0.6 \\
0.7\end{array}$ & $\begin{array}{l}0.9 \\
0.5 \\
0.6\end{array}$ & $\begin{array}{l}1.0 \\
0.5\end{array}$ & 0.9 \\
\hline 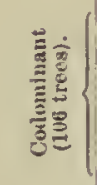 & $\begin{array}{r}21 \\
18 \\
34 \\
50 \\
66 \\
82 \\
98 \\
114\end{array}$ & $\begin{array}{l}1.6 \\
2.4 \\
2.6 \\
2.6 \\
2.2 \\
1.9 \\
1.6 \\
1.0\end{array}$ & $\begin{array}{l}1.9 \\
2.5 \\
2.5 \\
2.3 \\
2.1 \\
1.9 \\
1.3 \\
1.0\end{array}$ & $\begin{array}{l}1.8 \\
1.8 \\
1.9 \\
2.0 \\
1.8 \\
1.5 \\
1.3 \\
1.1\end{array}$ & $\begin{array}{l}1.7 \\
1.6 \\
1.6 \\
1.7 \\
1.5 \\
1.4 \\
1.2 \\
1.1\end{array}$ & \begin{tabular}{l|}
1.6 \\
1.3 \\
1.4 \\
1.5 \\
1.2 \\
1.2 \\
1.1 \\
1.0
\end{tabular} & $\begin{array}{l}1.4 \\
1.2 \\
1.2 \\
1.3 \\
1.1 \\
1.1 \\
1.1\end{array}$ & $\begin{array}{l}1.4 \\
1.2 \\
1.1 \\
1.0 \\
1.0 \\
1.0 \\
0.9\end{array}$ & $\begin{array}{l}1.5 \\
1.1 \\
1.0 \\
1.0 \\
0.9 \\
0.9 \\
1.1\end{array}$ & $\begin{array}{l}1.4 \\
1.0 \\
0.9 \\
0.9 \\
0.8 \\
0.8 \\
0.6\end{array}$ & $\begin{array}{l}1.3 \\
1.0 \\
0.9 \\
0.9 \\
0.8 \\
0.7 \\
0.6\end{array}$ & $\begin{array}{l}1.3 \\
0.9 \\
0.8 \\
0.8 \\
0.8 \\
0.7 \\
0.7\end{array}$ & $\begin{array}{l}1.4 \\
1.0 \\
0.8 \\
0.8 \\
0.7 \\
0.6\end{array}$ & $\begin{array}{l}1.2 \\
0.8 \\
0.7 \\
0.7 \\
0.7 \\
0.6\end{array}$ & $\begin{array}{l}1.1 \\
0.7 \\
0.7 \\
0.7 \\
0.6 \\
0.7\end{array}$ & $\begin{array}{l}1.1 \\
0.7 \\
0.0 \\
0.7 \\
0.7\end{array}$ & $\begin{array}{l}1.1 \\
0.7 \\
0.7 \\
0.6 \\
0.6\end{array}$ & $\begin{array}{l}1.0 \\
0.7 \\
0.6 \\
0.7 \\
0.6\end{array}$ & \begin{tabular}{l|}
0.9 \\
0.6 \\
0.6 \\
0.6
\end{tabular} & $\begin{array}{l}0.9 \\
0.6 \\
0.5 \\
0.0\end{array}$ & $\begin{array}{l}0.8 \\
0.6 \\
0.7\end{array}$ & $\begin{array}{l}0.7 \\
0.6 \\
0.6\end{array}$ & $\begin{array}{l}0.7 \\
0.6\end{array}$ & 0.7 \\
\hline 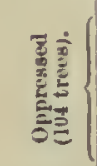 & $\begin{array}{r}21 \\
18 \\
34 \\
50 \\
66 \\
82 \\
100\end{array}$ & $\begin{array}{l}1.4 \\
2.1 \\
2.2 \\
2.1 \\
2.4 \\
2.3 \\
1.9\end{array}$ & $\begin{array}{l}1.7 \\
2.1 \\
2.2 \\
2.2 \\
2.3 \\
1.8 \\
1.9\end{array}$ & $\begin{array}{l}1.7 \\
1.0 \\
1.8 \\
1.9 \\
1.7 \\
1.6 \\
1.2\end{array}$ & $\begin{array}{l}1.6 \\
1.3 \\
1.7 \\
1.5 \\
1.5 \\
1.2 \\
0.9\end{array}$ & $\begin{array}{l}1.3 \\
1.0 \\
1.4 \\
1.4 \\
1.2 \\
0.9 \\
0.8\end{array}$ & $\begin{array}{l}1.2 \\
1.1 \\
1.2 \\
1.3 \\
1.2 \\
0.6 \\
0.7\end{array}$ & $\begin{array}{l}1.4 \\
0.9 \\
1.1 \\
1.2 \\
1.0 \\
0.7 \\
0.7\end{array}$ & $\begin{array}{l}1.2 \\
1.1 \\
1.1 \\
1.0 \\
0.9 \\
0.7 \\
0.5\end{array}$ & $\begin{array}{l}1.5 \\
1.2 \\
0.9 \\
1.0 \\
0.7 \\
0.4 \\
0.4\end{array}$ & $\begin{array}{l}1.3 \\
1.0 \\
0.8 \\
0.9 \\
0.6 \\
0.4\end{array}$ & $\begin{array}{l}1.4 \\
1.0 \\
0.8 \\
0.4 \\
0.5 \\
0.4\end{array}$ & $\begin{array}{l}1.2 \\
0.9 \\
0.8 \\
0.8 \\
0.5 \\
0.4\end{array}$ & $\begin{array}{l}1.2 \\
0.8 \\
0.7 \\
0.6 \\
0.5 \\
0.5\end{array}$ & $\begin{array}{l}1.1 \\
0.8 \\
0.7 \\
0.6 \\
0.5\end{array}$ & $\begin{array}{l}1.1 \\
0.8 \\
0.6 \\
0.4 \\
0.4\end{array}$ & $\begin{array}{l}1.0 \\
0.7 \\
0.4 \\
0.4\end{array}$ & $\begin{array}{l}1.0 \\
0.6 \\
0.4 \\
0.5\end{array}$ & $\begin{array}{l}0.9 \\
0.5 \\
0.3\end{array}$ & $\begin{array}{l}0.8 \\
0.4\end{array}$ & $\begin{array}{l}0.8 \\
0.4\end{array}$ & 0.6 & 0.5 & 0.5 \\
\hline
\end{tabular}

\begin{tabular}{|c|c|c|c|c|c|c|c|c|c|c|c|c|c|c|c|c|c|c|c|c|c|c|c|c|}
\hline \multirow{2}{*}{$\begin{array}{c}\text { Charac. } \\
\text { ter of } \\
\text { growth. }\end{array}$} & \multirow{2}{*}{$\begin{array}{l}\text { Hoight } \\
\text { of aection } \\
\text { from } \\
\text { gromind. }\end{array}$} & \multicolumn{23}{|c|}{ CORRESPONDING } \\
\hline & & 1 & $\mathbf{2}$ & 3 & \pm & j & 6 & 7 & 8 & 9 & 10 & 11 & 12 & 13 & 14 & 10 & 16 & 17 & 18 & 19 & 20 & 21 & 22 & 23 \\
\hline 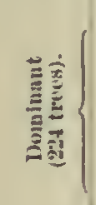 & $\begin{array}{r}\text { Feet. } \\
28 \\
18 \\
34 \\
30 \\
66 \\
82 \\
100 \\
115\end{array}$ & $\begin{array}{l}0.02 \\
.04 \\
.04 \\
.04 \\
.03 \\
.03 \\
.02 \\
.01\end{array}$ & $\begin{array}{l}0.07 \\
.12 \\
.12 \\
.13 \\
.11 \\
.07 \\
.08 \\
.03\end{array}$ & $\begin{array}{r}0.13 \\
.13 \\
.15 \\
.16 \\
.14 \\
.10 \\
.08 \\
.07\end{array}$ & $\begin{array}{l}0.16 \\
.16 \\
.17 \\
.18 \\
.15 \\
.11 \\
.11 \\
.01\end{array}$ & $\begin{array}{r}0.18 \\
.17 \\
.18 \\
.18 \\
.17 \\
.12 \\
.10 \\
.09\end{array}$ & $\begin{array}{r}0.20 \\
.17 \\
.18 \\
.19 \\
.16 \\
.13 \\
.12 \\
.10\end{array}$ & $\begin{array}{l}0.21 \\
.19 \\
.20 \\
.19 \\
.17 \\
.12 \\
.11 \\
.11\end{array}$ & $\begin{array}{r}0.24 \\
.20 \\
.20 \\
.18 \\
.12 \\
.12 \\
.12 \\
.10\end{array}$ & $\begin{array}{l}0.30 \\
.20 \\
.20 \\
19 \\
.17 \\
.14 \\
.12 \\
.11\end{array}$ & $\begin{array}{r}0.33 \\
.22 \\
.20 \\
.18 \\
.16 \\
.13 \\
.13 \\
\end{array}$ & $\begin{array}{r}0.35 \\
.23 \\
.21 \\
.17 \\
.17 \\
.12 \\
.12\end{array}$ & $\begin{array}{r}\text { (1. } 35 \\
.22 \\
.18 \\
.17 \\
.15 \\
.12 \\
.12\end{array}$ & $\begin{array}{r}0.36 \\
.22 \\
.19 \\
.18 \\
.14 \\
.14 \\
.16\end{array}$ & $\begin{array}{r}0.39 \\
.20 \\
.19 \\
.17 \\
.14 \\
.13 \\
.14\end{array}$ & $\begin{array}{r}0.35 \\
.21 \\
.19 \\
.17 \\
.15 \\
.13\end{array}$ & $\begin{array}{r}0.36 \\
.21 \\
.18 \\
.18 \\
.15 \\
.14\end{array}$ & $\begin{array}{r}0.38 \\
.20 \\
.18 \\
.15 \\
.14\end{array}$ & $\begin{array}{r}0.38 \\
.22 \\
.18 \\
.16 \\
.12\end{array}$ & $\begin{array}{r}0.37 \\
.20 \\
.20 \\
.15\end{array}$ & $\begin{array}{r}0.34 \\
.20 \\
.16 \\
.16\end{array}$ & $\begin{array}{r}0.32 \\
.14 \\
.16\end{array}$ & $\begin{array}{r}0.35 \\
.15\end{array}$ & 0.32 \\
\hline 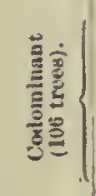 & $\begin{array}{r}23 \\
18 \\
34 \\
50 \\
66 \\
82 \\
98 \\
114\end{array}$ & $\begin{array}{l}.01 \\
.03 \\
.04 \\
.04 \\
.08 \\
.02 \\
.02 \\
.01\end{array}$ & $\begin{array}{l}.00 \\
.10 \\
.10 \\
.00 \\
.07 \\
.06 \\
.03 \\
.01\end{array}$ & $\begin{array}{l}.09 \\
.12 \\
.13 \\
.14 \\
.10 \\
.08 \\
.08 \\
.03\end{array}$ & $\begin{array}{l}.11 \\
.13 \\
.13 \\
.14 \\
11 \\
.09 \\
.00 \\
.05\end{array}$ & $\begin{array}{l}.13 \\
.12 \\
.14 \\
.15 \\
.12 \\
.09 \\
.07 \\
.05\end{array}$ & $\begin{array}{l}.15 \\
.14 \\
.14 \\
.15 \\
.11 \\
.10 \\
.08\end{array}$ & $\begin{array}{l}.16 \\
.14 \\
.14 \\
.13 \\
12 \\
.10 \\
.08\end{array}$ & $\begin{array}{l}.19 \\
.15 \\
.14 \\
.14 \\
11 \\
.10 \\
.10\end{array}$ & $\begin{array}{l}.21 \\
.15 \\
.14 \\
.14 \\
.10 \\
.10 \\
.07\end{array}$ & $\begin{array}{l}.21 \\
.15 \\
.14 \\
14 \\
.11 \\
.09 \\
.07\end{array}$ & $\begin{array}{l}.23 \\
.15 \\
.14 \\
.13 \\
.12 \\
10 \\
.09\end{array}$ & $\begin{array}{l}.27 \\
.17 \\
.13 \\
.14 \\
.11 \\
.09\end{array}$ & $\begin{array}{l}.24 \\
.15 \\
.13 \\
.13 \\
.12 \\
.08\end{array}$ & $\begin{array}{l}.23 \\
14 \\
13 \\
.13 \\
.10 \\
.10\end{array}$ & $\begin{array}{l}.24 \\
.14 \\
.12 \\
.13 \\
.11\end{array}$ & $\begin{array}{l}.27 \\
.15 \\
.14 \\
.12 \\
.10\end{array}$ & $\begin{array}{l}.24 \\
.14 \\
.13 \\
.14 \\
.12\end{array}$ & $\begin{array}{l}.23 \\
.14 \\
.13 \\
.12\end{array}$ & $\begin{array}{l}.23 \\
.18 \\
.12 \\
.13\end{array}$ & $\begin{array}{l}.22 \\
.14 \\
.15\end{array}$ & $\begin{array}{l}.20 \\
.14 \\
.13\end{array}$ & $\begin{array}{l}.21 \\
.15\end{array}$ & .21 \\
\hline 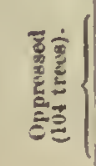 & $\begin{array}{r}21 \\
18 \\
34 \\
50 \\
66 \\
82 \\
100\end{array}$ & $\begin{array}{l}.01 \\
.02 \\
.03 \\
.02 \\
.03 \\
.03 \\
.02\end{array}$ & $\begin{array}{l}.04 \\
.08 \\
.08 \\
.08 \\
.00 \\
.06 \\
.06\end{array}$ & $\begin{array}{l}.07 \\
.08 \\
.11 \\
.11 \\
.11 \\
.09 \\
.06\end{array}$ & $\begin{array}{l}.10 \\
.09 \\
13 \\
.11 \\
.12 \\
.08 \\
.05\end{array}$ & $\begin{array}{l}.10 \\
.08 \\
.13 \\
.12 \\
.11 \\
.07 \\
.05\end{array}$ & $\begin{array}{l}.11 \\
.10 \\
.13 \\
.14 \\
.12 \\
.05 \\
.06\end{array}$ & $\begin{array}{l}.15 \\
.09 \\
.13 \\
14 \\
.12 \\
.07 \\
.06\end{array}$ & $\begin{array}{l}.14 \\
13 \\
.14 \\
.14 \\
.11 \\
.07 \\
.04\end{array}$ & $\begin{array}{l}19 \\
.15 \\
.13 \\
.13 \\
.10 \\
.05 \\
.04\end{array}$ & $\begin{array}{l}.20 \\
.14 \\
.12 \\
.13 \\
.09 \\
.04\end{array}$ & $\begin{array}{l}.22 \\
.15 \\
.12 \\
.13 \\
.07 \\
.05\end{array}$ & $\begin{array}{l}.20 \\
.14 \\
.13 \\
.13 \\
.08 \\
.05\end{array}$ & $\begin{array}{l}.22 \\
.14 \\
.13 \\
.10 \\
.07 \\
.06\end{array}$ & $\begin{array}{l}.22 \\
.13 \\
.12 \\
.11 \\
.08\end{array}$ & $\begin{array}{l}.23 \\
.14 \\
.12 \\
.08 \\
.07\end{array}$ & $\begin{array}{l}.23 \\
.12 \\
.08 \\
.07\end{array}$ & $\begin{array}{l}.21 \\
.11 \\
.08 \\
.10\end{array}$ & $\begin{array}{l}.22 \\
.10 \\
.08\end{array}$ & $\begin{array}{r}.20 \\
.08\end{array}$ & $\begin{array}{r}.20 \\
.08\end{array}$ & .15 & .14 & .13 \\
\hline
\end{tabular}




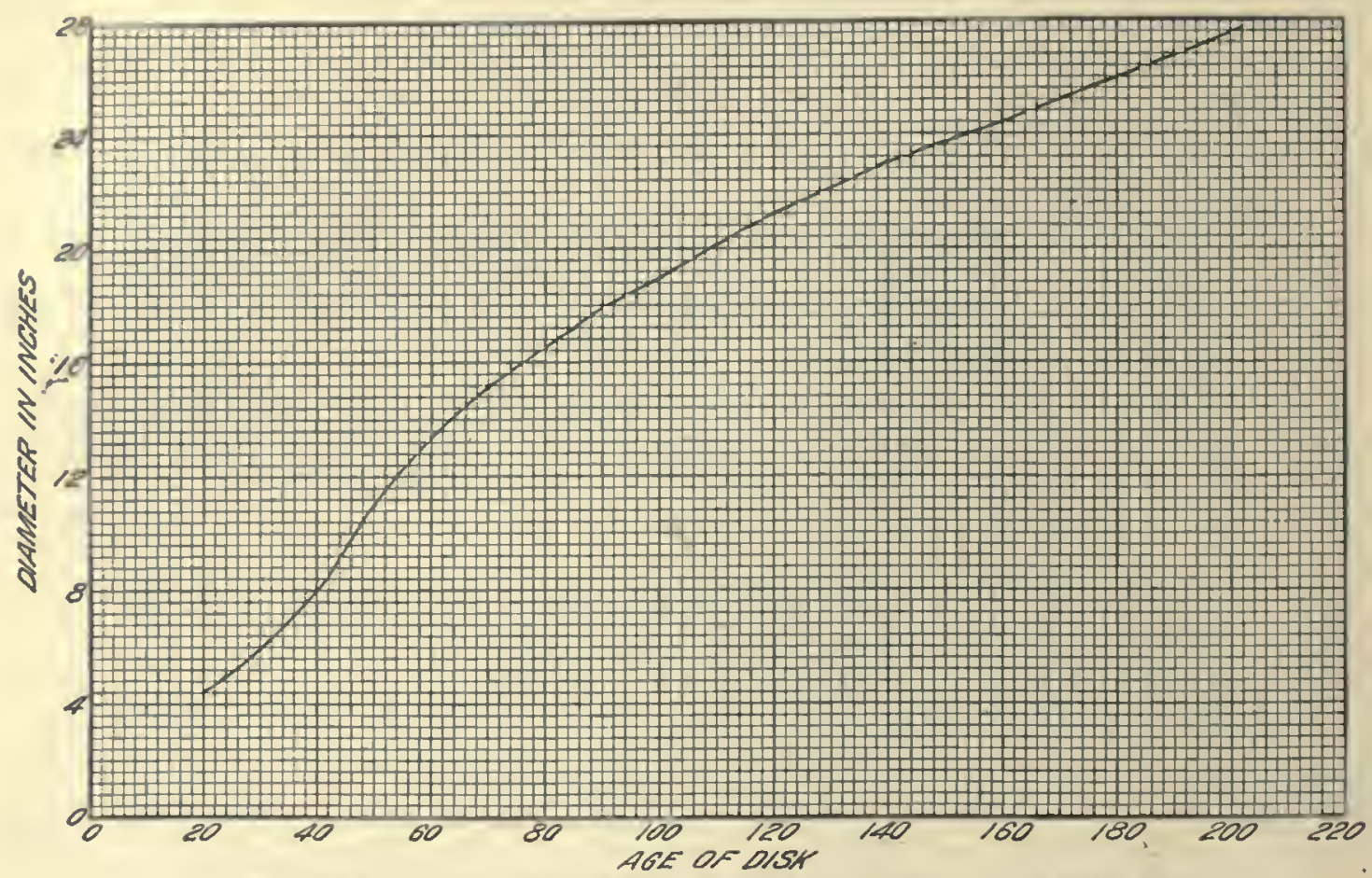

FIG. 30.-Diagram showing arerage progress of diameter growth (breast high) of dominant trees.

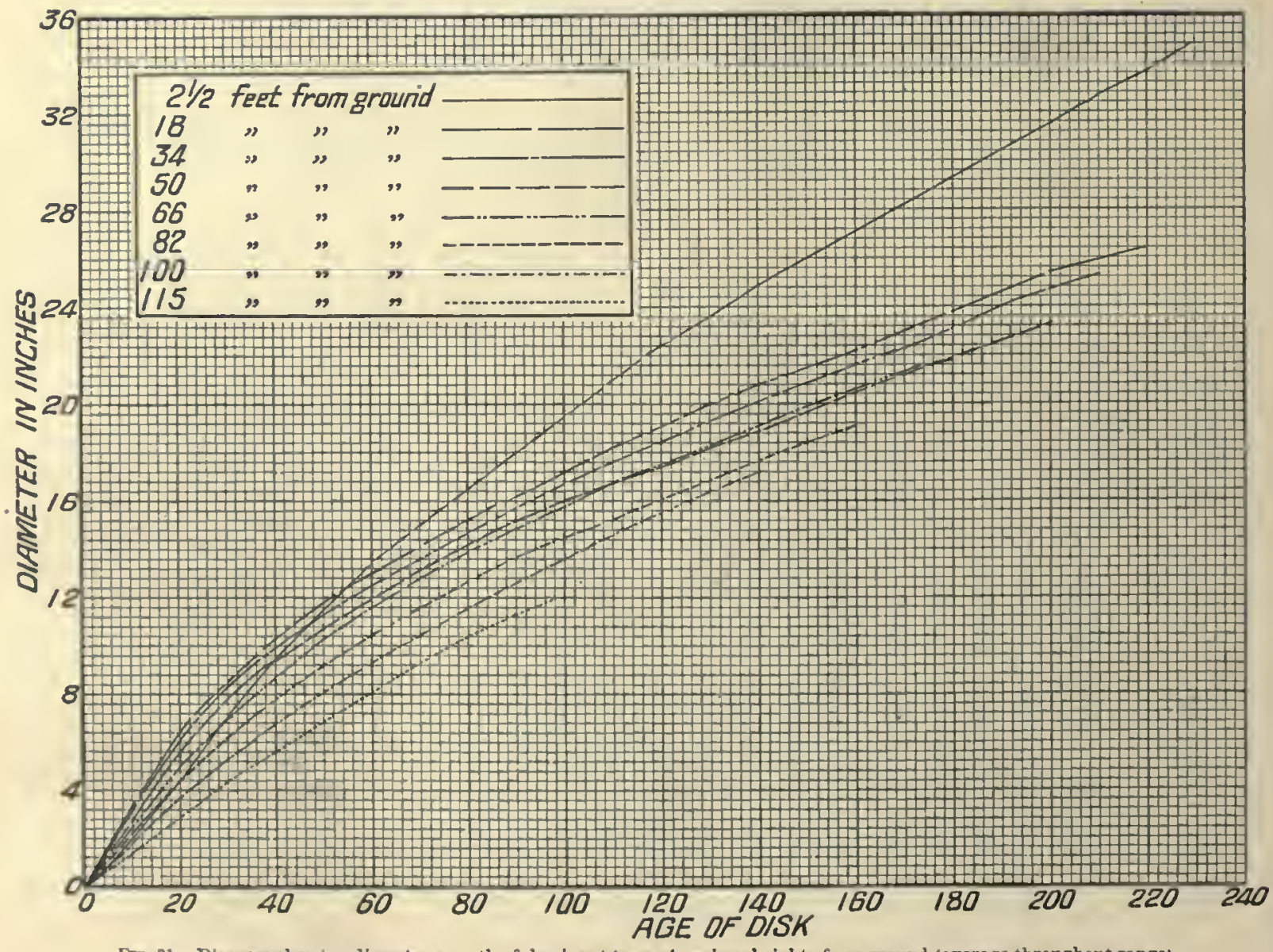

Fri. 31.-Dlagram thowing diancter growth of domlnant trees at varions beights from ground (arerage throughout range). 


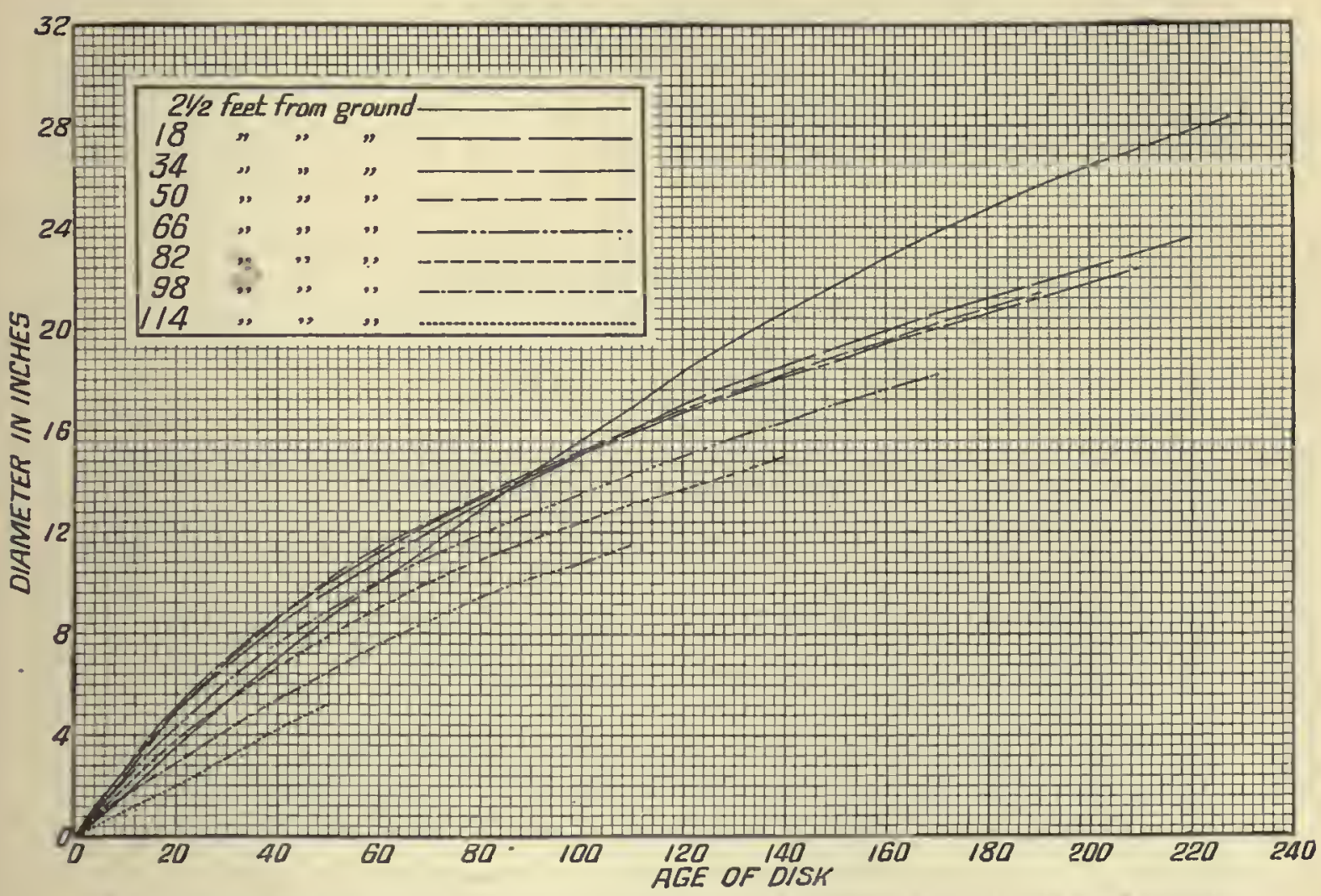

FTo. 32.-Diagram showing diameter growth of colominant trees at varions lieights from ground (average throughont range).

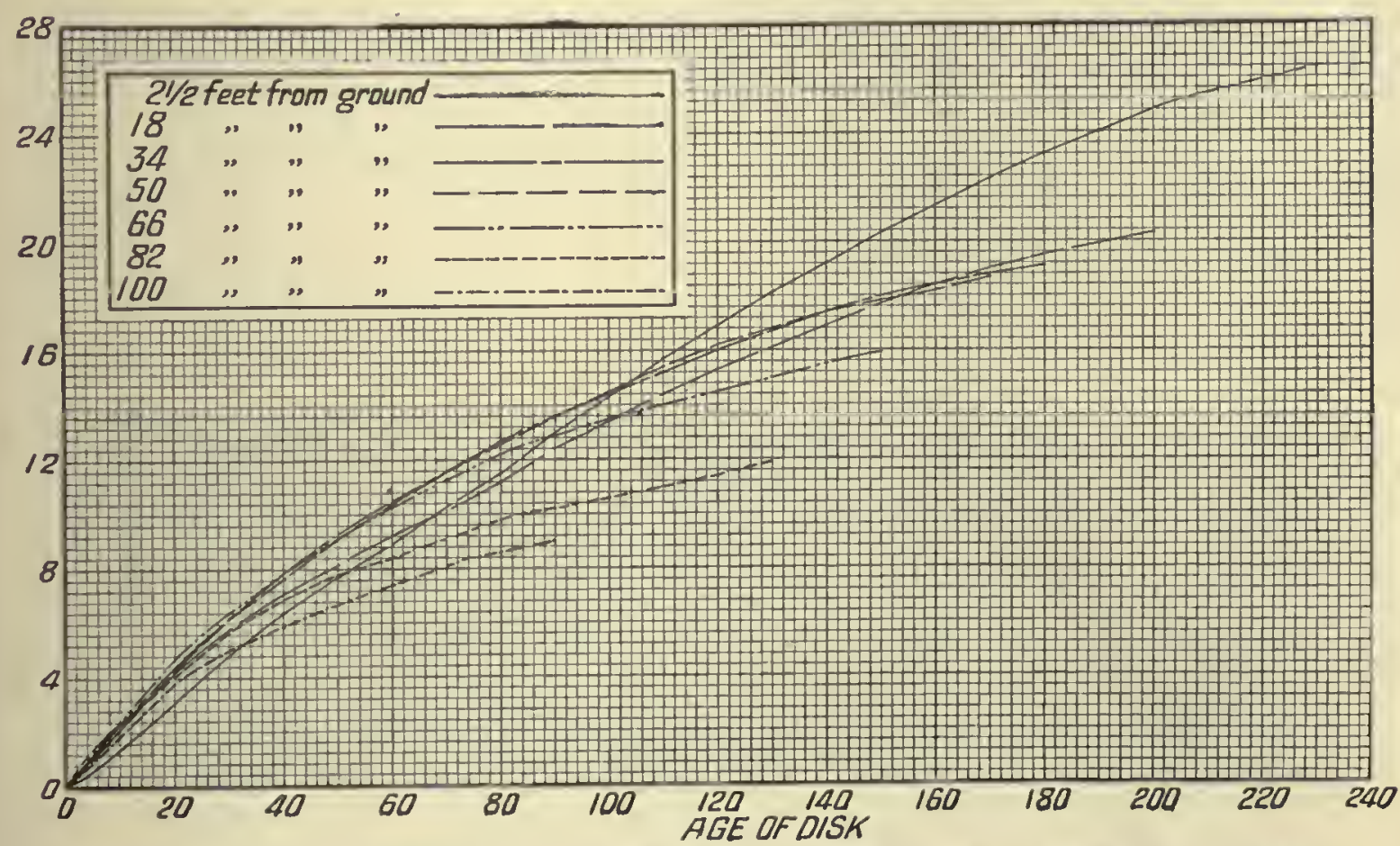

Fro. 33.-Diagram sliowing diameter growth of oppressed trees at various heights from ground (average throughout range). 
TABLE V.-Grouth of diameter and cross-section arca al various heights from the ground-Continued. (2) ATERAGE FOR WISCOSSL:

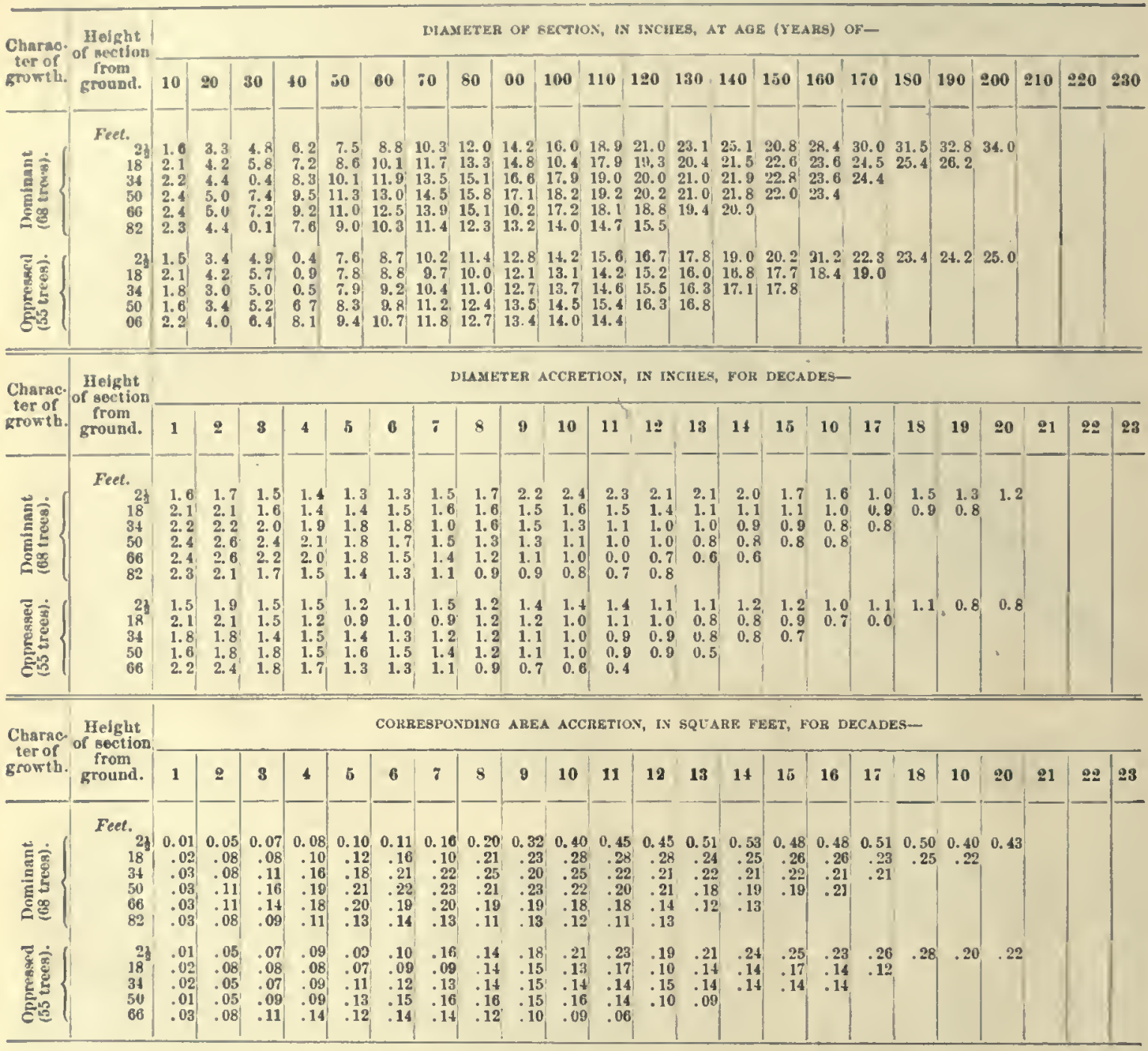




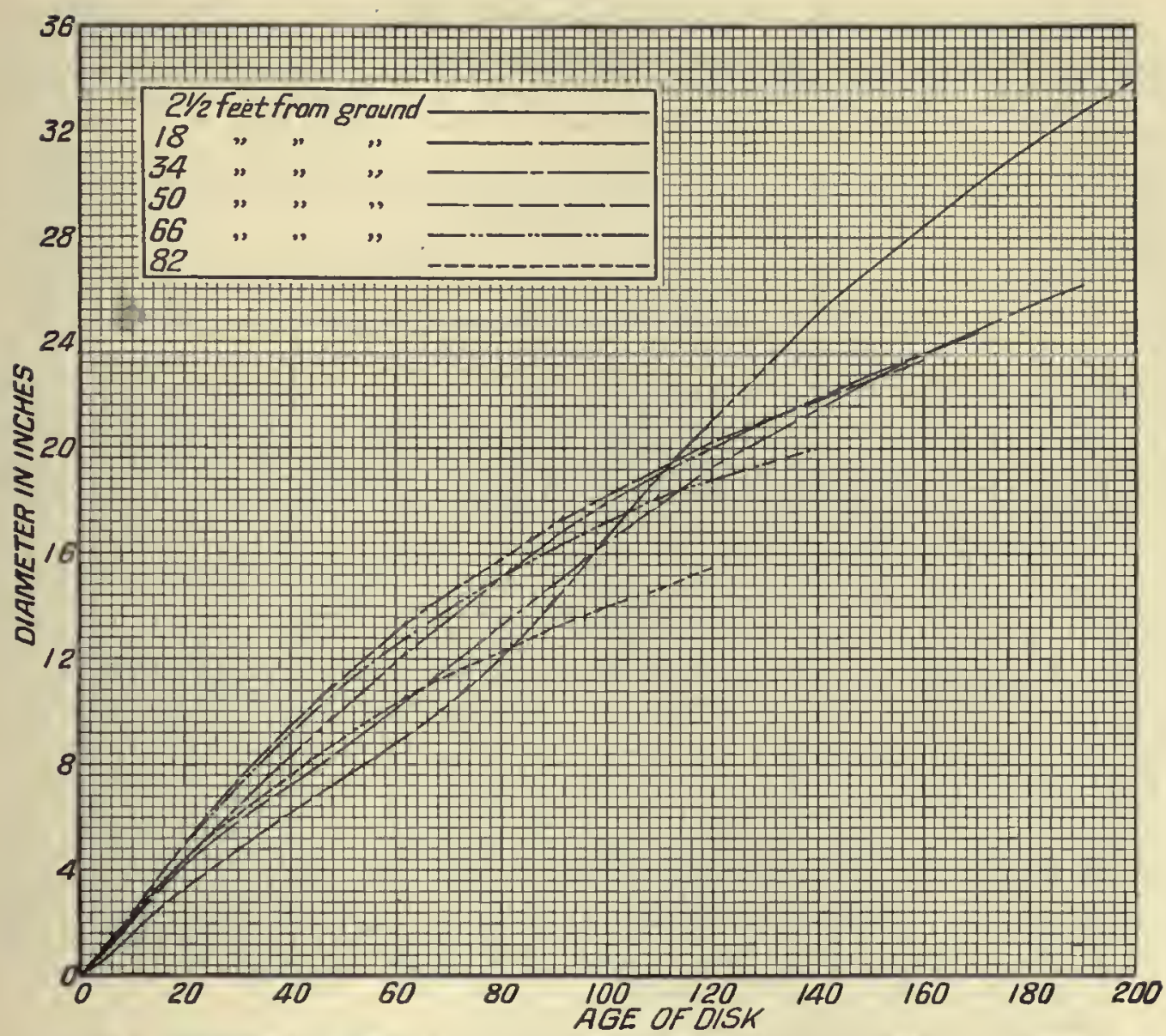

Fro. 34-Diagram showing diameter grow th of dominant trees at various height 8 from ground in Wisconsin.

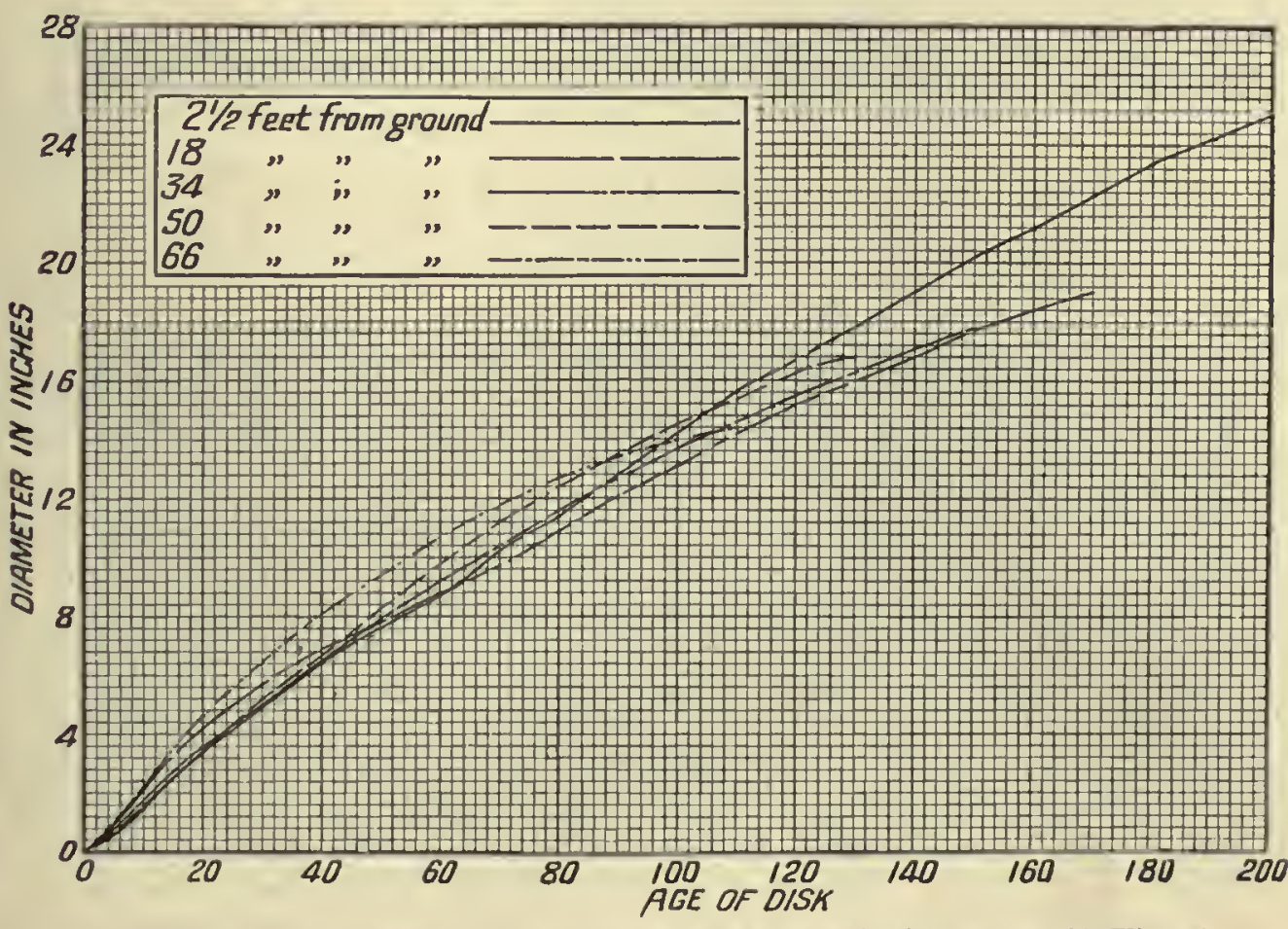

FI0. 35.-Diagram showing diameter growth of oppressed trees at rarious heights from ground in Wisconsin. 
TABLE V.-Grovoth of diameter and cross-section area at rarious heights from the ground-Continued.

(3) AVERAGE FOR PEXXXSYLANIA.

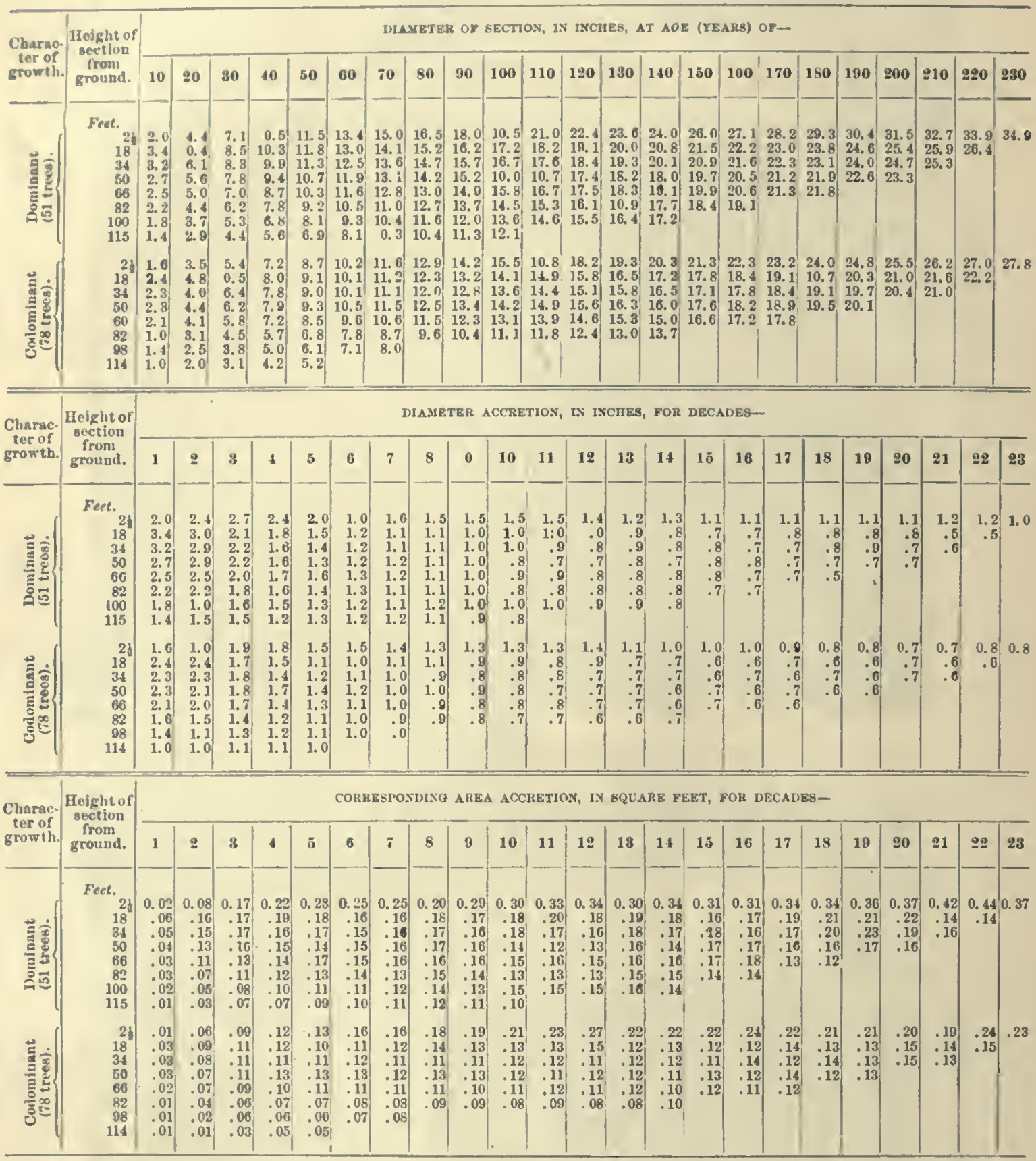




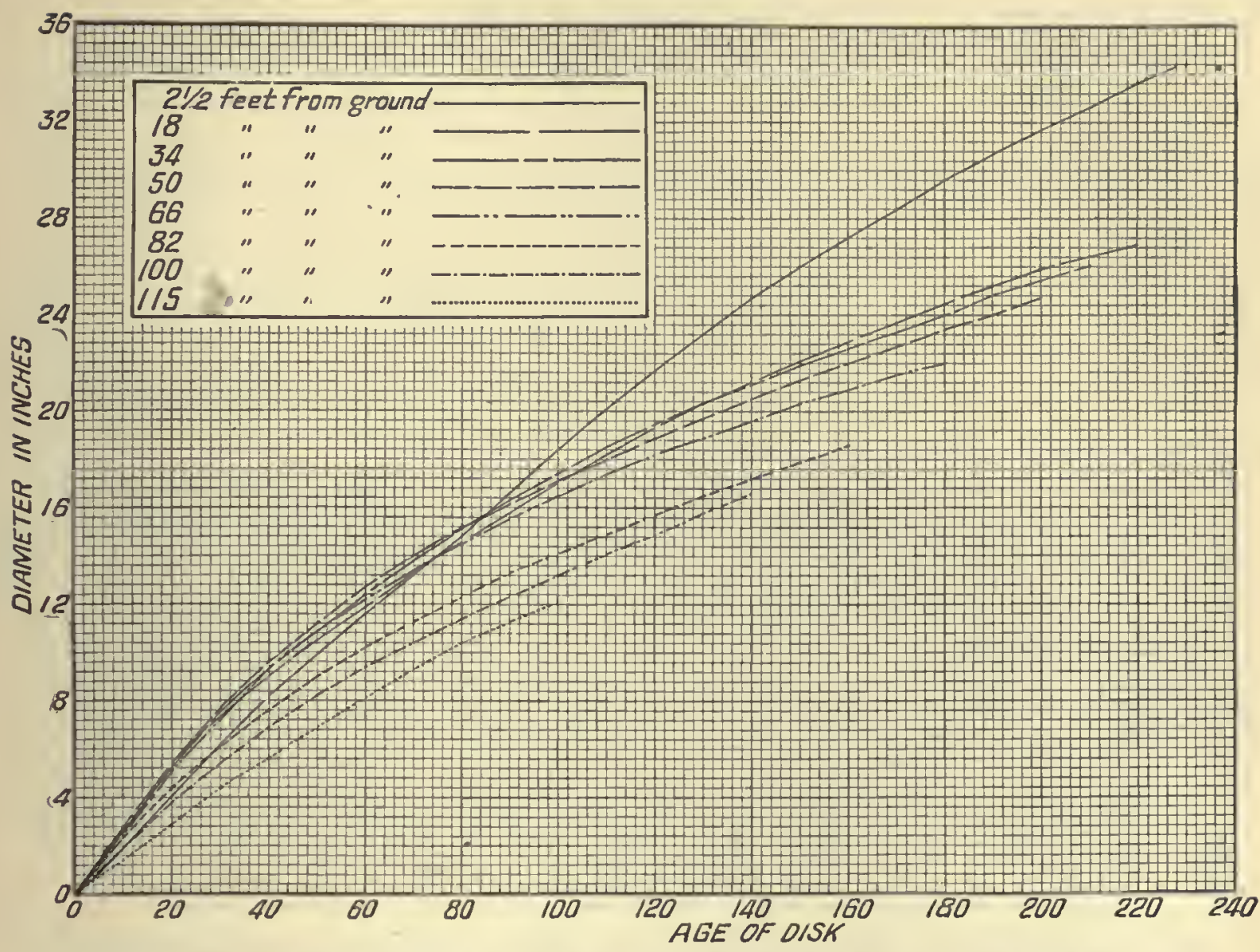

Fia. 30.-Diagram showing diameter growth of dominant trees at various heights from ground in Pennsylvania

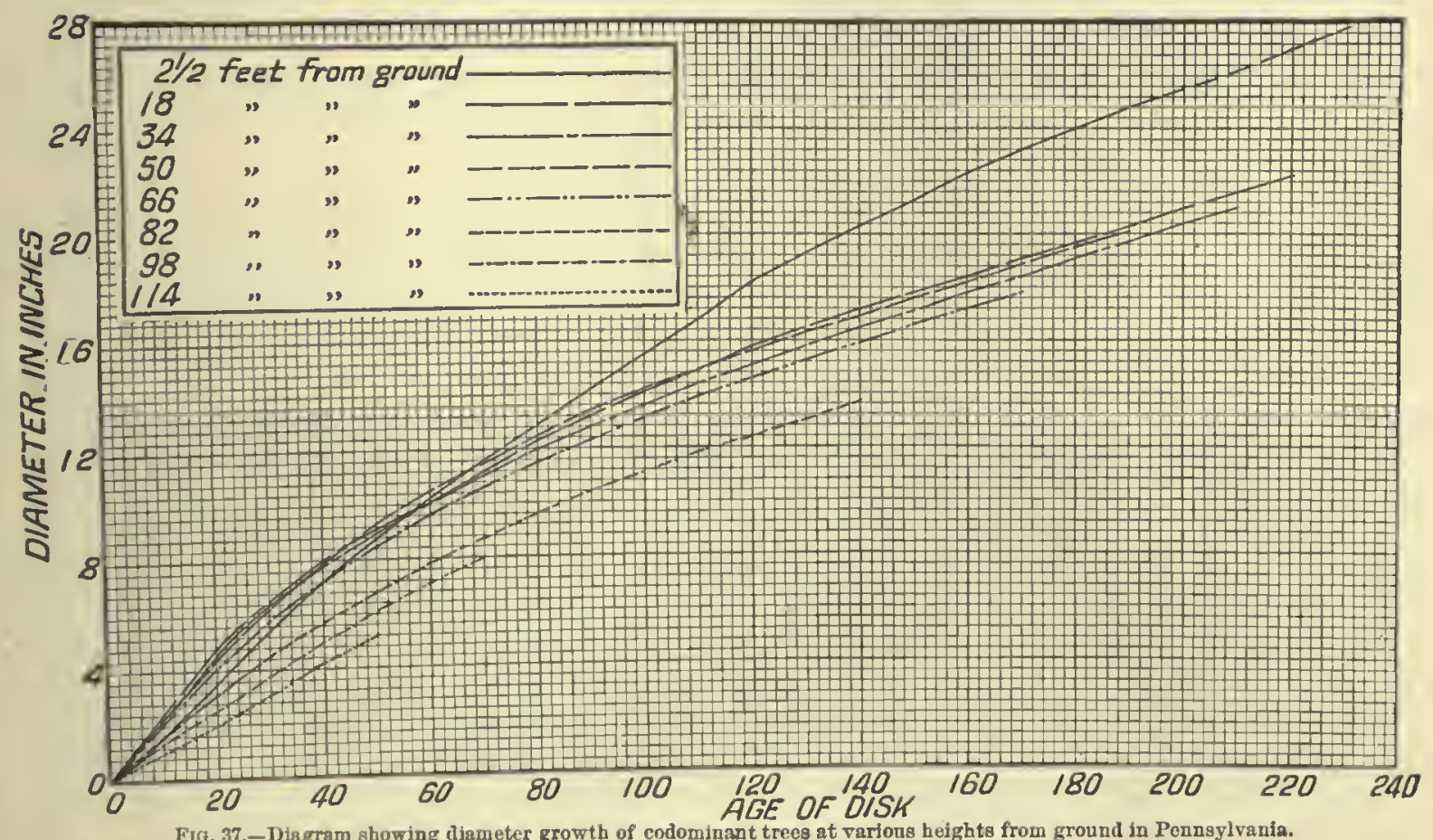
20233-No. 22-8 
TA1LX V. - Grouth of diameter and cross-section area at various heights from the ground-Continued. (4) ATELAGE FOR MICHIRAN.

\begin{tabular}{|c|c|c|c|c|c|c|c|c|c|c|c|c|c|c|c|c|c|c|c|c|c|c|c|c|}
\hline \multirow{2}{*}{$\begin{array}{l}\text { Characo } \\
\text { ter of } \\
\text { growth. }\end{array}$} & \multirow{2}{*}{$\begin{array}{c}\text { 11elght of } \\
\text { section } \\
\text { frotu } \\
\text { ground. }\end{array}$} & \multicolumn{23}{|c|}{ DIAMETER OF EECTION, IN INCHES, AT AOE (YRAHS) OF- } \\
\hline & & 10 & 80 & 30 & 40 & 50 & 00 & 70 & 80 & $0 \quad 10$ & 100 & 11012 & \begin{tabular}{l|l}
120 & 13
\end{tabular} & $\begin{array}{ll}130 & 14\end{array}$ & \begin{tabular}{l|l}
140 & 15
\end{tabular} & 15010 & 130,12 & 17015 & $\begin{array}{lll}150 & 18\end{array}$ & $190 \geq 0$ & 2002 & 210 2 & $220=$ & 280 \\
\hline 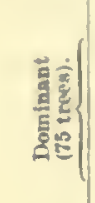 & $\begin{array}{r}\text { reet. } \\
21 \\
18 \\
34 \\
30 \\
60 \\
82 \\
100\end{array}$ & $\begin{array}{l}2.0 \\
2.8 \\
2.8 \\
2.8 \\
2.5 \\
2.3 \\
2.11 \\
1\end{array}$ & $\begin{array}{l}4.4 \\
5.6 \\
5.0 \\
5.7 \\
5.2 \\
4.2 \\
4.0\end{array}$ & \begin{tabular}{l|l}
6.6 & \\
7.7 & \\
7.9 & \\
8.0 & 1 \\
7.3 & \\
5.9 & \\
5.5 &
\end{tabular} & $\begin{array}{rl}8.7 & 1 \\
9.6 & 1 \\
9.8 & 1 \\
10.1 & 1 \\
8.8 & 1 \\
7.4 & \\
7.0 & \end{array}$ & $\begin{array}{cc}10.0 & 1 \\
11.3 & 1 \\
11.4 & 1 \\
11.8 & 1 \\
10.1 & 1 \\
8.7 & \\
8.2 & \end{array}$ & \begin{tabular}{r|l}
12.4 & 14 \\
12.8 & 14 \\
12.8 & 14 \\
13.3 & 14 \\
11.3 & 12 \\
9.7 & 10 \\
8.4 & 10
\end{tabular} & 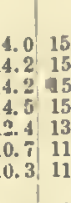 & $\begin{array}{ll}5.6 & 17 . \\
5.5 & 16 . \\
5.3 & 16 . \\
5.5 & 16 \\
3 & 14 \\
1.0 & 12 \\
1.1 & 11 .\end{array}$ & $\begin{array}{ll}7.2 & 18 \\
6.7 & 17 \\
6.3 & 17 \\
6.5 & 12 \\
4.5 & 15 \\
2.7 & 13 \\
1.0 & 12 \\
6 & \end{array}$ & $\begin{array}{ll}18.7 & 20 \\
17.7 & 18 \\
77.3 & 18 \\
17.4 & 18 \\
15.5 & 10 \\
1.6 & 14 \\
12.6 & 13\end{array}$ & $\begin{array}{ll}20.0 & 21 \\
18.7 & 19 \\
18.5 & 19 \\
18.3 & 19 \\
10.5 & 17 \\
14.4 & 15 \\
3.3 & \end{array}$ & \begin{tabular}{l|l}
11.2 & 22 \\
19.7 & 20 \\
19.4 & 20 \\
9.2 & 20 \\
7.4 & 18 \\
15.1 & 15
\end{tabular} & \begin{tabular}{l|l}
2.3 & 23 \\
0.6 & 21 \\
0.2 & 21 \\
0.1 & 20 \\
18.1 & 18 \\
15.8 & 16
\end{tabular} & \begin{tabular}{l|l}
3.5 & 24 \\
1.5 & 22 \\
1.0 & 21 \\
0.9 & 21 \\
0.8 & 19 \\
6.4 & 17
\end{tabular} & \begin{tabular}{l|l}
24.5 & 25 \\
22.4 & 23 \\
21.7 & 22 \\
21.6 & 22 \\
19.4 & 10 \\
17.1 &
\end{tabular} & \begin{tabular}{l|l}
25.5 & 20 \\
23.2 & 29 \\
22.4 & 23 \\
2.2 & 22 \\
10.9 & 20
\end{tabular} & \begin{tabular}{l|l}
26.5 & 27 \\
23.9 & 24 \\
22.1 & 23 \\
20.8 & 23 \\
20.1 &
\end{tabular} & 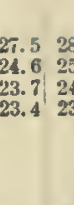 & 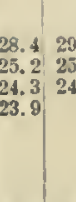 & $\begin{array}{ll}29.1 & 25 \\
25.8 & 2 \\
24.8 & \end{array}$ & $\begin{array}{ll}29.8 & 3 \\
26.3 & 2 \\
26 & \end{array}$ & $\begin{array}{l}30.6 \\
20.8\end{array}$ & 31.4 \\
\hline 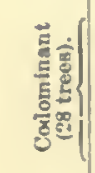 & $\begin{array}{r}23 \\
18 \\
34 \\
56 \\
66 \\
82 \\
100\end{array}$ & $\begin{array}{l}1.5 \\
2.3 \\
2.8 \\
2.9 \\
2.2 \\
2.2 \\
1.7\end{array}$ & $\begin{array}{l}3.4 \\
4.9 \\
5.5 \\
5.3 \\
4.3 \\
4.4 \\
3.2\end{array}$ & $\begin{array}{l}5.1 \\
6.8 \\
7.4 \\
7.5 \\
6.2 \\
6.0 \\
4.5\end{array}$ & $\begin{array}{l}0.7 \\
8.4 \\
9.11 \\
9.2 \\
7.7 \\
7.5 \\
5.6\end{array}$ & \begin{tabular}{r|r}
8.3 & \\
9.8 & 1 \\
10.6 & 1 \\
10.7 & 1 \\
0.0 & 1 \\
8.8 & \\
6.7 &
\end{tabular} & & $\begin{array}{ll}11.0 & 12 \\
2.4 & 13 \\
3.1 & 14 \\
3.0 & 14 \\
11.0 & 11 \\
10.9 & 11 \\
8.7 & 9\end{array}$ & $\begin{array}{ll}2.6 & 14 \\
3.5 & 14 \\
4.2 & 15 \\
4.0 & 14 \\
1.8 & 12 \\
1.8 & 12 \\
9.5 & 10\end{array}$ & \begin{tabular}{l|l}
4.1 & 15 \\
4.6 & 1 \\
5.2 & 1 \\
4.9 & 1 \\
2.5 & 1 \\
2.6 & 1 \\
0.3 & 11
\end{tabular} & \begin{tabular}{l|l}
15.4 & 16 \\
15.6 & 16 \\
16.1 & 16 \\
15.8 & 16 \\
13.3 & 14 \\
13.3 & 14 \\
11.0 & 1
\end{tabular} & \begin{tabular}{l|l}
10.7 & 18 \\
16.6 & 17 \\
16.9 & 1 \\
16.6 & 1 \\
14.1 & 1 \\
14.0 & 1 \\
11.7 &
\end{tabular} & \begin{tabular}{l|l}
18.1 & 19 \\
17.6 & 18 \\
17.7 & 18 \\
17.4 & 18 \\
14.8 & 15 \\
14.0 & 15
\end{tabular} & \begin{tabular}{l|l}
9.4 & 20 \\
8.5 & 18 \\
8.4 & 18 \\
8.1 & 18 \\
8. & 15 \\
5.1 & 15 \\
5. & 15
\end{tabular} & \begin{tabular}{l|l}
20.5 & 2 \\
19.2 & 1 \\
18.1 & 1 \\
8.8 & 1 \\
15.0 & 1 \\
15.7 &
\end{tabular} & \begin{tabular}{l|l}
21.6 & 2 \\
19.9 & 2 \\
18.7 & 2 \\
19.4 & 1 \\
19.4 & 1
\end{tabular} & $\begin{array}{ll}22.8 & 23 \\
20.6 & 21 \\
20.3 & 22 \\
19.9 & 2 \\
16.0^{\prime} & \end{array}$ & \begin{tabular}{l|l}
23.8 & 2. \\
21.3 & 21 \\
20.9 & 21 \\
20.5 & 21
\end{tabular} & $\begin{array}{ll}24.7 & 2 \\
21.9 & 22 \\
21.4 & 21 \\
21.0 & \end{array}$ & \begin{tabular}{l|l}
25.6 & 26 \\
22.4 & 22 \\
21.8 &
\end{tabular} & $\begin{array}{l}26.42 \\
22.92\end{array}$ & 27.1 & $\begin{array}{l}27.7 \\
23.9\end{array}$ & 28.3 \\
\hline 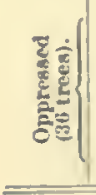 & $\begin{array}{r}23 \\
18 \\
34 \\
50 \\
66 \\
82 \\
100\end{array}$ & \begin{tabular}{l|}
1.2 \\
2.0 \\
2.5 \\
2.5 \\
2.5 \\
2.3 \\
1.9
\end{tabular} & $\begin{array}{l}2.6 \\
4.0 \\
5.1 \\
5.0 \\
4.7 \\
4.1 \\
3.8\end{array}$ & $\begin{array}{l}4.4 \\
5.6 \\
7.2 \\
6.0 \\
0.3 \\
5.7 \\
5.0\end{array}$ & \begin{tabular}{l|l}
6.1 & \\
7.0 & \\
9.0 & 1 \\
8.3 & \\
7.6 \\
6.9 \\
5.9
\end{tabular} & $\begin{array}{r}7.5 \\
8.1 \\
10.3 \\
9.5 \\
8.7 \\
7.8 \\
6.7 \\
\end{array}$ & \begin{tabular}{r|r|}
8.8 & 10 \\
9.2 & 10 \\
11.4 & 12 \\
30.0 & 11 \\
9.7 & 10 \\
8.4 & 8 \\
7.4 & 8 \\
\end{tabular} & \begin{tabular}{r|r}
10.1 & 11 \\
10.0 & 11 \\
12.4 & 13 \\
1.6 & 12 \\
10.6 & 11 \\
8.1 & 0 \\
8.1 & 8 \\
\end{tabular} & \begin{tabular}{r|r}
1.3 & 12 \\
1.0 & 12 \\
3.3 & 14 \\
2.4 & 13 \\
1.4 & 12 \\
0.8 & 10 \\
8.6 & 0 \\
& \\
\end{tabular} & \begin{tabular}{l|l}
2.8 & 1 \\
2.1 & 1 \\
4.0 & 1 \\
3.2 & 1 \\
2.1 & 1 \\
0.2 & 1 \\
0.0 &
\end{tabular} & \begin{tabular}{l|l}
14.0 & 1 \\
13.1 & 1 \\
14.6 & 1 \\
13.9 & 1 \\
12.7 & 1 \\
10.6 & 1
\end{tabular} & \begin{tabular}{l|l}
15.8 & 1 \\
14.0 & 1 \\
15.2 & 1 \\
14.6 & 1 \\
13.3 & 1 \\
11.0 & 1
\end{tabular} & $\begin{array}{ll}16.5 & 17 \\
14.7 & 11 \\
15.8 & 11 \\
15.2 & 12 \\
13.8 & 1 . \\
11.4 & 1 .\end{array}$ & \begin{tabular}{l|l}
17.7 & 18 \\
15.5 & 16 \\
11.4 & 16 \\
11.8 & 16 \\
11.3 & 14 \\
11.9 &
\end{tabular} & \begin{tabular}{l|l}
18.7 & 1 \\
16.2 & 1 \\
16.9 & 1 \\
16.4 & 1 \\
14.8 & 1
\end{tabular} & $\begin{array}{ll}19.7 & 2 \\
16.8 & 1 \\
17.4 & 1 \\
16.8 & 1 \\
15.2 & \end{array}$ & $\begin{array}{ll}20.6 & 2 \\
17.3 & 1 \\
17.8 & 1 \\
17.2 & 1\end{array}$ & $\begin{array}{l}21.42 \\
17.818 \\
18.21 \\
17.7\end{array}$ & \begin{tabular}{l|l}
22.1 & 2 \\
18.3 & 18 \\
18.5 &
\end{tabular} & $\begin{array}{ll}22.0 & 2 \\
18.7 & 1\end{array}$ & $\begin{array}{l}23.6 \\
19.1\end{array}$ & $24.2=$ & $24.7=$ & 25.2 \\
\hline \multirow{2}{*}{$\begin{array}{c}\text { Charac- } \\
\text { ter of } \\
\text { growth. }\end{array}$} & \multirow{2}{*}{$\begin{array}{l}\text { Height of } \\
\text { section } \\
\text { from } \\
\text { ground. }\end{array}$} & \multicolumn{23}{|c|}{ DIASETER ACCRETION, IN INCHES, FOR DECADES- } \\
\hline & & 1 & $\mathbf{2}$ & 3 & 4 & $\tilde{5}$ & 6 & 7 & 8 & 9 & 10 & 11 & 12 & 13 & 14 & 15 & 16 & 17 & 18 & 19 & $\mathbf{2 0}$ & 21 & 22 & 23 \\
\hline हैं & $\begin{array}{r}\text { Feet. } \\
26 \\
18 \\
34 \\
50 \\
66 \\
82 \\
100\end{array}$ & $\begin{array}{l}2.0 \\
2.8 \\
2.8 \\
2.8 \\
2.5 \\
2.3 \\
2.1\end{array}$ & $\begin{array}{l}2.4 \\
2.8 \\
2.8 \\
2.9 \\
2.7 \\
1.9 \\
1.0\end{array}$ & $\begin{array}{l}2.2 \\
2.1 \\
2.3 \\
2.3 \\
2.1 \\
1.7 \\
1.5\end{array}$ & $\begin{array}{l}2.1 \\
1.9 \\
1.9 \\
2.1 \\
1.5 \\
1.5 \\
1.5\end{array}$ & $\begin{array}{l}1.9 \\
1.7 \\
1.6 \\
1.7 \\
1.3 \\
1.3 \\
1.2\end{array}$ & $\begin{array}{l}1.8 \\
1.5 \\
1.4 \\
1.5 \\
1.2 \\
1.0 \\
1.2\end{array}$ & $\begin{array}{l}1.6 \\
1.4 \\
1.4 \\
1.2 \\
1.1 \\
0.9 \\
0.9\end{array}$ & $\begin{array}{l}1.6 \\
1.3 \\
1.1 \\
1.0 \\
1.1 \\
0.9 \\
0.8\end{array}$ & $\begin{array}{l}1.6 \\
1.2 \\
1.0 \\
1.0 \\
1.0 \\
1.1 \\
0.8\end{array}$ & $\begin{array}{l}1.5 \\
1.0 \\
1.0 \\
0.9 \\
1.0 \\
0.9 \\
0.7\end{array}$ & $\begin{array}{l}1.3 \\
1.0 \\
1.2 \\
0.0 \\
1.0 \\
0.8 \\
0.7\end{array}$ & $\begin{array}{l}1.2 \\
1.0 \\
0.9 \\
0.9 \\
0.9 \\
0.7\end{array}$ & $\begin{array}{l}1.1 \\
0.9 \\
0.8 \\
0.9 \\
0.7 \\
0.7\end{array}$ & $\begin{array}{l}1.2 \\
0.9 \\
0.8 \\
0.8 \\
0.7 \\
0.6\end{array}$ & $\begin{array}{l}1.0 \\
0.9 \\
0.7 \\
0.7 \\
0.6 \\
0.7\end{array}$ & \begin{tabular}{l|l}
1.0 \\
0.8 \\
0.7 \\
0.6 \\
0.5
\end{tabular} & $\begin{array}{l}1.0 \\
0.7 \\
0.7 \\
0.6 \\
0.5\end{array}$ & $\begin{array}{l}1.0 \\
0.7 \\
0.6 \\
0.6\end{array}$ & $\begin{array}{l}0.9 \\
0.6 \\
0.6 \\
0.5\end{array}$ & $\begin{array}{l}0.7 \\
0.6 \\
0.5\end{array}$ & $\begin{array}{l}0.7 \\
0.5\end{array}$ & $\begin{array}{l}0.8 \\
0.5\end{array}$ & 0.8 \\
\hline 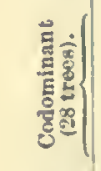 & $\begin{array}{r}21 \\
18 \\
34 \\
50 \\
68 \\
82 \\
100\end{array}$ & $\begin{array}{l}1.5 \\
2.3 \\
2.8 \\
2.9 \\
2.2 \\
2.2 \\
1.7\end{array}$ & $\begin{array}{l}1.9 \\
2.6 \\
2.7 \\
2.4 \\
2.1 \\
2.2 \\
1.5\end{array}$ & $\begin{array}{l}1.7 \\
1.0 \\
1.9 \\
2.2 \\
1.9 \\
1.6 \\
1.3\end{array}$ & $\begin{array}{l}1.6 \\
1.0 \\
1.7 \\
1.7 \\
1.5 \\
1.5 \\
1.1\end{array}$ & $\begin{array}{l}1.0 \\
1.4 \\
1.5 \\
1.5 \\
1.3 \\
1.3 \\
1.1\end{array}$ & $\begin{array}{l}1.3 \\
1.4 \\
1.3 \\
1.3 \\
1.0 \\
1.1 \\
1.1\end{array}$ & $\begin{array}{l}1.4 \\
1.2 \\
1.2 \\
1.0 \\
1.0 \\
1.0 \\
0.9\end{array}$ & $\begin{array}{l}1.6 \\
1.1 \\
1.1 \\
1.0 \\
0.8 \\
0.0 \\
0.8\end{array}$ & $\begin{array}{l}1.5 \\
1.1 \\
1.0 \\
0.9 \\
0.7 \\
0.8 \\
0.8\end{array}$ & $\begin{array}{l}1.3 \\
1.0 \\
0.8 \\
0.9 \\
0.8 \\
0.7 \\
0.7\end{array}$ & $\begin{array}{l}1.3 \\
1.0 \\
0.8 \\
0.8 \\
0.8 \\
0.7 \\
0.7\end{array}$ & $\begin{array}{l}1.4 \\
1.0 \\
0.8 \\
0.8 \\
0.7 \\
0.6\end{array}$ & $\begin{array}{l}1.3 \\
0.9 \\
0.7 \\
0.7 \\
0.6 \\
0.5\end{array}$ & $\begin{array}{l}1.1 \\
0.7 \\
0.7 \\
0.7 \\
0.5 \\
0.6\end{array}$ & $\begin{array}{l}1.1 \\
0.7 \\
0.6 \\
0.6 \\
0.5\end{array}$ & $\begin{array}{l}1.2 \\
0.7 \\
0.0 \\
0.5 \\
0.5\end{array}$ & $\begin{array}{l}1.0 \\
0.7 \\
0.6 \\
0.6 \\
0.4\end{array}$ & $\begin{array}{l}0.9 \\
0.6 \\
0.5 \\
0.3\end{array}$ & $\begin{array}{l}0.9 \\
0.5 \\
0.4\end{array}$ & $\begin{array}{l}0.8 \\
0.5\end{array}$ & 0.7 & $\begin{array}{l}0.6 \\
0.5\end{array}$ & 0.0 \\
\hline 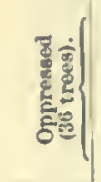 & $\begin{array}{r}21 \\
18 \\
34 \\
50 \\
66 \\
82 \\
100\end{array}$ & $\begin{array}{l}1.2 \\
2.0 \\
2.5 \\
2.5 \\
2.5 \\
2.3 \\
1.9\end{array}$ & $\begin{array}{l}1.4 \\
2.0 \\
2.6 \\
2.5 \\
2.2 \\
1.8 \\
1.8\end{array}$ & $\begin{array}{l}1.8 \\
1.6 \\
2.1 \\
1.9 \\
1.6 \\
1.6 \\
1.2\end{array}$ & $\begin{array}{l}1.7 \\
1.4 \\
1.8 \\
1.4 \\
1.3 \\
1.2 \\
0.8\end{array}$ & $\begin{array}{l}1.4 \\
1.1 \\
1.3 \\
1.2 \\
1.1 \\
0.9 \\
0.8\end{array}$ & $\begin{array}{l}1.3 \\
1.1 \\
1.1 \\
1.1 \\
1.0 \\
0.6 \\
0.7\end{array}$ & $\begin{array}{l}1.3 \\
0.8 \\
1.0 \\
1.0 \\
0.9 \\
0.7 \\
0.7\end{array}$ & $\begin{array}{l}1.2 \\
1.0 \\
0.9 \\
0.8 \\
0.8 \\
0.7 \\
0.5\end{array}$ & $\begin{array}{l}1.5 \\
1.1 \\
0.7 \\
0.8 \\
0.7 \\
0.4 \\
0.4\end{array}$ & $\begin{array}{l}1.2 \\
1.0 \\
0.6 \\
0.7 \\
0.6 \\
0.4\end{array}$ & $\begin{array}{l}1.3 \\
0.9 \\
0.6 \\
0.7 \\
0.0 \\
0.4\end{array}$ & $\begin{array}{l}1.2 \\
0.7 \\
0.6 \\
0.6 \\
0.5 \\
0.4\end{array}$ & $\begin{array}{l}1.2 \\
0.8 \\
0.0 \\
0.6 \\
0.5 \\
0.5\end{array}$ & \begin{tabular}{l|l}
1.0 \\
0.7 \\
0.5 \\
0.6 \\
0.5
\end{tabular} & $\begin{array}{l}1.0 \\
0.0 \\
0.5 \\
0.4 \\
0.4\end{array}$ & $\begin{array}{l}0.8 \\
0.5 \\
0.4 \\
0.4\end{array}$ & $\begin{array}{l}0.8 \\
0.5 \\
0.4 \\
0.5\end{array}$ & $\begin{array}{l}0.7 \\
0.5 \\
0.3\end{array}$ & $\begin{array}{l}0.8 \\
0.4\end{array}$ & $\begin{array}{l}0.7 \\
0.4\end{array}$ & 0.6 & 0.5 & 0.5 \\
\hline
\end{tabular}

\begin{tabular}{|c|c|c|c|c|c|c|c|c|c|c|c|c|c|c|c|c|c|c|c|c|c|c|c|c|}
\hline \multirow{2}{*}{$\begin{array}{l}\text { Charao- } \\
\text { ter of } \\
\text { growth. }\end{array}$} & \multirow{2}{*}{$\begin{array}{c}\text { Height of } \\
\text { section } \\
\text { from } \\
\text { ground. }\end{array}$} & \multicolumn{23}{|c|}{ CORRESPONDING AREA ACCEKTION, IN SQUARE FEET, FOR DECADES- } \\
\hline & & 1 & 2 & 3 & 4 & 5 & 6 & 7 & 8 & 9 & 10 & 11 & 12 & 13 & 14 & 15 & 10 & 17 & 15 & 10 & 20 & 21 & 22 & $\$ 8$ \\
\hline 总 & $\begin{array}{r}\text { Feet. } \\
23 \\
18 \\
34 \\
50 \\
60 \\
82 \\
100\end{array}$ & $\begin{array}{c}0.02 \\
.04 \\
.04 \\
.04 \\
.03 \\
.03 \\
.02\end{array}$ & $\begin{array}{r}0.08 \\
.13 \\
.13 \\
.14 \\
.12 \\
.07 \\
.07\end{array}$ & $\begin{array}{r}0.14 \\
.15 \\
.17 \\
.17 \\
.14 \\
.09 \\
.07\end{array}$ & $\begin{array}{r}0.18 \\
.18 \\
.18 \\
.21 \\
.13 \\
.11 \\
.11\end{array}$ & $\begin{array}{r}0.20 \\
.20 \\
.19 \\
.20 \\
.14 \\
.11 \\
.09\end{array}$ & $\begin{array}{r}0.23 \\
.19 \\
.18 \\
.20 \\
.14 \\
.10 \\
.12\end{array}$ & $\begin{array}{l}0.23 \\
.21 \\
.21 \\
.19 \\
.14 \\
.11 \\
.10\end{array}$ & $\begin{array}{r}0.26 \\
.21 \\
.18 \\
.16 \\
.15 \\
.11 \\
.09\end{array}$ & $\begin{array}{r}0.28 \\
.21 \\
.17 \\
.17 \\
.16 \\
.10 \\
.10\end{array}$ & $\begin{array}{r}0.30 \\
.19 \\
.18 \\
.17 \\
.16 \\
.13 \\
.10\end{array}$ & $\begin{array}{l}0.27 \\
.20 \\
.24 \\
.18 \\
.17 \\
.12 \\
.09\end{array}$ & $\begin{array}{r}0.27 \\
.21 \\
.18 \\
.18 \\
.17 \\
.11 \\
.08\end{array}$ & $\begin{array}{r}0.26 \\
.22 \\
.17 \\
.19 \\
.11 \\
.12\end{array}$ & \begin{tabular}{r|}
0.30 \\
.18 \\
.18 \\
.18 \\
.14 \\
.11
\end{tabular} & $\begin{array}{r}0.26 \\
.22 \\
.17 \\
.12 \\
.12\end{array}$ & $\begin{array}{r}0.28 \\
.19 \\
.17 \\
.15 \\
.11\end{array}$ & $\begin{array}{r}0.28 \\
.18 \\
.17 \\
.14 \\
.11\end{array}$ & $\begin{array}{r}0.29 \\
.19 \\
.15 \\
.16\end{array}$ & $\begin{array}{l}0.28 \\
.16 \\
.16 \\
.12\end{array}$ & $\begin{array}{l}0.22 \\
.17 \\
13\end{array}$ & $\begin{array}{r}0.22 \\
.14\end{array}$ & $\begin{array}{r}0.27 \\
.15\end{array}$ & \\
\hline 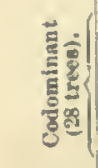 & $\begin{array}{r}23 \\
18 \\
34 \\
50 \\
68 \\
82 \\
100\end{array}$ & $\begin{array}{l}.01 \\
.03 \\
.04 \\
.05 \\
.03 \\
.08 \\
.02\end{array}$ & $\begin{array}{l}.05 \\
.10 \\
.12 \\
.10 \\
.07 \\
.07 \\
.04\end{array}$ & $\begin{array}{l}.08 \\
.12 \\
.14 \\
.10 \\
11 \\
10 \\
.05\end{array}$ & $\begin{array}{l}.10 \\
.13 \\
.15 \\
.15 \\
.11 \\
.11 \\
.06\end{array}$ & $\begin{array}{l}.13 \\
.14 \\
.16 \\
.10 \\
.12 \\
.11 \\
.08\end{array}$ & $\begin{array}{l}.13 \\
.10 \\
.16 \\
.16 \\
.10 \\
.11 \\
.09\end{array}$ & $\begin{array}{l}.16 \\
.16 \\
.17 \\
.14 \\
.12 \\
.12 \\
.08\end{array}$ & $\begin{array}{l}.20 \\
.15 \\
.16 \\
.15 \\
.10 \\
.11 \\
.08\end{array}$ & $\begin{array}{l}.22 \\
.17 \\
.16 \\
.14 \\
.09 \\
.11 \\
.09\end{array}$ & $\begin{array}{l}.21 \\
.17 \\
.15 \\
.15 \\
.11 \\
.09 \\
.08\end{array}$ & $\begin{array}{l}.23 \\
.17 \\
.15 \\
.14 \\
.12 \\
.11 \\
.00\end{array}$ & $\begin{array}{r}.27 \\
.19 \\
.15 \\
.11 \\
.11 \\
.00\end{array}$ & $\begin{array}{l}.20 \\
.18 \\
.14 \\
.14 \\
.10 \\
.08\end{array}$ & $\begin{array}{l}.24 \\
.14 \\
.14 \\
.14 \\
.09 \\
.10\end{array}$ & $\begin{array}{r}.25 \\
.15 \\
.13 \\
.12 \\
.09\end{array}$ & $\begin{array}{r}.29 \\
.18 \\
.13 \\
.11 \\
.09\end{array}$ & $\begin{array}{l}.26 \\
.13 \\
.13 \\
.13\end{array}$ & $\begin{array}{l}.24 \\
.14 \\
.11\end{array}$ & $\begin{array}{l}.24 \\
.13 \\
.10\end{array}$ & $\begin{array}{l}.23 \\
.12\end{array}$ & $\begin{array}{r}.20 \\
.13\end{array}$ & .18 & .19 \\
\hline 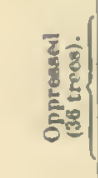 & $\begin{array}{r}213 \\
18 \\
84 \\
80 \\
66 \\
82 \\
100\end{array}$ & $\begin{array}{l}.01 \\
.02 \\
.03 \\
.03 \\
.03 \\
.03 \\
.02\end{array}$ & $\begin{array}{l}.03 \\
.07 \\
.11 \\
.11 \\
.00 \\
.06 \\
.06\end{array}$ & $\begin{array}{l}.00 \\
.08 \\
.14 \\
.12 \\
.09 \\
.09 \\
.00\end{array}$ & $\begin{array}{l}.10 \\
.10 \\
.10 \\
.12 \\
.09 \\
.08 \\
.05\end{array}$ & $\begin{array}{l}.11 \\
.09 \\
.14 \\
.11 \\
.10 \\
.07 \\
.05\end{array}$ & $\begin{array}{r}.11 \\
.10 \\
.13 \\
.12 \\
.10 \\
.05 \\
.06\end{array}$ & $\begin{array}{l}.14 \\
.08 \\
.12 \\
.12 \\
.10 \\
.07 \\
.06\end{array}$ & $\begin{array}{l}.14 \\
.12 \\
.13 \\
.11 \\
.10 \\
.07 \\
.04\end{array}$ & $\begin{array}{l}.10 \\
.14 \\
.11 \\
.11 \\
.09 \\
.05 \\
.04\end{array}$ & $\begin{array}{l}.18 \\
.14 \\
.09 \\
.10 \\
.08 \\
.04\end{array}$ & $\begin{array}{l}.21 \\
.13 \\
.10 \\
.08 \\
.05\end{array}$ & $\begin{array}{l}.20 \\
.11 \\
.10 \\
.10 \\
.08 \\
.05\end{array}$ & $\begin{array}{r}.23 \\
.13 \\
.11 \\
.10 \\
.07 \\
.00\end{array}$ & $\begin{array}{l}.20 \\
.12 \\
.09 \\
.11 \\
.08\end{array}$ & $\begin{array}{l}.21 \\
.11 \\
.09 \\
.07 \\
.07\end{array}$ & $\begin{array}{l}.22 \\
.09 \\
.08 \\
.07\end{array}$ & $\begin{array}{l}.16 \\
.10 \\
.08 \\
.10\end{array}$ & $\begin{array}{l}.16 \\
.10 \\
.06\end{array}$ & $\begin{array}{l}.20 \\
.08\end{array}$ & $\begin{array}{l}.18 \\
.08\end{array}$ & .15 & .14 & .13 \\
\hline
\end{tabular}




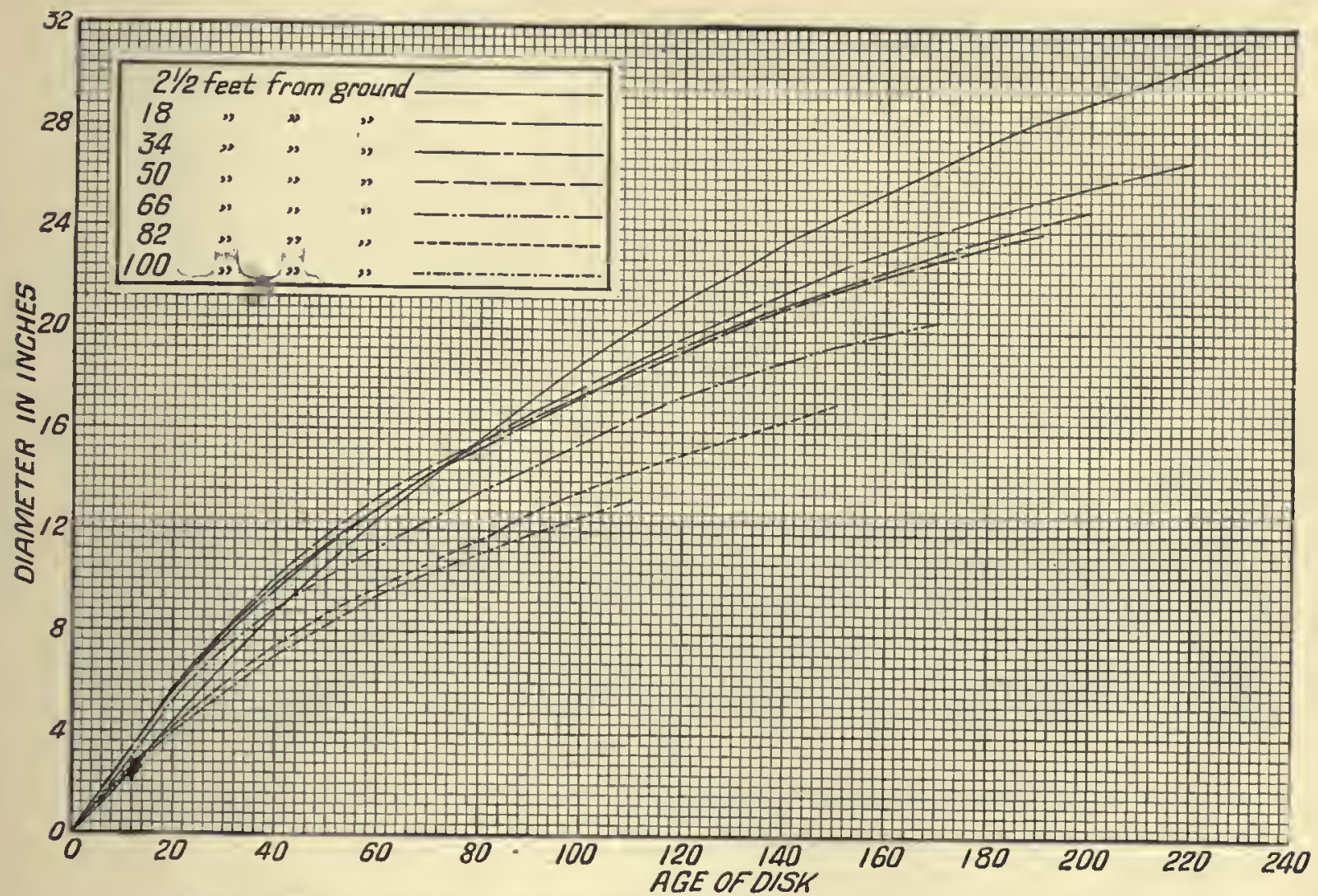

FiG. 38.-Diagram showing diameter growth of dominant trees at various heights from grouud iu Michigan.

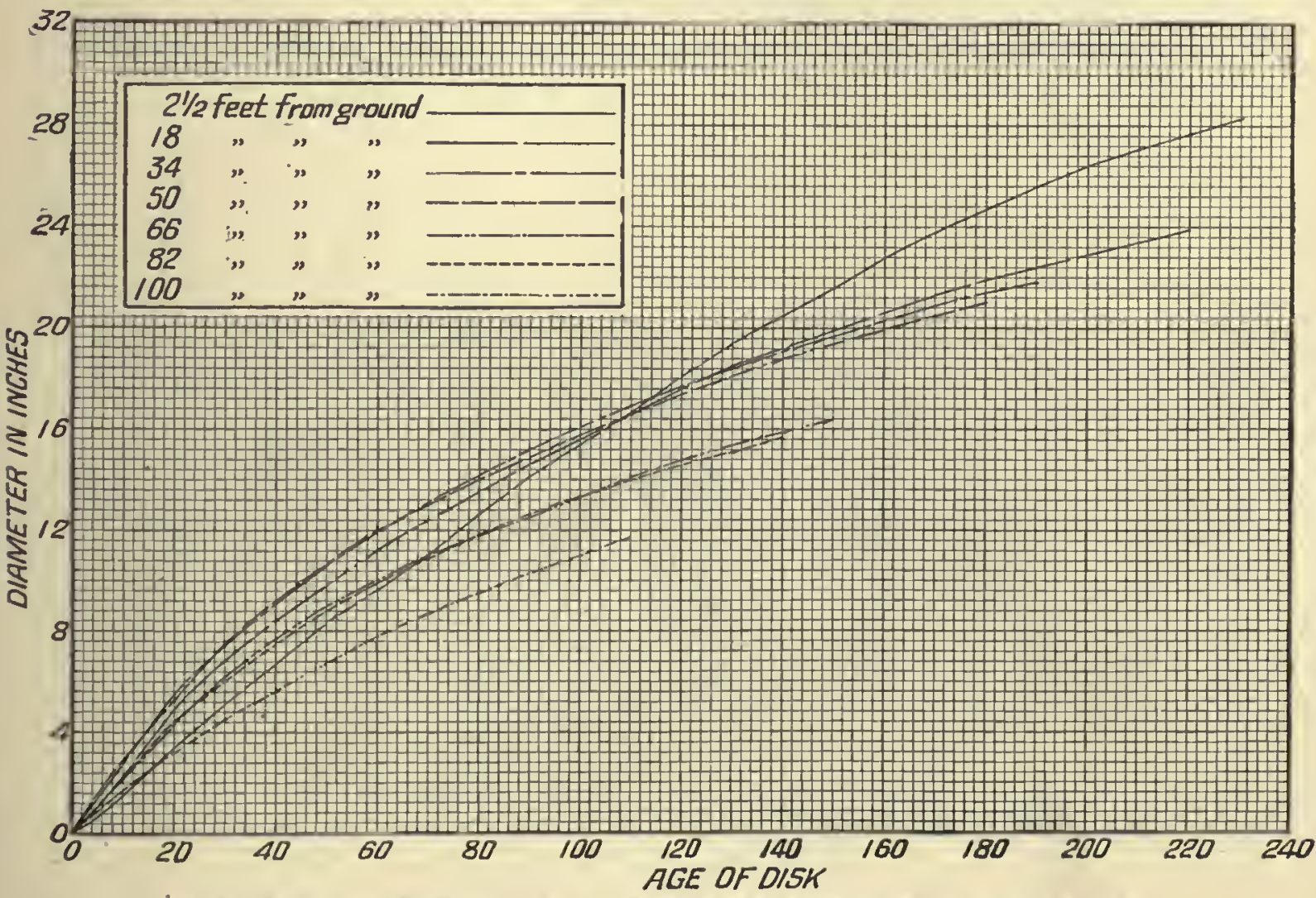

Fin. 39.-Dingram whowing diameter growth of codominant trees at varions heights from grouud iu Michigan. 


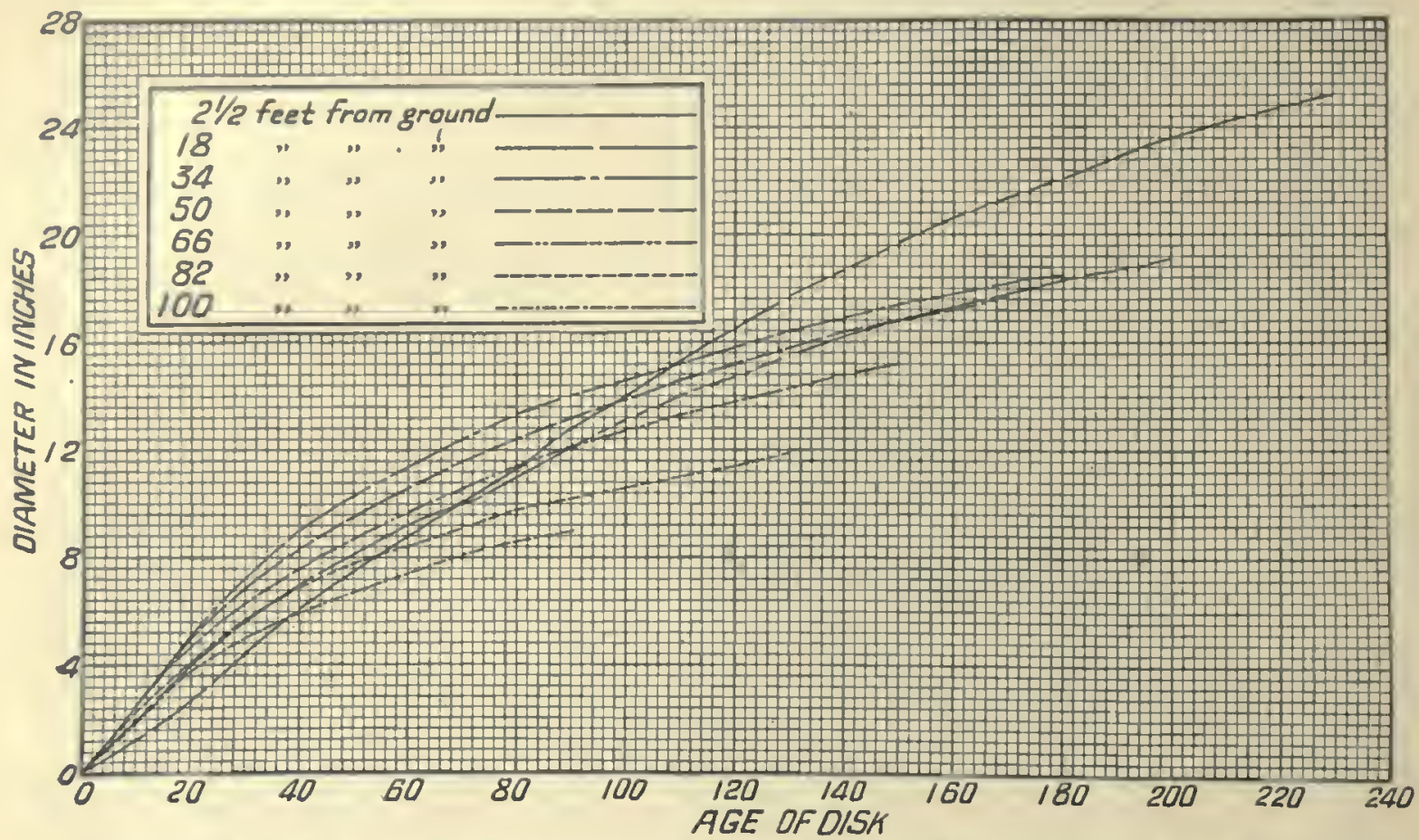

Fra. 40.-Diagram showing diameter growth of oppressed trees at various heights from ground in Miebigan.

\section{A.-MICHIGAN}

(1) SIrte $a$ :

TABLE VI.-Acre yields of White Pine and measurments of sample trees.

Soil: Fellow or gray sand, moderately loose, deep; subsoil with small stowes, surfaco corer of

Frakes, buckleberry otc., 01 per cent), mixed with Whito Pine (36 por cent), and occasional Maple, Poplar, Cedar (3 per cent), on level.

Trbite Pine. Red line.

Sample area: 1 acre.

[700 to 800 feet abore sen lerel.]

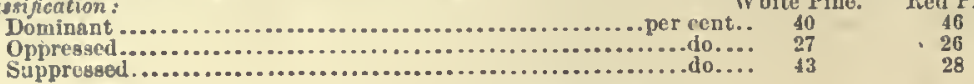

ACRE YIELD.

\begin{tabular}{|c|c|c|c|c|c|c|c|}
\hline \multicolumn{5}{|c|}{ Wbite Pine. } & \multicolumn{3}{|c|}{ lied Pine. } \\
\hline \multirow[b]{2}{*}{$\begin{array}{l}\text { Number } \\
\text { of trees. }\end{array}$} & \multirow[b]{2}{*}{$\begin{array}{c}\text { Diameter } \\
\text { (breast } \\
\text { bigh). }\end{array}$} & \multirow[b]{2}{*}{ II cight. } & \multicolumn{2}{|c|}{ Volume. } & \multirow[b]{2}{*}{$\begin{array}{l}\text { Ninmber } \\
\text { of trees. }\end{array}$} & \multirow{2}{*}{$\begin{array}{c}\text { Diameter } \\
\text { (breast } \\
\text { high). }\end{array}$} & \multirow[b]{2}{*}{ Height. } \\
\hline & & & Bole. & $\begin{array}{c}\text { Mier. } \\
\text { cliantable } \\
\text { timber. }\end{array}$ & & & \\
\hline $\begin{array}{r}4 \\
17 \\
1 \\
4 \\
2 \\
5 \\
6 \\
7 \\
4 \\
5 \\
3 \\
2 \\
2 \\
3 \\
1 \\
2\end{array}$ & $\begin{array}{r}\text { Inches. } \\
3 \text { to } 6 \\
6 \text { to } 10 \\
10 \\
11 \\
12 \\
13 \\
14 \\
15 \\
16 \\
17 \\
18 \\
19 \\
21 \\
22 \\
24 \\
27\end{array}$ & Feet. & $\begin{array}{r}\text { Cubicfeet. } \\
\cdots . . . . \\
170 \\
18 \\
100 \\
69 \\
175 \\
240 \\
322 \\
232 \\
325 \\
216 \\
158 \\
186 \\
303 \\
110 \\
366\end{array}$ & Feet B. 3 . & $\begin{array}{r}9 \\
25 \\
1 \\
7 \\
7 \\
5 \\
7 \\
9 \\
13 \\
12 \\
0 \\
3 \\
3 \\
\end{array}$ & \begin{tabular}{r} 
Inches. \\
\hdashline$\ldots$ to 10 \\
10 \\
11 \\
12 \\
13 \\
11 \\
15 \\
16 \\
17 \\
18 \\
19 \\
20
\end{tabular} & $\begin{array}{c}80 \\
10 \\
100\end{array}$ \\
\hline $\begin{array}{r}68 \text { trecs } \\
\text { Total } \\
\text { Total }\end{array}$ & $\begin{array}{l}\text { cubte feet } \\
\text { feet B. MI }\end{array}$ & $\ldots$ & $\ldots \ldots \ldots$ & $\begin{array}{r}2,090 \\
14,350\end{array}$ & $\begin{array}{l}113 \text { trees } \\
\text { Tota } \\
\text { Total }\end{array}$ & $\begin{array}{l}\text { cubic fect } \\
\text { feet } \mathbf{B} \text {. }\end{array}$ & $\begin{array}{r}3,813 \\
18,300\end{array}$ \\
\hline
\end{tabular}

Total yicld: Pine, 32,650 feet B. M. of which White Pine 44 per cent. Average annual accrelion: Wbite Pine, 57 cnbic fert.

Age of pine: 100 to 150 years. Density of crowr

Number of troes: 181 
TABLES OF MEASUREMENTS.

TABLE VI.-Aere yields of White Pine and measurements of sample trces-Contiuned.

A.-MICIIGAN-Continued.

MEASUREMENTS OF SAMPLE TREES.

Age class: 80 to 100 years.

DOMINANT GROWTH,

\begin{tabular}{|c|c|c|c|c|c|c|c|c|c|c|}
\hline Tree namber. & Age. & $\begin{array}{l}\text { Diameter } \\
\text { (breast } \\
\text { high). }\end{array}$ & Height. & $\begin{array}{l}\text { Rings } \\
\text { per inch } \\
\text { on } \\
\text { stump. }\end{array}$ & $\begin{array}{l}\text { Volume } \\
\text { of tree. }\end{array}$ & $\begin{array}{l}\text { Factor } \\
\text { of } \\
\text { shape. }\end{array}$ & $\begin{array}{l}\text { Ratio of } \\
\text { length } \\
\text { of crown } \\
\text { to total } \\
\text { height of } \\
\text { tree. }\end{array}$ & \multicolumn{2}{|c|}{$\begin{array}{l}\text { Cnrrent annual } \\
\text { accretion. }\end{array}$} & $\begin{array}{l}\text { Average } \\
\text { annual } \\
\text { accre. } \\
\text { tion. }\end{array}$ \\
\hline $\begin{array}{l}13 \ldots \ldots \ldots \ldots \ldots \\
29 \ldots \ldots \ldots \ldots \ldots\end{array}$ & $\begin{array}{c}\text { Years. } \\
100 \\
100 \\
95\end{array}$ & $\begin{array}{c}\text { Inches. } \\
19.0 \\
20.3 \\
21.5\end{array}$ & $\begin{array}{r}\text { Feet. } \\
94 \\
95 \\
100\end{array}$ & $\begin{array}{r}\text { No. } \\
5.2 \\
4.9 \\
4.1\end{array}$ & $\begin{array}{r}\text { Cu. } f t . \\
75.4 \\
99.6 \\
115.4\end{array}$ & $\begin{array}{r}0.40 \\
.48 \\
.45\end{array}$ & $\begin{array}{r}0.52 \\
.42 \\
.48\end{array}$ & $\begin{array}{c}\text { Per cent. } \\
2.0 \\
.8 \\
1.0\end{array}$ & $\begin{array}{r}C u . f t . \\
1.50 \\
.80 \\
1.15\end{array}$ & $\begin{array}{r}\text { Ou. ft. } \\
0.75 \\
1.00 \\
1.21\end{array}$ \\
\hline A rerage... & 98 & 20.2 & 96 & 4.7 & 96.8 & .44 & .47 & 1.3 & 1.15 & .99 \\
\hline
\end{tabular}

OPPRESSED GROWTH.

\begin{tabular}{|r|r|r|r|r|r|r|r|r|r|r|r|}
\hline $66 \ldots \ldots \ldots . . . . .$. & 98 & 14.5 & 78 & 5.9 & 46.9 & 0.52 & 0.42 & 2.2 & 1.03 & 0.47 \\
\hline
\end{tabular}

SU PPRESSED GROWTH.

\begin{tabular}{|c|c|c|c|c|c|c|c|c|c|c|}
\hline $19 \ldots \ldots \ldots \ldots \ldots$ & $\begin{array}{l}92 \\
84\end{array}$ & $\begin{array}{l}10.5 \\
10.0\end{array}$ & $\begin{array}{l}72.0 \\
73.0\end{array}$ & $\begin{array}{l}8.2 \\
7.6\end{array}$ & $\begin{array}{l}20.6 \\
20.9\end{array}$ & $\begin{array}{r}0.47 \\
.53\end{array}$ & $\begin{array}{r}0.26 \\
.48\end{array}$ & $\begin{array}{l}1.2 \\
3.7\end{array}$ & $\begin{array}{r}0.25 \\
.77\end{array}$ & $\begin{array}{r}0.22 \\
.25\end{array}$ \\
\hline Arerago... & 88 & 10.2 & 72.5 & 7.9 & 20.7 & .50 & .37 & 2.4 & .51 & .23 \\
\hline
\end{tabular}

Age class: 100 to 150 years.

DOMISANT GROWTH.

\begin{tabular}{|c|c|c|c|c|c|c|c|c|c|c|}
\hline \multirow[b]{2}{*}{$\begin{array}{l}1 \\
48 \\
47 \ldots \ldots \ldots \ldots \ldots \ldots\end{array}$} & \multirow[b]{2}{*}{$\begin{array}{l}123 \\
101 \\
105 \\
104\end{array}$} & & \multirow[b]{2}{*}{$\begin{array}{l}5.5 \\
4.7 \\
5.1 \\
4.7\end{array}$} & \multicolumn{2}{|c|}{+1} & \multirow[b]{2}{*}{$\begin{array}{r}0.54 \\
.51 \\
.44 \\
.59\end{array}$} & \multirow[b]{2}{*}{$\begin{array}{l}2.9 \\
2.0 \\
1.3 \\
1.5\end{array}$} & \multirow[b]{2}{*}{$\begin{array}{l}2.60 \\
1.85 \\
1.26 \\
1.55\end{array}$} & \multirow[b]{2}{*}{$\begin{array}{r}0.73 \\
.91 \\
.92 \\
.99\end{array}$} \\
\hline & & $\begin{array}{l}20.0 \\
20.8 \\
20.5 \\
22.7\end{array}$ & $\begin{array}{l}10.2 \\
90.0 \\
99.0 \\
94.0\end{array}$ & & $\begin{array}{r}89.7 \\
92.7 \\
90.7 \\
108.0\end{array}$ & $\begin{array}{l}0.40 \\
.42 \\
.42 \\
.39\end{array}$ & & & & \\
\hline Arerage... & 108 & 21.0 & 96.0 & 5.0 & 95.5 & .41 & .52 & 1.9 & 1.81 & .89 \\
\hline $\begin{array}{l}5 \\
6 \\
35 \ldots \ldots \ldots \ldots\end{array}$ & $\begin{array}{l}149 \\
135 \\
135\end{array}$ & $\begin{array}{l}20.2 \\
21.0 \\
22.0\end{array}$ & $\begin{array}{l}105.0 \\
114.0 \\
121.0\end{array}$ & $\begin{array}{l}7.0 \\
6.2 \\
5.5\end{array}$ & $\begin{array}{r}88.9 \\
107.9 \\
139.6\end{array}$ & $\begin{array}{l}.39 \\
.39 \\
.40\end{array}$ & $\begin{array}{l}.50 \\
.57 \\
.43\end{array}$ & $\begin{array}{l}2.0 \\
2.2 \\
1.5\end{array}$ & $\begin{array}{l}1.78 \\
2.37 \\
2.10\end{array}$ & $\begin{array}{r}.60 \\
.80 \\
1.03\end{array}$ \\
\hline Averago... & 139. 7 & 21.1 & 113.0 & 0.4 & 112.1 & .39 & .50 & 1. 9 & 2.08 & .81 \\
\hline
\end{tabular}

OPPAESSED GROWTH.

\begin{tabular}{|c|c|c|c|c|c|c|c|c|c|c|}
\hline $\begin{array}{l}9 \ldots \ldots \ldots \ldots \ldots \ldots \\
31 \ldots \ldots \ldots \ldots \ldots \ldots \ldots \ldots \\
45 \ldots \ldots \ldots \ldots \ldots \ldots \ldots \\
43 \ldots \ldots \ldots \ldots \ldots\end{array}$ & $\begin{array}{l}102 \\
102 \\
102 \\
105\end{array}$ & $\begin{array}{l}16.0 \\
15.1 \\
17.0 \\
16.8\end{array}$ & $\begin{array}{l}85.0 \\
86.0 \\
84.0 \\
87.0\end{array}$ & $\begin{array}{l}6.6 \\
6.7 \\
6.0 \\
6.1\end{array}$ & $\begin{array}{l}48.8 \\
49.4 \\
58.5 \\
67.3\end{array}$ & $\begin{array}{l}0.41 \\
.46 \\
.44 \\
.49\end{array}$ & $\begin{array}{l}0.46 \\
.40 \\
.61 \\
.42\end{array}$ & $\begin{array}{r}2.5 \\
1.4 \\
1.7 \\
.7\end{array}$ & $\begin{array}{r}1.22 \\
.69 \\
.99 \\
.47\end{array}$ & $\begin{array}{r}0.47 \\
.48 \\
.57 \\
.64\end{array}$ \\
\hline Arerage... & 103 & 16. 2 & 85.5 & 6.3 & 56. 0 & .45 & .47 & 1.6 & .84 & .54 \\
\hline $\begin{array}{l}40 \ldots \ldots \\
3 \ldots \ldots \ldots \ldots \ldots\end{array}$ & $\begin{array}{l}127 \\
134 \\
147\end{array}$ & $\begin{array}{l}17.0 \\
15.0 \\
18.0\end{array}$ & $\begin{array}{l}88.0 \\
94.0 \\
91.0\end{array}$ & $\begin{array}{l}6.7 \\
8.6 \\
7.9\end{array}$ & $\begin{array}{l}56.9 \\
57.6 \\
66.0\end{array}$ & $\begin{array}{l}.41 \\
.50 \\
.41\end{array}$ & $\begin{array}{l}.54 \\
.30 \\
.44\end{array}$ & $\begin{array}{l}5.2 \\
2.2 \\
4.9\end{array}$ & $\begin{array}{l}2.96 \\
1.26 \\
3.23\end{array}$ & $\begin{array}{l}.44 \\
.43 \\
.44\end{array}$ \\
\hline Average... & 130 & 16.7 & 91.0 & 7.7 & 60.2 & .44 & .43 & 4.1 & 2.48 & .44 \\
\hline
\end{tabular}

SUPPRESED GROWTH.

\begin{tabular}{|c|c|c|c|c|c|c|c|c|c|c|}
\hline 39.............. & 127 & 11.0 & 69 & 1.2 & 24.6 & 0.54 & 0.22 & 3.2 & 0.79 & 0.19 \\
\hline
\end{tabular}

Age class: 250 to 300 years.

DOMINANT GROWTIR.

\begin{tabular}{rl|r|r|r|r|r|r|r|r|r|}
\hline $7 \ldots \ldots \ldots \ldots \ldots$ & 284 & 33.0 & 135 & 8.7 & 319.2 & 0.39 & $\ldots \ldots \ldots \ldots$ & 0.6 & 1.91 \\
\hline
\end{tabular}


TanL: VI.-Acre yields of Whitc Pine and measurements of sample trees-Continued.

\section{A.-MICIICAX-Contlnued.}

(2) SITE b:
Presque Islo Connts.

[700 to 800 feet nivore sea lerel.]

Soll: Deep, loose, gray sand, covered with leaves; sald to be underiald by ciay.

Fureat conditions: White PIne (68 per cent), intermlxed with Red Pine (14 jer cent), Hemfock (18 per cent), with scattering Codar.

Clastiflcation

Oouninant.

Suppressod White pine. Aengits of crown cover: 0.7 to 0.8 .

u.8.

\begin{tabular}{|c|c|c|c|c|c|c|c|c|c|c|}
\hline \multicolumn{5}{|c|}{ White Pine. } & \multicolumn{3}{|c|}{ Red Pjne. } & \multicolumn{3}{|c|}{ H cmlock. } \\
\hline \multirow[b]{2}{*}{$\begin{array}{l}\text { Nimber } \\
\text { of trees. }\end{array}$} & \multirow[b]{2}{*}{$\begin{array}{l}\text { Diameter } \\
\text { (hreast } \\
\text { high). }\end{array}$} & \multirow[b]{2}{*}{ Helght. } & \multicolumn{2}{|c|}{ Volume. } & \multirow[b]{2}{*}{$\begin{array}{l}\text { Number } \\
\text { of trees. }\end{array}$} & \multirow[b]{2}{*}{$\begin{array}{l}\text { Dinmeter } \\
\text { (breast } \\
\text { high). }\end{array}$} & \multirow[b]{2}{*}{ Ilelght. } & \multirow[b]{2}{*}{$\begin{array}{l}\text { Numher } \\
\text { of trees. }\end{array}$} & \multirow[b]{2}{*}{$\begin{array}{l}\text { Dlameter } \\
\text { (breast } \\
\text { hig b). }\end{array}$} & \multirow[b]{2}{*}{ Hoight. } \\
\hline & & & Bole. & $\begin{array}{l}\text { Mer. } \\
\text { ohantahle } \\
\text { timber. }\end{array}$ & & & & & & \\
\hline $\begin{array}{r}28 \\
5 \\
6 \\
7 \\
6 \\
11 \\
9 \\
6 \\
10 \\
8 \\
7 \\
6 \\
6 \\
7 \\
1 \\
1 \\
3 \\
1 \\
1\end{array}$ & $\begin{array}{r}\text { Inches, } \\
6 \text { to } 10 \\
10 \\
11 \\
11 \\
12 \\
13 \\
14 \\
15 \\
16 \\
17 \\
18 \\
19 \\
20 \\
21 \\
22 \\
23 \\
24 \\
26 \\
27 \\
30\end{array}$ & $\begin{array}{c}100 \\
\text { to } \\
120\end{array}$ & $\begin{array}{c}\text { Cubicfeet. } \\
280 \\
95 \\
192 \\
206 \\
204 \\
550 \\
522 \\
384 \\
720 \\
640 \\
616 \\
690 \\
744 \\
945 \\
147 \\
153 \\
555 \\
199 \\
240\end{array}$ & Feet B.MIS & $\begin{array}{l}1 \\
1 \\
1 \\
5 \\
6 \\
1 \\
3 \\
2 \\
5 \\
1\end{array}$ & $\begin{array}{r}\text { Inches. } \\
6 \text { to } 10 \\
14 \\
15 \\
16 \\
17 \\
18 \\
19 \\
20 \\
21 \\
22\end{array}$ & $\begin{array}{c} \\
100 \\
\text { to } \\
120\end{array}$ & $\begin{array}{r}20 \\
11 \\
3\end{array}$ & $\begin{array}{l}\text { Inches. } \\
6 \text { to } 10 \\
10 \text { to } 14 \\
14 \text { to } 18\end{array}$ & $\begin{array}{c}\text { Feet. } \\
40 \\
\text { to } \\
60\end{array}$ \\
\hline \multicolumn{5}{|c|}{ 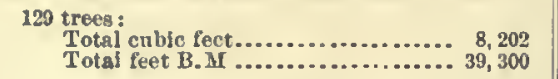 } & \multicolumn{3}{|c|}{$\begin{array}{l}26 \text { trees: } \\
\text { Total cnblo fect }-2,440\end{array}$} & \multicolumn{3}{|c|}{$\begin{array}{l}34 \text { trees: } \\
\text { Total cublc feet ... } 520\end{array}$} \\
\hline
\end{tabular}

Total yield: Afl specles, 11,162 cuhle feot, of which White Pine 73 per cent. Average annual aceretion: Wbite Pine, 63 cuhic foet.

MEASUREMENTS OF SAMPLE TREES.

Age class: 130 to 150 years.

DOMINANT OROWTE.

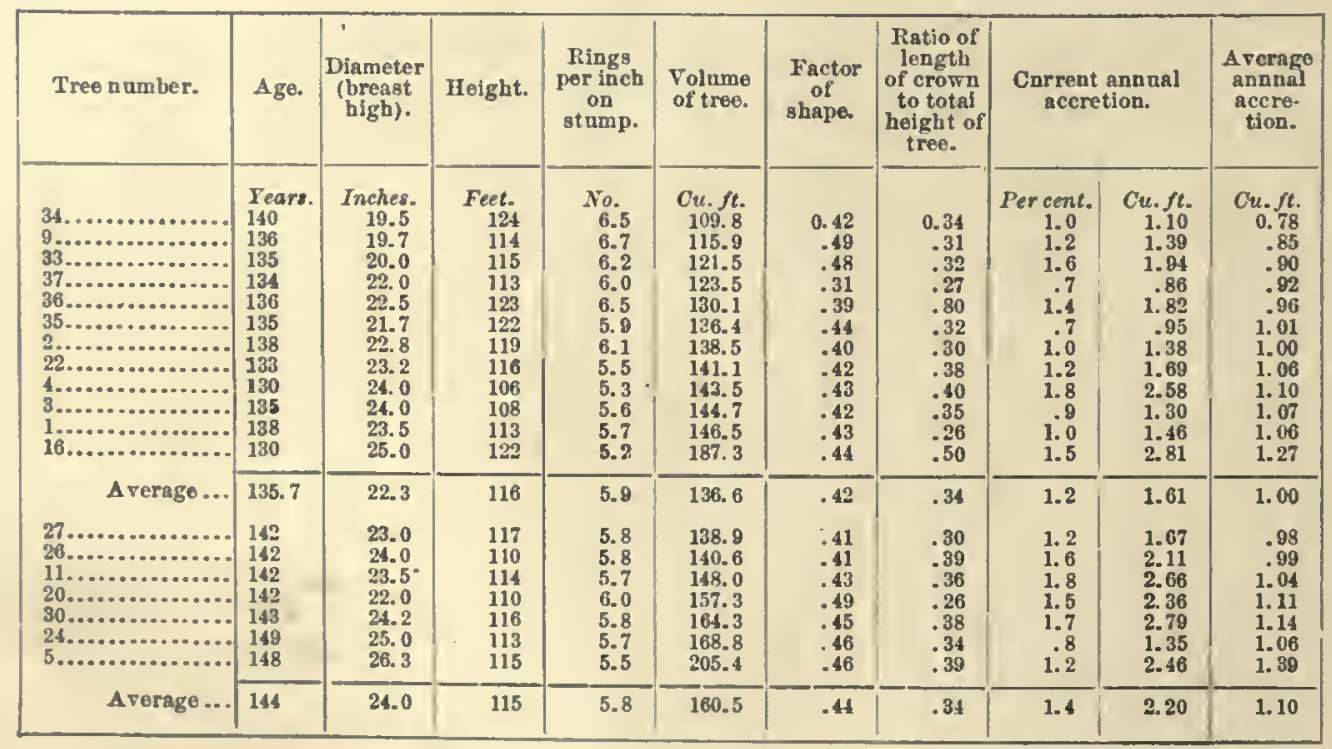


TABLES OF MEASUREMENTS.

TABLE: VI.-Acre yields of White Pine and measurements of sample trees-Continued.

A.-MICHIGAX-Continned.

MEASUREMENTS UF SAMPLE TREES-Continued.

OPPREASED GROWTR.

\begin{tabular}{|c|c|c|c|c|c|c|c|c|c|c|}
\hline Tree number. & Age. & $\begin{array}{c}\text { Diameter } \\
\text { (hreast } \\
\text { high). }\end{array}$ & $\begin{array}{l}\text { Height. } \\
\text { Feet. }\end{array}$ & $\begin{array}{c}\begin{array}{c}\text { Rings } \\
\text { per inch } \\
\text { on } \\
\text { stump. }\end{array} \\
\text { No. }\end{array}$ & $\begin{array}{l}\text { Volnme } \\
\text { of tree. } \\
\text { Cu. ft. }\end{array}$ & $\begin{array}{c}\begin{array}{c}\text { Factor } \\
\text { of } \\
\text { shape. }\end{array} \\
0.41\end{array}$ & $\begin{array}{l}\text { Ratio of } \\
\text { length } \\
\text { of erown } \\
\text { to total } \\
\text { height of } \\
\text { tree. }\end{array}$ & \multicolumn{2}{|c|}{$\begin{array}{l}\text { Cnrrent annual } \\
\text { accretion. }\end{array}$} & \multirow{2}{*}{ 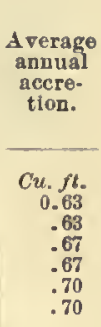 } \\
\hline 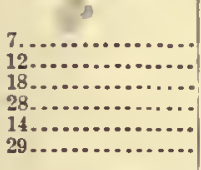 & $\begin{array}{c}\text { Tears. } \\
132 \\
139 \\
135 \\
135 \\
135 \\
140\end{array}$ & $\begin{array}{r}\text { Inches. } \\
17.8 \\
18.5 \\
18.0 \\
17.5 \\
19.5 \\
18.5\end{array}$ & $\begin{array}{r}\text { Feet. } \\
114 \\
112 \\
116 \\
110 \\
107 \\
102\end{array}$ & $\begin{array}{c}\text { No. } \\
6.7 \\
7.8 \\
7.2 \\
7.3 \\
6.8 \\
7.5\end{array}$ & $\begin{array}{r}C u . f t . \\
83.6 \\
88.4 \\
91.2 \\
92.0 \\
95.6 \\
98.2\end{array}$ & $\begin{array}{r}0.41 \\
.42 \\
.44 \\
.49 \\
.43 \\
.51\end{array}$ & $\begin{array}{l}0.42 \\
.38 \\
.27 \\
.36 \\
.42 \\
.27\end{array}$ & $\begin{array}{c}\text { Per cent. } \\
1.2 \\
1.1 \\
.9 \\
1.6 \\
.5 \\
1.9\end{array}$ & $\begin{array}{r}C u . f t . \\
1.00 \\
.97 \\
.82 \\
1.47 \\
. .48 \\
1.87\end{array}$ & \\
\hline Average... & 136 & 18.3 & 110 & 7.2 & 91.5 & .45 & .35 & 1.2 & 1.10 & .67 \\
\hline
\end{tabular}

SCPPRESSED GROWTH.

\begin{tabular}{|c|c|c|c|c|c|c|c|c|c|c|}
\hline $\begin{array}{l}8 \\
32 \\
31 \\
13 \ldots \ldots \ldots \\
17 \ldots \ldots \ldots\end{array}$ & $\begin{array}{l}131 \\
135 \\
238 \\
131 \\
138\end{array}$ & $\begin{array}{l}15.0 \\
17.5 \\
17.4 \\
16.4 \\
19.0\end{array}$ & $\begin{array}{l}115 \\
(?) \\
104 \\
114 \\
103\end{array}$ & $\begin{array}{l}\text { 8. } 5 \\
7.2 \\
7.3 \\
7.7 \\
7.0\end{array}$ & $\begin{array}{l}66.2 \\
73.9 \\
78.6 \\
79.7 \\
80.6\end{array}$ & $\begin{array}{l}0.47 \\
(1) \\
.45 \\
.47 \\
.39\end{array}$ & $\begin{array}{l}0.35 \\
(i) \\
.29 \\
.28 \\
.28\end{array}$ & $\begin{array}{l}1.0 \\
2.4 \\
1.7 \\
1.3 \\
1.6\end{array}$ & $\begin{array}{l}0.66 \\
1.77 \\
1.34 \\
1.04 \\
1.29\end{array}$ & $\begin{array}{l}0.50 \\
.55 \\
.57 \\
.61 \\
.58\end{array}$ \\
\hline Average... & 134.6 & 17.0 & 109 & 7.5 & 75.8 & .44 & .30 & 1.6 & 1.22 & .56 \\
\hline $\begin{array}{l}6 \\
25 \ldots \ldots \ldots \ldots\end{array}$ & $\begin{array}{l}142 \\
154\end{array}$ & $\begin{array}{l}21.0 \\
19.0\end{array}$ & $\begin{array}{r}109 \\
97\end{array}$ & $\begin{array}{l}7.2 \\
7.7\end{array}$ & $\begin{array}{r}121.7 \\
78.6\end{array}$ & $\begin{array}{l}.46 \\
.41\end{array}$ & $\begin{array}{r}.44 \\
.41\end{array}$ & $\begin{array}{l}1.5 \\
1.4\end{array}$ & $\begin{array}{l}1.82 \\
1.10\end{array}$ & $\begin{array}{l}.85 \\
.50\end{array}$ \\
\hline A verage... & 148 & 20.0 & 103 & 7.5 & 100.0 & .43 & .42 & 1.4 & 1.46 & .67 \\
\hline
\end{tabular}

(3) SITE $d$ :

Montmorency Connty.

Sample area: 1 acre.

Sorl: Fresh, loose gray sand, turning brown and red helow, with onrface cover of hrakes and checkerberry; suhsoil, hrown sand, sometimes loamy, and in spots clay.

Forest conditions: White Pine (54 per cent) mixed with Red Pine (35 per cent) and Henlock (11

Der cent).

Age of pine: 250 to 270 years. Density of crown cover: 0.5 . cent damaged by firo.

ACRE YIELD.

\begin{tabular}{|c|c|c|c|c|c|c|c|c|c|c|}
\hline \multicolumn{5}{|c|}{ White Pine. } & \multicolumn{3}{|c|}{ Red Pine. } & \multicolumn{3}{|c|}{ Hemlock. } \\
\hline \multirow[b]{2}{*}{$\begin{array}{l}\text { Nnmber } \\
\text { of trees. }\end{array}$} & \multirow[b]{2}{*}{$\begin{array}{c}\text { Diameter } \\
\text { (hreast } \\
\text { high). }\end{array}$} & \multirow[b]{2}{*}{ Height. } & \multicolumn{2}{|c|}{ Volume. } & \multirow[b]{2}{*}{$\begin{array}{l}\text { Number } \\
\text { of trees. }\end{array}$} & \multirow[b]{2}{*}{$\begin{array}{c}\text { Diameter } \\
\text { (hreast } \\
\text { high). }\end{array}$} & \multirow[b]{2}{*}{ Height. } & \multirow[b]{2}{*}{$\begin{array}{l}\text { Number } \\
\text { of trees. }\end{array}$} & \multirow[b]{2}{*}{$\begin{array}{c}\text { Diameter } \\
\text { (breast } \\
\text { high). }\end{array}$} & \multirow[b]{2}{*}{ Height. } \\
\hline & & & Bole. & $\begin{array}{c}\text { Mer- } \\
\text { chantahle } \\
\text { timher. }\end{array}$ & & & & & & \\
\hline $\begin{array}{l}2 \\
1 \\
3 \\
1 \\
3 \\
8 \\
1 \\
1 \\
3 \\
2 \\
6 \\
5 \\
8 \\
4 \\
1 \\
3 \\
2 \\
7 \\
2 \\
1 \\
1\end{array}$ & $\begin{array}{r}\text { Inches. } \\
10 \\
12 \\
13 \\
14 \\
15 \\
16 \\
17 \\
18 \\
19 \\
21 \\
22 \\
23 \\
24 \\
25 \\
26 \\
27 \\
28 \\
29 \\
30 \\
31 \\
33\end{array}$ & $\begin{array}{c}120 \\
\text { to } \\
140\end{array}$ & $\begin{array}{c}\text { Oubicfeet. } \\
36 \\
38 \\
159 \\
60 \\
207 \\
231 \\
86 \\
96 \\
315 \\
280 \\
906 \\
855 \\
1,611 \\
800 \\
216 \\
696 \\
498 \\
1,862 \\
360 \\
302 \\
340\end{array}$ & Feet B.MT. & $\begin{array}{l}2 \\
1 \\
3 \\
1 \\
3 \\
3 \\
6 \\
5 \\
4 \\
8 \\
1 \\
1 \\
1\end{array}$ & $\begin{array}{r}\text { Inches. } \\
13 \\
14 \\
15 \\
16 \\
17 \\
18 \\
19 \\
20 \\
21 \\
22 \\
23 \\
24 \\
30\end{array}$ & $\begin{array}{c}\text { Feet. } \\
\\
\\
120 \\
\text { to } \\
140\end{array}$ & $\begin{array}{l}2 \\
1 \\
1 \\
2 \\
6 \\
1\end{array}$ & $\begin{array}{r}\text { Inches. } \\
3 \text { to } 6 \\
9 \\
11 \\
12 \\
15 \\
20\end{array}$ & $\begin{array}{l}\text { Feet. } \\
40 \\
50 \text { to } \\
80\end{array}$ \\
\hline 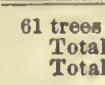 & $\begin{array}{l}\text { nbic feet } \\
\text { oet B. M }\end{array}$ & & & $\begin{array}{r}10,154 \\
60,900\end{array}$ & $\begin{array}{l}39 \text { trees } \\
\text { Tutal } \\
\text { Total }\end{array}$ & $\begin{array}{l}\text { icabio feet } \\
\text { foet B. M. }\end{array}$ & $\begin{array}{r}5,256 \\
25,200\end{array}$ & 13 trees. & & \\
\hline
\end{tabular}

Total vield: Pine, 86, 100 feet B. Mf., of which White Pine 66 yer cent. Average annual accretion: Pine, 59 cuhic foet. 
- TAnLE VI. - Acre yields of While l'ine and measurements of sample trecs-Continued.

\section{A.-NICIIGAX-Conthuml.}

(1) Sirte :

Montmoroncr County.

Noll: Irown or red snudy loam, llght, loose, drg, wth stones, and surfaco corer of brakes aul other weevls.

Forest condifions: Kevl Plne (59 jer cent) ulxed wlth Whlte PIne (4l jer cent:; no undergrowth; level.

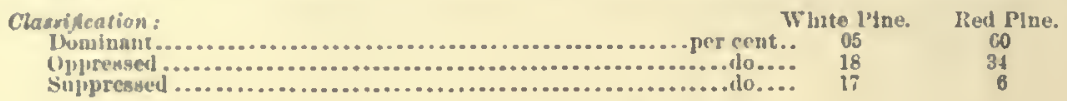

\section{HALF.ACRE TIFLD.}

\begin{tabular}{|c|c|c|c|c|c|c|c|}
\hline \multicolumn{5}{|c|}{ White I'fne. } & \multicolumn{3}{|c|}{ Red I'Jue. } \\
\hline \multirow[b]{2}{*}{$\begin{array}{l}\text { Nunuber } \\
\text { of trees. }\end{array}$} & \multirow[b]{2}{*}{$\begin{array}{c}\text { Dianueter } \\
\text { (breast } \\
\text { ligh). }\end{array}$} & \multirow[b]{2}{*}{ Height. } & \multicolumn{2}{|c|}{ Folune. } & \multirow[b]{2}{*}{$\begin{array}{l}\text { Number } \\
\text { of trees. }\end{array}$} & \multirow[b]{2}{*}{$\begin{array}{c}\text { Dlameter } \\
\text { (breast } \\
\text { blgh). }\end{array}$} & \multirow[b]{2}{*}{ Height. } \\
\hline & & & Bole. & $\begin{array}{l}\text { Mer. } \\
\text { chantable } \\
\text { timber. }\end{array}$ & & & \\
\hline $\begin{array}{l}2 \\
2 \\
4 \\
2 \\
2 \\
6 \\
8 \\
2 \\
6 \\
2 \\
4 \\
6\end{array}$ & $\begin{array}{r}\text { Inches. } \\
3 \text { to } 6 \\
6 \text { to } 10 \\
10 \\
11 \\
12 \\
13 \\
14 \\
15 \\
10 \\
17 \\
18 \\
19\end{array}$ & $\begin{array}{c}80 \\
\text { to } \\
100\end{array}$ & $\begin{array}{r}\text { Cubicfeed. } \\
20 \\
72 \\
56 \\
68 \\
234 \\
360 \\
104 \\
348 \\
130 \\
288 \\
474\end{array}$ & Feet B.3r. & $\begin{array}{r}4 \\
6 \\
4 \\
2 \\
6 \\
4 \\
6 \\
2 \\
2 \\
4 \\
10 \\
6 \\
4 \\
2 \\
2\end{array}$ & $\begin{array}{r}\text { Inches. } \\
3 \text { to } 0 \\
0 \text { to } 10 \\
10 \\
11 \\
12 \\
13 \\
14 \\
15 \\
16 \\
17 \\
18 \\
19 \\
20 \\
21 \\
22\end{array}$ & $\begin{array}{c}80 \\
\text { to } \\
100\end{array}$ \\
\hline $\begin{array}{l}46 \text { tree } \\
\text { To } \\
\text { To }\end{array}$ & $\begin{array}{l}\text { culbie fe } \\
\text { feet } B .\end{array}$ & 的 & …........ & $\begin{array}{l}2,154 \\
9,030\end{array}$ & 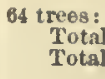 & $\begin{array}{l}\text { cubio feet } \\
\text { feot B. II }\end{array}$ & $\begin{array}{r}3,532 \\
14,800\end{array}$ \\
\hline
\end{tabular}

Total yield: PIne, 23,830 feet B. Mf., of whieh White Pine 38 por cent. Average annual accretion: Pino, 51 cubie feet.

MEASUREMENTS OF SAMPLE TREES.

DOMLNANT GROWTH.

\begin{tabular}{|c|c|c|c|c|c|c|c|c|c|c|}
\hline Tree nnmber. & Age. & $\begin{array}{l}\text { Dianueter } \\
\text { (breast } \\
\text { hlgh). }\end{array}$ & Height. & $\begin{array}{l}\text { Rings } \\
\text { per ineh } \\
\text { on } \\
\text { stump. }\end{array}$ & $\begin{array}{l}\text { Tolume } \\
\text { of tree. }\end{array}$ & $\begin{array}{l}\text { Factor } \\
\text { of } \\
\text { shape. }\end{array}$ & $\begin{array}{c}\text { Ratio of } \\
\text { length } \\
\text { of erown } \\
\text { to total } \\
\text { helght of } \\
\text { troe. }\end{array}$ & $\begin{array}{r}\text { Current } \\
\text { aeere }\end{array}$ & $\begin{array}{l}\text { annual } \\
\text { ior. }\end{array}$ & $\begin{array}{l}\text { Arerage } \\
\text { annnal } \\
\text { accre- } \\
\text { tlon. }\end{array}$ \\
\hline s................ & $\begin{array}{l}\text { Tears. } \\
120\end{array}$ & $\begin{array}{c}\text { Inches. } \\
18\end{array}$ & $\begin{array}{l}\text { Feet. } \\
\qquad 90\end{array}$ & Xio. & $\begin{array}{c}\text { Cu. feet. } \\
71.0\end{array}$ & 0.42 & 0.41 & $\begin{array}{c}\text { Per cent. } \\
1.1\end{array}$ & $\begin{array}{l}\text { Cu. feet. } \\
0.79\end{array}$ & $\begin{array}{l}\text { Cu. feet. } \\
0.60\end{array}$ \\
\hline
\end{tabular}

OPPRESSED GROWTH.

\begin{tabular}{|l|l|l|l|l|l|l|l|l|l|l|}
\hline $4 \ldots \ldots \ldots \ldots$ & 118 & 14 & 95 & 7.4 & 55.0 & 0.53 & 0.31 & 1.1 & 0.60 & 0.46 \\
\hline
\end{tabular}


TABle VI.-Acre yields of White Pine and measurements of sample trees-Continued.

A.-MICHIGAN-Continued.

(5) $\operatorname{SiTE} f$ :

Montmoreney Counts.

Sample area: 1 acre.

Soil: Brown, dry sand, with stones, and snrface cover of brakes and grass.

Age of pine: 160 to 180 years

Forest conditions: Red Pine (94 per cent) with scattering White Pine (6 per cent) on a level plain; no nndergrowth save very small slurn hs of scattered Oak (characteristic of this locality). Abont 15 per cent of trees injured hy fre in 1891.

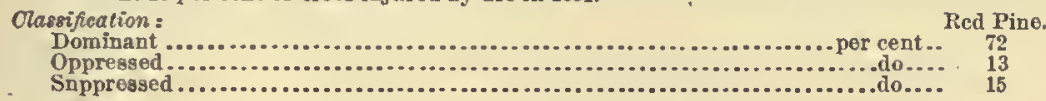
A

Number of trees : 115

ACRE YIELD.

\begin{tabular}{|c|c|c|c|c|c|c|c|}
\hline \multicolumn{5}{|c|}{ White Pine. } & \multicolumn{3}{|c|}{ Red Pine. } \\
\hline \multirow[b]{2}{*}{$\begin{array}{l}\text { Number } \\
\text { of irees. }\end{array}$} & \multirow{2}{*}{$\begin{array}{c}\text { Diameter } \\
\text { (breast } \\
\text { high). }\end{array}$} & \multirow[b]{2}{*}{ Height. } & \multicolumn{2}{|c|}{ Volnme. } & \multirow[b]{2}{*}{$\begin{array}{l}\text { Number } \\
\text { of trees. }\end{array}$} & \multirow{2}{*}{$\begin{array}{c}\text { Diameter } \\
\text { (breast } \\
\text { high). }\end{array}$} & \multirow[b]{2}{*}{ Height. } \\
\hline & & & Bole. & $\begin{array}{l}\text { Mer- } \\
\text { ohantable } \\
\text { timber. }\end{array}$ & & & \\
\hline $\begin{array}{l}1 \\
2 \\
1 \\
1 \text { (dead) } \\
1 \\
1\end{array}$ & $\begin{array}{r}\text { Inches. } \\
15 \\
16 \\
13 \\
21 \\
22 \\
23\end{array}$ & $\begin{array}{c}\text { Fect. } \\
90 \\
\text { to } \\
100\end{array}$ & $\begin{array}{c}\text { Cubie feet. } \\
52 \\
110 \\
\ldots \ldots \\
112 \\
122\end{array}$ & Feet B.M. & $\begin{array}{l}1 \\
1 \\
5 \text { (2 dead) } \\
5 \\
8 \text { (3 dead) } \\
13 \text { (1 dead) } \\
18 \text { is dead) } \\
20 \text { (3 dead) } \\
24 \text { (4 dead) } \\
5 \\
5 \\
2 \\
1\end{array}$ & $\begin{array}{c}\text { Inches. } \\
10 \\
11 \\
12 \\
13 \\
14 \\
15 \\
16 \\
17 \\
18 \\
19 \\
20 \\
21 \\
22\end{array}$ & $\begin{array}{c}90 \\
\text { to } \\
100\end{array}$ \\
\hline $\begin{array}{c}7 \text { trees : } \\
\text { Total } \\
\text { Total }\end{array}$ & $\begin{array}{l}\text { cuhic foet } \\
\text { feet B.MY. }\end{array}$ & & …..... & $\begin{array}{l}. .402 \\
\ldots . \\
\ldots\end{array}$ & $\begin{array}{r}108 \text { trees: } \\
\text { Total } \\
\text { Total }\end{array}$ & $\begin{array}{l}\text { thic foct } \\
\text { et B.M. }\end{array}$ & $\begin{array}{r}0,863 \\
: 28,800\end{array}$ \\
\hline
\end{tabular}

Total yield : Pine, 30,490 feet B.M., of which White Pine 5 per cent. Average annual accretion: Pine, 42 cubic feet.

(6) SITE $g$ :

Crawford County.

[A bout 1,200 feet ahove sea level.]

Soil: Brown, loamy sand, deep, fresh, snoderatoly loose, with surface cover of fern and grass; sand with stones underlies the soil.

Forest condilions: Two-story stand, upper story of White Pine (1 Red Pine of 26 incbes in dian. eter) with 0.3 density of crown cover, lower story of FIr (22 from 4 to 10 inches in diameter), Beech (4 from 4 to 10 inches in diameter), snd Hemlock (19 from 4 to 10 inches in diameter) ander I'ine, 50; Homlook, 20; Iir, 25; hard woods, 5 .

Clasrification:

Dominant

Oppressed

Suppressed.

ACRE YIELD.

\begin{tabular}{|c|c|c|c|c|}
\hline \multicolumn{5}{|c|}{ White Pine. } \\
\hline \multirow[b]{2}{*}{$\begin{array}{l}\text { Numher } \\
\text { of trees. }\end{array}$} & \multirow[b]{2}{*}{$\begin{array}{c}\text { Dianeter } \\
\text { (hreast } \\
\text { high). }\end{array}$} & \multirow[b]{2}{*}{ Height. } & \multicolumn{2}{|c|}{ Volnme. } \\
\hline & & & Bole. & $\begin{array}{c}\text { Mer- } \\
\text { chantable } \\
\text { timber. }\end{array}$ \\
\hline $\begin{array}{r}3 \\
1 \\
2 \\
1 \\
1 \\
1 \\
3 \\
2 \\
4 \\
7 \\
2 \\
5 \\
2 \\
5 \\
3 \\
1 \\
1 \\
1\end{array}$ & $\begin{array}{r}\text { Inches. } \\
10 \\
18 \\
21 \\
23 \\
24 \\
25 \\
26 \\
27 \\
28 \\
29 \\
30 \\
31 \\
32 \\
33 \\
35 \\
36 \\
42\end{array}$ & $\begin{array}{c}\text { Feet. } \\
100 \\
\text { to } \\
120\end{array}$ & $\begin{array}{c}\text { Oubicfeet. } \\
213 \\
79 \\
228 \\
134 \\
146 \\
471 \\
432 \\
464 \\
1,743 \\
532 \\
1,400 \\
604 \\
1,000 \\
1,020 \\
381 \\
401 \\
537\end{array}$ & Feet B. Mr. \\
\hline $\begin{array}{l}41 \text { trees } \\
\text { Tota } \\
\text { Total }\end{array}$ & $\begin{array}{l}\text { cubie foe } \\
\text { feet } B . M\end{array}$ & .... & $\cdots \cdots$ & $\begin{array}{l}.10,385 \\
. .62,300\end{array}$ \\
\hline
\end{tabular}

Average annual accetion: White Pine, 40 cuhic foet.
Sample area: 1 acre

Age of pine: 250 to 260 years Density of crown cover: 0.7 .

Nnmber of trees: (?). 
TanLE VI. - Acre yields of While Pine and measurements of sample trees-Continued.

MEASUREMENTS OF SAMPLE TREES

Age elass: 130 to 150 jears.

DOMINAYT GROWTH.

\begin{tabular}{|c|c|c|c|c|c|c|c|c|c|c|}
\hline $\begin{array}{l}\text { Tree number. } \\
32 . . . \ldots \ldots \ldots \ldots . . .\end{array}$ & $\frac{\text { Age. }}{\text { Teare. }}$ & $\begin{array}{c}\begin{array}{c}\text { Dlameter } \\
\text { (breast } \\
\text { ligh). }\end{array} \\
\text { Inches. }\end{array}$ & $\begin{array}{c}\text { Height. } \\
\text { Feet. }\end{array}$ & $\begin{array}{c}\begin{array}{c}\text { lings } \\
\text { per luch } \\
\text { on } \\
\text { stump. }\end{array} \\
\begin{array}{c}\mathrm{No}_{83} \\
8.3\end{array}\end{array}$ & 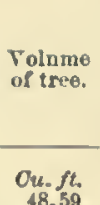 & $\begin{array}{c}\begin{array}{c}\text { Factor } \\
\text { of } \\
\text { Bhape. }\end{array} \\
\end{array}$ & $\begin{array}{c}\text { Ratlo of } \\
\text { length } \\
\text { of crown } \\
\text { to total } \\
\text { height of } \\
\text { tree. } \\
\end{array}$ & \multicolumn{2}{|c|}{$\begin{array}{l}\text { Current annual } \\
\text { accretion. }\end{array}$} & $\begin{array}{c}\text { A verage } \\
\text { annual } \\
\text { accre- } \\
\text { tion. }\end{array}$ \\
\hline 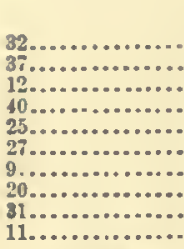 & $\begin{array}{c}\text { Tears. } \\
133 \\
141 \\
132 \\
145 \\
128 \\
152 \\
131 \\
148 \\
153 \\
136\end{array}$ & $\begin{array}{r}\text { Inches. } \\
15.2 \\
15.5 \\
16.3 \\
18.6 \\
20.5 \\
19.0 \\
22.5 \\
23.0 \\
.23 .0 \\
-24.6\end{array}$ & $\begin{array}{r}\text { Feet. } \\
02 \\
02 \\
88 \\
100 \\
98 \\
104 \\
112 \\
116 \\
100 \\
115\end{array}$ & $\begin{array}{l}\text { Yo. } \\
8.3 \\
6.2 \\
7.5 \\
7.0 \\
7.0 \\
7.3 \\
5.4 \\
6.8 \\
5.9 \\
5.2\end{array}$ & $\begin{array}{r}\text { Ou. } f t . \\
48.59 \\
55.32 \\
61.70 \\
71.11 \\
94.56 \\
84.97 \\
129.42 \\
137.91 \\
137.63 \\
154.12\end{array}$ & $\begin{array}{l}0.43 \\
.46 \\
.17 \\
.58 \\
.42 \\
.41 \\
.41 \\
.41 \\
.47 \\
.41\end{array}$ & $\begin{array}{l}0.43 \\
.42 \\
.80 \\
.44 \\
.47 \\
.38 \\
.46 \\
.46 \\
.30 \\
.40\end{array}$ & $\begin{array}{r}\text { Per eent. } \\
2.2 \\
2.3 \\
.8 \\
2.0 \\
1.5 \\
1.4 \\
.7 \\
1.0 \\
1.7 \\
1.4\end{array}$ & $\begin{array}{r}C u . f t . \\
1.07 \\
1.27 \\
.49 \\
1.42 \\
1.42 \\
1.19 \\
.91 \\
2.02 \\
2.40 \\
2.16\end{array}$ & $\begin{array}{r}C u . f t . \\
0.30 \\
.39 \\
.46 \\
.49 \\
.73 \\
.55 \\
.98 \\
.93 \\
.90 \\
1.13\end{array}$ \\
\hline Average.. & 140 & 10.8 & 102 & 6.0 & 97.5 & .13 & .43 & 1.6 & 1.49 & .69 \\
\hline
\end{tabular}

OPPREBSED GROWTH.

\begin{tabular}{|l|l|l|l|l|l|l|l|l|l|l|}
\hline $18 . \ldots \ldots \ldots \ldots \ldots$ & 109 & 14 & 82 & 7.5 & 40.53 & 0.46 & 0.56 & 4.5 & 1.82 & 0.37 \\
\hline
\end{tabular}

Age clase : 220 to 240 years.

DOMNANT GRONTH.

\begin{tabular}{|c|c|c|c|c|c|c|c|c|c|c|}
\hline 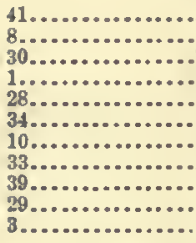 & $\begin{array}{l}245 \\
242 \\
226 \\
226 \\
220 \\
250 \\
219 \\
226 \\
237 \\
233 \\
245\end{array}$ & $\begin{array}{l}20.0 \\
24.5 \\
27.5 \\
27.5 \\
28.3 \\
30.2 \\
33.0 \\
33.0 \\
33.0 \\
37.0 \\
40.0\end{array}$ & $\begin{array}{l}120 \\
137 \\
138 \\
129 \\
143 \\
143 \\
121 \\
140 \\
144 \\
147 \\
125\end{array}$ & $\begin{array}{r}11.0 \\
9.9 \\
7.6 \\
7.6 \\
7.1 \\
8.7 \\
6.3 \\
7.1 \\
7.2 \\
6.1 \\
5.4\end{array}$ & $\begin{array}{l}112.56 \\
191.07 \\
215.28 \\
222.29 \\
264.49 \\
291.03 \\
317.85 \\
321.86 \\
380.57 \\
455.05 \\
479.51\end{array}$ & $\begin{array}{l}0.43 \\
.42 \\
.38 \\
.41 \\
.42 \\
.42 \\
.44 \\
.38 \\
.45 \\
.41 \\
.43\end{array}$ & $\begin{array}{r}0.40 \\
.41 \\
\cdots . . \\
.38 \\
.60 \\
.31 \\
.43 \\
.19 \\
.77 \\
.55 \\
.40\end{array}$ & $\begin{array}{l}0.9 \\
.5 \\
.4 \\
.4 \\
.8 \\
.4 \\
.7 \\
.8 \\
.0 \\
.6 \\
.5\end{array}$ & $\begin{array}{r}1.01 \\
.95 \\
.86 \\
.89 \\
2.11 \\
1.10 \\
2.22 \\
2.57 \\
2.34 \\
2.73 \\
2.40\end{array}$ & $\begin{array}{r}0.46 \\
.79 \\
.95 \\
.98 \\
1.20 \\
1.16 \\
1.45 \\
1.42 \\
1.64 \\
1.95 \\
1.96\end{array}$ \\
\hline Arerage... & 233 & 30.4 & 135 & 7.6 & 296.41 & 0.41 & .48 & .6 & 1.75 & 1.27 \\
\hline 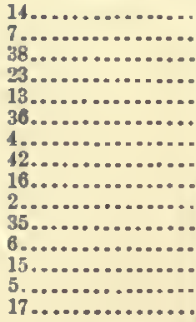 & $\begin{array}{l}258 \\
252 \\
252 \\
265 \\
253 \\
256 \\
260 \\
260 \\
251 \\
256 \\
265 \\
266 \\
250 \\
258 \\
260\end{array}$ & $\begin{array}{l}26.0 \\
25.2 \\
25.5 \\
27.0 \\
30.0 \\
32.0 \\
31.5 \\
29.5 \\
33.0 \\
31.0 \\
31.5 \\
33.0 \\
32.0 \\
34.0 \\
36.0\end{array}$ & $\begin{array}{l}119 \\
139 \\
115 \\
126 \\
135 \\
142 \\
132 \\
155 \\
144 \\
145 \\
144 \\
139 \\
154 \\
138 \\
140\end{array}$ & $\begin{array}{r}10.0 \\
9.5 \\
9.5 \\
10.4 \\
8.8 \\
8.1 \\
8.3 \\
8.9 \\
7.1 \\
7.6 \\
8.2 \\
8.0 \\
7.4 \\
7.6 \\
7.5\end{array}$ & $\begin{array}{l}162.54 \\
193.21 \\
205.21 \\
207.67 \\
259.13 \\
267.87 \\
275.89 \\
311.99 \\
313.07 \\
314.06 \\
314.38 \\
316.81 \\
360.75 \\
370.50 \\
404.18\end{array}$ & $\begin{array}{l}0.37 \\
.41 \\
.35 \\
.41 \\
.39 \\
.34 \\
.38 \\
.42 \\
.33 \\
.11 \\
.40 \\
.38 \\
.11 \\
.42 \\
.37\end{array}$ & $\begin{array}{l}0.40 \\
.46 \\
.58 \\
.44 \\
.45 \\
.59 \\
.48 \\
.48 \\
.41 \\
.30 \\
.33 \\
.51 \\
.33 \\
.59 \\
.45\end{array}$ & $\begin{array}{l}0.4 \\
.4 \\
.0 \\
.5 \\
.4 \\
.4 \\
.7 \\
.3 \\
.9 \\
.5 \\
.4 \\
.4 \\
.7 \\
.8 \\
.2\end{array}$ & $\begin{array}{l}0.65 \\
.77 \\
1.85 \\
1.05 \\
1.03 \\
1.07 \\
1.93 \\
.93 \\
2.82 \\
1.57 \\
1.25 \\
1.27 \\
2.52 \\
2.96 \\
.81\end{array}$ & $\begin{array}{l}0.63 \\
.76 \\
.81 \\
.78 \\
1.02 \\
1.04 \\
1.06 \\
1.20 \\
1.24 \\
1.22 \\
1.18 \\
1.19 \\
1.41 \\
1.43 \\
1.55\end{array}$ \\
\hline Arerage... & 258 & 30.5 & 138 & 8.5 & 285.15 & .39 & .45 & .5 & 1.50 & 1.10 \\
\hline
\end{tabular}


TARLE VI.-Acre yields of Thite Pine and measurements of sample trees-Continued.

A.-MICIIGAN-Continued.

(7) $\operatorname{Sire} h$ :

Craw ford County.

Soil: Brown, loamy sand, medium fine, light, loose, very deep, fresh, well drained, with surfaco

Forest conditions: IIoderately dense stand of White Pine intermixed wlth Hemiock and Beeeb, with scattering Yellow and White Birch and occasional Red Pine, on a level plain; nndergrowth of young Hemlock and hardwools.

MEASUREMENTS OF SAMPLE TREES.

Age class: 420 to 450 jears.

DOMINANT GROWTH.

\begin{tabular}{|c|c|c|c|c|c|c|c|c|c|c|}
\hline Tree nnmher. & Age. & $\begin{array}{c}\text { Diameter } \\
\text { (breast } \\
\text { high). }\end{array}$ & Height. & $\begin{array}{c}\text { Rings } \\
\text { per inch } \\
\text { on } \\
\text { stump. }\end{array}$ & $\begin{array}{l}\text { Volume } \\
\text { of tree. }\end{array}$ & $\begin{array}{c}\text { Factor } \\
\text { of } \\
\text { shape. }\end{array}$ & $\begin{array}{l}\text { Ratlo of } \\
\text { lengtí } \\
\text { of crown } \\
\text { to total }\end{array}$ & \multicolumn{2}{|c|}{$\begin{array}{l}\text { Cnrrent annual } \\
\text { accretion. }\end{array}$} & $\begin{array}{l}\text { Average } \\
\text { annnal } \\
\text { acere. } \\
\text { tlon. }\end{array}$ \\
\hline 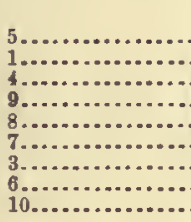 & $\begin{array}{c}\text { Years. } \\
417 \\
445 \\
455 \\
426 \\
460 \\
457 \\
461 \\
435 \\
458\end{array}$ & $\begin{array}{r}\text { Inches. } \\
37.0 \\
35.5 \\
11.0 \\
43.0 \\
46.0 \\
47.0 \\
46.0 \\
46.0 \\
47.0\end{array}$ & $\begin{array}{r}\text { Feet. } \\
155 \\
111 \\
152 \\
160 \\
150 \\
160 \\
170 \\
168 \\
162\end{array}$ & $\begin{array}{l}\text { No. } \\
14.0 \\
10.0 \\
11.0 \\
10.5 \\
(?) \\
(?) \\
10.0 \\
(?) \\
10.5\end{array}$ & $\begin{array}{r}\text { Cu. ft. } \\
\mathbf{4 3 3 . 2} \\
510.5 \\
583.7 \\
677.3 \\
694.1 \\
721.9 \\
737.9 \\
819.6 \\
855.3\end{array}$ & $\begin{array}{l}0.37 \\
.52 \\
.41 \\
.42 \\
.40 \\
.37 \\
.38 \\
.42 \\
.43\end{array}$ & $\begin{array}{l}0.45 \\
.39 \\
.53 \\
.56 \\
.48 \\
.45 \\
.56 \\
.51 \\
.57\end{array}$ & $\begin{array}{c}\text { Per cent. } \\
0.4 \\
.6 \\
.2 \\
.4 \\
.3 \\
.4 \\
.3 \\
.4 \\
.5\end{array}$ & $\begin{array}{r}C u . f t . \\
1.73 \\
3.06 \\
1.17 \\
2.71 \\
2.08 \\
2.89 \\
2.21 \\
3.28 \\
4.28\end{array}$ & $\begin{array}{r}C u . f t . \\
1.03 \\
1.15 \\
1.28 \\
1.59 \\
1.51 \\
1.59 \\
1.60 \\
1.88 \\
1.86\end{array}$ \\
\hline Average... & 446 & 43.0 & 157 & 11.0 & 670.4 & .41 & .50 & .4 & 2.60 & 1.50 \\
\hline
\end{tabular}

Age class : 270 to 290 years.

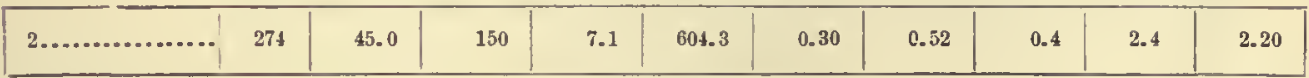

(8) SITE i:

Crawford County.

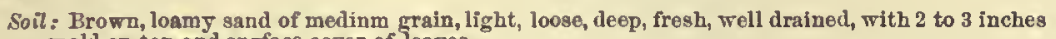
mold on top and snrface cover of leaves.

Forest conditions: White Pine ( 47 per cent) mixed with hardwoods (30 per cent) and Hemlock (23 per cent), on a

Dominant

Oppressed

White Pine. Wer cent.. 47 do.... 18
Sample area: 1 acre.

Age of pine: 05 to 105 years. Density of crown cover: 0.6

Numher of trees: 364

ACRE YIELD.

\begin{tabular}{|c|c|c|c|c|c|c|c|c|c|c|c|c|c|}
\hline \multicolumn{5}{|c|}{ White Pino. } & \multicolumn{3}{|c|}{ Hemlock. } & \multicolumn{3}{|c|}{ Maple. } & \multicolumn{3}{|c|}{ Beech. } \\
\hline \multirow[b]{2}{*}{$\begin{array}{l}\text { Num- } \\
\text { ber of } \\
\text { trees. }\end{array}$} & \multirow[b]{2}{*}{$\begin{array}{c}\text { Dlameter } \\
\text { (hreast } \\
\text { higb). }\end{array}$} & \multirow[b]{2}{*}{ Helght. } & \multicolumn{2}{|c|}{ Volnme. } & \multirow[b]{2}{*}{$\begin{array}{l}\text { Num- } \\
\text { ber of } \\
\text { trees. }\end{array}$} & \multirow[b]{2}{*}{$\begin{array}{l}\text { Diameter } \\
\text { (breast } \\
\text { high). }\end{array}$} & \multirow[b]{2}{*}{ Height. } & \multirow[b]{2}{*}{$\begin{array}{l}\text { Num. } \\
\text { her of } \\
\text { trees. }\end{array}$} & \multirow[b]{2}{*}{$\begin{array}{l}\text { Diameter } \\
\text { (hreast } \\
\text { high). }\end{array}$} & \multirow{2}{*}{ Height. } & \multirow[b]{2}{*}{$\begin{array}{l}\text { Nnm- } \\
\text { ber of } \\
\text { trees. }\end{array}$} & \multirow[b]{2}{*}{$\begin{array}{l}\text { Diameter } \\
\text { (breast } \\
\text { high). }\end{array}$} & \multirow[b]{2}{*}{ Height. } \\
\hline & & & Bole. & $\begin{array}{l}\text { Mer. } \\
\text { chantable } \\
\text { timber. }\end{array}$ & & & & & & & & & \\
\hline \multirow{3}{*}{$\begin{array}{r}4 \\
52 \\
9 \\
8 \\
12 \\
15 \\
16 \\
11 \\
11 \\
13 \\
8 \\
5 \\
1 \\
3 \\
1 \\
1\end{array}$} & \multirow{3}{*}{$\begin{array}{r}\text { Inches. } \\
3 \text { to } 6 \\
6 \text { to } 10 \\
10 \\
11 \\
12 \\
13 \\
14 \\
15 \\
16 \\
17 \\
18 \\
19 \\
20 \\
21 \\
23 \\
25\end{array}$} & \multirow{3}{*}{$\begin{array}{c}\text { Feet. } \\
\\
00 \\
\text { to } \\
110\end{array}$} & \multirow{3}{*}{$\begin{array}{c}\text { Cu.ft. } \\
\ldots \ldots \ldots \\
520 \\
162 \\
256 \\
456 \\
660 \\
800 \\
638 \\
704 \\
930 \\
640 \\
435 \\
384 \\
309 \\
122 \\
143\end{array}$} & \multirow{3}{*}{ Feet B. 1 . } & \multirow{3}{*}{$\begin{array}{r}18 \\
44 \\
3 \\
3 \\
4 \\
2 \\
2 \\
3 \\
1 \\
1 \\
2\end{array}$} & \multirow{3}{*}{$\begin{array}{r}\text { Inches. } \\
3 \text { to } 6 \\
6 \text { to } 10 \\
10 \\
11 \\
12 \\
18 \\
14 \\
16 \\
18 \\
20 \\
23\end{array}$} & \multirow[t]{3}{*}{ Feet. } & $\begin{array}{r}26 \\
28 \\
2\end{array}$ & $\begin{array}{r}\text { Inches. } \\
3 \text { to } 6 \\
6 \text { to } 10 \\
10\end{array}$ & $\left\{\begin{array}{c}\text { Feet. } \\
10\end{array}\right.$ & $\begin{array}{r}20 \\
14 \\
1\end{array}$ & $\begin{array}{r}\text { Inches. } \\
3 \text { to } 0 \\
6 \text { to } 10 \\
10\end{array}$ & $\left\{\begin{array}{c}\text { Feet. } \\
40 \\
\text { to } \\
50\end{array}\right.$ \\
\hline & & & & & & & & \multicolumn{3}{|c|}{ Whlte Birch. } & \multicolumn{3}{|c|}{ Fellow Birch. } \\
\hline & & & & & & & & $\begin{array}{l}6 \\
4 \\
2 \\
1 \\
2\end{array}$ & 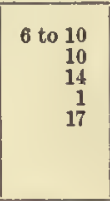 & $\begin{array}{l}40 \\
\text { to } \\
60\end{array}$ & 2 & 6 to 10 & \\
\hline \multicolumn{5}{|c|}{$\begin{array}{l}173 \text { trees: } \\
\text { Total cuhlc feet.............. } 7,165 \\
\text { Total feet } \mathbf{B} . \mathbf{M} \ldots \ldots \ldots \ldots \ldots .628,650\end{array}$} & \multicolumn{3}{|c|}{$\begin{array}{l}83 \text { trees: } \\
\text { Total cnhio ft.. } 1,330 \\
\text { Total feet B. MI. } 4,780\end{array}$} & \multicolumn{3}{|c|}{71 trees. } & \multicolumn{3}{|c|}{37 trees. } \\
\hline
\end{tabular}

Total yield: Whlte Pine and Hemlock, 33,430 feet B. M., of wblch White Pine 87 per cent. Average annual accretion: Whlte Pine, $71 \mathrm{cn}$ bic feet. 
Tanus: VI. - Acro yields of White I'ine and mensurements of sample trees-Continued.

DOMISANT GHOWTR.

\begin{tabular}{|c|c|c|c|c|c|c|c|c|c|c|}
\hline Treo number. & A ge. & $\begin{array}{c}\text { Diameter } \\
\text { (breast } \\
\text { high). }\end{array}$ & Iloight. & $\begin{array}{l}\text { Rings } \\
\text { per fucli } \\
\text { on } \\
\text { atutup. }\end{array}$ & $\begin{array}{l}\text { Volume } \\
\text { of tree. }\end{array}$ & $\begin{array}{l}\text { Factor } \\
\text { of } \\
\text { ehnpe. }\end{array}$ & $\begin{array}{l}\text { Ratio of } \\
\text { icnogth } \\
\text { of crown } \\
\text { to total }\end{array}$ & \multicolumn{2}{|c|}{$\begin{array}{l}\text { Corrent annual } \\
\text { accretion. }\end{array}$} & $\begin{array}{l}\text { Average } \\
\text { anumal } \\
\text { accre. } \\
\text { tion. }\end{array}$ \\
\hline $\begin{array}{l}8 \\
7 \\
7 \\
8 \\
8 \ldots \ldots \ldots \ldots \ldots \ldots \ldots \ldots \ldots \ldots \ldots \ldots\end{array}$ & $\begin{array}{c}\text { Tears. } \\
100 \\
98 \\
103 \\
100 \\
103\end{array}$ & $\begin{array}{c}\text { Inehes. } \\
10.5 \\
10.5 \\
17.0 \\
19.5 \\
18.5\end{array}$ & $\begin{array}{r}\text { Feet. } \\
98 \\
106 \\
104 \\
100 \\
109\end{array}$ & $\begin{array}{l}\text { No. } \\
\text { (?) } \\
\text { (1) } \\
5.3 \\
4.9 \\
4.8\end{array}$ & $\begin{array}{r}C u . f t . \\
64.5 \\
68.4 \\
71.7 \\
04.6 \\
95.0\end{array}$ & $\begin{array}{l}0.44 \\
.43 \\
.43 \\
.45 \\
.17\end{array}$ & $\begin{array}{l}0.45 \\
.40 \\
.45 \\
\text { (i) } \\
.87\end{array}$ & $\begin{array}{c}\text { Per cent. } \\
1.7 \\
2.2 \\
1.5 \\
1.7 \\
2.1\end{array}$ & $\begin{array}{l}\text { Cu.fu. } \\
1.10 \\
1.80 \\
1.07 \\
1.61 \\
2.01\end{array}$ & $\begin{array}{r}\text { Cu.jt. } \\
0.64 \\
.70 \\
.70 \\
.95 \\
.93\end{array}$ \\
\hline Arorago... & 101 & 17.6 & 103 & 5.0 & 79.0 & .44 & .42 & 1.8 & 1.46 & .78 \\
\hline
\end{tabular}

CODOMINAST GROWTH.

\begin{tabular}{|c|c|c|c|c|c|c|c|c|c|c|}
\hline 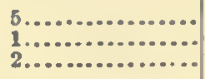 & $\begin{array}{r}95 \\
101 \\
101\end{array}$ & $\begin{array}{l}14.0 \\
15.3 \\
15.5\end{array}$ & $\begin{array}{l}94 \\
91 \\
90\end{array}$ & $\begin{array}{l}6.6 \\
5.8 \\
6.0\end{array}$ & $\begin{array}{l}49.6 \\
52.1 \\
62.8\end{array}$ & $\begin{array}{r}0.49 \\
.43 \\
.49\end{array}$ & $\begin{array}{l}0.38 \\
\text { (i) } \\
.57\end{array}$ & $\begin{array}{l}2.0 \\
4.2 \\
2.6\end{array}$ & $\begin{array}{l}0.99 \\
2.46 \\
1.63\end{array}$ & $\begin{array}{r}0.52 \\
.51 \\
.02\end{array}$ \\
\hline Arerago... & 80 & 15.0 & 94 & 0.1 & 54.8 & .47 & .44 & 2.9 & 1.69 & .55 \\
\hline
\end{tabular}

(9) STrE $j$ :

Crawford County:

Soil: Gray or light eand, medium the grain, porous, light, looee, dry (in places fresly), with a

moderatcly leafy eurface coter.
Forest conditions: Open etand ot mixcd Whitc Pine nud Norway Pine with scattering White Birch aud occasionnl Oak, Iackmatack, and Bankeian Pine on a lerel plain aiong the banks of a river; undergtowth scauty, of young Fir, Ccdar (Thuja occidentalis), nnd n few emall Onks.

MEASUREMENTS OF SAMPLE TREES.

Age class : 90 to 110 yeare.

DOMINANT GROWTH.

\begin{tabular}{|c|c|c|c|c|c|c|c|c|c|c|}
\hline Tree number. & Ago. & $\begin{array}{c}\text { Diameter } \\
\text { (breast } \\
\text { high). }\end{array}$ & Height. & $\begin{array}{c}\text { Rings } \\
\text { por iuch } \\
\text { on } \\
\text { stump. }\end{array}$ & $\begin{array}{l}\text { Volnmo } \\
\text { of trec. }\end{array}$ & $\begin{array}{l}\text { Factor } \\
\text { of } \\
\text { sliape. }\end{array}$ & $\begin{array}{l}\text { Ratio of } \\
\text { length } \\
\text { of crown } \\
\text { to totnl }\end{array}$ & \multicolumn{2}{|c|}{$\begin{array}{l}\text { Carrent nuuual } \\
\text { accretion. }\end{array}$} & $\begin{array}{l}\text { Average } \\
\text { amnual } \\
\text { accre. } \\
\text { tion. }\end{array}$ \\
\hline 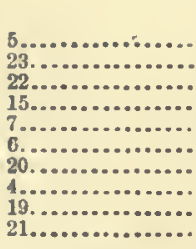 & $\begin{array}{l}\text { Years. } \\
109 \\
112 \\
109 \\
106 \\
110 \\
109 \\
112 \\
112 \\
108 \\
109\end{array}$ & $\begin{array}{l}\text { Inches. } \\
13.0 \\
14.0 \\
14.8 \\
15.3 \\
16.5 \\
17.0 \\
17.0 \\
18.3 \\
20.5 \\
20.8\end{array}$ & $\begin{aligned} \text { Feet. } \\
94.0 \\
96.0 \\
93.0 \\
85.0 \\
104.0 \\
101.0 \\
100.0 \\
103.0 \\
105.0 \\
105.0\end{aligned}$ & $\begin{aligned} & \text { No. } \\
& 7.6 \\
& 7.3 \\
& 6.7 \\
& 6.5 \\
& 6.5 \\
& 5.3 \\
& 6.1 \\
& 5.8 \\
& 4.8 \\
& 5.0\end{aligned}$ & $\begin{array}{r}\text { Cu.ft. } \\
45.7 \\
50.2 \\
51.4 \\
53.3 \\
64.3 \\
67.6 \\
72.4 \\
85.3 \\
99.1 \\
99.8\end{array}$ & $\begin{array}{l}0.52 \\
.47 \\
.45 \\
.47 \\
.41 \\
.42 \\
.45 \\
.44 \\
.41 \\
.39\end{array}$ & $\begin{array}{l}0.51 \\
.47 \\
.47 \\
.37 \\
.30 \\
.59 \\
(i) \\
.50 \\
.49 \\
.42\end{array}$ & $\begin{array}{c}\text { Percent. } \\
3.2 \\
3.5 \\
2.2 \\
2.5 \\
2.2 \\
1.8 \\
3.4 \\
2.5 \\
1.9 \\
1.6\end{array}$ & $\begin{array}{l}\text { Cu.ft. } \\
1 . \$ 6 \\
1.75 \\
1.14 \\
1.33 \\
1.41 \\
1.22 \\
2.46 \\
2.13 \\
1.88 \\
1.60\end{array}$ & $\begin{array}{r}C u . f t . \\
0.42 \\
.44 \\
.47 \\
.50 \\
.58 \\
.62 \\
.65 \\
.76 \\
.91 \\
.91\end{array}$ \\
\hline Average... & 109.0 & 16.7 & 98.6 & 6.3 & 68.9 & .44 & .46 & 2.5 & 1.64 & .63 \\
\hline
\end{tabular}

CODOMINANT GBOWFH.

\begin{tabular}{|c|c|c|c|c|c|c|c|c|c|c|}
\hline $\begin{array}{l}1 \\
24 \ldots \ldots \ldots \ldots \\
9 \ldots \ldots \ldots \ldots \ldots \ldots\end{array}$ & $\begin{array}{r}100 \\
96 \\
82 \\
90\end{array}$ & $\begin{array}{l}13.5 \\
14.4 \\
16.5 \\
20.0\end{array}$ & $\begin{array}{r}94.0 \\
90.0 \\
94.0 \\
100.0\end{array}$ & $\begin{array}{l}7.0 \\
6.6 \\
+.8 \\
4.4\end{array}$ & $\begin{array}{r}41.0 \\
48.7 \\
65.7 \\
.90 .9\end{array}$ & $\begin{array}{l}. .44 \\
.47 \\
.47 \\
.41\end{array}$ & $\begin{array}{l}0.57 \\
(?)^{-.83} \\
.40\end{array}$ & $\begin{array}{l}2.0 \\
4.3 \\
4.0 \\
3.3\end{array}$ & $\begin{array}{l}0.82 \\
2.08 \\
2.63 \\
3.00\end{array}$ & $\begin{array}{l}0.41 \\
.50 \\
.80 \\
.91\end{array}$ \\
\hline A vorago... & M & 16.1 & 94.5 & 5.7 & 61.6 & .45 & .52 & 3.4 & 2.13 & .65 \\
\hline
\end{tabular}

Age class: 150 to 160 years.

DOMINANT GROWTH.

\begin{tabular}{|c|c|c|c|c|c|c|c|c|c|c|}
\hline $\begin{array}{l}2 \\
13 . \ldots \ldots \ldots \ldots \ldots \ldots \ldots \\
\end{array}$ & $\begin{array}{l}158 \\
157\end{array}$ & $\begin{array}{l}22.5 \\
21.8\end{array}$ & $\begin{array}{l}114.0 \\
115.0\end{array}$ & $\begin{array}{l}6.6 \\
7.0\end{array}$ & $\begin{array}{l}124.9 \\
121.1\end{array}$ & $\begin{array}{r}0.40 \\
.40\end{array}$ & $\begin{array}{r}0.30 \\
.58\end{array}$ & $\begin{array}{l}2.4 \\
1.2\end{array}$ & $\begin{array}{l}3.06 \\
1.45\end{array}$ & $\begin{array}{r}0.80 \\
.80\end{array}$ \\
\hline Average... & 157.5 & 22.1 & 114.5 & 6.8 & 123.0 & .40 & .47 & 1.8 & 2. 22 & .80 \\
\hline
\end{tabular}


TABLe VI.-Acre yields of White Pine and measurements of sample trees-Continued.

\section{A.-MICHG AN-Coutinued.}

(10) SITE $k$ :
Roscommon County.

[A bout 1,000 feet above sea lerel.]

Soil: Brown, loamy sand, deep, fine (for sand), porous, loose, fresh, a nd well drained (water stnnds in low ground, with a moderstcly leafy surtace cover; subsoil, samo as soil.

Forest conditions: T'wo-story stand on a gentle slope, upper story of White $Y^{\prime}$ ine (80 per cent) aud

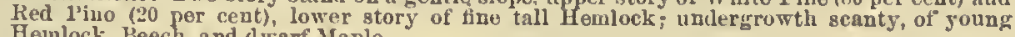
Heinlock, Beech, and dwarf Maple.

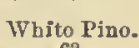

Sample aroa: 1 acre.

Ago of pine: 230 to 240 jenrs. Density of crown cover: 0.8 to

Number of trees: 180 .

HALF-ACRE YIELD.

\begin{tabular}{|c|c|c|c|c|c|c|c|c|c|c|}
\hline \multicolumn{5}{|c|}{ White Pine. } & \multicolumn{3}{|c|}{ Red Pine. } & \multicolumn{3}{|c|}{ Hemlock. } \\
\hline \multirow[b]{2}{*}{$\begin{array}{l}\text { Number } \\
\text { of trees. }\end{array}$} & \multirow{2}{*}{$\begin{array}{c}\text { Diameter } \\
\text { (breast } \\
\text { higl). }\end{array}$} & \multirow[b]{2}{*}{ Heigbt. } & \multicolumn{2}{|c|}{ Tolume. } & \multirow[b]{2}{*}{$\begin{array}{l}\text { Nnmber } \\
\text { of trees. }\end{array}$} & \multirow[b]{2}{*}{$\begin{array}{l}\text { Diametcr } \\
\text { (breast } \\
\text { high). }\end{array}$} & \multirow[b]{2}{*}{ Eleight. } & \multirow[b]{2}{*}{$\begin{array}{l}\text { Number } \\
\text { of trees. }\end{array}$} & \multirow[b]{2}{*}{$\begin{array}{c}\text { Diameter } \\
\text { (breast } \\
\text { high). }\end{array}$} & \multirow[b]{2}{*}{ Hoight. } \\
\hline & & & Bole. & $\begin{array}{l}\text { Mer- } \\
\text { cliantable } \\
\text { timber. }\end{array}$ & & & & & & \\
\hline $\begin{array}{r}6 \\
2 \\
2 \\
4 \\
2 \\
6 \\
6 \\
2 \\
4 \\
8 \\
12 \\
8 \\
6 \\
8 \\
2 \\
4\end{array}$ & $\begin{array}{r}\text { Inches. } \\
11 \\
15 \\
16 \\
17 \\
18 \\
19 \\
20 \\
21 \\
22 \\
24 \\
25 \\
21 \\
28 \\
30 \\
33\end{array}$ & $\begin{array}{c}\text { Feet. } \\
80 \\
\text { to } \\
125\end{array}$ & $\begin{array}{r}\text { Cu.feet. } \\
192 \\
116 \\
123 \\
288 \\
160 \\
528 \\
250 \\
5.0 \\
1,216 \\
2,076 \\
1,544 \\
1,344 \\
1,920 \\
540 \\
1,312\end{array}$ & Feet B.Ju. & $\begin{array}{r}2 \\
2 \\
4 \\
14 \\
6 \\
2 \\
2 \\
2\end{array}$ & $\begin{array}{r}\text { Inches. } \\
14 \\
16 \\
18 \\
19 \\
21 \\
23 \\
24 \\
25\end{array}$ & $\begin{array}{l}80 \\
\text { to } \\
150\end{array}$ & $\begin{array}{r}32 \\
4 \\
6 \\
2 \\
6 \\
8 \\
2 \\
2 \\
4 \\
2 \\
2 \\
2 \\
2 \\
2\end{array}$ & $\begin{array}{r}\text { Inches. } \\
6 \text { to } 10 \\
10 \\
11 \\
12 \\
14 \\
15 \\
17 \\
18 \\
19 \\
20 \\
21 \\
22 \\
23 \\
24\end{array}$ & $\begin{array}{c}\text { Feet. } \\
60 \\
70 \\
\text { to } \\
80\end{array}$ \\
\hline \multicolumn{3}{|c|}{$\begin{array}{l}76 \text { trees: } \\
\text { Total cy } \\
\text { Total fe }\end{array}$} & (n......... & $\begin{array}{l}. .12,174 \\
\therefore 58,400\end{array}$ & \multicolumn{3}{|c|}{$\begin{array}{l}34 \text { trees } \\
\text { Total cubic foet. } 4,270 \\
\text { Total feet B.M. } 20,500\end{array}$} & \multicolumn{3}{|c|}{$\begin{array}{l}76 \text { trees: } \\
\text { Totsl cubio feet. } 3,616 \\
\text { Total feet B.M. } 13,000\end{array}$} \\
\hline
\end{tabular}

Total yield: All species 20,060 cubic feet, of wlich White Pine was 61 per cent. Average annulal accretion: White Pine, $5 \%$ cubic fect.

MEASUREMENTS OF SAMPLE TREES.

Age class : 230 to 250 years. DONINANT GROWTH.

\begin{tabular}{|c|c|c|c|c|c|c|c|c|c|c|}
\hline Tree number. & Age. & $\begin{array}{c}\text { Diameter } \\
\text { (broast } \\
\text { higb). }\end{array}$ & Height. & $\begin{array}{l}\text { Rings } \\
\text { per inch } \\
\text { on } \\
\text { stump. }\end{array}$ & $\begin{array}{l}\text { Volnme } \\
\text { of tree. }\end{array}$ & $\begin{array}{l}\text { Factor } \\
\text { of } \\
\text { shape. }\end{array}$ & $\begin{array}{l}\text { Ratio of } \\
\text { length } \\
\text { of crown } \\
\text { to total }\end{array}$ & \multicolumn{2}{|c|}{$\begin{array}{c}\text { Cnrrent annual } \\
\text { accretion. }\end{array}$} & $\begin{array}{l}\text { Arerage } \\
\text { annnal } \\
\text { accre- } \\
\text { tion. }\end{array}$ \\
\hline 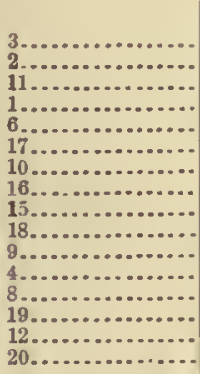 & $\begin{array}{c}\text { Tears. } \\
234 \\
230 \\
235 \\
237 \\
237 \\
232 \\
233 \\
237 \\
235 \\
215 \\
236 \\
236 \\
238 \\
244 \\
233 \\
251\end{array}$ & $\begin{array}{r}\text { Inches. } \\
23.2 \\
23.8 \\
24.5 \\
23.5 \\
24.5 \\
24.7 \\
25.5 \\
25.5 \\
26.0 \\
30.0 \\
20.2 \\
27.0 \\
29.0 \\
34.0 \\
32.0 \\
27.0\end{array}$ & $\begin{array}{r}\text { Feet. } \\
137 \\
142 \\
112 \\
110 \\
145 \\
145 \\
143 \\
145 \\
143 \\
122 \\
145 \\
150 \\
149 \\
130 \\
144 \\
120\end{array}$ & $\begin{array}{r}\text { Yo. } \\
10.0 \\
9.6 \\
9.2 \\
9.6 \\
0.0 \\
(?) \\
8.4 \\
9.1 \\
9.0 \\
(?) \\
9.0 \\
8.5 \\
7.8 \\
7.0 \\
7.0 \\
9.1\end{array}$ & $\begin{array}{l}\text { Cu.feet. } \\
169.0 \\
197.3 \\
199.1 \\
202.6 \\
205.4 \\
207.0 \\
212.6 \\
297.3 \\
231.1 \\
233.9 \\
240.2 \\
271.5 \\
281.1 \\
348.1 \\
349.6 \\
206.8\end{array}$ & $\begin{array}{r}0.43 \\
.44 \\
.43 \\
.46 \\
.43 \\
.43 \\
.42 \\
.44 \\
.43 \\
.39 \\
.44 \\
.45 \\
.43 \\
.42 \\
.43 \\
.43\end{array}$ & $\begin{array}{l}0.39 \\
.43 \\
.43 \\
.36 \\
.40 \\
.47 \\
.42 \\
.44 \\
.23 \\
.35 \\
.42 \\
.41 \\
.40 \\
.62 \\
.39 \\
.36\end{array}$ & $\begin{array}{c}\text { Per cent. } \\
0.8 \\
.7 \\
.7 \\
.8 \\
.5 \\
1.0 \\
.5 \\
.9 \\
.7 \\
.8 \\
.3 \\
.8 \\
.6 \\
.5 \\
1.0 \\
.5\end{array}$ & $\begin{array}{c}\text { Cu.feet. } \\
1.35 \\
1.38 \\
1.39 \\
1.62 \\
1.03 \\
2.07 \\
1.06 \\
2.04 \\
1.62 \\
1.87 \\
0.72 \\
2.17 \\
1.69 \\
1.74 \\
3.50 \\
1.03\end{array}$ & $\begin{array}{c}\text { Cu.feet. } \\
0.72 \\
.83 \\
.84 \\
.86 \\
.86 \\
.89 \\
.01 \\
.96 \\
.08 \\
.95 \\
1.01 \\
1.15 \\
1.18 \\
1.42 \\
1.50 \\
.82\end{array}$ \\
\hline Arerago... & 237 & 26.6 & 110 & 8.7 & 230.4 & .43 & .41 & .7 & 1.64 & .99 \\
\hline
\end{tabular}

OPPRESSED GROWTH.

\begin{tabular}{|l|l|l|l|l|l|l|l|l|l|}
\hline $14 \ldots \ldots \ldots \ldots \ldots$. & 237 & 21 & 136 & 11.0 & 133.8 & 0.41 & 0.51 & 0.7 & 0.94 \\
\hline
\end{tabular}

SUPPRESSED GROWTH.

\begin{tabular}{|c|c|c|c|c|c|c|c|c|c|c|}
\hline $7 \ldots \ldots \ldots$ & $\begin{array}{l}235 \\
229\end{array}$ & $\begin{array}{l}13.0 \\
15.3\end{array}$ & $\begin{array}{l}120 \\
126\end{array}$ & $\begin{array}{l}17.7 \\
15.2\end{array}$ & $\begin{array}{l}61.1 \\
86.7\end{array}$ & $\begin{array}{r}0.55 \\
.52\end{array}$ & $\begin{array}{r}0.31 \\
.41\end{array}$ & $\begin{array}{r}0.6 \\
.6\end{array}$ & $\begin{array}{r}0.37 \\
.52\end{array}$ & $\begin{array}{r}0.26 \\
.37\end{array}$ \\
\hline Average... & 232 & 14.1 & 123 & 16.4 & 73.9 & .53 & .36 & .6 & .45 & .31 \\
\hline
\end{tabular}


TABLE VI.-Acre yields of White Pine and measurements of sample trees-Continued.

\section{A.-MUCIIGAN-Continned.}

HaV acre No.8.

Soil: IColat low ground, near swamp. Forest conditions: Whito Pine ( 51 per cent) and Ilemlock ( 49 per cent).
Clasrifeufiun: Opprossed. Suppressed
Age of pine: 230 to 240 sears. Density of crown corer: 0.5 . White Pine. Nutuber of trees: 118. per cent.. $\quad 80$ 80
10
10

\section{HALF-ACIE FIELD.}

\begin{tabular}{|c|c|c|c|c|c|c|c|}
\hline \multicolumn{5}{|c|}{ Wulte Pino. } & \multicolumn{3}{|c|}{ Hemlock. } \\
\hline \multirow[b]{2}{*}{$\begin{array}{l}\text { Number } \\
\text { of trees. }\end{array}$} & \multirow[b]{2}{*}{$\begin{array}{c}\text { Diameter } \\
\text { (brenst } \\
\text { high). }\end{array}$} & \multirow[b]{2}{*}{ Height. } & \multicolumn{2}{|c|}{ Tolumo. } & \multirow{2}{*}{$\begin{array}{l}\text { Number } \\
\text { of trees. }\end{array}$} & \multirow{2}{*}{$\begin{array}{l}\text { Diameter } \\
\text { (broast } \\
\text { hlgh). }\end{array}$} & \multirow[b]{2}{*}{ Helght. } \\
\hline & & & Bole. & $\begin{array}{l}\text { Mrer. } \\
\text { chantable } \\
\text { timber. }\end{array}$ & & & \\
\hline $\begin{array}{r}2 \\
4 \\
2 \\
2 \\
2 \\
2 \\
4 \\
2 \\
4 \\
6 \\
2 \\
2 \\
4 \\
12 \\
2 \\
2 \\
4 \\
2 \\
2\end{array}$ & $\begin{array}{r}\text { Inches. } \\
15 \\
18 \\
19 \\
22 \\
24 \\
25 \\
213 \\
28 \\
29 \\
30 \\
31 \\
32 \\
33 \\
34 \\
35 \\
30 \\
37 \\
38\end{array}$ & $\begin{array}{l}\text { Freet. } \\
80 \\
\text { to } \\
125\end{array}$ & $\begin{array}{r}\text { Cu. feet. } \\
116 \\
320 \\
176 \\
304 \\
300 \\
400 \\
804 \\
408 \\
1,064 \\
1,660 \\
604 \\
1,280 \\
4,080 \\
720 \\
782 \\
1,604 \\
840 \\
890\end{array}$ & Feet B.M. & $\begin{array}{r}0 \\
6 \\
4 \\
4 \\
4 \\
6 \\
6 \\
6 \\
2 \\
10 \\
2 \\
2\end{array}$ & $\begin{array}{r}\text { Inches. } \\
6 \text { to } 10 \\
11 \\
12 \\
13 \\
14 \\
15 \\
16 \\
17 \\
19 \\
20 \\
24 \\
25\end{array}$ & $\begin{array}{c}\text { Feet. } \\
60 \\
70 \\
\text { to } \\
80\end{array}$ \\
\hline \multicolumn{5}{|c|}{$\begin{array}{l}60 \text { trees: } \\
\text { Total cubio feet ..................... 16,586 } \\
\text { Total feet B.M. .................... }\end{array}$} & \multicolumn{3}{|c|}{$\begin{array}{l}58 \text { trees: } \\
\text { Total cubic feet. } 4,490 \\
\text { Total feet B.M. 16,160 }\end{array}$} \\
\hline
\end{tabular}

Total yield : White Pine and Hemlock 21,076 cuhie feot, of which White Pine 71 per cent. Average annual accretion: Whito Pine, 70 cubio feet.

(11) SiTe l:

Roscommon County.

Sample area: 1 acro.

Soil : Light-brown, dry sand, loose, light, very deep, well drained ( 7 ), with 1 inch mold on top and

Forest conditions : Red Iine (84 per cent) Intermixed with White Pine (16 per cent), witl occa. sional Beech on a gentle slope (angle 50); no nndergrowth.

Classification:

Oppressed White Pine.

ACRE YIELD.

\begin{tabular}{|c|c|c|c|c|c|c|c|c|c|c|}
\hline \multicolumn{5}{|c|}{ Wbite Pine. } & \multicolumn{3}{|c|}{ Red Pine. } & \multicolumn{3}{|c|}{ Beecl. } \\
\hline \multirow[b]{2}{*}{$\begin{array}{l}\text { Number } \\
\text { of trees. }\end{array}$} & \multirow[b]{2}{*}{$\begin{array}{l}\text { Dinmoter } \\
\text { (breast } \\
\text { bigh). }\end{array}$} & \multirow[b]{2}{*}{ Height. } & \multicolumn{2}{|c|}{ Tolnme. } & \multirow[b]{2}{*}{$\begin{array}{l}\text { Number } \\
\text { of trees. }\end{array}$} & \multirow[b]{2}{*}{$\begin{array}{l}\text { Diameter } \\
\text { (breast } \\
\text { bigh). }\end{array}$} & \multirow[b]{2}{*}{ Height. } & \multirow[b]{2}{*}{$\begin{array}{l}\text { Number } \\
\text { of trees. }\end{array}$} & \multirow[b]{2}{*}{$\begin{array}{c}\text { Diameter } \\
\text { (breast } \\
\text { high). }\end{array}$} & \multirow[b]{2}{*}{ Meight. } \\
\hline & & & Bole. & $\begin{array}{l}\text { Mer. } \\
\text { chantable } \\
\text { timber. }\end{array}$ & & & & & & \\
\hline $\begin{array}{l}2 \\
1 \\
1 \\
2 \\
1 \\
2 \\
2 \\
3 \\
1 \\
2 \\
2 \\
1 \\
1\end{array}$ & $\begin{array}{r}\text { Inches. } \\
10 \\
11 \\
12 \\
13 \\
14 \\
15 \\
16 \\
18 \\
19 \\
21 \\
22 \\
23 \\
27\end{array}$ & $\begin{array}{l}100 \\
\text { to } \\
120\end{array}$ & \begin{tabular}{|c|} 
Cubicfeet. \\
36 \\
32 \\
38 \\
96 \\
55 \\
126 \\
142 \\
201 \\
96 \\
228 \\
246 \\
134 \\
199
\end{tabular} & Feet $B . M$ & $\begin{array}{r}1 \\
2 \\
3 \\
7 \\
7 \\
13 \\
26 \\
18 \\
18 \\
16 \\
5 \\
5 \\
1\end{array}$ & $\begin{array}{c}\text { Inches. } \\
6 \text { to } 10 \\
10 \\
11 \\
12 \\
13 \\
14 \\
15 \\
16 \\
17 \\
18 \\
19 \\
20\end{array}$ & $\begin{array}{c}\text { Feet. } \\
\\
90 \\
\text { to } \\
100\end{array}$ & $\begin{array}{l}1 \\
1\end{array}$ & $\begin{array}{l}\text { Inches. } \\
3 \text { to } 6 \\
6 \text { to } 10\end{array}$ & $\begin{array}{c}\text { Feet. } \\
40\end{array}$ \\
\hline \multicolumn{5}{|c|}{$\begin{array}{l}21 \text { troes: } \\
\text { Toral cuhic feet.. } \\
\text { Total feet B. M... }\end{array}$} & \multicolumn{3}{|c|}{$\begin{array}{l}113 \text { trces: } \\
\text { Total cubic fcet. } 6,207 \\
\text { Total foet B.M. } 26,060\end{array}$} & \multicolumn{3}{|l|}{2 trees. } \\
\hline
\end{tabular}

Total yield: Pino 7,890 cubic feet, of which White Pine 21 por cent. 
TABLE VI.-Acre yields of White Pine and measurements of sample trees-Continned.

A.-MICIIG AN-Continued.

(12) SrTE $m$ :
Roseommon County.

[900 to 1,000 feet above sea level.]

Acre No. 1.

Soit: Dry, ligbt-brown sand, medium fine, deep, well drained, with noderately leafy surface cover. Age of pine: 160 to 200 Jears. Forest conditions: Red Pine (53 per cent) witb White Pine (39 per cent) and hardwoods (8 per Density of crown cover: (1). cent) on uneven ground; stand open, and open places with Red Oak and Maple. Olassification: Domiuant. Sppressed per cent.. cent.. 73 $\begin{array}{cc}73 & \text { Rerl Pine. } \\ 79 & 87 \\ 8 & 11 \\ 2 & 2\end{array}$ Samplo area: 4 acres. Number of troes: 91 .

\section{ACRE YIETL.}

\begin{tabular}{|c|c|c|c|c|c|c|c|c|c|c|}
\hline \multicolumn{5}{|c|}{ W bite Pine. } & \multicolumn{3}{|c|}{ Red Pine. } & \multicolumn{3}{|c|}{ Oak. } \\
\hline \multirow[b]{2}{*}{$\begin{array}{l}\text { Number } \\
\text { of trees. }\end{array}$} & \multirow[b]{2}{*}{$\begin{array}{l}\text { Diameter } \\
\text { (breast } \\
\text { bigb). }\end{array}$} & \multirow[b]{2}{*}{ Hoigbt. } & \multicolumn{2}{|c|}{ Volnme. } & \multirow[b]{2}{*}{$\begin{array}{l}\text { Number } \\
\text { of trees. }\end{array}$} & \multirow[b]{2}{*}{$\begin{array}{c}\text { Diameter } \\
\text { (breast } \\
\text { high). }\end{array}$} & \multirow[b]{2}{*}{ Height. } & \multirow[b]{2}{*}{$\begin{array}{l}\text { Nnmber } \\
\text { of trees. }\end{array}$} & \multirow{2}{*}{$\begin{array}{l}\text { Diameter } \\
\text { (breast } \\
\text { bigh). }\end{array}$} & \multirow[b]{2}{*}{ Height. } \\
\hline & & & Bole. & $\begin{array}{c}\text { Mer- } \\
\text { cha utable } \\
\text { timber. }\end{array}$ & & & & & & \\
\hline \multirow{3}{*}{$\begin{array}{l}1 \\
1 \\
1 \\
3 \\
2 \\
2 \\
5 \\
2 \\
3 \\
2 \\
5 \\
5 \\
4 \\
2 \\
1 \\
1 \\
1\end{array}$} & \multirow{3}{*}{$\begin{array}{r}\text { Inches. } \\
14 \\
17 \\
18 \\
19 \\
20 \\
21 \\
22 \\
23 \\
24 \\
25 \\
26 \\
27 \\
28 \\
33 \\
34 \\
39\end{array}$} & \multirow{3}{*}{$\begin{array}{c}\text { Feet. } \\
- \\
100 \\
\text { to } \\
1 \approx 0\end{array}$} & \multirow{3}{*}{$\begin{array}{c}\text { Cubricfeet. } \\
55 \\
79 \\
88 \\
288 \\
210 \\
228 \\
615 \\
268 \\
438 \\
314 \\
845 \\
732 \\
392 \\
267 \\
283 \\
451\end{array}$} & \multirow{3}{*}{ Feet $B, \mu$. } & \multirow{3}{*}{$\begin{array}{l}1 \\
2 \\
1 \\
2 \\
6 \\
5 \\
7 \\
8 \\
3 \\
7 \\
2 \\
2 \\
1\end{array}$} & \multirow{3}{*}{$\begin{array}{r}\text { Inches. } \\
13 \\
14 \\
15 \\
16 \\
17 \\
18 \\
19 \\
20 \\
21 \\
22 \\
23 \\
24 \\
25\end{array}$} & \multirow{3}{*}{$\begin{array}{l}100 \\
\text { to } \\
120\end{array}$} & $\begin{array}{l}1 \\
3\end{array}$ & $\begin{array}{l}\text { Inches. } \\
\text { Under } 3 \\
3 \text { to } 6\end{array}$ & $\begin{array}{c}\text { Feet. } \\
40\end{array}$ \\
\hline & & & & & & & & & Maple. & \\
\hline & & & & & & & & $\begin{array}{l}2 \\
2\end{array}$ & $\begin{array}{l}3 \text { to } 6 \\
6 \text { to } 10\end{array}$ & 40 \\
\hline \multicolumn{3}{|c|}{$\begin{array}{l}36 \text { troes: } \\
\text { Total } \\
\text { Total }\end{array}$} & \multicolumn{2}{|c|}{$\begin{array}{r} \\
\cdots \ldots \ldots \ldots, 5,553 \\
\cdots \ldots \ldots, 600\end{array}$} & \multicolumn{3}{|c|}{$\begin{array}{l}47 \text { trees: } \\
\text { Total enbic feet. } 5,360 \\
\text { Total feet B. M . } 26,000\end{array}$} & \multicolumn{3}{|l|}{8 trees. } \\
\hline
\end{tabular}

Total yicld : Pine, 10.913 cubio feet.

Average annual aceretion: Pine, 61 enbic feet. 298 feet B. $\mathbf{H}$.

Aere No.

Soil : Dry, light-brown sand, medium fine, deep, well drained, witb moderately leafy surface cover. A ge of pine: 160 to 200 years. Forest conditions: Red Pine (75 per ceut) with Wbite Pine (25 per cent) intermixed; level. Classification:

Dominant. . per eent. $\begin{array}{lr}62 & \text { Red } \\ 25 & \\ 13 & \end{array}$ Number of crown cover: t.

ACRE TIELD.

\begin{tabular}{|c|c|c|c|c|c|c|c|}
\hline \multicolumn{5}{|c|}{ White Pine. } & \multicolumn{3}{|c|}{ Red Pine. } \\
\hline \multirow[b]{2}{*}{$\begin{array}{l}\text { Number } \\
\text { of trees. }\end{array}$} & \multirow[b]{2}{*}{$\begin{array}{c}\text { Diameter } \\
\text { (breast } \\
\text { high). }\end{array}$} & \multirow[b]{2}{*}{ Height. } & \multicolumn{2}{|c|}{ Volume. } & \multirow[b]{2}{*}{$\begin{array}{l}\text { Number } \\
\text { of trees. }\end{array}$} & \multirow[b]{2}{*}{$\begin{array}{l}\text { Diameter } \\
\text { (breast } \\
\text { higb). }\end{array}$} & \multirow[b]{2}{*}{ Heigut. } \\
\hline & & & Bole. & $\begin{array}{c}\text { Mer- } \\
\text { chantable } \\
\text { timber. }\end{array}$ & & & \\
\hline $\begin{array}{l}2 \\
1 \\
1 \\
4 \\
1 \\
7 \\
4 \\
3 \\
3 \\
1 \\
6 \\
2 \\
3 \\
1\end{array}$ & $\begin{array}{r}\text { Inches. } \\
6 \text { to } 10 \\
11 \\
12 \\
14 \\
15 \\
16 \\
17 \\
18 \\
19 \\
20 \\
21 \\
22 \\
23 \\
25\end{array}$ & $\begin{array}{l}100 \\
\text { to } \\
120\end{array}$ & Oubie feet. & Ficet $B . M$. & $\begin{array}{r}3 \\
9 \\
9 \\
12 \\
8 \\
32 \\
17 \\
18 \\
8 \\
4 \\
2\end{array}$ & $\begin{array}{r}\text { Inches. } \\
6 \text { to } 10 \\
10 \\
12 \\
13 \\
14 \\
15 \\
16 \\
17 \\
18 \\
19 \\
20\end{array}$ & $\begin{array}{l}100 \\
\text { to } \\
120\end{array}$ \\
\hline \multicolumn{5}{|c|}{ 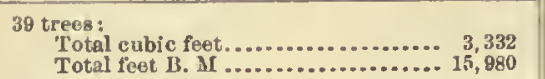 } & \multicolumn{3}{|c|}{$\begin{array}{l}113 \text { trees: } \\
\text { Total cubio feet. } 7,914 \\
\text { Total feet B. MI. } 33,240\end{array}$} \\
\hline
\end{tabular}

Total yicld: Pine, 11,246 cubic feet.

49,220 feet B. M., of whicb Wite Pine 32 per cent.

Average annual aceretion: Pino, 95 cubic feet. 
TAnL: VI. - Acre yielde of Thite Pine and mensurements of sample tree-Continued.

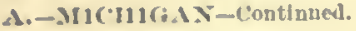

Acre No. 3. Soit: Light hrown. dry sand, medim fne, deel, weil drained, with a noderately leafy sarfare Age of pine: 160 to 200 years. Forest conditions: Ifrul Pine (90 per cent) intermixed with Whitw Pine (10 per cent); leval.
Clathification: Dhruminant.

Siupressedi. into Pine. Red I Nunlher of trees: 117 .

ACRE YIELD.

\begin{tabular}{|c|c|c|c|c|c|c|c|}
\hline \multicolumn{5}{|c|}{ White Pine. } & \multicolumn{3}{|c|}{ Red Pine. } \\
\hline \multirow[b]{2}{*}{$\begin{array}{l}\text { Xinuluer } \\
\text { of trees. }\end{array}$} & \multirow[b]{2}{*}{$\begin{array}{l}\text { Disueter } \\
\text { (bremst } \\
\text { high). }\end{array}$} & \multirow[b]{2}{*}{ Ileight. } & \multicolumn{2}{|c|}{ Volume. } & \multirow[b]{2}{*}{$\begin{array}{l}\text { Nunber } \\
\text { of trees. }\end{array}$} & \multirow{2}{*}{$\begin{array}{l}\text { Diameter } \\
\text { (ureast } \\
\text { high). }\end{array}$} & \multirow[b]{2}{*}{ IJ elght. } \\
\hline & & & Bole. & $\begin{array}{l}\text { Jier- } \\
\text { ehantable } \\
\text { tiulser. }\end{array}$ & & & \\
\hline $\begin{array}{l}1 \\
1 \\
2 \\
1 \\
1 \\
3 \\
2 \\
1\end{array}$ & $\begin{array}{r}\text { Inches. } \\
6 \text { to } 10 \\
13 \\
11 \\
19 \\
20 \\
20 \\
25 \\
26\end{array}$ & $\begin{array}{l}100 \\
\text { to } \\
120\end{array}$ & $\begin{array}{r}\text { Cubiefect. } \\
10 \\
48 \\
110 \\
96 \\
105 \\
369 \\
314 \\
169\end{array}$ & Feet R.JI. & $\begin{array}{r}5 \\
1 \\
1 \\
6 \\
3 \\
12 \\
10 \\
15 \\
25 \\
12 \\
4 \\
6 \\
2 \\
2 \\
1\end{array}$ & $\begin{array}{c}\text { Inches. } \\
6 \text { to } 10 \\
10 \\
11 \\
12 \\
13 \\
14 \\
15 \\
16 \\
17 \\
18 \\
19 \\
20 \\
21 \\
22 \\
23\end{array}$ & $\begin{array}{l}100 \\
\text { to } \\
120\end{array}$ \\
\hline \multicolumn{5}{|c|}{$\begin{array}{l}12 \text { trees: } \\
\text { Total cubic feet } \ldots \ldots \ldots \ldots \ldots \ldots \ldots \ldots \ldots \ldots 1,221 \\
\text { Total tect } \mathbf{B} . \mathbf{. 1} \ldots \ldots \ldots \ldots \ldots \ldots \ldots \ldots \ldots, 120\end{array}$} & \multicolumn{3}{|c|}{$\begin{array}{l}105 \text { trees : } \\
\text { Total cubic feet.. } 8,170 \\
\text { Total feet B. } \mathbf{I} . .34,300\end{array}$} \\
\hline
\end{tabular}

Total yield: Pine, 9,391 euhic feet.

9 420 fcet 13. MI. of which White Pine 15 per cent. dverage annual accretion: I'ine, 52 cnbio feet.

Aere No. 4.

Soil: Llght-brown, fresh, loose sand, medinm fine, deep, well drained, with a moderately leafy

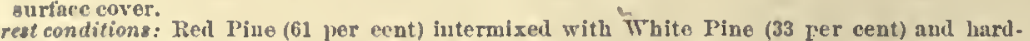
wools (0 per cent); scat tered joung Oak and Beech on unoven ground.

Doininant. per cent.

Oppregset hito $\mathbf{P}$

Pine. Red Pin (i).

Nomher of trees: ( $\beta$.

39

15

ACRE FIELD.

\begin{tabular}{|c|c|c|c|c|c|c|c|c|c|c|}
\hline \multicolumn{5}{|c|}{ White Pine. } & \multicolumn{3}{|c|}{ Red Pine. } & \multicolumn{3}{|c|}{ Oak. } \\
\hline \multirow[b]{2}{*}{$\begin{array}{l}\text { Num- } \\
\text { ber of } \\
\text { trees. }\end{array}$} & \multirow[b]{2}{*}{$\begin{array}{l}\text { Dismeter } \\
\text { (lirenst } \\
\text { light. }\end{array}$} & \multirow[b]{2}{*}{ Helght. } & \multicolumn{2}{|c|}{ Volume. } & \multirow[b]{2}{*}{$\begin{array}{l}\text { Num- } \\
\text { ber of } \\
\text { trees. }\end{array}$} & \multirow[b]{2}{*}{$\begin{array}{l}\text { Diameter } \\
\text { (breast } \\
\text { high). }\end{array}$} & \multirow[b]{2}{*}{ Helght. } & \multirow[b]{2}{*}{$\begin{array}{l}\text { Num. } \\
\text { ber of } \\
\text { trees. }\end{array}$} & \multirow[b]{2}{*}{$\begin{array}{l}\text { Diameter } \\
\text { (hrenst } \\
\text { ligh). }\end{array}$} & \multirow[b]{2}{*}{ Helght. } \\
\hline & & & Bole. & $\begin{array}{l}\text { Mer. } \\
\text { chant- } \\
\text { ahle } \\
\text { timher. }\end{array}$ & & & & & & \\
\hline \multirow{3}{*}{$\begin{array}{l}0 \\
3 \\
3 \\
1 \\
2 \\
2 \\
4 \\
3 \\
1 \\
2 \\
2 \\
2 \\
4 \\
2 \\
1 \\
3 \\
1 \\
1\end{array}$} & \multirow{3}{*}{$\begin{array}{c}\text { Inches. } \\
0 \text { to } 10 \\
10 \\
11 \\
12 \\
13 \\
11 \\
15 \\
16 \\
18 \\
19 \\
20 \\
22 \\
23 \\
25 \\
20 \\
27 \\
31\end{array}$} & \multirow[t]{3}{*}{ Feet. } & \multirow{3}{*}{$\begin{array}{c}\text { Cubicfect. } \\
63 \\
54 \\
96 \\
38 \\
96 \\
110 \\
252 \\
213 \\
352 \\
192 \\
210 \\
492 \\
268 \\
157 \\
507 \\
1 \times 3 \\
283\end{array}$} & \multirow{3}{*}{ Ft.B.M. } & \multirow{3}{*}{$\begin{array}{r}1 \\
2 \\
2 \\
6 \\
11 \\
11 \\
8 \\
13 \\
12 \\
12 \\
2 \\
2\end{array}$} & \multirow{3}{*}{$\begin{array}{c}\text { Inches. } \\
11 \\
12 \\
13 \\
14 \\
15 \\
16 \\
17 \\
18 \\
19 \\
20 \\
21 \\
22\end{array}$} & \multirow[t]{3}{*}{ Feet. } & 1 & $\begin{array}{l}\text { Inches. } \\
3 \text { to } 6\end{array}$ & $\begin{array}{c}\text { Feet. } \\
10\end{array}$ \\
\hline & & & & & & & & & Beech. & \\
\hline & & & & & & & & $\begin{array}{l}3 \\
3 \\
1 \\
1\end{array}$ & $\begin{array}{r}3 \text { to } 6 \\
6 . \operatorname{to~} 10 \\
13 \\
14\end{array}$ & $\begin{array}{l}40 \\
\text { to } \\
60\end{array}$ \\
\hline \multicolumn{5}{|c|}{$\begin{array}{l}\text { At trece: } \\
\text { Total culde feet.............. } 3,363 \\
\text { Total feot } 13 . \mathbf{1 1} \ldots \ldots \ldots \ldots \ldots, 060\end{array}$} & \multicolumn{3}{|c|}{$\begin{array}{l}83 \text { troes: } \\
\text { Total cuhic ft. } 7,572 \\
\text { Total ft. B. M. } 31,800\end{array}$} & \multicolumn{3}{|c|}{9 trees. } \\
\hline
\end{tabular}

Total yield : Pine, 11,135 cuble faet.

46, 760 feet $\mathrm{B}$. M.. of which Whito l'ine 32 per eent.

doerage annual accrefion: l'ine, 62 cuhic feet. 
TABLES OF MEASUREMENTS.

TABLE VI.-Acre yields of White Pine and measurements of ample trees-Continued.

MEASUREMENTS OF SAMPLE TREES.

Age class: 160 to 180 years.

DOMINANT GROWTH.

\begin{tabular}{|c|c|c|c|c|c|c|c|c|c|c|}
\hline Tree number. & Age. & $\begin{array}{c}\text { Diameter } \\
\text { (breast } \\
\text { high). }\end{array}$ & Height. & $\begin{array}{c}\text { Rings } \\
\text { per inch } \\
\text { on } \\
\text { stump. }\end{array}$ & $\begin{array}{l}\text { Volume } \\
\text { of tree. }\end{array}$ & $\begin{array}{l}\text { Factor } \\
\text { of } \\
\text { shape. }\end{array}$ & $\begin{array}{l}\text { Ratio of } \\
\text { length } \\
\text { of crown } \\
\text { to total } \\
\text { height of }\end{array}$ & \multicolumn{2}{|c|}{$\begin{array}{l}\text { Current annual } \\
\text { accretion. }\end{array}$} & $\begin{array}{c}\text { A rerage } \\
\text { annual } \\
\text { accre- } \\
\text { tion. }\end{array}$ \\
\hline $\begin{array}{l}9 \ldots \ldots \ldots \\
29 \ldots \ldots \ldots \\
24 \ldots \ldots \ldots\end{array}$ & $\begin{array}{c}\text { Tears. } \\
178 \\
173 \\
163\end{array}$ & $\begin{array}{r}\text { Inehes. } \\
24.2 \\
27.2 \\
26.5\end{array}$ & $\begin{array}{r}\text { Feet. } \\
118 \\
121 \\
120\end{array}$ & $\begin{array}{r}\text { No. } \\
7.5 \\
6.2 \\
6.2\end{array}$ & $\begin{array}{l}O u . f t . \\
170.1 \\
218.8 \\
211.0\end{array}$ & $\begin{array}{r}0.46 \\
.45 \\
.46\end{array}$ & $\begin{array}{r}0.54 \\
.28 \\
.31\end{array}$ & $\begin{array}{r}\text { Per cent. } \\
1.2 \\
.7 \\
.7\end{array}$ & $\begin{array}{r}C u . f t . \\
2.04 \\
1.53 \\
1.47\end{array}$ & $\begin{array}{r}\text { Cu. ft. } \\
0.05 \\
1.26 \\
1.29\end{array}$ \\
\hline A verage.. & 171 & 26.0 & 120 & 6.6 & 200.0 & .46 & .38 & .9 & 1.68 & 1.17 \\
\hline $\begin{array}{l}34 \ldots \ldots \ldots \ldots \ldots \ldots \\
18 \ldots \ldots \ldots \ldots \ldots \ldots . .\end{array}$ & $\begin{array}{l}182 \\
188 \\
186\end{array}$ & $\begin{array}{l}25.2 \\
26.7 \\
31.0\end{array}$ & $\begin{array}{l}118 \\
118 \\
119\end{array}$ & $\begin{array}{l}7.4 \\
6.9 \\
5.5\end{array}$ & $\begin{array}{l}173.0 \\
202.1 \\
286.6\end{array}$ & $\begin{array}{l}.43 \\
.45 \\
.45\end{array}$ & $\begin{array}{l}.53 \\
.59 \\
.40\end{array}$ & $\begin{array}{l}1.3 \\
1.2 \\
.7\end{array}$ & $\begin{array}{l}2.25 \\
2.42 \\
2.0\end{array}$ & $\begin{array}{l}.95 \\
1.07 \\
1.54\end{array}$ \\
\hline Average.. & 185 & 27.6 & 118 & 6.6 & 220.5 & .44 & .51 & 1.1 & 2.22 & 1.19 \\
\hline
\end{tabular}

CODOMINANT OROWTH.

\begin{tabular}{|c|c|c|c|c|c|c|c|c|c|c|}
\hline $15 \ldots \ldots \ldots \ldots \ldots$ & 179 & 19.0 & 125.0 & 9.9 & 118.4 & 0.48 & 0.26 & 0.8 & 0.95 & 0.66 \\
\hline $\begin{array}{l}7 \ldots \ldots \ldots \ldots \\
10 \ldots \ldots \ldots \\
63 \ldots \ldots \ldots \ldots \\
33 \ldots \ldots \ldots\end{array}$ & $\begin{array}{l}185 \\
185 \\
181 \\
182\end{array}$ & $\begin{array}{l}17.0 \\
20.3 \\
24.5 \\
22.0\end{array}$ & $\begin{array}{l}125.0 \\
105.0 \\
109.0 \\
111.0\end{array}$ & $\begin{array}{r}11.5 \\
9.1 \\
7.4 \\
7.7\end{array}$ & $\begin{array}{r}79.2 \\
111.8 \\
128.6 \\
131.3\end{array}$ & $\begin{array}{l}.41 \\
.46 \\
.36 \\
.45\end{array}$ & $\begin{array}{l}.51 \\
.32 \\
.38 \\
.44\end{array}$ & $\begin{array}{l}1.5 \\
.8 \\
1.0 \\
1.5\end{array}$ & $\begin{array}{l}1.19 \\
.89 \\
1.29 \\
2.01\end{array}$ & $\begin{array}{l}.42 \\
.60 \\
.70 \\
.73\end{array}$ \\
\hline Arerage... & 184 & 20.8 & 112.5 & 8.9 & 113.5 & .42 & .41 & 1.2 & 1.34 & .61 \\
\hline
\end{tabular}

OPPRESSED OROWTH.

\begin{tabular}{|l|l|l|l|l|l|l|l|l|l|l|}
\hline $36 . \ldots . \ldots . . . \ldots . .$. & 165 & 18 & 103 & 8.7 & 87.9 & 0.47 & 0.46 & 1.2 & 1.05 & 0.53 \\
\hline
\end{tabular}

Age class: Over 200 jears.

DOMINANT OROWTH.

\begin{tabular}{|c|c|c|c|c|c|c|c|c|c|c|}
\hline $19 . \ldots \ldots \ldots \ldots \ldots$ & 211 & 28.5 & 119 & 7.3 & 218.9 & 0.41 & 0.63 & 1.3 & 2.84 & 1.03 \\
\hline
\end{tabular}

OPPRESSED OROWTH.

\begin{tabular}{|c|c|c|c|c|c|c|c|c|c|c|}
\hline $13 . . . \ldots \ldots \ldots \ldots$ & 206 & 22 & 119 & 9.7 & 144.4 & 0.46 & 0.38 & 0.6 & 0.87 & 0.70 \\
\hline
\end{tabular}

20233-No. 22-9 
TABL. VI.-Acre yiclds of White I'ine and measurements of sample trees-Continued.

A.-MICIIG \&X-Contluned.

(13) Stre $n$ : 1roscommon County.

[800 to 1,000 feet nhovo sea lorel.]
Samplo area : 1 acro.

Age of plue: 100 to 200 sears. Denslty of crown corer: $(i)$

Soil. Lighb-brown, loams sand, fresh, light, loose, five, well iralved, with 2 to 3 inches moid on toj, and a surface covor of abuulaut leaves.

Forest conditions: IIardwoods (69 per cent) nilxed with Whlte Plue (31 per cent) situated ou a lopo (angle 100); undergrowtb seanty, of joung Oak and Beech. [Theslngle Red PIne stand. ing rather escoptioual. About 20 to 25 per cevt of Red Plve would have been more typleal.] Classiflcation:

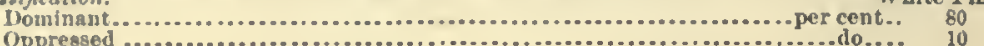

Suppressed ...................................................................... 10

Number of trees : 130

\section{ACRE TIELD.}

\begin{tabular}{|c|c|c|c|c|c|c|c|c|c|c|}
\hline \multicolumn{5}{|c|}{ White 1'ive. } & \multicolumn{3}{|c|}{ Beech. } & \multicolumn{3}{|c|}{ Rock Maplo. } \\
\hline \multirow[b]{2}{*}{$\begin{array}{l}\text { Number } \\
\text { of trees. }\end{array}$} & \multirow[b]{2}{*}{$\begin{array}{l}\text { Dlameter } \\
\text { (breast } \\
\text { high). }\end{array}$} & \multirow[b]{2}{*}{ Height. } & \multicolumn{2}{|c|}{ Volume. } & \multirow[b]{2}{*}{$\begin{array}{l}\text { Numbor } \\
\text { of trees. }\end{array}$} & \multirow[b]{2}{*}{$\begin{array}{l}\text { Dlameter } \\
\text { (lireast } \\
\text { bigb). }\end{array}$} & \multirow[b]{2}{*}{ Height. } & \multirow[b]{2}{*}{$\begin{array}{l}\text { Number } \\
\text { of trees. }\end{array}$} & \multirow[b]{2}{*}{$\begin{array}{l}\text { Dlameter } \\
\text { (breast } \\
\text { high). }\end{array}$} & \multirow[b]{2}{*}{ Height. } \\
\hline & & & IBolo. & $\begin{array}{l}\text { Mer- } \\
\text { cbantahlo } \\
\text { tlmber. }\end{array}$ & & & & & & \\
\hline \multirow{3}{*}{$\begin{array}{l}1 \\
3 \\
1 \\
1 \\
1 \\
2 \\
3 \\
3 \\
1 \\
3 \\
3 \\
4 \\
4 \\
1 \\
2 \\
2 \\
2 \\
.2 \\
1\end{array}$} & \multirow{3}{*}{$\begin{array}{c}\text { Inches. } \\
11 \\
13 \\
14 \\
15 \\
17 \\
20 \\
21 \\
23 \\
24 \\
25 \\
26 \\
27 \\
28 \\
29 \\
31 \\
32 \\
33 \\
34 \\
36\end{array}$} & \multirow{3}{*}{$\begin{array}{c}100 \\
\text { to } \\
130\end{array}$} & \multirow{3}{*}{$\begin{array}{c}\text { Cubic ft. } \\
32 \\
159 \\
60 \\
72 \\
80 \\
240 \\
387 \\
477 \\
166 \\
555 \\
600 \\
864 \\
924 \\
217 \\
560 \\
594 \\
630 \\
068 \\
373\end{array}$} & \multirow{3}{*}{ Feet $\mathbf{B . 3 r}$. } & \multirow{3}{*}{$\begin{array}{r}26 \\
34 \\
4 \\
0 \\
1 \\
1 \\
1 \\
1 \\
1\end{array}$} & \multirow[t]{3}{*}{$\begin{array}{r}\text { Inches. } \\
3 \text { to } 6 \\
6 \text { to } 10 \\
11 \\
12 \\
13 \\
14 \\
15 \\
16 \\
18\end{array}$} & \multirow[t]{3}{*}{ Feet. } & $\begin{array}{l}6 \\
1 \\
1 \\
1 \\
1 \\
1\end{array}$ & $\begin{array}{r}\text { Inches. } \\
6 \text { to } 10 \\
10 \\
12 \\
13 \\
14 \\
17\end{array}$ & Feet. \\
\hline & & & & & & & & & Red Oak. & \\
\hline & & & & & & & & $\begin{array}{l}1 \\
1 \\
1 \\
1\end{array}$ & $\begin{array}{r}6 \text { to } 10 \\
12 \\
13 \\
26\end{array}$ & , \\
\hline \multicolumn{5}{|c|}{$\begin{array}{l}40 \text { trees : } \\
\text { Total cuhlo feet.................... } 7,698 \\
\text { Total feet B. MI ................. }\end{array}$} & \multicolumn{3}{|l|}{73 trees. } & \multicolumn{3}{|l|}{15 trecs. } \\
\hline
\end{tabular}

Average annual accretion: Whito Pino, 42 cobio feet. 
TABLES OF MEASUREMENTS.

TABLE VI,-Acre yields of White Pine and measurements of sample trees-Continued.

\section{B.-WISConsin:}

(1) SITE $a$ :
Wasbburn County.

[1,200 feet abore sea lerel.]
Sample area: 2 acres.

Acre No. 1.

Soil: Fresb clay, nnderlaid by bardpan of clay and stones; 4 inches of mold, surface cover leafy. Age of pine: 200 to 220 years. Forest conditions: Two-story stand, W bite Pine occupying upper story, bardwoods (Maple, Density of crown cover: (I). Yellow Bircb, Elm or Basswoods, or Hornbeam) the lower story: undererowtb dense, of yonng bardwoods, 1 to 3 incbes in diameter, 20 to 30 feet higb. White Pine, 56 per cent; har foods, 44 per cent.

Olassification:

Dominant White Pine.

Number of trees: 76 .

Oppressed per cent.. 73

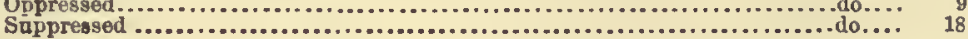

ACRE YIELD,

\begin{tabular}{|c|c|c|c|c|c|c|c|}
\hline \multicolumn{5}{|c|}{ Wbite Pine. } & \multicolumn{3}{|c|}{ Maple. } \\
\hline \multirow[b]{2}{*}{$\begin{array}{l}\text { Number } \\
\text { of trees. }\end{array}$} & \multirow[b]{2}{*}{$\begin{array}{c}\text { Diameter } \\
\text { (breast } \\
\text { higb). }\end{array}$} & \multirow[b]{2}{*}{ Heigbt. } & \multicolumn{2}{|c|}{ Volnme. } & \multirow[b]{2}{*}{$\begin{array}{l}\text { Nimber } \\
\text { of trees. }\end{array}$} & \multirow[b]{2}{*}{$\begin{array}{l}\text { Diameter } \\
\text { (breast } \\
\text { bigb). }\end{array}$} & \multirow[b]{2}{*}{ Height. } \\
\hline & & & Bole. & $\begin{array}{c}\text { Mer. } \\
\text { cbantable } \\
\text { timber. }\end{array}$ & & & \\
\hline \multirow{5}{*}{$\begin{array}{l}2 \\
3 \\
1 \\
1 \\
1 \\
1 \\
1 \\
1 \\
3 \\
3 \\
2 \\
3 \\
4 \\
1 \\
4 \\
1 \\
3 \\
4 \\
2 \\
1 \\
1\end{array}$} & \multirow{5}{*}{$\left.\begin{array}{r}\text { Inches. } \\
11 \\
14 \\
16 \\
17 \\
18 \\
19 \\
20 \\
21 \\
22 \\
24 \\
26 \\
27 \\
28 \\
29 \\
30 \\
31 \\
32 \\
33 \\
34 \\
35 \\
38\end{array}\right\}$} & \multirow{5}{*}{$\begin{array}{c}120 \\
\text { to } \\
135\end{array}$} & \multirow{5}{*}{\begin{tabular}{|c|} 
Cubicfeet. \\
64 \\
165 \\
71 \\
79 \\
88 \\
96 \\
105 \\
114 \\
420 \\
480 \\
384 \\
621 \\
924 \\
247 \\
1,040 \\
280 \\
891 \\
1,260 \\
694 \\
367 \\
429
\end{tabular}} & \multirow[t]{5}{*}{ Feet $\boldsymbol{B} . \boldsymbol{H}$. } & $\begin{array}{r}1 \\
18 \\
3\end{array}$ & $\begin{array}{l}\text { Inches. } \\
3 \text { to } 6 \\
6 \text { to } 10 \\
10 \text { to } 14\end{array}$ & $\begin{array}{r}\text { Feet. } \\
40 \\
60 \\
80\end{array}$ \\
\hline & & & & & & Elm. & \\
\hline & & & & & 2 & 6 to 10 & 60 \\
\hline & & & & & \multicolumn{3}{|c|}{ Yellow Bircb. } \\
\hline & & & & & $\begin{array}{l}1 \\
4 \\
4\end{array}$ & $\begin{array}{l}6 \text { to } 10 \\
10 \text { to } 14 \\
14 \text { to } 18\end{array}$ & $\begin{array}{l}60 \\
80\end{array}$ \\
\hline $\begin{array}{l}43 \text { trees } \\
\text { Tot } \\
\text { Tot }\end{array}$ & $\begin{array}{l}\text { al cn bic fee } \\
\text { al feet B. M }\end{array}$ & t............ & ...... & $\begin{array}{r}8,119 \\
52,920\end{array}$ & \multicolumn{3}{|l|}{33 trces: } \\
\hline
\end{tabular}

4verage annual accretion: White Pine, 38 cubic feet. 
TABLE VI.-Acre yields of Thite Pine and measurements of sample trees-Continued.

B.-IVISCONSrN-Continued.

Lere tio. 8.

Solt: Fresh olay, underlald hy hardpan of clay and stones; 4 inches of mold, surface corer

leafy, conditions: Tro-story stand, White Pino occupying the apper story snd hardwoods (Maple, Yellow Birch, EIm or Basgwood, or Hornbean) the lower story; undergrow th scanty. of young bardwoods and Wir. White $1^{\prime}$ ine, 52 per ceut; hardwoods, 48 per cent. Classifeation:

Dominant. White Pine.

Age of pine: 200 to 220 years. Density of erown cover: (1)

per ceut.. 75

Suppressed

ACRE TIELD.

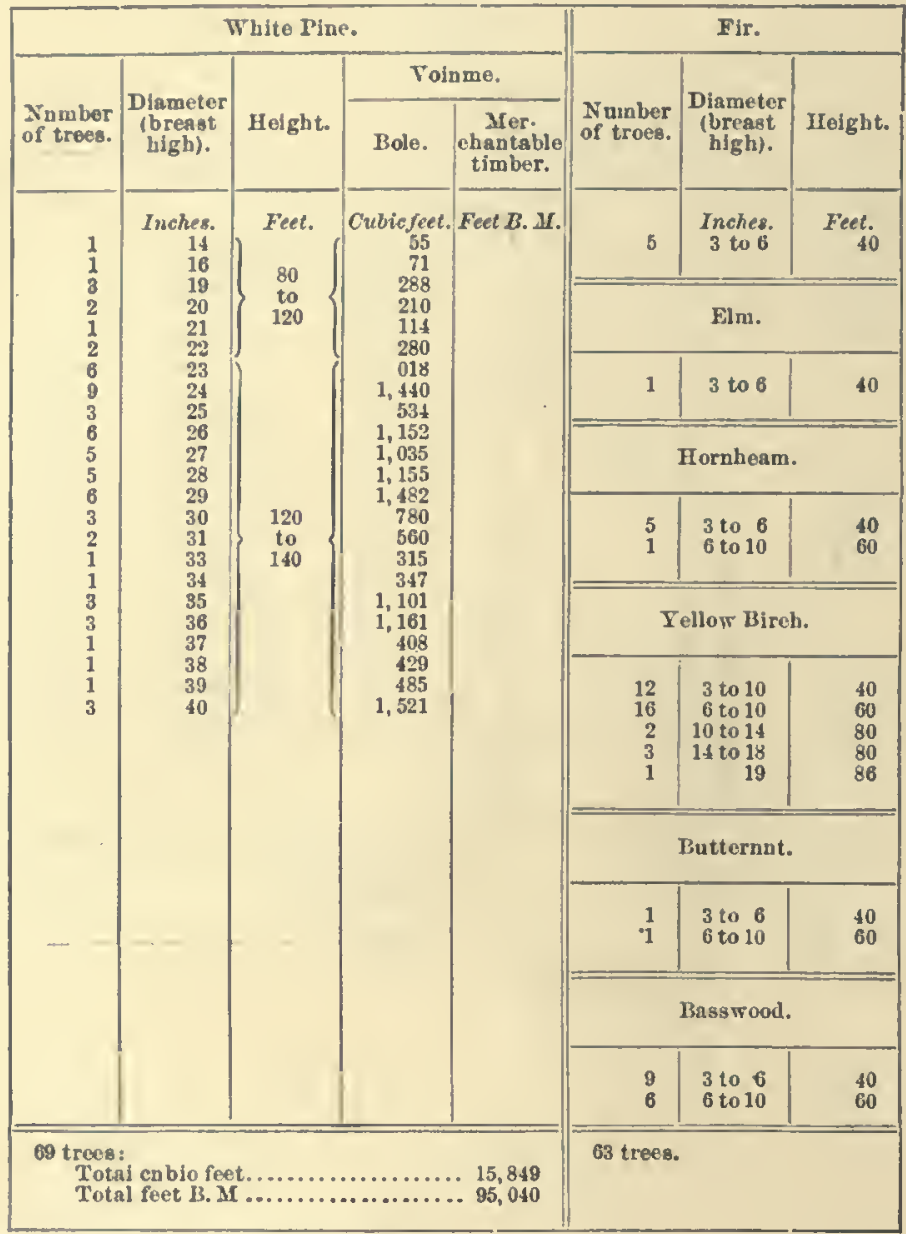

Average annual accretion: White Pine, 75 cubio feet.
452 feet B. Al.

MEASUREMENTS OF SAMPLE TREES.

\begin{tabular}{|c|c|c|c|c|c|c|c|}
\hline Tree nnmber. & Age. & $\begin{array}{c}\text { Dlameter } \\
\text { (breast } \\
\text { high). }\end{array}$ & Height. & $\begin{array}{l}\text { Volume } \\
\text { of tree. }\end{array}$ & $\begin{array}{l}\text { Factor } \\
\text { of } \\
\text { shape. }\end{array}$ & $\begin{array}{l}\text { Ratio of } \\
\text { lengtl } \\
\text { of erown } \\
\text { to total } \\
\text { helght of } \\
\text { tree. }\end{array}$ & $\begin{array}{l}\text { Arersge } \\
\text { annual } \\
\text { beere- } \\
\text { tion. }\end{array}$ \\
\hline 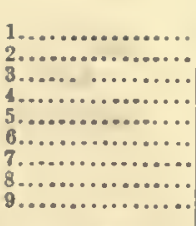 & $\begin{array}{c}\text { Tears. } \\
204 \\
221 \\
213 \\
214 \\
216 \\
202 \\
204 \\
212 \\
213\end{array}$ & $\begin{array}{r}\text { Inches. } \\
24.7 \\
27.0 \\
27.0 \\
26.0 \\
26.8 \\
24.0 \\
29.0 \\
20.0 \\
30.0\end{array}$ & $\begin{array}{l}\text { Feet. } \\
102.0 \\
113.0 \\
121.5 \\
120.0 \\
120.0 \\
134.0 \\
132.0 \\
133.0 \\
133.5\end{array}$ & $\begin{array}{c}\text { Cu. } f t . \\
166 \\
183 \\
191 \\
201 \\
210 \\
187 \\
238 \\
250 \\
291\end{array}$ & $\begin{array}{l}0.49 \\
.41 \\
.40 \\
.43 \\
.42 \\
.44 \\
.39 \\
.41 \\
.44\end{array}$ & $\begin{array}{l}0.45 \\
.37 \\
.53 \\
.52 \\
.40 \\
.40 \\
.39 \\
.42 \\
.47\end{array}$ & $\begin{array}{c}\text { Cru.ft. } \\
0.81 \\
.82 \\
.90 \\
.94 \\
.97 \\
.93 \\
1.17 \\
1.18 \\
1.37\end{array}$ \\
\hline Average... & 211 & 27.0 & 124.0 & 213 & .42 & .44 & 1.01 \\
\hline
\end{tabular}


TABLE VI.-Acre yields of Thite Pine and measurements of sample trees-Continued.

\section{B.-WISCONSIN-Continned.}

(2) SITE $c$ :

\author{
Washburn County. \\ [1,400 feet ahovo sea level.]
}

Samplo area: 3 acrea.

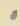

Soil, Ligbt-colored clay, nnderlaid hy sand at a depth of ahout 2 feet; fresb, moist in bollow, Age of pine: 200 to 220 (few 160) with 3 inches mold on top and surface cover of leaves.

Forest conditions Two-story stand of typical open pine growth, npper story of White Pine Density of crown cover: (i) (22 per cent), lower story of bardwoods (74 per ceut), mainly Rock iraple, scattering Yellow Birch, and occasioual Elm, Hornbeam, and Fir (4 per ceut); undergrowth, moderately dense, of young hardwoods.

Number of trees: 88 .

ACRE YIELD.

\begin{tabular}{|c|c|c|c|c|c|c|c|c|c|c|c|c|c|}
\hline \multicolumn{5}{|c|}{ White Pine. } & \multicolumn{3}{|c|}{ Rock Maple. } & \multicolumn{3}{|c|}{ Yellow Birch. } & \multicolumn{3}{|c|}{ Elm. } \\
\hline \multirow[b]{2}{*}{$\begin{array}{l}\text { Ninm. } \\
\text { ber of } \\
\text { trees. }\end{array}$} & \multirow[b]{2}{*}{$\begin{array}{c}\text { Diamo- } \\
\text { ter } \\
\text { (hreast } \\
\text { high). }\end{array}$} & \multirow[b]{2}{*}{ Height. } & \multicolumn{2}{|c|}{ Volnme } & \multirow[b]{2}{*}{$\begin{array}{l}\text { Num- } \\
\text { ber of } \\
\text { trees. }\end{array}$} & \multirow[b]{2}{*}{$\begin{array}{c}\text { Diameter } \\
\text { (hreast } \\
\text { high). }\end{array}$} & \multirow[b]{2}{*}{ Height. } & \multirow[b]{2}{*}{$\begin{array}{l}\text { Num- } \\
\text { her of } \\
\text { trees. }\end{array}$} & \multirow[b]{2}{*}{$\begin{array}{c}\text { Diameter } \\
\text { (breast } \\
\text { high). }\end{array}$} & \multirow[b]{2}{*}{ Height. } & \multirow[b]{2}{*}{$\begin{array}{l}\text { Num. } \\
\text { her of } \\
\text { trees. }\end{array}$} & \multirow[b]{2}{*}{$\begin{array}{c}\text { Diameter } \\
\text { (hreast } \\
\text { high). }\end{array}$} & \multirow[b]{2}{*}{ Heigbt. } \\
\hline & & & Bole. & $\begin{array}{l}\text { Mer- } \\
\text { chant- } \\
\text { able } \\
\text { timber. }\end{array}$ & & & & & & & & & \\
\hline \multirow{5}{*}{$\begin{array}{l}2 \\
1 \\
1 \\
2 \\
2 \\
1 \\
1 \\
1 \\
1 \\
2 \\
3 \\
1 \\
1\end{array}$} & \multirow{5}{*}{\begin{tabular}{|c|} 
Inches. \\
18 \\
19 \\
21 \\
23 \\
20 \\
28 \\
32 \\
33 \\
34 \\
35 \\
38 \\
40 \\
46
\end{tabular}} & \multirow{5}{*}{$\begin{array}{c}\text { Feet. } \\
80 \\
\text { to } \\
120\end{array}$} & \multirow{5}{*}{$\begin{array}{c}\text { Cu.ft. } \\
160 \\
87 \\
103 \\
318 \\
400 \\
231 \\
297 \\
315 \\
334 \\
706 \\
1,335 \\
490 \\
638\end{array}$} & \multirow[t]{5}{*}{ Ft.B.M. } & \multirow{5}{*}{$\begin{array}{r}18 \\
24 \\
6 \\
1 \\
1\end{array}$} & \multirow{5}{*}{$\begin{array}{r}\text { Tnches. } \\
3 \text { to } 6 \\
6 \text { to } 10 \\
10 \text { to } 14 \\
17 \\
19\end{array}$} & \multirow{5}{*}{$\begin{array}{r}\text { Feet. } \\
40 \\
60 \\
80 \\
80 \\
80\end{array}$} & \multirow{5}{*}{$\begin{array}{l}1 \\
3 \\
2 \\
1 \\
1 \\
1 \\
1 \\
1\end{array}$} & \multirow{5}{*}{$\begin{array}{r}\text { Inches. } \\
3 \text { to } 6 \\
6 \text { to } 10 \\
10 \text { to } 14 \\
15 \\
16 \\
17 \\
20 \\
31\end{array}$} & \multirow{5}{*}{$\begin{array}{r}\text { Feet. } \\
40 \\
60 \\
80 \\
80 \\
80 \\
80 \\
80 \\
\text { Orer } \\
80\end{array}$} & 1 & $\begin{array}{c}\text { Inches. } \\
15\end{array}$ & Feet. \\
\hline & & & & & & & & & & & \multicolumn{3}{|c|}{ Hornbeam. } \\
\hline & & & & & & & & & & & 3 & 3 to 6 & 40 \\
\hline & & & & & & & & & & & \multicolumn{3}{|c|}{ Fir. } \\
\hline & & & & & & & & & & & 4 & 3 to 6 & 4 \\
\hline \multicolumn{5}{|c|}{$\begin{array}{l}19 \text { trees: } \\
\text { Total cubic feet } \ldots \ldots \ldots \ldots \ldots, 5,414 \\
\text { Total feet } \mathrm{B} . \mathbf{M} . \ldots \ldots \ldots \ldots, 32,480\end{array}$} & \multicolumn{3}{|c|}{50 trees. } & \multicolumn{3}{|c|}{11 trees. } & \multicolumn{3}{|c|}{8 trees. } \\
\hline
\end{tabular}

Average annual accretion: White Pine, 26 cnhic feet.
155 feet B. If.

Acre No.2.

Soil: Light-colored clay, nnderlaid by sand at a depth of abont 2 feet; fresh, moist in bollow, Age of pine: 200 to 220 (few 160 )

with 3 inches mold on top and surface cover of leaves.
Forest conditions: Two-story stand of White Pine ( 44 per cent) mixed witb hardwoods (53 per Density of crown cover: (i) cent), upper story of pine, the lower story of hardwoods (Rock Maple intermixed with Yellow Jircb and scattering Hornheam and Elm) and occasional Fir (3 per cent); no undergrowth.

Clasrification:

White Pine.

Dominant t............................................................ per cent.. 68

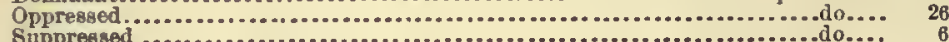

Niumber of trees: 136

ACRE YIELD.

\begin{tabular}{|c|c|c|c|c|c|c|}
\hline \multicolumn{4}{|c|}{ White Pine. } & \multicolumn{3}{|c|}{ Rock Maple. } \\
\hline \multirow[b]{2}{*}{$\begin{array}{l}\text { Nnmlier } \\
\text { of treos. }\end{array}$} & \multirow[b]{2}{*}{$\begin{array}{c}\text { Diameter } \\
\text { (breast } \\
\text { high). }\end{array}$} & \multicolumn{2}{|c|}{ Volnme. } & \multirow[b]{2}{*}{$\begin{array}{l}\text { Numher } \\
\text { of trees. }\end{array}$} & \multirow[b]{2}{*}{$\begin{array}{l}\text { Diameter } \\
\text { (hreast } \\
\text { high). }\end{array}$} & \multirow[b]{2}{*}{ Heigbt. } \\
\hline & & Bole. & $\begin{array}{l}\text { Mer- } \\
\text { chantahle } \\
\text { timber. }\end{array}$ & & & \\
\hline \multirow{5}{*}{$\begin{array}{r}4 \\
4 \\
4 \\
4 \\
4 \\
12 \\
4 \\
4 \\
8 \\
8 \\
4\end{array}$} & \multirow{5}{*}{$\begin{array}{r}\text { Inches. } \\
6 \text { to } 10 \\
14 \\
18 \\
19 \\
20 \\
24 \\
26 \\
29 \\
31 \\
32 \\
45\end{array}$} & \multirow{5}{*}{$\begin{array}{r}\text { Cubiefeet. } \\
40 \\
20 \\
320 \\
348 \\
384 \\
1,992 \\
800 \\
988 \\
2,240 \\
2,376 \\
2,448\end{array}$} & \multirow{5}{*}{ Feet B.M. } & $\begin{array}{l}36 \\
16\end{array}$ & $\begin{array}{l}\text { Inches. } \\
3 \text { to } 6 \\
6 \text { to } 10\end{array}$ & $\begin{array}{r}\text { Feet. } \\
\quad 40 \\
\quad 60\end{array}$ \\
\hline & & & & \multicolumn{3}{|c|}{ Yellow Bircb. } \\
\hline & & & & $\begin{array}{r}12 \\
4 \\
4 \\
\end{array}$ & $\begin{array}{r}6 \text { to } 10 \\
10 \text { to } 14 \\
14 \text { to } 18\end{array}$ & $\begin{array}{l}60 \\
80\end{array}$ \\
\hline & & & & \multicolumn{3}{|c|}{ Fir. } \\
\hline & & & & 4 & 3 to 6 & 40 \\
\hline \multicolumn{4}{|c|}{$\begin{array}{l}60 \text { trees: } \\
\text { Total cubic feet............ 12, } 136 \\
\text { Total feet B. M........... 72, } 810\end{array}$} & \multicolumn{3}{|l|}{76 trees: } \\
\hline
\end{tabular}

Average annual accretion: Wbite Pine, 58 cuhio foet.
347 foet 13. M. 
TARLE VI. - Acre yiclds of Thile Pine and measurements of sample trees-Continued. .

B. - WISCONSIX-Contiuued.

Acre Jio.s.

Soin: Lightecolored claj, underlaid bJ saud et a depth of abont 2 feet; fresh, molst In hollow, $\Delta$ ge of pine: 200 to 220 (few

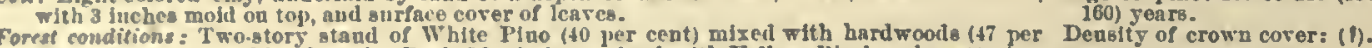
cent), upper stort of hardwoods (Rock Maple interulxed with Yellow Birch and geat teriug Cornbeam and bilı! and occasional Fir (13 per ceut); moderately dense undergrowth, of very Joung hard woods.
Claifleation:

Dominat ...................................................per cent.. Thite Pine.

Number of trees: 123 .

Suppressed.

ACRE TIELD

\begin{tabular}{|c|c|c|c|c|c|c|c|c|c|c|}
\hline \multicolumn{5}{|c|}{ White Pine. } & \multicolumn{3}{|c|}{ Rock Mraple. } & \multicolumn{3}{|c|}{ Elm. } \\
\hline \multirow[b]{2}{*}{$\begin{array}{l}\text { Number } \\
\text { of trues. }\end{array}$} & \multirow[b]{2}{*}{$\begin{array}{l}\text { Diameter } \\
\text { (breast } \\
\text { Ligh). }\end{array}$} & \multirow[b]{2}{*}{ Helght. } & \multicolumn{2}{|c|}{ Volume. } & \multirow[b]{2}{*}{$\begin{array}{l}\text { Number } \\
\text { of trees. }\end{array}$} & \multirow[b]{2}{*}{$\begin{array}{l}\text { Diameter } \\
\text { (breast } \\
\text { ligh). }\end{array}$} & \multirow[b]{2}{*}{ Height. } & \multirow[b]{2}{*}{$\begin{array}{l}\text { Number } \\
\text { of trees. }\end{array}$} & \multirow[b]{2}{*}{$\begin{array}{l}\text { Diameter } \\
\text { (breast } \\
\text { high). }\end{array}$} & \multirow[b]{2}{*}{ Height. } \\
\hline & & & Bole. & $\begin{array}{c}\text { Mer- } \\
\text { chantable } \\
\text { timber. }\end{array}$ & & & & & & \\
\hline \multirow{6}{*}{$\begin{array}{l}1 \\
1 \\
2 \\
3 \\
1 \\
5 \\
3 \\
3 \\
1 \\
1 \\
2 \\
3 \\
3 \\
2 \\
2 \\
5 \\
5 \\
2 \\
1 \\
1 \\
3 \\
1 \\
2 \\
1 \\
1 \\
1 \\
1\end{array}$} & \multirow{6}{*}{\begin{tabular}{r|} 
Inches. \\
13 \\
15 \\
17 \\
18 \\
19 \\
20 \\
23 \\
24 \\
25 \\
26 \\
27 \\
28 \\
20 \\
30 \\
31 \\
33 \\
34 \\
35 \\
36 \\
37 \\
42 \\
43 \\
44 \\
46
\end{tabular}} & \multirow{6}{*}{$\begin{array}{c}\text { Feet. } \\
80 \\
\text { to } \\
120\end{array}$} & \multirow{6}{*}{\begin{tabular}{|c} 
Culiejeet. \\
44 \\
58 \\
144 \\
240 \\
87 \\
480 \\
477 \\
498 \\
185 \\
400 \\
648 \\
093 \\
494 \\
520 \\
1,400 \\
630 \\
334 \\
353 \\
1,203 \\
423 \\
1,074 \\
562 \\
584 \\
639
\end{tabular}} & \multirow{6}{*}{ Feet B. 3 . } & \multirow[t]{2}{*}{$\begin{array}{r}18 \\
19 \\
6 \\
1\end{array}$} & \multirow[t]{2}{*}{$\begin{array}{l}\text { Inehes. } \\
3 \text { to } 6 \\
6 \text { to } 10 \\
10 \text { to } 14 \\
14 \text { to } 18\end{array}$} & \multirow[t]{2}{*}{$\begin{array}{r}\text { Feet. } \\
40 \\
60 \\
80\end{array}$} & 1 & $\begin{array}{l}\text { Inches. } \\
6 \text { to } 10 \\
14 \text { to } 18\end{array}$ & $\begin{array}{r}\text { Feet. } \\
60 \\
80\end{array}$ \\
\hline & & & & & & & & \multirow{2}{*}{\multicolumn{2}{|c|}{ Bass wood. }} & \\
\hline & & & & & \multicolumn{3}{|c|}{ Yellow Birch. } & & & \multirow{2}{*}{60} \\
\hline & & & & & \multirow{3}{*}{$\begin{array}{l}1 \\
2 \\
3 \\
1 \\
1 \\
1 \\
1\end{array}$} & \multirow{3}{*}{$\begin{array}{r}3 \text { to } 6 \\
6 \text { to } 10 \\
10 \text { to } 14 \\
14 \\
15 \\
18 \\
19\end{array}$} & \multirow{2}{*}{$\begin{array}{l}40 \\
60\end{array}$} & 1 & 60 to 10 & \\
\hline & & & & & & & & \multicolumn{3}{|c|}{ FYr. } \\
\hline & & & & & & & 80 & $\begin{array}{r}12 \\
4\end{array}$ & $\begin{array}{l}3 \text { to } 6 \\
6 \text { to } 10\end{array}$ & $\begin{array}{r}40 \\
60\end{array}$ \\
\hline \multicolumn{5}{|c|}{$\begin{array}{l}50 \text { trees : } \\
\text { Total cubic feet................... 12,169 } \\
\text { Total feet B.MI.................. }\end{array}$} & \multicolumn{3}{|l|}{54 trees. } & \multicolumn{3}{|l|}{19 trees. } \\
\hline
\end{tabular}

$\Delta$ verage annual aecretion: White Pine, 58 cubic feet.
348 feet $B$. M.

MEASUREMENTS OF SAMPLE TREES

Age elass : 100 to 150 jearв.

\begin{tabular}{|c|c|c|c|c|c|c|c|}
\hline Tree nnmber. & Age. & $\begin{array}{c}\text { Diameter } \\
\text { (breast } \\
\text { high). }\end{array}$ & Height. & $\begin{array}{l}\text { Volume } \\
\text { of tree. }\end{array}$ & $\begin{array}{c}\text { Factor } \\
\text { of } \\
\text { shape. }\end{array}$ & $\begin{array}{l}\text { Ratio of } \\
\text { length } \\
\text { of crown } \\
\text { to total } \\
\text { heiglit of } \\
\text { tree. }\end{array}$ & $\begin{array}{l}\text { Arerage } \\
\text { annual } \\
\text { acere. } \\
\text { tiou. }\end{array}$ \\
\hline 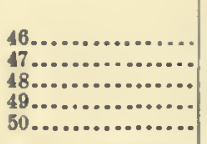 & $\begin{array}{l}\text { Years. } \\
107 \\
104 \\
102 \\
120 \\
101\end{array}$ & $\begin{array}{r}\text { Inehes. } \\
18.5 \\
18.0 \\
18.7 \\
19.3 \\
14.0\end{array}$ & $\begin{array}{l}\text { Feet. } \\
86.0 \\
80.0 \\
86.5 \\
90.0 \\
75.0\end{array}$ & $\begin{array}{r}\text { Ou. ft. } \\
63 \\
70 \\
71 \\
81 \\
41\end{array}$ & $\begin{array}{l}0.39 \\
.49 \\
.45 \\
.46 \\
.52\end{array}$ & $\begin{array}{l}0.44 \\
.63 \\
.61 \\
.55 \\
.40\end{array}$ & $\begin{array}{c}\text { Ou. } r t_{.} \\
0.59 \\
.67 \\
.73 \\
.68 \\
.11\end{array}$ \\
\hline Average... & 107 & 17.7 & 83.5 & 66 & .46 & .52 & .61 \\
\hline 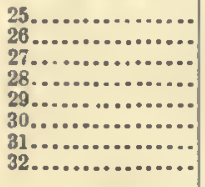 & $\begin{array}{l}102 \\
102 \\
100 \\
102 \\
103 \\
112 \\
118 \\
105\end{array}$ & $\begin{array}{l}12.8 \\
13.2 \\
14.0 \\
15.7 \\
22.2 \\
18.8 \\
17.0 \\
5.6\end{array}$ & $\begin{array}{l}77.5 \\
73.5 \\
75.0 \\
79.5 \\
83.0 \\
86.0 \\
86.5 \\
41.5\end{array}$ & $\begin{array}{r}34 \\
36 \\
46 \\
56 \\
97 \\
81 \\
69 \\
4\end{array}$ & $\begin{array}{l}.49 \\
.51 \\
.57 \\
.52 \\
.43 \\
.49 \\
.50 \\
.56\end{array}$ & $\begin{array}{l}.30 \\
.48 \\
.37 \\
.58 \\
.49 \\
.50 \\
.41 \\
.56\end{array}$ & $\begin{array}{l}.34 \\
.35 \\
.46 \\
.55 \\
.94 \\
.70 \\
.59 \\
.38\end{array}$ \\
\hline Arerage... & 105.5 & 15.0 & 75.0 & 53 & .51 & .46 & .54 \\
\hline 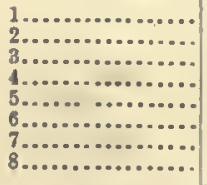 & $\begin{array}{l}104 \\
104 \\
101 \\
105 \\
100 \\
105 \\
102 \\
105\end{array}$ & $\begin{array}{l}15.3 \\
15.5 \\
10.5 \\
19.5 \\
14.0 \\
17.0 \\
16.5 \\
18.5\end{array}$ & $\begin{array}{r}01.0 \\
06.0 \\
08.0 \\
100.0 \\
94.0 \\
104.0 \\
100.0 \\
100.0\end{array}$ & $\begin{array}{l}52 \\
63 \\
65 \\
95 \\
50 \\
72 \\
68 \\
96\end{array}$ & $\begin{array}{l}.45 \\
.50 \\
.44 \\
.45 \\
.50 \\
.44 \\
.43 \\
.47\end{array}$ & $\begin{array}{c}.51 \\
.41 \\
\ldots . . . \\
. \quad .38 \\
.45 \\
.41 \\
.38\end{array}$ & $\begin{array}{l}.50 \\
.61 \\
.64 \\
.80 \\
.50 \\
.69 \\
.67 \\
.91\end{array}$ \\
\hline Average... & 103 & 16. 6 & 100.0 & 70 & .46 & .42 & .68 \\
\hline 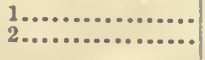 & $\begin{array}{l}137 \\
142\end{array}$ & $\begin{array}{l}24.0 \\
27.8\end{array}$ & $\begin{array}{l}105.0 \\
108.6\end{array}$ & $\begin{array}{l}118 \\
201\end{array}$ & $\begin{array}{l}.36 \\
.44\end{array}$ & .81 & $\begin{array}{r}.86 \\
1.42\end{array}$ \\
\hline Arcrago... & 139.5 & 26.0 & 106.5 & 159 & .40 & .37 & 1.14 \\
\hline
\end{tabular}


TABIES OF MEASUREMENTS.

TABLE VI.-Acre yields of Thite Pine and measurements of 8ample trees-Continued.

B.-WISCONSIN-Continued.

MEASUREMENTS OF SAMPLE TREES-Continued.

Age class: 150 to 200 years.

\begin{tabular}{|c|c|c|c|c|c|c|c|}
\hline Tree number. & Age. & $\begin{array}{c}\text { Diameter } \\
\text { (breast } \\
\text { high). }\end{array}$ & Height. & $\begin{array}{l}\text { Volnme } \\
\text { of tree. }\end{array}$ & $\begin{array}{l}\text { Factor } \\
\text { of } \\
\text { shape. }\end{array}$ & $\begin{array}{c}\text { Ratio of } \\
\text { length } \\
\text { of crown } \\
\text { to total } \\
\text { height of } \\
\text { tree. }\end{array}$ & $\begin{array}{l}\text { Average } \\
\text { annual } \\
\text { accro- } \\
\text { tion. }\end{array}$ \\
\hline 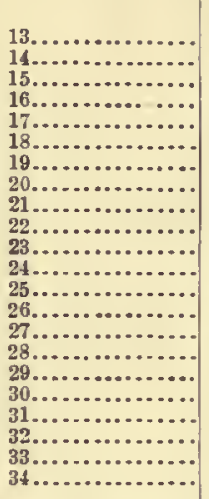 & $\begin{array}{c}\text { Teart. } \\
207 \\
200 \\
208 \\
195 \\
197 \\
196 \\
205 \\
198 \\
217 \\
197 \\
210 \\
202 \\
205 \\
205 \\
204 \\
225 \\
206 \\
207 \\
204 \\
205 \\
200 \\
201\end{array}$ & $\begin{array}{r}\text { Inches. } \\
19.0 \\
20.3 \\
22.6 \\
24.2 \\
24.2 \\
23.0 \\
23.5 \\
25.8 \\
29.5 \\
29.0 \\
31.0 \\
30.5 \\
33.3 \\
25.6 \\
25.3 \\
28.2 \\
28.5 \\
28.5 \\
32.0 \\
32.0 \\
34.0 \\
28.3\end{array}$ & $\begin{array}{r}\text { Feet. } \\
94.5 \\
101.0 \\
96.0 \\
97.0 \\
112.5 \\
116.0 \\
113.5 \\
106.5 \\
114.5 \\
115.0 \\
115.0 \\
127.5 \\
120.0 \\
100.5 \\
110.5 \\
110.0 \\
108.0 \\
119.0 \\
111.5 \\
115.0 \\
117.0 \\
119.0\end{array}$ & $\begin{array}{r}\text { Cu.ft. } \\
94 \\
100 \\
121 \\
133 \\
146 \\
154 \\
161 \\
166 \\
192 \\
236 \\
253 \\
282 \\
304 \\
161 \\
175 \\
175 \\
183 \\
213 \\
274 \\
281 \\
285 \\
208\end{array}$ & $\begin{array}{r}0.50 \\
.44 \\
.45 \\
.43 \\
.41 \\
.40 \\
.47 \\
.43 \\
.35 \\
.45 \\
.42 \\
.44 \\
.42 \\
.44 \\
.43 \\
.37 \\
.40 \\
.40 \\
.44 \\
.44 \\
.39 \\
.40\end{array}$ & $\begin{array}{l}0.45 \\
.55 \\
.40 \\
.32 \\
.54 \\
.46 \\
.42 \\
.42 \\
.58 \\
.63 \\
.59 \\
.47 \\
.43 \\
.39 \\
.51 \\
.50 \\
.43 \\
.34 \\
.54 \\
.69 \\
.43 \\
.61\end{array}$ & $\begin{array}{r}C u . f t . \\
0.45 \\
.50 \\
.58 \\
.68 \\
.74 \\
.79 \\
.78 \\
.84 \\
.88 \\
1.20 \\
1.20 \\
1.40 \\
1.48 \\
.78 \\
.86 \\
.78 \\
.89 \\
1.03 \\
1.34 \\
1.37 \\
1.43 \\
1.03\end{array}$ \\
\hline Arerage... & 204 & 27.0 & 111.0 & 195 & .47 & .49 & 1.75 \\
\hline $40 \ldots \ldots \ldots \ldots$ & 195 & 16.0 & 108.0 & 75 & .47 & .44 & .38 \\
\hline 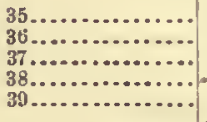 & $\begin{array}{l}201 \\
191 \\
216 \\
220 \\
207\end{array}$ & $\begin{array}{l}22.2 \\
29.0 \\
28.5 \\
34.5 \\
35.0\end{array}$ & $\begin{array}{r}95.0 \\
116.0 \\
120.0 \\
128.0 \\
126.0\end{array}$ & $\begin{array}{l}115 \\
216 \\
262 \\
308 \\
342\end{array}$ & $\begin{array}{l}0.45 \\
.41 \\
.49 \\
.37 \\
.41\end{array}$ & $\begin{array}{l}0.63 \\
.55 \\
.52 \\
.56 \\
.39\end{array}$ & $\begin{array}{l}0.67 \\
1.13 \\
1.21 \\
1.40 \\
1.65\end{array}$ \\
\hline Arerage... & 207 & 29.8 & 117.0 & 249 & .43 & .53 & 1.19 \\
\hline 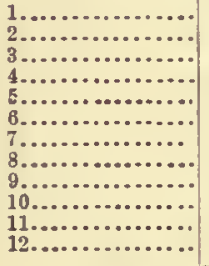 & $\begin{array}{l}204 \\
209 \\
200 \\
212 \\
210 \\
212 \\
214 \\
206 \\
220 \\
210 \\
210 \\
210\end{array}$ & $\begin{array}{l}34.0 \\
35.5 \\
35.0 \\
34.0 \\
33.5 \\
37.0 \\
38.0 \\
38.0 \\
37.0 \\
42.0 \\
43.0 \\
50.0\end{array}$ & $\begin{array}{l}118.0 \\
121.0 \\
116.0 \\
120.0 \\
141.0 \\
128.0 \\
114.0 \\
127.0 \\
127.0 \\
140.0 \\
144.0 \\
138.0\end{array}$ & $\begin{array}{l}274 \\
305 \\
306 \\
313 \\
323 \\
355 \\
357 \\
371 \\
399 \\
508 \\
577 \\
726\end{array}$ & $\begin{array}{l}.37 \\
.37 \\
.40 \\
.42 \\
.37 \\
.37 \\
.40 \\
.37 \\
.42 \\
.38 \\
.40 \\
.39\end{array}$ & $\begin{array}{l}.51 \\
.55 \\
.41 \\
.42 \\
.50 \\
.64 \\
.47 \\
.46 \\
.61 \\
.60 \\
.56 \\
.51\end{array}$ & $\begin{array}{l}1.34 \\
1.46 \\
1.53 \\
1.48 \\
1.54 \\
1.68 \\
1.67 \\
1.80 \\
1.81 \\
2.41 \\
2.75 \\
3.46\end{array}$ \\
\hline Average... & 210 & 38.0 & 128.0 & 401 & .39 & .52 & 1.91 \\
\hline 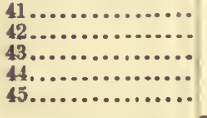 & $\begin{array}{l}166 \\
151 \\
167 \\
155 \\
155\end{array}$ & $\begin{array}{l}25.0 \\
29.5 \\
28.7 \\
29.0 \\
28.0\end{array}$ & $\begin{array}{r}105.0 \\
103.0 \\
96.0 \\
101.5 \\
113.5\end{array}$ & $\begin{array}{l}158 \\
175 \\
176 \\
201 \\
217\end{array}$ & $\begin{array}{l}.44 \\
.36 \\
.41 \\
.43 \\
.45\end{array}$ & $\begin{array}{l}.38 \\
.52 \\
.55 \\
.52 \\
.41\end{array}$ & $\begin{array}{l}.95 \\
1.16 \\
1.05 \\
1.30 \\
1.40\end{array}$ \\
\hline Average... & 159 & 28.0 & 104.0 & 185 & .42 & .47 & 1.17 \\
\hline
\end{tabular}


TAnL: VI.-Acre yields of Thite Pine and measurements of ample trees-Continued.

\section{B. - TrISCONSIN-Continued.}

(3) Sitre:

Barron County.

Aere Xio. 1.

Soit: Clarey loam mixed with sand and stones, leaf cover nuderlaid by 2 to 3 inches mold; subsoli, clay in places nail in others saud.

Foret conditions: liddres coverel with White Pine (65 per cent) Intermixed with hardwoods (32 per een(), manis liock Maple, few Follow Bireh, Hornbeam, Basswood, and occasioual Elm,

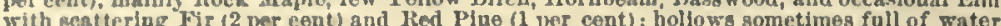
but more ofteu opcn, grassy awamps, with Alder and Hackmatack, friuged by pine. Claseifleation:
White Pino. Iominant.

Ojpreased

Suppresscd. \begin{tabular}{cc} 
White \\
pernt.. & 57 \\
\hline & 30
\end{tabular}

.do.... 30
Sauplo area : 3 acres.

Age of pine: 100 to 200 (fe 00 to 100 ) rears.

Density of erokn corer: (I)

Ninmber of trees: 166

ACRE YUELD.

\begin{tabular}{|c|c|c|c|c|c|c|c|}
\hline \multicolumn{5}{|c|}{ White Pine. } & \multicolumn{3}{|c|}{ Red Pine. } \\
\hline \multirow[b]{2}{*}{$\begin{array}{l}\text { Number } \\
\text { of trees. }\end{array}$} & \multirow[b]{2}{*}{$\begin{array}{l}\text { Diameter } \\
\text { (breast } \\
\text { higb). }\end{array}$} & \multirow[b]{2}{*}{ Height. } & \multicolumn{2}{|c|}{ Volume. } & \multirow[b]{2}{*}{$\begin{array}{l}\text { Number } \\
\text { of trees. }\end{array}$} & \multirow[b]{2}{*}{$\begin{array}{c}\text { Diameter } \\
\text { (hreast } \\
\text { high). }\end{array}$} & \multirow[b]{2}{*}{ Height. } \\
\hline & & & Bole. & \begin{tabular}{|} 
Mor- \\
chantahle \\
timber.
\end{tabular} & & & \\
\hline \multirow{11}{*}{$\begin{array}{r}4 \\
4 \\
6 \\
2 \\
6 \\
10 \\
8 \\
2 \\
6 \\
4 \\
8 \\
2 \\
4 \\
4 \\
6 \\
8 \\
6 \\
4 \\
2 \\
8 \\
4 \\
2\end{array}$} & \multirow{11}{*}{\begin{tabular}{r|} 
Inches. \\
6 to 10 \\
11 \\
12 \\
13 \\
14 \\
15 \\
16 \\
17 \\
18 \\
19 \\
20 \\
21 \\
22 \\
23 \\
21 \\
25 \\
26 \\
27 \\
28 \\
30 \\
32 \\
33
\end{tabular}} & \multirow{11}{*}{$\begin{array}{l}110 \\
20 \\
130\end{array}$} & \multirow{11}{*}{$\mid \begin{array}{r}\text { Oubic feet. } \\
40 \\
112 \\
204 \\
78 \\
270 \\
520 \\
464 \\
130 \\
432 \\
316 \\
688 \\
248 \\
536 \\
584 \\
918 \\
1,368 \\
1,110 \\
796 \\
426 \\
1,920 \\
548 \\
582\end{array}$} & \multirow{11}{*}{ Feet B.ar. } & 2 & $\begin{array}{r}\text { Inches. } \\
18\end{array}$ & $\begin{array}{l}\text { Feet. } \\
100\end{array}$ \\
\hline & & & & & \multicolumn{3}{|c|}{ Maple. } \\
\hline & & & & & $\begin{array}{l}20 \\
18\end{array}$ & $\begin{array}{l}3 \text { to } 6 \\
6 \text { to } 10\end{array}$ & $\begin{array}{l}40 \\
60\end{array}$ \\
\hline & & & & & \multicolumn{3}{|c|}{ Yellow Bireh. } \\
\hline & & & & & 4 & 3 to 6 & 40 \\
\hline & & & & & \multicolumn{3}{|c|}{ Hornbeam. } \\
\hline & & & & & 6 & 3 to 6 & 40 \\
\hline & & & & & \multicolumn{3}{|c|}{ Basswood. } \\
\hline & & & & & 4 & 3 to 6 & 40 \\
\hline & & & & & \multicolumn{3}{|c|}{ Fir. } \\
\hline & & & & & 4 & 3 to 6 & 40 \\
\hline \multicolumn{5}{|c|}{$\begin{array}{l}108 \text { trees: } \\
\text { Total cnbie foet..................... 12, } 290 \\
\text { Total feet B. M................... }\end{array}$} & \multicolumn{3}{|l|}{58 trees. } \\
\hline
\end{tabular}

Average annual aceretion: White Pine, 65 eubic feet. 
TABLE VI.-Acre yields of White Pine and measurements of sample trees-Continued.

\section{B.-WISCONSIN-Continued.}

Acre No.2.

Soil: Clayey loam mixed with sand and stones, loaf cover nndorlaid by 2 to 3 inches mold; subsoll, Ago of pine: 160 to 200 (few

Forest conditions: Rilges covered with White Pho ( 49 per cent) intermixed with hardwoods Density of crown cover: ( 1 ). (51 per cent), mainly Rock Maple, fow Tellow Birch, Hornbcam, Basswood, and occasional Eim, with seattering Fir and Red Pine, hollows sonetimes full of water, but anore often open,

grassy 8 wamps, with Alder and Hackmatack, fringed by pine. Olassification:

Oppressed

....do....

Spppressed do

78
22
0

ACRE YIELD.

\begin{tabular}{|c|c|c|c|c|c|c|c|}
\hline \multicolumn{5}{|c|}{ White Pine. } & \multicolumn{3}{|c|}{ Maple. } \\
\hline \multirow[b]{2}{*}{$\begin{array}{l}\text { Number } \\
\text { of trees. }\end{array}$} & \multirow[b]{2}{*}{$\begin{array}{c}\text { Diameter } \\
\text { (breast } \\
\text { high). }\end{array}$} & \multirow[b]{2}{*}{ Height. } & \multicolumn{2}{|c|}{ Volume. } & \multirow[b]{2}{*}{$\begin{array}{l}\text { Number } \\
\text { of trees. }\end{array}$} & \multirow[b]{2}{*}{$\begin{array}{l}\text { Diameter } \\
\text { (breast } \\
\text { high). }\end{array}$} & \multirow[b]{2}{*}{ Height. } \\
\hline & & & Bole. & $\begin{array}{c}\text { Mer. } \\
\text { chantable } \\
\text { timber. }\end{array}$ & & & \\
\hline \multirow{5}{*}{\begin{tabular}{r|}
2 \\
2 \\
2 \\
4 \\
4 \\
2 \\
10 \\
2 \\
10 \\
2 \\
2 \\
6 \\
2 \\
2 \\
2
\end{tabular}} & \multirow{5}{*}{$\begin{array}{r}\text { Inches. } \\
\text { 6 to } 10 \\
19 \\
20 \\
21 \\
22 \\
23 \\
24 \\
26 \\
27 \\
28 \\
29 \\
30 \\
32 \\
35 \\
42\end{array}$} & \multirow[t]{5}{*}{$\begin{array}{c}\text { Feet. } \\
80 \\
\text { to } \\
100\end{array}$} & \multirow{5}{*}{$\begin{array}{r}\text { Cubic feet. } \\
20 \\
158 \\
172 \\
496 \\
536 \\
292 \\
1,530 \\
370 \\
1,990 \\
426 \\
156 \\
480 \\
548 \\
652 \\
1,074\end{array}$} & \multirow[t]{5}{*}{ Feet B.M. } & $\begin{array}{r}26 \\
16 \\
2\end{array}$ & $\begin{array}{r}\text { Inches. } \\
3 \text { to } 6 \\
6 \text { to } 10 \\
10 \text { to } 14\end{array}$ & $\begin{array}{r}\text { Feet. } \\
40 \\
60 \\
80\end{array}$ \\
\hline & & & & & \multicolumn{3}{|c|}{ Yellow Birch. } \\
\hline & & & & & 2 & 23 & 80 \\
\hline & & & & & \multicolumn{3}{|c|}{ Hornbeam. } \\
\hline & & & & & 10 & 3 to 6 & 40 \\
\hline \multicolumn{5}{|c|}{$\begin{array}{l}54 \text { trees: } \\
\text { Total cubic feot................... } 9,200 \\
\text { Total feet B. M.................41, } 160\end{array}$} & \multicolumn{3}{|l|}{56 trees. } \\
\hline
\end{tabular}

$\Delta$ verage annual aceretion: Whito Pine, 48 cubic feet.
216 feet $\mathrm{B} . \mathbf{M}$ 
TAnLE VI.-Acre yields of Thile Pine and measurements of sample trees-Continued.

13.-WISCONSIx-Continued.

Acre No. 3.

Soil: Clayey lonen nixed with sand and stones, loaf coror underlald by 2 to 3 inches mold; anbooil,

Forest conditions: Klises covered witb Whito Pine (59 per cent) intermixel with hardwoods (38

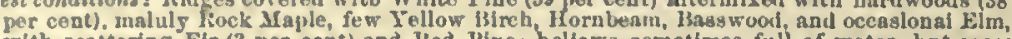
with scattering fir ( 3 per cont) and lked P'ine; hollows sometimes full of water, bat moro often open, grasoy swanps, with Aller and Hackmatack, friugerl by pine.

Claspificafion:

Agoof pine: 160 to 220 (fow 80

Density of crown cover: (i). ...per cent.. 61 Number of trees: 144. Suppressed. 61
15
24

$\triangle C K E$ YIELD.

\begin{tabular}{|c|c|c|c|c|c|c|c|}
\hline \multicolumn{5}{|c|}{ White Pine. } & \multicolumn{3}{|c|}{ Mapie. } \\
\hline \multirow[b]{2}{*}{$\begin{array}{l}\text { Ninmber } \\
\text { of trees. }\end{array}$} & \multirow[b]{2}{*}{$\begin{array}{c}\text { Diameter } \\
\text { (breast } \\
\text { higb). }\end{array}$} & \multirow[b]{2}{*}{ INeight. } & \multicolumn{2}{|c|}{ Volume. } & \multirow[b]{2}{*}{$\begin{array}{l}\text { Namber } \\
\text { of trees. }\end{array}$} & \multirow[b]{2}{*}{$\begin{array}{c}\text { Diameter } \\
\text { (breast } \\
\text { higb). }\end{array}$} & \multirow[b]{2}{*}{ IIoight. } \\
\hline & & & Bole. & $\left|\begin{array}{c}\text { Mer- } \\
\text { cbantabie } \\
\text { timber. }\end{array}\right|$ & & & \\
\hline \multirow{7}{*}{\begin{tabular}{r|}
3 \\
1 \\
1 \\
5 \\
1 \\
11 \\
5 \\
7 \\
6 \\
4 \\
4 \\
6 \\
4 \\
5 \\
3 \\
1 \\
4 \\
1 \\
5 \\
2 \\
1 \\
1 \\
1 \\
1 \\
1 \\
1
\end{tabular}} & \multirow{7}{*}{\begin{tabular}{r|} 
Inches. \\
6 to 10 \\
11 \\
13 \\
14 \\
15 \\
17 \\
18 \\
19 \\
20 \\
21 \\
22 \\
23 \\
24 \\
25 \\
26 \\
27 \\
28 \\
29 \\
30 \\
31 \\
32 \\
34 \\
35 \\
36 \\
38 \\
40
\end{tabular}} & \multirow{4}{*}{$\begin{array}{c}80 \\
\text { to } \\
100 \\
0\end{array}$} & \multirow{7}{*}{\begin{tabular}{|c} 
Cubic feet. \\
30 \\
28 \\
39 \\
295 \\
295 \\
512 \\
715 \\
360 \\
553 \\
516 \\
406 \\
536 \\
876 \\
612 \\
855 \\
555 \\
109 \\
852 \\
228 \\
1,200 \\
518 \\
284 \\
360 \\
380 \\
401 \\
445 \\
490
\end{tabular}} & \multirow{7}{*}{ Feet 13.MI. } & $\frac{22}{11}$ & $\begin{array}{l}\text { Inchee. } \\
3 \text { to } 6 \\
6 \text { to } 10\end{array}$ & $\begin{array}{r}\text { Fet. } \\
\quad 10 \\
60\end{array}$ \\
\hline & & & & & \multicolumn{3}{|c|}{ Hornbeam. } \\
\hline & & & & & 3 & 3 to $B$ & 40 \\
\hline & & & & & \multicolumn{3}{|c|}{ Basswood. } \\
\hline & & \multirow[t]{3}{*}{$\begin{array}{l}110 \\
\text { to } \\
130\end{array}$} & & & 2 & $\begin{array}{l}3 \text { to } 6 \\
6 \text { to } 10\end{array}$ & $\begin{array}{l}40 \\
60\end{array}$ \\
\hline & & & & & \multicolumn{3}{|c|}{ Fir. } \\
\hline & & & & & 5 & 3 to 6 &, 40 \\
\hline \multicolumn{5}{|c|}{ 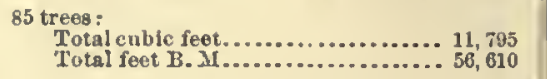 } & \multicolumn{3}{|l|}{49 trees. } \\
\hline
\end{tabular}

Average annual accretion: Thito Pine, 62 cublc feet. 
TABLE VI.-Acre yields of Thite Pine and mcasurements of sample trees-Continued. B.-WISCONSIX-Continned MEASUREMENTS OF SAMPLE TREES.

Age class : 200 to 220 years.

\begin{tabular}{|c|c|c|c|c|c|c|c|}
\hline Tree nuniber. & Age. & $\begin{array}{c}\text { Diameter } \\
\text { (breast } \\
\text { ligh). }\end{array}$ & Height. & $\begin{array}{l}\text { Volume } \\
\text { of tree. }\end{array}$ & $\begin{array}{c}\text { Factor } \\
\text { of } \\
\text { shape. }\end{array}$ & $\begin{array}{l}\text { Ratio of } \\
\text { length } \\
\text { of erown } \\
\text { to total } \\
\text { beight of } \\
\text { tree. }\end{array}$ & $\begin{array}{c}\text { A verage } \\
\text { anuual } \\
\text { acere. } \\
\text { tion. }\end{array}$ \\
\hline 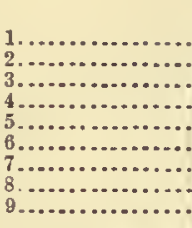 & $\begin{array}{c}\text { Tears. } \\
204 \\
210 \\
207 \\
200 \\
206 \\
205 \\
210 \\
214 \\
210\end{array}$ & $\begin{array}{r}\text { Inches. } \\
27.3 \\
25.2 \\
31.0 \\
29.5 \\
29.2 \\
30.0 \\
34.0 \\
36.0 \\
39.0\end{array}$ & $\begin{array}{l}\text { Feet. } \\
123.0 \\
137.0 \\
127.5 \\
116.0 \\
130.5 \\
133.0 \\
118.5 \\
113.5 \\
130.0\end{array}$ & $\begin{array}{r}\text { Cu. } f_{\text {. }} \\
210 \\
227 \\
246 \\
239 \\
282 \\
284 \\
292 \\
312 \\
415\end{array}$ & $\begin{array}{l}0.44 \\
.48 \\
.37 \\
.43 \\
.46 \\
.43 \\
.39 \\
.39 \\
.38\end{array}$ & $\begin{array}{l}0.59 \\
.40 \\
.35 \\
.51 \\
.29 \\
.52 \\
.37 \\
.38 \\
.49\end{array}$ & $\begin{array}{r}C u . f t . \\
1.07 \\
1.08 \\
1.19 \\
1.20 \\
1.37 \\
1.38 \\
1.40 \\
1.46 \\
1.98\end{array}$ \\
\hline Average... & 207 & 31.0 & 125.0 & 280 & .42 & .43 & 1.35 \\
\hline 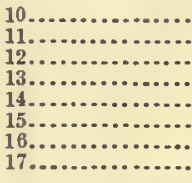 & $\begin{array}{l}211 \\
228 \\
220 \\
207 \\
204 \\
205 \\
212 \\
204\end{array}$ & $\begin{array}{l}20.2 \\
23.6 \\
22.8 \\
27.2 \\
27.0 \\
27.0 \\
27.8 \\
27.3\end{array}$ & $\begin{array}{l}116.0 \\
113.0 \\
121.0 \\
107.5 \\
121.0 \\
122.0 \\
104.5 \\
112.0\end{array}$ & $\begin{array}{l}132 \\
148 \\
153 \\
200 \\
204 \\
210 \\
180 \\
186\end{array}$ & $\begin{array}{l}.51 \\
.43 \\
.45 \\
.46 \\
.42 \\
.43 \\
.41 \\
.41\end{array}$ & $\begin{array}{l}.64 \\
.42 \\
.45 \\
.28 \\
.43 \\
.25 \\
.51 \\
.41\end{array}$ & $\begin{array}{r}.63 \\
.65 \\
.70 \\
.97 \\
1.00 \\
1.02 \\
.85 \\
.91\end{array}$ \\
\hline A rerage... & 211 & 25.0 & 114.0 & 177 & .44 & .42 & .84 \\
\hline
\end{tabular}

Age clase: 160 to 180 years.

\begin{tabular}{|c|c|c|c|c|c|c|c|}
\hline 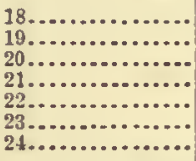 & $\begin{array}{l}168 \\
165 \\
173 \\
163 \\
162 \\
174 \\
166\end{array}$ & $\begin{array}{l}30.0 \\
28.4 \\
28.4 \\
17.8 \\
23.0 \\
28.0 \\
25.4\end{array}$ & $\begin{array}{r}121.5 \\
120.0 \\
127.0 \\
91.5 \\
101.0 \\
108.5 \\
164.0\end{array}$ & $\begin{array}{r}206 \\
224 \\
257 \\
72 \\
130 \\
167 \\
166\end{array}$ & $\begin{array}{l}0.35 \\
.41 \\
.46 \\
.46 \\
.46 \\
.36 \\
.45\end{array}$ & $\begin{array}{l}0.49 \\
.50 \\
.35 \\
.34 \\
.54 \\
.54 \\
.52\end{array}$ & $\begin{array}{r}1.22 \\
1.36 \\
1.49 \\
.44 \\
.80 \\
.96 \\
1.00\end{array}$ \\
\hline Average... & 167 & 26.0 & 110.0 & 174 & .42 & .47 & 1.04 \\
\hline
\end{tabular}


TABLE VI.-Acre yields of Thite Pine and measurenents of sample trees-Continued.

B. - WiscoNs1.X-Contluned.

(1) Srres:

Wrahburn Connty.

Soil: Llght brown sandy loam, melinm fine graiv, looso, deep, fresh, well drained, with abnn. dant leary surface cover.

Foreat conditions: An open stand of hardwoods (IRock Maplo, Fellow Birch, and scattering Basswool. with Homlock, and occaslonal Red Oak, White Birch, and Popias), in which White Pine is scat tened in varying proportions. on broken laul. with freqnent awamps in the hollow: undergrowth of yonng hardwoods, Fir and Hornlean, and few Homlock.

MEASCHEMEATS OF SAMPLE TREES.

Age class : 80 to 100 years.

\begin{tabular}{|c|c|c|c|c|c|c|c|c|c|c|}
\hline Tree number. & Ago. & $\begin{array}{c}\text { Diameter } \\
\text { (breast } \\
\text { high). }\end{array}$ & Ileight. & $\begin{array}{c}\text { Rings } \\
\text { perinch } \\
\text { on } \\
\text { stump. }\end{array}$ & $\begin{array}{l}\text { Volnme } \\
\text { of treo. }\end{array}$ & $\begin{array}{l}\text { Factor } \\
\text { of } \\
\text { ghrpe. }\end{array}$ & $\begin{array}{l}\text { Ratio of } \\
\text { length } \\
\text { of crown } \\
\text { to total } \\
\text { helght of }\end{array}$ & \multicolumn{2}{|c|}{$\begin{array}{l}\text { Current annual } \\
\text { accretion. }\end{array}$} & $\begin{array}{l}\text { Average } \\
\text { aunual } \\
\text { accre- } \\
\text { tion. }\end{array}$ \\
\hline 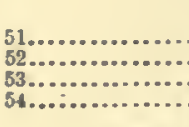 & $\begin{array}{l}\text { Tears. } \\
54 \\
62 \\
68 \\
90 \\
\end{array}$ & $\begin{array}{r}\text { Inehes. } \\
5.5 \\
6.0 \\
6.8 \\
6.8\end{array}$ & $\begin{array}{r}\text { Feet. } \\
37 \\
40 \\
46 \\
38\end{array}$ & 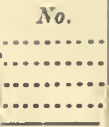 & \begin{tabular}{|c|} 
Cubicfeet. \\
3.2 \\
4.2 \\
5.5 \\
4.8
\end{tabular} & $\begin{array}{r}0.52 \\
.53 \\
.48 \\
.50\end{array}$ & $\begin{array}{r}0.57 \\
.50 \\
.72 \\
.45 \\
\end{array}$ & \begin{tabular}{c} 
Per cene. \\
\hdashline$\ldots \ldots$ \\
\hdashline$\ldots \ldots$ \\
\hdashline$\ldots \ldots$ \\
$\ldots \ldots$
\end{tabular} & 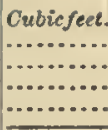 & $\begin{array}{c}\text { Cubiefoet. } \\
.06 \\
.07 \\
.08 \\
.05\end{array}$ \\
\hline Arerage..: & 68.5 & 6.3 & $\$ 0$ & & 4.4 & .51 & .56 & .......... & -............ & .00 \\
\hline
\end{tabular}

DGMISANT OROWTH.

\begin{tabular}{|c|c|c|c|c|c|c|c|c|c|c|}
\hline 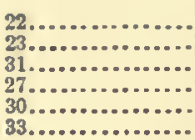 & $\begin{array}{l}82 \\
81 \\
83 \\
79 \\
81 \\
83\end{array}$ & $\begin{array}{l}14.0 \\
14.7 \\
15.0 \\
15.0 \\
19.0 \\
18.7\end{array}$ & $\begin{array}{l}82 \\
84 \\
82 \\
83 \\
85 \\
96\end{array}$ & $\begin{array}{l}5.5 \\
5.0 \\
4.6 \\
4.8 \\
3.9 \\
3.9\end{array}$ & $\begin{array}{l}43.0 \\
48.0 \\
48.1 \\
50.8 \\
78.2 \\
85.7\end{array}$ & $\begin{array}{r}0.49 \\
.30 \\
.48 \\
.48 \\
.46 \\
.47\end{array}$ & $\begin{array}{r}0.39 \\
.42 \\
.41 \\
.31 \\
.37 \\
.51\end{array}$ & $\begin{array}{l}4.0 \\
2.7 \\
5.2 \\
3.2 \\
2.4 \\
4.6\end{array}$ & $\begin{array}{l}1.72 \\
1.30 \\
2.50 \\
1.62 \\
1.88 \\
3.94\end{array}$ & $\begin{array}{l}0.52 \\
.60 \\
.58 \\
.64 \\
.96 \\
.96\end{array}$ \\
\hline A vorage... & 82.5 & 16.0 & 85 & 4.6 & 59.0 & .48 & .40 & 3.7 & 2.16 & .71 \\
\hline
\end{tabular}

OPPRESSED GROWTH.

\begin{tabular}{|c|c|c|c|c|c|c|c|c|c|c|}
\hline 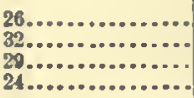 & $\begin{array}{l}82 \\
81 \\
80 \\
92\end{array}$ & $\begin{array}{l}11.3 \\
11.8 \\
11.9 \\
14.5\end{array}$ & $\begin{array}{r}101 \\
77 \\
81 \\
79\end{array}$ & $\begin{array}{l}6.6 \\
6.2 \\
5.7 \\
5.6\end{array}$ & $\begin{array}{l}30.0 \\
30.5 \\
32.8 \\
39.7\end{array}$ & $\begin{array}{r}0.42 \\
.50 \\
.51 \\
.43\end{array}$ & $\begin{array}{l}0.40 \\
.37 \\
.33 \\
.54\end{array}$ & $\begin{array}{l}8.1 \\
4.0 \\
4.6 \\
3.6\end{array}$ & $\begin{array}{l}0.93 \\
1.22 \\
1.51 \\
1.43\end{array}$ & $\begin{array}{r}0.36 \\
.37 \\
.41 \\
.43\end{array}$ \\
\hline Arerage... & 84 & 12.4 & 84.5 & 6.0 & 33.3 & .46 & .41 & 3.8 & 1. 27 & .39 \\
\hline
\end{tabular}

SCPPRESSED GROWTH.

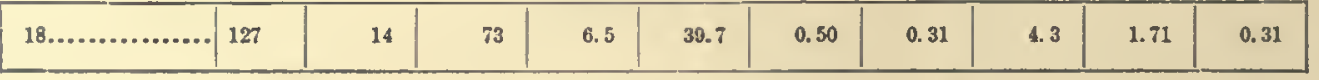

Age class: 120 to 130 years.

DOMISAST OROWTH.

\begin{tabular}{|c|c|c|c|c|c|c|c|c|c|c|}
\hline 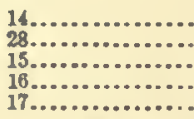 & $\begin{array}{l}121 \\
125 \\
125 \\
125 \\
119\end{array}$ & $\begin{array}{l}20.2 \\
24.5 \\
26.5 \\
26.3 \\
29.0\end{array}$ & $\begin{array}{r}91 \\
89 \\
90 \\
105 \\
97\end{array}$ & $\begin{array}{l}5.4 \\
4.0 \\
4.0 \\
4.1 \\
3.8\end{array}$ & $\begin{array}{r}90.9 \\
131.8 \\
141.5 \\
176.8 \\
184.5\end{array}$ & $\begin{array}{r}0.45 \\
.45 \\
.39 \\
.47 \\
.42\end{array}$ & $\begin{array}{l}0.50 \\
.58 \\
.46 \\
.53 \\
.57\end{array}$ & $\begin{array}{l}3.4 \\
2.9 \\
1.5 \\
1.6 \\
1.5\end{array}$ & $\begin{array}{l}3.09 \\
3.82 \\
2.12 \\
2.83 \\
2.77\end{array}$ & $\begin{array}{l}0.75 \\
1.05 \\
1.13 \\
1.41 \\
1.55\end{array}$ \\
\hline Arerago... & 123 & 25.3 & 95 & 4.3 & 145.1 & .44 & .53 & 2.2 & 2.92 & 1.18 \\
\hline
\end{tabular}

$\triangle$ ge class: 220 to 230 years.

DOMINANT GROWTH.

\begin{tabular}{|c|c|c|c|c|c|c|c|c|c|c|}
\hline 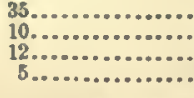 & $\begin{array}{l}223 \\
223 \\
228 \\
219\end{array}$ & $\begin{array}{l}30.5 \\
31.0 \\
35.3 \\
35.0\end{array}$ & $\begin{array}{l}116 \\
112 \\
124 \\
118\end{array}$ & $\begin{array}{l}7.0 \\
7.0 \\
6.0 \\
6.0\end{array}$ & $\begin{array}{l}237.4 \\
246.6 \\
322.2 \\
359.9\end{array}$ & $\begin{array}{r}0.40 \\
.42 \\
.40 \\
.45\end{array}$ & $\begin{array}{r}0.38 \\
.56 \\
.48 \\
.44\end{array}$ & $\begin{array}{l}0.8 \\
.6 \\
.5 \\
.7\end{array}$ & $\begin{array}{l}1.90 \\
1.48 \\
1.61 \\
2.52\end{array}$ & $\begin{array}{l}1.06 \\
1.10 \\
1.41 \\
1.64\end{array}$ \\
\hline Arerage... & 223 & 33.0 & 117 & 6.5 & 291.5 & .62 & .46 & .0 & 1.88 & 1.30 \\
\hline
\end{tabular}


TABLE VI.-Acre yields of White Pine and measurements of sample trees-Continued.

\section{B.-WISCONSIN-Continned.}

(5) SITE $g$ :

Soil: Loam, generally fresh, sand and stons mlred, 2 to 3 Inches mold on top, and a surfacs cover of leaves.

Forest conditions: Two-story stand, upper story of TV bite Pine (54 par cent) and Red Pins (9 per cent), second trors of fir (13 , aper story of White and Yellow Birch, scanty, of ronne hardwoods uneven iand fill of drift rides and inclines, the hollows freqnently full of water. Classification:

Dominant.

Snppressed

White Pins. per cent.. 70
Sampls area: 1 acrs.

Age of pins : 160 to 230 jears. Density of crown cover: (i)

Nnmbor of trees: 143

ACRE YIELD.

\begin{tabular}{|c|c|c|c|c|c|c|c|c|c|c|}
\hline \multicolumn{5}{|c|}{ White Pine. } & \multicolumn{3}{|c|}{ Red Pine. } & \multicolumn{3}{|c|}{ Maple. } \\
\hline \multirow[b]{2}{*}{$\begin{array}{l}\text { Ninmber } \\
\text { of trees. }\end{array}$} & \multirow[b]{2}{*}{$\begin{array}{l}\text { Diameter } \\
\text { (breast } \\
\text { high). }\end{array}$} & \multirow[b]{2}{*}{ Height. } & \multicolumn{2}{|c|}{ Folnme. } & \multirow[b]{2}{*}{$\begin{array}{l}\text { Nnmber } \\
\text { of trees. }\end{array}$} & \multirow[b]{2}{*}{$\begin{array}{l}\text { Diamster } \\
\text { (hreast } \\
\text { high). }\end{array}$} & \multirow[b]{2}{*}{ Height. } & \multirow[b]{2}{*}{$\begin{array}{l}\text { Number } \\
\text { of tress. }\end{array}$} & \multirow[b]{2}{*}{$\begin{array}{l}\text { Diameter } \\
\text { (hreast } \\
\text { hlgh). }\end{array}$} & \multirow[b]{2}{*}{ Height. } \\
\hline & & & Bole. & $\begin{array}{c}\text { Mer- } \\
\text { chantahle } \\
\text { timber. }\end{array}$ & & & & & & \\
\hline \multirow{5}{*}{$\begin{array}{l}3 \\
3 \\
1 \\
3 \\
3 \\
4 \\
5 \\
2 \\
5 \\
2 \\
5 \\
5 \\
8 \\
4 \\
3 \\
3 \\
5 \\
6 \\
2 \\
3 \\
1 \\
1 \\
1 \\
2\end{array}$} & \multirow{5}{*}{\begin{tabular}{|c|} 
Inches. \\
6 to 10 \\
11 \\
12 \\
13 \\
14 \\
15 \\
16 \\
17 \\
18 \\
19 \\
20 \\
21 \\
22 \\
23 \\
24 \\
25 \\
26 \\
27 \\
29 \\
31 \\
32 \\
33 \\
34
\end{tabular}} & \multirow{5}{*}{$\begin{array}{c}100 \\
\text { to } \\
120\end{array}$} & \multirow{5}{*}{$\begin{array}{c}\text { Cubic feet. } \\
30 \\
84 \\
34 \\
117 \\
180 \\
260 \\
116 \\
325 \\
176 \\
480 \\
525 \\
912 \\
492 \\
402 \\
438 \\
785 \\
1,014 \\
364 \\
627 \\
237 \\
251 \\
267 \\
566\end{array}$} & \multirow{5}{*}{ Feet $B . M$} & \multirow{5}{*}{$\begin{array}{l}1 \\
2 \\
1 \\
2 \\
1 \\
3 \\
1 \\
1 \\
1\end{array}$} & \multirow{5}{*}{\begin{tabular}{r|} 
Inches. \\
15 \\
16 \\
17 \\
18 \\
10 \\
20 \\
24 \\
25 \\
26
\end{tabular}} & \multirow[t]{5}{*}{ Feet. } & $\begin{array}{r}9 \\
16 \\
3\end{array}$ & $\begin{array}{l}\text { Inches. } \\
3 \text { to } 6 \\
6 \text { to } 10 \\
10 \text { to } 14\end{array}$ & $\begin{array}{r}\text { Feet. } \\
40 \\
60 \\
80\end{array}$ \\
\hline & & & & & & & & & Birch. & \\
\hline & & & & & & & & $\begin{array}{l}2 \\
3 \\
1 \\
1\end{array}$ & $\begin{array}{r}3 \text { to } 6 \\
6 \text { to } 10 \\
14 \\
16\end{array}$ & $\begin{array}{l}40 \\
60 \\
80\end{array}$ \\
\hline & & & & & & & & & Fir. & \\
\hline & & & & & & & & $\begin{array}{r}16 \\
2\end{array}$ & $\begin{array}{l}3 \text { to } 6 \\
6 \text { to } 10\end{array}$ & $\begin{array}{l}40 \\
60\end{array}$ \\
\hline \multicolumn{5}{|c|}{ 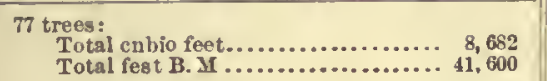 } & \multicolumn{3}{|c|}{$\begin{array}{l}13 \text { trees: } \\
\text { Total cuhic feet.. } 1,469 \\
\text { Total fest B. M.. } 6,160\end{array}$} & \multicolumn{3}{|l|}{53 trses. } \\
\hline
\end{tabular}

Average annual accetion: Pine, 51 cuhic feet.
239 feet $\mathrm{B}$. $\mathrm{M}$.

MEASUREMENTS CF SAMPLE TREES.

Age cluse: 220 to 230 years.

\begin{tabular}{|c|c|c|c|c|c|c|c|}
\hline Tree nnmber. & Age. & $\begin{array}{c}\text { Diamster } \\
\text { (breast } \\
\text { high). }\end{array}$ & Height. & $\begin{array}{l}\text { Volnme } \\
\text { of tree. }\end{array}$ & $\begin{array}{l}\text { Factor } \\
\text { of } \\
\text { sbape. }\end{array}$ & $\begin{array}{l}\text { Ratio of } \\
\text { length } \\
\text { of crown } \\
\text { to total } \\
\text { beight of } \\
\text { tree. }\end{array}$ & $\begin{array}{l}\text { Average } \\
\text { annual } \\
\text { accre. } \\
\text { tion. }\end{array}$ \\
\hline 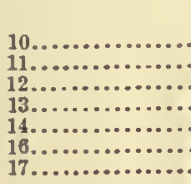 & $\begin{array}{c}\text { Tears. } \\
216 \\
222 \\
228 \\
220 \\
208 \\
220 \\
218\end{array}$ & $\begin{array}{r}\text { Inches. } \\
31.8 \\
35.0 \\
24.8 \\
24.0 \\
15.0 \\
24.5 \\
29.0\end{array}$ & $\begin{array}{r}\text { Feet. } \\
121.5 \\
123.5 \\
116.5 \\
100.0 \\
90.0 \\
107.5 \\
118.0\end{array}$ & $\begin{array}{c}\text { Oubic feet. } \\
287 \\
344 \\
160 \\
156 \\
58 \\
157 \\
240\end{array}$ & $\begin{array}{l}0.43 \\
.42 \\
.41 \\
.49 \\
.50 \\
.45 \\
.44\end{array}$ & $\begin{array}{l}0.40 \\
.46 \\
.40 \\
.27 \\
.47 \\
.35 \\
.49\end{array}$ & $\begin{array}{c}\text { Oubicfeet } \\
1.33 \\
1.55 \\
.70 \\
.78 \\
.28 \\
.71 \\
1.10\end{array}$ \\
\hline Average... & 219 & 26.3 & 112.0 & 200 & .45 & .40 & .92 \\
\hline
\end{tabular}

Age class : 160 to 180 years.

\begin{tabular}{|c|c|c|c|c|c|c|c|}
\hline 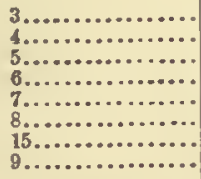 & $\begin{array}{l}160 \\
170 \\
178 \\
170 \\
175 \\
168 \\
185 \\
173\end{array}$ & $\begin{array}{l}23.5 \\
24.0 \\
24.2 \\
25.7 \\
27.3 \\
30.5 \\
23.2 \\
26.0\end{array}$ & $\begin{array}{l}104.5 \\
119.0 \\
114.0 \\
111.5 \\
122.0 \\
114.0 \\
110.5 \\
112.0\end{array}$ & $\begin{array}{l}127 \\
172 \\
170 \\
181 \\
217 \\
256 \\
138 \\
190\end{array}$ & $\begin{array}{l}0.40 \\
.46 \\
.48 \\
.45 \\
.43 \\
.44 \\
.42 \\
.46\end{array}$ & $\begin{array}{l}0.40 \\
.41 \\
.38 \\
.41 \\
.46 \\
.42 \\
.34 \\
.28\end{array}$ & $\begin{array}{r}0.79 \\
1.01 \\
.99 \\
1.07 \\
1.24 \\
1.52 \\
.74 \\
1.10\end{array}$ \\
\hline Average... & 172 & 25.5 & 113. 0 & 182 & .44 & .39 & 1.00 \\
\hline
\end{tabular}


TABLE VI.-Acro yields of White Pine and measurements of sample trees-Continued.

\section{B.-WISCONSN-Continned.}

(6) Strz v:

Livcoln Conaty.

Soil : Ired, compact elas (black on top), well drained, with leafy surfaco corer.

Forest conditions: A mixed atand of White P'ue ( 30 per cent), Hemlock (30 per cent), aud Birch (20 per cent), rolling country.

MEASUREMENTS OF SAMPLE TREES.

Age clase : 100 to 150 jears.

\begin{tabular}{|c|c|c|c|c|c|c|c|c|c|}
\hline Treo number. & $\begin{array}{c}\text { Diameter } \\
\text { (breant } \\
\text { bigh). }\end{array}$ & Height. & $\begin{array}{l}\text { Folume } \\
\text { of tree. }\end{array}$ & $\begin{array}{l}\text { Factor } \\
\text { of } \\
\text { ahape. }\end{array}$ & Trec number. & $\begin{array}{l}\text { Diameter } \\
\text { (breast } \\
\text { hlgh). }\end{array}$ & Height. & $\begin{array}{l}\text { Tolume } \\
\text { of tree. }\end{array}$ & $\begin{array}{l}\text { Factor } \\
\text { of } \\
\text { shape. }\end{array}$ \\
\hline \multirow{2}{*}{ 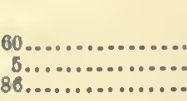 } & \multirow{2}{*}{$\begin{array}{r}\text { Inches. } \\
21.0 \\
20.5 \\
36.5\end{array}$} & \multirow{2}{*}{$\begin{array}{r}\text { Feet. } \\
97 \\
97 \\
104\end{array}$} & \multirow{2}{*}{$\begin{array}{l}\text { Cu. } / t^{\prime} . \\
108.1 \\
105.8 \\
276.2\end{array}$} & \multirow{2}{*}{$\begin{array}{r}0.48 \\
.48 \\
.37\end{array}$} & \multirow{2}{*}{$\begin{array}{r}25 \ldots . . . . . . . . . . \\
\text { Arerage... }\end{array}$} & $\begin{array}{l}\text { Inches. } \\
30.5\end{array}$ & $\begin{array}{l}\text { Feet. } \\
114\end{array}$ & $\begin{array}{l}\text { Ou. fle. } \\
308.5\end{array}$ & .38 \\
\hline & & & & & & 28.6 & 103 & 198.6 & .43 \\
\hline
\end{tabular}

Age class: 130 to 200 years.

\begin{tabular}{|c|c|c|c|c|c|c|c|c|c|}
\hline & & & 1222 & 0.33 & $40 .$. & 310 & 132 & 273.2 & \\
\hline $79 .$. & 24.0 & 08 & 137.7 & .44 & $88 .$. & 35.0 & 118 & 287.7 & .36 \\
\hline $85, \ldots \ldots, \ldots$ & 27.0 & 101 & 140.5 & .35 & $38 .$. & 34.0 & 133 & 313.8 & .37 \\
\hline $45, \ldots, \ldots$ & 24.0 & 104 & $\begin{array}{l}136.7 \\
136.0\end{array}$ & .42 & $44 .$. & 35.0 & $\begin{array}{l}138 \\
138\end{array}$ & $\begin{array}{l}0 \\
311.4\end{array}$ & .34 \\
\hline $48, \ldots, \ldots, \ldots$, & 25.0 & 87 & 140.1 & .47 & & 32.0 & $\begin{array}{l}140 \\
140\end{array}$ & 318.6 & .011 \\
\hline $76 . . . . . . . . . . . . . . .$. & 24.0 & 121 & 178.6 & .47 & $84 \ldots . . . . . . . . . . . .$. & 36.0 & 127 & 283.2 & .35 \\
\hline $19 . . . . . .$. & 24.0 & 121 & 180.7 & .47 & $27 \ldots \ldots \ldots \ldots \ldots$ & 36.0 & 157 & 365.8 & .83 \\
\hline $\begin{array}{r}78 \ldots \ldots \ldots \ldots \ldots \\
94 \ldots \ldots \ldots \ldots\end{array}$ & $\begin{array}{l}33.0 \\
34.0\end{array}$ & $\begin{array}{l}107 \\
105\end{array}$ & $\begin{array}{l}236.8 \\
249.0\end{array}$ & $\begin{array}{r}.37 \\
.38\end{array}$ & \multirow[t]{2}{*}{ Arerage... } & \multirow{2}{*}{30.0} & \multirow[t]{2}{*}{120} & \multirow[t]{2}{*}{231.2} & \multirow[t]{2}{*}{.88} \\
\hline 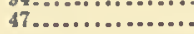 & 33.0 & 136 & 257.1 & .32 & & & & & \\
\hline
\end{tabular}

Age class: 200 to 250 sears.

\begin{tabular}{|c|c|c|c|c|c|c|c|c|c|}
\hline 80 & 25.0 & 105 & $102 ?$ & 0.29 & & 360 & 108 & & \\
\hline $22 .$. & 25.0 & 111 & 105.2 & .28 & $23 .$. & 33.5 & 114 & 207.8 & .38 \\
\hline $13 . . . . . . . .$. & 22.0 & 118 & 120.8 & .42 & $89 .$. & 33.5 & 113 & 267.8 & .38 \\
\hline $67 . . . . . .$. & 25.0 & 97 & 136.6 & .41 & 35. & 29.0 & 123 & 277.3 & .48 \\
\hline 92................... & 25.0 & 101 & 139.4 & .40 & $99 .$. & 37.0 & 110 & 274.4 & .33 \\
\hline 6................. & 24.0 & 115 & 151.7 & .42 & $34 \ldots . . . .$. & 32.0 & 129 & $\begin{array}{l}280.4 \\
280.2\end{array}$ & .00 \\
\hline $57 . . . . . . . . . . . . .$. & 24.0 & 115 & 153.5 & .42 & $82 .$. & 38. 0 & 123 & 290.5 & .30 \\
\hline 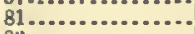 & 27.0 & 100 & 173.5 & .41 & & 35.0 & 133 & 314.0 & .35 \\
\hline $83 . . . . . . . . . . . .$. & 30.0 & 119 & 180.4 & .31 & & 38.0 & 149 & 315.7 & .27 \\
\hline gR......................... & 31.0 & 97 & 181.5 & .36 & & 35.0 & 149 & 335.6 & 34 \\
\hline $100 \ldots . . . . . . . . .$. & 29.0 & 97 & 182. 7 & .41 & $61 .$. & 35.0 & 148 & 339.8 & .34 \\
\hline $71 \ldots . . . \ldots \ldots . . . . .$. & 27.0 & 98 & 185.6 & .48 & $20 .$. & 34.0 & 138 & 361.5 &.$\$ 1$ \\
\hline $31 \ldots \ldots \ldots \ldots \ldots$ & 27.0 & 126 & 194.2 & .39 & $10 \ldots$ & 51.5 & 148 & 034.8 & .30 \\
\hline 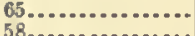 & 30.0 & 115 & 194.6 & .34 & A rerace & 31.7 & 119 & 235.5 & . 36 \\
\hline 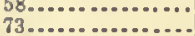 & $\begin{array}{l}28.3 \\
35.0\end{array}$ & $\begin{array}{l}127 \\
108\end{array}$ & $\begin{array}{l}208.0 \\
208.0\end{array}$ & .290 & & & & & \\
\hline $28 \ldots \ldots \ldots \ldots$ & 29.0 & $133^{\circ}-(-1$ & 209.7 & .34 & & 20.0 & 126 & 159.1 & .34 \\
\hline (14.................. & 26.0 & 117 & 215.4 & . 50 & $69 \ldots$ & 27.0 & 119 & 104.6 & .35 \\
\hline 63 & $\begin{array}{l}26.0 \\
28.5\end{array}$ & 127 & $\begin{array}{l}216.6 \\
216.8\end{array}$ & .50 & (52... & 27.0 & 152 & 107.0 & .36 \\
\hline (54... & $\begin{array}{l}28.5 \\
30.0\end{array}$ & $\begin{array}{l}127 \\
129\end{array}$ & $\begin{array}{l}210.8 \\
217.2\end{array}$ & (.34 & $\begin{array}{l}52 . . \\
12 .\end{array}$ & 27.0 & $\begin{array}{l}152 \\
152\end{array}$ & $\begin{array}{l}188.3 \\
104.3\end{array}$ & .31 \\
\hline (88.......... & 31.0 & 04 & 218.8 & .46 & & 30.0 & 126 & 207.8 & .34 \\
\hline $66 . . . . . . . .$. & 31.0 & 101 & 220.7 & .42 & & $\begin{array}{l}31.0 \\
31.0\end{array}$ & 113 & 227.1 & .38 \\
\hline & 32.0 & 136 & 221.1 & .29 & & 34.0 & 129 & 240.6 & .30 \\
\hline $7 \ldots .$. & 31.0 & 114 & 223.5 & .37 & & 33.0 & 116 & 250.8 & .37 \\
\hline $50 \ldots \ldots$ & 31.0 & 121 & 228.4 & .36 & & 32.0 & 137 & 257.0 & .34 \\
\hline 91....................... & 32.0 & 119 & 230.8 & .85 & & 32.0 & 137 & 203.0 & .34 \\
\hline $2, \ldots \ldots \ldots \ldots$ & 31.0 & 122 & 233.1 & 0.36 & & 32.0 & 108 & 272.3 & .05 \\
\hline $87 \ldots . . . . . . . . . . . . . .$. & 36.0 & 110 & 237.6 & .31 & & 34.0 & $137^{\circ}$ & 276.2 & .32 \\
\hline $24 \ldots . . . . . . . . . . . .$. & 36.0 & 110 & 239.6 & .28 & 18. & 36.0 & 126 & 270.6 & .31 \\
\hline $30 \ldots \ldots \ldots$ & 38.0 & 137 & 243.2 & .22 & & 32.0 & 138 & 293.4 & .38 \\
\hline $1 \ldots \ldots \ldots \ldots$ & 35.0 & 128 & 247.5 & .29 & & 36.0 & 135 & 303.6 & .32 \\
\hline $16 \ldots$ & 35.0 & 128 & 2482 & .29 & $29 \ldots \ldots$. & 34.0 & 134 & 310.0 & .87 \\
\hline $97 \ldots . . . . . . . . . . . .$. & 33.0 & 105 & 255.4 & .41 & $70 \ldots \ldots$ & 34.0 & 134 & 321.9 & .38 \\
\hline $93 . . . \ldots \ldots \ldots \ldots \ldots$ & & 101 & & & \multirow[t]{3}{*}{ 11............. } & 35.0 & 129 & $3+1.6$ & .40 \\
\hline $74 \ldots \ldots \ldots \ldots \ldots . . .$. & $\begin{array}{l}38.0 \\
33.5\end{array}$ & $\begin{array}{l}110 \\
139\end{array}$ & $\begin{array}{l}258.8 \\
260.1\end{array}$ & .28 & & 31.5 & 130 & 248,6 & .35 \\
\hline $77 \ldots . . . . . . . . . . . . . . .$. & 34.0 & $\begin{array}{l}104 \\
104\end{array}$ & $\begin{array}{l}260.1 \\
261.4\end{array}$ & . . . .40 & & & 130 & & \\
\hline
\end{tabular}

Age class: 300 to 350 years.

\begin{tabular}{|c|c|c|c|c|c|c|c|c|c|}
\hline $\begin{array}{l}98 \ldots \ldots \ldots \ldots \ldots \\
53 \ldots \ldots \ldots\end{array}$ & $\begin{array}{l}31.0 \\
30.0 \\
30.0 \\
30.0\end{array}$ & $\begin{array}{l}115 \\
132 \\
120 \\
124\end{array}$ & $\begin{array}{l}215.9 \\
219.8 \\
231.9\end{array}$ & $\begin{array}{r}0.80 \\
.34 \\
.39\end{array}$ & 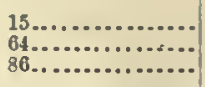 & $\begin{array}{l}33.0 \\
36.0 \\
34.0\end{array}$ & $\begin{array}{l}136 \\
124 \\
140\end{array}$ & $\begin{array}{l}332.0 \\
237.0 \\
380.4\end{array}$ & $\begin{array}{r}0.41 \\
.27 \\
.41\end{array}$ \\
\hline $13 \ldots \ldots, \ldots, \ldots, \ldots$ & $\begin{array}{l}30.0 \\
33.0 \\
40.0\end{array}$ & $\begin{array}{l}129 \\
140\end{array}$ & $\begin{array}{l}296.2 \\
800.4\end{array}$ & $: 39$ & Average... & 34.3 & 129 & 273.6 & .33 \\
\hline
\end{tabular}


TABLE VI.-Aore yields of White Pine and measurements of sample trees-Continued.

\section{C.-PENYSYLVANIA :}

(1) SITE $d$ :

Clinton County.

[2,000 feet ahore sea level.]

Soil: Rocky, underlaid by sand, stone, or slates in places, sand or clay or a mixture of both in Age of pine: 240 to 260 years. rarying proportions; no soil to depth of 4 to 5 feet, rocks covered with 3 inches mold, and Density of crown corer: 0.4 Rock Fern, Laurel, Green Brier, and in openings some Blackberries aro seen.

Forest conditions: Hemlock (60 per cent) intermixed with White Pine (24 per cent), scattering

Black Birch and Tollow Birch and occasional Oak, Chestnnt, and Maple, on steep slopes

horderjng Hyner Run; nndergrowth, moderately dense, of young Hemlock near tbe rnn and Number of trees per acre: 90. Birch and hardwoods a bove named near top of slope.

FIELD FOR THE TWO ACRES.

\begin{tabular}{|c|c|c|c|c|c|c|c|c|c|c|}
\hline \multicolumn{5}{|c|}{ White Pine. } & \multicolumn{3}{|c|}{ Hemlock. } & \multicolumn{3}{|c|}{ Oak. } \\
\hline \multirow[b]{2}{*}{$\begin{array}{l}\text { Number } \\
\text { of trees. }\end{array}$} & \multirow[b]{2}{*}{$\begin{array}{l}\text { Diameter } \\
\text { (hreast } \\
\text { high). }\end{array}$} & \multirow[b]{2}{*}{ Height. } & \multicolumn{2}{|c|}{ Volnme. } & \multirow[b]{2}{*}{$\begin{array}{l}\text { Nnmher } \\
\text { of trees. }\end{array}$} & \multirow[b]{2}{*}{$\begin{array}{c}\text { Diameter } \\
\text { (hreast } \\
\text { high). }\end{array}$} & \multirow[b]{2}{*}{ Height. } & \multirow[b]{2}{*}{$\begin{array}{l}\text { Nnmber } \\
\text { of trees. }\end{array}$} & \multirow[b]{2}{*}{$\begin{array}{l}\text { Diametor } \\
\text { (breast } \\
\text { high). }\end{array}$} & \multirow[b]{2}{*}{ Height. } \\
\hline & & & Bole. & $\begin{array}{c}\text { Mrer- } \\
\text { chantable } \\
\text { tímber. }\end{array}$ & & & & & & \\
\hline \multirow{7}{*}{$\begin{array}{l}1 \\
2 \\
1 \\
3 \\
4 \\
1 \\
5 \\
2 \\
2 \\
\frac{2}{3} \\
2 \\
3 \\
1 \\
3 \\
5 \\
1 \\
2 \\
2 \\
2 \\
1 \\
1 \\
1\end{array}$} & \multirow{7}{*}{$\begin{array}{r}\text { Inches. } \\
10 \\
11 \\
13 \\
19 \\
22 \\
23 \\
25 \\
26 \\
27 \\
28 \\
29 \\
30 \\
31 \\
32 \\
33 \\
34 \\
35 \\
39 \\
40 \\
41 \\
42\end{array}$} & \multirow{7}{*}{$\begin{array}{r}\text { Feet. } \\
80 \\
80 \\
80 \\
130 \\
130 \\
130 \\
130 \\
135 \\
135 \\
135 \\
135 \\
135 \\
145 \\
145 \\
145 \\
145 \\
145 \\
145 \\
145 \\
145 \\
145\end{array}$} & $\begin{array}{r}\text { Cu. ft. } \\
108\end{array}$ & $\begin{array}{c}\text { Feet B. } \mathrm{A} \text {. } \\
432\end{array}$ & \multirow{7}{*}{$\begin{array}{r}10 \\
24 \\
3 \\
4 \\
4 \\
5 \\
9 \\
3 \\
7 \\
3 \\
8 \\
5 \\
2 \\
3 \\
8 \\
5 \\
1 \\
3 \\
4 \\
2 \\
1\end{array}$} & \multirow{7}{*}{\begin{tabular}{|r} 
Inches. \\
3 to 6 \\
6 to 10 \\
11 \\
12 \\
13 \\
14 \\
15 \\
16 \\
17 \\
18 \\
19 \\
20 \\
21 \\
22 \\
23 \\
25 \\
26 \\
27 \\
28 \\
30 \\
36
\end{tabular}} & \multirow[t]{7}{*}{ Feet. } & $\frac{2}{3}$ & $\begin{array}{l}\text { Inches. } \\
6 \text { to } 10 \\
10 \text { to } 14\end{array}$ & $\begin{array}{c}\text { Feet. } \\
35 \text { to } \\
60\end{array}$ \\
\hline & & & 959 & 4,494 & & & & \multicolumn{3}{|c|}{ Birch. } \\
\hline & & & $\begin{array}{r}180 \\
1,085 \\
514\end{array}$ & $\begin{array}{l}1,000 \\
6,150 \\
2,780\end{array}$ & & & & $\begin{array}{r}5 \\
10 \\
1 \\
1 \\
\end{array}$ & $\begin{array}{r}3 \text { to } 8 \\
0 \text { to } 10 \\
10 \text { to } 14 \\
14 \text { to } 18\end{array}$ & $\begin{array}{l}40 \\
\text { to } \\
60\end{array}$ \\
\hline & & & 1,995 & \multirow{2}{*}{$\begin{array}{l}9,800 \\
5,850 \\
2,000 \\
6,900\end{array}$} & & & & \multicolumn{3}{|c|}{ Chestnnt. } \\
\hline & & & $\begin{array}{r}915 \\
310 \\
1,170\end{array}$ & & & & & $\begin{array}{l}3 \\
1 \\
1\end{array}$ & $\begin{array}{r}0 \text { to } 10 \\
10 \text { to } 14 \\
14 \text { to } 18\end{array}$ & $\begin{array}{l}40 \\
\text { to } \\
60\end{array}$ \\
\hline & & & $\begin{array}{r}960 \\
900\end{array}$ & \multirow[t]{2}{*}{$\begin{array}{r}14,400 \\
5,600\end{array}$} & & & & \multicolumn{3}{|c|}{ Maple. } \\
\hline & & & 3,066 & & & & & $\begin{array}{l}1 \\
3 \\
1\end{array}$ & $\begin{array}{r}3 \text { to } 6 \\
0 \text { to } 10 \\
10 \text { to } 14\end{array}$ & \\
\hline \multicolumn{5}{|c|}{$\begin{array}{l}47 \text { trees: } \\
\text { Total } \\
\text { Total }\end{array}$} & \multicolumn{6}{|c|}{ 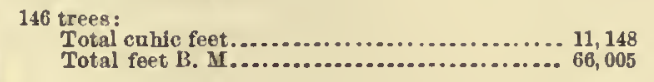 } \\
\hline
\end{tabular}

Average annual aceretion: All species, 49 cahic feet.

MEASUREMEXTS OF SAMPLE TREES.

Age cluss: 180 to 200 sears.

\begin{tabular}{|c|c|c|c|c|c|c|c|c|c|c|}
\hline \multirow[b]{2}{*}{ Tree number. } & \multirow[b]{2}{*}{ Age. } & \multirow[b]{2}{*}{$\begin{array}{c}\text { Diameter } \\
\text { (breast } \\
\text { bigh). }\end{array}$} & \multirow[b]{2}{*}{ Height. } & \multirow[b]{2}{*}{$\begin{array}{l}\text { Height to } \\
\text { haso of } \\
\text { crown. }\end{array}$} & \multirow[b]{2}{*}{$\begin{array}{c}\text { Rings } \\
\text { per inch } \\
\text { on } \\
\text { stump. }\end{array}$} & \multicolumn{2}{|c|}{ Folume. } & \multirow[b]{2}{*}{$\begin{array}{l}\text { Factor } \\
\text { of } \\
\text { shape. }\end{array}$} & \multirow[b]{2}{*}{$\begin{array}{l}\text { Ratio of } \\
\text { length } \\
\text { of crown } \\
\text { to total } \\
\text { height of } \\
\text { tree. }\end{array}$} & \multirow{2}{*}{$\begin{array}{l}\text { Lnmber } \\
\text { product } \\
\text { under } \\
\text { present } \\
\text { practice } \\
\text { (per cent } \\
\text { nsed of } \\
\text { total } \\
\text { rolume } \\
\text { of stem). }\end{array}$} \\
\hline & & & & & & Tree. & $\begin{array}{c}\text { Mer. } \\
\text { chantahlo } \\
\text { timber. }\end{array}$ & & & \\
\hline $\begin{array}{l}10 \ldots \ldots \\
11 \\
13 \\
13 \\
14 \\
15 \\
16 \ldots \ldots \\
17 \\
18 \ldots \ldots \\
19 \ldots \ldots \ldots\end{array}$ & $\begin{array}{c}\text { Tears. } \\
194 \\
199 \\
197 \\
196 \\
199 \\
189 \\
180 \\
189 \\
197 \\
183\end{array}$ & $\begin{array}{r}\text { Inches. } \\
26.0 \\
30.0 \\
26.5 \\
23.0 \\
29.0 \\
23.0 \\
22.0 \\
25.5 \\
26.0 \\
26.5\end{array}$ & $\begin{array}{r}\text { Feet. } \\
116 \\
114 \\
105 \\
05 \\
103 \\
104 \\
104 \\
105 \\
101 \\
88\end{array}$ & $\begin{array}{r}\text { Feet. } \\
\mathbf{5 6} \\
\mathbf{5 6} \\
\mathbf{5 0} \\
40 \\
\mathbf{5 2} \\
60 \\
\mathbf{5 4} \\
\mathbf{4 5} \\
\mathbf{6 0} \\
40\end{array}$ & $\begin{array}{l}\text { To. } \\
6.6 \\
5.6 \\
7.0 \\
7.4 \\
6.3 \\
8.0 \\
7.8 \\
6.9 \\
7.3 \\
7.2\end{array}$ & $\begin{array}{l}\text { Cu.ft. } \\
170.8 \\
214.4 \\
183.3 \\
111.1 \\
220.6 \\
106.4 \\
128.0 \\
176.1 \\
155.7 \\
151.2\end{array}$ & $\begin{array}{r}\text { Feet } B . M . M \\
908 \\
1,273 \\
997 \\
490 \\
1,290 \\
534 \\
043 \\
892 \\
791 \\
760\end{array}$ & $\begin{array}{l}0.40 \\
.38 \\
.45 \\
.40 \\
.40 \\
.35 \\
.40 \\
.47 \\
.42 \\
.45\end{array}$ & $\begin{array}{l}0.51 \\
.51 \\
.46 \\
.58 \\
.49 \\
.42 \\
.48 \\
.57 \\
.50 \\
.54\end{array}$ & $\begin{array}{l}44 \\
49 \\
45 \\
87 \\
48 \\
41 \\
42 \\
42 \\
42 \\
41\end{array}$ \\
\hline Average... & 198 & 26.0 & 103 & 51 & 7.0 & 162.0 & 858 & .42 & .51 & 43 \\
\hline
\end{tabular}

A.ge class : 230 to 250 Jears.

DOMINANT GROWTH.

\begin{tabular}{|c|c|c|c|c|c|c|c|c|c|c|}
\hline $21 \ldots \ldots \ldots \ldots \ldots \ldots$ & $\begin{array}{l}256 \\
242\end{array}$ & $\begin{array}{l}34.0 \\
35.0\end{array}$ & $\begin{array}{l}158 \\
150\end{array}$ & $\begin{array}{l}94 \\
82\end{array}$ & $\begin{array}{l}7.5 \\
6.2\end{array}$ & $\begin{array}{l}416.3 \\
376.1\end{array}$ & $\begin{array}{l}2,600 \\
2,261\end{array}$ & $\begin{array}{r}0.42 \\
.37\end{array}$ & $\begin{array}{r}0.40 \\
.45\end{array}$ & $\begin{array}{l}53 \\
50\end{array}$ \\
\hline A verage... & 249 & 34.5 & 154 & 88 & 6. 8 & 396.0 & 2,460 & .40 & .42 & 51 \\
\hline $4 \ldots \ldots . . . . . . . .$. & 201 & 40.0 & 129 & 64 & 5.0 & 401.7 & 2,300 & .36 & .50 & 47 \\
\hline
\end{tabular}


TABLF: VI.-Acre yiclds of White Pine and measurements of sample trees-Continued.

C.-IPENXSTVANIA-Continned.

MEASUREMENTS OF SAMILL T'LEES-Continued.

Age class: 230 to 250 years.

CODOMINANT GROWTH.

\begin{tabular}{|c|c|c|c|c|c|c|c|c|c|c|}
\hline \multirow[b]{2}{*}{ Tree nnmber. } & \multirow[b]{2}{*}{ Age. } & \multirow[b]{2}{*}{$\begin{array}{l}\text { Dinmeter } \\
\text { (breast } \\
\text { high). }\end{array}$} & \multirow[b]{2}{*}{ Ifeight. } & \multirow[b]{2}{*}{$\begin{array}{l}\text { Heigbt to } \\
\text { base of } \\
\text { crow'n. }\end{array}$} & \multirow[b]{2}{*}{$\begin{array}{l}\text { Rings } \\
\text { per incb } \\
\text { on } \\
\text { gtump. }\end{array}$} & \multicolumn{2}{|c|}{ Tolume. } & \multirow[b]{2}{*}{$\begin{array}{l}\text { Factor } \\
\text { of } \\
\text { shape. }\end{array}$} & \multirow[b]{2}{*}{$\begin{array}{l}\text { Ratio of } \\
\text { length } \\
\text { of erown } \\
\text { to totai } \\
\text { beiglit of } \\
\text { tree. }\end{array}$} & \multirow{2}{*}{$\begin{array}{l}\text { Lnmber } \\
\text { product } \\
\text { nnder } \\
\text { present } \\
\text { practice } \\
\text { (per cent } \\
\text { used of } \\
\text { tolal } \\
\text { rolume } \\
\text { of stem). }\end{array}$} \\
\hline & & & & & & T'ree. & $\begin{array}{c}\text { Mer- } \\
\text { cbantablo } \\
\text { timber. }\end{array}$ & & & \\
\hline $\begin{array}{l}1 \\
2 \\
20 \\
20 \ldots \ldots \ldots \ldots \ldots \ldots \ldots\end{array}$ & $\begin{array}{l}\text { Years. } \\
245 \\
232 \\
256\end{array}$ & $\begin{array}{l}\text { Inches. } \\
28.5 \\
23.0 \\
23.5\end{array}$ & $\begin{array}{r}\text { Feet. } \\
132 \\
132 \\
141\end{array}$ & $\begin{array}{r}\text { Feet. } \\
94 \\
78 \\
90\end{array}$ & $\begin{array}{r}\text { Vo. } \\
7.0 \\
9.3 \\
10.1\end{array}$ & $\begin{array}{l}\text { Cr.ft. } \\
256.6 \\
160.6 \\
192.7\end{array}$ & $\begin{array}{c}\text { Feet } B, 14 \\
1,583 \\
700 \\
1,060\end{array}$ & $\begin{array}{r}0.44 \\
.42 \\
.45\end{array}$ & $\begin{array}{r}0.29 \\
.41 \\
.32\end{array}$ & $\begin{array}{l}51 \\
39 \\
46\end{array}$ \\
\hline Aremge... & 244 & 25.0 & 135 & 89 & 8.8 & 203.0 & 1,138 & .41 & .34 & 45 \\
\hline 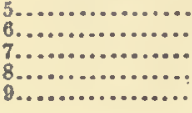 & $\begin{array}{l}229 \\
234 \\
(1) \\
231 \\
229\end{array}$ & $\begin{array}{l}25.0 \\
23.0 \\
28.0 \\
27.0 \\
30.0\end{array}$ & $\begin{array}{l}120 \\
116 \\
124 \\
110 \\
120\end{array}$ & $\begin{array}{l}60 \\
60 \\
72 \\
60 \\
52\end{array}$ & $\begin{array}{l}7.1 \\
9.3 \\
(7)^{3} \\
7.8 \\
7.7\end{array}$ & $\begin{array}{l}197.6 \\
160.4 \\
224.2 \\
190.2 \\
288.0\end{array}$ & $\begin{array}{r}1.100 \\
888 \\
1,348 \\
1,070 \\
1,535\end{array}$ & $\begin{array}{l}.48 \\
.48 \\
.42 \\
.43 \\
.45\end{array}$ & $\begin{array}{l}.50 \\
.48 \\
.42 \\
.45 \\
.56\end{array}$ & $\begin{array}{l}46 \\
46 \\
50 \\
47 \\
48\end{array}$ \\
\hline Averago... & 231 & 26.5 & 118 & 61 & 8.0 & 208.0 & 1,188 & .45 & .48 & 47 \\
\hline
\end{tabular}

(2) Srref:

Clearfield County.

Sample area: 1 acre.

[1,200 to 1,500 feet above sea level.]

Soil: Tellow clayey loam of medium grain (fne shales in it), deep, fresh, well drained, witb 2 Age of pine: 240 to 200 years, to 3 inches mold on top, and surface cover of scanty leares, Fern, Tealerries, and scattcring Density of crown corer: 0.7 ;
Dogwood (Laurel northeast corver and north slde); subsoil, laminated shale of lndefinite in places, 0.8 . Dogwood

Forest conditions: Hemlock (62 per cent) mixed witb White Pine (28 per cent), with occasional Number of troes: 132 bard woods (10 per cent), Japle, Beecb, and Birch, on hili sioping toward southwest, bordered by left-hand branch of Narrow Creek; nndergrowth, moderatcly dense, of rery young Beech, by left-hand branch of Narrow Croek; nndergro

ACRE YIELD.

\begin{tabular}{|c|c|c|c|c|c|c|c|c|c|c|}
\hline \multicolumn{5}{|c|}{ White Pine. } & \multicolumn{3}{|c|}{ Hemlock. } & \multicolumn{3}{|c|}{ Maple. } \\
\hline \multirow[b]{2}{*}{$\begin{array}{l}\text { Number } \\
\text { of trees. }\end{array}$} & \multirow[b]{2}{*}{$\begin{array}{c}\text { Diameter } \\
\text { (breast } \\
\text { high). }\end{array}$} & \multirow[b]{2}{*}{ Helght. } & \multicolumn{2}{|c|}{ Yolnme. } & \multirow[b]{2}{*}{$\begin{array}{l}\text { Number } \\
\text { of trees. }\end{array}$} & \multirow[b]{2}{*}{$\begin{array}{l}\text { Diameter } \\
\text { (breast } \\
\text { higb). }\end{array}$} & \multirow[b]{2}{*}{ Heiglit. } & \multirow[b]{2}{*}{$\begin{array}{l}\text { Nnmber } \\
\text { of trees. }\end{array}$} & \multirow[b]{2}{*}{$\begin{array}{l}\text { Diameter } \\
\text { (breast } \\
\text { high). }\end{array}$} & \multirow[b]{2}{*}{ Helgbt. } \\
\hline & & & Bole. & $\begin{array}{l}\text { Mer. } \\
\text { cliantable } \\
\text { timber. }\end{array}$ & & & & & & \\
\hline \multirow{5}{*}{$\begin{array}{l}2 \\
2 \\
2 \\
1 \\
1 \\
4 \\
2 \\
2 \\
1 \\
3 \\
1 \\
2 \\
1 \\
1 \\
2 \\
4 \\
1 \\
2 \\
1 \\
1 \\
1\end{array}$} & \multirow{5}{*}{$\begin{array}{r}\text { Inches. } \\
15 \\
17 \\
18 \\
19 \\
20 \\
21 \\
22 \\
23 \\
24 \\
25 \\
26 \\
27 \\
28 \\
29 \\
30 \\
31 \\
32 \\
34 \\
40 \\
41 \\
45\end{array}$} & \multirow{5}{*}{$\begin{array}{r}\text { Feet. } \\
120 \\
120 \\
130 \\
130 \\
130 \\
130 \\
130 \\
130 \\
130 \\
135 \\
135 \\
135 \\
135 \\
135 \\
145 \\
145 \\
145 \\
145 \\
145 \\
145 \\
145\end{array}$} & $\left\{\begin{array}{l}\text { Cubicfeet. } \\
\{\end{array}\right.$ & Feet $B .1$. & \multirow{5}{*}{$\begin{array}{r}17 \\
4 \\
3 \\
4 \\
1 \\
8 \\
6 \\
6 \\
8 \\
5 \\
8 \\
3 \\
3 \\
1 \\
4 \\
1 \\
1 \\
1\end{array}$} & \multirow{5}{*}{\begin{tabular}{|r} 
Inches. \\
6 to 10 \\
10 to 14 \\
14 \\
15 \\
16 \\
17 \\
18 \\
19 \\
20 \\
21 \\
22 \\
23 \\
25 \\
26 \\
27 \\
28 \\
29 \\
30
\end{tabular}} & \multirow[t]{5}{*}{ Feet. } & $\begin{array}{l}2 \\
3\end{array}$ & $\begin{array}{l}\text { Inches. } \\
6 \text { to } 10 \\
14 \text { to } 18\end{array}$ & $\begin{array}{l}\text { Feet. } \\
40 \text { to } 60\end{array}$ \\
\hline & & & 1,370 & 6,420 & & & & & Beech. & \\
\hline & & & $\begin{array}{l}570 \\
651 \\
257\end{array}$ & $\begin{array}{l}3,000 \\
3,690 \\
1,390\end{array}$ & & & & $\begin{array}{l}2 \\
1\end{array}$ & $\begin{array}{l}10 \text { to } 14 \\
14 \text { to } 18\end{array}$ & 50 \\
\hline & & & $\begin{array}{r}1,140 \\
610\end{array}$ & 6,600 & & & & & Blrch. & \\
\hline & & & $\begin{array}{r}1.220 \\
390 \\
800 \\
511 \\
511 \\
638\end{array}$ & $\begin{array}{l}3,800 \\
2,300 \\
4,800 \\
3,300 \\
3,300 \\
4,400\end{array}$ & & & & $\frac{1}{2}$ & $\begin{array}{r}6 \text { to } 10 \\
10 \text { to } 14\end{array}$ & 40 \\
\hline \multicolumn{5}{|c|}{$\begin{array}{l}37 \text { trees: } \\
\text { Total cnbie feet................... } 9,028 \\
\text { Total feet B. II ................. } 52,260\end{array}$} & \multicolumn{6}{|c|}{$\begin{array}{l}95 \text { trees: } \\
\quad \text { Total cnbic feet } \ldots \ldots \ldots \ldots \ldots \ldots \ldots \ldots \ldots \ldots \ldots \ldots \ldots, 15,680 \\
\text { Total feet B. } \mathbf{M} \ldots \ldots \ldots \ldots \ldots \ldots \ldots \ldots \ldots \ldots .9,103\end{array}$} \\
\hline
\end{tabular}
Average annual accretion: All species, 63 cnlie feet.
360 feet B. 11. 
TABLES OF MEASUREMENTS.

TABLE VI.-Acre yiclds of White Pine and measurements of sample trees-Continued.

C.-PEXYSYLVANIA-Continued.

MEASUREMENTS OF SAMPLE TREES.

DOMIMANT GROWTH.

\begin{tabular}{|c|c|c|c|c|c|c|c|c|c|c|}
\hline \multirow[b]{2}{*}{ Tree nithber. } & \multirow[b]{2}{*}{ Age. } & \multirow[b]{2}{*}{$\begin{array}{c}\text { Diameter } \\
\text { (breast } \\
\text { high). }\end{array}$} & \multirow[b]{2}{*}{ Hoight. } & \multirow[b]{2}{*}{$\begin{array}{c}\text { Height to } \\
\text { base of } \\
\text { crown. }\end{array}$} & \multirow[b]{2}{*}{$\begin{array}{l}\text { Rings } \\
\text { per inch } \\
\text { on } \\
\text { stump. }\end{array}$} & \multicolumn{2}{|c|}{ Volnme. } & \multirow[b]{2}{*}{$\begin{array}{c}\text { Factor } \\
\text { of } \\
\text { shape. }\end{array}$} & \multirow[b]{2}{*}{$\begin{array}{c}\text { Ratio of } \\
\text { length } \\
\text { of crown } \\
\text { to total } \\
\text { height of } \\
\text { tree. }\end{array}$} & \multirow{2}{*}{$\begin{array}{l}\text { Lumber } \\
\text { product } \\
\text { under } \\
\text { present } \\
\text { practico } \\
\text { (per cent } \\
\text { used of } \\
\text { total } \\
\text { volumo } \\
\text { of stem). }\end{array}$} \\
\hline & & & & & & Tree. & $\begin{array}{c}\text { Mer. } \\
\text { chantable } \\
\text { timber. }\end{array}$ & & & \\
\hline 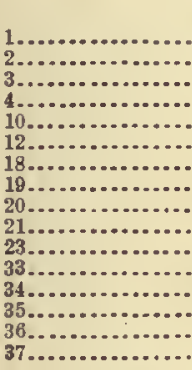 & $\begin{array}{r}\text { Fears. } \\
260 \\
260 \\
259 \\
241 \\
244 \\
262 \\
265 \\
250 \\
266 \\
245 \\
248 \\
259 \\
262 \\
263 \\
241 \\
261\end{array}$ & $\begin{array}{r}\text { Inches. } \\
35.5 \\
36.0 \\
32.0 \\
32.0 \\
33.0 \\
28.0 \\
39.0 \\
34.0 \\
44.0 \\
34.0 \\
34.0 \\
33.0 \\
33.0 \\
31.0 \\
31.5 \\
37.0\end{array}$ & $\begin{array}{r}\text { Feet. } \\
158 \\
157 \\
152 \\
150 \\
146 \\
156 \\
153 \\
150 \\
144 \\
146 \\
142 \\
133 \\
146 \\
144 \\
134 \\
146\end{array}$ & $\begin{array}{r}\text { Feet. } \\
00 \\
. \quad 90 \\
84 \\
62 \\
86 \\
88 \\
88 \\
78 \\
100 \\
92 \\
90 \\
91 \\
90 \\
82 \\
88 \\
106\end{array}$ & $\begin{array}{l}\text { No. } \\
7.6 \\
7.0 \\
7.8 \\
6.6 \\
6.8 \\
9.0 \\
6.0 \\
6.3 \\
5.7 \\
7.1 \\
7.2 \\
8.0 \\
7.4 \\
8.5 \\
7.1 \\
6.7\end{array}$ & $\begin{array}{l}\text { Cu.ft. } \\
435.1 \\
481.3 \\
396.0 \\
347.7 \\
365.9 \\
285.8 \\
511.1 \\
402.4 \\
638.4 \\
366.7 \\
373.4 \\
304.5 \\
369.2 \\
275.2 \\
307.7 \\
482.9\end{array}$ & $\begin{array}{c}\text { Ft. } B .3 .1 . \\
3,030 \\
3,401 \\
2,637 \\
2,079 \\
2,384 \\
1,648 \\
3,318 \\
2,397 \\
4,388 \\
2,248 \\
2,318 \\
1.770 \\
2,220 \\
1,458 \\
1,853 \\
2,970\end{array}$ & $\begin{array}{l}0.40 \\
.43 \\
.46 \\
.41 \\
.42 \\
.43 \\
.40 \\
.42 \\
.42 \\
.40 \\
.42 \\
.40 \\
.42 \\
.36 \\
.42 \\
.44\end{array}$ & $\begin{array}{r}0.43 \\
.42 \\
.44 \\
.58 \\
.34 \\
.43 \\
.42 \\
.48 \\
.30 \\
.37 \\
.37 \\
.31 \\
.38 \\
.43 \\
.34 \\
.27\end{array}$ & $\begin{array}{l}58 \\
59 \\
55 \\
50 \\
54 \\
47 \\
54 \\
49 \\
57 \\
51 \\
51 \\
48 \\
50 \\
44 \\
50 \\
50\end{array}$ \\
\hline Average... & 255 & 34 & 147 & 88 & 7.0 & 390.0 & 2,507 & .41 & .39 & 52 \\
\hline
\end{tabular}

CODOMNANT GROWTH.

\begin{tabular}{|c|c|c|c|c|c|c|c|c|c|c|}
\hline $28 \ldots \ldots \ldots \ldots \ldots$ & 262 & 28.5 & 138 & 75 & 9.8 & 264.3 & 1,551 & $\cdot 0.43$ & $0 . \$ 5$ & 49 \\
\hline $25 \ldots \ldots \ldots \ldots \ldots$ & 244 & 28.5 & 138 & 107 & 7.7 & 298.1 & 1,054 & .49 & .22 & 54 \\
\hline $24 \ldots . . . \ldots \ldots \ldots$ & 245 & 25.0 & 130 & 84 & 8.3 & 192.1 & 1,102 & .43 & .35 & 48 \\
\hline $22 \ldots \ldots \ldots \ldots \ldots$ & 246 & 31.0 & 130 & 82 & 7.3 & 310.3 & 1,731 & .45 & .37 & 46 \\
\hline $5 \ldots \ldots \ldots \ldots \ldots$ & 264 & 29.0 & 140 & 100 & 8.4 & 300.4 & 1,905 & .47 & .28 & 52 \\
\hline $6 \ldots \ldots \ldots \ldots \ldots$ & 264 & 29.0 & 140 & 110 & 8.5 & 291.4 & 1.631 & .45 & .21 & 47 \\
\hline $7 . . . \ldots \ldots$ & 262 & 29.0 & 152 & 112 & 0.5 & 302.8 & 1,854 & .46 & .26 & 51 \\
\hline $8 \ldots . . . . . . . . . .$. & 235 & 29.0 & 142 & 86 & ...... & 248.6 & 1,318 & .38 & .39 & 44 \\
\hline $9 \ldots \ldots \ldots \ldots \ldots \ldots$ & 236 & 32.0 & 142 & 84 & $\ldots$ & 287.7 & 1,648 & .36 & .41 & 48 \\
\hline $11 . . . \ldots \ldots \ldots$ & 244 & 30.0 & 141 & 81 & 7.5 & 305.3 & 1,947 & .44 & .42 & 53 \\
\hline $13 . . . . . . . . . .$. & 258 & 23.0 & 147 & 98 & 9.6 & 206.0 & 1,048 & .48 & .37 & 42 \\
\hline $14 \ldots \ldots \ldots \ldots \ldots$ & 242 & 25.0 & 139 & 98 & .......... & 217.1 & 1,233 & .46 & .30 & 47 \\
\hline $15 . . . . . . . . . . .$. & 262 & 26.0 & 136 & 98 & ...... & 257.2 & 1,389 & .51 & .28 & 45 \\
\hline $16 \ldots . . . . . . . . . .$. & 235 & 24.5 & 124 & 93 & $\therefore \ldots$. & 163.8 & 815 & .40 & .25 & 41 \\
\hline $17 \ldots \ldots \ldots \ldots \ldots$ & 262 & 25.0 & 128 & 108 & ......... & 214.4 & 1,183 & .49 & .16 & 46 \\
\hline $26 \ldots \ldots \ldots \ldots \ldots$ & 245 & 26. 0 & 136 & 98 & 9.3 & 109.2 & 1, 021 & .40 & .28 & 47 \\
\hline $30 . . . \ldots . . . . . . .$. & 259 & 26.5 & 134 & 00 & 0.2 & 228.6 & 1,336 & .44 & .32 & 48 \\
\hline & 264 & 28.0 & 141 & 84 & 9.2 & 276.5 & 1,577 & .46 & .40 & 47 \\
\hline 31................... & 262 & 25.5 & 132 & 88 & 10.0 & 191.8 & 863 & .41 & .33 & 37 \\
\hline $32 \ldots \ldots \ldots \ldots$ & 261 & 26.0 & 142 & 99 & 9.1 & 239.9 & 1,322 & .46 & .30 & 46 \\
\hline Arerago ... & 253 & 27 & 138 & 93 & 9.0 & 250.0 & 1,421 & .44 & .32 & 47 \\
\hline
\end{tabular}

OPPRESBED GROWTH.

\begin{tabular}{|c|c|c|c|c|c|c|c|c|c|c|}
\hline $\begin{array}{l}27 \ldots \ldots \ldots \ldots \ldots \ldots \\
38 \ldots \ldots \ldots \ldots \ldots \ldots \ldots \\
39 \ldots \ldots \ldots \ldots \ldots \ldots \ldots \\
40 \ldots \ldots \ldots \ldots \ldots \ldots\end{array}$ & $\begin{array}{l}250 \\
260 \\
258 \\
261\end{array}$ & $\begin{array}{l}19.0 \\
23.0 \\
20.5 \\
16.5\end{array}$ & $\begin{array}{l}132 \\
137 \\
123 \\
120\end{array}$ & $\begin{array}{r}94 \\
96 \\
109 \\
82\end{array}$ & $\begin{array}{l}11.6 \\
11.1 \\
13.0 \\
13.7\end{array}$ & $\begin{array}{r}138.8 \\
189.6 \\
130.9 \\
89.6\end{array}$ & $\begin{array}{l}689 \\
987 \\
558 \\
339\end{array}$ & $\begin{array}{r}0.53 \\
.48 \\
.46 \\
.50\end{array}$ & $\begin{array}{r}0.29 \\
.30 \\
.11 \\
.31\end{array}$ & $\begin{array}{l}41 \\
43 \\
35 \\
31\end{array}$ \\
\hline Average... & 258 & 20.0 & 128 & 05 & 12.3 & 137.0 & 642 & .49 & .25 & 37 \\
\hline
\end{tabular}

$20233-$ No. $22-10$ 
TABLE VI.-Acre yields of White Fine and measurements of sample trees-Continued.

MeasUremexts OF SAMTLE Trees.

DOMLAANT GROWTH.

\begin{tabular}{|c|c|c|c|c|c|c|c|c|c|c|}
\hline \multirow[b]{2}{*}{ Tree numher. } & \multirow[b]{2}{*}{ Age. } & \multirow[b]{2}{*}{$\begin{array}{c}\text { Diameter } \\
\text { (breast } \\
\text { high). }\end{array}$} & \multirow[b]{2}{*}{ Height. } & \multirow[b]{2}{*}{$\begin{array}{l}\text { Height to } \\
\text { hase of } \\
\text { crowa. }\end{array}$} & \multirow[b]{2}{*}{$\begin{array}{l}\text { Rings } \\
\text { per inch } \\
\text { on } \\
\text { stump. }\end{array}$} & \multicolumn{2}{|c|}{ Voiume. } & \multirow[b]{2}{*}{$\begin{array}{l}\text { Factor } \\
\text { of } \\
\text { sbape. }\end{array}$} & \multirow{2}{*}{$\begin{array}{l}\text { Ratio of } \\
\text { length } \\
\text { of erown } \\
\text { to totai } \\
\text { height of } \\
\text { tree. }\end{array}$} & \multirow{2}{*}{$\begin{array}{l}\text { Lambor } \\
\text { yroduct } \\
\text { under } \\
\text { present } \\
\text { practice } \\
\text { (per cent } \\
\text { usca of } \\
\text { totai } \\
\text { roinmo } \\
\text { of stem). }\end{array}$} \\
\hline & & & & & & Tree. & $\begin{array}{c}\text { Mer- } \\
\text { chantahie } \\
\text { timber. }\end{array}$ & & & \\
\hline 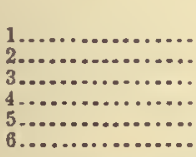 & $\begin{array}{c}\text { Teare. } \\
228 \\
239 \\
234 \\
240 \\
239 \\
239\end{array}$ & $\begin{array}{l}\text { Inches. } \\
30.5 \\
40.0 \\
37.0 \\
31.5 \\
37.0 \\
35.5\end{array}$ & $\begin{array}{r}\text { Feet. } \\
136 \\
138 \\
146 \\
140 \\
148 \\
140\end{array}$ & $\begin{array}{r}\text { Feet. } \\
80 \\
80 \\
72 \\
86 \\
96 \\
80\end{array}$ & $\begin{array}{l}\text { No. } \\
5.6 \\
5.6 \\
5.4 \\
9.6 \\
6.1 \\
6.1\end{array}$ & $\begin{array}{c}\text { Cubie feet. } \\
300.0 \\
487.1 \\
482.8 \\
278.2 \\
466.6 \\
401.2\end{array}$ & $\begin{array}{c}\text { Feet } B . \mathbf{M} \text {. } \\
1,682 \\
3,056 \\
2,626 \\
1,425 \\
3,129 \\
2,605\end{array}$ & $\begin{array}{l}0.43 \\
.40 \\
.44 \\
.37 \\
.42 \\
.42\end{array}$ & $\begin{array}{r}0.41 \\
.42 \\
.51 \\
.39 \\
.35 \\
.43\end{array}$ & $\begin{array}{l}47 \\
52 \\
45 \\
42 \\
56 \\
54\end{array}$ \\
\hline A verage... & 236 & 35.0 & 141 & 82 & 0.4 & 403.0 & 2,420 & .41 & .42 & 49 \\
\hline
\end{tabular}

OPPRESSED GROWTH.

\begin{tabular}{|c|c|c|c|c|c|c|c|c|c|c|}
\hline $8 \ldots \ldots \ldots \ldots \ldots$ & $\begin{array}{l}235 \\
238\end{array}$ & $\begin{array}{l}23.0 \\
24.5\end{array}$ & $\begin{array}{l}122 \\
126\end{array}$ & $\begin{array}{l}86 \\
92\end{array}$ & $\begin{array}{l}9.3 \\
8.7\end{array}$ & $\begin{array}{l}152.3 \\
174.9\end{array}$ & $\begin{array}{l}656 \\
820\end{array}$ & $\begin{array}{r}0.43 \\
.42\end{array}$ & $\begin{array}{r}0.29 \\
.27\end{array}$ & $\begin{array}{l}35 \\
36\end{array}$ \\
\hline A verage... & 236 & 23.5 & 124 & 89 & 9.0 & 163.0 & 738 & .42 & .28 & 35 \\
\hline
\end{tabular}

SCPPRESSED GROWTH.

\begin{tabular}{|c|c|c|c|c|c|c|c|c|c|c|}
\hline $10 \ldots \ldots \ldots \ldots \ldots \ldots$ & \}$_{240}^{230}$ to & $\begin{array}{l}19 \\
17\end{array}$ & $\begin{array}{r}102 \\
99\end{array}$ & $\begin{array}{l}50 \\
80\end{array}$ & (?) & $\begin{array}{l}90.3 \\
70.2\end{array}$ & $\begin{array}{l}386 \\
236\end{array}$ & $\begin{array}{r}0.44 \\
.44\end{array}$ & $\begin{array}{r}0.51 \\
.19\end{array}$ & $\begin{array}{l}35 \\
28\end{array}$ \\
\hline Average... & ........ & 18 & - $\quad 100$ & 65 & .............. & 80.0 & 311 & .44 & .35 & 31 \\
\hline
\end{tabular}

(5) Site $k$ :

Jefierson County.

[1,500 to 1,600 feet ahove sen level.]

Soil: Reddish-brown clayey loam, deep, fresh, and cirained by $\mathrm{W}$ indfaii Run.

Forest conditions: White Pine, with Hemiock and occasionai hard woods; Hemiock comparattreis

8 mall, acting as an underwood, giving ample shade to the stems of the White Pine.

MEASUREMENTS OF SAMPLE TREES.

\begin{tabular}{|c|c|c|c|c|c|c|c|c|c|c|}
\hline \multirow[b]{2}{*}{ Tree number. } & \multirow[b]{2}{*}{ Ago. } & \multirow[b]{2}{*}{$\begin{array}{c}\text { Diameter } \\
\text { (hreast } \\
\text { high). }\end{array}$} & \multirow[b]{2}{*}{ Height. } & \multirow[b]{2}{*}{$\begin{array}{c}\text { Height to } \\
\text { base of } \\
\text { crown. }\end{array}$} & \multirow[b]{2}{*}{$\begin{array}{l}\text { Rings } \\
\text { per inch } \\
\text { on } \\
\text { stnmp. }\end{array}$} & \multicolumn{2}{|c|}{ Voinme. } & \multirow[b]{2}{*}{$\begin{array}{l}\text { Factor } \\
\text { of } \\
\text { shape. }\end{array}$} & \multirow[b]{2}{*}{$\begin{array}{l}\text { Ratio of } \\
\text { ieagtb } \\
\text { of crown } \\
\text { to total } \\
\text { beight of } \\
\text { tree. }\end{array}$} & \multirow{2}{*}{$\begin{array}{l}\text { Lumher } \\
\text { product } \\
\text { under } \\
\text { prescnt } \\
\text { practico } \\
\text { (per cent } \\
\text { used of } \\
\text { totai } \\
\text { volume } \\
\text { of stom). }\end{array}$} \\
\hline & & & & & & Tree. & $\begin{array}{c}\text { Mer. } \\
\text { chantabie } \\
\text { timbar. }\end{array}$ & & & \\
\hline 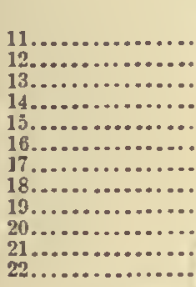 & $\begin{array}{c}\text { Tears. } \\
247 \\
241 \\
238 \\
236 \\
238 \\
241 \\
233 \\
227 \\
342 \\
236 \\
210 \\
236\end{array}$ & $\begin{array}{r}\text { Inches. } \\
32.5 \\
35.0 \\
32.5 \\
32.5 \\
34.0 \\
30.0 \\
31.0 \\
29.5 \\
32.0 \\
35.0 \\
34.5 \\
32.5\end{array}$ & $\begin{array}{r}\text { Feet. } \\
146 \\
176 \\
142 \\
158 \\
148 \\
143 \\
145 \\
142 \\
153 \\
158 \\
152 \\
158\end{array}$ & $\begin{array}{r}\text { Feet. } \\
96 \\
90 \\
06 \\
06 \\
96 \\
96 \\
90 \\
88 \\
100 \\
112 \\
90 \\
02\end{array}$ & $\begin{array}{l}\text { No. } \\
0.3 \\
7.3 \\
6.2 \\
8.2 \\
6.2 \\
8.0 \\
6.5 \\
6.6 \\
7.2 \\
6.2 \\
6.2 \\
5.8\end{array}$ & $\begin{array}{c}\text { Cubic feet } \\
398.0 \\
499.2 \\
359.7 \\
386.3 \\
382.4 \\
322.2 \\
323.4 \\
255.8 \\
335.5 \\
485.3 \\
396.8 \\
387.9\end{array}$ & \begin{tabular}{|c|} 
Feet $\boldsymbol{B} . \boldsymbol{M}$. \\
2,221 \\
3,003 \\
2,053 \\
2,244 \\
2,236 \\
1,832 \\
2,464 \\
1,391 \\
1,985 \\
2,795 \\
2,312 \\
2,243
\end{tabular} & $\begin{array}{l}0.47 \\
.42 \\
.44 \\
.42 \\
.41 \\
.46 \\
.42 \\
.38 \\
.39 \\
.46 \\
.45 \\
.42\end{array}$ & $\begin{array}{l}0.34 \\
.49 \\
.32 \\
.40 \\
.35 \\
.33 \\
.38 \\
.38 \\
.34 \\
.29 \\
.41 \\
.41\end{array}$ & $\begin{array}{l}46 \\
50 \\
48 \\
48 \\
49 \\
47 \\
63 \\
45 \\
46 \\
48 \\
49 \\
48\end{array}$ \\
\hline Arerage... & 238 & 32.5 & 152 & 95 & 6.7 & 378.0 & 2,231 & .43 & .37 & 49 \\
\hline
\end{tabular}




\section{YIELD OF SECOND-GROWTH WEITE PINE, WITH MEASUREMENTS OF YOUNG PINE TAKEN FOR ANALYSIS.}

The yield of second-growth Wlite Pine on selected sample areas in the States named is shown in the following notes and tabulations, which also give, for illustration, the number of trees, volume, and average anuual accretion of pine, the soil, forest conditions, acre yields, and measure. ments of sample young pines taken for anlysis:

TABLE VII.-Acre yields of second-growth IThite Pine, with measurements of young pine taken for analysis.

\section{A.-PENXSTLVANIA:}

(1) StrE c:

$$
\begin{aligned}
& \text { Inzerne Connty. } \\
& \text { [1,400 to 1,500 feot above sea level.] } \\
& \text { Half acre No. } 1 .
\end{aligned}
$$$$
\text { Sample area: I acro. }
$$

Soil: Darl-hrown loamy sand, mellinm grain, with pebbles and gravel, Iight, loose, deep, fresh, face cover of abundant leares and scanty fern.

Forent conditions: White Pine, nixed with Mapie, Beech, Hemlock, and scattering Teliow and

White 1Birch, White and Red Oak, and occasional Black Cherry, in a valies sloping towari sonthwest and bordered on all sides by hills orer 300 feet above station; underctowt moder. ately dense, of young Hemlock, Beech, Maple, Birch.'

age of pine: 60 to 80 jears.

Density of crowa cover: 0.5 .

\begin{tabular}{|c|c|c|c|c|}
\hline \multicolumn{5}{|c|}{ Whito Pine. } \\
\hline \multirow[b]{2}{*}{$\begin{array}{l}\text { Ninmber } \\
\text { of trees. }\end{array}$} & \multirow[b]{2}{*}{$\begin{array}{c}\text { Diameter } \\
\text { (breast } \\
\text { bigh). }\end{array}$} & \multirow[b]{2}{*}{ Height. } & \multicolumn{2}{|c|}{ Volume. } \\
\hline & & & Bole. & $\begin{array}{l}\text { Mer. } \\
\text { chantable } \\
\text { timber. }\end{array}$ \\
\hline $\begin{array}{r}2 \\
2 \\
2 \\
10 \\
4 \\
6 \\
6 \\
8 \\
8 \\
4 \\
4 \\
8 \\
2 \\
4 \\
6 \\
2 \\
2\end{array}$ & $\begin{array}{r}\text { Inches. } \\
6 \\
7 \\
8 \\
9 \\
9 \\
10 \\
11 \\
12 \\
13 \\
14 \\
15 \\
16 \\
17 \\
18 \\
19 \\
20 \\
22 \\
23\end{array}$ & $\begin{array}{r}\text { Feet. } \\
50 \\
50 \\
50 \\
50 \\
50 \\
60 \\
60 \\
60 \\
60 \\
80 \\
80 \\
80 \\
80 \\
80 \\
80 \\
80 \\
80\end{array}$ & $\begin{array}{c}\text { Cubicfeet. } \\
11 \\
12 \\
19 \\
115 \\
60 \\
126 \\
150 \\
208 \\
240 \\
170 \\
184 \\
456 \\
135 \\
276 \\
750\end{array}$ & Feet $B .3$. \\
\hline $\begin{array}{l}80 \text { trees } \\
\text { Tota } \\
\text { Tota }\end{array}$ & $\begin{array}{l}\text { ouhio f } \\
\text { ect } B \text {. }\end{array}$ & & & $\begin{array}{r}2,018 \\
\therefore 14,006\end{array}$ \\
\hline
\end{tabular}

Number of trees: 216 .

HALF-ACRE YIELD.

'Intermixed species: Japle, 68; Beech, 22; Hemlock, 18; Yellow and White Birch, 14; White and Red Oak, 12; Cherry 2. Undergrowth: Yonng Hemlock, 280; Beech, 146; Japle, 84; Birch, 12. 
TABLE VII.-Acre yields of second-growth White Pine, with measurements of young pine taken for analysio-Continued.

A.-PENXSYLVANIA-Continned.

Half acre No. 2.

Soil: Reddish.brown sandy loam, fine grain, medium looso, deep, fresh, drained by Brar Creek, Age of pine: 60 to 80 years. 2 to 3 inches mold on top, and snrface cover of abundant leaves; Laurel and few Fern. sional Spruce, on aneven ground of a valley sloping toward northeast and hordered on all lock, Bcech, Maple, snd a few young Spruoo."

HALF.ACRE YIELD.

\begin{tabular}{|c|c|c|c|c|}
\hline \multicolumn{5}{|c|}{ White Pine. } \\
\hline \multirow[b]{2}{*}{$\begin{array}{l}\text { Numher } \\
\text { of trees. }\end{array}$} & \multirow{2}{*}{$\begin{array}{l}\text { Diameter } \\
\text { (breast } \\
\text { high). }\end{array}$} & \multirow[b]{2}{*}{ Height. } & \multicolumn{2}{|c|}{ Volume. } \\
\hline & & & Bole. & $\begin{array}{c}\text { Mer- } \\
\text { chantahle } \\
\text { timber. }\end{array}$ \\
\hline $\begin{array}{r}14 \\
2 \\
4 \\
12 \\
10 \\
14 \\
10 \\
8 \\
12 \\
16 \\
4 \\
4 \\
14 \\
8 \\
6 \\
6 \\
4 \\
4 \\
2\end{array}$ & $\begin{array}{r}\text { Inches. } \\
3 \text { to } 6 \\
6 \\
7 \\
8 \\
9 \\
10 \\
11 \\
12 \\
13 \\
14 \\
15 \\
16 \\
17 \\
19 \\
20 \\
21 \\
22 \\
24 \\
25\end{array}$ & $\begin{array}{r}\text { Feet. } \\
40 \\
50 \\
56 \\
50 \\
50 \\
50 \\
60 \\
60 \\
60 \\
60 \\
80 \\
80 \\
80 \\
80 \\
80 \\
80 \\
80 \\
80 \\
80\end{array}$ & $\begin{array}{c}\text { Oubic feet. } \\
11 \\
24 \\
114 . \\
115 \\
210 \\
210 \\
200 \\
312 \\
480 \\
176 \\
184 \\
798 \\
552 \\
\\
1,650\end{array}$ & Feet B.M. \\
\hline $\begin{array}{r}154 \text { tree } \\
\text { Tot } \\
\text { Tot }\end{array}$ & $\begin{array}{l}\text { cnhic fe } \\
\text { feet } B \text {. }\end{array}$ & 政 & & $\begin{array}{r}5,036 \\
-24,173\end{array}$ \\
\hline
\end{tabular}

Average annual occretion: White Pine, 72 cubic feet.

\section{MEASUREMENTS OF SAMPLE YOUNG PINE TREES.}

Foreat conditions: Ridge land densely covered with young hardwoods-mainly White Oak and - Red Oak, among which White Pine is scattered.

\begin{tabular}{|c|c|c|c|c|c|c|c|c|c|c|}
\hline \multirow[b]{2}{*}{ Tree number. } & \multirow[b]{2}{*}{ Age. } & \multirow[b]{2}{*}{$\begin{array}{c}\text { Diameter } \\
\text { (hreast } \\
\text { high). }\end{array}$} & \multirow[b]{2}{*}{ Height. } & \multirow[b]{2}{*}{$\begin{array}{l}\text { Height to } \\
\text { hase of } \\
\text { crown. }\end{array}$} & \multirow[b]{2}{*}{$\begin{array}{l}\text { Rings } \\
\text { per inch } \\
\text { on } \\
\text { stnmp. }\end{array}$} & \multicolumn{2}{|c|}{ Volnme. } & \multirow[b]{2}{*}{$\begin{array}{l}\text { Factor } \\
\text { of } \\
\text { shape. }\end{array}$} & \multirow{2}{*}{$\begin{array}{l}\text { Ratio of } \\
\text { length } \\
\text { of crown } \\
\text { to total } \\
\text { height of } \\
\text { tree. }\end{array}$} & \multirow{2}{*}{$\begin{array}{c}\text { Lumber } \\
\text { prodnct } \\
\text { nnder } \\
\text { present } \\
\text { practice } \\
\text { (per cent } \\
\text { used of } \\
\text { total } \\
\text { volume } \\
\text { of stem). }\end{array}$} \\
\hline & & & & & & True. & $\begin{array}{l}\text { Mer- } \\
\text { chantahle } \\
\text { timber. }\end{array}$ & & & \\
\hline $\begin{array}{l}1 \\
2 \\
3 \\
3 \\
4 \ldots \ldots \ldots \ldots \ldots \ldots \ldots \ldots \ldots\end{array}$ & $\begin{array}{l}\text { Teare. } \\
123 \\
132 \\
134 \\
128\end{array}$ & $\begin{array}{r}\text { Inches. } \\
29.0 \\
20.0 \\
22.0 \\
31.0\end{array}$ & $\begin{array}{r}\text { Feet. } \\
84 \\
81 \\
81 \\
90\end{array}$ & $\begin{array}{r}\text { Feet. } \\
34 \\
20 \\
16 \\
20\end{array}$ & $\begin{array}{r}\text { No. } \\
3.5 \\
5.7 \\
5.7 \\
3.8\end{array}$ & $\begin{array}{c}\text { Cubic feet } \\
140.6 \\
78.1 \\
81.6 \\
193.8\end{array}$ & Feet $\begin{array}{c}\text { B. } 31 \\
627 \\
369 \\
369 \\
-935\end{array}$ & $\begin{array}{l}0.36 \\
.44 \\
.38 \\
.41\end{array}$ & $\begin{array}{r}0.60 \\
.75 \\
.80 \\
.77\end{array}$ & $\begin{array}{r}37 \\
a 39 \\
a 38 \\
40\end{array}$ \\
\hline Average... & 129 & 25.5 & 84 & 22 & 4.7 & 124.0 & 575 & .40 & .73 & 38 \\
\hline
\end{tabular}

a Oppressed for the last forty years. 


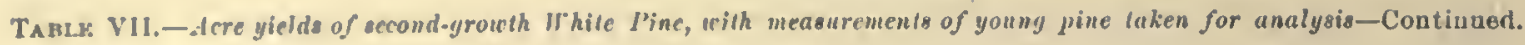

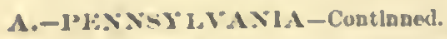

Soil: Remhliah.lurown snoly loam, medilum loose, fresh, deep, sul well drained, wlth surface corer of abnodane cearta.

Foreut conditions: Unrwwoods-mninls Bhech. Oak, Maplo, Chestunt, and Birch-mixed with

White Pue, I'lich L'lne, Uemlock, andi occasional Spruce.

MEASURFMENTS OF SAMPLE IOUNG PINE TIRES.

DOMINAST GROWTR.

\begin{tabular}{|c|c|c|c|c|c|c|c|c|c|c|}
\hline \multirow[b]{2}{*}{ Treo number. } & \multirow[b]{2}{*}{ Age. } & \multirow[b]{2}{*}{$\begin{array}{c}\text { Diameter } \\
\text { (breast } \\
\text { high). }\end{array}$} & \multirow[b]{2}{*}{ Hefght. } & \multirow[b]{2}{*}{$\begin{array}{l}\text { Helght to } \\
\text { baso of } \\
\text { crown. }\end{array}$} & \multirow[b]{2}{*}{$\begin{array}{l}\text { Rings } \\
\text { per lnch } \\
\text { on } \\
\text { stump. }\end{array}$} & \multicolumn{2}{|c|}{ Folume. } & \multirow[b]{2}{*}{$\begin{array}{l}\text { Factor } \\
\text { of } \\
\text { shaje. }\end{array}$} & \multirow[b]{2}{*}{$\begin{array}{l}\text { Ratio of } \\
\text { length } \\
\text { of crown } \\
\text { to total } \\
\text { helglit of } \\
\text { treo. }\end{array}$} & \multirow{2}{*}{$\begin{array}{l}\text { Lumbor } \\
\text { product } \\
\text { uoder } \\
\text { present } \\
\text { practice } \\
\text { (prer cont } \\
\text { used of } \\
\text { total } \\
\text { rolume } \\
\text { of stem). }\end{array}$} \\
\hline & & & & & & Tree. & $\begin{array}{l}\text { Mer. } \\
\text { chantable } \\
\text { tImber. }\end{array}$ & & & \\
\hline $1 . \ldots \ldots \ldots \ldots . . . . .$. & $\begin{array}{c}\text { Fears. } \\
163\end{array}$ & $\begin{array}{r}\text { Inches. } \\
29\end{array}$ & $\begin{array}{l}\text { Feet. } \\
116\end{array}$ & $\begin{array}{r}\text { Feet. } \\
50\end{array}$ & $\begin{array}{l}\text { No. } \\
5.0\end{array}$ & $\begin{array}{c}\text { Culic feet. } \\
101.4\end{array}$ & Feet ${ }_{0 i 7} . M$. & 0.36 & 0.57 & 40 \\
\hline $\begin{array}{l}1 \\
2 \\
2 \\
3 \\
1 \ldots \ldots \ldots \ldots \ldots \ldots \ldots \ldots \ldots\end{array}$ & $\begin{array}{l}08 \\
98 \\
92 \\
97\end{array}$ & $\begin{array}{l}25.0 \\
20.0 \\
31.0 \\
19.5\end{array}$ & $\begin{array}{l}84 \\
73 \\
97 \\
76\end{array}$ & $\begin{array}{l}32 \\
32 \\
32 \\
26\end{array}$ & $\begin{array}{l}3.5 \\
4.3 \\
2.5 \\
4.3\end{array}$ & $\begin{array}{r}121.2 \\
76.1 \\
210.0 \\
67.0\end{array}$ & $\begin{array}{l}530 \\
360 \\
976 \\
363\end{array}$ & $\begin{array}{r}.42 \\
.48 \\
.41 \\
.42\end{array}$ & $\begin{array}{l}.62 \\
.56 \\
.67 \\
.66\end{array}$ & $\begin{array}{l}36 \\
40 \\
10 \\
45\end{array}$ \\
\hline Arerago.. & 96 & 24.0 & 82 & 30 & 3.5 & 118.0 & 557 & .43 & .63 & 40 \\
\hline
\end{tabular}

Soil: Fresh sand, well drained.

Foreat conditions: $A$ young White Pine grove mixed with rature Sprnce, Hemlock, and scattering hard wools.

\begin{tabular}{|c|c|c|c|c|c|c|c|c|c|c|}
\hline \multirow[b]{2}{*}{ Tree numher. } & \multirow[b]{2}{*}{ Age. } & \multirow[b]{2}{*}{$\begin{array}{c}\text { Dlameter } \\
\text { (breast } \\
\text { blgh). }\end{array}$} & \multirow[b]{2}{*}{ Helght. } & \multirow[b]{2}{*}{$\begin{array}{l}\text { Height to } \\
\text { haso of } \\
\text { crown. }\end{array}$} & \multirow[b]{2}{*}{$\begin{array}{l}\text { Rings } \\
\text { per loch } \\
\text { on } \\
\text { stmup. }\end{array}$} & \multicolumn{2}{|c|}{ Folume. } & \multirow[b]{2}{*}{$\begin{array}{c}\text { Factor } \\
\text { of } \\
\text { shape. }\end{array}$} & \multirow[b]{2}{*}{$\begin{array}{l}\text { Ratio of } \\
\text { length } \\
\text { of crown } \\
\text { to total } \\
\text { height of } \\
\text { trec. }\end{array}$} & \multirow{2}{*}{$\begin{array}{l}\text { Lumber } \\
\text { product } \\
\text { under } \\
\text { present } \\
\text { practlco } \\
\text { (per cent } \\
\text { used of } \\
\text { total } \\
\text { rolume } \\
\text { of stem). }\end{array}$} \\
\hline & & & & & & Tree. & $\begin{array}{c}\text { MI er- } \\
\text { ohantahle } \\
\text { tlmber. }\end{array}$ & & & \\
\hline 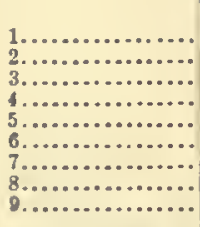 & $\begin{array}{c}\text { Fears. } \\
64 \\
57 \\
50 \\
47 \\
52 \\
10 \\
52 \\
54 \\
54\end{array}$ & $\begin{array}{r}\text { Inches. } \\
14.5 \\
14.5 \\
8.5 \\
8.0 \\
11.0 \\
11.5 \\
9.5 \\
8.0 \\
10.0\end{array}$ & $\begin{array}{r}\text { Feet. } \\
54 \\
58 \\
50 \\
46 \\
50 \\
46 \\
53 \\
54 \\
56\end{array}$ & $\begin{array}{r}\text { Feet. } \\
18 \\
20 \\
20 \\
18 \\
20 \\
18 \\
18 \\
18 \\
18\end{array}$ & $\begin{array}{l}\text { No. } \\
4.0 \\
2.7 \\
4.8 \\
5.0 \\
3.7 \\
3.6 \\
4.0 \\
5.7 \\
4.3\end{array}$ & $\begin{array}{c}\text { Cubic feet. } \\
28.7 \\
31.4 \\
9.5 \\
7.3 \\
14.2 \\
15.7 \\
12.1 \\
10.1 \\
14.7\end{array}$ & $\begin{array}{c}\text { Feet B. } M . \\
110 \\
144 \\
43 \\
32 \\
54 \\
59 \\
48 \\
34 \\
50\end{array}$ & $\begin{array}{l}0.46 \\
.47 \\
.48 \\
.45 \\
.43 \\
.47 \\
.46 \\
.53 \\
.48\end{array}$ & $\begin{array}{l}0.66 \\
.66 \\
.60 \\
.61 \\
.60 \\
.61 \\
.66 \\
.66 \\
.68\end{array}$ & $\begin{array}{l}31 \\
38 \\
36 \\
37 \\
31 \\
81 \\
33 \\
27 \\
33\end{array}$ \\
\hline Arerago... & 33 & 10.5 & 52 & 19 & 4.2 & 16.0 & 65 & .47 & .64 & 33 \\
\hline
\end{tabular}

(2) SrEE $e$ :

Clinton Connty.

$[1,500$ to 1,600 feet abore sea level. $]$

Soil: Lonmy and with rocks on face of slope, the brown-yellowish coarse grain full of shales, snrface cover of 2 to 3 inches mold and abundant leates.

Forest conditions: 13rush of very ronng White. Red and Chestuut Oak, with scattering White Pine (14). and occaslonal Chestnnt Uak (6), Jack Plne (3), and Norw ny Pine (2), on a steep hil 200 feot above station, facing south; undergrowth, dense, of young bardwoods of same species as abore.
Sample area: 1 acro.

Age of plne: 120 to 130 years Density of crown coter: 0.2 (scattered).

Numbor of trees : 25. ACRE TIELD.

\begin{tabular}{|c|c|c|c|c|}
\hline \multicolumn{5}{|c|}{ Whlte Pine. } \\
\hline \multirow[b]{2}{*}{$\begin{array}{l}\text { Number } \\
\text { of trees. }\end{array}$} & \multirow[b]{2}{*}{$\begin{array}{c}\text { Diameter } \\
\text { (brenst } \\
\text { high). }\end{array}$} & \multirow[b]{2}{*}{ Height. } & \multicolumn{2}{|c|}{ Folnme. } \\
\hline & & & Bole. & $\begin{array}{c}\text { Mer- } \\
\text { chantable } \\
\text { timbor. }\end{array}$ \\
\hline $\begin{array}{l}1 \\
1 \\
1 \\
3 \\
1 \\
3 \\
3 \\
1\end{array}$ & $\begin{array}{r}\text { Inehes. } \\
10 \\
15 \\
19 \\
21 \\
22 \\
24 \\
25 \\
29\end{array}$ & $\begin{array}{c}\text { Feet. } \\
70 \\
76 \\
84 \\
85 \\
87 \\
85 \\
85 \\
85\end{array}$ & $\begin{array}{c}\text { Cubic feet. } \\
19 \\
46 \\
66 \\
270 \\
99 \\
345 \\
372 \\
151\end{array}$ & $\begin{array}{r}\text { Feet } B . M . \\
161 \\
370 \\
1,245 \\
432 \\
1,449 \\
2,004 \\
760\end{array}$ \\
\hline $\begin{array}{l}14 \text { trees } \\
\text { Tot } \\
\text { Tot }\end{array}$ & cable I & & & $\begin{array}{l}1.368 \\
\ldots 6,421\end{array}$ \\
\hline
\end{tabular}


TABLE VII. - Acre yields of second-growth While Pine, with measurements of young pine taken for analysis-Continued.

\section{A.-I'ENXSYLVANIA-Continued.}

MEASUREMENTS OF SAMPLE YOUNG PINE TREES.

\begin{tabular}{|c|c|c|c|c|c|c|c|c|c|c|}
\hline \multirow[b]{2}{*}{ Tree nnmber. } & \multirow[b]{2}{*}{ Age. } & \multirow[b]{2}{*}{$\begin{array}{c}\text { Diameter } \\
\text { (hreast } \\
\text { high). }\end{array}$} & \multirow[b]{2}{*}{ Height. } & \multirow[b]{2}{*}{$\begin{array}{l}\text { Height to } \\
\text { base of } \\
\text { erown. }\end{array}$} & \multirow[b]{2}{*}{$\begin{array}{l}\text { Rings } \\
\text { per inch } \\
\text { on } \\
\text { stump. }\end{array}$} & \multicolumn{2}{|c|}{ Volumo. } & \multirow[b]{2}{*}{$\begin{array}{l}\text { Factor } \\
\text { of } \\
\text { ehapo. }\end{array}$} & \multirow[b]{2}{*}{$\begin{array}{l}\text { Ratio of } \\
\text { length of } \\
\text { crown } \\
\text { to total } \\
\text { beight of } \\
\text { treo. }\end{array}$} & \multirow{2}{*}{$\begin{array}{l}\text { Lumber } \\
\text { product } \\
\text { under } \\
\text { present } \\
\text { practice } \\
\text { (per cent } \\
\text { used of } \\
\text { total } \\
\text { rolume } \\
\text { of stem). }\end{array}$} \\
\hline & & & & & & Treo. & $\begin{array}{c}\text { Mer- } \\
\text { chantable } \\
\text { timber. }\end{array}$ & & & \\
\hline $\begin{array}{l}1 \\
2 \\
3 \\
4 \\
5 \\
6 \\
7 \\
8 \\
8 \\
9 \\
10 \\
11 \\
12 \ldots\end{array}$ & $\begin{array}{l}\text { Fears. } \\
125 \\
124 \\
124 \\
116 \\
122 \\
(1) \\
120 \\
128 \\
127 \\
122 \\
125 \\
(1)\end{array}$ & $\begin{array}{r}\text { Inches. } \\
21.0 \\
24.0 \\
22.0 \\
18.5 \\
19.5 \\
24.5 \\
21.0 \\
19.0 \\
19.5 \\
15.0 \\
17.0 \\
20.5\end{array}$ & $\begin{array}{r}\text { Feet. } \\
78 \\
86 \\
87 \\
79 \\
85 \\
83 \\
89 \\
84 \\
88 \\
76 \\
84 \\
76\end{array}$ & $\begin{array}{r}\text { Feet. } \\
40 \\
28 \\
34 \\
36 \\
40 \\
36 \\
38 \\
40 \\
40 \\
36 \\
38 \\
38\end{array}$ & $\begin{array}{l}\text { To. } \\
4.8 \\
5.4 \\
5.5 \\
6.2 \\
5.9 \\
(?) \\
5.4 \\
6.4 \\
5.7 \\
7.1 \\
6.9 \\
(7)\end{array}$ & \begin{tabular}{|c|} 
Cubicfeet. \\
88.6 \\
115.8 \\
99.0 \\
63.0 \\
79.7 \\
124.5 \\
94.5 \\
66.2 \\
02.0 \\
46.2 \\
61.4 \\
78.0
\end{tabular} & $\begin{array}{c}\text { Feet } B . H . \\
404 \\
483 \\
432 \\
280 \\
364 \\
668 \\
429 \\
370 \\
446 \\
161 \\
267 \\
293\end{array}$ & $\begin{array}{l}0.47 \\
.42 \\
.43 \\
.43 \\
.45 \\
.46 \\
.44 \\
.40 \\
.50 \\
.49 \\
.46 \\
.45\end{array}$ & $\begin{array}{l}0.48 \\
.67 \\
.61 \\
.54 \\
.53 \\
.56 \\
.57 \\
.52 \\
.54 \\
.52 \\
.57 \\
.50\end{array}$ & $\begin{array}{l}39 \\
34 \\
36 \\
36 \\
38 \\
44 \\
37 \\
46 \\
40 \\
30 \\
36 \\
31\end{array}$ \\
\hline Arerage... & 123 & 20 & 83 & 37 & 6.0 & 84.0 &.$^{383}$ & .45 & .55 & 37 \\
\hline
\end{tabular}

(3) SiTz g:

Clearfield County.

Sample area: 1 acre. $[1,200$ to 1,500 feet abore sea level. $]$

Soil: Fellow clayey loam, medium grain. deep, fresh, well drained (three small streams cross the Age of pine: 25 to 35 yeare. hollow in different directions). With 2 to 3 inches mold on top, eurface cover of leares. Fern, Gronnd Pine, Wintergreen, Elderberry, Blackberry, and Dogwood; subsoil laminated shalo of indefinite depth.

Forest conditions : Yomg White Pine intermixed with young hardwoods in hollow extending north and sonth. and bounded on the went by lill over 2 feet ahore statiou : undergrowth dense, of rery smail and varions hardwoods, wainly Black Birch, Maple, and Beecb, and fow White Birch and Hemlock.1

- ACRE YIELD.

Density of crown corer: 0.5 to 0.6 .

Number of trecs : (?)

\begin{tabular}{|c|c|c|c|c|}
\hline \multirow[b]{3}{*}{$\begin{array}{l}\text { Number } \\
\text { of trees. }\end{array}$} & \multicolumn{4}{|c|}{ Whito Pine. } \\
\hline & \multirow[b]{2}{*}{$\begin{array}{c}\text { Diamcter } \\
\text { (breast } \\
\text { higu). }\end{array}$} & \multirow[b]{2}{*}{ Height. } & \multicolumn{2}{|c|}{ Volume. } \\
\hline & & & Bole. & $\begin{array}{c}\text { Mer. } \\
\text { chantable } \\
\text { timber. }\end{array}$ \\
\hline 154 & $\begin{array}{l}\text { Inches. } \\
\text { Under } 3\end{array}$ & Feet. & Oubicfeet. & Feet B. $1 \%$. \\
\hline 41 & 3 to 5 & 16 to 37 & 61.5 & \\
\hline 54 & 6 to 10 & 40 to 47 & 432.0 & \\
\hline 34 & 10 to 14 & 42 to 50 & 612.0 & \\
\hline 2 & 14 to 18 & . . . . . . . & 42.0 & \\
\hline
\end{tabular}

dverage annual accretion: Whito Pine, 38 cubic feet.

1 Internixed species : White Pine, $131+154$ small; Aspen, $12+54$ small; Besch, $1+137$ small; Maple, 6+254 small; Oak, $5+12$ emall; White Ash, 3+21 small; Cnenmher, $6+90$ small: Black Cherry, 2-77 small; Black Birch, 17+415 small; Hamamelis, 4 small; Basswood, 6 small;

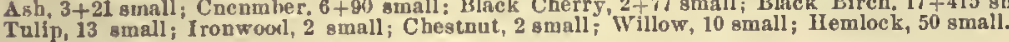


TABL: VII.-Acre yields of second-growth Thife Pine, with measurements of young pine taken for analysis-Continued.

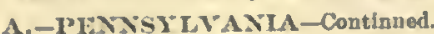

MEASUREMEXTS OF SAMPLE YOUTG PIXF TIRES.

DOMIYANT OROWTH

\begin{tabular}{|c|c|c|c|c|c|c|c|c|}
\hline Treo nnmber. & Age. & $\begin{array}{c}\text { Diameter } \\
\text { (breast } \\
\text { higb). }\end{array}$ & Height. & $\begin{array}{l}\text { Hoight to } \\
\text { base of } \\
\text { crown. }\end{array}$ & $\begin{array}{l}\text { Ring: } \\
\text { per incb } \\
\text { on } \\
\text { stump. }\end{array}$ & $\begin{array}{l}\text { Volnme } \\
\text { of tree. }\end{array}$ & $\begin{array}{c}\text { Factor } \\
\text { of } \\
\text { shape. }\end{array}$ & $\begin{array}{l}\text { Jatio of } \\
\text { leugth } \\
\text { of crown } \\
\text { to total } \\
\text { heigbt of } \\
\text { tree. }\end{array}$ \\
\hline $\begin{array}{l}10 \ldots \ldots \ldots \ldots \ldots \\
17, \ldots \ldots \ldots \ldots \ldots \\
9 \ldots \ldots \ldots \ldots \ldots \ldots \\
11 \ldots \ldots \ldots \ldots \ldots \ldots\end{array}$ & $\begin{array}{c}\text { Tearz. } \\
33 \\
36 \\
35 \\
34\end{array}$ & $\begin{array}{r}\text { Inches. } \\
13.5 \\
14.0 \\
12.5 \\
13.5\end{array}$ & $\begin{array}{r}\text { Feet. } \\
43.8 \\
47.0 \\
49.0 \\
43.0\end{array}$ & $\begin{array}{l}\text { Feet. } \\
11.0 \\
14.0 \\
18.5 \\
12.0\end{array}$ & $\begin{array}{l}\text { Yo. } \\
1.0 \\
1.9 \\
2.1 \\
1.9\end{array}$ & $\begin{array}{c}\text { Oubie ft. } \\
21.0 \\
20.9 \\
18.8 \\
18.1\end{array}$ & $\begin{array}{l}0.48 \\
.41 \\
.45 \\
.42\end{array}$ & $\begin{array}{r}0.75 \\
.70 \\
.62 \\
.72\end{array}$ \\
\hline Arerage.. & 34 & 13.4 & 46.0 & 14.0 & 1.9 & 10.7 & .44 & .70 \\
\hline
\end{tabular}

CODOMINANT GROWTH.

\begin{tabular}{|c|c|c|c|c|c|c|c|c|}
\hline 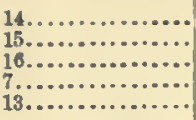 & $\begin{array}{l}32 \\
31 \\
34 \\
34 \\
34\end{array}$ & $\begin{array}{r}11.2 \\
9.5 \\
8.0 \\
8.0 \\
7.2\end{array}$ & $\begin{array}{l}42.5 \\
47.0 \\
45.0 \\
41.8 \\
41.5\end{array}$ & $\begin{array}{l}19.5 \\
28.0 \\
28.0 \\
22.5 \\
14.8\end{array}$ & $\begin{array}{l}1.7 \\
2.5 \\
3.1 \\
3.5 \\
3.9\end{array}$ & $\begin{array}{r}12.0 \\
10.9 \\
7.7 \\
6.7 \\
5.2\end{array}$ & $\begin{array}{l}0.45 \\
.47 \\
.48 \\
.45 \\
.47\end{array}$ & $\begin{array}{r}0.54 \\
.40 \\
.38 \\
.46 \\
.64\end{array}$ \\
\hline Average... & 33 & 8.8 & 43.0 & 22.0 & 2.9 & 8.6 & .46 & .48 \\
\hline
\end{tabular}

OPPRESSED GROWTH.

\begin{tabular}{|c|c|c|c|c|c|c|c|c|}
\hline $12 \ldots \ldots \ldots \ldots \ldots \ldots \ldots$ & $\begin{array}{l}31 \\
33 \\
29\end{array}$ & $\begin{array}{l}6.0 \\
5.2 \\
5.0\end{array}$ & $\begin{array}{l}30.8 \\
37.0 \\
32.5\end{array}$ & $\begin{array}{l}25.0^{\circ} \\
21.5 \\
14.0\end{array}$ & $\begin{array}{l}3.8 \\
4.7 \\
4.3\end{array}$ & $\begin{array}{l}4.0 \\
2.8 \\
2.1\end{array}$ & $\begin{array}{r}0.51 \\
.55 \\
.48\end{array}$ & $\begin{array}{r}0.37 \\
.42 \\
.57\end{array}$ \\
\hline Averago... & 31 & 5.4 & 36.0 & 20.0 & 4.3 & 3.0 & .51 & .45 \\
\hline
\end{tabular}

SUPPRESSED OROWTH.

\begin{tabular}{|c|c|c|c|c|c|c|c|c|}
\hline $\begin{array}{l}5 \\
2 \\
3 \\
3 \ldots \ldots \ldots \ldots \ldots \ldots \ldots \ldots \ldots \ldots\end{array}$ & $\begin{array}{l}27 \\
30 \\
27\end{array}$ & $\begin{array}{l}3.0 \\
3.3 \\
3.1\end{array}$ & $\begin{array}{l}27.0 \\
23.5 \\
27.8\end{array}$ & $\begin{array}{r}13.0 \\
9.0 \\
14.0\end{array}$ & $\begin{array}{l}7.0 \\
7.9 \\
7.4\end{array}$ & $\begin{array}{r}0.7 \\
.7 \\
.6\end{array}$ & $\begin{array}{r}0.53 \\
.44 \\
.47\end{array}$ & $\begin{array}{r}0.51 \\
.61 \\
.49\end{array}$ \\
\hline Average... & 27 & 3.1 & 26.0 & 12.0 & 7.4 & .7 & .48 & .54 \\
\hline $1, \ldots \ldots \ldots \ldots \ldots \ldots$ & $\begin{array}{l}22 \\
24\end{array}$ & $\begin{array}{l}3.0 \\
2.5\end{array}$ & $\begin{array}{l}16.0 \\
24.0\end{array}$ & $\begin{array}{r}16.0 \\
7.0\end{array}$ & $\begin{array}{l}4.8 \\
5.9\end{array}$ & .4 & $\begin{array}{l}.59 \\
.41\end{array}$ & $\begin{array}{r}1.00 \\
.71\end{array}$ \\
\hline Average... & 23 & 2.7 & 20.0 & 11.0 & 5. 3 & .3 & .50 & .85 \\
\hline
\end{tabular}

(4) SITE j:

Forest County.

Sample area: 1 acre.

[1,100 to 1,200 feet above sea level.]

Soil: Tellowish-brown clayer loam, with shales, deep, fresh, drained on south by Beaver Creek Age of pine: 40 to 50 years. and on the west by Hickory Creek, 3 to 4 inches mold on top, and surtace cover of leaves Density of crown cover: 0.8 and on the west by Hckory Creek, 3 to 4 inches mold on top, and surtace cover of leaves Density of crown cover: 0.8 a slope facing sontliwest; undergrowth dense, of very yonng Hemlock, Birch, Beech, some 8lope facis southwest; undergrowth donse, of Traple and Iron wood, and a forr other bardwoods. n places thick and crowded and in other places opon-

Ninger of trees: ( $?$.

ACRE YIELD

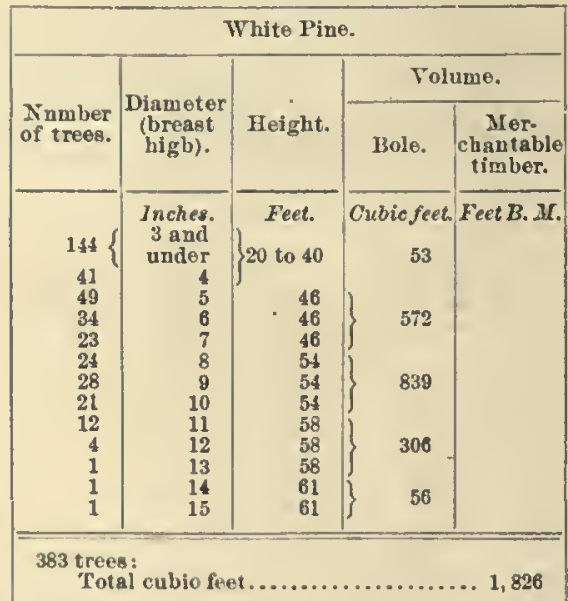

Average annual accetion: Thite Pine, 40 cubic feet.

Intermixed species: W'bite Pine, 239+144 small; Homlock, $78+248$ amall; Beech, $50+160$ amall; 1 aple, $6+108$ small; Oak (White and

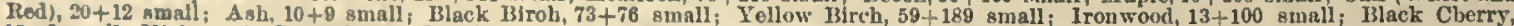
$15+2$ small, Illckory, 2; Cnoumber, 2; Juneberry, 60; fow small $\Lambda$ speu, Butternut, and Waterbeech. 
TABLE VII.-Acre yields of second-growth White Pine, with measurements of young pine taken for analysis-Continned. A.-PEXXSYLAYIA-Continued.

MEASUREMENTS OF SAMPLE YOUNG PINE TREES.

DOMINANT GROWTH.

\begin{tabular}{|c|c|c|c|c|c|c|c|c|}
\hline Tree number. & Age. & $\begin{array}{l}\text { Diameter } \\
\text { (brenst } \\
\text { high). }\end{array}$ & Height. & $\begin{array}{l}\text { Height to } \\
\text { base of } \\
\text { crown. }\end{array}$ & $\begin{array}{l}\text { Rings } \\
\text { per inch } \\
\text { on } \\
\text { stump. }\end{array}$ & $\begin{array}{l}\text { Volume } \\
\text { of treo. }\end{array}$ & $\begin{array}{c}\text { Factor } \\
\text { of } \\
\text { ehape. }\end{array}$ & $\begin{array}{l}\text { Ratio of } \\
\text { length } \\
\text { of crown } \\
\text { to total } \\
\text { leight of } \\
\text { tree. }\end{array}$ \\
\hline 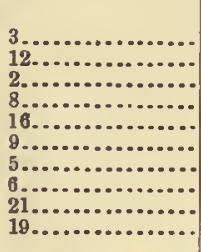 & $\begin{array}{c}\text { Years. } \\
46 \\
44 \\
44 \\
47 \\
47 \\
45 \\
47 \\
47 \\
48 \\
47\end{array}$ & $\begin{array}{r}\text { Inches. } \\
12.0 \\
11.5 \\
12.5 \\
11.0 \\
11.5 \\
11.0 \\
10.5 \\
10.0 \\
10.5 \\
11.0\end{array}$ & $\begin{array}{l}\text { Feet. } \\
60.0 \\
58.5 \\
55.0 \\
59.0 \\
66.0 \\
58.5 \\
60.0 \\
59.0 \\
58.0 \\
55.0\end{array}$ & $\begin{array}{r}\text { Feet. } \\
23 \\
26 \\
18 \\
30 \\
28 \\
28 \\
34 \\
32 \\
30 \\
28\end{array}$ & $\begin{array}{r}\text { No. } \\
3.5 \\
3.4 \\
3.4 \\
8.8 \\
3.3 \\
2.7 \\
3.7 \\
8.3 \\
3.6 \\
3.1\end{array}$ & $\begin{array}{c}\text { Cubic ft. } \\
20.2 \\
20.0 \\
10.4 \\
18.7 \\
18.3 \\
17.9 \\
17.3 \\
16.4 \\
16.3 \\
15.4\end{array}$ & $\begin{array}{l}0.43 \\
.47 \\
.41 \\
.48 \\
.45 \\
.49 \\
.48 \\
.51 \\
.46 \\
.42\end{array}$ & $\begin{array}{l}0.62 \\
.55 \\
.67 \\
.49 \\
.50 \\
.52 \\
.43 \\
.46 \\
.48 \\
.49\end{array}$ \\
\hline Average... & 46 & 11.0 & 58.0 & 28 & 3.3 & 18.0 & .45 & .52 \\
\hline $\begin{array}{l}7 \\
15 . \ldots \ldots \ldots \ldots \ldots \ldots \ldots \ldots\end{array}$ & $\begin{array}{l}47 \\
46\end{array}$ & $\begin{array}{l}14.0 \\
14.0\end{array}$ & $\begin{array}{l}64.0 \\
58.0\end{array}$ & $\begin{array}{l}34 \\
22\end{array}$ & $\begin{array}{l}2.9 \\
3.0\end{array}$ & $\begin{array}{l}29.6 \\
26.9\end{array}$ & $\begin{array}{l}.43 \\
.43\end{array}$ & $\begin{array}{l}.47 \\
.62\end{array}$ \\
\hline Average... & 46 & 14.0 & 61.0 & 28 & 3.0 & 28.2 & .43 & .54 \\
\hline
\end{tabular}

CODOMINANT GROWTH.

\begin{tabular}{|c|c|c|c|c|c|c|c|c|}
\hline 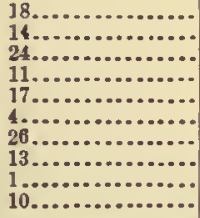 & $\begin{array}{l}43 \\
43 \\
46 \\
45 \\
44 \\
45 \\
45 \\
43 \\
47 \\
44\end{array}$ & $\begin{array}{r}9.5 \\
10.0 \\
10.0 \\
9.5 \\
9.0 \\
9.0 \\
8.5 \\
8.0 \\
8.0 \\
8.0\end{array}$ & $\begin{array}{l}56.0 \\
52.5 \\
53.0 \\
58.0 \\
58.0 \\
46.0 \\
50.0 \\
54.0 \\
50.0 \\
56.0\end{array}$ & $\begin{array}{l}28 \\
80 \\
28 \\
30 \\
32 \\
23 \\
30 \\
28 \\
20 \\
36\end{array}$ & $\begin{array}{l}4.1 \\
4.2 \\
3.9 \\
4.9 \\
3.9 \\
4.9 \\
4.6 \\
3.7 \\
5.1 \\
5.1\end{array}$ & $\begin{array}{r}13.9 \\
13.9 \\
13.7 \\
13.1 \\
12.9 \\
11.4 \\
10.0 \\
9.6 \\
9.2 \\
8.6\end{array}$ & $\begin{array}{l}0.50 \\
.48 \\
.47 \\
.46 \\
.47 \\
.46 \\
.51 \\
.51 \\
.53 \\
.44\end{array}$ & $\begin{array}{r}0.50 \\
.43 \\
.47 \\
.48 \\
.44 \\
.58 \\
.40 \\
.48 \\
.60 \\
.53\end{array}$ \\
\hline Average... & 44 & 9.0 & 54.0 & 28 & 4.4 & 11.5 & .48 & .49 \\
\hline
\end{tabular}

OPPRESSED GROWTH.

\begin{tabular}{|c|c|c|c|c|c|c|c|c|}
\hline 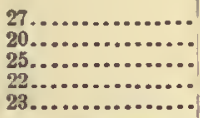 & $\begin{array}{l}43 \\
42 \\
43 \\
43 \\
44\end{array}$ & $\begin{array}{l}7.5 \\
7.0 \\
7.5 \\
5.0 \\
5.5\end{array}$ & $\begin{array}{l}48 \\
46 \\
46 \\
45 \\
46\end{array}$ & $\begin{array}{r}22 \\
-\quad 30 \\
30 \\
28 \\
38\end{array}$ & $\begin{array}{l}5.0 \\
5.0 \\
5.2 \\
6.9 \\
6.8\end{array}$ & $\begin{array}{l}7.9 \\
6.6 \\
6.1 \\
3.1 \\
3.6\end{array}$ & $\begin{array}{l}0.54 \\
.53 \\
.43 \\
.50 \\
.47\end{array}$ & $\begin{array}{r}0.54 \\
.34 \\
.35 \\
.38 \\
.17\end{array}$ \\
\hline Average.. & 43 & 6.5 & 46 & 30 & 5.8 & 5.4 & .49 & .35 \\
\hline
\end{tabular}


TAHL: VII.-Acre yields of second-grorth White l'ine, rith measurements of young pine taken for analysis-Continned.

\section{3.-WAIXIE:}

(1) Srrua:

York County:

Soll: Gray or brown the, loamy and, deep, fresh, 2 to 3 inches mold on top and leafy surfaco cover, aud elat probably some feet lielow surfince.

Forest condition: White Pine, whth seattering lied ()ak and Whlte Oak and occaslonal Norway 1'lue on a level; autlergrowth, molerately dease, of small Hemlock and Beech and numerous mall Maplo and Uak.

Clasrifteation:

Jominant

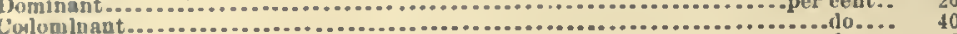

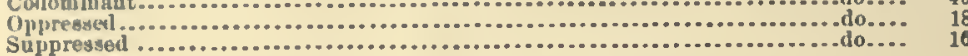

HALF ACRE IIELD.

\begin{tabular}{|c|c|c|c|c|}
\hline \multirow[b]{3}{*}{$\begin{array}{l}\text { Number } \\
\text { of trees. }\end{array}$} & \multicolumn{4}{|c|}{ Whlte Pine. } \\
\hline & \multirow[b]{2}{*}{$\begin{array}{c}\text { Diameter } \\
\text { (hreast } \\
\text { blgh). }\end{array}$} & \multirow[b]{2}{*}{ Helght. } & \multicolumn{2}{|c|}{ Tolumc. } \\
\hline & & & Bole. & $\begin{array}{c}\text { Mer- } \\
\text { chantahle } \\
\text { timber. }\end{array}$ \\
\hline $\begin{array}{r}2 \\
8 \\
8 \\
4 \\
6 \\
1 \\
8 \\
8 \\
8 \\
8 \\
10 \\
18 \\
2 \\
4 \\
6 \\
6 \\
2 \\
2 \\
4\end{array}$ & $\begin{array}{r}\text { Inches. } \\
10 \\
11 \\
12 \\
12 \\
13 \\
14 \\
14 \\
15 \\
16 \\
17 \\
18 \\
19 \\
20 \\
21 \\
22 \\
23 \\
24 \\
25 \\
26\end{array}$ & $\begin{array}{r}\text { Feet. } \\
75 \\
75 \\
75 \\
85 \\
85 \\
85 \\
75 \\
85 \\
85 \\
85 \\
85 \\
85 \\
85 \\
85 \\
85 \\
85 \\
85 \\
95 \\
95 \\
05\end{array}$ & $\begin{array}{c}\text { Cubicfeet. } \\
42 \\
192 \\
233 \\
120 \\
222 \\
154 \\
332 \\
384 \\
408 \\
528 \\
690 \\
1,323 \\
152 \\
320 \\
534 \\
660 \\
250 \\
280 \\
560\end{array}$ & Feet $\mathrm{R} . \mathrm{Ar}$. \\
\hline $\begin{array}{l}118 \text { tree } \\
\text { Tot }\end{array}$ & . & & & 383 \\
\hline
\end{tabular}

Average annual accretion: White Pine, 77 cuhic foet.

Current annual accretion: White Pive, 160 cubic feet.

MEASUREMENTS OF SAMPLE YOUXG PINE TREES,

Age class : 90 to 100 years.

DOMINAXT OROWTH.

\begin{tabular}{|c|c|c|c|c|c|c|c|c|c|c|}
\hline Treo nnmber. & Age. & $\begin{array}{c}\text { Diameter } \\
\text { (hreast } \\
\text { blgh). }\end{array}$ & Height. & $\begin{array}{l}\text { Rings } \\
\text { per inch } \\
\text { on } \\
\text { stump. }\end{array}$ & $\begin{array}{l}\text { Folume } \\
\text { of tree. }\end{array}$ & $\begin{array}{l}\text { Factor } \\
\text { of } \\
\text { shape. }\end{array}$ & $\begin{array}{c}\text { Ratio of } \\
\text { leugth } \\
\text { of erown } \\
\text { to total } \\
\text { helght of } \\
\text { iree. }\end{array}$ & $\begin{array}{r}\text { Current } \\
\text { secre }\end{array}$ & $\begin{array}{l}\text { annnal } \\
\text { tlon. }\end{array}$ & $\begin{array}{l}\text { Average } \\
\text { annual } \\
\text { accro- } \\
\text { tion. }\end{array}$ \\
\hline $\begin{array}{l}7 \\
12 \ldots \ldots \\
8 \\
17 \ldots \ldots \ldots \\
18 \ldots \ldots \\
23 \\
21 \\
16 \ldots \ldots \\
9 \\
9 \\
20 \\
20\end{array}$ & $\begin{array}{c}\text { Yearr. } \\
98 \\
92 \\
98 \\
02 \\
02 \\
97 \\
97 \\
90 \\
102 \\
100\end{array}$ & $\begin{array}{l}\text { Inches. } \\
28.0 \\
28.0 \\
25.0 \\
25.5 \\
25.0 \\
22.0 \\
20.6 \\
22.5 \\
20.0 \\
20.3\end{array}$ & $\begin{array}{r}\text { Feet. } \\
100 \\
103 \\
92 \\
91 \\
88 \\
98 \\
102 \\
91 \\
100 \\
103\end{array}$ & $\begin{array}{r}\text { Xo. } \\
2.9 \\
2.7 \\
3.2 \\
3.0 \\
3.2 \\
3.8 \\
4.1 \\
3.4 \\
4.1 \\
4.3\end{array}$ & $\begin{array}{c}\text { Cubic ft. } \\
175.3 \\
161.0 \\
140.3 \\
136.3 \\
131.7 \\
119.4 \\
118.1 \\
115.1 \\
104.0 \\
98.8\end{array}$ & $\begin{array}{l}0.41 \\
.36 \\
.46 \\
.42 \\
.44 \\
.46 \\
.35 \\
.46 \\
.47 \\
.41\end{array}$ & $\begin{array}{l}0.60 \\
.61 \\
.48 \\
.56 \\
.46 \\
.49 \\
.45 \\
.52 \\
.43 \\
.40\end{array}$ & 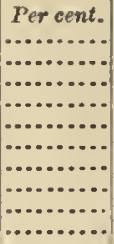 & 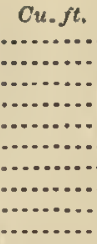 & 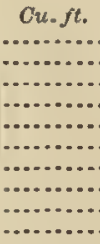 \\
\hline A rerage... & 96 & 23.7 & 97 & 3.5 & 130.0 & .42 & .50 & & & . \\
\hline
\end{tabular}

CODOMINANT OROWTH.

\begin{tabular}{|c|c|c|c|c|c|c|c|c|c|c|}
\hline 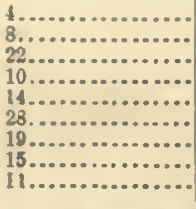 & $\begin{array}{r}101 \\
98 \\
08 \\
89 \\
03 \\
93 \\
89 \\
09 \\
89\end{array}$ & $\begin{array}{l}20.5 \\
19.5 \\
10.0 \\
16.8 \\
18.5 \\
1 \% .5 \\
18.7 \\
17.2 \\
17.2\end{array}$ & $\begin{array}{l}95 \\
99 \\
96 \\
09 \\
92 \\
80 \\
79 \\
87 \\
89\end{array}$ & $\begin{array}{l}3.8 \\
3.8 \\
4.1 \\
3.8 \\
4.3 \\
4.6 \\
4.1 \\
4.6 \\
4.0\end{array}$ & $\begin{array}{l}93.3 \\
88.4 \\
84.9 \\
71.3 \\
69.9 \\
68.4 \\
67.2 \\
67.0 \\
60.7\end{array}$ & $\begin{array}{l}0.43 \\
.43 \\
.45 \\
.46 \\
.41 \\
.48 \\
.45 \\
.49 \\
.43\end{array}$ & $\begin{array}{l}0.40 \\
.33 \\
.35 \\
.40 \\
.52 \\
.41 \\
.48 \\
.46 \\
.38\end{array}$ & 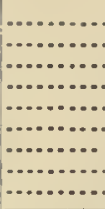 & 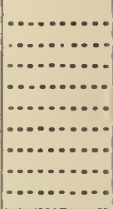 & $\begin{array}{l}\cdots \ldots \ldots \\
\cdots \ldots \ldots \\
\cdots \ldots \ldots \\
\cdots \ldots \ldots\end{array}$ \\
\hline Arerage... & 04 & 18.3 & 91 & 4.1 & 74.5 & .45 & .41 & & & \\
\hline
\end{tabular}


TABLE VII.-Acre yields of second-growth White Pine, rith measurements of young pine taken for analysis-Continued. B.-MALE-Continued.

MEASUREMENTS OF SAMPLE YOUNG PINE TREES-Continued.

OPPRESBED GROWTH.

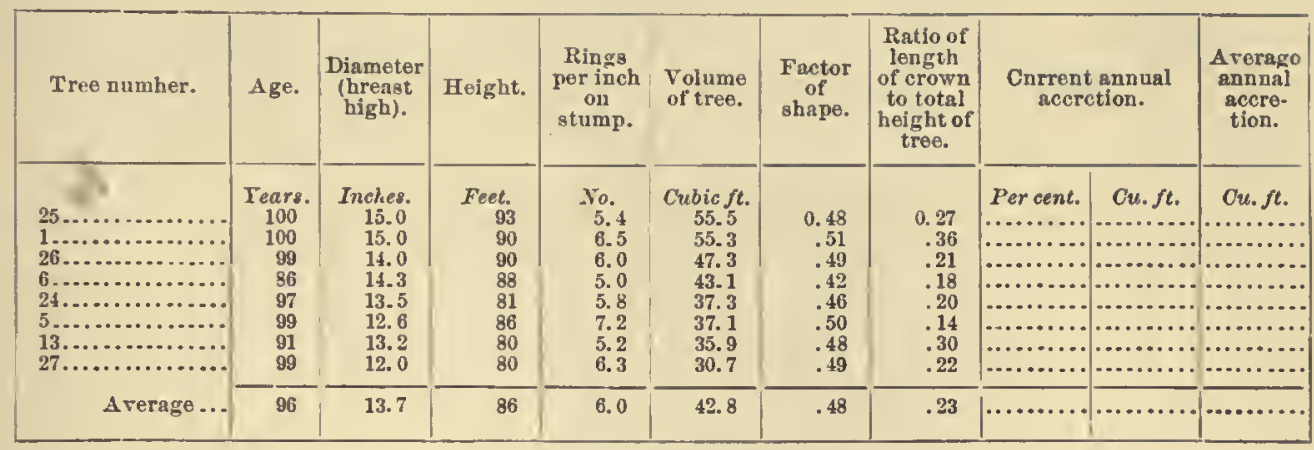

A ge class : 50 to 60 years.

DOMINANT GROWTH.

\begin{tabular}{|c|c|c|c|c|c|c|c|c|c|c|}
\hline 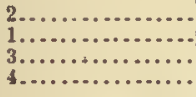 & $\begin{array}{l}55 \\
60 \\
60 \\
59\end{array}$ & $\begin{array}{l}14.0 \\
14.7 \\
17.0 \\
19.1\end{array}$ & $\begin{array}{l}61 \\
69 \\
61 \\
65\end{array}$ & $\begin{array}{l}3.2 \\
3.3 \\
3.1 \\
2.8\end{array}$ & $\begin{array}{l}34.2 \\
39.8 \\
42.8 \\
60.7\end{array}$ & $\begin{array}{r}0.52 \\
.50 \\
.44 \\
.47\end{array}$ & $\begin{array}{l}0.69 \\
.47 \\
.64 \\
.69\end{array}$ & $\begin{array}{l}5.4 \\
4.0 \\
4.6 \\
4.4\end{array}$ & $\begin{array}{l}1.85 \\
1.59 \\
1.97 \\
2.07\end{array}$ & $\begin{array}{r}0.62 \\
.66 \\
.71 \\
1.03\end{array}$ \\
\hline Average... & 58.5 & 16.2 & 64 & 3.1 & 44.4 & .48 & .62 & 4.6 & 2.02 & .75 \\
\hline
\end{tabular}

(2) SITE e:

York Connty:

One-fourth acre No. 1.
Sample area: 1 acre. Soil: Grsy sand, sometimes brown or loamy, deep, fresh, with 3 inches vegetahle mold, and a Age of pine: 50 to 60 years.
leafy snrface cover; snhsoil chayey, prohahly 4 or 5 feet below surface. Forest conditions: White Pine, with scattering Hemlock and occasional Spruce and Fir, on a level Number of trees: 328. piain; undergrowth, scanty, of Hazel sud yonng Hemlock.t

Classification:

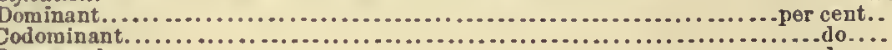

Oppressed

Snppressed.

- do... 9
45
23 23

ONE-FOURTH ACRE YIELD.

\begin{tabular}{|c|c|c|c|c|}
\hline \multicolumn{5}{|c|}{ White Pinc. } \\
\hline \multirow[b]{2}{*}{$\begin{array}{l}\text { Number } \\
\text { of trees. }\end{array}$} & \multirow[b]{2}{*}{$\begin{array}{c}\text { Diameter } \\
\text { (bresst } \\
\text { high). }\end{array}$} & \multirow[b]{2}{*}{ Height. } & \multicolumn{2}{|c|}{ Folume. } \\
\hline & & & Bole. & $\begin{array}{c}\text { Mrer- } \\
\text { chantable } \\
\text { timher. }\end{array}$ \\
\hline $\begin{array}{r}4 \\
32 \\
60 \\
84 \\
8 \\
36 \\
8 \\
52 \\
8 \\
12 \\
12 \\
4 \\
8\end{array}$ & $\begin{array}{r}\text { Inches. } \\
6 \\
7 \\
7 \\
8 \\
8 \\
9 \\
10 \\
10 \\
11 \\
12 \\
12 \\
13 \\
17\end{array}$ & $\begin{array}{r}\text { Feet. } \\
45 \\
55 \\
45 \\
55 \\
45 \\
55 \\
65 \\
55 \\
65 \\
55 \\
55 \\
65 \\
75\end{array}$ & $\begin{array}{c}\text { Oubicfeet. } \\
20 \\
256 \\
330 \\
840 \\
72 \\
414 \\
144 \\
780 \\
144 \\
306 \\
240 \\
116 \\
408\end{array}$ & Feet $B . M$. \\
\hline $\begin{array}{l}328 \text { tree } \\
\text { Tot }\end{array}$ & . & & & $\ldots 4,070$ \\
\hline
\end{tabular}

Average annual aceretion: White Pine, 74 cuhic feet.

Current annual aceretion: WVhite Pine, $133 \mathrm{cnbic}$ feet.

${ }^{1}$ Intermixed species: loung White Pine, 160; Hemlock, 20 mature and 20 small. 
TABL: VII. - Acre yields of second-grouth Whilo Pine, wilh measurenents of young pino taken for analysis-Contiuued.

DOMINANT GROWTH.

\begin{tabular}{|c|c|c|c|c|c|c|c|}
\hline Tree ntumber. & Age. & $\begin{array}{l}\text { Diameter } \\
\text { (lireast } \\
\text { high). }\end{array}$ & Height. & $\begin{array}{c}\text { Rings } \\
\text { yer inch } \\
\text { on } \\
\text { stump. }\end{array}$ & $\begin{array}{l}\text { Volume } \\
\text { of tree. }\end{array}$ & $\begin{array}{l}\text { Factor } \\
\text { of } \\
\text { shape. }\end{array}$ & $\begin{array}{l}\text { Ratio of } \\
\text { length } \\
\text { of crown } \\
\text { to tuital } \\
\text { belghe of } \\
\text { tree. }\end{array}$ \\
\hline $\begin{array}{l}8 \ldots \ldots \ldots \\
8 \ldots \ldots \ldots \ldots \ldots \ldots\end{array}$ & $\begin{array}{c}\text { Teari. } \\
50 \\
59 \\
55 \\
50 \\
59 \\
50\end{array}$ & $\begin{array}{r}\text { Inches. } \\
14.5 \\
13.3 \\
12.8 \\
11.8 \\
10.2 \\
11.0\end{array}$ & $\begin{array}{c}\text { Feet. } \\
64 \\
60 \\
61 \\
58 \\
65 \\
62\end{array}$ & $\begin{array}{l}\text { No. } \\
2.8 \\
3.8 \\
3.3 \\
3.5 \\
4.4 \\
3.7\end{array}$ & $\begin{array}{c}\text { Cubicfeet. } \\
33.1 \\
26.4 \\
25.6 \\
20.1 \\
22.0 \\
21.1\end{array}$ & $\begin{array}{r}0.45 \\
.44 \\
.45 \\
.52 \\
.59 \\
.50\end{array}$ & $\begin{array}{l}0.55 \\
.58 \\
.38 \\
.41 \\
.35 \\
.35\end{array}$ \\
\hline Average... & 54 & 12.3 & 62 & 3.6 & 24.7 & .49 & .44 \\
\hline
\end{tabular}

CODOMINANT GROWTH.

\begin{tabular}{|c|c|c|c|c|c|c|c|}
\hline 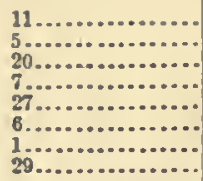 & $\begin{array}{l}52 \\
50 \\
51 \\
50 \\
51 \\
50 \\
49 \\
52\end{array}$ & $\begin{array}{r}10.0 \\
8.0 \\
8.8 \\
9.4 \\
8.1 \\
8.4 \\
8.1 \\
8.0\end{array}$ & $\begin{array}{l}59 \\
58 \\
58 \\
51 \\
56 \\
55 \\
56 \\
57\end{array}$ & $\begin{array}{l}4.3 \\
4.3 \\
4.6 \\
4.3 \\
5.1 \\
4.5 \\
5.0 \\
5.5\end{array}$ & $\begin{array}{l}16.1 \\
13.4 \\
13.3 \\
12.3 \\
10.7 \\
10.6 \\
10.2 \\
10.1\end{array}$ & $\begin{array}{l}0.50 \\
.52 \\
.54 \\
.46 \\
.55 \\
.50 \\
.52 \\
.50\end{array}$ & $\begin{array}{l}0.40 \\
.41 \\
.38 \\
(1) \\
.35 \\
.40 \\
.34 \\
.37\end{array}$ \\
\hline Average... & 51 & 8.7 & 57 & 4.7 & 12.1 & .51 & . 39 \\
\hline
\end{tabular}

OPPREBSRD GROWTH.

\begin{tabular}{|c|c|c|c|c|c|c|c|}
\hline 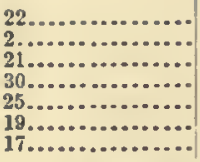 & $\begin{array}{l}49 \\
52 \\
49 \\
48 \\
50 \\
51 \\
50\end{array}$ & $\begin{array}{l}7.7 \\
7.8 \\
8.0 \\
7.7 \\
7.4 \\
8.2 \\
7.4\end{array}$ & $\begin{array}{l}53 \\
54 \\
51 \\
54 \\
58 \\
47 \\
54\end{array}$ & $\begin{array}{l}5.2 \\
5.0 \\
5.0 \\
5.1 \\
5.6 \\
5.1 \\
5.6\end{array}$ & $\begin{array}{l}9.6 \\
y .5 \\
9.5 \\
9.0 \\
9.0 \\
8.9 \\
8.0\end{array}$ & $\begin{array}{l}0.56 \\
.50 \\
.53 \\
.52 \\
.50 \\
.51 \\
.50\end{array}$ & $\begin{array}{l}0.30 \\
.26 \\
.39 \\
.40 \\
.33 \\
.34 \\
.30\end{array}$ \\
\hline Average... & 50 & 7.8 & 73 & 5.2 & 9.1 & .52 & .33 \\
\hline
\end{tabular}

SCPPRESSED GROWTH.

\begin{tabular}{|c|c|c|c|c|c|c|c|}
\hline $\begin{array}{l}14 \ldots \\
16 \ldots \ldots \\
26 \ldots \ldots \\
13 \ldots \ldots \\
15 \ldots \ldots \\
28 \ldots \ldots \\
23 \ldots \ldots \\
24 \ldots \ldots \\
18 \ldots \ldots\end{array}$ & $\begin{array}{l}55 \\
48 \\
46 \\
46 \\
48 \\
50 \\
48 \\
52 \\
52\end{array}$ & $\begin{array}{l}6.3 \\
6.9 \\
6.3 \\
6.2 \\
5.6 \\
6.0 \\
5.3 \\
5.0 \\
5.0\end{array}$ & $\begin{array}{l}57 \\
49 \\
51 \\
47 \\
50 \\
39 \\
46 \\
48 \\
46\end{array}$ & $\begin{array}{l}(?) \\
5.7 \\
5.5 \\
5.8 \\
7.0 \\
8.0 \\
7.6 \\
8.3 \\
10.0\end{array}$ & $\begin{array}{l}6.3 \\
5.8 \\
5.5 \\
5.1 \\
4.3 \\
3.7 \\
3.6 \\
3.4 \\
3.2\end{array}$ & $\begin{array}{l}0.51 \\
.44 \\
.47 \\
.51 \\
.52 \\
.48 \\
.47 \\
.52 \\
.50\end{array}$ & $\begin{array}{l}0.31 \\
.28 \\
.25 \\
.27 \\
.20 \\
.56 \\
.26 \\
.43 \\
.27\end{array}$ \\
\hline Average... & 50 & 5.8 & 48 & 7.2 & 4.5 & .49 & .31 \\
\hline
\end{tabular}


TABLE VII.-Acre yields of second-growth White Fine, with measurements of young pine taken for analysis-Continued. B.-MAINE-Continued.

\section{One-fourth acre No. 2 .}

Sort: Brown sandy loam with little pebbles in It, deep, fresh, 3 inches black soil and mold on top, Age of plne: 50 to 60 years. and leafy aurface cover; clay probably 8 to 12 inches below surface. undergrowth scanty, of Hemlock, Oak, and Flr.

Classification:

Dominant..........................................................per cent.. 18

Oppressed. do....

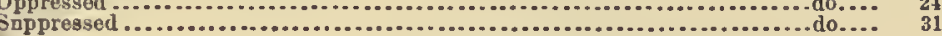

ONE-FOURTH ACRE YIELD.

\begin{tabular}{|c|c|c|c|c|}
\hline \multicolumn{5}{|c|}{ White Plue. } \\
\hline \multirow[b]{2}{*}{$\begin{array}{l}\text { Number } \\
\text { of trees. }\end{array}$} & \multirow[b]{2}{*}{$\begin{array}{l}\text { Diameter } \\
\text { (breast } \\
\text { high). }\end{array}$} & \multirow[b]{2}{*}{ Height. } & \multicolumn{2}{|c|}{ Volume. } \\
\hline & & & Bole. & $\begin{array}{c}\text { Mer. } \\
\text { cbantable } \\
\text { tlmber. }\end{array}$ \\
\hline & Inches. & Feet. & Oubicfeet. & Feet B.M. \\
\hline $\begin{array}{r}4 \\
28\end{array}$ & $\begin{array}{l}6 \\
6\end{array}$ & $\begin{array}{l}65 \\
55\end{array}$ & $\begin{array}{r}28 \\
168\end{array}$ & \\
\hline 20 & 7 & $\begin{array}{l}55 \\
65\end{array}$ & $\begin{array}{l}108 \\
190\end{array}$ & \\
\hline 20 & 7 & 55 & 160 & \\
\hline 84 & 8 & 65 & 1,008 & \\
\hline $\begin{array}{l}24 \\
36\end{array}$ & $\begin{array}{l}8 \\
9\end{array}$ & $\begin{array}{l}55 \\
65\end{array}$ & $\begin{array}{l}240 \\
522\end{array}$ & \\
\hline $\begin{array}{l}00 \\
32\end{array}$ & 10 & 65 & 576 & \\
\hline 8 & 10 & 75 & 168 & \\
\hline 40 & 11 & 65 & 880 & \\
\hline 4 & 11 & 75 & 100 & \\
\hline 16 & 12 & 65 & 408 & \\
\hline 24 & 12 & 75 & 696 & \\
\hline $\begin{array}{r}8 \\
16\end{array}$ & $\begin{array}{l}13 \\
13\end{array}$ & $\begin{array}{l}65 \\
75\end{array}$ & $\begin{array}{l}232 \\
552\end{array}$ & \\
\hline 4 & 14 & 65 & 132 & \\
\hline 12 & 14 & 75 & 462 & \\
\hline 8 & 15 & 65 & 292 & \\
\hline 4 & 16 & 75 & 181 & \\
\hline 4 & 17 & 75 & 204 & \\
\hline $\begin{array}{l}6 \text { trees } \\
\text { Tot } 3\end{array}$ & culbl & & & 7,202 \\
\hline
\end{tabular}

Average annual accretion: White Plne, 131 cubic feot.

One-half acre No.s.

Soil: Brown sand, deep, fresh, and leafy surface cover; clay probably 4 to 6 feot below surface. Age of plne: 50 to 60 jears. Forest conditions: White Pine intermixed with Norway Pine and occaslonal Spruce and Fir, on Density of crown cover: 0.8 . a slope w north; nndergrowth seanty, of small and fow Hemlock, Fir, and spruce.

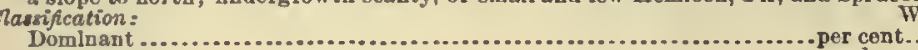

Codominant.

per cent..

Oppressed

do....

Suppressed ite Pine. Number of trees: 314 .

IALF-ACRE YIELD.

\begin{tabular}{|c|c|c|c|c|}
\hline \multicolumn{5}{|c|}{ White Plne. } \\
\hline \multirow[b]{2}{*}{$\begin{array}{l}\text { Nnmber } \\
\text { of trees. }\end{array}$} & \multirow[b]{2}{*}{$\begin{array}{c}\text { Diameter } \\
\text { (breast } \\
\text { high). }\end{array}$} & \multirow[b]{2}{*}{ Height. } & \multicolumn{2}{|c|}{ Volume. } \\
\hline & & & Bole. & $\begin{array}{c}\text { Mer- } \\
\text { chantable } \\
\text { timher. }\end{array}$ \\
\hline & Inches. & Feet. & Cubicfeet. & Feet B. BS. \\
\hline 18 & 7 & 65 & 162 & \\
\hline $\begin{array}{l}48 \\
60\end{array}$ & 8 & 65 & $\begin{array}{r}304 \\
-720\end{array}$ & \\
\hline 26 & 8 & 55 & 260 & \\
\hline 44 & 9 & 65 & 638 & \\
\hline 6 & 9 & 55 & 69 & \\
\hline 4 & 10 & 75 & 82 & \\
\hline 38 & 10 & 65 & 684 & \\
\hline 10 & 11 & 75 & 250 & \\
\hline 28 & 11 & 65 & 616 & \\
\hline 4 & 12 & 75 & 116 & \\
\hline 14 & 12 & 65 & 357 & \\
\hline 4 & 13 & 75 & 138 & \\
\hline 6 & 13 & 65 & 174 & \\
\hline 2 & 14 & 75 & 77 & \\
\hline 2 & 15 & 65 & 73 & \\
\hline
\end{tabular}


TAnL: VII.--dere yields of second-growth White Pine, with measurements of young pine taken for analysis-Continued. B.-MAINE-Continued. MEASUREAENTS OF SAMPLE YOUNG P1NE TRERS.

DOMIYAT GROWTR.

\begin{tabular}{|c|c|c|c|c|c|c|c|}
\hline Tree number. & Age. & $\begin{array}{c}\text { Diameter } \\
\text { (breast } \\
\text { high). }\end{array}$ & Height. & $\begin{array}{l}\text { Kings } \\
\text { per luch } \\
\text { on } \\
\text { stump. }\end{array}$ & $\begin{array}{l}\text { Volume } \\
\text { of tree. }\end{array}$ & $\begin{array}{l}\text { Factor } \\
\text { of } \\
\text { shape. }\end{array}$ & $\begin{array}{l}\text { Ratio of } \\
\text { length } \\
\text { of crown } \\
\text { to total } \\
\text { height of } \\
\text { tree. }\end{array}$ \\
\hline 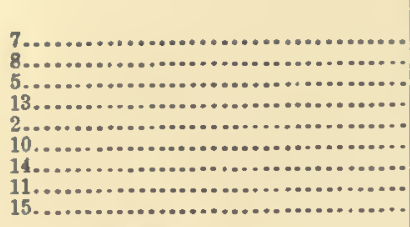 & $\begin{array}{c}\text { Years. } \\
89 \\
85 \\
92 \\
92 \\
82 \\
82 \\
96 \\
91 \\
91 \\
\end{array}$ & $\begin{array}{r}\text { Inches. } \\
21.8 \\
19.8 \\
17.3 \\
19.3 \\
18.8 \\
17.7 \\
18.5 \\
17.2 \\
17.2\end{array}$ & $\begin{array}{r}\text { Feet. } \\
80 \\
85 \\
87 \\
70 \\
80 \\
85 \\
75 \\
85 \\
82\end{array}$ & $\begin{array}{l}\text { No. } \\
3.7 \\
4.0 \\
4.4 \\
4.2 \\
3.8 \\
4.4 \\
4.4 \\
4.5 \\
4.4\end{array}$ & $\begin{array}{r}\text { Cu.ft. } \\
89.3 \\
76.5 \\
69.5 \\
69.3 \\
68.6 \\
67.4 \\
68.6 \\
66.4 \\
63.7\end{array}$ & $\begin{array}{l}0.40 \\
.43 \\
.48 \\
.42 \\
.43 \\
.40 \\
.42 \\
.49 \\
.49\end{array}$ & $\begin{array}{l}0.42 \\
.50 \\
.52 \\
.47 \\
.39 \\
.41 \\
.46 \\
.48 \\
.45\end{array}$ \\
\hline Average.................. & 89 & 18.6 & 83 & 4.2 & 70.8 & .45 & .46 \\
\hline 9................................... & 89 & 24.0 & 85 & 3.3 & 123.5 & .45 & .54 \\
\hline
\end{tabular}

SCPPRESSED GROWTH.

\begin{tabular}{|c|c|c|c|c|c|c|c|}
\hline 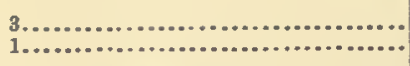 & $\begin{array}{l}100 \\
190\end{array}$ & $\begin{array}{l}12.6 \\
10.0\end{array}$ & $\begin{array}{l}57^{\circ} \\
69\end{array}$ & $\begin{array}{l}8.0 \\
8.7\end{array}$ & $\begin{array}{l}24.9 \\
20.1\end{array}$ & $\begin{array}{r}0.50 \\
.53\end{array}$ & $\begin{array}{r}0.54 \\
.39\end{array}$ \\
\hline Average.................... & 95 & 11.3 & 63 & 8.3 & 22.5 & .51 & .46 \\
\hline
\end{tabular}

PENOBSCOT COLATY.

\begin{tabular}{|c|c|c|c|c|c|c|c|c|c|}
\hline $\begin{array}{l}\text { Tree number. } \\
0 \ldots \ldots . . . \ldots \ldots \ldots\end{array}$ & $\begin{array}{l}\Delta \text { ge. } \\
\begin{array}{c}\text { Sears. } \\
66\end{array}\end{array}$ & $\begin{array}{c}\begin{array}{c}\text { Diameter } \\
\text { (breast } \\
\text { bigh). }\end{array} \\
\text { Inches. }\end{array}$ & $\begin{array}{l}\text { Ileight. } \\
\text { Eeet. }\end{array}$ & $\begin{array}{l}\begin{array}{l}\text { Volume } \\
\text { of tree. }\end{array} \\
\begin{array}{c}C_{u-f t} \\
31.83\end{array}\end{array}$ & $\begin{array}{l}\begin{array}{c}\text { Factor } \\
\text { of } \\
\text { shape. }\end{array} \\
\end{array}$ & $\begin{array}{c}\text { Ratio of } \\
\text { length } \\
\text { of crown } \\
\text { to total } \\
\text { height of } \\
\text { tree. } \\
\end{array}$ & \multicolumn{2}{|c|}{$\begin{array}{l}\text { Current annual } \\
\text { accretion. }\end{array}$} & $\begin{array}{c}\begin{array}{c}\text { A rerage } \\
\text { annual } \\
\text { accre. } \\
\text { tion. }\end{array} \\
\text { Cu.ft. }\end{array}$ \\
\hline 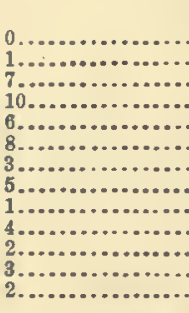 & $\begin{array}{c}\text { Fear } 8 . \\
66 \\
77 \\
73 \\
74 \\
70 \\
69 \\
73 \\
75 \\
70 \\
73 \\
79 \\
77 \\
72\end{array}$ & $\begin{array}{r}\text { Inches. } \\
12.5 \\
16.0 \\
12.7 \\
13.0 \\
13.0 \\
13.2 \\
13.5 \\
14.7 \\
15.7 \\
14.5 \\
17.0 \\
16.5 \\
15.2\end{array}$ & \begin{tabular}{r|} 
Feet. \\
76 \\
62 \\
80 \\
80 \\
77 \\
82 \\
83 \\
83 \\
81 \\
82 \\
74 \\
78 \\
85
\end{tabular} & $\begin{array}{l}\text { Cu. ft. } \\
31.83 \\
34.55 \\
35.51 \\
36.00 \\
35.15 \\
38.49 \\
40.43 \\
43.20 \\
42.34 \\
45.10 \\
51.14 \\
51.28 \\
51.91\end{array}$ & $\begin{array}{r}0.49 \\
.39 \\
.52 \\
.48 \\
.50 \\
.51 \\
.49 \\
.45 \\
.40 \\
.47 \\
.43 \\
.44 \\
.48\end{array}$ & $\begin{array}{r}0.40 \\
.69 \\
.45 \\
.40 \\
.52 \\
.35 \\
.32 \\
.35 \\
.43 \\
.39 \\
.43 \\
.65 \\
.30\end{array}$ & $\begin{array}{r}\text { Per cent. } \\
2.8 \\
3.3 \\
3.7 \\
3.1 \\
3.0 \\
3.6 \\
2.1 \\
2.5 \\
3.6 \\
3.2 \\
2.0 \\
3.8 \\
2.0\end{array}$ & $\begin{aligned} \text { Cu.ft. } \\
0.89 \\
1.14 \\
1.31 \\
1.12 \\
1.05 \\
1.38 \\
.85 \\
1.08 \\
1.51 \\
1.44 \\
1.02 \\
1.05 \\
1.04\end{aligned}$ & $\begin{array}{r}C u_{0} f t . \\
0.48 \\
.44 \\
.48 \\
.48 \\
.50 \\
.55 \\
.55 \\
.57 \\
.60 \\
.61 \\
.65 \\
.66 \\
.72\end{array}$ \\
\hline A rerage... & 73 & 14.4 & 79 & 41.30 & .40 & .44 & 3.0 & 1.21 & .56 \\
\hline
\end{tabular}


TABLE VII.-Acre yields of second-growth White Pine, with measurements of young pine taken for analysis-Continued.

\section{C.-MASSACHUSETTS:}

(1) SITE $a$ :

Holbrook, Norfolk Connty.

Soil: Fellowish-brown sandy loam, shallow, loose, dry, with 1 or 2 inches mold on top and a mod. crately leafy surface cover; subsoil, sand with stones and gravel.

Frest conditions: White Pine on a slope (angle ahout $10^{\circ}$ ); nudergrowth scanty, of Red Cedar with scattering Hemlock and White and Red Oak.1

$\triangle C R E$ IIELD.

\begin{tabular}{|c|c|c|c|c|}
\hline \multicolumn{5}{|c|}{ White Pine. } \\
\hline \multirow[b]{2}{*}{$\begin{array}{l}\text { Number } \\
\text { of trees. }\end{array}$} & \multirow{2}{*}{$\begin{array}{c}\text { Diameter } \\
\text { (hreast } \\
\text { high). }\end{array}$} & \multirow[b]{2}{*}{ Height. } & \multicolumn{2}{|c|}{ Volnme. } \\
\hline & & & Bole. & $\begin{array}{c}\text { Mer } \\
\text { chantahle } \\
\text { timber. }\end{array}$ \\
\hline 169 & Inches. & Feet. & Cubicjeet. & Feel B.Mr. \\
\hline 5 & 10 & 60 & $\begin{array}{r}1,00 \\
80\end{array}$ & \\
\hline 18 & 10 & 70 & 342 & \\
\hline 24 & 11 & 70 & 528 & \\
\hline 23 & 12 & 70 & 598 & \\
\hline 28 & 13 & 70 & 868 & \\
\hline 11 & 14 & 70 & 385 & \\
\hline 7 & 15 & 70 & 230 & \\
\hline 1 & 17 & 70 & 51 & \\
\hline
\end{tabular}

Average annual accretion: White Pine, 131 cnlic feet.

(2) SITE $b$ :

Pemliroke, Plymonth County.

Soil: Tellowish.brown sandy loam, medium grain, light, loose, fresh, with 2 to 3 inclues mold on Teles of alonndant leaves.

Forest conditions: White Pine with scattering Oak, Maple, Gray Birch, and occasional Sassafras and Hornbeam; nudergrowth moderately dense of ahove species of hardwoods."
Samplo arca : 1 acre.

Ago of pine: 85 to 38 years.
ACRE YIELD.
Sample area : 1 acre.

Age of pine: 50 to 55 years. Density of crown cover: Thick and quite even.

and quite even.

\begin{tabular}{|c|c|c|c|c|}
\hline \multicolumn{5}{|c|}{ White Pine. } \\
\hline \multirow[b]{2}{*}{$\begin{array}{l}\text { Ninmber } \\
\text { of trees. }\end{array}$} & \multirow[b]{2}{*}{$\begin{array}{c}\text { Diameter } \\
\text { (breast } \\
\text { high). }\end{array}$} & \multirow[b]{2}{*}{ Height. } & \multicolumn{2}{|c|}{ Volume. } \\
\hline & & & Bole. & \begin{tabular}{|l} 
Mer- \\
chantahle \\
timher.
\end{tabular} \\
\hline & Inches. & Feet. & Orbic feet. & Feet B. $\boldsymbol{M}$. \\
\hline 226 & 8 & 60 & 2,260 & \\
\hline $\begin{array}{l}19 \\
18\end{array}$ & 10 & 60 & 304 & \\
\hline $\begin{array}{l}18 \\
38\end{array}$ & $\begin{array}{l}10 \\
11\end{array}$ & $\begin{array}{l}70 \\
70\end{array}$ & $\begin{array}{l}342 \\
836\end{array}$ & \\
\hline 22 & 12 & 70 & 572 & \\
\hline 10 & 13 & 70 & 310 & \\
\hline 2 & 14 & 70 & 70 & \\
\hline 3 & 15 & 70 & 120 & \\
\hline 1 & 16 & 70 & 45 & \\
\hline
\end{tabular}

Arerage annual accretion: White $P i n e, 92$ culic fcet

Intermixed ppecies: Red Cedar, 2 from 6 to 10 inches diameter and nnder 60 feet high; 8 from 3 to 6 incles diameter and nnder 40 feet high. Red Oak, 1 over 6 lnches diameter and aniler 60 feet high; 1 over 3 inches diameter and under 40 feet ligh. Hemlock, 4 from 3 to inches diameter and under 40 feet $\mathrm{hlgh}$. White Oak, 3 from 3 to 6 Incles diameter and under 40 feet high. Yonng White Pine, 85 .

Indergronth: Red Cedar, 29; Whito Oak, 1 ; and Hemlock, 3 . 6 to 10 inches 1 lameter and nnder 60 fcet high; 2 from 3 to 6 inches diameter and over 40 feet higli. Maple, 4 from 3 to 6 inchos diameter and oter 40 feet blgls; 8 from 3 to 6 inches diameter and under 40 feot high. Gray Birch, 1 over 6 inches diameter and over 60 feet high; 6 from 6 to 30 inches diameter and nnder to feet high; 43 from a to 6 inehes diameter and over 40 feet ligh. Young Whito Pine, 69.

Cndergronoth: Gray Birch, 21; Maple, 38; Horabeam, 1, and Sassafras, 3. 
TABLE VII.-Acre yields of second-growth White Pine, with measurements of young pine taken for analysis-Continued.

C. -MASSACIIUSETTS-Continuet.

(3) Stre $c:$

IIanson. Plsmouth Counts.

Sample area : 1 acre.

Soil: Fellowish loamy onnd, mollum graln, porous, Ight, loose, deep, dry, and well drained, with bout 2 inclies moln on top and surfaco cover of Rhundant leares; snboil, sand and gravel. Forest conditions: Pure White 1 'jne on lovol plain, originnliy mixed with lardwoods, but ton yoars ago hardwools and dying pin

ACRE YIELD.

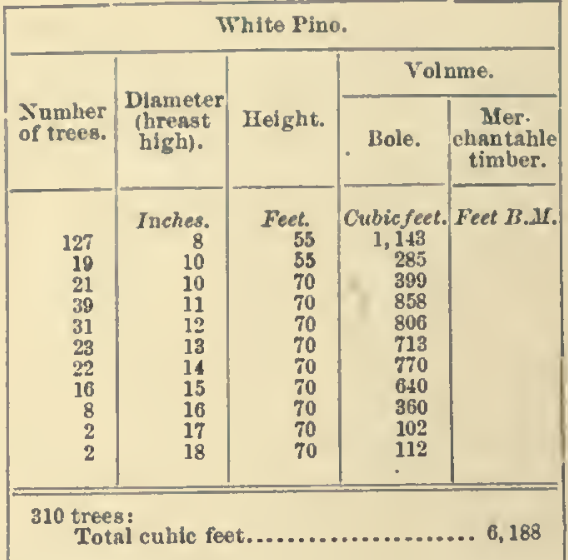

Avenage annual aceretion: White Pine, 123 cubio feet.

(4) SITE d:

Wermouth, Norfolk County.

Sample area: 1 acre

[180 feet above sea level.]

Soil: Brown or jellow sandy loam, medium grain, shallow, light, loose, drs, and well drained, with 1 or 2 inches mold on top and surface eover of ahundant leares; subsoll, gravel and stone. Forest conditions: TWhite Pino, with gcattering Red Oak and oceasional Maple and Hornheam on fomerhat billy site; undergrowth dense, of White Oak, Red Oak, Gray Birch, and Black Aounerist

ACRE YIELD.

Age of pino: 50 years.

Numher of trees: 295

\begin{tabular}{|c|c|c|c|c|}
\hline \multicolumn{5}{|c|}{ White Pine. } \\
\hline \multirow[b]{2}{*}{$\begin{array}{l}\text { Nnmher } \\
\text { of trees. }\end{array}$} & \multirow[b]{2}{*}{$\begin{array}{c}\text { Diameter } \\
\text { (hreast } \\
\text { high). }\end{array}$} & \multirow[b]{2}{*}{ Height. } & \multicolumn{2}{|c|}{ Volume. } \\
\hline & & & Bole. & $\begin{array}{c}\text { Mler. } \\
\text { chantahle } \\
\text { timher. }\end{array}$ \\
\hline $\begin{array}{r}174 \\
36 \\
26 \\
21 \\
16 \\
10 \\
4 \\
3 \\
1 \\
3 \\
1\end{array}$ & $\begin{array}{r}\text { Inches. } \\
8 \\
10 \\
11 \\
12 \\
13 \\
14 \\
15 \\
16 \\
17 \\
19 \\
21\end{array}$ & $\begin{array}{r}\text { Feet. } \\
60 \\
65 \\
70 \\
70 \\
70 \\
70 \\
70 \\
70 \\
70 \\
70 \\
70\end{array}$ & \begin{tabular}{|r} 
Oubic feet. \\
1,740 \\
612 \\
572 \\
$\mathbf{5 4 6}$ \\
496 \\
350 \\
160 \\
135 \\
51 \\
183 \\
78
\end{tabular} & Feet B. 1 . \\
\hline 295 tre & conic & & & .. 4,923 \\
\hline
\end{tabular}

Average annual aceretion: White Pine, 98 cuhic feet.

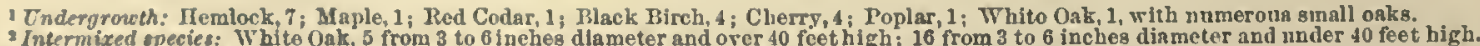
2Intermixed opecies: Whito Oak, 5 from 3 to 6 inehes dlameter and orer 40 feethigh; 16 from 3 to 6 inches din meter and under 40 feet high.
Gray Birch, 8 from 3 to 6 inches diameter and over 40 foot high; 7 from 3 to 6 inches diameter nnd undor 40 feet high. Red Oak, 2 froin 10 to 14 ing fect hich 23 fom 3 dom

A Chorry, 2. Red Cedar, 1; Rod Oak, 4; Black Birch, 19, snd numerous small ones: Howlock, 1, Gray IIrch, 2; Ilornbean, 1. 
TABLE: VII. - Acre yields of second-growth White Pine, with measurements of young pine taken for analysis-Continued. C.-IISSACTUSETTS-Continned.

(5) SITE $e$ :

Soit: Dark-brown loamy sand, medinm grain, light, loose, shallow, fresh, with abont 2 lnebes mold on top, and surfaee cover of ahmnlant leaves; subsoil, yellow fine sand.

Forest conditions: Cnltivated White Pine, wlth oceasional Gray Blrch, on level plain; undergrowt of scattering Oak and Maplo.

ACRE YIELD.

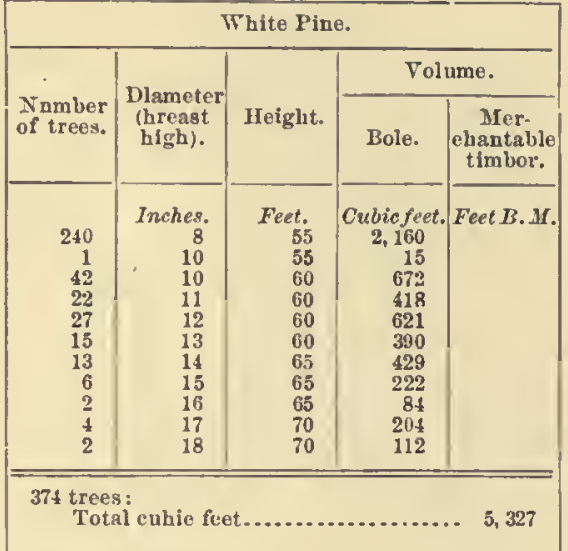

Average annual accretion: White Pine, 118 enhie feet.

(0) $\operatorname{Sit} f$ :

Bridgewater, Plymouth Connty.

[100 feet above sea level.]

Soil: Light-hrown sandy loam, medium grain, shallow, light, loose, dry, well drained, with ahont Forest conditions: Cultivated White Ine, intermixed with young lardwoods and Piteh Pine.

8: Cultivated White 1 ine, intermixed with young liardwoods and ACRE YIELD.

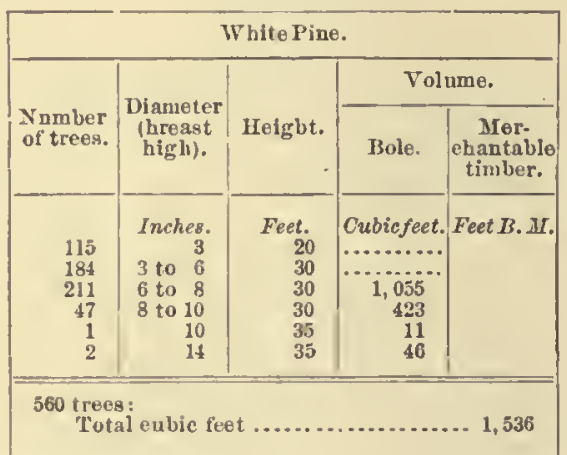

Average annual accretion: Whito I'ine, 61 euble feet.

Intermixed species: Gray Birch, 4 from 6 to 10 lnehes diameter and nnder 60 feet hlgh; 7 from 3 to 6 iuchos dlameter and over 40 feet high. Tndergrouth: Whito Oak, 23; Maple, 3.

Intermixed rpecies: Gray lilreh, 13 from 3 to 6 inehes diameter and under 30 feet high. Pltch Pine, 1 over 8 inehes diameter and under 30 feet hiph; 5 frum 6 to 8 inches diameter and nnder 30 feet high; 28 from 3 to 6 inebes diameter and under 30 foet bigh. Led Cedar, 1 over 3 inches diameter and under 30 feet high.

Lndergruwth: Oak, 07; Gray Birch, 54; Pitch Pino, 10; Maple, 8; Clierry, 3; Hiekory, 1.

$20233-$ No. $22-11$ 
TABLE VII. - Aere yiclds of sccond grouch White Pine, with measurements of young pine taken for analysis-Continued.

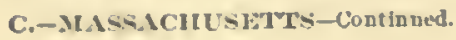

(6) Sirา g:
Grafion, Mllullosux Connty.

[500 fot abore sea level.]
Sample area : 1 acre.

Age of pine: 40 rears.

Deusity of crown cover: 0.8 to 0.2 .

Number of trees: 323.

Soil: Brown, nearly black, andy loam, medinm grain, shallow, freslı. well drained, with 1 or 2 Inches ninld ou top, and moderatoly loafy surfnce cover; subsult, rook on ridge, yollowish vand on low gronn. Cherry, Uray Birch, aud other harlwoods.

ACRF: T1ELD.

\begin{tabular}{|c|c|c|c|c|}
\hline \multicolumn{5}{|c|}{ Whito Pln!. } \\
\hline \multirow[b]{2}{*}{$\begin{array}{l}\text { Ninmber } \\
\text { of trees. }\end{array}$} & \multirow[b]{2}{*}{$\begin{array}{c}\text { Diameter } \\
\text { (brcast } \\
\text { hlgli). }\end{array}$} & \multirow[b]{2}{*}{ Height. } & \multicolumn{2}{|c|}{ Volıume. } \\
\hline & & & Bole. & $\begin{array}{c}\text { Mer. } \\
\text { chantable } \\
\text { tinber. }\end{array}$ \\
\hline $\begin{array}{r}176 \\
2 \\
43 \\
44 \\
23 \\
21 \\
8 \\
4 \\
2\end{array}$ & $\begin{array}{r}\text { Inches. } \\
8 \\
10 \\
10 \\
11 \\
12 \\
13 \\
14 \\
15 \\
18\end{array}$ & $\begin{array}{r}\text { Feet. } \\
60 \\
60 \\
70 \\
70 \\
70 \\
70 \\
70 \\
70 \\
70\end{array}$ & $\begin{array}{c}\text { Cubic feet. } \\
1,760 \\
32 \\
817 \\
968 \\
598 \\
651 \\
280 \\
160 \\
112\end{array}$ & Feet B.Mr \\
\hline $\begin{array}{l}323 \text { tree } \\
\text { Tot }\end{array}$ & al cuble fee & ........ & & ... 5,378 \\
\hline
\end{tabular}

Acerage annual acoretion: White Pinc, $134 \mathrm{cnhlc}$ feot.

(8) Site $h$ :
Worcester, Worcester Coanty.

[Abont 600 foet aboro sea level.]
Sample area : 1 acre.

Age of plne: 30 to 35 yeara. Density of crown corer: 0.0 to 0.8 (in placeg 0.2 and 0.4 ). Number of trees: 301 orest conditions: White Pine, with senttering (iray Birch and oceasional Poplar and Pitch Pino on a hill; undergrowth, scanty, of Hemlock.?

ACRE YIELD.

\begin{tabular}{|c|c|c|c|c|}
\hline \multicolumn{5}{|c|}{ Whlte Pine. } \\
\hline \multirow[b]{2}{*}{$\begin{array}{l}\text { Nininber } \\
\text { of trees. }\end{array}$} & \multirow[b]{2}{*}{$\begin{array}{l}\text { Dlameter } \\
\text { (hreast } \\
\text { higli). }\end{array}$} & \multirow[b]{2}{*}{ Height. } & \multicolumn{2}{|c|}{ Volnme. } \\
\hline & & & Bole. & $\begin{array}{l}\text { Mer. } \\
\text { chantable } \\
\text { timber. }\end{array}$ \\
\hline & Inches. & Feet. & Cubicfeet. & Feet B.M. \\
\hline $\begin{array}{r}193 \\
39\end{array}$ & $\begin{array}{r}8 \\
10\end{array}$ & $\begin{array}{r}60 \\
70\end{array}$ & 1,930 & \\
\hline 34 & 11 & 70 & 748 & \\
\hline 13 & 12 & 70 & 338 & \\
\hline 12 & 13 & 70 & 372 & \\
\hline 5 & 14 & \%o & 175 & \\
\hline 3 & 15 & 70 & 120 & \\
\hline 1 & 10 & 70 & 45 & \\
\hline 1 & 17 & 70 & 51 & \\
\hline
\end{tabular}

301 trees:

Total cubio feet 000000000000000000004,590

A rerage annual aceretion: White I'lne, 141 cublc feet.

Inlermixed species: Pltch Pine, 1 over 3 lnches diameter and over 40 feet hlgh; 1 orer 6 inclies diameter and nnder 60 feet hlgl, 1 over 10 inchrs diameter and nnder 80 feet bigh. Whito Jirch, 2 frem 3 to 6 inches diameter and over 40 feet high. Gray $13 i r c h, 6$ from 3 to 6

lnches dianeter aud under 40 feet high. Yonng White Pine, 35. Gray Blrch. 6; Thorn, 4; 13nmamelis, 3; Hiekory, 1; Henloek, 1; Elı, 2.

Jnermixed mpecles: Pitch Pine, 3 from 6 to 10 lnches dismeter and under 60 feet hlgh. Tomulus grandidentata, 1 over 0 luchen dians. r.ter and under 60 feet hiph. Gray Jirch, 6 from 0 to 10 inelieg diameter and uniler 60 feet ligh; 31 from 3 to 6 inclios dianeter and over 40 feet hlgh. Poplar, 2 from 6 to 10 inches dianeter aud nuler 60 feet high. I emlock, 1 over 3 inches diamoter and inder 40 fect hlgh. Young White Ine, ow.

Indergrouth: Oak, 53; Gray Blrch, 1, and a few amall Cherry, not counted. 
TABLE VII.-Acre yields of second-growth White Pine, with measurements of young pine taken for analysis-Continuod.

\section{C.-MASSACHUSETTS-Continued.}

(9) SITE i:

Northhridgo, Worcester Connty.

[500 foet ahore sea lorol.]

Soil: Fellow sandy loam, fine grain, deep, fresh. well drained, with ahout 4 inches mold on top,

Soil: Tellow sandy loam, fine grain, deep, fresh, well drained, with ahout $\$$ inches mold on top, Age of pine: 35 yenrs.
and a moderately leafy snrface cover; suhsol, prohahly lelgo rock.
Forest conditions: White Pine, with occasional Birch and Aiple, on a hill; nndergrowth, moder- Number of trees: 413 . atcly ders:

ACRE TIELD.

\begin{tabular}{|c|c|c|c|c|}
\hline \multicolumn{5}{|c|}{ White Piuo. } \\
\hline \multirow[b]{2}{*}{$\begin{array}{l}\text { Number } \\
\text { of trees. }\end{array}$} & \multirow[b]{2}{*}{$\begin{array}{l}\text { Diameter } \\
\text { (hreast } \\
\text { high). }\end{array}$} & \multirow[b]{2}{*}{ Height. } & \multicolumn{2}{|c|}{ Volnme. } \\
\hline & & & Bole. & $\begin{array}{c}\text { Mrer. } \\
\text { chantalle } \\
\text { timber. }\end{array}$ \\
\hline $\begin{array}{r}284 \\
53 \\
36 \\
20 \\
11 \\
7 \\
2\end{array}$ & $\begin{array}{r}\text { Inches. } \\
8 \\
10 \\
11 \\
12 \\
13 \\
14 \\
15\end{array}$ & $\begin{array}{r}\text { Feet. } \\
50 \\
70 \\
70 \\
70 \\
70 \\
70 \\
70\end{array}$ & $\begin{array}{c}\text { Cubic fret. } \\
2,556 \\
1,007 \\
792 \\
520 \\
311 \\
215 \\
80\end{array}$ & Feet $B .1$. \\
\hline $\begin{array}{l}413 \text { tree } \\
\text { Tot }\end{array}$ & entin $f$ & & & ... 5,540 \\
\hline
\end{tabular}

Average annual accretion: White Pine, 158 cubic feet.

(10) Sirz j:

Brookfleld, Worcester Connty.

Sample area: 1 acre.

[800 to 900 feet abovo sea lovel.]

Soil: Dark bromn or black loam, fine grain, llght, decp, fresl, woll drained, with about 2 inches mold on top and a moderately Jeafy snrface cover; subsoil, rock not far below surface. land; undergrowth dense, of various hard woods, with Oak and Chestnut prodominating. ${ }^{2}$

ACRE YIELD.

\begin{tabular}{|c|c|c|c|c|}
\hline \multicolumn{5}{|c|}{ Whito Pine. } \\
\hline \multirow[b]{2}{*}{$\begin{array}{l}\text { Nnmher } \\
\text { of trees. }\end{array}$} & \multirow[b]{2}{*}{$\begin{array}{l}\text { Dianueter } \\
\text { (hreast } \\
\text { high). }\end{array}$} & \multirow[b]{2}{*}{ Heiglit. } & \multicolumn{2}{|c|}{ Volume. } \\
\hline & & & Bole. & $\begin{array}{c}\text { Mer- } \\
\text { claantahle } \\
\text { timher. }\end{array}$ \\
\hline $\begin{array}{r}165 \\
43 \\
1 \\
33 \\
25 \\
14 \\
14 \\
7 \\
1\end{array}$ & $\begin{array}{r}\text { Inches. } \\
8 \\
9 \\
10 \\
10 \\
11 \\
12 \\
13 \\
14 \\
15\end{array}$ & $\begin{array}{r}\text { Feet. } \\
55 \\
55 \\
55 \\
60 \\
60 \\
60 \\
60 \\
65 \\
65\end{array}$ & \begin{tabular}{|c|c} 
Cubicfeet. \\
1,485 \\
516 \\
15 \\
528 \\
475 \\
322 \\
364 \\
231 \\
37
\end{tabular} & Feet $B . M$. \\
\hline $\begin{array}{l}303 \text { treo } \\
\text { Tot }\end{array}$ & hin & & & $\ldots 3,973$ \\
\hline
\end{tabular}

Averageannual accretion: White Pine, 104 euhic feet.

1 Intermixed epecies: Whito Maple, 1 over 6 inches diameter and nuder 60 feet ligh ; 2 from 3 to 6 inches diameter and over 40 feet high. Iaple, 2 from 10 to 14 inches dianoter and nader 80 feet hlgh; 8 from 3 to 0 inelres diamets and over 40 feet high; 1 ovor 3 inchos diameter and 11 nder 40 feet high. A pple, 1 over 3 inclieg dianeter and over 40 feet high. Young White Pine, 77.

Undergroicth: Wak, 152 (und nnmerons small trees); Chestnut, 52; Gray 13irch, 1; ITaple, 12 (and numerons small treos); JWhite Japle, 3. 2 Intermixed species: Pitch Pine, 2 fron 10 to 14 inches diameter and undor 80 feot high; 5 from 6 to 10 inches diaweter aud under 60 feet hlgh. Oak, 1 orer 6 inches diameter and under 60 feet high; 1 over 3 inches diameter and over 40 feet higl;; 1 over 3 inches diameter and nniler 40 feet high. Gray Jirch, 21 from 3 to 6 inches dianeter and over 40 feet ligh; 4 from 3 to 6 inclies iliameter and nuler 40 feet ligh. White lbirch, 1 over 3 fnches diametor and over 40 feot high. Maple, 1 over 6 inclues diametor and under 60 feet high; 1 orer 3 inches diame. ter aud inder 40 feet high. Chestnint, 1 ovor 10 inches diameter and under 80 feet high; 1 over 3 inches diameter and under 40 feet high.

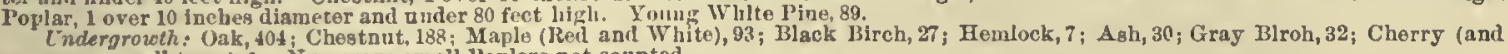
nnmerous small trees), 1. Jumerons small loplars not counted. 
TABLE VII.-Acro yields of second-grosoth White line, with measurements of young pine taken for analysis-Continued. C.-M.LSACHUSFTTS-Continned.

\section{(11) $\operatorname{Sir} k$ :}

Chariton, Worcester County.

[Abont 800 feet abovo sea ferel.]
Samplo area : 1 acre.

Ago of pine: 48 jears. Density of crown cover: 0.6 .

Soll : Dark-browa sandy lonm, medinm grain, jooso, doop, freeh, weil drained, $w$ Forest conditions: White Pine, meariy ynre, with 18 young trees on a hili; nndergrow th scanty, of Chow tnut, Mople, Oak, and Cherry.

$$
\text { ACRE YIELD. }
$$

Nomber of trees: $4 \mathbf{4 6 .}$

\begin{tabular}{|c|c|c|c|c|}
\hline \multicolumn{5}{|c|}{ Whifte Pine. } \\
\hline \multirow[b]{2}{*}{$\begin{array}{l}\text { Number } \\
\text { of trecs. }\end{array}$} & \multirow[b]{2}{*}{$\begin{array}{l}\text { Diamoter } \\
\text { (bryast } \\
\text { high). }\end{array}$} & \multirow[b]{2}{*}{ Keigut. } & \multicolumn{2}{|c|}{ Volnme. } \\
\hline & & & Bole. & $\begin{array}{l}\text { Mer- } \\
\text { chantablo } \\
\text { timber. }\end{array}$ \\
\hline $\begin{array}{r}277 \\
62 \\
50 \\
29 \\
13 \\
0 \\
3 \\
3\end{array}$ & $\begin{array}{r}\text { Inches. } \\
8 \\
10 \\
11 \\
12 \\
13 \\
14 \\
15 \\
16\end{array}$ & $\begin{array}{c}\text { Feet. } \\
60 \\
70 \\
70 \\
70 \\
70 \\
70 \\
70 \\
70\end{array}$ & $\begin{array}{c}\text { Cubic feet. } \\
2,770 \\
1,178 \\
1,100 \\
754 \\
408 \\
315 \\
120 \\
135\end{array}$ & Feet R. 1 r. \\
\hline $\begin{array}{l}46 \text { tre } \\
\text { Tot }\end{array}$ & blo & & & $\ldots 6,775$ \\
\hline
\end{tabular}

Average annual accretion: White Pjae, 141 enbio feet.

MEASUREMENTS OF SAMPLE YOUNG PINE TREES.

SITE $b$.

\begin{tabular}{|c|c|c|c|c|c|c|c|}
\hline Tree number. & Age. & $\begin{array}{c}\text { Diametor } \\
\text { (breast } \\
\text { high). }\end{array}$ & Hoight. & $\begin{array}{l}\text { Folume } \\
\text { of tree. }\end{array}$ & $\begin{array}{c}\text { Factor } \\
\text { of } \\
\text { shape. }\end{array}$ & $\begin{array}{l}\text { Ratio of } \\
\text { length } \\
\text { of erown } \\
\text { to total } \\
\text { hoight of } \\
\text { tree. }\end{array}$ & $\begin{array}{c}\text { A rerage } \\
\text { annnal } \\
\text { accre. } \\
\text { tjon. }\end{array}$ \\
\hline $\begin{array}{l}1 \\
2 \\
3\end{array} \ldots \ldots \ldots$ & $\begin{array}{c}\text { Tear8. } \\
52.0 \\
50.0 \\
48.0\end{array}$ & $\begin{array}{r}\text { Inches. } \\
13.0 \\
9.0 \\
9.2\end{array}$ & $\begin{array}{r}\text { Feet. } \\
71.5 \\
60.0 \\
62.5\end{array}$ & $\begin{array}{r}\text { Cu. } f t . \\
31.7 \\
13.8 \\
15.6\end{array}$ & $\begin{array}{l}0.47 \\
.52 \\
.54\end{array}$ & $\begin{array}{r}0.47 \\
.22 \\
.36\end{array}$ & $\begin{array}{r}C u . f t . \\
0.01 \\
.28 \\
.32\end{array}$ \\
\hline A rerago.. & 50.0 & 10.4 & 05.0 & 20.4 & .51 & .35 & .40 \\
\hline
\end{tabular}

SITE $c$.

\begin{tabular}{|c|c|c|c|c|c|c|c|}
\hline 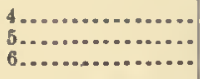 & $\begin{array}{l}54.0 \\
52.0 \\
50.0\end{array}$ & $\begin{array}{r}11.3 \\
13.8 \\
9.5\end{array}$ & $\begin{array}{l}59.0 \\
71.5 \\
04.0\end{array}$ & $\begin{array}{l}19.7 \\
36.3 \\
16.3\end{array}$ & $\begin{array}{r}0.48 \\
.49 \\
.52\end{array}$ & $\begin{array}{r}0.37 \\
.42 \\
.28\end{array}$ & $\begin{array}{r}0.36 \\
.70 \\
.33\end{array}$ \\
\hline Averago... & 52.0 & 11.5 & 65.0 & 27.4 & .50 & .36 & .46 \\
\hline
\end{tabular}

SITE $e$.

\begin{tabular}{r|r|r|r|r|r|r|r|}
\hline $7 \ldots \ldots \ldots \ldots \ldots \ldots \ldots$ & 39.0 & 8.3 & 52.0 & 8.8 & 0.45 & 0.40 & 0.22 \\
$0 . \ldots \ldots \ldots \ldots \ldots \ldots \ldots$. & 39.0 & 9.2 & 58.0 & 13.0 & .49 & .36 & .33 \\
\hline Averago... & 39.0 & 12.0 & 59.0 & 22.4 & .48 & .50 \\
\hline & 39.0 & 56.0 & 14.7 & .47 & .42 & .37 \\
\hline
\end{tabular}

SITE $i$.

\begin{tabular}{|c|c|c|c|c|c|c|c|}
\hline $\begin{array}{l}19 \ldots \ldots \ldots \\
20 \ldots \ldots \ldots \\
21 \ldots \ldots \ldots \ldots \ldots \ldots\end{array}$ & $\begin{array}{l}40.0 \\
36.0 \\
33.0\end{array}$ & $\begin{array}{r}9.5 \\
11.2 \\
0.5\end{array}$ & $\begin{array}{l}55.0 \\
53.0 \\
51.0\end{array}$ & $\begin{array}{r}14.3 \\
18.4 \\
6.7\end{array}$ & $\begin{array}{r}0.53 \\
.51 \\
.57\end{array}$ & $\begin{array}{r}0.42 \\
.55 \\
.37\end{array}$ & $\begin{array}{r}0.36 \\
.51 \\
.20\end{array}$ \\
\hline A verage... & 36.3 & 9.0 & 53.0 & 13.1 & .54 & .45 & .36 \\
\hline
\end{tabular}

SITE $j$.

\begin{tabular}{|c|c|c|c|c|c|c|c|}
\hline $\begin{array}{l}22 \ldots \ldots \ldots \ldots \ldots \ldots \\
23 \ldots \ldots \ldots \ldots \ldots \ldots \\
24 . \ldots \ldots \ldots \ldots \ldots \ldots\end{array}$ & $\begin{array}{l}37.0 \\
39.0 \\
39.0\end{array}$ & $\begin{array}{r}10.5 \\
9.8 \\
7.0\end{array}$ & $\begin{array}{l}58.0 \\
55.0 \\
52.0\end{array}$ & $\begin{array}{r}16.4 \\
13.8 \\
7.9\end{array}$ & $\begin{array}{l}0.51 \\
.54 \\
.56\end{array}$ & $\begin{array}{r}0.45 \\
.44 \\
.37\end{array}$ & $\begin{array}{r}0.44 \\
.35 \\
.20\end{array}$ \\
\hline Averago... & 38.3 & 8.9 & 58.0 & 12.7 & .54 & .42 & .33 \\
\hline
\end{tabular}

BITE $k$.

\begin{tabular}{|c|c|c|c|c|c|c|c|}
\hline $\begin{array}{l}25 \ldots \ldots \ldots \ldots \ldots \ldots \\
26 \ldots \ldots \ldots \ldots \ldots \ldots \\
27 . \ldots \ldots \ldots \ldots \ldots\end{array}$ & $\begin{array}{l}48.0 \\
48.0 \\
48.0\end{array}$ & $\begin{array}{r}10.0 \\
12.8 \\
0.1\end{array}$ & $\begin{array}{l}63.0 \\
60.5 \\
04.0\end{array}$ & $\begin{array}{l}17.0 \\
33.0 \\
16.0\end{array}$ & $\begin{array}{r}0.50 \\
.53 \\
.54\end{array}$ & $\begin{array}{r}0.20 \\
.38 \\
.40\end{array}$ & $\begin{array}{r}0.35 \\
.60 \\
.33\end{array}$ \\
\hline Arorago... & 48.0 & 10.0 & 65.5 & 22.0 & .52 & .35 & .46 \\
\hline
\end{tabular}


TABLE VII.-Acre yields of second-growth White Pine, with measurements of young pine taken for analysis-Continned. D.-NEW HAMPSHIRE:

(1) StTE l:

[300 feet above sea level.]

Soil: Dark-brown loamy sand, coarse grain, porous, loose, shaliow, dry, weil drained, with 1 inch Forest conditions. White Pine,

east to the Merrimack lock and emall whito Pine! ACRE YIEL,D.

\begin{tabular}{|c|c|c|c|c|}
\hline \multicolumn{5}{|c|}{ White Pine. } \\
\hline \multirow[b]{2}{*}{$\begin{array}{l}\text { Number } \\
\text { of trees. }\end{array}$} & \multirow[b]{2}{*}{$\begin{array}{c}\text { Diameter } \\
\text { (hreast } \\
\text { high). }\end{array}$} & \multirow[b]{2}{*}{ Height. } & \multicolumn{2}{|c|}{ Voinme. } \\
\hline & & & Bole. & $\begin{array}{c}\text { Mer- } \\
\text { chantable } \\
\text { timber. }\end{array}$ \\
\hline $\begin{array}{r}150 \\
619 \\
195 \\
65 \\
30 \\
7 \\
4 \\
5 \\
1 \\
1\end{array}$ & $\begin{array}{r}\text { Inche }_{\text {. }} \\
\text { Under } 3 \\
3 \text { to } 6 \\
6 \text { to } 8 \\
8 \text { to } 10 \\
10 \\
11 \\
12 \\
13 \\
14 \\
16\end{array}$ & $\begin{array}{r}\text { Feet. } \\
20 \\
40 \\
50 \\
50 \\
50 \\
50 \\
50 \\
50 \\
50 \\
50\end{array}$ & $\begin{array}{r}\text { Oubicfeet. } \\
\ldots . . . \\
1.365 \\
715 \\
390 \\
112 \\
76 \\
110 \\
25 \\
39\end{array}$ & Feet $\boldsymbol{B}, \boldsymbol{M r}$. \\
\hline $\begin{array}{r}1,077 \text { tr } \\
\text { Tot }\end{array}$ & $:$ & & & \\
\hline
\end{tabular}

A verage annual accretion: White Pine, $71 \mathrm{cuhie}$ feet.

(2) SrTE $m$ :

Franklin, Merrimack County.

[900 to 1,000 feet ahove sea level.]

Soil : Brown sandy loam, medinm grain, compact, moist, well drained, with 1 to 3 incbes mold on top and moderately leafy surface cover; eubsoil, rock. Forest conditions: White Pine intermixed with Maple and Biroh, on a hili; undergrowth, moder
ately dense, of young Maple, Birch, and other gcattering hardwoods.2

ACRE YIELD.

\begin{tabular}{|c|c|c|c|c|}
\hline \multicolumn{5}{|c|}{ White Pine. } \\
\hline \multirow[b]{2}{*}{$\begin{array}{l}\text { Number } \\
\text { of trees. }\end{array}$} & \multirow[b]{2}{*}{$\begin{array}{c}\text { Diameter } \\
\text { (hreast } \\
\text { high). }\end{array}$} & \multirow[b]{2}{*}{ Heigbt. } & \multicolumn{2}{|c|}{ Tolume. } \\
\hline & & & Bole. & $\begin{array}{c}\text { Mer- } \\
\text { chantahle } \\
\text { timber. }\end{array}$ \\
\hline $\begin{array}{r}298 \\
7 \\
47 \\
38 \\
9 \\
7 \\
2 \\
1 \\
1\end{array}$ & $\begin{array}{r}\text { Inches. } \\
8 \\
9 \\
10 \\
11 \\
12 \\
13 \\
14 \\
15 \\
16\end{array}$ & $\begin{array}{r}\text { Feet } \\
60 \\
60 \\
70 \\
70 \\
70 \\
70 \\
70 \\
70 \\
70\end{array}$ & $\begin{array}{c}\text { Cubicfeet. } \\
2,980 \\
91 \\
893 \\
836 \\
234 \\
217 \\
70 \\
40 \\
45\end{array}$ & Feet $\boldsymbol{B} . \boldsymbol{M}$. \\
\hline $\begin{array}{l}410 \text { trees } \\
\text { Tot }\end{array}$ & al cubio fo & & & . 5,406 \\
\hline
\end{tabular}

Average annual accretion: White Pine, 120 enbie feet.

1Intermixed species: Red Pine, 1 over 10 inches dianeter and nnder 40 feet high; 2 from 8 to 10 inches diameter and under 40 feet high: 4 from 6 to 8 inches diameter and over 40 feet high; 4 from 6 to 8 inches diameter and nnder 40 feet high; 3 from 3 to 6 inches diameter and inches diameter and over 40 feet high; 1 over 3 incbes diameter and under 40 feet high.

Undergrowth. Hemlock, 26. Gray Tireh,

Undergrowth: Hemlock, 26: Gray Birch, 1 . 10 inches diameter and over 60 feet high; 6 from 6 to 10 inches diameter anl under 60 foot high Intermized Apecied: Terl Mapie, 11 from 6 to high; 30 from 3 to 6 inches dameter axd orer 40 feet high; 3 from 3 tn 6 hiches dameter and 29 from 3 to 6 inches diameter and over 40 11 inches dameter and ancler feet high. led 0 ak, 2 from 360 inches diamer and orer 40 feet high. 2 frum 3 to 6 inches dianeter and under 40 feet high. Cbestnut, 1 Poplar 2 rom 6 to

Undergrowth: Red Maple, 23; Cherry, 3; Hamameils, 14; White Bireh, 2; Hemiock, 4; Asb, 1; Poplar, 1.
A ge of pine: 40 years.

Nuuhor of treee: 1,077 .
Sample area : 1 acre.

Age of pine: 40 to 45 years. Nnmher of trees: 410. 
TAlBLE VII._Acro yields of second-grouth White line, with mensurements of young pine taken for analysis-Continued.

D.- NFW ILAMISIIRH-Contlnued.

(3) Sitr $n$ :

Hopkluton, II rrinack County.

[800 to 900 feet ubove ara level.]

Soil: Rrown. sray, or neariy black sandy loam, fine graln, molst, weli dmined, with mold on top and molingtely leafy surface cover; subsoil, rock.

Foreat eondicion: Whito Pine, with occasional Red Pine, on a hill; undergrowth, moderately dense, of Ilemlock and seattering Lariwools; on occaslons dead aud little suppressed irees cut out and trimming dovo.1

ACIE IIELD.

\begin{tabular}{|c|c|c|c|c|}
\hline \multicolumn{5}{|c|}{ Whlte Pine. } \\
\hline \multirow[b]{2}{*}{$\begin{array}{l}\text { Number } \\
\text { of trees. }\end{array}$} & \multirow[b]{2}{*}{$\begin{array}{l}\text { Diameter } \\
\text { (breast } \\
\text { hlgh). }\end{array}$} & \multirow[b]{2}{*}{ Height. } & \multicolumn{2}{|c|}{ Folume. } \\
\hline & & & Bole. & $\begin{array}{l}\text { Mer. } \\
\text { chantable } \\
\text { tlmber. }\end{array}$ \\
\hline $\begin{array}{r}54 \\
43 \\
48 \\
36 \\
37 \\
27 \\
14 \\
14 \\
8 \\
3 \\
3 \\
1 \\
2 \\
1\end{array}$ & $\begin{array}{r}\text { Inehes. } \\
8 \\
10 \\
11 \\
12 \\
13 \\
14 \\
15 \\
16 \\
17 \\
18 \\
19 \\
20 \\
22 \\
23\end{array}$ & $\begin{array}{c}\text { Feet. } \\
60 \\
70 \\
70 \\
70 \\
70 \\
70 \\
70 \\
70 \\
80 \\
80 \\
80 \\
80 \\
80 \\
80\end{array}$ & \begin{tabular}{|c} 
Crebicjeut. \\
540 \\
817 \\
1.056 \\
936 \\
1,147 \\
945 \\
560 \\
630 \\
464 \\
192 \\
210 \\
77 \\
192 \\
104
\end{tabular} & Feet R. $\boldsymbol{I}$. \\
\hline $\begin{array}{r}291 \text { tree } \\
\text { Tot }\end{array}$ & whe 8 & & & $.7,870$ \\
\hline
\end{tabular}

A verage annual acoretion: White Pine, 127 cubic feet.

(1) Sirz: :

Hopkinton, Merrimack County. [800 to 900 feet above sea level.]

Soil: Brown loam, fine graln, moderately loose, fresl, well drained, with 3 to 4 inches mold on ton and leafy snrface corer; snbsoil, rocks not very far down. Forest eondifions: White Pine with occasional Red Plne on a north slope of hill; nndergrowth,
moderately dense, of Elm, Maple, Hemlock, and occasional bardwookls.2

\section{ACRE YIELD.}

\begin{tabular}{|c|c|c|c|c|}
\hline \multicolumn{5}{|c|}{ White Pine. } \\
\hline \multirow[b]{2}{*}{$\begin{array}{l}\text { Nimber } \\
\text { of trees. }\end{array}$} & \multirow{2}{*}{$\begin{array}{c}\text { Diameter } \\
\text { (breast } \\
\text { high). }\end{array}$} & \multirow[b]{2}{*}{ Height. } & \multicolumn{2}{|c|}{ Folume. } \\
\hline & & & Bole. & $\begin{array}{c}\text { Mer- } \\
\text { chantable } \\
\text { timber. }\end{array}$ \\
\hline & Inches. & Feet. & Cubie feet. & Feet $B . M$. \\
\hline $\begin{array}{r}63 \\
189\end{array}$ & $\begin{array}{ll}3 & \text { to } 6 \\
6 \text { to } & 10\end{array}$ & $\begin{array}{l}40 \\
50\end{array}$ & 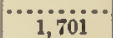 & \\
\hline 56 & 10 & 60 & 876 & \\
\hline 52 & 11 & 60 & 988 & \\
\hline 20 & 12 & 60 & 598 & \\
\hline 27 & 13 & 60 & 702 & \\
\hline 8 & 14 & 60 & $24 J$ & \\
\hline 11 & 15 & 65 & 418 & \\
\hline 3 & 16 & 65 & 128 & \\
\hline
\end{tabular}

135 trees:

Total cublc feet

5,649

Average annual aceretion: White Plne, 148 cuble feet.

1 Intermized opecies: Red Pine, 6 from 10 to 14 inches diameter and under 80 foet high; Maple, 1 orer 10 inches dlameter and under 80 feet high.

Cndergroncth: Hemlock, 98; Beech, 4.

2 Intermixed speeies: Rel Pine, 3 from 10 to 14 inches diamiler and under 80 feet bigh. Maple, 2 from 3 to 6 inches diameter and over 40 fent high. White 13 irch, 1 over 3 inches diameter and over 40 feet high. A pple, 2 from 10 to 14 tnchee diameter and under 80 feet hlgh. Hemlock, 3 froun 3 to 6 lnclies diamoter and under 40 feet high.

Undergrowth: Ilm, 04; Cornu alternifolia, 1; Bech, 1; Hemlock, 30; Cherry, 2; Asb, 1; Hammelis, 1; Maple, 62; nnmerons small Maples ; anall Oaks. 
TABLE VII. -Acre yields of second-growth White Pine, with measurements of young pine taken for analysis-Continued. D.-NEW HAMPSIIIRE-Continued.

(5) SITE $p$ :

[A hout $\mathbf{2 5 0}$ feet above sea level.] abont 2 inches sandy loam, fine grain, porous, light, loose, shaliow. dry, well drained, wlth abont 2 inches mold on top and moderately leafy surface cover; subsoil, wellowish fin with

Forest conditions: White Pine with seattering Pitel Pine ou level piaill undergrowth seanty, of Maple, Birch, and fow ot her hardwoods.'

\section{ACRE YIELD.}

\begin{tabular}{|c|c|c|c|c|}
\hline \multicolumn{5}{|c|}{ White Pine. } \\
\hline \multirow[b]{2}{*}{$\begin{array}{l}\text { Nomber } \\
\text { of trees. }\end{array}$} & \multirow{2}{*}{$\begin{array}{c}\text { Diameter } \\
\text { (breast } \\
\text { high). }\end{array}$} & \multirow{2}{*}{ Height. } & \multicolumn{2}{|c|}{ Volnme. } \\
\hline & & & Bole. & $\begin{array}{l}\text { Mer. } \\
\text { chantahle } \\
\text { timher. }\end{array}$ \\
\hline $\begin{array}{r}5 \\
182 \\
233 \\
30 \\
19 \\
13 \\
10 \\
12 \\
6 \\
2 \\
2 \\
1 \\
1 \\
1\end{array}$ & $\begin{array}{r}\text { Inehes. } \\
\text { Under } 3 \\
3 \text { to } 6 \\
6 \text { to } 10 \\
10 \\
11 \\
12 \\
13 \\
14 \\
15 \\
16 \\
17 \\
18 \\
19 \\
22\end{array}$ & $\begin{array}{r}\text { Feet. } \\
20 \\
40 \\
50 \\
60 \\
60 \\
60 \\
60 \\
65 \\
65 \\
65 \\
70 \\
70 \\
70 \\
70\end{array}$ & \begin{tabular}{|r|} 
Cubicfeet. \\
\hdashline 2,097 \\
480 \\
361 \\
199 \\
260 \\
396 \\
222 \\
84 \\
102 \\
56 \\
01 \\
78
\end{tabular} & Feet $B . \boldsymbol{I}$. \\
\hline $\begin{array}{l}517 \text { tree } \\
\text { Tot }\end{array}$ & euhie 1 & & & 4,396 \\
\hline
\end{tabular}

Average annual aecretion: White Pine, 15 eubio feet.

(6) SITE $\eta:$

Hilisuoro County.

Sample area : 1 acre.

[A bout 700 feet above sea level.]

Soil : Brown loam, fine grain, deep, moist, weli drained, with 2 to 4 inches mold on top and ahandant leafy surface cover; onbsoii, compact, eiayey sand.

Forest conditions: White Pine with scattering Mlaplo and Hemiock on hill; nndergrowth dense, of Maple, Oak, Chestnut mainly, and few other seattering hariw uods.?

ACRE TIELD.

\begin{tabular}{|c|c|c|c|c|}
\hline \multicolumn{5}{|c|}{ White Pine. } \\
\hline \multirow[b]{2}{*}{$\begin{array}{l}\text { Ninmber } \\
\text { of trees. }\end{array}$} & \multirow{2}{*}{$\begin{array}{c}\text { Dianaeter } \\
\text { (hreast } \\
\text { hlgh). }\end{array}$} & \multirow{2}{*}{ Height. } & \multicolumn{2}{|c|}{ Foiume. } \\
\hline & & & Bolo. & $\begin{array}{l}\text { Mer. } \\
\text { ehantahle } \\
\text { timber. }\end{array}$ \\
\hline & $\begin{array}{l}\text { Inehes. } \\
3 \text { to } 6\end{array}$ & Feet. & Cubicfeet. & Feet B.M. \\
\hline 153 & 6 to 10 & 50 & $\dddot{j}, 377$ & \\
\hline 36 & 10 & 60 & 576 & \\
\hline 40 & 11 & 60 & 760 & \\
\hline 31 & 12 & 60 & 713 & \\
\hline 17 & 13 & 60 & 442 & \\
\hline$\varepsilon$ & 14 & 60 & 240 & \\
\hline $\begin{array}{l}6 \\
3\end{array}$ & $\begin{array}{l}15 \\
16\end{array}$ & $\begin{array}{l}65 \\
65\end{array}$ & 222 & \\
\hline 1 & 17 & 65 & $\begin{array}{r}120 \\
47\end{array}$ & \\
\hline $\begin{array}{l}371 \text { tree } \\
\text { Tot }\end{array}$ & . & & & .. 4,503 \\
\hline
\end{tabular}

Average annual aceretion: White Pine, 107 cubic feet.

Intermixed species: Gray Blreh, 1 over 3 inehes diameter and over 40 feet high; 1 orer 3 inches dianeter and undor 40 feot high. Maple, 1 over 6 inches diameter and under 60 feet ligh; 1 over 3 inehes dinmeter aud over 40 foet hlgh; 2 over 3 inches diamotor and ander 40 feet high. I'ltch Pine, 1 over 10 inches diameter and ovor 80 feet high; 9 from 10 to 14 inches diameter and mander 80 feet high.

Cndergrouth: Maple, 9; Gray Bireh, 8; Cherry, 1; Oak, 4; Spruee, 1; numerous small Oak8 and Poplars.

Intermixed species: Hemlock, 12 from 6 to 10 inches diameter and under 60 feet high; 8 from 3 to 6 inehes diameter and under 40 feet high. Maple, 1 over 10 inches dlameter and under 80 feet high; 2 from 6 to 10 inehes diameter and orer 60 feet high; 21 from 6 to 10 inehe diameter and nnder 60 fert high: 26 from 3 to 6 inches diameter and over 40 feet ill ls; 11 fron 3 to 6 incbes diameter and under 40 feet high. White $O a k, 5$ from 3 to 6 ineies diameter and over 40 feet high; 3 from 3 to 6 juches diameter and under 40 feet hlgh. Cherry, 1 over 10 inches diameter and nnder 80 feet high; 1 over 6 inches dianeter and under 60 feet high; 2 from 3 to 6 inehes diameter and over 40 foet high.

Undergrowoth: Chostnnt, 202; Chorry, 8; Maple, 492; Blaek Birch, 3; Ash, 21; White Oak, 229; Hemlock, 20; Elm, 9; Thorn, 1. 
TAnt.: VII._Aero yielde of second-gronth While Pine, with measurements of young pine taken for analysis-Continued.

1).-NEW IIAMISIIIRE -Continued.

(7) SITR $r$ :

Milford, 1Iillsboro Connts.

Sample area : 2 acres.

[300 to 400 feot above sen level.]

Acre No. 1.

Soil: Dark.brown sandy loam, fino grain, shallow. dry, well dral ned, with 1 to 2 lnches mold on top und surface cover of ahuudant leaves; subsoll, light colored and powdery, 6 to 10 inches

Forest conditions: White Pine on slope; undergrowth, dense, of Oak mixed with Maple, Chestnut. and other scattering haril woods.

ACRE YIELD.

Number of trees: 794.

ge of pine: 35 to 40 years.

gensity of crow cover: Fnll.

\begin{tabular}{|c|c|c|c|c|}
\hline \multicolumn{5}{|c|}{ W' hito Pine. } \\
\hline \multirow[b]{2}{*}{$\begin{array}{l}\text { Ninmber } \\
\text { of trees. }\end{array}$} & \multirow[b]{2}{*}{$\begin{array}{c}\text { Diameter } \\
\text { (breast } \\
\text { ligili). }\end{array}$} & \multirow[b]{2}{*}{ Height. } & \multicolumn{2}{|c|}{ Volune. } \\
\hline & & & IBole. & $\begin{array}{l}\text { Mer- } \\
\text { chantable } \\
\text { timber. }\end{array}$ \\
\hline & Tnches. & Feel. & Cubicfeet. & Feet B. M. \\
\hline $\begin{array}{l}339 \\
323 \\
323\end{array}$ & 6 to 8 & 50 & 2,261 & \\
\hline 108 & 8 to 10 & 50 & 1.188 & \\
\hline 11 & 10 & 50 & 143 & \\
\hline$\stackrel{9}{2}$ & 11 & $\begin{array}{l}50 \\
50\end{array}$ & $\begin{array}{l}144 \\
38\end{array}$ & \\
\hline 2 & 13 & 50 & 44 & \\
\hline
\end{tabular}

Average annual aceretion: Whito Plne, 109 cuhic feet.

Acre No. 2.

$\Delta$ ge of pine: 35 to 40 years.

Density of crown cover: 0.6 to 0.7 .

Soil: Brown sandy loam, medinm grain, loose, freah, 1 foot deep, wilh 2 inches mold ou top and a moderately leafy sturface corer.

Forest condition: White Pine with scattering Maple on north slope of hill; uudergrowth, in parts morterately dense, of $\mathbf{A s b}$, Maple, and fow other liardwoods, and in denser parts very littlo undergrowth. 3

ACRE TIELD.

\begin{tabular}{|c|c|c|c|c|}
\hline \multicolumn{5}{|c|}{ White Pine. } \\
\hline \multirow[b]{2}{*}{$\begin{array}{l}\text { Number } \\
\text { of trees. }\end{array}$} & \multirow[b]{2}{*}{$\begin{array}{c}\text { Diameter } \\
\text { (breast } \\
\text { high). }\end{array}$} & \multirow[b]{2}{*}{ Height. } & \multicolumn{2}{|c|}{ Volume. } \\
\hline & & & Bole. & $\begin{array}{l}\text { Mer. } \\
\text { chantable } \\
\text { timber. }\end{array}$ \\
\hline $\begin{array}{r}151 \\
236 \\
44 \\
21 \\
17 \\
10 \\
11 \\
5 \\
3 \\
2 \\
1 \\
1 \\
1\end{array}$ & $\begin{array}{r}\text { Inches. } \\
3 \text { to } 6 \\
6 \text { to } 10 \\
10 \\
11 \\
12 \\
13 \\
14 \\
15 \\
16 \\
17 \\
19 \\
20 \\
21\end{array}$ & $\begin{array}{r}\text { Feet. } \\
\mathbf{4 0} \\
\mathbf{5 0} \\
55 \\
55 \\
55 \\
55 \\
60 \\
60 \\
60 \\
60 \\
60 \\
70 \\
\mathbf{7 0}\end{array}$ & $\begin{array}{r}\text { Cubicfeet. } \\
\text { 2. } 121 \\
660 \\
378 \\
357 \\
240 \\
330 \\
175 \\
117 \\
86 \\
57 \\
72 \\
78\end{array}$ & Feet B.Mr. \\
\hline $\begin{array}{l}503 \text { tree } \\
\text { Tot }\end{array}$ & cubic fe & & & $\ldots 4,674$ \\
\hline
\end{tabular}

Average annual accretion: Whito Pine, 123 cnbic foot.

1 Intermixed species: Oak, 1 over 10 inches dlameter nnd over 50 feet high; 1 orer 8 inches siameter and under 50 feet high; 3 from 3 to 6 Inches diameter and over 40 feot high.

Undergronoth: Oak, 381; IInplo, 64; Chestnnt, 41; Gray Birch, 4; Tellow Bireh, 1; Hemlock, 1; Cherry, 14, with numerous simall trecs.

2ntermixed species: Alaple, 1 orer 10 inches diametor and under 80 feet high: 5 from 6 to 10 inchcs diameter and under 60 feet high; 4 from 3 to 6 Juches dimeter aud orer 40 feet high; 2 from 3 to 6 inches dimueter and under 40 feot high. Clierry, 1 orer 6 inches diameter and under 60 leet bigh; 2 from 3 to 6 inches dianeter and under 40 fiet high. Apple, 1 orer 6 inches diameter aud uuder 60 feet high; 1 ore 3 inches diameter and nnder 40 feet bigh. I'itch l'ine, 2 from 6 to 10 inches diametor anu uncler 60 feet high. White $13 t r c h, 1$ orer 6 inches

Undergrowth: $1 \mathrm{sb}, 45$; Iaple, 8; Cherry, 3; Oak, 5; 11amamells, 10; Chestnut, 1; Elu, 2. 
TABLE VII.-Acre yields of second-growth White Pine, with measurements of young pine taken for analysis-Continued. D.-NEW HAMTSHIRE-Continued.

MEASUREMENTS OF SAMPLE YOUNG PINE TREES.

Age class: Under 50 years.

SITE $l$.

\begin{tabular}{|c|c|c|c|c|c|c|c|c|c|c|}
\hline Tree nninber. & Age. & $\begin{array}{c}\text { Diameter } \\
\text { (hreast } \\
\text { high). }\end{array}$ & Helght. & $\begin{array}{l}\text { Rings } \\
\text { per inch } \\
\text { on }\end{array}$ & $\begin{array}{l}\text { Volume } \\
\text { of tree. }\end{array}$ & $\begin{array}{c}\text { Factor } \\
\text { of } \\
\text { sliape. }\end{array}$ & $\begin{array}{c}\text { Ratio of } \\
\text { length } \\
\text { of crown } \\
\text { to total }\end{array}$ & \multicolumn{2}{|c|}{$\begin{array}{l}\text { Currentiannual } \\
\text { accretion. }\end{array}$} & $\begin{array}{l}\text { Arerage } \\
\text { annual } \\
\text { accre- }\end{array}$ \\
\hline $\begin{array}{l}28 \ldots \ldots \ldots \\
30 \ldots \ldots \ldots \ldots \ldots\end{array}$ & $\begin{array}{c}\text { Years. } \\
41 \\
41 \\
41\end{array}$ & $\begin{array}{c}\text { Inches. } \\
6.8 \\
7.1 \\
8.2\end{array}$ & $\begin{array}{r}\text { Feet. } \\
44 \\
52 \\
55\end{array}$ & 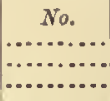 & $\begin{array}{r}\text { Cubic ft. } \\
5.6 \\
8.0 \\
10.0\end{array}$ & $\begin{array}{r}0.51 \\
.56 \\
.51\end{array}$ & $\begin{array}{r}0.43 \\
.51 \\
.51\end{array}$ & $\begin{array}{c}\text { Per cent. } \\
\ldots \ldots \ldots \\
\ldots \ldots \\
\ldots \ldots\end{array}$ & \begin{tabular}{c} 
Cubic ft. \\
$\ldots \ldots$ \\
\hdashline$\ldots \ldots$ \\
$\cdots \ldots \ldots$
\end{tabular} & $\begin{array}{c}\text { Cubic } / t . \\
0.30 \\
.20 \\
.24\end{array}$ \\
\hline A verage... & 41 & 7.4 & 50 & ....... & 7.9 & .53 & .48 & $\ldots$ & .......... & .25 \\
\hline
\end{tabular}

SITE $m$.

\begin{tabular}{|c|c|c|c|c|c|c|c|c|c|}
\hline $\begin{array}{l}31 \ldots \ldots \ldots \\
32 . \ldots \ldots \ldots \\
33 \ldots \ldots \ldots\end{array}$ & $\begin{array}{l}42 \\
42 \\
42\end{array}$ & $\begin{array}{r}9.7 \\
10.4 \\
8.7\end{array}$ & $\begin{array}{l}63 \\
70 \\
65\end{array}$ & (n) & $\begin{array}{l}16 \\
21.3 \\
13.1\end{array}$ & $\begin{array}{l}0.50 \\
.51 \\
.49\end{array}$ & $\begin{array}{l}0.38 \\
.34 \\
.34\end{array}$ & 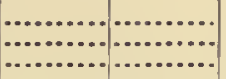 & $\begin{array}{l}0.38 \\
.51 \\
.31\end{array}$ \\
\hline Average... & 42 & 9.6 & 66 & ............. & 16.8 & .50 & .35 & $\cdots$ & .40 \\
\hline
\end{tabular}

SITE 0 .

\begin{tabular}{|c|c|c|c|c|c|c|c|c|c|c|}
\hline $\begin{array}{l}35 \ldots \ldots \ldots \ldots \ldots \ldots \\
36 \ldots \ldots \ldots \ldots \ldots \ldots \ldots\end{array}$ & $\begin{array}{l}38 \\
39\end{array}$ & $\begin{array}{r}9.3 \\
10.3\end{array}$ & $\begin{array}{l}57.5 \\
62.5\end{array}$ & (.......... & $\begin{array}{l}13.8 \\
18.0\end{array}$ & $\begin{array}{r}0.51 \\
.50\end{array}$ & $\begin{array}{r}0.39 \\
.40\end{array}$ & …........ & …....... & $\begin{array}{r}0.36 \\
.46\end{array}$ \\
\hline Average... & 38.5 & 9.8 & 60 & ........... & 15.9 & .50 & .39 & & & .41 \\
\hline
\end{tabular}

SITE $r$.

\begin{tabular}{|c|c|c|c|c|c|c|c|c|c|c|}
\hline $1 \ldots \ldots \ldots \ldots \ldots$ & $\begin{array}{l}81 \\
77\end{array}$ & $\begin{array}{l}17 \\
17\end{array}$ & $\begin{array}{l}73 \\
74\end{array}$ & 4 & $\begin{array}{l}48.2 \\
52.4\end{array}$ & $\begin{array}{r}0.42 \\
.44\end{array}$ & $\begin{array}{r}0.53 \\
.55\end{array}$ & $\begin{array}{l}4.6 \\
3.0\end{array}$ & $\begin{array}{l}2.22 \\
1.57\end{array}$ & $\begin{array}{r}0.59 \\
.68\end{array}$ \\
\hline Arerage... & 79 & 17 & 73.5 & 4 & 50.3 & .43 & .54 & 3.8 & 1.89 & .63 \\
\hline
\end{tabular}



SCHEDULES AND SAMPLE RECORDS. 



\title{
SCHEDULES AND SAMPLE RECORDS.
}

\author{
FORMS USED IN THE INVESTIGATION.
}

FORM NO. 1.

\author{
United States Department of Agriculture. \\ DIVISION OF FORESTRY.
}

RECORDS OF TREE MEASUREMENTS.

Name of collector: $\mathrm{N}$.

Species: White Pine.

Year: 1897.

GENERAL DESCRIPTION OF STATION.

[Denoted by capital letter.]

Stato: Pennsylvania. Connty: Clearfield. Town: Dubois.

Longitude: $78^{\circ} 45$. Latitude: $41^{\circ} 3^{\prime}$. Altitude: 1,200 to 1,500 feet.

General configuration: Plains lails plateau mountainous.

Gencral trend of valleys or hills: (Not noted.)

Climatic features: (Meteorologieal tables firnished.)

General forest conditions of the region: This region in 1876 extended over 20,000 acres. The lumber operation carried on for twenty years by Mr. Dn Bois left for the present only from 1,500 to 2,000 acres stancling timber iu a primeval condition.

Tlirce typical forms of forest conditions are suggosted to the ohserver:

(1) lentock and White Pine forest, with an admixture of mature hardwoods aud a number of young hardwoods and yonng Hemlock, which form tho uudergrowth.

(2) Hcmloek mixed with White Pine, with seattering hard woods; the undergrowth usually moderately dense, eonsists mainly of young Hemlock with the admixture of yonng hardwoods.

(3) Hardwoods intermixed with White Pine and seattering Hemloek. The undergrowth hero consists mainry of young liardwoods.

Anong the hardwoods, the Oak, Birch, and Maple form the staple of the hardwood forest, while the Beech, Chestunt, Hickory, Cnellmher, Ash, Cherry, and Basswood are comparatively fow in number. 'The region has a uniform soil and subsoil as it may be judged by the sample areas NN, 5,6 , and 7, and is woll provided with moisture by the many streams erossing it all over in different directious. 


\section{FORM NO. 2.}

\section{DESCMPTION OF SITK.}

Sample area, No. 5: (One acre.)

[Denoted ly small lettor.]

Conformation of surface: Hill sloping toward sonthwest, where it is berdered by the loft-hand branch of Irish Narrow Crcek.

Seil and drainage conditlons: Yellow clay loam of a medinn grain (fine shale in it), deep, fresh, well draincd, nitl 2 to 3 inclies meld on top.

Subsoll: Laminated shale of an indefinite deptl.

Soil cover: Scauty Icaves, fern, and teaberries.

Origin of stand: Natural regeneration.

Form: Uniform; storied. Whito Pine forms first and Hemlock the secend.

Composition: Astanc of Hemleck inixed with White Pine, intermixed with seattering Maple, Beoch, and Birch.

Undergrewth: Absent; dense; uedcrately dense; scauty; consists of very young Beech, Hemleck, and occaslenal birch, Cncumber, and Dogweorl (Laurel in northeast corner).

Deusity of stand: 0.7 (in places 0.8 ).

ReMArks.-Crowns of White Pine generally well developed; clear and straight stems. Age of White Pine 230 to 260 ycurs. Age of Hemleck almost the same as that of White Pine.

ACRE.FIELD MEASUREMEXTS.

\begin{tabular}{|c|c|c|c|c|c|c|c|c|c|c|c|c|c|c|c|c|c|c|}
\hline$\vec{\Xi}$ & \multicolumn{15}{|c|}{ Name of apecles. } & \multicolumn{3}{|c|}{ Undergrowth. } \\
\hline$\Phi$ & \multicolumn{3}{|c|}{ White Pine. } & \multicolumn{3}{|c|}{ Hemlock. } & \multicolumn{3}{|c|}{ Maple. } & \multicolumn{3}{|c|}{ Beeeh. } & \multicolumn{3}{|c|}{ Birch. } & \multicolumn{3}{|c|}{$\begin{array}{c}\text { Diameter } \\
\text { (breast high). }\end{array}$} \\
\hline 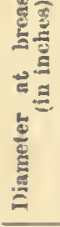 & 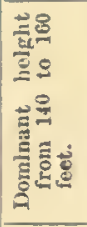 & 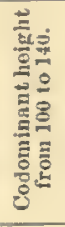 & 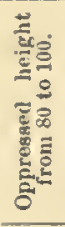 & 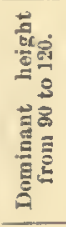 & 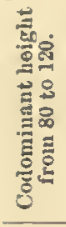 & 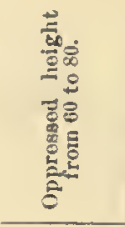 & 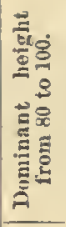 & 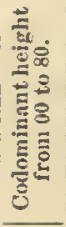 & 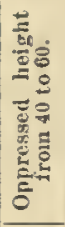 & 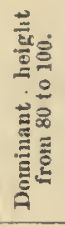 & 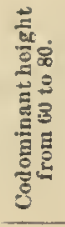 & 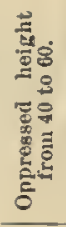 & 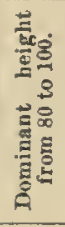 & 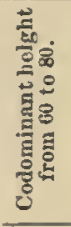 & 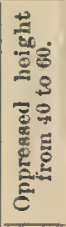 & 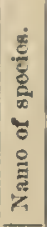 & $\begin{array}{c}3-6 \\
\text { tnehes. }\end{array}$ & $\begin{array}{l}\text { Under } \\
3 \text { fuebes. }\end{array}$ \\
\hline $\begin{array}{l}6 \\
7 \\
8 \\
9 \\
90 \\
11 \\
12 \\
13 \\
14 \\
15 \\
16 \\
17 \\
18 \\
19 \\
20 \\
21 \\
22 \\
23 \\
24 \\
25 \\
26 \\
27 \\
28 \\
29 \\
30 \\
31 \\
32 \\
33 \\
34 \\
35 \\
36 \\
37 \\
33 \\
39 \\
40 \\
41 \\
42 \\
43 \\
16 \\
43\end{array}$ & $\begin{array}{l}\text { I } \\
11 \\
11 \\
11 / \\
1 / \\
1\end{array}$ & $\begin{array}{l}\text { I } \\
\text { Ax/I } \\
\text { IIII } \\
\text { IIII } \\
\text { III }\end{array}$ & ' & $\begin{array}{l}1111 \\
111 \\
111 \\
111 \\
111 \\
1111 \\
1 / 1 \\
1\end{array}$ & $\begin{array}{l}111 \\
111 \\
111 \\
11 \\
\text { Ixy }\end{array}$ & $\begin{array}{l}\text { IxUIXNII } \\
111 \\
11 \\
1111 \\
111 \\
111 \\
\text { ne } \\
1\end{array}$ & $\begin{array}{l}1 \\
1 \\
11\end{array}$ & - & & // & & & $\begin{array}{l}1 \\
1\end{array}$ & & & 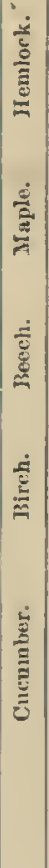 & & $\begin{array}{l}29 \\
36 \\
43 \\
37 \\
31 \\
11 \\
47 \\
38 \\
31 \\
42 \\
38\end{array}$ \\
\hline
\end{tabular}

DEDLCED RESULTS.

Total number of trees on the acre: 132, of which there were-

First species: White Pine, 37; dominant, 41 per cent; colominant, 48 per cent; oppressed, 11 per cent.

Second : llemlock, 81 ; dominant, 32 per cent; cedominant, 26 per ceut; oppresser, 42 per cent.

Thirl: Maple, 5.

Fourth: Beerl, 3.

Fiftl: : Birch, 3.

Total yield of the acre: Volume of stems, 15,686 cubie feet; merchantable timber, 90,103 feet B. M.

of which there were-

First species: W'hite Pine, 58 per cent of total yield.

Seconl specics: licmlock, 42 per cent of total rield.

Third, fourth, and fifth species: Hemlock net taken into consideration.

Average annual accretion: In cubic feet, 65 ; merchantable timber, in feet 13. M., 375. 


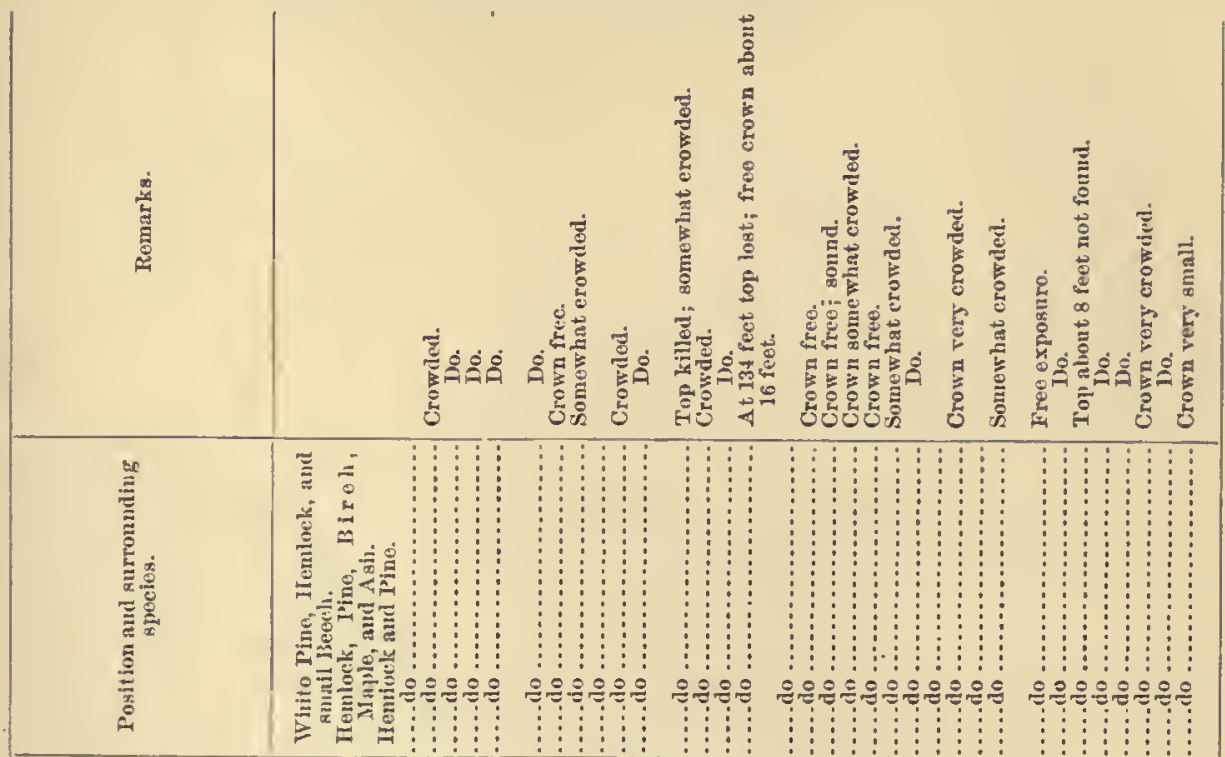

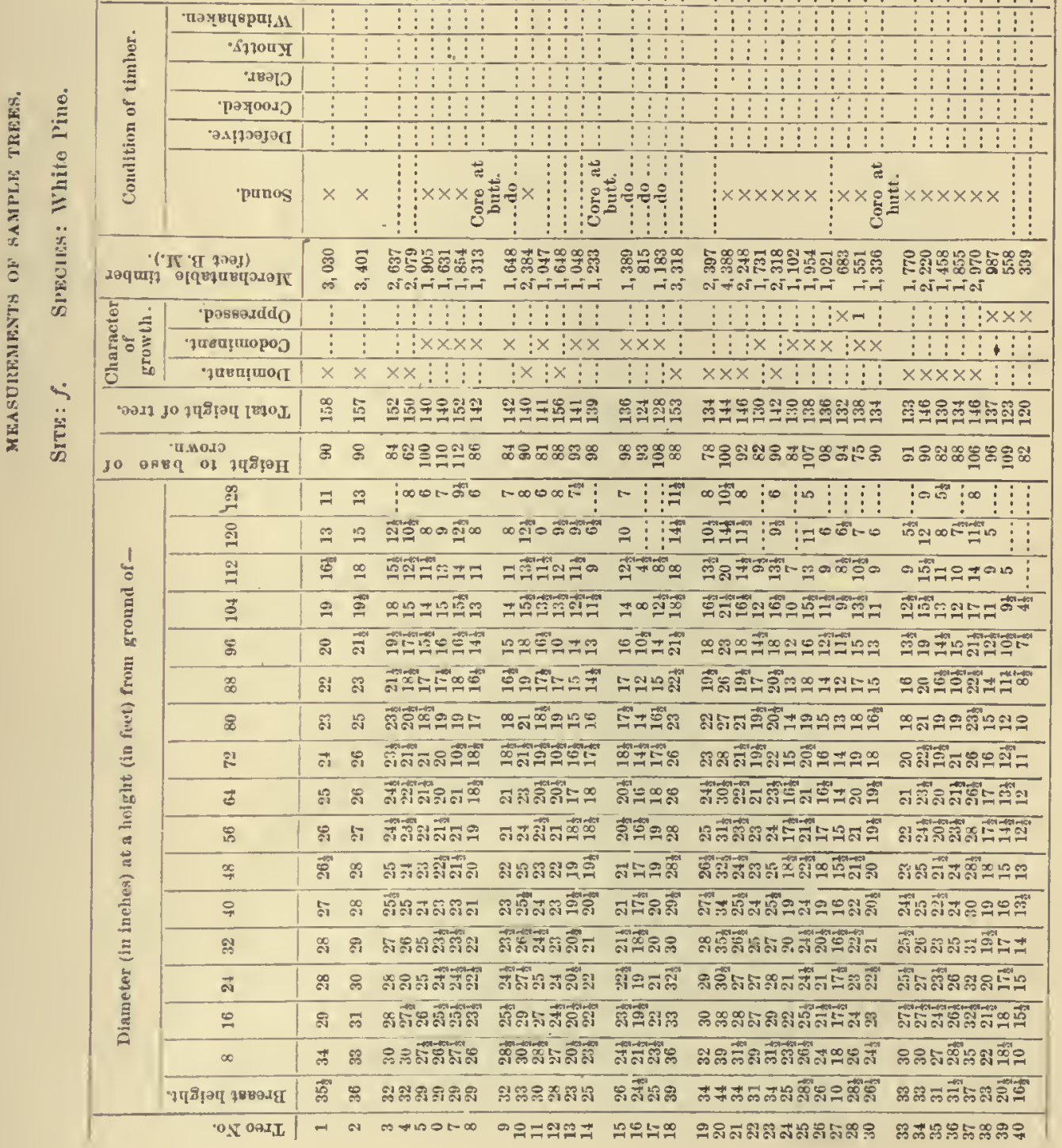




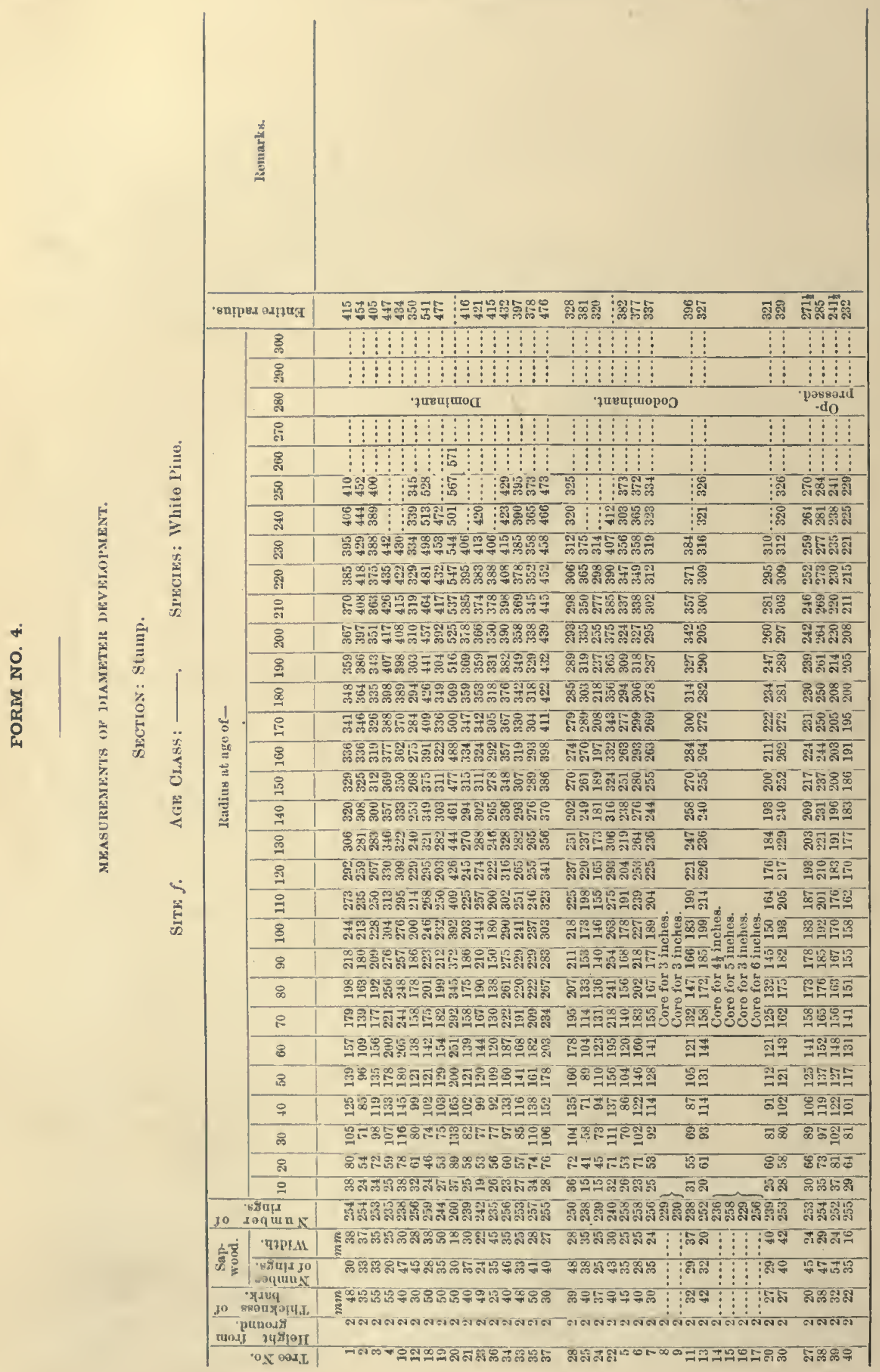




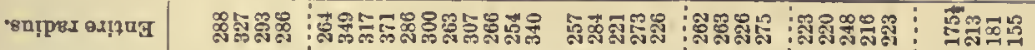

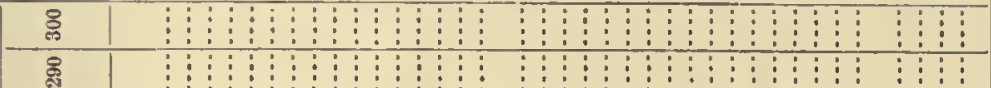

产 1 (1)

\begin{tabular}{|c|}
\hline ఫ్ \\
\hline
\end{tabular}

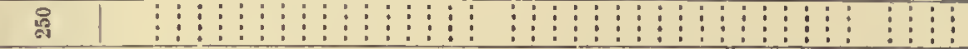
인

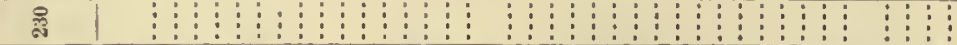
㤀 |

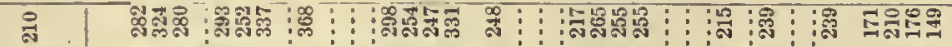

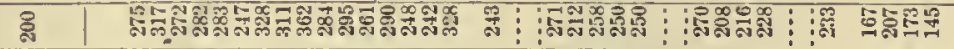

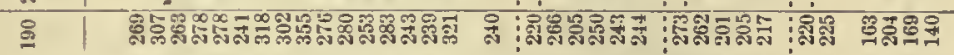
¿ |

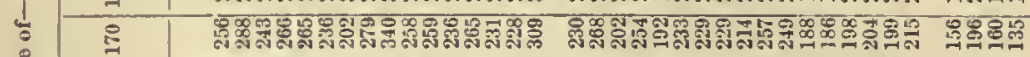

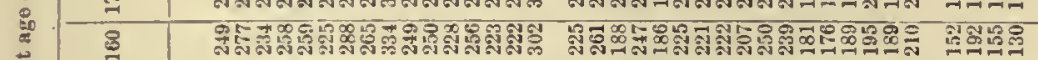

范

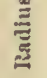

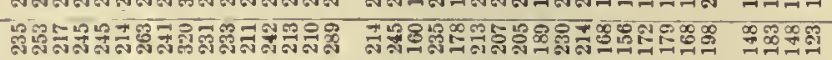

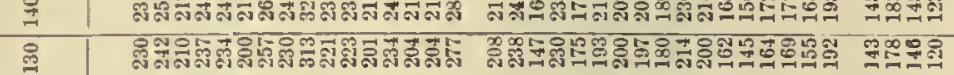

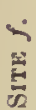

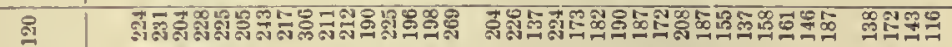

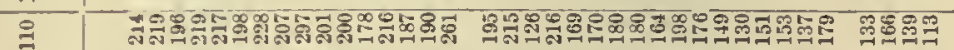

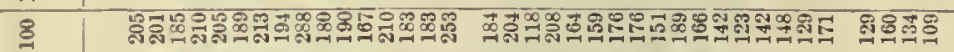
ㄴ|

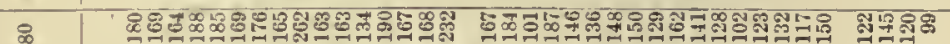

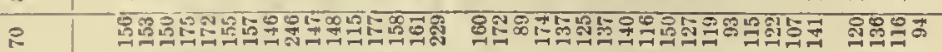

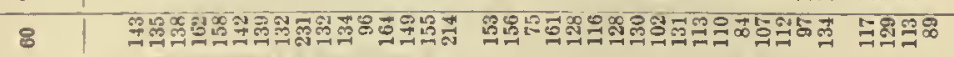

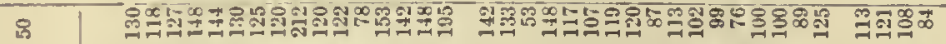

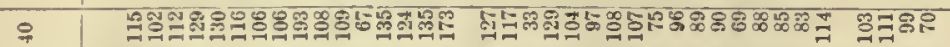

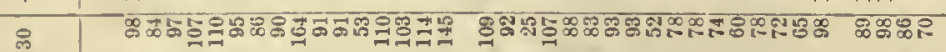

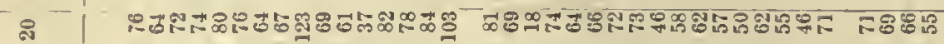

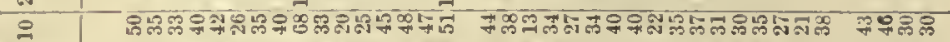

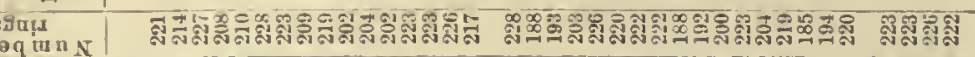

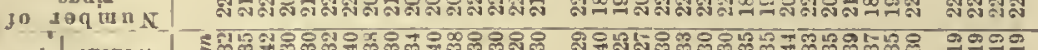

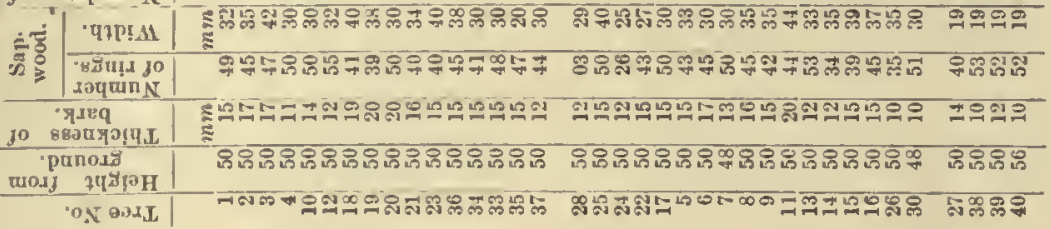
20233-No. 22-12 
FORM NO. 5.

Site: $f . \quad$ Age chass : 240 to 260 years. Specres: White Pine.

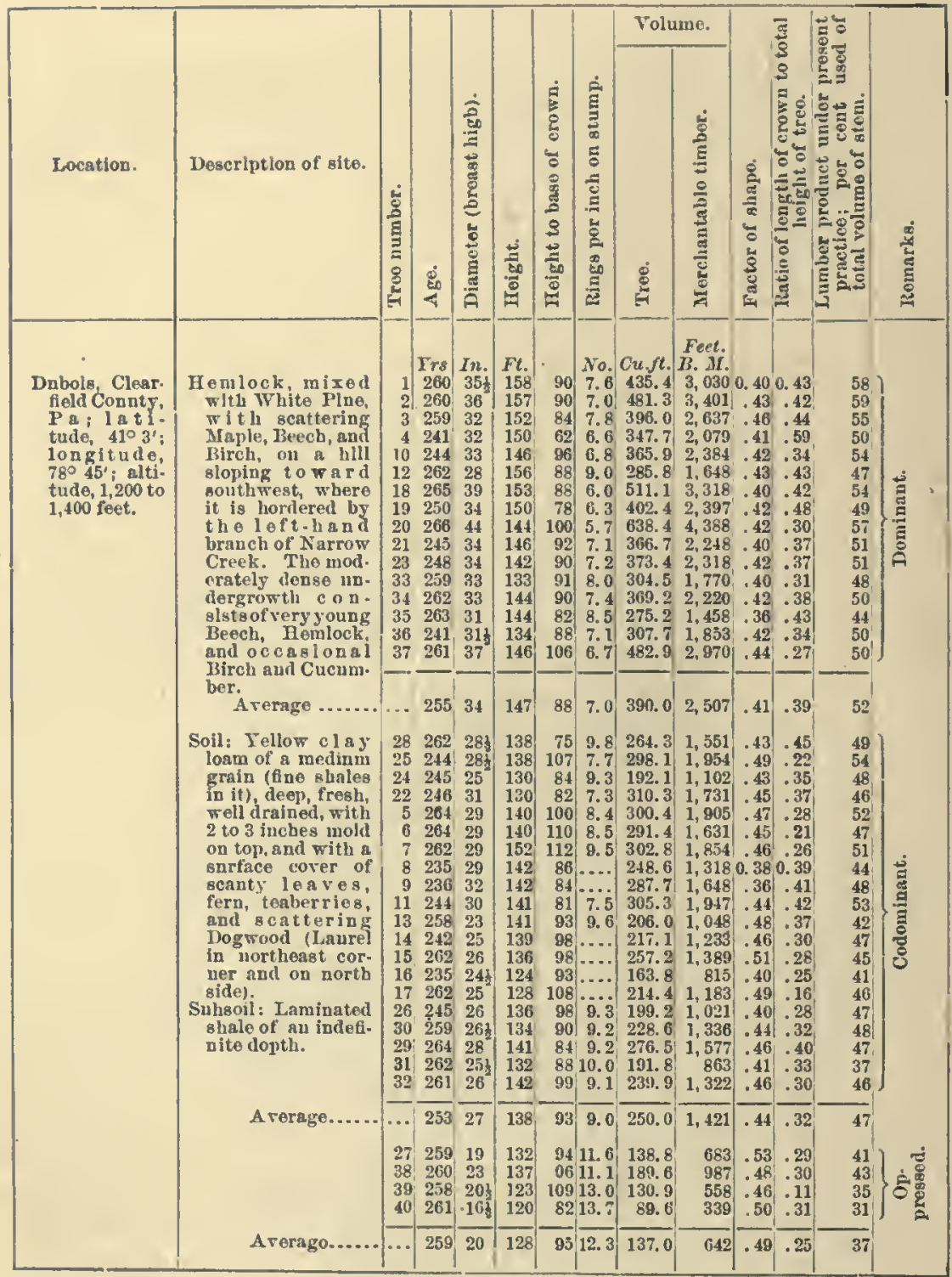


SCHEDULFS AND SAMPLE RECORDS.

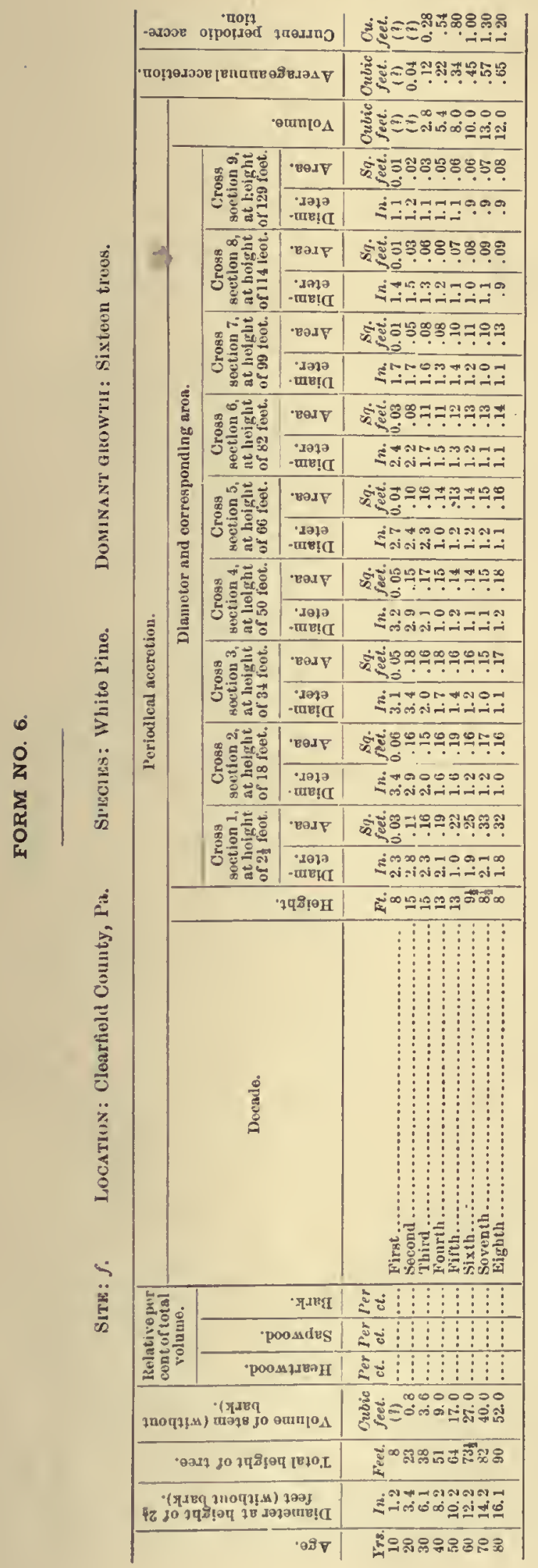





\section{INDEX.}

Abbot's wite-pinu sawe.

Accretion, area, in While Pine average annual, for old trees diameter, of pine, disc nasion yearis, of White Pine, notes

Acre yield of second-growth White Pine, with measnrements of roung pine

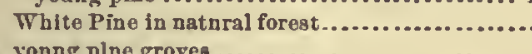

rields of TW bite Pine ${ }^{2}$.

Adlrondack mills, on tput of White Pine.................... if region, destruction of yonng pine growth by fire..

Adirondacks, composition of forest condition ns to reprodnction of Whlte Pine....... growth of White Pine........................

$\Delta$ ga ricus melleus, injury to White Pine......................

Age classes of White Pine, tahles of measurements........... 88-98

Alleghenies, occnrrence of White Pine .................... 13

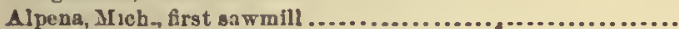

Ann Arbor, Mich , growth of pine.

Annnal height grnwth of White Pine in first hnndred rears.. rings, comparison for varietios of pines................

A phis, White Plne, note................................

Arhorvite, concomitant of $\mathrm{W}$ bite Pine

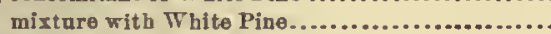

Area accretion of Whlte Pine.

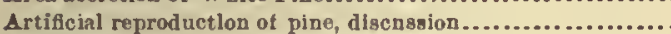

Ash. resnit of plantlng with White Plne.

Atlantlc, injury by raw winds to Whlte Pine.

Baisam Fir, admixture with White Pine.

Bark-beetic, destructive to pine, discnssion................... pine, description and lnjury

Bark-beeties other than plne bark-beetlo, Injuricns to pine trees. 56 , 57

Bark of pine, manner of growth and function ................ Whito $P i n e$, slight protection against fire..............

Barn Inmber, uso of pino.

Bobh, M. S., note on W blte Pine in Illinols ...................

Beech, Birch, and Maple, effoct of shude on White Pine........

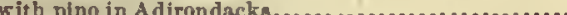

Becties, hark, destructlre to pine......................... 55-57 Bnprcstidso, Injurions to pine, description............

Belfast, $\mathrm{Yl}$. tracle in WVhlte Pine

Bhotan Pine, rclatlonship to White Plne....................

Birch, Maple, and Beech, effect of shade on White Pine....... witls pine in Adirondack

Biack Spruce, usefniness for planting with pine ................

Board and cubio contents of White Pine, tables ............. 85

Boards, plank, and "dimension stuff" of White Pine, sizes...

Boat bnilding, use of White Pine..

Boles of pines, variatlon with charncter of associated trees....

Borers and plne sawyers, disc11ssion........................

Botan leal description of White Pine.......................... range of White Pine.

Box Eider, resnlt of plantlog with Whlte Pine ...............

Bozes, use of Whito Pioe ................................

Boynton, F. E., note on occurrence of White Pine in the Carolinas

Branch, root, aod stem syotem of White Plne ................. Britton, N. L. note on occurrence of White Pine in New Jersey. Brookings, S. Dak., fallure of plantings of White Pine.........
Buprestlde, specics injarious to page. Camhinm of pine, characteristles ...........................

Canada, field of cenmercial pine ........................ 15 occurrence of White Pine........................ 18 original nnd present snpplies of White Pine.............. 19 "rossing" as protection from pine bark-borer........ 56 trade in White Pine............................. 18 Canadian pinery, note .................................. 14 Canby, William M., note on occurrence of Thite Pine in Dela-

ware 0.0000000000.

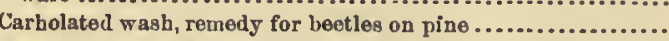
Carholic acid, use against pine weevil.......................

Cary, Austin, measnrements of White Pine..................

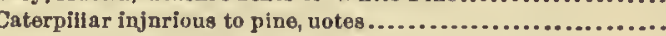

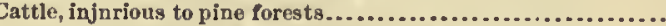
Cedar, White, and Cypress as substitntes for White Pine...... Cells in plne wood, discussion............................ 25, 26 Cerambycld beetles, injury to pine......................... 57 Chalcophora, species injurions to pine ...................... 58 Champalgn, Ill., instructivo plat of White Pine.............. 65 Chermes pinicorticis, "pine blight," note ................... 59 Chicago, growth of White Pine trade.................... 18 Chionaspis pinifolice, manner of injury to pine............... 61 Crittenden, F. R., discussion of "Insect enemies of White Pine" ....................................... 55 Chlorophyll, occurrence $\ln$ young pine ...................... Circnmference of pine trecs, measurements of annual gain.... 35 Classification of White Piue................. 82 Clay and loam lands, reprodnction of White Pine............. 62 land, relation of specific weiglit of pine wood.......... 74 Climate and soil, demands for development of White Pine..... 39 lnfuence on height growth............... 33 Coleoptern, adult, injury to plnè ......................... 61 cnemies of White Pine........................ 55 Coleosporium enecionis, cause of disease ln pine............... 53 Compresslon endwlse, tests of White Pine .............. 77, 78, 79 Cones, age of trces at first production...................... qnantity to produce pound of seed.................. 23 Conifers and hard woods, planting in al ternate rows.......... 66 danger of drying ntmosphere in planting........... 51 necessity of shading............................ 03

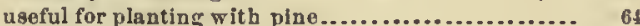
Cork Pine" of Michignn, locality of growth............... 12 Cortex of pine, characters............................... 25 Criocephalus agrestis and other species Injurions to White Pine 58 Cronartium ribicola, relation to cause of disease in pine ....... 53 Crop of Thite Pine, time for matnrity.................... of Crown of White Pine, description......................... Cuhio and hoard contents of White Pine, tahles................ Cultivation of pine nursery at Unlversity of Illinels ........... White Pine, area of prohable success............

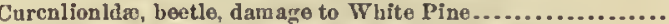
Cypress and White Cedar as substitutes for White Pine....... "Damping off" parasitle organisms as cause................. relief measures ............................. Dangcrs and discases of White Pine, discussion ............... 49-55 Dawsen, J.. statement as to seed crop of White Plne .......... 23 De Fries, nsanmption as use of resin in plant growt b......... 24 Delaw nre, occurrence of White Pine ...................... 15 Dendroctonus frontalis, pine bark-beetle, description........... 55 
Page.

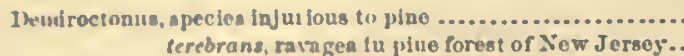

1) relopment of pine in foreat.

$$
\text { npen stand }
$$

Tibite Pine, conditions.

1)iagrams and tahies of measurenents.

Diameter accretion of ulve, discussion.

"Dimension atuf," boaris and piank, of White Pine, sizes....

Discuses and dangers of Whito Pine, discus sion............... of plac duacussion.

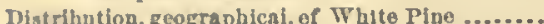

ant nrat, of White Pinc, concinsions ...............

of White l'ine, hy regions

Doruentio avimals, notes on, danger to forest ..................

Ionglas, liobert, remarks on transplanting pine

Drought and heat effeet on pine.

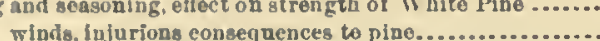

Durability of Thite Pine, discussion

Eigin nurscries, Whito Pines of forty-flre years' growth ......

Enemies, ingect, of Whito Pine...

Eagiand, introduction of Thite Pine pote on Introcluction of Tile Plo .0.

Enrope, comparison of pine growth with America ............. experience regarding reforeeting ...................... notes on Stone Pine.

planting of Scotch l'ine

prodnction of aced hy Whito Pine.

European Larch, use as nurse treo for White Pine............ Experiment stutlons, noto on reports as to "damping off" ..... Fixport of $1 \mathrm{w}^{\circ}$ hite Pine, note

Fector of shape for White Pine.............................

in find ing cuhic and hoard contents of tree, nse.

Farn impiements, nse of White Pine.

Farmington, X. II, record of growth of White Pine.

Fencing, uge of White Pine

Fernew, Dr, method of forest planting.

Fields, abendoned, measurements of pine

problem of protectlou of pin

Fir, note on growth in the Paintlneto, Germany ................

Fish-oll moap, 1tso areingt pine weerif .

Floral organs of White Pinc, discussion .....................

Forest, effect of composition ou height growth ................. fires, suggestions for iaws

growth, elassification of trees ........................ of pine, classiflcation

iusects, injurions, natirity.

menagement, hiscussion

thod adrorated by Dr. Fernew.......

tnble showing first six jears' grow th of White Pine ...

tree in Germany, White Pine, diseussion ...............

Forester, The, facts on trimning pines.

Forest-grow n trees, diameter growth at rarious heights ......

Forests of White Pine, note on prohahle cxhanstion ............

Form development of pine ..................................

Forms nsed in the investigation.

Frane honso, use of plne ..................................

Fran kfort on the Main, prodinet of seed of White Pine ........

Freals air, 1180 ag uinst "damping of "

Fun

Fongus, A ga ricus melleus, injnry to Wh i te Pine ...............

Coleosporium senecionis, canse of disease in pines.....

I'olyporus annosus, injury to coniferous trees ..........

Finrniture nien. use of White Pino.

Gerdner \& Sons, measurenents of hoight growth of pine......

German Spracc, nse of tables for finding yield of White Pine..

Germany, injury to pine hy heat and drought.

piantations of puno ....................

statementa regarding acro jieid of pine under forester

Whito Pine ns forcest trce, dlscusaion

Germinntion of ine sceds. cuuditions

Girditag of young pine, effect..

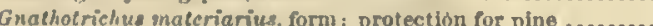

Graves and Pinchot, Jleasrs., figures for slejd of pine per acre.

Growth and dereiopmint of White Pluo.....................

beight of White line in forest. Brst six jears ..........

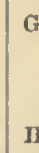

Growth in thickness of pine .......................... Page.

volume of White Plne........ 37

of dismeter and cross section. tahles and diegrams .. 107-116 pinc, rate................................... $\quad 27$

IIell, S. E. statement as to time of setting pine.............. 65

Hard pine, veriation in welght......................... 77

Hardwood forest, notes on growth of White Pino............ 43

intermixture with Whito Pine.............. 12

species nsefnl for planting with pine.............. 64

Hardwoode and conifers, pianting in aiteraate rows.......... 66 mixture with Whito Pino ....................... 14

IIarmonia pini, enemy of pino, note..................... 59

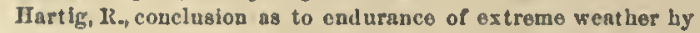

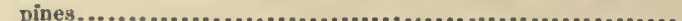
Ileartwool of Wlite Pine, instances of renarkehle dnrahility. rariation in moistnre ............................

II cat and drought, effect on pine ........................... Helght growth of piae, seelling stage ........................ trees after first centnry of lifo .............. Whito Pine, tahíes ......................... Hemlock, concomitant of White Pino. crowth of Whito Pino in mixtnre............... mixture in grow th with White Pino.................. occurrence mith White Pine in Pennsylranie........ IIII, E.J, note on White Pine at head of Lake Mfichigen..... IIistological characters of pine.............................. Hohbs, John $E_{\text {., }}$ statements es to seed production of White Pino

tahlo on height growt th of pine............... Hoyt, B. F., statement as to offect of wind on White Pines..... Ilumidity, rclation to derelopment of Whito Pino.............. Hnnt, Thomas, piantation of White Pine et Ridott, Iil ......... Hypothenemus, twig heeties injurions to pino ................ Ice roads, note on use in logging ............................ Illinois, growth of sprico and pine in forty-flve years .......... occurrenco of Whito Pine............................ University, note on forest plantation .................

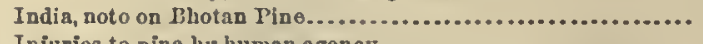
Injuries to pine hy hurnan agency.

Insect onemics of White Pine, discnssion.................... Iowa A gricultnrai College, notes ou plenting of pino, larch, end broad-leafed trees of $1875 . . . . . . . . . . . . . . . . . . . . . . . .$.

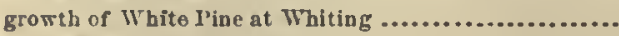
occurrenco of White Pinc............................. Jack Pine, admixture with White Pine ...................... 12, It associate of White Pine ........................ 40 Jerome, Governor, estimate of Michigan products............. 11 Jurenile stage, determination of limit for pino............... 36 Kerosene emulaion, remerly for heetles on pine................ 57 use against plaut-lic $0 . . . \ldots \ldots \ldots \ldots \ldots \ldots .60$

Kleehahn, investigetion of hister rust .................... 53

Lachnus strobi, enemy of pine............................. 59

Lako Michigan, note on gro rcth of White Pine on shore....... 22 region, condition a to reproduction of Whito Pine...... 62 original stand and present supplies of White Plne 19 trade in white Pine, and present snpply ........ 17, 18

Lond in Massaclsusetts, estimato of vaiue edded hy fifty years' growth of pine...

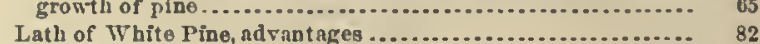

Laths and pickets, $u$ se of White Pine....................... 81

Laws egainst injuries to forosts, s11g gestion................. 49

Lazenhy, W. R., note on White Pino in Olio ................ 15

Leaf-feeding insects injurions to pine, discussion ............. 60

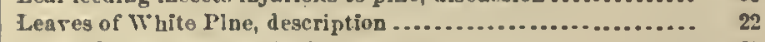

Leonard, sponcer, practico in sutting out pine................ 65

Lifo zones of Whito Piue.................................... It

Light requirements of Whito Pine........................... 43

Lime and Paris green, used against pine hark-beetle.......... 56

Lincolu, Nehr., comparative failure in growing White Pine.... 6

Loam end elay inads, reproduction of 1 hite Pine........... 62 efiect on growth of hardwoods......................... prairie, growt h of pine in Illinols.................... stiff clay, growth of pine at Windom. Minn.............

Loamy and eandy soils, reprodnction of White Pine ...........

Locality, effect un height growtî of trecs.....................

Loggers' rlsl:s in hreakages. tetc.. allowance...

Loggine ralizay, note on effect on lumbering.................

51

80

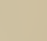

2

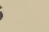

2

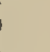

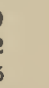

3


Logs, small, reduction of loss ........ Long.horned beetles, enemies of pine

Longieaf Pine, comparison of annual rlngs with Thit pine... speciflc weight for cromn part of stem..........

Lnmber contents ln 16-foot logs of trees

cut in

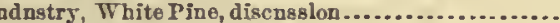
markets, infuencu of White Pine

of stem of tree, reckoning................

pine, importance of production

pine, in

Lumhering districts for Thito Ping in Car of White Pine, change of methods

iu Yichigan, note.

$$
\text { raste. }
$$

Lumbermen, name for diseaso of pine tree

Machride, T. H. note on White Pine in Iowa.

Mrine, acre yleld of White Pine.

character of Thite Pine growth

second-growth pins, note...

trade in White Pine, and supply.

Maple, Birch, and Beech, effect of shade on White Pine........ with Beecl and pine ln Adirondacks...

Market for aecondl-growth pine in ylasgaclusetts White Pine, change in Germany .

Markets for lumber, inflnence of Whito Pine

Maryland, occurrence of Whito Pine.

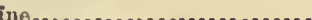

Massachnsetts, market for second-growth plne. second-growth plac, note soil of pine groves and ralue of young pine growtb.

tahle of annual rain iu circnmference...........

Measurements, detail, of aunual gain ln clrcumference of pine. diamcter, of trees............................. of sample trees and acre yields of White Pine. 116-147

White Pine, tahles ........................ 85-179

Mednllary rays in plno, notes ..............................

Meohan, Thomas, sons, statements as to growth of seedling pine on occurrence of White Pine ln Psnn. syanla.................................

Mico, spread of fungus direaso.

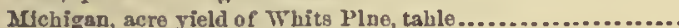
yields of White l'ine and measnrements of sam-

plo trees ............................... 116-131 destruction of yonng pire growth hy fre ........... Maine, and Wiaconsin, comparison of growth of plne. need of need for reforesting baro pine lands ......... occurrenco of Whlto Pine.

original stand and present snppiy of White Pine ...

valne of pine and other proulncts in 1879 ...........

Wisconsio, and Minnesota, annnal cnt of White

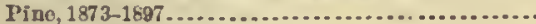

yield of Whlto Pine, per ncre......................

IIIl construetion nse of Whi te Pine

Minnesota, beginning of pino lumbering..................... dsstruction of young pine growth by fire .......... Michlgan, and Wlaccasin, annual cut of Whlte

Pine, 1873-1897 occurrence of White Pine

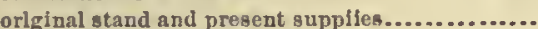

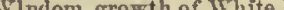

Mlasond (river) bottoms, growth of Wbite Plne................ growing a peclmens of Whito Pins at Colnmhla .......

Mlixed growth, adrantages for pino...

Mlodzisnsky, A.K., measurements and calculations of Whlte Pino.

Todel makers, nse

Whito Plne.

Modnlos of clasticity of Whito Pine.

Molature cootent of White Ploe, tahle.

Monohanmns, beetles most destructice to pine ................ confusor and other species injurlons to pine....

Iorphological characters of Whito Plne ....................
Nathaniel, experience ln trlmming pincs .............

Moth caterpillars and piant.lice on trunks and limbs ......... 59

Moths, speclos lnjurious to pine.............................

Names symonymons with White Pino ........................ 20

Natural history of Whito Pine.................................

reproduction of White Pine, discnsslon..............

Nebraska, White Pino at Arbor Lodgo........................ 67

Now England, condition as to reproduction of White Plne .... 62 eariy commercial use of White Plne........... 16

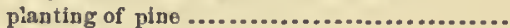
present supply of White Pine

Newfoundiand, occnrrence of Whito Plos....................

New Hampsblre, distribution of Whito Pine ..................

Now Jersey, occnrrence of Thito Pine ..................... 13,15

Nsw Fork and Pennsyivania, present suppiy of White Pins... 19 distrihotlon of White Pine ..................... 12,13 occurrence of White Pine......................... 13 trade in White Pine; preseot supply ............ 17

Nomenclature, synonyms of White Pino.................. 9

North Carolina, oocurrence of White Pine ..................... 13

Middishoro, Mass., notes ou pine grotes of fouty years' growth .......

North restern Inmherman flgares for annual cut of lumber

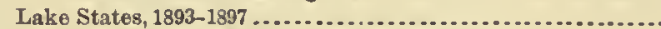
Norway Pine, growth in mixture with White Pine............. Spruce, growth in forty-five years at Princeton, Ili... Nurse crop of trees, cheap method of use .................... Nursery, growth of White Pine ........................... Nurserymen, practice in sowing pine seeds .................... Ohio, occurrence of White Pinc ............................. Old-growth pine, tables of measurements and diagrams ....... 93-100 Ontario and Qnebec, a verago annual dnes on crown timher..... 18 Orientation, relation to specifie woight of pine wood ........... 74

Pacific coast timbers, barrier to suhstitution for White Pine on Eastern markets

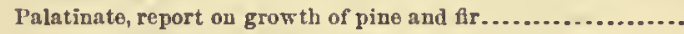
s upply of cones for seed organisms, cause of "damping of " ln pines........... Paris gresn and lime, use against pine hark-heetío ............. uso against pine weevil . saw fly, larva, caterpiliars, and heetles.
28 15
Pennsylrania, acre yleld of second-growth White Piue, with mensurcments of young pine.. 148-169 White Pine ................. 12 and Jew York, prescnt supily of White I'ine.. 19 conditions as to reproduction of White Pine.... 62 occurrence of White Pine.................... 13, 15 trade in White Pine; present sapply.......... 17

Psnobscot, White Pine trado and snpily..................... 17

Peridermium strobi, cause of dissase in $W$ bite Pine........... Phioem of pine, charactsristics............................. 25 Physical properties and character of Whlte Pine wood....... 73 Pickets and laths, use of White P'ins...................... 81 Pinchot and Graves, Messrs, Agures for yieid of piue per acre. $\quad 45$ Pine hark-heetle, destructivo, discnsslon of injuries........... 55 hlight, note ...................................... 59 hllster disease caused hy Coleosporium senecionis......... leaf scale insect, manner of lnjury to pine .............. 61 numher of seed to ounce; of ounces to 100 fcet of drill... 63 percentage of heartwood iu several klnds............... 73 sawyers and other hors rs, discussion................... 57 valne per acre of tifty ysars' growth, note............... 65 Plnes, comparison weight and strength, tahle................ 81 note as to shrinkage............................... 77 Pinipestis zimmermanni, ensmy of pine, note............... 59 Pinus nana, varioty of White Pine, doscriptlon................ 20 nivea, viridis, aurea, brevifolia, ctc., rarietics of $\mathrm{White}$ 1ine............................................ 21 Pissodes strobi, enemy of White Pine, discussion; description. 58 Pistlilato fiowers of White Pino, description................ 23 Pltch Pine, associate of White Pine ........................ 40 raluo for pianting on Atlantic coast.............. 51

Pits in pine wood, focation, number, and size ............... 25, 26 Pittshurg, trude In White Pinc ........................ 17 Pityoph thorus, species injurious to pino.................... 57 
Plains, resen fur slight snceess In cultiration of plno......... Plank, Lourls, aud "dimeneion stuf" of White Pine, slres... Plantlag notes for IF hito Pise.

of pine, comparisou of narsery-grown seedlings wlth nowing aced.

diatanco between trees ....................... notes...

White Pine, note on experiment at lliinois Unirersity......................................

tlme for White Pine, noto .........................

Plaat-lice, and moth catorpiliars, on trunks and limbs......... keronenc euulsion as remedy

ivuse, attacks on pine, noto ......................... Poilen, ripeniag, and polínation.

Pollination of Whito l'ine, notes

Polyprome annotue injary to coulferous

Poplar, groweth ou pino alashings

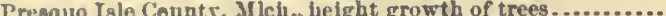

Iriuceton, Ili., pine of furty-ffvo ycara" growth..............

Protective waslies against pine hark beetio...

I'ublio sentimont, valuo in preservation of foreste

Pythium de baryanum, canse of "damping off" in young pines Quobeo and Ontarlo, arerago annnal dnes on crown timhor.....

Rate of growth and rolnme of White Pine, tahles ........... 93-108 of $W$ hite Pino ............................. 27

Recorils of tree measn rements, forms .................... 173-179

Red Pino, almixture with White Pine ...................... associate of White I'ue...

mixturo with White I'ine

Reforeating with IT hito Pine, ease

Remedies for pino bark-heet lo

Reproduction, artifleial, of pine, discnssion of White Pine, naturai, discnssion ..............

Reseeding, importanco in reforesting with pino.

lesin dnots, discussion

in cortex of plae...

of pino, effect of fanmns diseases ......................

Ithizomorpis, action In fungus disense of White Pine ........

Rings, annnai, comparison for varietics of pine ...............

liocky Ilountains, nete on White Pine.

Root, stem, and hranch of Whlto Pinc.......................

gystem of White I'ine, reiation to piace of growth.......

Roots, seat of fuugus dlsense of pines ......................

"Rossing " protection against pine hark-horer................

Rotation of trees in forest unanagement.

RoTu, FuUHEHT, artlcio on "W concinsions as to allowanco fur waste in aawing..

Saginaw, Mich., first an winill.

St. Law renco Rirer, occurrence of Wibite Pine ................

St. Lonis, growtin of Whito Pino tralo

Sand, loamy, growt h of $W$ hito Pine...

preference of Whlte Pine.

Sandy and loamy soils, reproduction of White Pino ...........

soils, reiation to sinecifie weight of pine wood...........

Sapword of tree, variation of molsturo...

White I'ino, note on clrange to heartwood .............

Sin wfilieg, enemies of pine, notes.............................

Sa wing of inmber from Whito Pine, nutes....................

Sawyer, posalihle wasto of pine.

Sa wyers, pino, nud other burers, discussion.....................

Scalo insects, koroseno emuision as renedy.

Schizoneura pinicola, cneny of Whito Pine, noto ...............

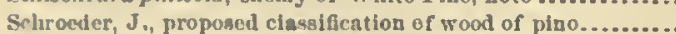

Sculytidn, enemies of Whito Pine

otiver, timber heetles..

Scotch I'iue, cotnparison of resiu dnets with Whito Pine..... growth in forty-fvo years at Princcton, Ill........ Germany .............................

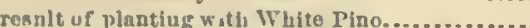

Seagoniug aul drylug. offect on strength of White Pino........ of White Iine, comparison with other pincs. nute

freconi-growth phe, devilopunent ......................... age.
Sacond-grow th pine, market and nse in Massachusetts .... Page. tables of measurement and diagram...... 100-166 Whito Pine, acre ylell, with measnements of young pine.............................. 148-169

Seeding of White Plne ia Germans, note....................

Seedling stago of pine, helght growth .................... 27

Seedlinge of pine, growth; destructlon hy firo ................ 62 protection........................... 27

Seed, numher to the ounce for pine; to 100 feet of drill......... 63

of pine, motholl of sowing ............................

White Pine, cfrect of exposnre upon vitality .......... B2

production, discuseion................................ 23

Seeds of pino, conditions for gormination ................... 27 percentage germinating...................... 64

retention of vitality......................... 26

White Pine, description............................. 23 riponing...

Shade endurance of White Plne, noto........................

for seed heds of pine

Shape, factor, in White Piue................................ use la flading cnluc and board contents of tree. Shingles, iatlis, etc., note on output in lake States.............. of White Pine, dnrahility nge of $W$ bite Pine...

Shiphnilding, use of White Plne ............................ Shipping case of Whito l'ine, ad vantages...................... Shortienf Pine, associate of White Pino ...

Shrinkage of White Pine, disenssion ......................... tahlo

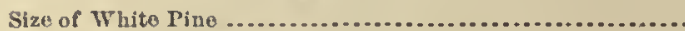
Soap, fish-oil, nse against pine wcevil.

soft, uso against pinc-hark beetlo

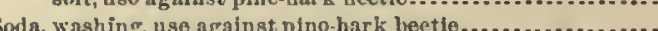
Soil and cimato demands for dereiopment of Whito Pino..... infuenco on height growth of trees.

black loam, growth of pine

character for nse against "damping off" ".................

for White Pine, notes.................................

of Paiatiante character for growth of pine Soils and soil conditions for White Pine .................. 12, 13,14 light, advisability of sowing seed of pine hroalcast ...... 64 Sonti Carelina, occurrence of Whito Pine.................. 15 Dakota, failuro of plantings of Whito Pineat Brookings. $\quad 67$ Srecifio woight of pine, notos ........................... 73,74 Spercs of Polyporns annosis, spread of disense in piaes....... 52 Springer, J.S., note on White Pine....................... 16 Spruce, concomitaut of White Pine ........................ 40

forest of Canada, note........................... 15 llahility to being uproeted ......................... 58 mlxture with White Pine .......................... 14

Nurway, record of growth in Germany............... 69 Spruces, almixture with White Pine ....................... 12 Staminate flowers of $W$ inite I'ine, description ................. 23 Stem, root, and hrancin system of White I'ine ................ 21 Storms, injinries to forest .................................... 50 Strongth and woight of pines, comparison ................. 81 of pine, variation with location of woed in tree..... 78 Whito Pino, discussion .......................... $77-79$

Sitructure of Whito Pine, notes . .......................... 73 Subsoll, stiff, offect on joutng pine .......................... 60 Sugar $\mathbf{M}$ aple, usefulness for planting with pino.............. 64 Pino, relationship to White Pine Sunlight, vaine against " vlamping of" " in pines................ Snpplics of Whico Pine, original and present, discnesion....... Swamp treog, noto on specific wcight ........................ Swiss Stone Pino, rointionship to White Pine ................. Synonyms of White Pine ................................. Tamarack, mixtnre with White Pine......................... Taper of piue treo, reiation to conditlons of growth White Pino, variations

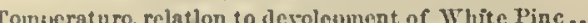
to prevent "daruping off"

Tennessce and West Virginia, present suppiy of Whito Pino... Thecla nijhon, injury to piue ............................... Tininning of piue, noto White Pino, concinsion from record at Farming.

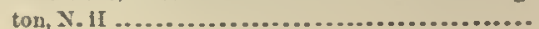

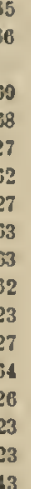

63

(1)

4



coumercially valuahlo, distribution of Tr bito pine of White Pine, diagraus on weight ................... rariation in strength wits loration in treo

prodncts of Michigan, comparison for 1879 with other products

Tomices cacographus, injury to pines, dearription .............. pini and other species, lnjury to pinc. ................

Tortricid moths, enemics of piue, remedies...

Transplanting the seediings, notes...

Treo, largest pino actnally mcasured. measercatens and ealculation fo

Trees, cnbic and lumher contents, note...................... deformed, damaged hy White Pine weevil............... forest-grow n, dianeter growth at varions leights ....... living, danger of attacks from hark heetles ............. of different ages, talile slowing arerage weight, moisture content, and shrinkage..................... 74,75 young, average taper.............................. 37

Trunks and limbs of pine, moth caterpiilars and piaut-lice .... (See also Steus aud Boles.)

Tuhe-builder, pine, manner of injury

Turpentine flow from boles mate by bark b

Twig beetles, genera injurions to pine ......................

Upbuu, Warren, note on soif for Whito Pine..................

Upland trees, note on specific weight.

Uprooting, danger of White Pine.

Uses of White Pinc, diacnssion.

Varieties of White Pine and rate of growth of White Pine, talles ............ growth of pine, variatio of treo, mossurements and calculation -

Wadeworth, S. B., noto on Whlte Plue in Iliinois ..............

Wapres, L., Bararian forestor, report on White Pino

Ward, Lester $F_{-}$, note on ocenrrence of W hite Pino in Marylanil and Virginia

Wash, composition for nse agalnst bark beetles............... for protection agalnst Whito Pine wocvil

IV ashes, protective, agningt plue hark-beotle - .... Washington Clty, first gpring visitatlon of White Pino weevii. Watering, netlool for prevention of "slanjping off" ........... Weatlier, relation to shading of plno scedlings .

WF

Weevil, White Pine, discussion . measures for protection of pino time of appea ranco $\ldots . . . . . . . . . . . . . . . .$. $2023,-N o .23-13$ 年 woml of White l'ine, diamisslon ............ 73 West Virginia and Tennesseo, prosent supply of Whito Plue.. 19 Westeru prairies, estahlisilment of pine groves.............. 63 White Iine, advantage over other plnes in reprotuction from ser.l. ..................... trees in wind sterm ........ burning of wilting tormiual as protection agalust weevil .................................... insect enemles, general statement............... weevil, disenssion ............................ Whiting, A.H. growtlu of White Pine at home ................ Williams, Re, note on White Pino in Iilinois................... Williamsport, Pa., trale in Whito Pine..................... Wind, immmnity of White p'iue fron lnjury ................. Windom, Minn., growth of Whito I'ine in thirteen years ...... Winds, drying, lnjurions consequences to pine............... Wisconsin, acre yield of Whito 1 ine, tahle................... sields of Whito Pine and measurements of sample trees......................... 131-147 destruetion of young plne growth liy fire......... 63 first logs taken to St. Lou is ...................... I8 heavy production of pine seed ................. 23 Maine and Mlchigan, comparison of grow th of pine 33 Michigan and Minuesota, annuai ent of White

Plue, 1873-1897 te Pine......................... 14 origing and and present suppiy of White Piue.. 19 yield of Whito Pino, per acre .................... 20 Wood, amonnt formed in pine lu different decades of growth .. 37 function lu econony of tree........................... 2

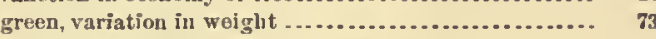
kiln-dry, variation in speciftc weight................ 73 note on change in Wh blto Pine ........................ of Whito Pine, character and plysical properties....... 73 discussion .......................... $73-82$

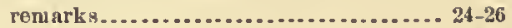
Wools, other, comparison with White Pine................ 80 Wurtemhurg, growtl of White Pine........................ 68 Ylohl, acre, of White Pine in natural forest .................. 46 young piuo groves........................ $\quad 43$

of White Pine, discnsslon ......................... 44 per acre............................... 20 second-growth White Pine with neasurements of young pine taken for analysis .................. 148-169 Yields, acre, of White Pine and mensurements of sample trees .............................................. 116-147 York County, Me., statement as to reprodiuetion of pint...... 62 


.

4 


$$
\text { . }
$$




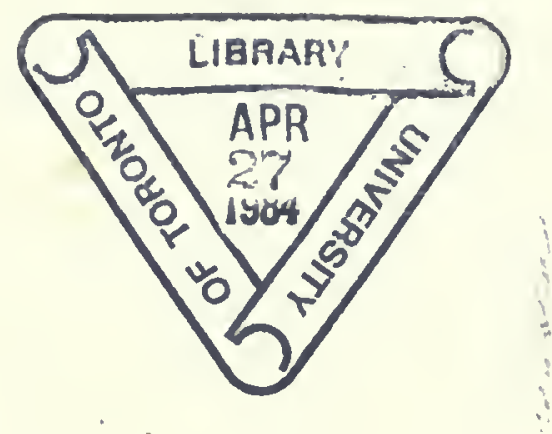




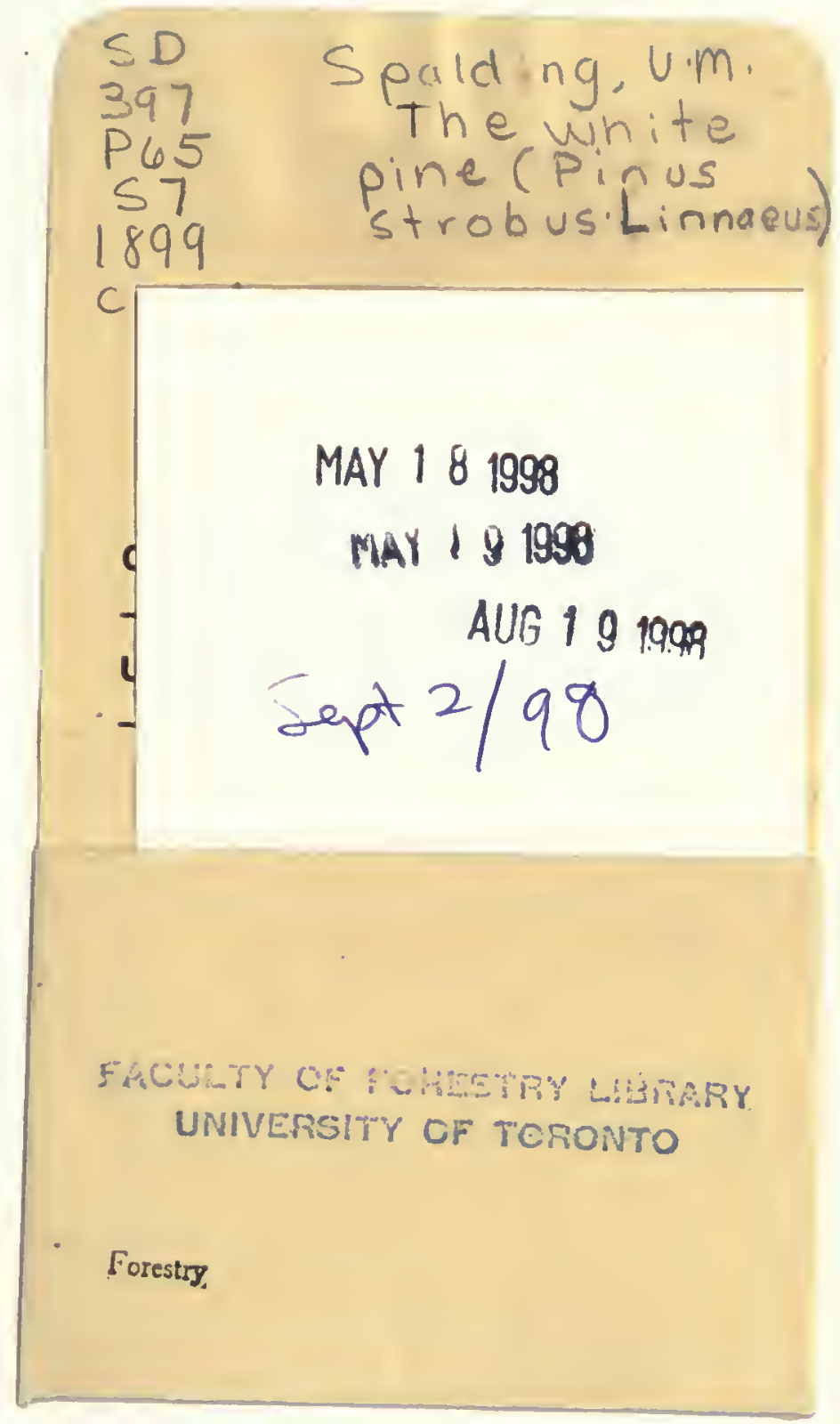




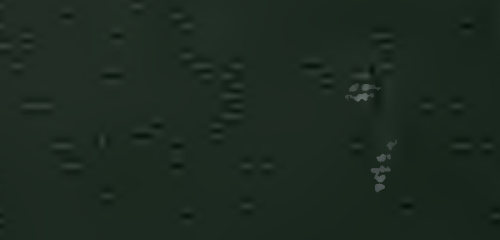

